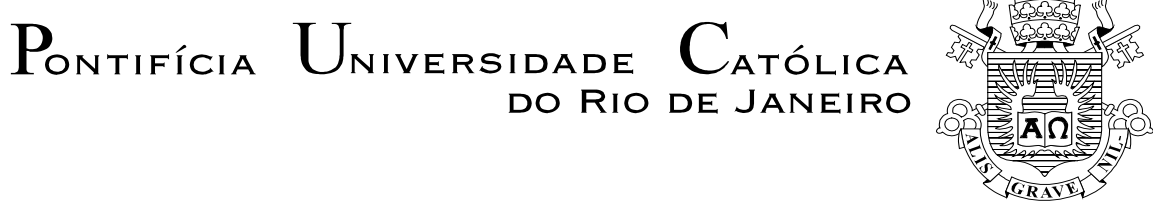

Teresa Dias Carneiro

\title{
CONTRIBUIÇÕES PARA UMA \\ TEORIA DO PARATEXTO DO LIVRO TRADUZIDO: \\ caso das traduções de obras literárias francesas no Brasil \\ a partir de meados do século $X X$
}

\section{Tese de Doutorado}

Tese apresentada ao Programa de Pós-graduação em Estudos da Linguagem da PUC-Rio como requisito parcial para obtenção do título de Doutor em Letras/Estudos da Linguagem.

Orientadora: Profa. Marcia do Amaral Peixoto Martins

Volume I

Rio de Janeiro

Fevereiro de 2014 


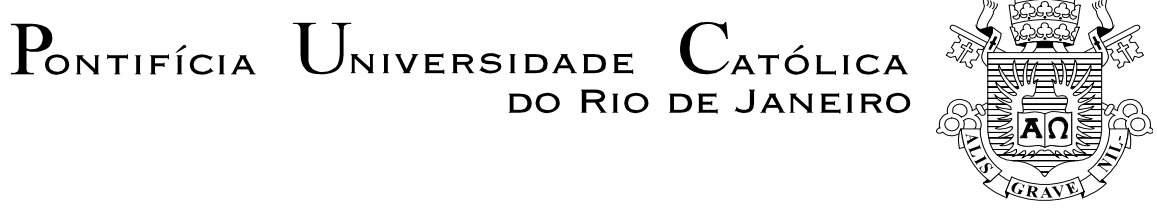

Teresa Dias Carneiro

\section{CONTRIBUIÇÕES PARA UMA \\ TEORIA DO PARATEXTO DO LIVRO TRADUZIDO: \\ caso das traduções de obras literárias francesas no Brasil \\ a partir de meados do século $X X$}

\section{Tese de Doutorado}

Tese apresentada ao Programa de Pós-graduação em Estudos da Linguagem da PUC-Rio como requisito parcial para obtenção do título de Doutor em Letras/Estudos da Linguagem.

Orientadora: Profa. Marcia do Amaral Peixoto Martins

Volume II

Rio de Janeiro

Fevereiro de 2014 


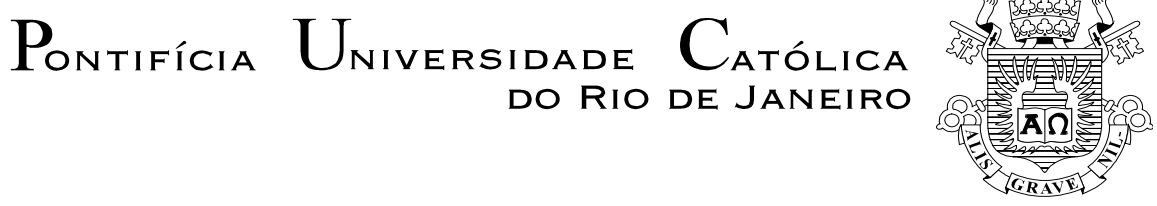

Teresa Dias Carneiro

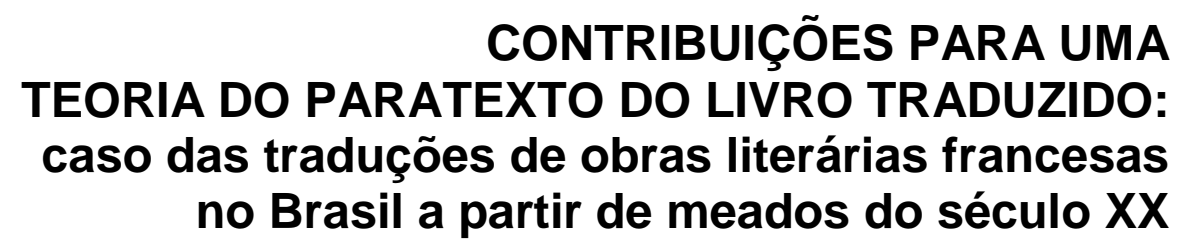

Tese apresentada como requisito parcial para obtenção do grau de Doutor pelo Programa de Pós-Graduação em Estudos da Linguagem da PUC-Rio. Aprovada pela Comissão Examinadora abaixo assinada.

Profa. Marcia do Amaral Peixoto Martins

Orientadora

Departamento de Letras - PUC-Rio

Profa. Barbara Jane Wilcox Hemais Departamento de Letras - PUC-Rio

Prof. Paulo Fernando Henriques Britto Departamento de Letras - PUC-Rio

Profa. Márcia Atálla Pietroluongo

UFRJ

Profa. Marie Helene Catherine Torres

UFSC

Profa. Denise Berruezo Portinari Coordenadora Setorial do Centro de Teologia e Ciências Humanas - PUC-Rio

Rio de Janeiro, 07 de fevereiro de 2014 
Todos os direitos reservados. É proibida a reprodução total ou parcial do trabalho sem autorização da universidade, da autora e da orientadora.

\section{Teresa Dias Carneiro}

Bacharel em Economia pela UFRJ em 1983. Concluiu o curso de Especialização em Tradução Francês-Português pela UFBA em 1992 e o Curso de Especialização em Tradução Inglês-Português pela PUC-Rio em 1997. Mestre em Ciência da Literatura/Literatura Comparada pela UFRJ em 1999. Tradutora profissional de inglês e francês desde 1987. Tradutora Pública e Intérprete Comercial do idioma inglês desde 2001, no Rio de Janeiro. Professora do Curso de Formação de Tradutores Inglês-Português (CCE/PUC-Rio) desde 2004 e de cursos livres sobre tradução jurídica e juramentada na PUC-Rio e em outras instituições. Membro da Diretoria da Associação dos Tradutores Públicos e Intérpretes Comerciais do Rio de Janeiro (ATP-Rio) desde 2001.

Ficha Catalográfica

Carneiro, Teresa Dias

Contribuições para uma teoria do paratexto do livro traduzido: caso das traduções de obras literárias francesas no Brasil a partir de meados do século XX / Teresa Dias Carneiro; orientadora: Marcia do Amaral Peixoto Martins. - 2014.

398 f.; $30 \mathrm{~cm}$

Tese (doutorado) - Pontifícia Universidade Católica do Rio de Janeiro, Departamento de Letras, 2014.

Inclui bibliografia

1. Letras - Teses. 2. Teoria do paratexto. 3. Estudos de tradução. 4. Historiografia da tradução. 5. Relações FrançaBrasil. 6. Tradutores. I. Marcia do Amaral Peixoto Martins. II. Pontifícia Universidade Católica do Rio de Janeiro. Departamento de Letras. III. Título. 
Aos meus pais, Lilian e Octávio Augusto, que, apesar de ausentes fisicamente, estarão sempre ao meu lado, me guiando. 


\section{Agradecimentos}

Agradeço à prof ${ }^{\mathrm{a}}$ Marcia do Amaral Peixoto Martins, pela orientação e leitura cuidadosa do meu trabalho, e por todo o estímulo que sempre me deu como pesquisadora, professora e profissional, desde que nos conhecemos em 1997.

Aos professores Barbara Wilcox Hemais e Paulo Henriques Britto, pelas sugestões apresentadas na ocasião do exame de qualificação, bem como pelas indicações bibliográficas preciosas.

À prof ${ }^{\mathrm{a}}$ Márcia Atálla Pietroluongo, pelo apoio nas várias fases deste trabalho e pela parceria acadêmica e profissional tão generosa e atenta, que se delineou na construção dessa nova velha amizade.

À prof ${ }^{a}$ Marie-Hélène Torres por ter aceitado o convite para vir participar da banca examinadora na defesa da tese, apesar de suas inúmeras atividades e demandas acadêmicas e profissionais.

Aos pesquisadores ligados ao grupo do Projet TTT: Textes théoriques sur la traduction/Theoretical Texts on Translation, que se reuniu em novembro de 2013 na Université Sorbonne Nouvelle - Paris 3 para a realização do seminário "Quand les traducteurs prennent la parole: préfaces et projets traductifs”, sob a organização de Isabelle Génin e Jessica Stephens. As trocas experimentadas nesse contato foram muito profícuas e ajudaram a aprofundar as conclusões deste estudo.

Aos organizadores e participantes da $6^{\text {th }}$ International Conference for Graduate Students and Young Scholars: New Research in Translation and Interpreting Studies 2013, realizada na Universidade Rovira i Virgili, em Tarragona, Espanha, em julho de 2013, e, em especial a Esther Torres Simón, pelo intercâmbio acadêmico e interessantes insights suscitados pelas comunicações tão instigantes.

À prof ${ }^{\text {a }}$ Sehnaz Tahir-Gurçaglar, da Universidade do Bósforo, Turquia, cujo curso “Topics on the Sociology of Translation”, ministrado na USP em abril de 2013, abriu para mim toda uma nova perspectiva para pensar a atuação dos tradutores, de forma mais ampla, em sua plena agentividade.

À minha família, pelo apoio e torcida constantes ao longo do meu caminho. Em especial, às minhas belas filhas, Julia e Maria Clara, que me dão ânimo e coragem para perseverar. 
Ao meu querido companheiro de vida, José Maria, pelas longas conversas e muitos aconselhamentos que me ajudam sempre a querer me tornar a melhor versão de mim mesma.

Aos funcionários da Biblioteca Nacional, pela atenção dispensada.

Aos funcionários da Pós-Graduação em Letras da PUC-Rio, em especial ao trabalho sempre tão cuidadoso de Francisca Ferreira de Oliveira, e a Marcia Guerra, pela revisão e formatação da tese. 


\section{Resumo}

Carneiro, Teresa Dias; Martins, Marcia do Amaral Peixoto (Orientadora). Contribuições para uma teoria do paratexto do livro traduzido: caso das traduções de obras literárias francesas no Brasil a partir de meados do século XX. Rio de Janeiro, 2014, 398p. Tese de Doutorado Departamento de Letras, Pontifícia Universidade Católica do Rio de Janeiro.

Esta tese de doutorado apresenta algumas contribuições para a construção de uma teoria do paratexto do livro traduzido. A teoria do paratexto, que tem por sua obra seminal Paratextos editoriais, de Gérard Genette, não inclui como objeto de análise esse tipo de paratexto. A proposta desta tese é, portanto, complementar a teorização de Genette, contemplando um tipo específico de paratexto do livro traduzido, o prefácio/posfácio do tradutor, com interesse especial pelos prefácios/posfácios do tradutor que tratam da tradução e do projeto tradutório. Os aportes teóricos utilizados são os oriundos dos Estudos de Tradução, Historiografia da Tradução e Teoria dos Gêneros Discursivos, com base em observações recolhidas na pesquisa em um corpus constituído por obras literárias francesas traduzidas no Brasil a partir de meados do século XX, em sua maioria parte integrante do acervo da Biblioteca Nacional no Rio de Janeiro.

\section{Palavras-chave}

Teoria do paratexto; estudos de tradução; historiografia da tradução; relações França-Brasil; tradutores. 


\section{Abstract}

Carneiro, Teresa Dias; Martins, Marcia do Amaral Peixoto (Advisor). Contributions to a Theory of Paratext of the Translated Book: the case of translations of French literary works in Brazil since the middle of the $2^{\text {th }}$ century. Rio de Janeiro, 2014, 398p. Doctoral Thesis Departamento de Letras, Pontifícia Universidade Católica do Rio de Janeiro.

This Ph.D. dissertation provides with some contributions to the construction of a theory of paratext of the translated book. The theory of paratext is mainly based on the seminal work by Gérard Genette, Seuils, in which the author doesn't enter the field of this kind of paratext. Therefore, this dissertation aims at complementing the theorization by Genette, focusing on the analysis of translators' prefaces/postfaces and, among them, of prefaces/postfaces in which translators talk about the translation and their translation project. The theory approaches employed in this work came from Translation Studies, Translation Historiography and the Theory of Textual/Discoursive Genres, based on data gathered in the research of a corpus compounded of French literary works translated in Brazil and published since the middle of the 20th century. The books selected to be examined are part of the collection of the Brazilian National Library, located in Rio de Janeiro, mainly.

\section{Keywords}

Theory of Paratext; translation studies; translation history; France-Brazil relations, translators. 


\section{Sumário}

1. Introdução

2. Fundamentação teórica historiográfica $\quad 19$

2.1. Estudos da Tradução e História da Tradução 19

2.2. História Intelectual - conceitos de tradução e (in)fidelidade 28

$\begin{array}{ll}2.2 .1 \text { História das mentalidades } & 29\end{array}$

2.2.2 História das idéias $\quad 35$

2.2.3 História dos conceitos $\quad 50$

2.3 As teorias de linguagem e tradução através dos tempos 57

3. Teorias do paratexto $\quad \mathbf{7 0}$

$\begin{array}{ll}\text { 3.1. A teoria geral do paratexto } & 70\end{array}$

3.2. Estudos sobre o paratexto de livros traduzidos $\quad 80$

4. Estudos de gênero: o prefácio do tradutor como gênero discursivo 94

4.1. Estudos de gênero $\quad 94$

4.2. Exemplos selecionados 112

5. Análise de dados 143

5.1. Considerações metodológicas 143

5.2. Visão geral da posição das línguas, autores e tradutores no cenário literário mundial 153

5.3. Análise dos dados levantados na pesquisa 158

5.3.1. Tipos de prefácios 158

5.3.2. Tipos de tradutores 161

5.3.3. Os prefácios de tradutores que não tratam de tradução 163

5.3.4. Os prefácios de tradutores que tratam de tradução 165

5.3.5. Menções à tradução e ao tradutor em edições que não contêm prefácio/posfácio de tradutor ou cujo prefácio/posfácio do tradutor não fala de tradução

6. Conclusões da pesquisa e contribuições para a área de Estudos da Tradução

$\begin{array}{lr}\text { Bibliografia } & 250\end{array}$

$\begin{array}{lr}\text { Anexo I } & 259\end{array}$

$\begin{array}{ll}\text { Anexo II } & 380\end{array}$ 
O prólogo, quando os astros são favoráveis, não é uma forma subalterna do brinde; é uma espécie lateral da crítica.

Jorge Luis Borges, Prólogos, com um prólogo dos prólogos 


\section{1 \\ Introdução}

Na época da minha pesquisa de Mestrado (Letras/Ciência da Literatura, UFRJ-1999), que deu origem à dissertação intitulada As obras de Mário de Andrade traduzidas na França: história, concepção e crítica, surpreendi-me com a incipiente bibliografia sobre o paratexto do livro traduzido dentro da teoria geral do paratexto. Os escritos teóricos existentes sobre esse assunto em geral não se debruçam sobre a especificidade do paratexto de obras traduzidas, mas sim sobre o de obras originais. É por essa vertente que discorrem Gérard Genette (2011), Antoine Compagnon (1979), Henri Mitterand (1980), Geneviève Idt (1977) e Jacques Derrida (1972 e 2002). Os poucos trabalhos que tratam do paratexto do livro traduzido são eminentemente aplicados e não teóricos, o que me despertou para um campo de investigação importante ainda praticamente inexplorado naquele momento e ainda hoje. Em 2006, o tradutor português Jorge Almeida e Pinho lançou um estudo em que procurou tratar deste e de outros assuntos relacionados com o livro traduzido em Portugal, com repercussões teóricas gerais significativas. Esse trabalho de Pinho será citado no Capítulo 3, “Teorias do paratexto”. O objetivo da presente pesquisa de Doutorado é contribuir para a construção de uma teoria do paratexto do livro traduzido, com foco principalmente na análise de prefácios/posfácios de tradutores e, dentre estes, nos prefácios/posfácios em que os tradutores falem de seu trabalho. Esse objetivo vem associado a uma contribuição para a área de Estudos de Gêneros Discursivos, analisando o (sub)gênero prefácio de tradutor, e integrando os dois enfoques, advindos da Teoria do Paratexto e dos Estudos de Gêneros Discursivos, para uma compreensão mais aprofundada do paratexto do livro traduzido. Esses objetivos foram perseguidos a partir da compilação de um corpus de prefácios/posfácios, a partir de um recorte bem delimitado, a fim de depreender suas características comuns. Mais detalhes sobre o corpus coletado e a metodologia adotada serão informados posteriormente nesta tese.

O interesse pelos prefácios de tradutores foi registrado por Paulo Rónai, em Escola de tradutores (2012): 
Devo a tais reminiscências o interesse que me leva a voltar a esse assunto tão pouco estudado e que me faria acrescer à biblioteca dos candidatos a tradutor uma pequena antologia, ainda inexistente, que se poderia compilar dos prefácios em que os tradutores fazem confidências ao público, explicando os seus processos e os seus truques, confessando seus fracassos, queixando-se das dificuldades do ofício. Faz tempo, ando anotando o que há de aproveitável nessas advertências, prefácios, preâmbulos e notas de tradutor que tantas vezes nem sequer se leem. (RÓNAI 2012, p. 90)

A ideia de compilar e analisar prefácios de tradutores para servir como tema de um estudo de interesse para a teoria da tradução foi complementada pela sugestão de Rónai de fazer uma antologia desses prefácios, para fins de publicação. A seleção dos prefácios mais significativos que será realizada a partir do presente estudo pode, no futuro, dar origem a um trabalho de antologização, tal como Rónai sugere. Nesse caso, de periférico e acessório ao texto, o paratexto ganharia vida própria, uma situação limite em que o elemento paratextual poderia extrapolar o texto para conquista de sua independência própria, como bem apontou Rodney Caetano, em Poesia e paratexto: a descida de Sant'Anna aos infernos da modernidade, no caso de certos prefácios a obras poéticas (CAETANO, 2011, p. 80). Não mais um vestíbulo, soleira ou antessala ao texto, como veremos ser a definição original de Genette, no Capítulo 3, o paratexto seria lido como texto independente e autônomo, exorbitando a área de influência em relação aos textos originais a que foi agregado em um primeiro momento.

A presente tese de doutorado, para alcançar o objetivo de formular uma contribuição à teoria do paratexto do livro traduzido, analisará o discurso dos tradutores encontrado em prefácios/posfácios de tradutores falando da tradução como arte e como ofício, para lançar luz sobre as seguintes indagações:

1. Existem conceitos/ideias que se repetem no discurso de tradutores sobre seu trabalho em prefácios/posfácios?;

2. Esses conceitos/ideias sofrem modificações com o passar do tempo?;

3. O discurso do tradutor sofre, com o passar do tempo, influências perceptíveis das teorias de tradução?

Antes de mais nada, é importante precisar a que conceito de "discurso" me refiro aqui. Em vez de buscar na Linguística o conceito de discurso ao qual me alinho, foi a Ernesto Laclau - um teórico da Economia, que por suas reflexões 
profundas e amplas, acabou abarcando considerações pertinentes a outros campos do saber - a quem recorri:

(...) Essa totalidade que inclui em si o linguístico e o não linguístico é o que chamamos de discurso. Em determinado momento, justificaremos essa denominação, mas o que tem que ficar claro desde o começo é que, por discurso, não queremos nos referir a uma combinação de discurso e escrita, mas que discurso e escrita não passam de componentes internos de totalidades discursivas. Agora, voltando-nos para o termo "discurso" em si, nós o usamos para enfatizar o fato de que toda configuração social é significativa. Se eu chutar um objeto esférico na rua ou se chutar uma bola em um jogo de futebol, o fato físico é o mesmo, mas seu significado é diferente. O objeto é uma bola de futebol somente na proporção em que estabelece um sistema de relações com outros objetos e essas relações não são dadas pela mera materialidade referencial dos objetos, mas são socialmente construídas. Esse conjunto sistemático de relações é o que chamamos de discurso. (LACLAU, 1980, p. 100) ${ }^{1}$

O conceito de "discurso" por Laclau, por ser mais amplo e abarcar tanto aspectos linguísticos quanto não linguísticos e, principalmente, por ser um conjunto sistemático de relações socialmente construídas, se adequa bastante bem ao que analisaremos nesta tese: o discurso dos tradutores nos seus prefácios. Esse conceito de discurso de Laclau dialoga com o conceito de gênero como ação social de Carolyn Miller (MILLER, 1994), como veremos no Capítulo 4, Seção 4.1, Estudos de gênero discursivo, pois ambos ultrapassam as fronteiras do meramente linguístico, buscando apontar para a construção de relações sociais que o discurso e o gênero propiciam. Como veremos mais adiante no Capítulo 5, Análise de dados, os tradutores, por meio de seus prefácios, criam uma teia de relações com outros prefácios de tradutores ao repetirem o que já foi dito ou se contraporem a ideias repetidas, referendando ideias e conceitos ou, por outro lado, apresentando posições novas. Esses discursos podem servir à mudança social, ao inspirarem leitores a (re)pensar questões de fidelidade e traduzibilidade, e o próprio papel dos tradutores na sociedade.

O discurso dos tradutores a ser analisado está contido em um corpus de obras literárias francesas traduzidas no Brasil e publicadas a partir de meados do século XX até os nossos dias. A justificativa para a escolha de obras literárias francesas e não de outro sistema literário é meu conhecimento aprofundado desse

\footnotetext{
${ }^{1}$ Esta como todas as outras citações em inglês e francês retiradas de livros não publicados em traduções no Brasil foi feita por mim.
} 
universo, o que ajudou bastante na seleção de autores mais representativos e na compreensão do conteúdo dos prefácios/posfácios a serem analisados. Esta é, portanto, a justificativa de ordem idiossincrática. Já a justificativa para o recorte temporal, dos anos 1950 aos anos 2010, é dupla. Em primeiro lugar, antes desse período histórico, é relativamente raro encontrar prefácios/posfácios de tradutores, principalmente do tipo que mais interessa à pesquisa, que são os prefácios/posfácios de tradutores falando de seu trabalho. Essa é uma justificativa histórica. Em segundo lugar, na Biblioteca Nacional, local principal de levantamento dos dados, a maioria dos livros publicados antes desse período histórico ainda não consta no catálogo virtual, disponível no sistema interno e na Internet, o que dificultaria a pesquisa e alongaria em demasia o seu tempo de duração. Essa é uma justificativa funcional. Sem dúvida, outros pesquisadores têm aí um campo muito vasto de estudos, pois esse levantamento pode se estender a obras das literaturas espanhola, italiana, inglesa, americana, etc. Pelas questões apontadas acima e mais questões de tempo e de escopo gerenciáveis, o recorte foi determinado como tal, mas poderia, obviamente, ser outro, se feito em outras condições e por outros pesquisadores.

O interesse pela procura de prefácios/posfácios de tradutores em obras clássicas da literatura francesa também adveio do fato de que, apesar de estes serem menos traduzidos do que outras obras de ficção (infanto-juvenil, histórias em quadrinhos e ficção de massa, principalmente) no Brasil (TORRES, 2011a, p. 17-27), as obras francesas canônicas seduziram muitos grandes escritores a traduzi-las, exercendo grande influência em suas obras autorais. Isso me fez pensar que esses clássicos traduzidos trariam muitos prefácios/posfácios de tradutores, por serem eles figuras conhecidas, o que angariaria espaço editorial para expor suas ideias.

Segundo Marie-Hélène Torres:

A tradução de obras clássicas francesas feita por escritores brasileiros canonizados tem como benefício certa legitimidade. (...) Traduzir os clássicos é fundamental porque estas obras carregam em si as marcas das leituras que precedem as nossas, os traços que deixaram em nossa cultura ou nas culturas que atravessaram. As obras clássicas têm um papel crucial na elaboração das culturas porque transmitem valores e visões do mundo que contribuem para a formação de cânones literários e a formação das culturas modernas. (TORRES, 2011a, p. 25). 
Por tudo isso, seria de se esperar que esses escritores-tradutores tivessem deixado um número representativo de prefácios/posfácios, o que não se confirmou no corpus da pesquisa. Por outro lado, nos últimos anos, vem havendo um movimento de retraduções ${ }^{2}$ dos clássicos de várias línguas, principalmente do inglês, francês, espanhol e russo. Nessas retraduções, os tradutores, que podem ser tradutores-escritores ou tradutores profissionais, ou parcerias dos dois, vêm buscando um espaço prefacial para explicar e justificar o empreendimento (por que retraduzir?) e as suas escolhas (em que a nova tradução se diferencia das mais antigas?). Esse fenômeno das retraduções de clássicos pode ser explicado por dois motivos: 1. muitas das antigas traduções foram traduções indiretas, principalmente do russo e do alemão, o que não se aplica à literatura francesa, que tradicionalmente foi traduzida diretamente, pois sempre houve bons tradutores de francês - uma língua que no início do século era mais falada, e bem falada por muitos do que o inglês no Brasil —, e durante todo o século XX ensinada em colégios tradicionais; e 2. muitas das antigas traduções de clássicos “envelheceram”, obrigando os novos tradutores a reverem opções vocabulares, sintáticas e gramaticais, e a opção de muitos dos antigos tradutores de não respeitarem as variedades dialetais/linguísticas contidas nos falares dos vários personagens, para dar um tom mais contemporâneo às traduções, mesmo que ambientadas nos séculos passados. Um bom exemplo disso foi a troca do título da obra de Proust, À l'ombre des jeunes-filles en fleur, de À sombra das raparigas em flor, por Mário Quintana, para À sombra das moças em flor, por Fernando Py, por ser "um vocábulo de uso corrente no Brasil”, em contraposição a "raparigas" que teria um uso mais corrente em Portugal e por ter caído em desuso no Brasil, além de ter adquirido um sentido pejorativo com o passar dos anos.

Um adendo: o fenômeno das retraduções no Brasil vem atraindo a atenção de vários pesquisadores. Apesar de não ser do meu interesse no âmbito desta tese me alongar sobre o assunto, tenho uma percepção que, obviamente, precisaria ser confirmada por um estudo mais aprofundado. Acredito que as primeiras traduções dos clássicos visavam mais aclimatar a obra estrangeira ao sistema alvo, muitas vezes facilitando o trabalho do leitor. Outra característica das primeiras traduções

\footnotetext{
${ }^{2} \mathrm{O}$ termo "retraduções" aqui é entendido como sendo as novas traduções feitas após a primeira tradução publicada de uma obra.
} 
parece ser uma falta de preocupação com a integralidade do texto original, pois são observados saltos ou omissões de trechos ao se fazer um cotejo mais acurado. As segundas traduções parecem querer chamar a atenção para a diferença cultural, suscitando o estranhamento por parte do leitor, aliada a um maior respeito pela integralidade do texto. Em muitos casos, percebe-se a coexistência de mais de uma retradução, com publicações quase simultâneas, como foram as de Samuel Titan Jr. (Editora 34) e Mário Laranjeira (Penguin-Companhia das Letras) de Cândido ou o otimismo, de Voltaire, em 2013, cada qual seguindo um projeto tradutório próprio. Como se pode ver, o assunto das retraduções no Brasil é fascinante e certamente estimulará ainda muitas pesquisas.

Assim sendo, foram incorporados ao corpus alguns prefácios/posfácios de tradutores em obras clássicas recentemente retraduzidas ou reeditadas. As retraduções, que precisam ser justificadas para explicar ao leitor por que devem comprar uma obra que já leram e/ou já têm em casa — e essa explicação pode sair da "boca" do editor, do tradutor ou de um terceiro - acabaram se tornando veículos interessantes para os tradutores exporem suas ideias e escolhas tradutórias.

Os objetivos da pesquisa, esboçados acima, se consubstanciarão em duas linhas de questionamento e análise: 1. análise do discurso do tradutor nos paratextos; 2. marcas da visibilidade geral do tradutor na edição. O primeiro dos dois itens será examinado à luz dos estudos de gêneros discursivos com o suporte teórico da História Intelectual, dando atenção especial aos conceitos de tradução e fidelidade $^{3}$ que os tradutores veiculam. O segundo será mais profundamente analisado à luz da contribuição teórica de Lawrence Venuti (1996) e das teorias do paratexto.

Quanto à fundamentação teórica da pesquisa, ela é múltipla, concentrandose em quatro áreas de estudo:

1. os Estudos da Tradução, principalmente os ligados à História da Tradução;

2. a História Intelectual, partindo da História das Mentalidades e das Ideias, e chegando até a História dos Conceitos;

\footnotetext{
${ }^{3}$ A partir da conceituação de "norma" por parte dos teóricos dos polissistemas e dos Estudos Descritivos de Tradução, o conceito de "fidelidade" tendeu a se complexificar ou relativizar, e a ser posto de lado por alguns pesquisadores. Contudo, o senso comum (e muitos tradutores) desconhece essa conceituação e continua a bater na mesma tecla da fidelidade. Por isso, foi um dos conceitos escolhidos para serem analisados nesta pesquisa.
} 
3. as Teorias do Paratexto;

4. os Estudos de Gêneros Discursivos.

As duas primeiras áreas serão contempladas no Capítulo 2 da tese. Às Teorias do Paratexto, por sua importância central neste trabalho, será consagrado um capítulo em separado, o Capítulo 3. Por se tratar de aporte teórico que se diferencia da linha tanto dos Estudos de Tradução/História da Tradução, quanto das Teorias do Paratexto, mas por ter sido acrescentado ao presente trabalho por uma "exigência” dos dados coletados, o Capítulo 4 se dedicará exclusivamente aos Estudos de Gênero Textuais/Discursivos na medida em que possam esclarecer a análise de recorrências nos prefácios/posfácios de tradutores, apresentando nesse capítulo exemplos selecionados. De fato, os autores dos Estudos de Gêneros Discursivos, com a exceção de Carolyn Miller, não “dialogam” facilmente com os teóricos mais proeminentes da História da Tradução ou das Teorias do Paratexto, apresentados nos Capítulos 2 e 3. Porém, os Estudos de Gênero não são a base teórica principal deste trabalho, servindo mais como aporte instrumental para lidar com um aspecto particular do discurso dos tradutores em seus prefácios - a recorrência.

O Capítulo 5 fará uma descrição da metodologia utilizada e tratará da análise dos dados levantados. Por fim, o Capítulo 6 enfocará as conclusões da pesquisa e as contribuições para a área dos Estudos da Tradução de enfoque historiográfico na análise de paratextos dos livros traduzidos.

Quanto à metodologia utilizada, o corpus foi compilado primordialmente na Biblioteca Nacional e, secundariamente, em acervo próprio originalmente existente ou adquirido conforme descobertas mais recentes em livrarias. No acervo da Biblioteca Nacional, o trabalho de levantamento foi empreendido da seguinte forma: 1. determinação de uma lista de autores clássicos da literatura francesa dos séculos XVIII, XIX e XX; ${ }^{4}$ 2. busca nas referências bibliográficas, em entradas por autor, nos computadores da Biblioteca Nacional, na seção de obras gerais, a partir da lista descrita anteriormente; 3. levantamento por autor das obras traduzidas; 4. busca e manuseio das obras do levantamento; 5. transcrição

\footnotetext{
${ }^{4}$ A lista de autores franceses á basicamente a delineada no website oficial de França (france.fr) em http://www.france.fr/pt/arte-e-cultura/quiz-os-grandes-autores-franceses-e-suas-obras-primas.html, com alguns acréscimos considerados por mim importantes, em vista do número de traduções que encontrei no acervo da Biblioteca Nacional. O critério de seleção de autores, portanto, foi híbrido, com base no que o site oficial francês considera canônico e na disponibilidade na BN.
} 
em arquivo eletrônico dos trechos encontrados nos prefácios/posfácios de tradutores falando da sua tradução, além de anotações gerais sobre a apresentação do nome e das características do tradutor na obra (ver Anexo I).

Após o levantamento feito conforme descrito acima, passei à análise do material segundo os parâmetros determinados: características do discurso dos tradutores, principalmente no que concerne aos conceitos de tradução e fidelidade, e marcas da visibilidade do tradutor na publicação, enfatizando as perguntas de trabalho apresentadas no início desta tese, a saber: Existem conceitos/ideias que se repetem no discurso de tradutores sobre seu trabalho em prefácios/posfácios?; Esses conceitos/ideias apresentam modificações com o passar do tempo?; O discurso do tradutor sofre, com o passar do tempo, influências perceptíveis da teoria de tradução? Essa análise será então descrita com detalhes no Capítulo 5.

O Anexo I foi organizado em forma de quadro descritivo, com informações sobre publicação e tradutor, possibilitando depreender estatísticas pertinentes. Alguns exemplos de prefácios/posfácios mais significativos, selecionados de épocas diferentes, da prosa, teatro e poesia, serão analisados em mais profundidade no próprio Capítulo 5. Os achados e conclusões foram compilados, dando origem ao Capítulo 6.

Passemos, então, aos capítulos teóricos desta tese, antes de chegar à explicação sobre a metodologia utilizada no levantamento e à análise dos dados propriamente dita. 


\section{Fundamentação teórica historiográfica}

\section{1}

\section{Estudos da Tradução e História da Tradução}

A História pode conter várias subdivisões: história militar, política, econômica, social, intelectual. A História Intelectual, que lida com a noção de ideias, mentalidades e conceitos e sua recorrência, em maior e em menor grau, em discursos, é menos uma história factual do que discursiva. Nesse rastro, a história da tradução pode ser incluída nesse enfoque e desenvolvida a partir dele.

A História da Tradução, apesar de vir chamando a atenção e suscitando cada vez mais interesse, ainda é incipiente no Brasil e no mundo. Segundo o que veio se fazendo nos últimos 40 anos, a partir da emergência e consolidação do campo disciplinar dos Estudos da Tradução, ela pode se debruçar sobre a história das teorias de tradução, da prática da tradução, dos textos traduzidos, do desenvolvimento da profissão como ofício instituído (leis, regulamentos, concursos, cursos acadêmicos, criação de sindicatos e associações etc.), do discurso sobre tradução ou da história dos tradutores ou outros agentes envolvidos nas traduções, como editores, por exemplo. Apesar de esses aspectos estarem muito inter-relacionados, o interesse desta pesquisa está principalmente nos últimos aspectos: a história do discurso sobre tradução e a história dos tradutores. Em grande parte, esse interesse foi suscitado pelas reflexões de Anthony Pym (1998) amparado pelas ideias de outros teóricos/historiadores da tradução, como, por exemplo, James Holmes.

Pym afirma que uma história da tradução centrada no tradutor deve levar em conta dois lados de uma mesma moeda, o aspecto biográfico e o aspecto sociológico, sem que um se sobreponha ao outro. Privilegiar o aspecto biográfico pode levar a uma investigação fútil ou que pode derivar para a psicanálise (quais acontecimentos e traumas vividos pelo tradutor explicam suas preferências tradutórias, por exemplo), ao passo que privilegiar o aspecto sociológico pode 
significar perder de vista que o tradutor não é uma entidade amorfa, mas sim um sujeito de carne e osso. Diz Pym:

Para quase toda causação interna que se encontre na biografia pessoal do tradutor existe um modo social mais amplo de causação que possibilita ou aceita fatores internos que deixam sua marca no mundo público das traduções. Nenhum dos lados pode ser adequadamente entendido sem o outro: vidas privadas não devem se tornar buracos negros. (PYM, 1998, 171-172)

Nesse sentido, Pym atribui ao tradutor um papel causal e trata o tradutor como causa eficiente. Em primeiro lugar, e obviamente, ele é uma causa eficiente porque sem tradutor não há tradução (ele não está levando aqui em consideração traduções produzidas por máquina, que além de ainda não terem alcançado a mesma qualidade das traduções feitas pelo homem, são mais usadas no contexto da tradução técnica do que da literária). Em segundo lugar, porque nem tudo está no texto-fonte, nem tudo se decide no sistema-meta, o propósito da tradução é depreendido ou determinado pelo tradutor e porque não vivemos em um mundo puramente de formas, mas de leituras e interpretações. Os tradutores, ao exercerem sua função (e eu acrescento, ao escreverem seus prefácios) podem mudar o estado de coisas (PYM, 1998, p. 157). Aqui Pym, quando fala nos tradutores como causas eficientes, parece ressaltar a agentividade (agency) dos tradutores, que atuam como muito mais do que simples intermediadores de uma língua para outra.

Antes de Pym, contudo, Antoine Berman (1995) já havia suscitado o interesse pelo tradutor e sua posição tradutória, seu projeto e seu horizonte em uma seção intitulada “À la recherche du traduteur”, interesse este não especificamente voltado para a historiografia da tradução, mas para a crítica e a análise de traduções publicadas que fugissem do enfoque negativo e prescritivo e dessem contribuições para o campo teórico da tradução.

Berman (1995) foge do biografismo no interesse pelo tradutor, afirmando que a vida e os estados de alma do tradutor não têm importância para a análise de sua produção - diferentemente do autor —, sem com isso querer dizer que o tradutor deve continuar a ser "esse perfeito desconhecido que ainda é na maior parte do tempo” (BERMAN, 1995, p. 73). É significativo saber se o tradutor é cidadão nacional ou estrangeiro, se ele é “somente” tradutor ou se exerce outra 
profissão significativa, como a de professor, por exemplo, se também é autor, de quais línguas traduz, quais são suas relações com essas línguas, se é bilíngue e em que grau, que tipo de obras costuma traduzir e quais outras obras já traduziu, quais são suas traduções mais importantes, se escreveu artigos, estudos, teses, textos sobre as obras que traduziu, enfim, se escreveu sobre sua prática de tradutor, sobre seus princípios orientadores, sobre as traduções que realizou e sobre a tradução em geral. Esse interesse não é mera curiosidade inócua, pois essas informações podem auxiliar na determinação de sua posição, seu projeto e seu horizonte tradutórios.

Berman passa então a definir as diferenças entre esses três itens. A posição tradutória (BERMAN, 1995, p. 74-75) é a concepção ou percepção por parte do tradutor do ato de traduzir, seu sentido, suas finalidades, formas e modos. Essa concepção e percepção não são puramente pessoais, já que o tradutor é marcado por todo um discurso histórico, social, literário, ideológico sobre a tradução, que é internalizado por ele de uma certa forma. A posição tradutória é fruto de uma elaboração, definindo um posicionamento e um compromisso com a atividade que exerce. Segundo Berman, não há tradutor sem posição tradutória, mesmo quando não fala sobre ela. Nesse caso, ela pode ser reconstituída a partir de suas próprias traduções ou das várias enunciações que faz sobre suas traduções, como no caso dos prefácios/posfácios.

Já o projeto tradutório (BERMAN, 1995, p. 76-79), ele define como sendo uma "visada articulada”, determinada por sua posição tradutória em geral e as exigências específicas apresentadas pela obra a ser traduzida. O projeto tradutório define a maneira como o tradutor vai realizar a translação literária de uma língua a outra e escolher um modo de traduzir aquela obra específica. O projeto tradutório pode incluir publicar em uma edição sustentada/escorada (étayée), isto é, acompanhada de paratextos. Portanto, a existência de prefácios/posfácios de tradutores na obra já fala de seu projeto tradutório.

Por fim, o conceito de horizonte tradutório (BERMAN, 1995, p. 79-83), segundo o teórico, advém da hermenêutica literária moderna e é adaptado para uma hermenêutica tradutória. Em uma primeira aproximação, Berman definiu o horizonte tradutório como sendo o conjunto de parâmetros linguísticos, literários, culturais e históricos que “determinam” o sentir, o agir e o pensar de um tradutor. 
As aspas acrescentadas pelo autor chamam a atenção para o fato de que não se trata de uma determinação no sentido de condicionamentos, pensados seja de forma causal seja de forma estrutural. A noção de horizonte tradutório é mais ampla e filosófica do que as duas anteriores, como se apreende da passagem a seguir:

\begin{abstract}
A noção de horizonte tem uma dupla natureza. Por um lado, designando esse- $a$ partir-do-que o agir do tradutor tem sentido e pode se desenvolver, ela aponta para o espaço aberto desse agir. Porém, por outro lado, ela designa o que fecha, o que encerra o tradutor em um círculo de possibilidades limitadas. $\mathrm{O}$ uso da língua o confirma, falando, no primeiro sentido, de uma "vida sem horizonte" (sem abertura, sem perspectivas) e, no segundo, de alguém que vive um "horizonte limitado". (BERMAN, 1995, p. 80-81)
\end{abstract}

Em conclusão, Berman afirma que esses três momentos — estudo da posição tradutória, estudo do projeto de tradução e estudo do horizonte tradutório - não se sucedem de forma linear. Apesar de o horizonte tradutório poder ser analisado em princípio preliminarmente, os dois outros não podem ser separados. E a própria análise do projeto comporta duas fases: 1. análise baseada na leitura da tradução e de tudo que o tradutor disse em textos (prefácios, posfácios, artigos, entrevistas, sobre tradução ou não), que nos dão indícios desse projeto; 2. análise comparativa da tradução e do original, e dos modos de realização do projeto. Como, no presente trabalho, não trabalharei com análise de traduções nem com comparação de traduções e originais, tentarei depreender dos prefácios/posfácios coletados o projeto tradutório subjacente à tradução, a partir de afirmações e traços do discurso do tradutor a esse respeito. Com base nas questões a serem analisadas, conforme apresentadas no Capítulo 1, a posição e o projeto tradutórios ficarão expressados no conceito de tradução e de fidelidade que o tradutor tem em mente e nas influências recebidas de leituras sobre teorias da tradução e outras afins.

Diferentemente de Berman, que se interessou pelo tradutor, em sua posição, projeto e horizonte tradutórios, como um dos itens a serem levados em conta na formulação de uma crítica de traduções, Anthony Pym, em sua obra Method in Translation History (1998), está interessado nesse mesmo tradutor enquanto inserido nos estudos historiográficos da tradução propriamente dita. Ele começa relembrando a classificação feita em um dos textos fundadores do campo 
dos estudos de tradução, escrito em 1972 por James Holmes e intitulado “The Name and Nature of Translation Studies”. Nesse texto, o autor apresenta um esquema em que identifica e inter-relaciona os vários campos de estudo em tradução, montando o arcabouço da futura disciplina. Os assim chamados “Translation Studies” seriam divididos em dois grandes grupos, "Puros” e “Aplicados”, sendo que os Estudos de Tradução Puros seriam subdivididos em “Teóricos” e “Descritivos”, e os Estudos Teóricos novamente divididos em “Gerais” e "Parciais”. Os Estudos Teóricos Parciais seriam "restritos ao meio”, “restritos à área”, “restritos à ordem”, “restritos ao tipo de texto”, “restritos ao tempo" e "restritos ao problema”. Os Estudos Descritivos seriam “orientados para o produto”, “orientados para o processo” e “orientados para a função”, e, por fim, os Estudos Aplicados seriam subdivididos em “formação de tradutores”, “auxílios à tradução” e “crítica às traduções” (PYM, 1998, p. 66-80).

Pym chama a atenção, com muita propriedade, para o fato de que a possibilidade de se estudar a história da tradução só entra nesse esquema de forma enviesada e parcial nas "teorias restritas ao tempo", principalmente no subconjunto que lida com textos antigos. Bem mais do que um esquema hipotético, o gráfico de Holmes refletia na época os caminhos que os Estudos da Tradução efetivamente trilhavam ou inauguravam, deixando de fora a pesquisa histórica que não se restringia ao tempo, nem aos textos antigos (PYM, 1998, p. 1$3)$.

$\mathrm{Na}$ Introdução, Pym formula quatro princípios para a pesquisa historiográfica em tradução: (1) “a história da tradução deveria explicar por que algumas traduções foram produzidas em um determinado lugar e tempo social” (p. ix), isto é, descrever os fenômenos só não basta, é preciso explicá-los sociologicamente; (2) “o objeto central do conhecimento histórico não deveria ser o texto da tradução, nem seu sistema contextual, nem mesmo seus aspectos linguísticos, mas o tradutor” (p. ix), já que é somente por meio deste e de suas relações sociais (clientes, patronos, leitores) que se pode entender as condições de produção de suas traduções; (3) os tradutores vivem não em um ambiente monocultural, mas em interseções ou sobreposições de culturas, que o autor chama de “interculturas”, sendo que é a inserção do tradutor no ambiente intercultural que fornece a chave para a explicação de seus projetos tradutórios; 
(4) só vale fazer história da tradução se ela explicar os problemas enfrentados pelos tradutores no momento presente e se com ela se tentar solucionar esses problemas. Com base nesses quatro princípios, é possível, segundo Pym, propor alguma ideia inicial e embrionária do que seria uma história da tradução, guardando a ideia de que esta deveria ser antes de tudo a história dos tradutores, e não principalmente a história dos textos traduzidos (1998, p. ix-xi).

Quando Pym fala em “biografia”, acredito que não queira enfatizar o viés do biografismo, tão criticado como ferramenta para o estudo da obra literária, que deveria ser estudada por si só, sem referência aos dados biográficos do autor — e, no caso da tradução, ao estudo das decisões tradutórias sem referência aos dados biográficos do tradutor —, mas o viés da “sociologia da tradução”, isto é, a "visão de tradução como uma prática social e como interação simbolicamente transferida” (WOLF, 2007, p. 31). Os estudos de sociologia da tradução discutem a questão da tradução por meio de três abordagens diferentes: a sociologia dos agentes, a sociologia do processo tradutório e a sociologia do produto cultural. O enfoque que Pym defende para a historiografia da tradução seria eminentemente referente a esse segundo nível, isto é, uma mudança de ênfase de textos e contextos para as figuras individuais de tradutores como objetos centrais de pesquisa, visando a reconstruir o domínio da subjetividade socialmente condicionada como base para o entendimento da história da tradução. Pode-se inferir que, para Pym, uma arqueologia dos discursos sobre tradução, paratextos incluídos, ressaltaria fatos sociológicos fundamentais para o exame do papel das traduções em sua dimensão ideológica. A subjetividade socialmente condicionada não visa a perceber motivações (in)conscientes dos tradutores, mas sim uma prática tradutória baseada no conceito de habitus de Pierre Bourdieu (WOLF, 2007, p. 14-15). Voltaremos a essa questão no próximo capítulo desta tese, quando delinearmos um possível diálogo da sociologia da tradução com a teoria do paratexto do livro traduzido.

As posições de Berman e Pym, apesar de com objetivos e bases diferentes, se complementam e se fortalecem. Nessa vertente, é que entendo o foco no tradutor como sendo o mais significativo para uma história da tradução. Não são as particularidades de sua vida que interessam por si, mas como essas 
particularidades, bem como suas crenças, posicionamentos e compromissos, influenciam a sua atitude e projeto tradutórios.

Delisle \& Woodsworth (1998, p.102-104) classificam os textos escritos sobre história da tradução em alguns tipos, divididos de acordo com:

1. espaço e/ou tempo (a tradição em países, regiões ou comunidade linguística e/ou segundo convenções cronológicas como séculos, reinos e dinastias);

2. tipos de tradução (literária, religiosa, bíblica, teatral, de um autor específico, interpretação);

3. grandes momentos na história da tradução (Escola de Bagdá, Escola de Toledo, Monastério Vadstena);

4. outras divisões (gênero, influência das instituições e ideologias sobre as traduções etc.);

5. antologias de afirmações sobre a tradução.

De toda essa variedade de enfoques, o escolhido por Delisle \& Woodsworth em Os tradutores na História foi o mesmo privilegiado por Pym: o papel e o status do tradutor nas várias épocas ou regiões. “Os tradutores foram considerados não tanto sob uma perspectiva sociológica como em termos da sua posição no espaço cultural e temporal” (DELISLE \& WOODSWORTH, 1998, p. 15). Apontam que o livro não pretende ser "em estudo exaustivo da história da tradução, mas simplesmente um exame seletivo e temático dos principais papéis exercidos pelos tradutores ao longo do tempo" (1998, p. 15). Portanto, seu enfoque, semelhante ao que Pym privilegia, está no homem ou mulher tradutor(a) e não nos textos traduzidos:

Elaborar uma história da tradução significa trazer à luz a trama complexa de trocas culturais entre os povos, as culturas e civilizações, através dos tempos. Significa retratar esses trabalhadores da importação e exportação e tentar descobrir as razões profundas que os levaram a traduzir uma obra em particular, e não outra. Significa descobrir porque os patronos (monarcas, aristocratas, autoridades clericais, etc.) lhes encomendam a tradução de determinadas obras. Significa levar em conta o que os próprios tradutores escreveram sobre o seu trabalho, suas dificuldades e limites. (DELISLE \& WOODSWOTH, 1998, p. 11)

Ora, a formulação de historiadores da tradução como Pym e Delisle \& Woodsworth de que a história da tradução deveria acima de tudo focar na história 
dos tradutores ou na história de seu status e papel na história é também uma luta por uma maior visibilidade do tradutor. A noção de (in)visibilidade do tradutor foi principalmente desenvolvida por Venuti em seu livro The Translator's Invisibility: a History of Translation, publicado originalmente em 1995 e que se tornou um clássico nos Estudos de Tradução (VENUTI, 1996). Ele aí aponta para “dois fenômenos inter-relacionados; um diz respeito à reação do leitor de traduções, o outro ao critério segundo o qual elas são produzidas e avaliadas" (1996, p. 111). Por um lado, os leitores, de modo geral, encaram as traduções como textos escritos originariamente em sua língua e, por outro, uma tradução é considerada aceitável quando sua leitura é fluente. O público leitor age como se o tradutor não existisse. E uma tradução é tanto melhor quanto menos interferente for a atuação do tradutor. A visibilidade do tradutor se dá, de forma negativa, por meio do erro e do equívoco, quando então sua atuação suscita críticas. A questão da (in)visibilidade se bifurca em uma (in)visibilidade social e em uma (in)visibilidade textual. A invisibilidade social se dá pelo apagamento da figura do tradutor nas trocas culturais e pela falta de ênfase em sua função social. A invisibilidade textual se dá pela falta de suas marcas ou de seu viés de leitura na tradução considerada “fluente" e aceita pela sociedade e pelos críticos. Daí decorre a defesa por Venuti de uma “tradução estrangeirizadora” (em contraposição a uma "tradução domesticadora”), em que o tradutor busca trazer para a língua/cultura de chegada traços literários, linguísticos e culturais do texto de partida, criando estranhamentos e questionamentos na língua/cultura de chegada e proporcionando mudanças. A busca de uma maior visibilidade textual, por meio de uma tradução estrangeirizadora, e de uma maior visibilidade social do tradutor, por meio da assinatura dos trabalhos, referência a seu nome nas críticas e referências bibliográficas e escritura de prefácios/posfácios, dentre outras medidas, seria, segundo Venuti, um ideal a ser buscado, para que esse tradutor possa sair da sombra do texto e do autor originais.

A historiografia da tradução elege diferentes focos de estudo, sendo os dois principais a historiografia das teorias da tradução e das práticas tradutórias, com diferentes abordagens. Neste estudo, optarei por pôr em evidência aquele que é o ator principal nessa história - o próprio tradutor - com suas decisões, pressões e questionamentos, além de sua posição e projeto tradutórios explícitos 
ou implícitos, pondo em cheque a questão da liberdade de escolha do tradutor e sua busca, assumida ou velada, de uma maior visibilidade.

Nessa mesma vertente, é de especial interesse a dissertação de Mestrado (PUC-Rio) de Mariluce Pessoa (PESSOA, 2009), que justamente se intitula $O$ paratexto e a visibilidade do tradutor. A autora defende a elaboração de paratextos por tradutores como forma de promover um aumento de visibilidade dos tradutores e uma participação mais ativa desse profissional na construção de sua imagem perante o público. A questão é que poucas vezes esse espaço de visibilidade é concedido pelos editores, a menos que o tradutor seja uma figura famosa e prestigiada (e com seu prefácio possa aumentar a curiosidade pela obra e, consequentemente, sua vendagem).

Mas como efetivamente fazer uma história da tradução calcada nos tradutores? Vislumbro algumas possibilidades gerais de enfoque, dependendo do objetivo do pesquisador: (1) foco na vida dos tradutores e na sua formação acadêmica e cultural; (2) foco no discurso dos tradutores a respeito de seu trabalho, em artigos, prefácios, cartas, entrevistas etc.; (3) foco na ênfase dada à assinatura de trabalhos, observando se neles consta o nome do tradutor, seu posicionamento no livro, no texto, no filme etc. e ênfase dada ao nome (tamanho e tipo da fonte e aparecimento na capa, folha de rosto, quarta capa, ou só na página de créditos); (4) foco na constância do trabalho dos tradutores a alguns clientes/editores/patronos e sua influência na escolha de títulos; (5) foco no trabalho editorial que ultrapassa o trabalho de tradução (alguns tradutores atuam como antologizadores, agentes literários, assistentes na negociação de direitos autorais, revisores de trabalhos de outros profissionais etc.); (6) foco nos interesses e expertise dos tradutores, e a influência exercida por essas questões na sua contratação por parte dos clientes/patronos/editores; (7) foco na rede de indicações de tradutores a clientes/editores/patronos por parte de colegas, amigos e redes sociais, ressaltando a construção de uma confiabilidade e de um "nome" na profissão; (8) foco nas condições de trabalho (trabalho contratado, autônomo, ferramentas de trabalho etc.) e remuneração. Enfim, estas são algumas possibilidades de se construir uma historiografia da tradução em certa área de interesse, local, língua, período histórico, em que a luz central seja lançada sobre os tradutores. A história da tradução fundamentada somente nas teorias de 
tradução e práticas tradutórias me parece restrita diante do que a vida e a atuação dos tradutores podem revelar em termos de relações, restrições, influência social e cultural, e, principalmente, mudança.

Apesar de todos esses aspectos estarem muito imbricados, o presente trabalho pretende se concentrar especialmente no segundo item, a saber, o enfoque no discurso dos tradutores a respeito de seu trabalho, em prefácios/posfácios. Deixar de lado outros aspectos significa reduzir o campo de análise, abrindo mão de um foco mais amplo e completo de realidade. Contudo, em todo trabalho acadêmico o recorte de pesquisa é fundamental para lhe dar consistência.

No que concerne à metodologia utilizada para analisar os dados coletados, o que norteará a análise serão quatro abordagens principais — Martins (1996), Pagano (2001), Pym (1998) e Simeoni (2007) — às quais serão referidas e explicadas no Capítulo 5 desta tese.

\section{2 \\ História Intelectual - conceitos de tradução e (in)fidelidade}

Além do suporte da teoria geral do paratexto, dos estudos de gênero e da história da tradução, proponho-me a analisar os trechos encontrados segundo um enfoque historiográfico, apoiado na História Intelectual. O paratexto de uma obra literária, como já mencionado, é constituído por vários elementos (capa, quarta capa, orelhas, folha de rosto, verso da folha de rosto, prefácios, posfácios, artigos críticos, etc.) de autorias variadas. Grande parte desse material é gerado na ou pela própria editora e por seus funcionários e contratados, mas dele também podem fazer parte textos encomendados a outros profissionais, tais como o autor, o tradutor, críticos, especialistas em literatura e outros, que são convidados a falar do seu trabalho ou a dar esclarecimentos a respeito da obra. No caso da literatura traduzida, muitos desses textos contêm também informações ou opiniões a respeito do autor e da literatura de origem, principalmente quando estes são pouco conhecidos dos leitores alvo ou têm grande importância na literatura mundial. Seja na quarta capa ou nas orelhas, em que se faz uso de uma linguagem mais publicitária, com o intuito claro de convencer o suposto leitor a comprar o livro, já que esses elementos do paratexto são quase sempre lidos ainda de pé na livraria, 
seja nos prefácios e artigos críticos, que são lidos muitas vezes somente após a leitura da obra e por leitores mais interessados ou especializados, neles seus autores têm oportunidade de expressar opiniões e juízos de valor que, ainda que subjetivos, contêm um certo "espírito da época”, “ideias” e "mentalidades” que não são só suas, mas compartilhadas por aqueles que de alguma forma trabalham e contribuem, como ele, para a produção cultural.

Ao começar a analisar o material levantado na pesquisa, logo chamou atenção a repetição intensa de ideias feitas e chavões, seja a respeito do autor, da literatura francesa, dos personagens das obras e/ou da biografia dos autores (a metodologia utilizada na pesquisa será explicada em capítulo posterior). Assim, para poder analisar com mais propriedade esse material, senti a necessidade de aprofundar meus estudos sobre História Intelectual, começando pela Nova História e seus desdobramentos na história das mentalidades e na história das ideias e culminando na história dos conceitos. A História Intelectual aborda as grandes questões intelectuais ao longo dos tempos, em interação com os movimentos culturais e científicos, e respectivas repercussões, na dimensão histórico-social. É, pois, o âmbito da história que estuda os intelectuais enquanto agentes da história, que criam, escrevem, discutem e propagam ideias.

Assim sendo, passo, então, a resumir o que representou para a pesquisa histórica a verdadeira "revolução" empreendida pelos fundadores da revista Annales d'histoire économique et sociale, Lucien Febvre e Marc Bloch, e pelos pesquisadores que os seguiram, em contraponto à pesquisa histórica tradicional que a precedeu.

\subsection{1}

\section{História das mentalidades}

O que se convencionou chamar de "Nova História” ("Nouvelle Histoire”, em francês) foi um movimento que renovou não só o domínio tradicional da história, como também teve repercussões importantes nas outras ciências humanas ou sociais. Essa corrente histórica buscou repensar os acontecimentos e as crises em função dos movimentos lentos e profundos da história, interessar-se menos pelos "grandes homens" do que pelos homens comuns, preferir a história das 
realidades concretas materiais e mentais da vida quotidiana do que os fatos marcantes de guerras e batalhas, enfim metamorfosear a memória coletiva dos homens e obrigar o conjunto das ciências sociais a se ressituar em outra duração, segundo uma outra concepção de mundo e de sua evolução.

O nascimento da Nova História, tal como é compreendida hoje, se deu simultaneamente à criação em Estrasburgo, em 1929, da revista Annales d'histoire économique et sociale por Lucien Febvre e Marc Bloch. O próprio nome da revista já marcava a grande diferença de concepção da Nova História em relação à história tradicional. Enquanto esta baseava-se principalmente na erudição, na política e na diplomacia das nações, a Nova História inaugurava uma disposição original de basear a análise histórica no econômico e no social, dando grande ênfase à questão do espaço geográfico. E mais do que isso, Febvre e Bloch redefiniram o papel do historiador por meio de suas convicções epistemológicas de que o objeto da história, assim como o da sociologia, é um objeto construído por hipóteses e pelo raciocínio, e de que existe uma interdependência complexa e fundamental entre todos os fatos ocorridos no seio de uma dada civilização. A necessidade de construir uma interdisciplinaridade e uma história global, que hoje nos parece totalmente aceitável para não dizer incontornável, foi na época um bastião contra um arraigado espírito de especialidade e uma noção positivista de progresso.

Georges Duby (1993) resume a situação de transição ocorrida entre as décadas de 1920 e de 1930 na França, em consequência das mudanças ocorridas no pós-guerra e da crise de 1929, no que concerne ao estudo da história:

Na época a que me refiro, a maioria dos historiadores consagrados limitava-se ainda ao estudo do poder, político, militar ou religioso, em suas manifestações exteriores. Empenhavam-se em reconstituir uma cadeia de acontecimentos, pequenos e grandes, questionando-se sobre seus protagonistas e suas causas acidentais, ou então consideravam a evolução e o jogo formal das instituições. Desde o início dos anos trinta, entretanto, abrira-se uma frente pioneira sob o impacto do grande abalo que sacudiu na Europa as bases da produção e das trocas. Historiadores mais empreendedores, e que se multiplicavam, haviam voltado sua atenção para os fenômenos econômicos. [...] Tratavam, com esta finalidade, de garimpar nos arquivos os documentos até então negligenciados. (p. 9) 
Como se vê, além da novidade de criação de uma história total, a Nova História também alargou o campo do documento histórico. Em vez de uma história essencialmente fundada sobre os textos e os documentos escritos, tal como o era a história tradicional, ela criou uma história fundada sobre uma multiplicidade de documentos: escritos de todo tipo, figuras, resultados de buscas arqueológicas, documentos orais, etc. Os métodos utilizados pela Nova História não diferiam substancialmente dos utilizados pela história tradicional, mas sob o epíteto de história econômica e, principalmente, social, poder-se-ia falar de quase tudo, utilizando fontes as mais diversas.

A Nova História e a Escola dos Annales buscaram igualmente criticar a concepção de fato histórico. A história política era voltada para acontecimentos destacados, cujo foco escondia o verdadeiro jogo da história que se passa muito mais nas coxias do que no primeiro plano da cena teatral. Faltava profundidade, riqueza e globalidade, devido principalmente à noção de fato histórico, tido como dado e não como construído pelo analista. A Nova História apressou-se em mostrar que os fatos a serem analisados são resultado de uma escolha do historiador, não arbitrária e anárquica, mas proposital e seletiva, uma construção científica do documento cuja análise permite a criação de uma explicação do passado.

Segundo a Nova História, uma interferência maior do historiador não se dá, contudo, somente na escolha dos documentos, mas na própria maneira de analisá-los. Os fatos são relativos e não objetivos, o historiador lhes dá vida com sua interpretação, considerando a neutralidade uma busca impossível. O passado não é um dado, mas, em última instância, uma invenção do historiador, em função de seus interesses e influenciada por sua própria história pessoal. Essa concepção da história como criação, como construção, como ficção, já que preenche lacunas com sua imaginação, criando um discurso enviesado e subjetivo, não implica que a Nova História seja anárquica e completamente livre. Existem traços nos documentos históricos que fazem com que somente alguns discursos sejam possíveis, e aí reside a grande diferença entre o historiador e o romancista. A este respeito, Duby afirma: “A diferença entre o romancista e o historiador é que este é obrigado a levar em consideração um certo número de coisas que se impõem a ele; é tolhido por uma preocupação com a “veracidade”, mais talvez do que com a 
noção de "realidade" (DUBY \& LARDREAU, 1980, p. 41). Com essa nova perspectiva, a noção de "verdade histórica” passou a ser questionada, e os campos da história e da literatura, antes dissociados, com a exceção do sempre existente romance histórico, encontraram um meio de se aproximarem.

A partir de 1946, com o desaparecimento de Marc Bloch, judeu membro da Resistência e morto pelos alemães, a revista foi rebatizada em sua homenagem com o nome de Annales. Economies. Sociétés. Civilisations. A ideia de multiplicidade, contida nos plurais das palavras do título, e o conceito de “civilização”, não encarada como recenseamento das civilizações existentes, à moda de Arnold Toynbee, mas como concepção que une o material e o espiritual, eram caras a Bloch. A inclusão da palavra “civilizações” mostrava também claramente a intenção da revista de se internacionalizar, de fugir do eurocentrismo. Duby explica as mudanças ocorridas:

\begin{abstract}
A economia continuava à frente, mas o social instalava-se no cerne do projeto, em posição de comando, e o lugar que lhe havia sido atribuído pelos fundadores em 1929, complementar, não acessório, pelo contrário, aberto para o futuro da pesquisa, incumbia agora às “civilizações”, ou seja, ao que hoje denominaríamos cultura. Com efeito, ao contrário de Braudel, cuja maneira de escrever a história deriva de uma conjunção entre as abordagens do geógrafo e do economista, e que confessava sem reticências hesitar arriscar-se pelo terreno da cultura, particularmente do religioso, Lucien Febvre, de sua parte, extraindo sua informação mais das obras literárias que das cartas e muito mais das estatísticas, sentia-se mais à vontade neste terreno que em qualquer outro. (DUBY, 1993, p.87)
\end{abstract}

Fundamentalmente, a remodelação da revista ocorrida no pós-guerra buscava cada vez mais problematizar e desautomatizar a análise histórica e, mais do que nunca, criticar a ideia de “origem”, construindo uma história para o tempo presente e compreendendo as relações entre presente e passado. Segundo Bloch, o método regressivo deveria ser usado com prudência, pois apesar de o historiador identificado com as novas tendências dever compreender as mentalidades de uma época passada e a interpenetração característica do palpável e do não palpável em determinada civilização, seu olhar seria sempre o olhar de um indivíduo de seu tempo.

A História das Mentalidades se impõe por volta do fim dos anos 1960, principalmente em torno do grupo dos Annales. Esse grupo de historiadores teve 
seus nomes mais intimamente relacionados ao da história das mentalidades devido à sua organização e combatividade. Houve, no entanto, outras personalidades independentes e solitárias, segundo Philippe Ariès, que desempenharam o mesmo papel pioneiro, como Huizinga, Norbert Elias e Mario Praz. Todos esses autores têm em comum o fato de terem reconhecido na história um domínio composto pelo imaginário, pelo sentimento, pelo jogo e pela gratuidade, que se diferencia do domínio do econômico, sem contudo ser menos importante.

Segundo a classificação de Ariès (1978, p. 405), em contraponto à história tradicional estaria a história social, que se subdivide em história econômica e em história cultural, sendo que esta última se identificaria com a denominação “história das mentalidades”. A história social teria como objeto primordial as massas da sociedade, mantidas ao largo dos poderes constituídos. Na primeira geração dos Annales, no entanto, não se fazia qualquer diferenciação nítida entre a história econômica e a história das mentalidades, em seu afã por uma história que se pretendia total. A preocupação naquele momento era muito mais a de inaugurar uma história dos humildes, dos vencidos e dos submissos, que não eram contemplados como objeto da história tradicional.

A partir de 1945, a história econômica foi privilegiada devido à existência de grande número de documentos históricos referentes à economia à disposição e ao ranço, ainda perceptível, de se tratar os fatos relativos às mentalidades como menores. Foi, no entanto, o desenvolvimento da demografia, uma das grandes bases do estudo da economia, que se incumbiria de fazer ressaltar a importância das mentalidades no estudo da história. A demografia interessa-se, dentre outras coisas, pelo estudo dos movimentos das populações, pela relação entre as populações e suas subsistências, a fome, as epidemias e a morte. Em suma, a demografia procura estabelecer relações entre a conjuntura econômica e os fatos da vida, entre o momento do nascimento e o momento da morte, procurando entender por que, diante de certas limitações ou restrições materiais, os homens se afastam de sua região de origem. Ora, isso não pode ser explicado unicamente pelos ciclos econômicos, mas também pela psicologia dos povos. Abriu-se então a possibilidade de se estudar as mentalidades com base em uma documentação estatística e com um aparato científico, bastante afastado do impressionismo anedótico que marcava as possibilidades anteriores de se estudar o não-escrito. 
O reaparecimento do estudo das mentalidades na década de 1960, utilizando esse aparato científico da demografia e da economia, representou um acontecimento capital. A partir da década de 1970, cada vez mais historiadores passam a se dedicar a assuntos tais como a família, a morte, a sexualidade, a criminalidade, a sociabilidade, os idosos, a religiosidade, etc., tornando a história das mentalidades um fenômeno significativo da cultura contemporânea. Esses novos caminhos trilhados pela história escapam ao controle dos especialistas, alcançando um público mais amplo. Os pesquisadores das várias ciências humanas passaram a se dedicar a assuntos que não faziam parte da seara tradicional de seus campos de origem. A interdisciplinaridade, apontada como possibilidade nos primórdios da Nova História, com a história das mentalidades, passa a ser uma prática comum na pesquisa contemporânea. O território da história se ampliou para além de suas fronteiras tradicionais e os historiadores perderam a pretensão de fazer uma história definitiva.

Apesar do avanço que representou essa abertura do campo da história, o conceito de mentalidade, que permanece até hoje muito fluido, é fonte de inúmeras críticas. Muitos apontam uma aproximação entre os conceitos de mentalidade e de inconsciente coletivo, de Carl Jung. O inconsciente coletivo estaria fortemente ligado ao misticismo, fazendo com que a história das mentalidades perdesse aos olhos da comunidade científica muito de sua seriedade. Philippe Ariès contesta a semelhança:

Mas o que é o inconsciente coletivo? Seria melhor falar em não-consciente coletivo. Coletivo: comum a toda uma sociedade num certo momento. Nãoconsciente: mal percebido ou não de todo percebido pelos contemporâneos, porque tendo vida própria, faz parte dos dados imutáveis da natureza, idéias recebidas ou idéias no ar, lugares comuns, códigos de conveniência e de moral, conformismos ou proibições, expressões permitidas, impostas ou excluídas dos sentimentos e dos fantasmas. Os historiadores falam de "estrutura mental", de "visão de mundo", para designar os traços coerentes e rigorosos de uma totalidade psíquica que se impõe aos contemporâneos sem que o saibam. (ARIÈS, 1978, p. 423)

Quando Ariès fala em imutabilidade não quer dizer que as atitudes e os gestos costumeiros da vida quotidiana, que os atos repetidos e irrefletidos do dia a dia, não mudem, mas sim que eles parecem imutáveis, já que mudam muito lentamente. Daí a necessidade da perspectiva da longa duração e a predileção 
pelas fontes seriais, que nos informam a respeito das disposições recorrentes e das preocupações comuns a determinada época, região ou sociedade. E, acima de tudo, demonstra a necessidade de se tratar de épocas remotas e de se perceber a coerência própria de cada época.

Duby faz suas ressalvas quanto à utilização do termo “mentalidade”, que para ele parece por demais desencarnado das condições materiais da vida, e da noção de estabilidade de "um certo resíduo psicológico que subsiste em todos os indivíduos de uma mesma sociedade”, conforme a significação de mentalidade introduzida por Gaston Bouthoul, em 1952 (DUBY, 1993, p.88). Sua crítica era a de que dentro de uma sociedade este resíduo não apresenta a mesma consistência nos diversos meios ou estratos de sua composição social. O termo "mentalidade" seria, assim, insatisfatório, mas quando surgiu na década de 1950 convinha justamente por sua imprecisão, que ajudava a abrir o campo da história e a mente dos historiadores.

A fim de que se possa entender a diferença entre a proposta da história das mentalidades e a da história das ideias, é importante guardar a noção de que a “mentalidade” é uma disposição irrefletida, muitas vezes fazendo parte do terreno do não-dito, o que faz com que a história das mentalidades seja muito passível de ataque por parte dos que acham que ela escapa demais do terreno da história para cair no da psicologia ou no da psicanálise, enquanto que a história das ideias se interessa por definição pelo pensamento discursivo e escrito, isto é, pela reflexão explícita (PELCKMANS, 1987, p. 254).

\subsection{2}

\section{História das ideias}

A história das ideias está muito mais ligada à literatura e aos estudos literários, por ter como base o texto escrito, podendo, por esta razão, servir perfeitamente como base teórica para fundamentar uma teoria do paratexto. Em muitos textos literários, encontramos de forma mais ou menos original e mais ou menos sistemática a enunciação de ideias filosóficas, religiosas, políticas, etc. A própria história literária sempre se ocupou em recensear essas ideias por períodos, escolas ou autores. Étienne Gilson, em Les idées et les lettres (1932), chega 
mesmo a afirmar que a "história das ideias pode ser uma ciência auxiliar da história literária” (apud HALLYN, 1987, p. 242), pois pode ajudar na pesquisa das fontes na medida em que se dedica a estudar as ideias disseminadas, em uma determinada época, de forma variável e isolada na consciência coletiva. Fernand Hallyn explica melhor o que seriam essas “ideias difusas” de Gilson: “traços do que chamaríamos hoje de intertexto anônimo, ao qual os escritores se referem e que eles transformam, mas do qual é impossível definir a origem ou a fonte precisa, própria” (HALLYN, 1987, p. 242).

Foi nos países anglófonos, sobretudo graças aos trabalhos de Arthur Lovejoy, fundador da revista Journal of the History of Ideas em 1940, que a história das ideias se afirmou como uma disciplina distinta da história do pensamento, mais próxima da literatura. Para ele, a história das ideias estuda o que chama de "unit-ideas", elementos isolados capazes de se integrarem nos textos mais variados, mas que não constituem sistemas de pensamento, objeto próprio da história da filosofia. O número de “unit-ideas” é limitado e dentre elas estariam: (1) hábitos “endêmicos” ou pressuposições mentais pouco conscientes; (2) “motivos dialéticos" que determinam uma maneira de raciocinar ou uma posição metodológica; (3) tipos de "pathos metafísico" (por exemplo, o pathos da obscuridade, do monismo ou do panteísmo); (4) elementos da "semântica filosófica” ou a significação de expressões típicas no pensamento de uma época (HALLYN, 1987, p. 243).

Percebe-se facilmente que a história das ideias só pode funcionar de forma pluridisciplinar, seja porque permite às disciplinas particulares situar as formas de pensamento em um contexto geral, seja porque ultrapassa o domínio de cada disciplina particular, basicamente restritas e fragmentadas, permitindo que se tenha uma visão mais global de como o pensamento humano se desenvolve e se modifica.

Há uma clara semelhança entre as noções de “ideias difusas” de Gilson e de unit-ideas de Lovejoy com a noção de Zeitgeist, desenvolvida por Wilhelm Dilthey por volta de 1900, pois todas elas nos falam de elementos idênticos em práticas discursivas diversas. O Zeitgeist ou “espírito do tempo” seria um conjunto de ideias que constituiriam um verdadeiro "hábito mental” de autores de uma dada época. 
A utilização dessas noções na análise literária é problemática por reduzir muitas vezes a complexidade do texto literário e do tempo histórico em questão, por mascarar as diferenças reais entre práticas culturais distintas, por se preocupar mais em achar analogias do que diferenciações e por muitas vezes permanecer exterior ao texto literário propriamente dito. Enunciadas da forma que foram, as noções de "ideias difusas”, unit-ideas e Zeitgeist parecem sem dúvida redutivas, mas parece que o interessante não é descartá-las simplesmente, mas ampliá-las e problematizar a questão. Hallyn diz que foi justamente isso que vários pensadores tentaram fazer (HALLYN, 9187, p. 248-249), aproximando-se, por sua vez, mais do programa da história das mentalidades ou da sociocrítica. Analisar estruturas de pensamento recorrentes em vez de pesquisar ideias isoladas semelhantes em uma determinada época possibilita uma análise menos empobrecedora. Não se quer dizer que em cada momento haja uma verdadeira pasteurização do pensamento individual, mas sim que há um entrelaçamento entre formas de pensamento individual e formas de pensamento coletivo, que funcionam segundo durações diversas.

As críticas que a história das ideias e a história das mentalidades receberam desde os anos 1960 contribuíram não só para que a proposta inicial dos Annales fosse parcialmente revista, mas também para que novos caminhos da pesquisa histórica fossem trilhados. Dois dos principais teóricos que se destacaram nesse campo não são historiadores: o sociólogo Pierre Bourdieu e o filósofo Michel Foucault.

Tomando emprestada a terminologia da economia, Bourdieu (1999) inseriu a história da leitura na história da literatura e a obra de arte no jogo das forças produtivas. O capital simbólico de uma obra de arte não se reduz à sua fabricação material pelo artista, mas é também definido por sua recepção por parte do público, da crítica e das várias instâncias de reconhecimento social. As discussões relativas ao julgamento de valor de uma obra de arte, à determinação do cânone literário e à trajetória do livro após sua publicação ficaram bastante enriquecidas com a contribuição de Bourdieu e seu enfoque mercadológico da arte.

A importância das várias instâncias de poder ou dos micropoderes na sociedade, à parte dos poderes constituídos, ressaltada por Michel Foucault (1986) 
deixou claro que as ideias e as formas de pensamento não evoluem ou variam, mas funcionam por meio de rupturas, descontinuidades e simultaneidades. São certas rupturas nas formas de pensamento que possibilitam a emergência, o desenvolvimento e a difusão de certas ideias e não de outras. Segundo Hallyn:

Dentre os constituintes do discurso, Foucault não se interessa, em resumo, pela história dos elementos postos, pelos progressos eventuais nas ideias, mas pela distinção de quadros sucessivos que asseguram a coerência de um conjunto de campos discursivos: história não das posições, mas das configurações epistemológicas pressupostas pelas práticas discursivas. (HALLYN, 1978, p. 249)

Portanto, para Foucault o que importa não é fazer a histórias das ideias detectando elementos em comum, mas perceber semelhanças entre campos discursivos e rupturas entre conjuntos de campos discursivos que compõem as várias epistemes. Não se pode falar que a teoria de Foucault seja um desdobramento direto ou uma evolução da Nova História ou da história das ideias, mas, seguindo suas próprias considerações, sua teoria pode ser encarada mais como uma ruptura epistemológica em relações a estas. Sem a Nova História e o contato profícuo com os historiadores do grupo dos Annales, na própria revista e no Collège de France, do qual fez parte, possivelmente Foucault não teria sido capaz de formular seu pensamento original.

Pode-se dizer que a Nova História e a História das Mentalidades estavam mais embasadas na realidade econômico-social, o que as diferencia da História das Ideias, que possui uma forte vertente na história das ideias políticas, e, em seus desdobramentos, acaba por se aproximar da linguística e da filosofia da linguagem. Nesse sentido, essa vertente da História Intelectual, a História das Ideias, e subsequentemente a História dos Conceitos, que igualmente privilegia o componente da linguagem em sua análise, servem como embasamento muito adequado para tratar das questões levantadas pela teoria do paratexto, pelo menos em sua vertente de abordagem historiográfica. Por essa razão, constituirão uma das fundamentações teóricas principais no tratamento dos dados levantados nesta pesquisa. A História das Ideias e a História dos Conceitos, no entanto, dialogam constantemente com a História das Mentalidades e pagam tributo à verdadeira revolução empreendida pela Nova História na análise dos fatos quotidianos, a dita 
micro-história. O enfoque historiográfico da teoria do paratexto do livro traduzido é duplamente a história dos esquecidos, por sua própria concepção (a da microhistória) e por seu sujeito - o tradutor -, que de "invisível”, ou quase, no texto traduzido, ganha importância por sua voz e destaque nos prefácios/posfácios de sua autoria.

O enfoque historiográfico mais pertinente, na minha opinião, para a análise do discurso dos tradutores em seus prefácios/posfácios é aquele desenvolvido a partir de dois historiadores anglófonos, John. G. A. Pocock (2003) e Quentin Skinner (2001), influenciados por Lovejoy (1948), mas de certa forma contrapondo-se a ele, e especialmente a contribuição de Koselleck, com sua História dos Conceitos.

Pocock e Skinner estabeleceram uma ponte com as ideias do linguista Ferdinand de Saussure, do filósofo da linguagem John Austin, e, subsidiariamente, com os teóricos da literatura Wolfgand Iser (1979) e Stanley Fish (1990) e o filósofo Jacques Derrida (1973), aproximando-se, portanto, de questões tão caras aos Estudos de Tradução. Skinner é o maior expoente da vertente de estudo da história do pensamento político na Escola de Cambridge, mais tarde rebatizada por ele como enfoque collingwoodiano, em homenagem ao filósofo R. G. Collingwood. Junto com Pocock, Skinner é um dos grandes representantes da chamada "virada historicista" que procura entender os textos de teoria política do passado segundo os significados que tinham em seu contexto histórico original. Essa "virada historicista” faz parte do movimento filosófico mais amplo do século XX chamado de "virada linguística", pois seu objeto de estudo, a relação entre texto e contexto, e suas abordagens centrais são eminentemente linguísticos. Para tanto, Skinner e Pocock se basearam na compreensão da teoria dos atos de fala de Austin (1970), no contexto histórico da filosofia da linguagem, em referências a Saussure (2006) e Fish. É este diálogo entre história e filosofia da linguagem que pretendo usar também como embasamento teórico para a análise dos textos selecionados na pesquisa. Por fim, a grande contribuição teórica para esta reflexão historiográfica vem do historiador alemão Reinhart Koselleck, o maior expoente da História dos Conceitos, que empreendeu um estudo da semântica de conceitos fundamentais e sua transformação com as mutações sociais. Para a discussão tradutória, os conceitos 
de fidelidade e infidelidade são fundamentais. Propomo-nos a utilizar o suporte teórico desse autor para analisar tais conceitos no discurso dos tradutores.

Em seu texto mais polêmico "Meaning and Understanding in the History of Ideas” (1969), Skinner apresenta dois objetivos principais: 1. promover uma revisão das abordagens mais importantes do estudo da história do pensamento político que incorrem no erro de projetar expectativas do presente sobre o estudo de autores do passado, produzindo interpretações anacrônicas e 2. oferecer uma alternativa metodológica às variantes da história do pensamento contaminadas com as mitologias do presentismo, apropriando-se da teoria dos atos de fala de Austin (JASMIN \& FERES JÚNIOR, 2006, p. 140).

Em relação a esse segundo objetivo, que é o que nos interessa mais aqui, Skinner diz: "Para entender qualquer elocução séria, precisamos captar não apenas o significado do que é dito, mas, ao mesmo tempo, a força intencional com a qual a elocução foi proferida. Precisamos captar não apenas o que as pessoas estão dizendo, mas também o que estão fazendo ao dizer isso” (SKINNER, 2002b, p. 82). O interesse maior de Skinner é entender a linguagem no uso. Com esse intuito em mente, Skinner chega a duas conclusões: 1 . em relação ao método a ser adotado para se estudar a história das ideias e para se chegar a uma compreensão dos textos, é preciso captar o que pretendiam significar e como se pretendia que esse significado fosse apreendido, isto é, captar a intenção a ser entendida e a intenção de que essa intenção fosse entendida, que o texto como ato intencional de comunicação teria que incorporar; 2. em relação ao valor de se estudar a história das ideias, estabelece um diálogo entre a análise filosófica e a evidência histórica.

Quanto ao método vislumbrado no item 1, Skinner estabelece dois passos a cumprir: 1. tentar delinear o amplo leque de comunicações que poderiam ter sido convencionalmente praticadas em dada ocasião pela emissão de certa elocução e 2. traçar as relações entre uma dada elocução e seu contexto linguístico mais amplo como meio de decodificar as intenções de um dado autor (SKINNER, 2002b, p. 86-87). No que concerne a encarar o texto histórico como ato de fala, apesar de isso levantar algumas questões, já que Austin fundamentou sua teoria em atos de fala e não de escrita, de modo geral Skinner foi aplaudido; no que concerne à determinação das intenções do autor, Skinner foi duramente criticado, como estando cego a todos os desenvolvimentos teóricos literários e filosóficos 
pós-estruturalistas, como de Barthes e Foucault, que, ao decretarem "a morte do autor”, enterravam junto qualquer possibilidade de determinar suas intenções. Skinner, em seus escritos posteriores, de certa forma revê parte de suas afirmações iniciais (SKINNER, 2001). Pocock diz que esta crítica procede, mas nem sempre, já que "pode haver indícios, não confiáveis e traiçoeiros, mas ainda assim utilizáveis, em outros textos do autor ou em sua correspondência privada” (POCOCK, 2003, p. 27).

Austin, em sua construção teórica, parte da constatação de que existem declarações que escapam da tradicional categorização da filosofia grega entre verdadeiras e falsas. Sua intenção era estudar “o tipo de elocução que parece uma declaração e gramaticalmente, suponho, seria classificada como uma declaração, que não é desprovida de sentido, mas, ainda assim, não é nem falsa nem verdadeira” (AUSTIN, 1970, p. 235). São estas elocuções claras e diretas, na primeira pessoa do singular do Presente do Indicativo e que servem para fazer algo em vez de meramente dizer algo, ou elocuções performativas, como ele mesmo as chamou. Como exemplo, entre outros, Austin cita o "Sim”, respondido à pergunta "Você aceita este homem/esta mulher como seu/sua legítimo(a) esposo(a)?” na cerimônia de casamento. Austin ressalta que não basta dizer essas palavras para estar casado, mas que as palavras precisam ser ditas nas circunstâncias apropriadas, pelas pessoas certas.

Apesar de essas elocuções performativas não serem nem falsas nem verdadeiras em si (apesar de implicarem que certas coisas são verdadeiras e não falsas), elas podem ser satisfatórias ou insatisfatórias, pois existem regras simples a serem seguidas para que alcancem o sucesso. A primeira regra para alcance do sucesso é que a convenção invocada precisa existir e ser aceita. A segunda regra é que as circunstâncias em que expressamos invocar esse procedimento têm que ser apropriadas para sua invocação, senão cometemos um misfire (na acepção primeira da palavra, uma falha na detonação de uma arma; na acepção metafórica, uma falha de realização). Se essas duas regras simples não forem seguidas, o ato é nulo, sem efeito. A terceira regra é que esses procedimentos verbais precisam ser usados por pessoas que têm certas crenças ou determinados sentimentos ou intenções. Se você profere uma elocução desse tipo sem os sentimentos ou intenções necessários, então há insinceridade. A quarta regra é que não basta que 
o ato seja praticado nem a elocução proferida, mas isso tudo tem que acontecer pelas mãos (ou pela boca) da pessoa certa. A quinta regra é que a pessoa que profere a elocução performativa tem que estar levando isso a sério, e não estar brincando, fazendo uma piada ou escrevendo um poema. Se alguma dessas regras não for seguida, a elocução se torna uma infelicity (insucesso) (AUSTIN, 1970, p. 237-241).

Austin, então, estabelece critérios de determinação de se uma elocução é performativa ou não. Há, em primeiro lugar, um critério gramatical: nas formas padrão, as elocuções performativas começam com o verbo na primeira pessoa do singular no presente do Indicativo, podendo também o verbo estar na voz passiva e na segunda ou terceira pessoas, e não somente na primeira (por exemplo, nos documentos escritos que dizem “Autoriza-se pelo presente que...”, seguido de assinatura). É possível, segundo Austin estabelecer uma lista de verbos usados nas elocuções performativas, distribuídos em classes (por exemplo, a classe dos verbos para proferir vereditos, fazer estimativas e avaliações, a classe de verbos usados para assumir compromissos e a classe dos verbos com os quais se exercem direitos e poderes, como nomear e votar). Ao usar esses verbos nas formas padrão, estaríamos proferindo uma elocução performativa explícita, que não deixa margens a mal-entendidos (do tipo "Ordeno-lhe que feche a porta”). Em segundo lugar, há um critério contextual ou circunstancial: a elocução proferida em determinado contexto demonstra sua força performativa, sua intenção clara, apoiada por um determinado tom de voz, um ritmo e um certo gestual (AUSTIN, 1970, p. 241-244).

Como se vê, as elocuções performativas tais como estudadas por Austin ficam mais circunscritas a atos de fala, praticados em determinadas circunstâncias, por certas pessoas, com uma dada força ilocutória, e também perlocutória (o efeito que causam sobre outras pessoas), apesar de não excluir documentos escritos. Contudo, Skinner fez uma apropriação bastante livre dessa teoria, estendendo-a a textos escritos de uma gama mais variada de tipos. Afastando-se de sua formulação original, em casos concretos tais como apresentados por Austin, Skinner concentrou-se na ideia bastante produtiva, que está na base da formulação de Austin, apesar de não nos seus desdobramentos, de investigar o que os autores estão fazendo ao dizerem/escreverem algo. A segunda crítica, esta muito mais 
contundente, se refere à busca por Skinner da determinação de uma intenção dos autores em seus textos, na contramão de todas as proposições pós-estruturalistas e desconstrutivistas, de Foucault a Derrida, que falam da impossibilidade de recuperar significados e intenções nos textos.

Nesse sentido, Skinner destaca três sentidos para o termo "significado": 1. significado ${ }_{1}$ : o que significam as palavras? ou o que significam certas palavras ou frases específicas num texto determinado?; 2. significado ${ }_{2}$ : o que significa este texto para mim?; 3. significado 3 : o que quer significar um autor através do que diz em um texto determinado? (SKINNER, 2002b, p. 90-93). O significado $_{1}$ é o que parece que Derrida tinha em mente ao atacar o "logocentrismo". Derrida se contrapõe frontalmente à tradição linguística que encara a linguagem escrita como representação da linguagem falada, que por sua vez é representação das coisas no mundo e das afecções da alma, como na cadeia especular aristotélica. Para Derrida, a metafísica tradicional incorre no equívoco de tomar a escritura como secundária, ou duplamente secundária, já que, se o signo fônico seria secundário, o signo gráfico surgiria como seu significante. A desconstrução responderia ao fonocentrismo (superioridade do signo fônico) e ao logocentrismo da tradição, tratando criticamente de toda referência a um centro e a uma centralidade das noções de “verdade”, “origem”, “significado”. Para Derrida, o significado é construído na cadeia infinita e incessante de significantes, que corresponderia ao conceito de “disseminação”, e não é dado a priori.

A ideia de que o significado não é estável nem dado a priori - mas só se constituindo no discurso e não fora dele - só pôde ser afirmada com o advento do Pós-Estruturalismo e do pensamento desconstrutivista de Derrida. Aliada a esta ideia revolucionária de constituição da significação, Derrida também apresentou outra ideia central em seu pensamento, a “différance”, palavra não existente no francês, mas que remete a uma bem conhecida, “différence”. Na primeira delas, “différance”, está forjada a interseção dos sentidos espacial e temporal do verbo “différer”: diferir e deferir, diferentemente da palavra "différence”, que remete somente ao primeiro sentido. Assim no termo “différance”, que só se diferencia de “différence” quando se escreve (e assim ele também chama atenção para o papel central da palavra escrita em nossa sociedade), já que os dois termos são pronunciados da mesma maneira, Derrida designa o movimento de diferenciação e 
deferimento, espaçamento e temporalização, que deve ser pensado como precedendo e compreendendo qualquer estabelecimento de diferenças e oposições identificáveis. Assim, uma palavra ganha sentido quando oposta a outra (sentido de diferir) e quando relacionada a outras que a antecedem e a seguem na cadeia de significantes no discurso (sentido de deferir). No sentido de deferir também está a questão de que a leitura necessariamente vem depois da escritura do texto, tendo o autor nenhum controle sobre as interpretações dos leitores.

Além do conceito de “différance”, Derrida, no interior de sua teoria sobre uma gramatologia aplicada, que é uma espécie de ciência geral da escrita, lança o conceito de "arquiescritura", inserindo-se na discussão sobre a hierarquia entre língua falada e língua escrita. Segundo Aristóteles, “os sons falados são símbolos das afecções na alma, e os itens escritos são símbolos dos sons falados” [De Int, 16a3]. Portanto, a língua falada precederia histórica e hierarquicamente a língua escrita. Em contraposição, quando Derrida fala em arquiescritura, fala da escritura que precede a fala e nela se concretiza. Não se trata da definição tradicional da escrita como registro gráfico nem se pressupõe a referência a um mundo exterior ou ulterior ao texto. É ao que sobrevive a estes limites tradicionais de significação que Derrida chama de arquiescritura. Nesse sentido, só haveria escritura, mesmo na linguagem falada, sendo "texto" entendido não como papel escrito, mas como tessitura composta por significantes, que se remetem uns aos outros, criando os significados, que não estão fora do texto, em um mundo que os precede.

Já no significado 2 , Skinner lança mão das questões suscitadas pela Estética da Recepção e pelas teorias de leitura, na determinação do efeito e do impacto que um texto causaria em seu leitor. Dois autores são emblemáticos quando se fala em teorias de leitura: Wolfgang Iser e Hans Robert Jauss. Apesar de apoiado na fenomenologia e não na hermenêutica, a teoria da leitura de Wolfgang Iser possui alguns pontos de contato com a Estética da Recepção de Hans Robert Jauss, principalmente no que diz respeito à valorização do leitor e a um esvaziamento da autonomia e da autoridade da obra de arte. Mas, enquanto Jauss privilegiava a historicidade da leitura e da recepção, Iser parte do conceito de interação na leitura. Em seu ensaio "A interação entre o texto e o leitor" (ISER, 1979, p. 83132), explica a diferença entre a interação face a face, onde há um alto grau de imprevisibilidade na comunicação, regulada pela contingência, e a possibilidade 
de obtenção de respostas imediatas, que fazem com que os parceiros revejam continuamente seus "planos de conduta", e a interação do texto com o leitor, em que este último "nunca retirará do texto a certeza explícita de que a sua compreensão é a justa" (ISER, 1979, p. 87) e em que "os códigos que poderiam regular esta interação são fragmentados no texto e, na maioria dos casos, precisam primeiro ser construídos” (ISER, 1979, p. 88). Nesse tipo de interação são os vazios, na relação assimétrica entre texto e leitor, que possibilitam a comunicação no processo de leitura. O leitor é incitado a preencher os vazios com suas projeções, que sofrem mudanças no decorrer do processo e que são dependentes dos sinais enviados pelo texto. Assim, as possibilidades de comunicação são múltiplas, mas não são infinitas, já que o texto estabelece os seus próprios mecanismos de controle da interpretação.

Skinner cita ainda Stanley Fish como sendo um entusiasta desse tipo de enfoque dentro da Estética da Recepção, levando ainda mais longe suas proposições ao dizer que a resposta do leitor não é ao significado, mas constitui “o” significado de um texto literário (SKINNER, 2002b, p. 92). Em sua coletânea de ensaios intitulada Is There a Text in This Class? (1990), Fish propõe a noção de "comunidades interpretativas”, que não só constroem interpretações de textos com base em suas suposições, como determinam de forma coercitiva que interpretações são aceitáveis ou não. Existem, portanto, estratégias interpretativas e mecanismos que regem as leituras, apesar de serem mutáveis e poderem ser retraçadas. Assim sendo, os cânones de aceitabilidade podem mudar, todavia essa mudança não é aleatória, mas ordenada e, em certa medida, previsível (FISH, 1993, p. 349).

Quanto ao significado ${ }_{3}$, Skinner procura estabelecer quais são as convenções linguísticas do ato de comunicação no interior de protocolos públicos e notórios de comunicação. Sua intenção é determinar a intenção inscrita no próprio texto e não a motivação que antecede o texto e pode estar relacionada com a biografia do autor e com o que se passava na sua cabeça ao escrever o texto. Como a motivação é incognoscível, Skinner se concentra nessa definição de intenção particular apresentada por ele:

Conhecer as motivações e intenções é conhecer a relação que o escritor estabelece com o que escreveu. Conhecer as intenções é conhecer fatos do tipo se 
o autor estava brincando ou falava sério ou estava sendo irônico ou, em geral, que atos de fala pode ter praticado ao escrever o que escreveu. Conhecer motivações é conhecer o que provocou esses atos de fala específicos, afastados do seu caráter e do status de verdade de suas expressões. (SKINNER, 2002b, p. 96)

Assim as motivações seriam externas ao texto e a intenção seria interna ao texto, inscrita em seus interstícios. É esta segunda que Skinner quer investigar, sem perder de vista sua força ilocutória e perlocutória. O historiador pode querer se perguntar sobre as intenções perlocucionárias incorporadas em uma obra (por exemplo, querer fazer criar no leitor o sentimento de solidão) ou se perguntar sobre as intenções ilocucionárias dos autores, isto é, “perguntar não se eles alcançaram o que pretendiam alcançar, mas quais eram suas intenções exatas ao escrever o que escreveram” (SKINNER, 2002b, p. 99). Chegando à questão central de sua investigação entre as relações entre as intenções de um autor e o significado de um texto, Skinner se afasta da análise das intenções perlocucionárias e se concentra nas intenções ilocucionárias, aproximando-se do significado 3 : "Ser capaz de caracterizar uma obra dessa forma, em termos de sua força ilocucionária pretendida, é equivalente a entender o que o autor pode ter querido dizer ao escrever essa forma específica”. (SKINNER, 2002b, p. 100) E ainda: "saber o que um autor queria dizer por uma obra particular é saber quais eram seus intenções principais ao escrevê-la”. Skinner, termina o capítulo com a seguinte passagem:

Para entender o que um autor pode ter estado fazendo ao usar algum conceito ou argumento específico, precisamos, antes de tudo, captar a natureza e o leque de coisas que se pode reconhecer como tendo sido feitas ao usar esse conceito específico, no tratamento daquele tema em particular, naquele momento determinado. Precisamos, em suma, estar prontos para tomar como nosso terreno nada menos do que o todo do que Cornelius Castoriadis descreveu como imaginário social, a gama completa de símbolos e representações herdadas que constituem a subjetividade de uma era. (SKINNER, 2002b, p. 102)

Com isso, pela restrição de seu objeto de observação ao muito pontual que produz uma mudança conceitual abrupta, Skinner imaginou ter refutado as críticas pós-estruturalistas a seu trabalho.

Pocock seguiu o espírito geral de Skinner, na esteira da investigação do que o autor "estava fazendo" ao escrever o texto, mas pretendeu alargar seu enfoque para além de atos individuais, tentando abarcar a noção de "discurso", 
especificamente do discurso político. Com isso, Pocock, ao contrário de Skinner, orienta-se para o estudo da "linguagem” e não da intencionalidade autoral. A tarefa do historiador é estudar um autor em relação às linguagens políticas de sua época e de seu contexto. Ele não abandona a intencionalidade autoral tal como vista por Skinner, isto é, aquilo que um dado autor fez em relação ao seu universo de possibilidades linguísticas, mas também investiga as linguagens políticas disponíveis no contexto. Segundo Jasmim e Feres Júnior:

Isso fica claro, por exemplo, na apropriação que o autor faz da terminologia de Ferdinand de Saussure para denominar as características da língua como um todo (langue) e as performances particulares empreendidas no seu interior por autores também particulares (parole). Para Pocock, existe uma relação metodológica de estreita complementaridade entre essas categorias, pois a langue só pode ser reconstruída por meio da leitura e da análise das várias paroles; enquanto que as paroles devem ser compreendidas à luz da langue da qual recebem os seus sentidos de maneira mais ou menos complexa. (JASMIM \& FERES JÚNIOR, 2006, p. 20)

Os conceitos de langue e parole aparecem em Saussure após descrever a natureza do signo linguístico e suas características. Saussure se opõe à noção de língua como nomenclatura, que pressupõe ideias feitas, preexistentes às palavras. A unidade linguística é dupla, isto é, constituída da união de dois termos, mas de uma outra forma. O signo linguístico une um conceito e uma imagem acústica, que não é o som material, mas a impressão psíquica desse som, sendo tal imagem sensorial. Os dois elementos (conceito, chamado de "significado", e imagem acústica, chamada de "significante”) estão intimamente unidos e um reclama o outro, e, aos dois combinados, Saussure chama de “signo”. (SAUSSURE, 2006, p. 79-81)

O signo linguístico exibe duas características primordiais. O primeiro princípio é o da arbitrariedade do signo. A ideia de um significado não está ligada por relação alguma interior à sequência de sons da palavra que lhe serve de significante, mas poderia ser representada por qualquer outra sequência. Esta é a regra geral, à qual há exceções como a de signos motivados, como as onomatopeias. O segundo princípio é que, sendo o significante de natureza auditiva, “desenvolve-se no tempo e tem as características que toma do tempo: a) representa uma extensão e b) essa extensão é mensurável numa só dimensão: é uma linha” (SAUSSURE, 2006, p. 84). 
Se, com relação à ideia que representa, o significante é arbitrário e parece ser escolhido livremente, em relação à comunidade linguística que dele se serve, ele é imposto. A língua é uma herança da época precedente, mas é passível de mudança, só que essa mudança se dá no longo prazo, pois existe uma resistência da inércia coletiva a toda renovação linguística. Nesse sentido, pode-se falar, ao mesmo tempo, da imutabilidade (entendida como herança social e cultural) e da mutabilidade do signo (entendida como deslocamento da relação entre o significado e o significante). Segundo Saussure: "Em última análise, os dois fatos são solidários: o signo está em condições de alterar-se porque se continua. O que domina, em toda alteração, é a persistência da matéria velha; a infidelidade ao passado é apenas relativa. Eis porque o princípio de alteração se baseia no princípio de continuidade” (SAUSSURE, 2006, p. 89).

Em seguida, Saussure distingue dois fatores, a língua (langue) e a fala (parole), no seio do fenômeno total que representa a linguagem. A língua é, para Saussure, a linguagem menos a fala, “o conjunto de hábitos linguísticos que permitem a uma pessoa compreender e fazer-se compreender”, é, portanto, um fato social e coercitivo (SAUSSURE, 2006, p. 92). Para que essa língua mude, é preciso introduzir o tempo no esquema.

Como Saussure, considerado o pai da Linguística moderna, estava interessado em estudar as regras e o funcionamento deste sistema, depois de apresentar as diferenças entre língua e a fala e introduzir o tempo como agente proporcionador da mudança, ele abandona a fala e a diacronia, concentrando-se na língua e na sincronia. Como a fala é idiossincrática, ela apresenta as regras de funcionamento do sistema “contaminadas” por hábitos e costumes erráticos, de caráter subjetivo.

Pocock, apesar de creditar um grande avanço para a historiografia ao diálogo com a teoria dos atos de fala de Austin, faz algumas objeções à determinação da intencionalidade de um autor:

Mas a objeção com a qual estamos lidando é mais radical. Ela questiona não apenas que as intenções possam existir antes de ser articuladas em um texto, como também que se possa dizer que elas existem independentemente da linguagem em que o texto será construído. $\mathrm{O}$ autor habita um mundo historicamente determinado, o que é apreensível somente por meios disponíveis graças a uma série de linguagens historicamente constituídas. Os modos de discurso disponíveis dão-lhe as intenções que ele pode ter, ao proporcionar-lhe os 
únicos meios de que ele poderá dispor para efetuá-las. Neste ponto, a objeção que estamos analisando levanta a questão da langue bem como a da parole, do contexto linguístico bem como do ato de fala (ou de discurso). (POCOCK, 2003, p. 27-28)

Ora, vemos aqui que Pocock se apropriou de termos cunhados por Saussure (langue, parole) de uma forma muito própria, assim como vimos que Skinner se apropriou de termos e formulações de Austin de forma também sui generis. Há uma confusão entre o conceito de langue, utilizado por Saussure para designar um sistema determinado por regras de funcionamento, imutável no curto prazo e coercitivo, com a ideia de línguas(s)/linguagem(s) de autores no discurso político, em suas interações. Diz Pocock:

O método de Skinner, portanto, nos impeliu na direção tanto do resgate da linguagem do autor quanto do resgate de suas intenções, bem como a tratá-lo como habitante de um universo de langues que confere sentido às paroles que ele emite nessas línguas. (...) A história do pensamento político torna-se uma história da fala e do discurso, das interações entre langue e parole. (POCOCK, 2003, p. 28)

A ideia de que dentro de um sistema de língua (langue), os autores se expressem de forma particular em seu discurso (parole) e nisso sejam seguidos ou criticados por outros e influenciem não só o discurso de outros, como a própria realidade, é muito interessante. Contudo, parece-me que Pocock faz confusão entre os termos tais como usados por Saussure e Austin e a sua forma própria de empregá-los. Especialmente, entre fala e discurso, de um lado, e langue e parole, de outro. O mesmo se pode dizer do conceito linguístico usado de forma bastante determinada na linguística como "idioma” com a forma como Pocock o utiliza, aproximando este conceito de “jogos de linguagem”.

O diálogo entre história intelectual e filosofia da linguagem, ou mesmo a linguística propriamente dita, é muito rico e profícuo e pode, sem dúvidas, trazer avanços para os dois campos do saber. Todavia, parece-nos que é preciso especificar com bastante clareza se os termos vão ser usados pelos historiadores da forma como entendidos ou criados por linguísticas ou filósofos da linguagem ou se vão ser apropriados de forma diferente, explicitando essa diferença. O que ocorre tanto com Skinner em relação a Austin quanto com Pocock em relação a Saussure é uma verdadeira apropriação indébita, em que não fica claro se estão 
pretendendo usar conceitos tais como em sua origem ou se pretendem fazer modificações nestes conceitos. O que resulta é confusão, tanto por parte de quem conhece linguística e filosofia da linguagem, que se espanta com esse uso livre dos conceitos, quanto por parte dos historiadores e pesquisadores da área de história que, sem conhecerem de primeira mão os textos onde esses conceitos surgiram, podem passar a acreditar que compreendem esses conceitos tais como em sua formulação original, quando o que estão lendo é uma interpretação e um uso muito particulares desses conceitos. Nada contra a apropriação, afinal todos são livres para ler, interpretar e recriar textos de outrem (a "disseminação” de Derrida guarda relações muito próximas com o intertexto e o hipertexto), mas que fique claro que se trata de uma apropriação, guardando suas diferenças, de textos de outrem. Se isso não fica claro, o que resulta é a possibilidade de se tomar um caminho muito diferente do original, sem que o estudioso nem se dê conta de que está trilhando um caminho novo, sob uma nova paisagem. Para que a contribuição desses historiadores possa ser aplicada aos Estudos da Tradução, cujo diálogo com a linguística e a filosofia da linguagem é constante e muito profícuo, e especificamente à historiografia da tradução, a definição desses conceitos precisa ficar muito bem delimitada e esclarecida.

\subsection{3}

\section{História dos conceitos}

Outra corrente relevante para a construção de uma abordagem historiográfica ao discurso dos tradutores em prefácios/posfácios é a história conceitual alemã tal como desenvolvida por Reinhart Koselleck. Apesar de anterior à perspectiva skinneriana, a Begriffsgeschichte (história dos conceitos) só passou a ser divulgada no mundo anglo-saxão depois dela. Esse projeto surge como uma percepção da insuficiência da história do espírito (Geistesgeschichte) de enfoque hegeliano e da história das ideias (Ideengeschichte) como explorada por Dilthey e seus seguidores. As principais críticas eram quanto à baixa contextualização de ideias e conceitos utilizados no passado, no anacronismo que daí se deriva e na insistência metafísica da essencialidade das ideias. Percebeu-se uma transferência descuidada para o passado de expressões modernas, 
contextualmente determinadas, e uma prática na história das ideias de tratá-las como "um conjunto de grandezas constantes, capazes de se articular em diferentes formas históricas sem qualquer alteração essencial” (KOSELLECK, 2006, p. 104). Segundo Koselleck, os conflitos políticos e sociais devem ser descobertos e interpretados por meio do horizonte conceitual que lhes é contemporâneo e os termos linguísticos tal como compartilhados e desempenhados por seus atores (JASMIM, 2005, p. 57).

É este enfoque contextualista da história dos conceitos que permite uma aproximação teórico-metodológica com as perspectivas de Skinner e Pocock. Tal como na perspectiva skinneriana e pocockiana, a história dos conceitos lida com o uso da linguagem específica em situações específicas, em que os conceitos são elaborados e usados por falantes específicos, ultrapassando a visão essencialista da história das ideias, em que as ideias assumem um conteúdo permanente. A história dos conceitos, no entanto, ultrapassa o caráter sincrônico do historicismo metodológico skinneriano, pois, se os atos de fala são únicos e os conceitos também dependentes da experiência que os formulou, a recepção desses atos (e seus efeitos perlocutórios) se dá ao longo do tempo, constituindo uma tradição interpretativa diacrônica.

Koselleck faz uma diferenciação importante entre "palavra” e "conceito":

(...) Todo conceito se prende a uma palavra, mas nem toda palavra é um conceito social e político. Conceitos sociais e políticos contêm uma exigência concreta de generalização, ao mesmo tempo em que são sempre polissêmicos.

(...) O sentido de uma palavra pode ser determinado pelo uso. Um conceito, ao contrário, para poder ser um conceito, deve manter-se polissêmico. Embora o conceito também esteja associado à uma palavra, ele é mais do que uma palavra: uma palavra se torna um conceito se a totalidade das circunstâncias políticosociais e empíricas, nas quais e para as quais essa palavra é usada, se agrega a ela. (KOSELLECK, 2006, p. 108-109)

Koselleck resume ainda: "Uma palavra contém possibilidades de significado, um conceito reúne em si diferentes totalidades de sentido" (KOSELLECK, 2006, p. 109). Assim sendo, o conceito reúne a diversidade da experiência histórica assim como a soma das características objetivas em uma única circunstância. O conceito abre horizontes, mas limita as experiências.

A história dos conceitos ressalta a diferença que predomina entre um núcleo conceitual do passado e um núcleo conceitual contemporâneo. Ela abrange 
uma zona de convergência na qual o passado, com seus conceitos, adentra os conceitos atuais. Necessita, portanto, compreender as divergências e convergências nos conceitos.

Lendo os prefácios/posfácios dos tradutores recolhidos, datados de um espaço de cerca de 60 anos, fica claro que o conceito de (in)fidelidade intimamente ligado ao conceito de tradução — sofreu modificações, mas manteve um núcleo de significação intacto. O conceito é polissêmico e, apesar de claro em cada situação, é subjetivo (o termo é o mesmo, mas com nuances de significado muito pessoais), porém contém um referencial objetivo - a fidelidade ao literalismo, no sentido de que tudo que está no original deve aparecer reproduzido na tradução. Propomo-nos, então, a aplicar o método da história conceitual, tal como o próprio Koselleck fez com vários conceitos (progresso/declínio, p. ex.) (KOSELLECK, 2002, p. 219-357), para estudar os conceitos de fidelidade/infidelidade, bem como o conceito de tradução, a partir do discurso dos tradutores em seus prefácios/posfácios, visando a apreciar as alterações observadas no tempo e entre os atores, e as influências sofridas. Será necessário, para isso, retraçar uma história desses conceitos e suas variações sofridas pelos aportes teóricos de vários autores, de posicionamentos os mais diversos.

Para se entender a genealogia do conceito de tradução no Ocidente, é preciso primeiro lembrar que um dos primeiros registros do termo "fidelidade" data de Horácio na Epistola ad Pisones (13 a.C.) e desde então essa noção baseada na relação estabelecida entre texto original e sua tradução vem ocupando lugar central no cenário da tradução. A passagem, traduzida do latim por Dante Tringali, em questão é a seguinte:

Matéria pública virá a ser de direito privado se não te retardares em redor de um círculo batido e aberto a todos; nem te empenhares, como tradutor fiel, em verter palavra por palavra; nem caíres, como imitador, em um buraco estreito, de onde a vergonha e as leis da obra te impedem de tirar os pés. (TRINGALI, 1993, p. 30) (Grifo meu)

Apesar de Horácio estar falando de arte poética, seu exemplo de uma tradução boa é de uma tradução fiel, vertida palavra por palavra. É a esse conceito de tradução palavra por palavra, ou, no limite, ao conceito de tradução literal, que André Lefevere faz menção em “Translation: Its Genealogy in the West”. Nele, Lefevere afirma que, na Antiguidade, os romanos traduziam, mas não tinham 
muita necessidade de fazê-lo. Os romanos cultos, que eram um número reduzido em relação à população total do império, liam obras gregas no original. Uma situação semelhante prevaleceu na Idade Média: a população culta não precisava de tradução e não a praticava muito. Normalmente, já escrevia diretamente em latim e não em sua própria língua. A cultura europeia de cerca de 500 a.C. até 1800 era essencialmente bilíngue, ou até mesmo multilíngue. A língua de autoridade foi, em primeiro lugar, o latim, e depois o francês. Além destas, os acadêmicos, o clero e os literatos, sabiam suas próprias línguas maternas e mais uma ou duas línguas adicionais. Assim sendo, nessa cultura e nesse intervalo de tempo, as traduções não eram lidas para se obter informações ou como uma forma de mediação ao texto estrangeiro. Elas eram produzidas e lidas como exercícios, em primeiro lugar, pedagógicos, e mais tarde, como exercícios de apropriação cultural, uma usurpação consciente e controlada da autoridade. Essa usurpação sofreu resistência por parte das figuras de autoridade. Os membros das rodas seletas não podiam pôr seu conhecimento ao dispor dos de fora e quem o fazia tinha que arcar com as consequências. A mudança desse estado de coisas ocorre por volta de 1800 (LEFEVERE, 1990, 16-17), com o rompimento com a cultura das rodas seletas.

A partir desse momento, começam a ser identificados diferentes públicos potenciais para traduções e formas diferentes de traduzir surgem para satisfazer esses diferentes públicos. Surgem dois objetivos principais para as traduções: 1 . tradução para informação e mediação para quem não conhece a língua do original, mas é cada vez mais capaz de ler em sua própria língua; 2. tradução como um atalho para o original ou desafio intelectual e estético para quem, pelo menos em teoria, é capaz de ler na língua do original. Por volta de 1900, o inglês começa a tomar o lugar do francês como língua de autoridade e surge uma tendência para o aumento da monolingualização dos públicos e, por conseguinte, aumenta o número de traduções feitas com o objetivo de informação. A ideia de língua como forma de resistência nacional e meio de afirmação da identidade nacional, lançada pelos historiadores e autores românticos, toma força (LEFEVERE, 1990, p. 17).

Antes de 1800, não se veicula a ideia de que as línguas deveriam resistir, nem as traduções eram vistas como uma tarefa impossível. A linguagem era considerada um veículo de troca de ideias, em que os mesmos pensamentos 
poderiam ser expressos em diferentes línguas. A palavra latina para traduzir, translatare, pode significar simplesmente “troca de significados” (LEFEVERE, 1990, p. 17), sem muita atenção às conotações culturais e outras expressas pelos significantes. O conceito de translatio pode ser visto como levando às últimas consequências o ideal da tradução fiel das figuras de autoridade, que acreditavam na possibilidade de transmitir a imagem “correta” do texto fonte em uma língua diferente. Segundo Lefevere, translatio só é possível para textos acadêmicos e não literários. Nos textos literários, não se pode ignorar as nuances ideológicas e poetológicas dos significantes e essa ideia, contida no conceito de translatio, da troca de significados em um tipo de vácuo intelectual e emocional não é uma possibilidade. Como resume Lefevere: “Translatio tenta regularizar os componentes linguísticos do processo tradutório, sem prestar atenção em mais nada” (LEFEVERE, 1990, p. 18).

Seu oposto, que pode ser designado em uma palavra latina que nunca existiu de verdade, traductio, é a contraparte mais criativa da mais conservadora translatio. Na traductio, pesos pelo menos iguais devem ser dados ao componente linguístico e ao componente cultural/ideológico do processo tradutório. O conceito de tradução como traductio está presente em pelo menos dois autores referência nos primórdios da teoria da tradução: Nicolas Perrot d'Ablancourt e Friedrich Schleiermacher.

D’Ablancourt, cujas traduções o gramático e lexicógrafo Gilles Ménage (1613-1692) chamou de belles infidèles, o mesmo nome que dava a uma de suas amantes, explica seu método ao falar de uma tradução feita por ele de um texto de Luciano, escrito em grego no original. A passagem abaixo foi originalmente parte de uma carta ao senhor Conrart, conselheiro e secretário do rei, escrita em 1664:

(...) pois suprimi o que havia de mais grosseiro e suavizei em algumas passagens o que era demasiado livre; e aqui entro na explicação de meu procedimento (...) Direi apenas que deixei suas opiniões intactas, porque senão não seria uma tradução, mas que respondo no argumento ou nas observações ao que há de mais forte, a fim de que isso não possa causar prejuízo.

(...) Foi preciso então mudar tudo isso, para fazer algo agradável; de outro modo, não seria Luciano; e o que agrada na sua língua, não seria suportável na nossa. (...) Assim, não me apego sempre às palavras ou aos pensamentos do autor e, mantendo a sua finalidade, arranjo as coisas a nosso gosto e a nosso modo. As diversas épocas pedem não somente palavras, mas pensamentos diferentes (...). (D’ABLANCOURT, 2004, p. 55) 
Aí se vê uma defesa veemente, e adiante de seu tempo, de uma tradução que privilegie o conceito de traductio, em detrimento do conceito de translatio. Ele defende posições ainda hoje consideradas ousadas, como a de "atualizar" as traduções com palavras e pensamentos próprios de cada época, suprimir passagens de tradução difícil ou impossível ou passagens consideradas por ele pedantes ou antiquadas ou que provocassem um efeito diferente do efeito do original, como, por exemplo, as passagens sobre o amor aos rapazes, que não era um costume estranho na Grécia, mas que horrorizaria os franceses do século XVII. Ele empreende uma verdadeira cirurgia do texto original, sem se furtar à missão primordial do tradutor, segundo ele, que é avaliar diferentes procedimentos para diferentes passagens e intervir, se necessário: “Há muitas passagens que traduzi palavra por palavra, pelo menos na medida em que se pode fazê-lo em uma tradução elegante; há ainda outras em que considerei mais o que seria preciso dizer, ou o que podia dizer, que o que ele havia dito" (D’ABLANCOURT, 2004, p. 57).

Já Schleiermacher faz uma distinção entre o trabalho do intérprete e do tradutor, que pode ser aproximada aos conceitos de translatio e traductio, respectivamente. Após determinar os campos de atuação das duas figuras ("O intérprete exerce sua profissão no campo dos negócios; o verdadeiro tradutor, primordialmente no campo da ciência e da arte” (SCHLEIERMACHER, 2001, p. 27)), ele acrescenta que as obras mais artísticas precisam de uma tradução em que o tradutor aplique suas habilidades mais elevadas do que a de um simples intérprete:

(...) quanto mais a maneira própria do autor de ver e relacionar for dominante na apresentação, quanto mais ele tiver seguido alguma ordem escolhida livremente ou por determinadas impressões, tanto mais seu trabalho entra no âmbito mais elevado da arte, e então o tradutor também precisa trazer outras forças e habilidades ao seu trabalho e ter conhecimento do seu autor e de sua língua de modo diferente que o intérprete. (SCHLEIERMACHER, 2001, p. 31)

À semelhança do que Lefevere disse em relação à distinção entre translatio e traductio, a distinção que faz Schleiermacher em relação à função do intérprete e do tradutor se refere ao fato de que o primeiro privilegia os aspectos linguísticos do seu trabalho, enquanto que o segundo privilegia os aspectos 
culturais, ideológicos e literários, sem perder de vista os aspectos linguísticos de sua função. Implícita nessas distinções, está a distinção entre tradução técnica (afeita ao trabalho do intérprete e ao conceito de translatio) e tradução literária (afeita ao trabalho do tradutor e ao conceito de traductio). Pelas observações de Schleirmacher que se seguem no mesmo texto, toda tradução literária teria que ser traductio, já que translatio seria impossível. Ele chega até mesmo a lançar uma ideia ousada de que o único método viável seria o tradutor deixar o autor em paz e levar o leitor até ele, uma atitude que veio a inspirar o conceito de "tradução estrangeirizadora” de Venuti. Schleiermacher, bem como d'Ablancourt, privilegia a tradução do sentido e do efeito causado pelo texto original, em relação a propriamente a tradução das palavras.

Já no século IV d.C., São Jerônimo empreendeu uma tradução criativa, “estrangeirizante” e que levava o conceito de traductio às suas últimas consequências. Na época em que Jerônimo viveu, a língua dos romanos começou a suplantar o grego na parte ocidental do Império. A Bíblia estava disponível em grego; a versão oficial do Antigo Testamento era a tradução para o grego a partir do hebraico, conhecida como a Septuaginta, e o Novo Testamento ainda se preservava no idioma original, o grego. Com o crescimento do latim como língua predominante, uma versão oficial da Bíblia em latim se tornou imprescindível, já que cada vez menos pessoas eram capazes de ler em grego e versões latinas não oficiais começaram a circular. Jerônimo foi incumbido pelo papa de fazer uma revisão das versões do Antigo Testamento e traduzir o Novo Testamento, o que constituiu a versão para o latim conhecida como a Vulgata. Porém, Jerônimo foi mais além, depois de seu exílio no deserto: passou a traduzir diretamente do hebraico para o latim todo o original do Antigo Testamento, em detrimento da orientação oficial da Igreja Católica de preservar a Septuaginta como a versão oficial do Antigo Testamento. Segundo Maria Esther Maciel:

Hebraizar o latim, inscrever a diferença no mesmo, reconfigurar uma língua a partir da estranheza da outra, desviar-se da literalidade e arriscar-se na interpretação dos sentidos do texto foram algumas das diretrizes da obra de Jerônimo. Como um bom precursor dos modernos, ousou na invenção de neologismos, reimaginou metáforas, recusou as regras e os artifícios da retórica do tempo, experimentou novas dicções, aliou o rigor à transparência do dizer. (MACIEL, 2001, p. 54) 
Como se vê, não só Jerônimo foi além do conceito de translatio, como foi além até mesmo do conceito de traductio, incorporando a estranheza na tradução e recriando um texto que mais do que qualquer outro imaginava-se que deveria ser traduzido literalmente. A prática da tradução latina, ou toda a cultura latina, se tornou a base da tradução ocidental, já então nela convivendo posições mais tendentes a privilegiar o conceito de traductio com as que privilegiavam o conceito de translatio. Ainda hoje, como veremos nos exemplos de prefácio coletados nesta pesquisa, os dois conceitos convivem e se contrapõem, muitas vezes ignorando a verdadeira revolução que significou a desconstrução para os conceitos de tradução e fidelidade. Veremos qual é esse conceito desconstrutivista da tradução, após fazer uma breve recensão sobre as teorias da linguagem e da tradução através dos tempos, no próximo item deste capítulo.

\section{3}

\section{As teorias de linguagem e tradução através dos tempos}

A tradução é um dos ofícios mais antigos do mundo, mas, como campo de reflexão teórica, é uma área relativamente nova. Isso se deve muito aos conceitos tradicionais, que vigoram em grande parte até hoje, principalmente fora dos meios acadêmicos, de tradutor e de tradução. Segundo tais concepções, traduzir é um talento inato, que não se aprende, mas no máximo se aperfeiçoa, e a tradução só é aceitável quando é fiel ao texto original, sendo que seria possível reproduzir totalmente o sentido do original, e nada mais do que este, no texto traduzido. Assim, o tradutor perfeito seria aquele que é invisível, que não interfere e que ocupa um lugar necessariamente inferior em relação ao autor, que naturalmente é o criador de sentido, sendo o tradutor, por mais que se esforce, somente o "transportador" do sentido do original. Foi somente no século XX, após a Segunda Grande Guerra, mas principalmente, na década de 1970, que essas concepções passaram a ser questionadas, tornando a reflexão teórica sobre a tradução uma das áreas mais profícuas, não só nas Letras, mas principalmente em bases multidisciplinares, nesse início de século.

Como fenômeno, a tradução remonta ao mito bíblico da Torre de Babel. Segundo o mito, um certo povo havia decidido construir uma torre tão alta que 
atingisse os céus, para tornar célebre o seu nome e para que não fosse disperso por toda a terra. Deus desceu dos céus para ver a torre e disse: "Eis que todos constituem um só povo e falam uma só língua. Isso é o começo de suas iniciativas! Agora, nenhum desígnio será irrealizável para eles” (Bíblia de Jerusalém, Gênesis 11, 6). Deus decidiu então confundir a sua linguagem, de forma que já não se compreendessem uns aos outros. O povo, não mais se entendendo, abandonou a construção e se dispersou pela face da terra. A necessidade da tradução se coloca então neste momento, fruto de um castigo.

A reflexão teórica sobre a tradução surgiu como um desdobramento das várias teorias de linguagem que se desenvolveram desde a Grécia e Roma Antigas. Segundo Helena Martins, na Grécia, o caminho “racional” de olhar a linguagem se bifurca radicalmente entre os filósofos chamados sofistas, por um lado, e os filósofos socráticos, por meio de Sócrates, Platão e Aristóteles (MARTINS, 2004, p. 447). Os filósofos sofistas adotam uma perspectiva pragmática, de que “a verdade só pode resultar 'de nossas opiniões sobre as coisas e do consenso que se forma em torno disso, sendo, portanto, 'múltipla, relativa e mutável’” (MARTINS, 2004, p. 448). Já o pensamento socrático, ou platônicoaristotélico, adota uma perspectiva realista e mentalista, de que as coisas têm uma essência de alguma forma permanente, havendo uma verdade única e fixa, que ultrapassa a experiência humana concreta e múltipla do real. As posturas realista (as coisas estão no mundo e nós as denominamos) e mentalista (as ideias estão na cabeça e nós as denominamos) dos socráticos percebiam os objetos e ideias como anteriores à linguagem e dela determinantes. Daí decorre a visão da língua como uma nomenclatura, uma atribuição de nomes a coisas e ideias preexistentes. Assim sendo, a tradução seria fácil e simples, já que bastaria procurar na língua de chegada o termo correspondente para a coisa ou ideia de partida e a tradução poderia ser feita palavra por palavra.

Já Cícero, tribuno e filósofo romano posterior aos socráticos, problematizou um pouco mais a questão da tradução ao dizer que a tradução não poderia ser feita palavra por palavra, mas sentido por sentido. Cícero, apesar de avançar em direção a uma teoria da tradução, ainda via os objetos e ideias como anteriores às línguas, com a ideia associada de que a função maior da linguagem é descrever ou representar o real, não escapando da concepção de língua como 
nomenclatura. Introduz, contudo, a questão do sentido, que seria central a toda teoria da tradução a partir de então.

Os sofistas, em sua abordagem pragmática e relativista da linguagem, inauguram na Grécia noções que seriam retomadas com toda força no século XX: a "linguagem entendida não como um sistema de representação, mas antes como uma práxis circunstanciada pela cultura, pela história, pelas idiossincrasias de cada ocasião do contato verbal” (MARTINS, 2004, p. 470).

No final do século XVIII e início do XIX, o linguista alemão Wilhelm Von Humboldt identifica a linguagem humana como um sistema governado por regras, e não simplesmente uma coleção de palavras e frases acompanhadas de significados. E mais, recusou-se a encarar a língua como um instrumento passivo da expressão. Segundo Mounin, Humboldt “considerava-a antes um princípio ativo que impõe ao pensamento um conjunto de distinções e de valores: Todo sistema linguístico contém uma análise do mundo exterior, que lhe é peculiar e que difere da de outras línguas ou de outras etapas da mesma língua”. (MOUNIN, [1963] 1975, p. 50). Vários de seus descendentes, conhecidos como neohumboldtianos, como Saussure, Bloomfield, Harris, Hjelmslev e Cassirer, expressando-se de formas diferentes, operam uma inversão em relação às concepções realista e mentalista e introduzem a ideia de que a visão de mundo e a maneira de viver dos indivíduos são determinadas pela linguagem. Essas teses vão ser revalorizadas pela linguística estruturalista.

De todos os citados acima, Saussure é o linguista mais célebre. O Cours de linguistique générale apresenta ideias muito frutíferas e, sob certo aspecto, conflitantes. Opondo-se à ideia de que a língua é uma nomenclatura, afirma que o signo linguístico, que é arbitrário, une não uma coisa e uma palavra, mas um conceito (significado), que reside no plano do conteúdo, e uma imagem acústica (significante), que reside no plano da forma (SAUSSURE, 2006, p. 80), e que "não existem ideias preestabelecidas, e nada é distinto antes do aparecimento da língua” (SAUSSURE, 2006, p. 131). Sua teoria do valor postula que os signos linguísticos estão em relação entre si no sistema da língua. Contudo essa relação é diferencial e negativa, pois um signo só encontra o seu valor na medida em que não é outro signo qualquer. Resumindo, um signo é aquilo que outros signos não são. 
Saussure retoma essa reflexão sobre o valor um pouco mais adiante na mesma obra, quando analisa o signo em sua totalidade, e muda de posição ao afirmar que "na língua só existem diferenças” (SAUSSURE, 2006, p. 139). Para ele, dizer que na língua tudo é negativo, só é verdade em relação ao significado e significante tomados separadamente; o signo em sua totalidade é, ao contrário, positivo em sua ordem.

Um sistema linguístico é uma série de diferenças de sons combinadas com uma série de diferenças de ideias; mas essa confrontação de um certo número de signos acústicos com outras tantas divisões feitas na massa do pensamento engendra um sistema de valores, e é tal sistema que constitui o vínculo efetivo entre os elementos fônicos e psíquicos no interior de cada signo. Conquanto o significado e o significante sejam considerados, cada qual à parte, puramente diferenciais e negativos, sua combinação é um fato positivo; é mesmo a única espécie de fatos que a língua comporta, pois o próprio da instituição linguística é justamente manter o paralelismo entre essas duas ordens de diferenças. (SAUSSURE, 2006, p. 139-140)

Saussure efetua, em sua teorização, uma diferença entre língua (langue) e fala (parole). Língua "é o conjunto de hábitos linguísticos que permitem uma pessoa compreender e fazer-se compreender” (SAUSSURE, 2006, p. 92), é um sistema depositado como produto social na mente de cada falante de uma comunidade, possui homogeneidade e é passível de estudo pela linguística, disciplina que, segundo Saussure, deveria privilegiar a sincronia. Diferente da língua, a fala é um ato individual, sujeito a fatores externos, muitos deles não linguísticos, não constituindo, portanto, o objeto da linguística. Com este pressuposto, de que o objeto da linguística é a língua e não a fala, Saussure afasta a subjetividade de sua análise, concentrando-se na objetividade.

Maria Paula Frota percebe então pelo menos dois Saussure no Curso: o primeiro, e mais conhecido, que privilegia a significação, a positividade e a oposição, fortalecendo a noção de estrutura (langue), em sobreposição ao segundo, que privilegia o valor, a negatividade e a diferença, e que permite a manifestação da subjetividade do falante da língua (parole) (FROTA, 2000, p. 31). Buscando um ato teórico que investigue a possibilidade de um ponto em que se entrecruzem sujeito e estrutura, Frota se debruçou sobre a noção de sujeito em Freud e Lacan, lançando mão do suporte teórico da psicanálise. O sujeito que se pode inferir da teoria da langue pressupõe uma posição subjetiva cientificista do 
teórico frente a seu objeto de estudo e, consequentemente, do tradutor diante do texto original a traduzir, assumindo uma postura de neutralidade, passividade e externalidade, impossíveis de alcançar. Por outro lado, o sujeito da parole é acientífico, indomável e caótico. Se a teoria da tradução não incluir o sujeito da parole, ficando só no domínio da langue, visão do senso comum, a tradução é uma operação complexa, mas factível. Se o sujeito da parole é incluído, as diferenças individuais e sociais ficam tão amplificadas, que a tradução torna-se uma operação muitas vezes impossível. A teoria da tradução baseada na teoria estruturalista saussureana chega a essa constatação da impossibilidade da tradução (MOUNIN, 2006, p. 19), apesar de que a tradução como função, atividade e ofício sempre se deu, face às diferenças entre as línguas e a necessidade de comunicação.

Nos anos 1930, os linguistas Edward Sapir e Benjamin Lee Whorf tinham formulado a Hipótese Sapir-Whorf de que os grupos culturais vivem segundo suas línguas em universos mentais muito diferentes, determinados pelas diferentes línguas que falam. Assim sendo, o estudo da estrutura de uma língua poderia levar à elucidação de uma concepção de mundo. Segundo essa hipótese, o pensamento não precederia a língua, mas a língua moldaria o pensamento. Esse relativismo linguístico reforçaria a impossibilidade da tradução. No limite, uma civilização seria impenetrável a qualquer outra.

A pesquisa de Anna Wierzbicka busca ultrapassar o impasse das "duas teorias extremas a respeito da relação entre o significado e a linguagem: a teoria de que os significados não podem ser de maneira alguma transferidos de uma língua para outra e a teoria de que os significados podem ser transferidos integralmente” (WIERZBICKA, 1992, p. 6). Já que a experiência mostra que traduzir é possível, a questão seria pesquisar "até que ponto as línguas são formadas pela 'natureza humana' e até que ponto elas são moldadas pela cultura” (WIERZBICKA, 1992, p. 7). A questão então seria buscar uns poucos conceitos humanos universais nas línguas, transcendendo ao cultural; olhar não para o mundo em volta, mas para nossas mentes. Em sua busca dos universais lexicais, Wierzbicka monta uma lista de primitivos semânticos, que seriam intuitivamente claros e autoexplanatórios e cuja definição seria impossível, com base em extensa pesquisa descritiva de muitas línguas do mundo todo. 
Outra tentativa de solucionar o impasse entre as posições universalista e relativista de linguagem e de tradução, já tinha surgido na década de 1940, com Eugene Nida. Em 1943, Nida ingressa na Bible Society e passa a realizar, junto com uma equipe, traduções da Bíblia para as mais diversas línguas. Diante das dificuldades encontradas, propõe a noção de equivalência dinâmica entre as línguas. Na falta de um conceito e consequentemente de um termo numa língua de chegada que traduza o conceito e o termo da língua de partida, a solução é buscar na língua de chegada algum conceito ou termo semelhante, que, se não permite a tradução total, pelo menos permite uma aproximação ao conceito. Se a equivalência linguística não existe, a equivalência dinâmica deveria ser buscada.

Em todos esses teóricos relativistas citados acima, o foco do questionamento estava na recodificação (busca de equivalências) e não na decodificação (leitura) de um texto. Foi preciso que as teorias de Marx e Freud surgissem e fossem divulgadas em meados do século XX para que essa visão começasse a mudar. O pós-estruturalismo, que se desenvolveu na década de 1960, tomando mais força em 1968, viria trazer para a teoria da tradução um novo enfoque. Um teórico especialmente importante nesse sentido foi Roland Barthes, que fez parte da escola estruturalista e foi muito influenciado por Saussure, mas acabou se distanciando da visão estruturalista, para estudar a semiótica. Num texto capital, “A morte do Autor” (não por acaso escrito justamente em 1968), Barthes explica que a noção de autoria é um construto moderno, desenvolvido a reboque do empirismo inglês, do racionalismo francês, da Reforma, do capitalismo e do positivismo. Nessa época, a importância da biografia ganhava destaque na história literária e a interpretação do texto se baseava na intenção do autor. Ora, as escolas artísticas e literárias do século XX, e principalmente o Surrealismo, que aceitou o princípio de uma escrita a várias mãos, dessacraliza a figura do Autor. A morte do Autor não é um fato histórico; o scriptor moderno nasce ao mesmo tempo que seu texto: "não existe outro tempo para além do da enunciação, e todo texto é escrito eternamente aqui e agora” (BARTHES, 2004, p. 3). É a leitura que dá vida ao texto, que não tem um sentido único, mas é um espaço de dimensões múltiplas, um tecido de citações. Afastado o autor, não há mais a pretensão de se “decifrar” um texto, mas sim o de "deslindá-lo”; a escrita faz incessante sentido, o texto não esconde um segredo que precisa ser revelado, 
ele se refaz a cada leitura. Segundo Barthes, "para devolver à escrita o seu devir, é preciso inverter o seu mito: o nascimento do leitor tem que pagar-se com a morte do Autor” (BARTHES, 2004, p.6).

Num texto intitulado "From Work to Text”, Barthes faz uma diferenciação entre a noção de “obra” e de “texto”. Contrapondo-se à noção de “obra”, o autor propõe a noção de “texto”. A obra seria um objeto definido, que ocupa um espaço físico numa biblioteca, mas o texto se revela e se articula na linguagem, só existe como discurso, e pode ser transversal perpassando várias obras (intertextual). Ele é subversivo em relação a antigas classificações, é sempre paradoxal. É plural, comportando inúmeras leituras. Não é o caso de buscar estabelecer fontes e influências de uma obra, já que o texto é sempre intertextual, pondo em dúvida inclusive a ideia de série de influências cronológicas. A metáfora da obra é o organismo, mas a do texto é a rede. O texto exige do leitor uma colaboração ativa. O sentido não está lá a priori, esperando para ser revelado, mas se faz no ato da leitura (BARTHES, 1989, p.1).

Ora, essas ideias provocam um profundo impacto sobre a reflexão teórica da tradução. O tradutor é um leitor, talvez o mais atento de todos. Sua tradução é resultado de uma leitura, que é a sua. A tradução, portanto, não só é possível, como uma tarefa criativa e autoral. Teóricos pós-modernos, principalmente Jacques Derrida, se debruçaram sobre a tradução não como uma reflexão acessória, mas como central à questão da linguagem e da construção de sentido.

Rosemary Arrojo, ${ }^{5}$ em seu livro Oficina de tradução, contrapõe uma visão que chama de logocêntrica - em que o sentido estaria no texto original, visto como um objeto estável, e em que ao tradutor só caberia "transportar" seu conteúdo para o texto traduzido —-, a uma visão desconstrutivista (ARROJO, 1986, p. 12). Essa visão desconstrutivista ficaria mais clara em sua interpretação do conto de Jorge Luis Borges, de título instigante, "Pierre Menard, autor do Quixote”. O conto nos apresenta o personagem Pierre Menard, homem de letras francês da primeira metade do século XX, através de um narrador, que se diz seu

\footnotetext{
${ }^{5}$ Rosemary Arrojo é a única teórica brasileira que cito explicitamente nesta parte da tese, mas não quer dizer que tenha sido a única a pensar as noções de tradução e fidelidade. Para não me alongar em demasia, nem fugir ao escopo do trabalho, me ative às suas reflexões teóricas. Ressalto, contudo, que os estudos sobre história da tradução no Brasil já compõem um corpus considerável no nosso país e no exterior.
} 
amigo, e que tem como objetivo fazer uma resenha póstuma, identificando e dissociando o que chama de obra “visível” da obra “invisível” deste autor.

Sua obra "visível” é constituída por monografias, traduções, análises e poemas, perfazendo um total de 19 escritos publicados e não-publicados. Sua obra teórica identifica-se sobremaneira com a que chamamos de visão logocêntrica da tradução e o personagem título pode ser visto como uma metáfora do tradutor submisso e reverente ao texto original, o que fica patente quando ele se lança à sua obra "invisível”, a reprodução dos capítulos IX e XXXVIII da Primeira Parte do Dom Quixote, de Miguel de Cervantes, além de parte do capítulo XXII.

O objetivo de Menard não é o de reproduzir, copiar, interpretar ou traduzir o Quixote, ele pretende recuperar não apenas a totalidade do texto de Cervantes, mas também o contexto em que fora escrito: “Não queria compor outro Quixote - o que é fácil — mas o Quixote” (BORGES, 1995, p. 57). Com esse intuito, experimenta algumas estratégias: primeiro pensa transformar-se em Cervantes (conhecendo bem o espanhol, recuperando a fé cristã, guerreando contra os mouros ou contra os turcos, esquecendo a história da Europa entre os anos de 1602 e de 1918), abandonando tal método logo em seguida por considerá-lo pouco estimulante; depois, pretende chegar ao Quixote, continuando a ser Pierre Menard, tarefa bem mais árdua. Impõe-se então o "misterioso dever de reconstruir literalmente a obra espontânea de Cervantes” (1985, p. 58).

Rosemary Arrojo interpreta este dever como uma alegoria do papel a que se impõe todo tradutor, identificado com a visão logocêntrica da tradução:

Esse "misterioso dever" pode ser interpretado como uma alegoria do que tradicionalmente se pretende atingir em toda tradução: Menard se impõe a tarefa de repetir um texto estrangeiro, escrito em outra língua, por um outro autor e num outro momento, sem deixar de ser ele próprio, isto é, sem poder anular seu contexto e suas circunstâncias. Menard parece, inclusive, uma caricatura exagerada do tradutor imaginado por Tytler (Alexander Fraser Tytler), refletido nos três princípios básicos (...): 1) a tradução deve reproduzir em sua totalidade a ideia do texto original; 2) a tradução deve ter o mesmo estilo do original; e, (3) a tradução deve ser fluente e natural como o original. (ARROJO, 1986, p. 20)

Pierre Menard até consegue produzir alguns fragmentos verbalmente idênticos do Quixote, mas o que ele reproduz como sendo o verdadeiro Quixote é interpretado pelo narrador/crítico como algo diferente. A repetição não consegue ser total porque as palavras do texto de Cervantes não conseguem delimitar seu 
significado “original”, sem relação com um contexto ou uma interpretação. Assim como o tradutor logocêntrico, Menard quer ser fiel ao texto de partida, mas fracassa, pois, mesmo ao reproduzir as palavras, não tem controle sobre a leitura e a interpretação do texto pelo narrador/crítico, sendo que elas assumem um determinado valor ao serem confrontadas com o contexto de Cervantes e com o contexto de Pierre Menard. As palavras podem ser iguais, mas o contexto de recepção é diferente e os leitores, sujeitos históricos, são diferentes. O pretenso fracasso de Menard é o mesmo pretenso fracasso do tradutor tradicional que, apesar de todos os seus esforços, não consegue "transportar" neutramente significados de uma língua para outra, nem controlar as leituras. Para a visão desconstrutivista da tradução, é neste "fracasso" que está a força do tradutor de se impor, sair da sombra, deixar de pedir perdão por existir e exigir um reconhecimento, não mais como guardião das verdades do original, mas como leitor produtor de sentidos.

Arrojo se inspira nas ideias do filósofo Jacques Derrida e do teórico norteamericano Stanley Fish, já mencionado anteriormente. Fish introduz a noção de “comunidade interpretativa”, dizendo que a literatura é uma decisão comunitária do que se entende por literatura. O texto literário não possui características intrínsecas e atemporais que o definiriam como literário. Em suma, o autor se define como alguém "que prega a instabilidade do texto e a indisponibilidade de significados determinados" (FISH, 1980, p. 305). Ele nem cai num extremo de achar que existe um sentido literal na elocução que deveríamos ser capazes de dizer qual é, nem no outro extremo de dizer que existem tantos significados de um texto quanto há leitores (FISH, 1980, p.305-306). Ele defende a ideia de que existe um "ninho institucional” que indica um caminho para a interpretação, isto é, que os significados são o produto de circunstâncias (1980, p. 308-309). Levando-se essa ideia ao extremo, poder-se-ia pensar que só poderia haver uma leitura em cada comunidade interpretativa, mas Fish refuta essa radicalização, dizendo:

(...) isso não quer dizer que a pessoa está presa para sempre nas categorias de compreensão à sua disposição (ou das categorias a cuja disposição essa pessoa está), mas que a introdução de novas categorias ou a expansão de categoria antigas incluindo dados novos (e, portanto, recém-vistos) tem sempre que vir de fora ou do que é recebido, naquele momento, como sendo de fora. (FISH, 1980, 
p. 314)

Em suma, a leitura e a interpretação de um texto nunca partem do zero. O leitor, e consequentemente o tradutor, partem de pressupostos de leitura definidos ou apontados pela comunidade interpretativa onde se insere. A comunidade interpretativa teria, portanto, uma "compreensão compartilhada” do texto pelos membros dessa comunidade (FISH, 1980, p. 320) Acrescentando a isso ideias advindas da psicanálise, poderíamos ampliar essa noção e dizer que a leitura pelo leitor/tradutor é produto não só da visão de sua comunidade interpretativa, mas também de sua história de vida, de seus desejos conscientes ou inconscientes e de seus recalques.

Antes de passarmos à visão desconstrutivista da tradução, através dos escritos de Derrida, seria interessante refletir sobre as ideias de Walter Benjamin em “A tarefa do tradutor”. Esse texto se localiza, em termos teóricos, a meio caminho entre as duas visões (logocêntrica e desconstrutivista). Como se vê, a questão cronológica não tem importância aqui, pois as ideias mais contraditórias podem - e efetivamente o fazem - , conviver no tempo e no espaço. O texto de Benjamin, de 1921, é mais “avançado” do que o texto de Mounin, de 1963, que por sua vez, é muito mais "reacionário" — o uso desta terminologia se faz por falta de melhor —, do que o texto de Derrida, escrito logo depois em 1966.

Benjamin, apesar de inverter os conceitos de fidelidade ao conteúdo e servilidade ao original da teoria da tradução tradicional, mantém a diferença de status entre o original e sua tradução, deslocando-o, no entanto, como diz Haroldo de Campos, "para um plano ontológico, onde o que importa, de parte do original, não é a sua mensagem, mas o seu 'modo de intencionar', sua tensão para a 'língua pura’ ou 'língua da verdade’, recapitulação da história adâmica da nomeação do original no fim messiânico da história” (CAMPOS, 1996, p. 205)

Vejamos o que diz Benjamin a respeito da sobrevida dos originais, propiciada pelas traduções:

(...) a tradução surge do original. Não tanto, a bem da verdade, de sua vida que de sua "sobrevida". Pois a tradução é mais tardia do que o original, e para as obras importantes, que nunca encontram o tradutor eleito na época de seu surgimento, ela marca o estágio de sua sobrevivência. (...) As traduções que são mais do que transmissões nascem quando, na sua sobrevivência, uma obra atinge o tempo de sua glória. (...) Pois na sua sobrevivência, que não mereceria este nome se não 
fosse transformação e renovação daquilo que vive, o original se modifica. (BENJAMIN, 1994, p. 54)

As traduções, portanto, segundo Benjamin, fazem aumentar a sobrevida das obras originais. As traduções, no entanto, “envelhecem” com o passar do tempo e com a transformação da língua, precisando assim ser refeitas de tempos em tempos, como se vê na seguinte passagem:

Com efeito, assim como o tom e a significação das grandes obras literárias se transformam totalmente com o passar dos séculos, também se transforma a língua materna do tradutor. Sim, enquanto que a palavra do escritor perdura naquilo que lhe é próprio, é o destino mesmo da maior das traduções desaparecer com o crescimento da sua língua, de soçobrar na sua renovação. (...) Diante disso, é claro, só nos resta admitir que toda tradução não passa de uma maneira um tanto provisória de se explicar com a estranheza das línguas. (...) Quanto à tradução, mesmo que ela não possa aspirar à pretensão de duração de suas obras, no que a faz diferir da arte, ela também não desiste de se orientar rumo a um estágio último, definitivo e decisivo de todo o agregado das línguas. (1994, p. 56)

Por fim, gostaria de salientar o que Benjamin diz a respeito da intraduzibilidade das traduções, para melhor entendermos a crítica de Derrida, que se seguirá:

Quanto mais uma obra é de uma natureza elevada, mais ela permanece, mesmo no mais fugitivo contato com o seu sentido, ainda traduzível. Eis o que vale, o que é evidente, somente para os originais. As traduções, no entanto, se revelam intraduzíveis, não por causa do peso que o sentido faz tombar sobre elas, mas porque ele as afeta de maneira demasiadamente fugitiva. (BENJAMIN, 1994, p. 58)

Em contraponto à visão apresentada anteriormente, o filósofo Jacques Derrida apresenta uma concepção revolucionária para a época, e ainda para muitos nos dias de hoje, a respeito da tradução. O trecho um pouco longo, mas singularmente rico, que aqui irei reproduzir, é parte da transcrição de uma entrevista concedida a Julia Kristeva:

Embora esta oposição ou esta diferença (entre significado e significante) não possa ser radical e absoluta, isso não a impede de funcionar e mesmo de ser indispensável dentro de certos limites - limites muito amplos. Por exemplo, nenhuma tradução seria possível sem ela. E foi efetivamente no horizonte de uma traduzibilidade absolutamente pura, transparente e unívoca, que se constitui o tema de um significado transcendental. Dentro dos limites em que é possível, em que pelo menos parece possível, a tradução pratica a diferença entre significado e 
significante. Mas, se esta diferença nunca é pura, a tradução também não o é, e temos que substituir a noção de tradução por uma noção de transformação: transformação regulada de uma língua para outra, de um texto para outro. De fato nunca temos nem teremos contato com qualquer "transporte" de significados puros que o instrumento - ou o "veículo" — significante tivesse deixado virgem e intacto, de uma língua para outra, ou no interior de uma mesma e única língua. (DERRIDA, 1966, p. 29-30)

Para Derrida, a meu ver, o tradutor é quase um “coautor” do texto original na medida em que é traduzido, já que, se o transforma, imprime nele suas marcas de criatividade e de vida, seu talento e suas motivações. Isto não quer dizer que o tradutor faz e inventa qualquer coisa a partir do texto original; a transformação é “regulada” pelo próprio texto original e pelas línguas em questão. O trabalho do tradutor não é mecânico, nem inocente, ele é uma reescrita que se insere na cadeia da intertextualidade. Quanto à questão da relação entre endividamento e tradução, Geoffrey Bennington, na biografia Jacques Derrida, salienta com muita propriedade que:

Num longo comentário do célebre texto de Benjamin sobre a tradução ("A tarefa do tradutor"), Derrida descreve as relações de endividamento recíproco entre original e tradução. Segundo Benjamin, o tradutor está endividado em relação ao original, no sentido de que o original lhe impõe sua tarefa, seu dever, do qual lhe é necessário dar conta. Como um filho, ou pelo menos um legatário, o tradutor herda uma responsabilidade pela sobrevivência do original; mas na medida em que o original depende do tradutor para esta mesma sobrevivência, ele se endivida antecipadamente junto a todo tradutor que tomar para si a tarefa assim prescrita. (...) Todo texto está endividado em relação a seus futuros leitores, ao mesmo tempo em que permanece indiferente à morte de todo destinatário empírico em geral: endividado, então na sua própria destinerrância, aberto ao acaso do endividamento. (...)

Benjamin faz uma distinção entre original e tradução: o original se deixa traduzir e retraduzir um número indefinido de vezes, enquanto que a tradução, por sua vez, não se deixa traduzir. Deve-se seguir o conselho implícito de Derrida e reconhecer que tal critério não é infalível: é original o que se deixa traduzir e retraduzir, portanto ler e reler. (BENNINGTON \& DERRIDA, 1991, p. 156-158)

$\mathrm{Na}$ concepção tradicional do trabalho do tradutor, a questão do endividamento entre original e tradução é vista como uma via de mão única, só existindo endividamento do tradutor em relação ao original. A recíproca, levantada por Benjamin e realçada por Derrida, do endividamento do original em relação ao tradutor, tem o valor de patentear a generosidade dos tradutores que, apesar de sempre tão mal vistos e geralmente tão mal pagos, atribuem uma vida 
mais longa aos originais, permitindo que sejam lidos por um público mais amplo, que sejam redescobertos por um público esquecido ou que sejam relidos por um público cativo, implicando em novas interpretações, que gerarão novas escrituras, engendrando novas leituras e assim por diante, numa trajetória impossível de ser determinada ou regulada. Isto é, a tradução permite que o intertexto se dê num nível mais amplo e mais complexo do que se as obras só fossem lidas em originais.

A concepção de Derrida e de todos os teóricos da linha desconstrutivista não posiciona a tradução em um nível inferior em relação ao original. Além disso, fica claro, pelo que foi dito, que os originais, assim como as traduções, também sofrem a ação do tempo e do espaço, sendo passíveis de "envelhecer” e de serem esquecidos, pois não estão em posição hierárquica superior à tradução. Em tese, ao menos para aqueles que têm fé, o único texto que não "envelhece”, que não sofre as vicissitudes do tempo, que é perene, é o texto sagrado. A concepção de valor estético, que confere ao original a qualidade de belo e à tradução a qualidade de feia e deformada, também cai por terra, levando-se em conta as questões mais amplas do endividamento recíproco entre original e tradução e da intertextualidade, que une indelevelmente todos os textos já escritos e os que ainda estão por surgir.

Tendo em vista, o que se disse a respeito dos vários conceitos de tradução e, por conseguinte, de fidelidade, retomaremos, no Capítulo 5, quais os conceitos de tradução - tradução como translatio, como traductio ou um conceito desconstrutivista de tradução - que os tradutores apresentam, ou deixam entrever, nos prefácios/posfácios selecionados. No próximo capítulo, apresentaremos, em linhas gerais, as Teorias do Paratexto e os estudos existentes sobre o paratexto do livro traduzido. 


\section{Teorias do paratexto}

\section{1}

\section{A teoria geral do paratexto}

Nos Estudos da Tradução, alguns teóricos chamam a atenção para a importância do paratexto nas obras literárias, sejam elas autorais ou traduzidas. Um desses teóricos foi, sem dúvida, André Lefevere.

O principal interesse de estudo e pesquisa de Lefevere (2007) foram os intermediários que não escrevem literatura, mas a reescrevem, tornando-se corresponsáveis pela recepção geral e pela sobrevivência de obras literárias entre leitores não-profissionais, isto é, leitores não-acadêmicos, e conhecedores profundos da literatura. Lefevere chamou a atenção para o fato de que o "valor intrínseco” de uma obra literária, se é que isso existe, tem um papel muito menor no processo de recepção, leitura e canonização do que se supunha no passado. O conceito de “reescrita”, com seus componentes políticos e ideológicos vistos em sentido amplo, é portanto central ao seu pensamento, como se pode depreender pela passagem abaixo:

(...) Insisto, de minha parte, que o processo que resulta na aceitação ou 'rejeição, canonização ou não-canonização de trabalhos literários não é dominado pela moda, mas por fatores bastante concretos que são relativamente fáceis de discernir assim que se decide procurar por eles, isto é, assim que se evita a interpretação como o fundamento dos estudos literários e se começa a enfrentar questões como o poder, a ideologia, a instituição e a manipulação. Quando isso ocorre, logo também se percebe que a reescritura, em todas as suas formas, ocupa uma posição central entre os fatores concretos aos quais acabamos de nos referir. (LEFEVERE, 2007, p. 14)

A tradução, segundo Lefevere (2007, p. 17), seria um tipo de reescrita, assim como as produções de histórias da literatura e suas compilações, obras de referência, antologias, críticas, ensaios ou edições de livros em geral. Os prefácios e ensaios críticos contidos no livro são um tipo de reescrita, mas, quando esses prefácios são escritos pelos próprios tradutores, assumem um caráter especial: são 
a reescrita da reescrita. Deste caráter especial decorre que o discurso dos tradutores é uma reflexão sobre o que fizeram, o que não fizeram, o que dizem ter feito, mas efetivamente não fizeram, e o que fizeram, mas não foi dito. Um discurso cheio de silêncios, contradições, defesas e alusões.

Dentre os teóricos do paratexto não pertencentes aos Estudos da Tradução, o mais citado é Gérard Genette, semiólogo e teórico da literatura francês. Em sua obra Seuils (1987), traduzida no Brasil como Paratextos editoriais (2011), apresentou pela primeira vez um estudo sistemático dos elementos paratextuais, explicando suas especificidades e características, inclusive dos seus elementos iconográficos, além dos textuais. Afirma Genette:

Assim, para nós o paratexto é aquilo por meio de que um texto se torna livro e se propõe como tal a seus leitores, e de maneira mais geral ao público. (...) O paratexto compõe-se, pois, empiricamente, de um conjunto heteróclito de práticas e de discursos de todos os tipos e de todas as idades que agrupo sob esse termo, em nome de uma comunidade de interesse, ou convergência de efeitos, que me parece mais importante do que a diversidade de aspecto. (GENETTE, 2011, p. 910)

Estranhamente, no entanto, Genette deixa de notar elementos paratextuais ligados em termos específicos à tradução, como a existência e posição do nome do tradutor, se o texto é ou não apresentado como uma tradução (ou como adaptação, imitação etc.) e outros sinais de tradução, apesar de serem partes evidentes do paratexto. Mesmo fazendo essa ressalva, as perguntas gerais que ele propõe para definir um elemento do paratexto continuam valendo e levantando pontos esclarecedores para a análise desse elemento paratextual. São elas: lugar do elemento paratextual (onde?), sua data de aparecimento e às vezes de desaparecimento (quando?), seu modo de existência, verbal ou outro (como?), as características de sua instância de comunicação, destinador e destinatário (de quem? a quem?) e as funções que animam sua mensagem (para fazer o quê?).

Genette subdivide o paratexto entre peritexto e epitexto. Peritexto é o que está em torno do texto no âmbito do livro, no espaço do mesmo volume (capa, quarta capa, folha de rosto e anterrosto, verso da folha de rosto, orelhas, prefácios, posfácios, introduções autorais ou alográficas, notas, glossários, etc.). O epitexto também está em torno do texto, mas à distância, no exterior do livro, apoiado em 
um suporte mediático (entrevistas e críticas), ou se localiza longe dos olhos do público (correspondências, diários, etc.).

Yves Chevrel propõe outra nomenclatura para os mesmos dois fenômenos: textos de acompanhamento (equivalentes a peritexto) e discurso de mediação (equivalente a epitexto) (CHEVREL, 1989, p. 80). A nomenclatura usada em outra obra por Genette (1982) é: paratexto (equivalente a peritexto e a textos de acompanhamento) e metatexto (equivalente a epitexto e discurso de mediação). O metatexto seria visto como a relação crítica, por excelência, isto é, o resultado da relação de comentário que une um texto a outro, que se realiza com a inclusão de citações. Nesse sentido, metatexto também se diferenciaria de hipertexto, que é o produto da relação que une um texto a outro, que se realiza por meio de alusões textuais ou paratextuais, não incluindo intertextos citacionais. Para não criar confusão entre toda essa terminologia, utilizarei uma nomenclatura simples, baseada em Genette (1982), diferenciando paratexto (textos e outros elementos, inclusive iconográficos, que acompanham o texto literário no âmbito do livro publicado) e metatexto (textos críticos fora do âmbito do livro publicado).

Os escritos analíticos sobre o paratexto geralmente se debruçam sobre a especificidade do paratexto não de obras traduzidas mas, sim, de obras originais, e são eminentemente aplicados e não teóricos, o que abre um grande campo de pesquisa a ser explorado pelos teóricos e historiadores da tradução.

Na introdução de seu livro, Genette apresenta um questionário sucinto para o estudo dos elementos do paratexto/metatexto, segundo suas características espaciais, temporais, substanciais e pragmáticas/funcionais. Como são questões genéricas, podem também se aplicar a obras traduzidas, como mencionei acima. As características espaciais visam a determinar a posição do paratexto/metatexto a ser analisado em relação ao texto. Assim sendo, o paratexto estaria localizado: (a) antes do texto (p. ex. prefácio); (b) nos seus interstícios (p. ex. notas de pé-depágina); (c) depois do texto (p. ex. posfácio); (d) afastado do texto (no caso dos metatextos).

Em relação às características temporais, é interessante determinar se o elemento paratextual/metatextual surgiu antes, ao mesmo tempo ou depois (ou muito depois) em relação à publicação original. No que concerne às características substanciais, é importante definir se o elemento paratextual/metatextual é textual 
ou iconográfico. Em relação às características pragmáticas, é necessário observar qual é a instância de comunicação do elemento a ser analisado: a natureza do emissor e do destinatário, o grau de responsabilidade e de autoridade do primeiro e a força ilocutória de sua mensagem. Quanto à natureza do emissor, os elementos paratextuais podem ser autorais ou alógrafos isto é, escritos por alguém que não o autor, ou heterográficos, segundo a terminologia usada por Geneviève Idt (1977, p. 67). Else Vieira em sua tese de doutorado (1992, p. 159) apontou aí uma ambiguidade em relação aos prefácios dos tradutores, o que remete diretamente à questão do próprio status autoral do tradutor: o prefácio do tradutor seria alográfico, quando relacionado à publicação original, e autoral, em relação à tradução, já que ela é efetivamente de sua autoria.

Quanto ao destinatário, alguns elementos do paratexto/metatexto se endereçam a públicos diferentes: ao público em geral, aos críticos, aos livreiros, aos bibliotecários e a alguns leitores especiais, ou mais profissionais, como é o caso do(s) prefácio(s). A isso está relacionada a força ilocutória de sua mensagem. Um elemento paratextual/metatextual pode comunicar uma simples informação, uma intenção ou uma interpretação, de caráter mais ou menos apelativo, ideológico, político, programático. Daí as características funcionais do elemento paratextual/metatextual. Percebo que os elementos paratextuais que o leitor costuma ler ainda na livraria, como a quarta capa e as orelhas, possuem características do discurso publicitário e uma recorrência da função conativa, por exemplo.

Genette (2011) afirma que as observações sobre a força ilocutória dos elementos paratextuais o conduziram ao que lhe parece mais essencial, que é o aspecto funcional do paratexto. A situação espacial, temporal, substancial e pragmática de um elemento paratextual se determina por uma escolha a partir de uma grade geral e constante de alternativas possíveis, das quais normalmente um termo é adotado à exclusão do outro. No caso do prefácio, este é: 1 . necessariamente peritextual (situação espacial), 2. original, posterior ou tardio (situação temporal), 3. autoral ou alógrafo (situação substancial) e daí por diante. Porém, as escolhas funcionais não são de ordem alternativa e exclusiva. Um prefácio pode ter variados fins, sem que um deva necessariamente rejeitar outro. Contudo, as opções não são ilimitadas e percebe-se, na prática, que a diversidade 
de práticas e mensagens se reduzem a alguns temas fundamentais e recorrentes, pois o discurso nos prefácios/posfácios é mais restritivo do que muitos outros e percebe-se que seus autores inovam com menos frequência do que imaginam. Se essa afirmativa de Genette é válida para os prefácios escritos por autores, veremos que ela é ainda mais válida para os prefácios de tradutores. Na análise dos prefácios/posfácios de tradutores, a ser empreendida no Capítulo 5, a situação funcional ficará bastante ressaltada, e a questão da recorrência será tratada mais a fundo no Capítulo 4.

As ideias acima dispostas foram apresentadas na Introdução da sua obra Paratextos editoriais (GENETTE, 2011). Passarei agora a levantar as questões mais pertinentes para este estudo, contidas nos capítulos em que Genette se dedica especificamente aos prefácios e à existência e localização do nome do autor. São eles: “A instância prefacial”, “As funções do prefácio original” e "Outros prefácios, outras funções”, em relação aos prefácios, e “O nome do autor”, em relação à existência e localização do nome do autor. A partir dessas observações, tentarei traçar paralelos aos aspectos específicos dos prefácios/posfácios de tradutores e da existência e localização do nome do tradutor.

Logo de início, no capítulo “A instância prefacial”, Genette define prefácio, definição essa que me autorizou a usar sempre neste trabalho a palavra prefácio seguida ou não da palavra posfácio, como se constituíssem uma só instância:

Chamarei aqui de prefácio toda espécie de texto liminar (preliminar ou pósliminar), autoral ou alógrafo, que consiste num discurso produzido a propósito do texto que segue ou que antecede. Assim, o "posfácio" será considerado uma variedade de prefácio, cujos traços específicos, incontestáveis, parecem-me menos importantes do que aqueles que ele tem em comum com o tipo geral. (GENETTE, 2011, p. 145)

Sob a denominação de "prefácio”, Genette reuniu elementos que são denominados sinonimicamente de formas muito variadas, como, por exemplo: introdução, prefácio, nota, notícia, aviso, apresentação, exame, preâmbulo, advertência, prelúdio, discurso preliminar, exórdio, proêmio; e de "posfácio", elementos que igualmente são denominados em sinonímia como, por exemplo, epílogo, pós-escrito, remate, fecho etc. Alguns desses elementos podem ter 
nuances diferentes, principalmente em situação de copresença, como a Introdução e o Prefácio propriamente dito, e serem escritos por autores diferentes, como, por exemplo, o autor, o tradutor, o editor, o organizador do volume ou da série, um crítico ou especialista etc. Porém, para fins de facilitação de análise, serão agrupados sob a denominação geral de “prefácios/posfácios”, ou simplesmente “prefácios”.

Outra observação muito óbvia, mas bastante pertinente para este estudo, é que o prefácio não é um elemento paratextual obrigatório, como são hoje o título e o nome do autor. O fato de ser opcional e facultativo, e de com mais frequência não existir, como no caso dos prefácios/posfácios de tradutores, é importante. No caso deste estudo, a ausência desse elemento paratextual fala tanto ou mais do que sua presença, pois dá indícios da importância que a figura do tradutor tem ou não diante da comunidade interpretativa, importância essa forjada por decisões editoriais, mais do que por questões práticas ou mera vontade do tradutor, como veremos no item seguinte.

Quanto à função dos prefácios/posfácios, Genette afirma que esta pode ser derivada dos tipos de prefácios: 1. o prefácio autoral original; 2. o posfácio autoral original; 3. o prefácio/posfácio autoral posterior (escrito após a primeira publicação da obra); 4. o prefácio/posfácio autoral tardio; 5. o prefácio/posfácio alógrafo autêntico, em que o personagem-prefaciador é uma variante do prefaciador alógrafo e 6. o prefácio/posfácio ficcional. Muitas funções podem ser deslocadas de um tipo para outro, e um prefácio pode cumprir funções sucessivas ou simultâneas. O primeiro tipo e mais importante tem a função principal de garantir ao texto uma boa leitura. Para Genette, essa função pode parecer simples, mas é muito significativa, pois denota duas ideias: que se obtenha uma leitura, isto é, que o leitor seja incitado a ler o livro, e que a leitura seja boa, ou bem-sucedida. Seu caráter original e sua localização preliminar garantem que duas funções sejam cumpridas: uma ligada ao porquê de se ler a obra e a outra a como lê-la (GENETTE, 2011, p. 175-176). Isso partindo-se do princípio de que o leitor lê o prefácio antes do texto propriamente dito, o que nem sempre é verdade.

O leitor costuma ler o prefácio somente depois de comprar ou tomar o livro de empréstimo, já em casa. Ao contrário, a quarta capa costuma ser lida ainda na livraria ou diante da estante da biblioteca, e por isso contém elementos 
tipicamente retóricos de persuasão. No prefácio, o autor não precisa mais persuadir o leitor a comprar/pegar/levar o livro, mas sim valorizar o texto de forma nem tão imodesta demais, nem tão visível demais, para não indispor o leitor, afinal o autor aí estaria se autoelogiando. Para não correr o risco de parecer imodesto, o autor costuma valorizar o assunto ou a forma como foi tratado (GENETTE, 2011, p. 176-177). Estendendo-se essas considerações para o prefácio escrito pelo tradutor, considerado autor da tradução, costuma-se perceber que o tradutor se apresenta de forma modesta, para, de forma semelhante, não indispor o leitor. Assim sendo, os elementos retóricos de humildade são usados por vezes de forma insincera, simplesmente para não irritar o leitor com autoelogios. Neste caso, é comum o tradutor chamar atenção, em seu prefácio, mais para o autor da obra original e para seu tema do que propriamente para a tradução, às vezes mencionando-a en passant ou nem mesmo traçando qualquer comentário sobre ela.

Genette aponta ainda uma outra função do prefácio autoral que se aplica como uma luva aos prefácios dos tradutores: a função de para-raios.

Mais de acordo com o topos da modéstia, e mais eficaz sob muitos aspectos, é a atitude inversa, codificada pela retórica sob o termo excusatio propter infirmitatem. Era, na eloquência clássica, a contrapartida inevitável da amplificatio do assunto. Em face da importância de seu tema, às vezes exagerada além de toda medida, o orador queixava-se de sua incapacidade de tratá-lo com todo o talento necessário, contando aparentemente com o público para estabelecer uma justa medida. Mas essa era, sobretudo, a maneira mais segura de prevenir as críticas, isto é, de neutralizá-las, ou mesmo de impedi-las tomando a dianteira. (GENETTE, 2011, p. 185)

O que aqui se disse acima sobre o autor, aplica-se igualmente ao tradutor em seus prefácios. A fim de cultivar a modéstia, o tradutor valoriza o autor original, a obra, o tema, etc., amplificando suas qualidades, também utilizando-se da atitude inversa das desculpas em relação a seu próprio trabalho, à sua incapacidade de fazer um trabalho melhor ou de se equiparar ao autor. Essa atitude amplificadora, de um lado, e excusatória, de outro, é, como explica Genette, uma prática conhecida dos oradores antigos, sendo encontrada em Heródoto, Tucídides e Tito Lívio. O interessante é notar que, séculos mais tarde, os tradutores continuam a se valer dessa prática retórica antiga em seus prefácios, de forma recorrente e repetitiva, sem se darem conta de sua origem já 
ultrapassada. Segundo Genette (2011), desde o século XIX, é prática mais comum na edição de obras originais se encomendar um prefácio alógrafo ou heterográfico elogioso, poupando o autor de se utilizar desses recursos retóricos ultrapassados ou, o que é pior, poupando-o da posição incômoda de se autoelogiar. Percebe-se então nos prefácios dos autores o desaparecimento das funções de valorização e excusa, em prol das funções de informação ou de orientação de leitura. Não é que os tradutores em seus prefácios se furtem dessas funções mais contemporâneas, mas muitos ainda se aferram a reproduzir funções retóricas muito antigas, que soam insinceras e exageradas.

Quanto ao destinatário ou à escolha do público, Genette afirma que, no prefácio autoral original, o autor orienta o leitor, para situá-lo e determiná-lo. Alguns se dirigem ao público feminino, outros ao público jovem ou, ao contrário, adulto. Em seus prefácios, os tradutores, apesar de não ser comum se endereçarem a um público em particular, de maneira velada se dirigem a uma parcela muito temida do público, a dos críticos de tradução, que pode ser constituída de críticos profissionais ou leitores-críticos. Muitas vezes o tradutor se desculpa para não ser condenado, assumindo sua culpa antes mesmo de ser julgado, grita logo antes que o esfolem. Isso faz com que o ímpeto da crítica negativa fique apaziguado ou reduzido pela mea culpa de antemão feita pelo tradutor. É como se este dissesse: “ninguém precisa me julgar, eu mesmo já me condeno”. Ocorre uma situação paradoxal, o discurso exculpatório do tradutor pode não corresponder em absoluto ao que ele pensa de seu trabalho. Seria improvável que um tradutor se expusesse a escrever um prefácio se julgasse, de verdade, que fizera um trabalho pífio. O que vemos, portanto, são meros exercícios retóricos que não necessariamente correspondem às ideias e crenças verdadeiras dos tradutores.

No capítulo intitulado “Outros prefácios, outras funções”, Genette passa a falar dos posfácios, chamando a atenção para o fato de alguns prefácios desempenharem, na verdade, o papel de posfácios, por serem lidos somente após a leitura da obra, e não antes como sua localização sugeriria:

O maior inconveniente do prefácio é o fato de que ele constitui uma instância de comunicação desigual, e mesmo desprovida de rigor, pois nele o autor propõe ao leitor o comentário antecipado de um texto que este ainda não conhece. Por isso se diz que muitos leitores preferem ler o prefácio depois do texto, quando souberem “do que se trata”. A lógica dessa situação deveria, então, levar a 
constatar semelhante movimento e propor antes (isto é, mais tarde) um posfácio, no qual o autor poderia epilogar, quando ambas as partes têm conhecimento de causa: "Agora os senhores sabem tanto quanto eu, vamos então conversar". Confesso aliás que, no início desta pesquisa, esperava encontrar um corpus de posfácios originais quase tão copioso quanto o dos prefácios. Não foi o que aconteceu (...). (GENETTE, 2011, p. 211)

Genette explica a exiguidade dos posfácios autorais, lembrando que estes, por sua localização no final da obra, não podem mais exercer as duas principais funções dos prefácios: reter e guiar o leitor, explicando-lhe por que e como ele deve ler o texto. O leitor do posfácio é um leitor não mais potencial, mas efetivo. Assim sendo, a função primordial do posfácio autoral é curativa ou corretiva, isto é, uma tentativa derradeira de corrigir uma má leitura. Eles aparecem em menor número porque é compreensível que os autores queiram antes prevenir do que remediar (GENETTE, 2011, p. 212). Em relação à pesquisa feita para o presente trabalho, da mesma forma o número de posfácios encontrados foi menor do que o de prefácios. Suas características, contudo, não foram consideradas tão distintivas em relação às dos prefácios, como aponta Genette para o caso dos posfácios autorais.

Quanto ao nome do autor, Genette afirma que a inscrição do nome do autor, que nos parece hoje tão necessária e “natural”, nem sempre foi assim devido à prática do anonimato, mostrando que a invenção do livro impresso não impôs esse elemento do paratexto tão imediatamente quanto se poderia pensar em um primeiro momento. Portanto, aqui vale se fazer a primeira pergunta: o nome do autor aparece no livro? Em caso afirmativo, impõe-se a segunda pergunta: em que local paratextual o nome do autor se encontra? Genette afirma que esse lugar é ao mesmo tempo muito errático e muito circunscrito (GENETTE, 2011, p. 39). Errático por que se dissemina em todo o epitexto (anúncios, resenhas, prospectos, catálogos, etc.) e circunscrito porque seu lugar canônico e oficial limita-se à página de rosto e à capa (primeira capa, com eventual menção na lombada e na quarta capa). Porém, as inscrições na página de rosto e na capa não têm

(...) a mesma função: a primeira é modesta e por assim dizer legal, em geral mais discreta do que a do título; a segunda tem dimensões muito variáveis, conforme a notoriedade do autor e, quando as normas de coleção impedem toda e qualquer variação, uma sobrecapa lhe dá campo livre, ou uma cinta permite repeti-lo em caracteres mais chamativos e, por vezes, sem o prenome, para mostrar como é 
famoso. O princípio dessa variação na aparência é simples: quanto mais o autor é conhecido, mais seu nome é exibido, mas essa proposição exige, pelo menos, dois corretivos: primeiro, o autor pode ser famoso por razões extraliterárias, antes de ter publicado o que quer que seja; depois, uma prática promocional de tipo mágico (fazer como se fosse para conseguir que) impele o editor, às vezes, a aproveitar-se um pouco da glória imitando seus efeitos. (GENETTE, 2011, p. 40)

Em relação ao livro traduzido, a obrigatoriedade legal de localização do nome do tradutor, pelo menos no Brasil, é na ficha catalográfica e nos créditos, no verso na página de rosto, como veremos a seguir. Qualquer outra localização é determinada pelo editor ou pelas regras da coleção, que, em última instância, derivam de decisões editoriais. $\mathrm{O}$ fato de o nome do tradutor constar na página de rosto já é uma benesse, que dirá constar na capa. Tal como em relação ao nome do autor, a localização do nome do tradutor com destaque maior ou menor (em local mais visível e/ou com tipo maior) depende de sua notoriedade, que pode ser acadêmica (o fato de ser professor universitário, ter títulos de pós-graduação ou ser especialista naquele autor ou obra) ou autoral (o fato de ter obras publicadas em seu nome). Veremos, na análise dos dados, no Capítulo 5 desta tese, que essa afirmação se confirma e que os tradutores-escritores recebem bem mais destaque na capa do que os tradutores profissionais não autores. No caso dos tradutoresescritores, o profissional empresta uma identidade e uma fama em destaque a serviço do livro, para fins midiáticos. Em suma, o destaque do nome do tradutorescritor famoso ajuda a vender o livro, sendo do interesse dos editores que ele apareça. Se o tradutor for um ilustre desconhecido para o público em geral, seu nome em destaque seria uma prática inútil e contraproducente. O nome do tradutor famoso avaliza a qualidade da tradução e o editor atua como garante do tradutor, assim como o é do autor, pois o introduz e nomeia, dando-lhe o destaque devido à sua posição. Essa posição destacada pode ser reforçada por menções a afiliações acadêmicas ou graus e funções universitárias, além de menções a outros livros traduzidos ou escritos pelo tradutor. No corpus analisado, chegou-se a ver casos de existência de minicurrículos dos tradutores, com essas menções constando nas orelhas ou em páginas separadas. Alguns exemplos serão dados no Capítulo 5.

Genette diz ainda que o nome do autor da obra se reveste de três condições principais: o onimato (o fato de o nome do autor existir e estar visível no 
paratexto), o pseudonimato (o autor se assinar por nome falso, emprestado ou inventado) e o anonimato (inexistência do nome do autor) (GENETTE, 2011, p. 41). Em relação aos livros traduzidos do corpus analisado, os casos de onimato do tradutor são os mais frequentes, os de anonimato bem raros e os de pseudonimato não detectados, como veremos na análise dos dados. Portanto, toda a reflexão que Genette desenvolve a esse respeito não concerne a este trabalho diretamente.

\section{2}

\section{Estudos sobre o paratexto de livros traduzidos}

Em relação especificamente ao prefácio de tradutores, Sherry Simon (1990) destaca o papel híbrido do prefácio do tradutor, que é, ao mesmo tempo, discurso e ação. Pode-se encontrar aí o projeto de tradução, justificativas para estratégias e opções mais passíveis de crítica e discussão, apresentação do autor e da obra, etc. Simon aponta a possibilidade de os prefácios de tradutores serem estudados como um gênero literário específico, por conterem características próprias e reiterativas. Essa observação gerou a tentativa, apresentada no Capítulo 4 do presente trabalho intitulada "Estudos de gênero: o prefácio do tradutor como gênero discursivo", de se estudar o prefácio do tradutor como um gênero discursivo. A autora destaca duas características específicas de prefácios de tradutores: 1. distância entre seus significados respectivos e sua função efetiva (nem sempre o tradutor diz que fez o que realmente fez, além do que, nem tudo que fez é mencionado); 2. insistente repetição de um número limitado de temas, assim como claras indicações do papel essencialmente político das traduções e do ofício do tradutor. É preciso ter um cuidado especial na análise: nem sempre os prefácios de tradutores podem ser entendidos ao pé da letra, pois podem conter imprecisões, atenuações e meias-verdades com o intuito exclusivo de agradar a editores e leitores (SIMON, 1990, p. 110-117), observação também feita por Lefevere (2007), como apontado acima. Apesar de Simon dar essa indicação de o prefácio do tradutor poder ser estudado como gênero textual, não aprofunda ou estende essa análise.

Cristina Carneiro Rodrigues (2010), em sua análise dos paratextos escritos por tradutores de relatos de viagem de estrangeiros pelo Brasil, observou: 
A maior parte dos tradutores constrói o discurso de acolhimento ao autor nos prefácios, mas as traduções, os prefácios e as notas revelam certa tensão entre o declarado e o efetivamente realizado, havendo momentos de ruptura em que os sentidos do autor estrangeiro são questionados ou até mesmo negados. Em minha análise, isso ocorre porque as várias forças que atuam sobre o traduzir, como o autor, o tradutor, o texto a ser traduzido, as línguas envolvidas, o leitor, não agem linearmente, estão em constante tensão. (RODRIGUES, 2010, p. 47)

Rodrigues conclui a sua análise afirmando que os paratextos analisados por ela mostram interferências explícitas do tradutor, acolhendo ou questionando o autor traduzido. Apesar de essas interferências serem bem menos comuns na contemporaneidade, os tradutores continuam interferindo. A diferença é que, segundo ela, "eles o fazem do mesmo modo que os viajantes atribuem sentidos aos lugares que visitam” (RODRIGUES, 2010, p. 57).

Theo Hermans (1985, p. 103-135) diz que os prefácios de tradutores seguem convenções retóricas, que se modificam segundo a época. Em muitos, o tom é de modéstia (muitas vezes falsa), fazendo sobressair a dificuldade da tarefa, a excelência do modelo e a erudição do autor, ressaltando as relações hierárquicas entre os textos fonte e meta.

Lieven D’hulst, em sua obra Cent ans de théorie française de la traduction: de Batteux à Littré (1748-1847), analisa os prefácios de tradutores franceses a textos canônicos nos séculos XVIII e XIX e tira algumas conclusões a respeito da retórica dos prefácios desses tradutores. Apesar de o presente objeto de estudo estar circunscrito a obras traduzidas e publicadas no Brasil, no século XX e XXI, por estas serem obras clássicas e igualmente canônicas, algumas de suas conclusões podem igualmente se aplicar. Para D’hulst, o prefácio é um discurso normativo, cuja retórica determina a atitude do tradutor diante do texto original. Assim sendo, os traços textuais do original que se mostram incompatíveis com o modelo prefacial não são ressaltados ou são omitidos. O prefácio do tradutor, então, oscila entre dois padrões: comentários sobre as dificuldades da tradução, principalmente quando o original e a tradução estão muito apartados no tempo, e comentários próprios do historiador ou do crítico literário. O prefácio, então, pode aparecer como complemento do tratado literário ou do texto de crítica literária (D’HULST, 1991, p. 104-105). Assim sendo, o tradutor poderia assumir papéis diferentes ao longo do prefácio: o de tradutor, o de historiador e o de crítico. No 
papel de tradutor propriamente dito, pode ter uma postura ambivalente em relação ao texto original, ao mesmo tempo de compromisso com a fidelidade, como quer que definida, e com seu espírito recriador, que muitas vezes pode distanciá-lo desse conceito de fidelidade. Já no papel de historiador/crítico, ele adotaria um discurso didático e moralizador que sugere a conformidade do texto com modelos tradutórios canônicos, enquanto se posiciona como especialista ou exímio conhecedor do autor e da obra, afastando a possibilidade de questionamento a respeito de suas decisões e escolhas. É ao mesmo tempo um discurso que desvenda fragilidades, enquanto reforça uma posição de especialista e leitor atento, acima de qualquer possibilidade de crítica.

Além desses papéis apontados por D’hulst, Patrizia Bastianetto aponta um quarto: o de mediador cultural, que é partilhado com o editor e com outros que façam intervenções no paratexto do livro traduzido, facilitando ou dificultando sua legibilidade. Segundo Bastianetto: “(...) a inclusão, na edição traduzida, de textos elucidativos sobre a tradução, a obra e seu autor é um recurso que favorece a apreensão discursiva” (BASTIANETTO, 2005, p. 69). Porém, acredito que, se o discurso prefacial for de encontro ao que efetivamente foi feito na tradução, a legibilidade da obra pode ficar bastante prejudicada, criando no leitor uma apreensão discursiva ambígua ou equivocada.

Partindo das observações de Simon, Hermans, D’hulst e Bastianetto, interessa ver, entre outras características, se nos paratextos levantados na pesquisa ocorre essa repetição insistente de um número limitado de temas, convenções retóricas, posições ambivalentes e assunção de diferentes papéis por parte do tradutor. Em relação à recorrência de temas e convenções retóricas, no capítulo a seguir se poderá perceber uma forte correlação com a questão dos gêneros, quando desenvolvi um embrião de aplicação do modelo CARS ao subgênero prefácio de tradutor. Antes de se passar à descrição da metodologia utilizada e à análise mais aprofundada dos dados, no Capítulo 5, é interessante ressaltar outras posições teóricas muito pertinentes ao tema. Essas abordagens mais interessadas nos aspectos culturais e sociológicos da tradução podem ser incluídas sob a denominação geral de "sociologia da tradução", e estendem as conclusões de Genette para além do paratexto da obra original e para além dos aspectos retóricos dos prefácios, visando a englobar o “mundo externo” à edição e ao texto. 
Iulia Andreea Milica, em seu artigo sobre aspectos paratextuais de traduções de obras shakespearianas na Romênia, traça alguns comentários que concernem ao paratexto de obras traduzidas em geral (MILICA, 2012).

\begin{abstract}
A função de mediação e adaptação do texto aos leitores se torna ainda mais importante no caso de prefácios a traduções de obras literárias, em que o esforço do autor do prefácio é triplo, no sentido de que ele deve se referir ao texto, ao contexto da publicação do texto específico, bem como aos problemas que naturalmente derivam do processo de tradução e adaptação de um texto de uma língua para outra. Nesse caso, o foco e os tipos de explicações dadas no prefácio são diferentes. Assim, visto sob essa luz, o autor do prefácio se torna um participante importante nesse processo complexo envolvendo a criação, produção, publicação e recepção de literatura. (MILICA, 2012, p. 21)
\end{abstract}

Nesse sentido, dentre as funções do prefácio apontadas por Genette, a saber, definição, explicação, exploração, informação e recomendação, Milica ressalta essa última, acrescentando que a reputação do autor do prefácio é de grande importância para recomendar um texto e criar credibilidade para uma edição publicada específica (MILICA, 2012, p. 21). Essa recomendação pode ser feita de formas variadas quer se destine a um leitor mais sofisticado ou a um público geral. Na análise realizada no Capítulo 5, percebe-se que nas edições didáticas, visando a um público de estudantes principalmente, o tradutor quando escreve prefácios está mais preocupado em ilustrar e informar esse público, que pode ainda não conhecer aquele autor ou obra. Nessa posição de autor esclarecedor, o tradutor age como qualquer outro prefaciador especialista e não propriamente como tradutor. Entende-se, então, o fato de não tocar nos assuntos ligados à tradução. Em princípio, esses assuntos não interessariam ao público composto principalmente de estudantes jovens, muitas vezes secundaristas, que muitas vezes nem se dá conta da instância de tradução, encarando a obra traduzida como um original de fato. Outra posição é assumida pelo tradutor prefaciador quando a edição visa a um leitor mais sofisticado. É aí então que pode se “dar ao luxo” de tratar de assuntos pertinentes à tradução e suas dificuldades. Assim sendo, Milica ressalta, falando dos prefácios às obras de Shakespeare na Romênia, mas que se assemelham ao presente caso:

(...) é interessante notar como os autores de prefácios sutilmente adaptam seus textos de acordo com diferentes leitores alvo e são compelidos pelo tipo de publicação de um tipo específico de edição ou tipo de coleção. Esses prefácios 
contêm elementos comuns (...) As diferenças entre os prefácios decorrem principalmente do contexto político da publicação de uma edição ou tradução específica, do tipo de livro (livro de arte, capa dura ou brochura), do tipo de coleção e, muito importante, da personalidade do prefaciador, seja ele tradutor do texto prefaciado ou não, um escritor/poeta ou crítico, sendo que todos esses elementos contribuem para um resultado diferente. (MILICA, 2012, p. 26)

Já Sehnaz Tahir-Gurçaglar (2002) chama atenção para a decisão de Genette de deixar de lado a análise dos paratextos de livros traduzidos, bem como de publicações em série e ilustrações. Isso mostra a relutância de Genette em tratar dos aspectos problemáticos de se pensar a tradução como paratexto (ou metatexto, segundo a denominação que estou usando aqui). Isto é, ao se considerar a tradução uma atividade derivativa sempre baseada em outro texto cronologicamente anterior a ela, a tradução se torna um comentário sobre o texto original, uma característica paratextual que apresenta o original. Em consequência, muitas das questões caras aos Estudos de Tradução ficam desproblematizadas, a visão de tradução fica restringida (pois ficam excetuadas as pseudotraduções, obras que, apesar de se apresentarem como traduções, não se baseiam em textos originais anteriores), além de reforçar uma relação hierárquica entre o texto-fonte e o texto-meta, prevendo, entre outros, uma ascendência cronológica do texto-fonte sobre o texto-meta. Contudo, segundo TahirGurçaglar, o conceito de paratexto em Genette serve como base importante para um projeto de história da tradução que se proponha a estudar paratextos, porque oferece insights valiosos para a apresentação e recepção dos livros traduzidos. Ademais, segundo ela, o estudo do material paratextual e extratextual revela fenômenos tradutórios que ou estão ausentes dos próprios textos traduzidos ou apenas implícitos neles.

Tahir-Gurçaglar admite que os paratextos (principalmente epitextos) podem contribuir para processos ideológicos na sociedade, mas prefere se ater à análise de como os paratextos dão indicações sobre a definição de tradução por uma cultura ou, melhor ainda, perceber as definições divergentes de tradução e original dentro de uma mesma cultura. No Capítulo 5, ao falar da metodologia empregada, apresentaremos as questões que Tahir-Guçaglar considera pertinentes levantar na pesquisa tradutória histórica com base em paratextos. 
A abordagem que se convencionou chamar de "sociologia da tradução", adotada por teóricos como Michaela Wolf, Daniel Simeoni, Jean-Marc Gouanvic e outros, traz uma nova luz para o estudo do paratexto, especialmente para o prefácio do tradutor, por chamar atenção para o tradutor real e não para o tradutor ideal. Dessa feita, passou-se a investigar o tradutor como “agente”, não apenas sujeito a normas e restrições definidas de fora para dentro, que funcionam por reação, mas como um ser social que age e interage, podendo, em algumas situações e sob algumas circunstâncias, modificar essas limitações. Nas palavras de Eric Prunc:

O objetivo provisório desse desdobramento [sociologia da tradução] é a (re)incarnação do tradutor ideal — que agora se tornou o tradutor real — e sua reintegração nos espaços sociais e históricos em que são ao mesmo tempo aliados e rivais de outros agentes, e simultaneamente marionetes e atores centrais buscando garantir sua posição no campo social da tradução. (PRUNC, 2007, p. 43)

A abordagem da sociologia da tradução liga a noção de agentividade (agency) à de habitus, segundo a concepção do sociólogo Pierre Bourdieu, que diz respeito à capacidade de uma determinada estrutura social ser incorporada por seus agentes por meio de disposições para sentir, pensar e agir, uma verdadeira lei social incorporada. O habitus dos tradutores, de acordo com a abordagem sociológica de Prunc, não só envolve a internalização da subalternidade e da marginalidade, como também a atitude de ser superior a todos os outros, criando uma visão bipolarizada, para não dizer esquizofrênica, de si mesmo. Prunc aproxima essas duas atitudes das figuras do sacerdote, de um lado, e do pária, de outro. Como veremos no Capítulo 5 , as duas atitudes podem se expressar às vezes em um único prefácio, em que o tradutor começa alardeando seu conhecimento do autor e da obra, impondo-se como voz de prestígio de especialista respeitável, e termina com um pedido de desculpas por não ter atingido toda a grandeza do original. No trecho a seguir, Prunc nos explica no que concerne esses dois habitus do tradutor:

Os tradutores-sacerdotes se veem como guardiães da palavra e como guardiães do portal e construtores da cultura. Eles sabem que têm poder para selecionar, transformar e definir, o que também lhes fornece a chave para valores e verdades socialmente aceitas. (...) O habitus do pária é a mais extrema versão do habitus da "quintessência do servo" (...). Este habitus é a relíquia da marginalização 
histórica de tradutores e o resultado da invisibilidade imposta pelos outros ou por si mesmo. Os tradutores que adotam este habitus consideram o autor e poeta seu mestre e o cliente seu rei. Continuam a trabalhar por preços cada vez mais baixos e são ao mesmo tempo vítimas e originadores da espiral atual de redução dos preços que ameaça não apenas sua própria existência como também a reputação da profissão de tradutor. (PRUNC, 2007, p. 49)

Esses dois posicionamentos opostos, mas às vezes quase simultâneos, dos tradutores guardam uma clara ligação com o conceito de tradução que os tradutores expressam em seus prefácios, como vimos no Capítulo 2, quando discuti os conceitos preponderantes ao longo da história. De fato, os conceitos de tradução como traductio ou translatio são concomitantes na história da tradução mais contemporânea, muitas vezes ignorando por completo o conceito desconstrutivista de tradução e toda a sua implicação para o status do tradutor na sociedade. Apesar de, no mundo pós-moderno, a crença na identidade da palavra e da verdade ter sido posta em dúvida, e a noção da abertura de interpretações do texto ser bem aceita, os tradutores continuam a se esconder por trás da ilusão da objetividade. Prunc afirma: "Isso leva a uma constelação quase esquizofrênica de identidades de tradutores autoconstruídas que combinam o habitus de pária e o autossacrifício e automutilação exigidos por outrem” (PRUNC, 2007, p. 51). Os tradutores, em geral, relutam em aceitar seu envolvimento criativo na construção dos textos e encontram dificuldades para ultrapassar o habitus do servo, reforçando seu status de pária imposto ou autoconstruído e deixando de buscar uma autoimagem mais positiva e adequada a seu lugar importante inquestionável no mundo das trocas culturais. Veremos exemplos de expressão do habitus de pária nos exemplos levantados no Capítulo 5.

Outra contribuição muito importante para a teoria do paratexto do livro traduzido veio do tradutor português Jorge Almeida e Pinho, mencionado na Introdução desta tese. Pinho fez uma pesquisa semelhante ao estudo empreendido por mim, só que com tradutores portugueses de obras de autores de expressão inglesa. Na primeira fase de coleta de material, Pinho se defrontou com insuficiência de dados para análise (problema parecido com o enfrentado na minha pesquisa), inicialmente concebida para contemplar somente obras de prosa, problema este parcialmente solucionado com o alargamento do corpus para obras teatrais e poéticas. Reputou essa insuficiência de dados a quatro fatores: 
1. as obras traduzidas sofrem uma séria limitação no número de páginas concedidas pelos editores para as considerações dos tradutores;

2. na primeira edição, a exiguidade dos prazos para a tradução faz com que falte o tempo necessário para que os tradutores empreendam manifestações ponderadas sobre os processos de tradução utilizados;

3. muitos dos tradutores com maior "liberdade de expressão" são, não por acaso, autores de obras literárias, o que faz com que muitas das informações veiculadas nos prefácios/posfácios se adéquem mais a propósitos de pesquisa biográfica sobre os autores, de formulação de considerações estilístico-literárias acerca das obras traduzidas, ou mesmo de análise de dados relevantes sobre as correntes literárias em que se inseriam os autores traduzidos, em vez de privilegiar a análise de informações pertinentes sobre o ato tradutório (PINHO, 2006, p. 15).

A estes acrescento um quarto fator: o desinteresse das editoras, principalmente as maiores, em chamar atenção para o trabalho do tradutor. Ressaltar as considerações dos tradutores sobre seu trabalho pode ter duas consequências, que os editores podem querer evitar: 1 . o componente autoral do trabalho do tradutor pode pôr em dúvida a qualidade de certas traduções por parte do leitor (se as traduções são tão diferentes, algumas são melhores e outras piores); 2. se o ato tradutório é autoral e intelectual, envolvendo escolhas bem informadas, e não mecânico, deveria ser mais bem pago.

Não é por acaso, portanto, que encontramos mais prefácios/posfácios em editoras universitárias e editoras de menor porte, que podem ter interesse em ressaltar a qualidade das traduções feitas, no primeiro caso, por seus professores e, no segundo caso, por tradutores mais bem selecionados, o que constitui um diferencial das editoras de menor porte (muitas de propriedade de intelectuais). Hoje em dia, muitos dos editores de várias casas editoras grandes são executivos do setor editorial globalizado, às vezes com pouca identificação intelectual-afetiva com os livros que editam, selecionados muitas vezes somente pelo critério de vendagem no exterior. Quanto a isso, Pinho ressalta:

É até frequente verificar-se que os editores parecem esquecer-se convenientemente dos tradutores, como aliás já foi referido e veio a testemunharse ao longo desta investigação, remetendo-os para simples fichas técnicas das obras e parecendo conceder-lhes algum destaque apenas quando eles ocupam 
posição proeminente no mundo literário, também como autores de outras obras. (PINHO, 2006, p. 26)

Entre outros motivos que podem explicar, segundo Pinho, a falta de considerações teórico-práticas sobre a tradução está a falta de tempo de que os tradutores normalmente dispõem, tendo que lidar com prazos curtos e pagamento irrisório, compensado com a realização de vários trabalhos simultâneos. Por outro lado, às vezes o próprio tradutor não consegue se aperceber de tudo o que está envolvido no desempenho de sua atividade até o momento em que se detém para fazer algum tipo de reflexão crítica sobre o trabalho que efetuou. Essa atitude está enraizada na noção de que a tradução é uma atividade prática, isolada de teorizações ou mesmo de reflexões metodológicas (PINHO, 2006, p. 22). Desse modo, afirma Pinho: “o tradutor acaba por se tornar um estranho na análise da sua própria atividade, permitindo que outros, mais ou menos capacitados, discorram sobre a melhor forma de exercer uma atividade da qual muitas vezes desconhecem certos aspectos” (2006, p. 22). E mesmo quando fazem essa reflexão, muitos tradutores menosprezam seu próprio valor e o caráter interventivo de seu trabalho, acabando por dar razão aos que neles veem meros transmissores etéreos de uma mensagem original, essa sim valorizada e importante, em função do grande nome que a produziu. No caso de paratextos de traduções de clássicos em prosa da literatura francesa, esse estado de coisas é muito patente: o trabalho a ser ressaltado é o do autor e não o do tradutor, que basta fazer uma tradução fiel ${ }^{6}$ para ser bem sucedido. O número de prefácios/posfácios de tradutor em obras dramáticas e poéticas cresce, pois nesse caso aceita-se, e até espera-se, uma atitude mais intervencionista dos tradutores, um trabalho de adaptação - em que o tradutor teria mais liberdade para recriar, inserir e suprimir elementos e aproximar o texto da cultura de chegada - e não de mera "tradução", vista como mais literal. Pinho faz considerações acerca do conceito de tradução entre gêneros de texto, com base nos próprios prefácios dos tradutores. A tradução poética e dramática apresentaria um componente de recriação muito maior do que a tradução de prosa, sendo mais adaptativa (isto é, tendo um maior "grau de alterações sobre o texto poético original de modo a que a sua transposição seja

\footnotetext{
${ }^{6}$ A discussão sobre o conceito de fidelidade foi extensamente realizada no Capítulo 2, item 2.2, e todas as considerações lá tecidas valem para embasar as ideias apresentadas neste capítulo.
} 
possível” (PINHO, 2006, p. 88)). No Capítulo 5, Análise dos Dados, mostraremos os dados referentes às questões tratadas acima.

Pinho, em seu trabalho de análise, procurou extrair dos prefácios/posfácios de tradutores trechos referentes:

1. à motivação para a tradução daquela obra;

2. ao conceito de tradução que subjaz à tradução, diferenciando entre obras de prosa, teatro e poesia;

3. aos problemas mais concretos e próximos da execução do trabalho de tradução, isto é, os que decorrem de imposições editoriais, do estilo do autor, das opções tomadas pelo tradutor para transpor esse mesmo estilo ou mesmo dos recursos usados para suprir possíveis falhas (PINHO, 2006, p. 95).

No material levantado na presente pesquisa, pouco ou nada se diz sobre o primeiro item, e as considerações referentes aos dois outros itens aparecem bastante imbricadas, dificultando o trabalho de diferenciação dos dois aspectos. Como os trechos em que os tradutores falam de seu trabalho não são tão frequentes nem tão longos, os dois aspectos serão tratados ao mesmo tempo. Será, portanto, empreendida uma análise dos trechos compilados, fazendo a mesma diferenciação que Pinho considerou adequada, entre textos de prosa, poesia e teatro, sobre os assuntos mencionados acima (conceito de tradução e execução da tradução), para se tentar traçar um panorama da atividade tradutória no corpus reunido. O trabalho de Pinho será de grande valia para ajudar a empreender essa tarefa.

Com base nas observações realizadas em relação ao lugar e posicionamento do nome do tradutor na obra traduzida, depreendi uma hierarquização, em ordem decrescente de importância:

1. na capa (junto ou abaixo do nome do autor, normalmente em fonte menor);

2. na quarta capa;

3. nas orelhas;

4. na folha de rosto ou folhas iniciais;

5. no verso da folha de rosto (página de créditos); 
6. na ficha catalográfica;

7. não consta.

Antes de tecer quaisquer considerações a respeito dessas observações, é importante verificar o que diz a lei de direitos autorais brasileira a respeito da obrigatoriedade de constar o nome do tradutor em traduções publicadas.

A história dos direitos autorais no Brasil se inicia em 1831, no Código Criminal do Império, parte III, título III, sob o título “Crimes contra a propriedade”, art. 261, que criou indiretamente um direito autoral de reprodução a partir de um tipo incriminador que proibia a reprodução de escritos e estampas, compostos ou traduzidos por cidadãos brasileiros. A proteção conferida durava a vida do autor e mais dez anos após sua morte, na existência de herdeiros.

O Código Penal de 1890 continuou a legislar sobre a matéria, já de forma mais específica, no título XII, capítulo V, sob o título “Dos crimes contra a propriedade litteraria, artística, industrial e comercial”, arts. 342-350, determinando direitos autorais sobre leis e regulamentos oficiais, mantendo o prazo de vigência para os direitos de reprodução estabelecidos no Código Criminal do Império. Importante, ainda, foi uma menção à tradução, no art. 347, proibindo traduções não autorizadas, excetuando-se citações parciais para fins de crítica, polêmica ou ensino.

A normativa pátria de direitos autorais só deixa de estar circunscrita aos códigos penais para ser introduzida em dispositivo constitucional na Constituição de 1891. Sob o título IV ("Dos cidadãos brasileiros”), Seção II ("Declaração de direitos”), art. 72, o Parágrafo 26 estabeleceu: “Aos autores de obras literárias e artísticas é garantido o direito exclusivo de reproduzi-las pela imprensa ou por qualquer outro processo mecânico. Os herdeiros dos autores gozarão desse direito pelo tempo que a lei determinar”. As Constituições seguintes, com a exceção da de 1937, mantiveram a disposição em termos quase idênticos.

A legislação civil só viria a dispor sobre direitos autorais com a Lei no. 496, de $1^{\circ}$ de agosto de 1898 (Lei Medeiros de Albuquerque), sendo efetivamente a primeira lei de direitos autorais brasileira. A lei encara o direito do autor como privilégio, conferindo-lhe duração de cinquenta anos após o primeiro de janeiro do ano da publicação (art. $3^{\circ}, 1^{\circ}$ ), condicionada a proteção e depósito na Biblioteca Nacional, dentro de dois anos (art. 13), sob pena de o direito perecer. O 
direito de o autor fazer ou autorizar traduções, representações ou execuções também era limitado no tempo, pelo prazo de dez anos (art. $3^{\circ}, 2^{\circ}$ ). $\mathrm{O}$ art. 19 definiu contrafação ("todo o atentado doloso ou fraudulento contra o direito do autor”). A Lei Medeiros Albuquerque também inaugurou o mecanismo do rol de limitações aos direitos autorais, mantido até hoje.

A Lei n ${ }^{0} 2577$ de 17 de janeiro de 1912 estenderia as disposições da Lei Medeiros e Albuquerque a obras editadas no estrangeiro, bastando que se comprovasse o cumprimento das formalidades impostas pelo país de origem (art. $\left.2^{\circ}\right)$.

O Código Civil de 1916 substituiu as disposições da Lei Medeiros e Albuquerque, mas nela se inspirando, e assegurou o direito exclusivo de reprodução de obras literárias, científicas ou artísticas ao autor pelo período de sua vida, mais sessenta anos a herdeiros e cessionários, a contar do dia do falecimento (art. 649). O art. 66 trouxe um rol estendido a dez limitações aos direitos do autor e o art. 673 criou uma polêmica se o depósito da obra constituiria um direito ou se seria simplesmente comprobatório.

A Lei $n^{0}$ 5988/73 teve espírito mais empresarial, eliminando a ambiguidade do art. 673 do CC/16, acrescentando em seu art. 17 que o autor da obra pode registrá-la, sem estar a isso obrigado. O prazo de proteção para direitos patrimoniais foi modificado para a vida do autor, acrescido da vida dos sucessores, se filhos, pais ou cônjuge, ou 60 anos no caso de outros sucessores (art. 42, Parágrafos $1^{\circ}$ e $2^{\circ}$ ). A Lei de 1973 dá a entender que o nome do tradutor deve constar na edição, sendo sua redação pouco explícita nesse sentido.

A Lei de 1973 seria substituída pela Lei 9610 de 1998, que, juntamente com a Lei 9609 de 1998 (programas de computador), contém as principais normas de direitos autorais atualmente vigentes. Dentre as modificações relevantes inseridas na Lei 9610/98, podem-se citar as sérias restrições ao sistema de limitações, sob o ponto de vista do usuário (art. 46), modificação do prazo de proteção para a vida do autor, acrescida de setenta anos aos sucessores (art. 41) e setenta anos após a fixação para direitos conexos (art. 96) e proteção a bases de dados (art. 87). ${ }^{7}$

\footnotetext{
${ }^{7}$ Este breve resumo sobre a história dos direitos autorais no Brasil foi feito com base na dissertação de Mestrado, Função social da propriedade intelectual: compartilhamento de arquivos
} 
A obrigatoriedade de constar o nome do tradutor na obra está explicitada nesta Lei de 1998 (LDA, Título IV ("Da Utilização de Obras Intelectuais e dos Fonogramas”), Cap. I (“Da Edição”), art. 53, Lei 9610 de 19/02/1998).

Art. 53. Mediante contrato de edição, o editor, obrigando-se a reproduzir e a divulgar a obra literária, artística ou científica, fica autorizado, em caráter de exclusividade, a publicá-la e a explorá-la pelo prazo e nas condições pactuadas com o autor.

Parágrafo único. Em cada exemplar da obra o editor mencionará:

I - o título da obra e seu autor;

II - no caso de tradução, o título original e o nome do tradutor; ${ }^{8}$

III - o ano de publicação;

IV - o seu nome ou marca que o identifique.

Tal disposição, embora breve, é clara. Contudo, a lei 9610/98 não determina o lugar de inclusão desse nome, mas os regulamentos de produção da ficha catalográfica em vigor, determinados pela Biblioteca Nacional para obtenção do ISBN, estabelecem que o nome do tradutor tem que constar na ficha catalográfica. Ao se fazer a solicitação de número do ISBN com código de barras para constar na edição publicada, é preciso preencher uma ficha online onde é perguntado o nome do tradutor, tal como deverá constar na ficha catalográfica e nos registros na BN. Vê-se, portanto, que a lei vigente determina que o nome do tradutor obrigatoriamente tem que constar na obra e os procedimentos de registro na Biblioteca determinam que o nome do tradutor apareça minimamente na ficha catalográfica. A decisão de o nome do tradutor estar presente em outras partes do livro é uma decisão puramente editorial. Conclui-se ainda que a obrigatoriedade de constar o nome do tradutor na obra traduzida no Brasil data somente de 1973/1974 (alteração à lei de 1973). ${ }^{9}$

A hierarquização do aparecimento do nome do tradutor na obra traduzida proposta acima foi regida por critérios de visibilidade de leitura. Ainda nas livrarias ou nas bibliotecas, o leitor em primeiro lugar é atraído pelos dizeres da capa, quarta capa e orelhas, nesta ordem. São estes os elementos paratextuais com forte carga publicitária e imagética. Toda a arte de capa é trabalho de designers

e direitos autorais na CF/88, de Pedro Mizukami, de 2007, citada no blog http://hiperficie.wordpress.com/2010/01/06/historico-dos-direitos-autorais-no-brasil, de Paulo Rená, visualizado em 26/12/2013.

${ }^{8}$ Grifo meu.

${ }^{9}$ A advogada especializada em direito autoral brasileiro, Eliane Abrão, nos prestou alguns esclarecimentos neste sentido. 
cada vez mais especializados, que procuram trazer para o invólucro elementos significativos do miolo, empreendendo um pequeno resumo apelativo por meio de imagens e diagramação. O nome do tradutor na capa, e sequencialmente na quarta capa e nas orelhas, passa a fazer parte de todo esse apelo artístico e publicitário que envolve a programação visual das capas, conferindo-lhe uma maior projeção e destaque. No Brasil, ainda é considerado raro constar o nome do tradutor na capa, prática bem mais comum nas obras literárias traduzidas na França, por exemplo, mesmo que esse tradutor não seja um autor ou poeta de renome, mas, por sua atividade tradutória, tenha construído uma reputação de bom profissional.

Depois de apreciar a capa e quarta capa, o leitor normalmente abre o livro em suas primeiras folhas. Se nelas consta o nome do tradutor, é mais uma oportunidade para que se atente para quem foi que traduziu o livro. Por fim, no verso da folha de rosto, o nome do tradutor pode constar nos créditos acima da ficha catalográfica e necessariamente nesta. Desde 1998, a inexistência do nome do tradutor na obra traduzida é bem mais rara, por estar em flagrante violação à Lei 9610. 


\section{Estudos de gênero: o prefácio do tradutor como gênero discursivo}

\section{1}

\section{Estudos de gênero}

Ao término da fase da pesquisa na Biblioteca Nacional, uma constatação se fez presente: os prefácios/posfácios lidos têm características em comum e apresentam regularidades. Logo então surgiu a indagação de se o prefácio do tradutor não poderia constituir um gênero discursivo, ou pelo menos um subgênero dentro da categoria mais ampla de prefácios. Ficou clara desde então a necessidade do amparo na teoria dos gêneros discursivos, a fim de tentar trazer elementos que pudessem lançar luz a essa questão. Não pretendo, de forma alguma, fazer um trabalho específico na área dos gêneros, mas tão somente introduzir algumas das questões e discussões da teoria dos gêneros na teoria do paratexto. As pesquisas específicas nessa área estão hoje muito sofisticadas, com o auxilio de software para análise de corpora, como o WordSmith Tools, e se aplicam, de modo geral, a textos muito menos extensos do que os prefácios. Uma pesquisa específica da área de gêneros aplicada a prefácios de tradutores seria objeto de toda uma tese. Meu objetivo aqui é tão somente perceber recorrências nos prefácios de tradutor, a partir de aportes teóricos oriundos da teoria dos gêneros discursivos, para ajudar a teorizar os prefácios de tradutor dentro de uma teoria do paratexto do livro traduzido.

John Swales (1990), um dos principais teóricos dos estudos de gênero, de viés sociorretórico, mostra que o conceito de gênero surgiu, historicamente, na literatura e no folclore. Os estudos pioneiros de gênero no folclore datam do início do século XIX, sobre mitos, lendas e contos folclóricos germânicos, empreendidos pelos Irmãos Grimm, continuando posteriormente, sempre com uma preocupação de determinar categorias classificatórias para os gêneros. Outras abordagens de estudos subsequentes perceberam os gêneros como formas, consideradas permanentes, mudando apenas seu papel na sociedade. Os 
funcionalistas, como Malinowski, reforçaram o valor sociocultural dos gêneros folclóricos, contribuindo para a manutenção e sobrevivência de grupos sociais por servirem a suas necessidades sociais e espirituais. Apesar de alguns folcloristas atentarem para a evolução dos gêneros como uma reação necessária a um mundo em mutação, a maioria dos estudos de gêneros no folclore dá forte ênfase à estabilidade.

Ao contrário dos estudos de gênero no folclore, que se baseiam em sua maior parte na permanência da forma, os estudos de gênero na literatura desenfatizaram a estabilidade, pois sua preocupação sempre foi mostrar como um autor específico quebrava os moldes da convenção, apresentando sua importância e originalidade, enfatizando, portanto, a mudança e a transgressão. Todorov (1976, apud SWALES, 1990) mostra que o fato de as obras “desobedecerem” a seus gêneros não significa necessariamente que estes desaparecem, pois, para haver transgressão, é preciso que haja regulações a serem transgredidas. A mudança poderia vir da experimentação individual dos autores, mas também de fontes institucionais, ressaltando processos que permitem dizer que a questão das convenções dos gêneros e seu realinhamento é central para a evolução literária. A apreciação do gênero seria necessária para a apreciação literária, pois fornece um enquadramento interpretativo e avaliativo para a obra de arte, sendo esse enquadramento tanto textual quanto cultural, histórico, socioeconômico ou político.

Apesar de hoje a situação estar mudada, ao contrário dos estudos de gênero na literatura, os estudos de gênero na linguística historicamente desempenharam um papel secundário, perdendo em importância para o registro. Em muitos casos, gênero e registro eram usados como sinônimos, sofrendo diferenciação só muito recentemente na escola sistêmica. A discussão linguística a esse respeito é aprofundada e profícua, mas o que nos interessa aqui principalmente é ressaltar que o interesse, relativamente recente, da linguística pela teoria de gêneros teve um efeito muito produtivo, expandindo-a e enriquecendo-a com estudos de gênero oriundos dos ambientes acadêmicos, profissionais e institucionais. Segundo Swales (1990, p. 42), as contribuições linguísticas para o estudo do gênero em expansão enfatizam três aspectos: (a) gêneros vistos como tipos de eventos comunicativos orientados para uma meta; 
(b) gêneros como tendo estruturas esquemáticas; e (c) gêneros como dissociados dos registros e estilos.

Importante também é o estudo de gêneros na retórica. Desde Aristóteles, a investigação retórica veio assumindo um método mais dedutivo, construindo um sistema fechado de categorias de discursos do tipo expressivo, persuasivo, literário e referencial, com base nos componentes do processo de comunicação. Mais recentemente, os estudiosos da retórica assumiram uma abordagem mais indutiva e tenderam a levar o contexto mais em consideração. Essa abordagem tem maior interesse em esclarecer determinados aspectos sociais e históricos da retórica do que em classificar os tipos de texto. Nesse sentido, Carolyn Miller (1984) assume uma abordagem antitaxonomista, encarando os gêneros como entidades instáveis e os gêneros como ação social. Sua importância deriva de ter abarcado tipos de discurso normalmente desconsiderados pelos acadêmicos da retórica, e ter centrado a definição de gênero não no teor ou forma do discurso, mas nos objetivos comunicativos que se busca alcançar.

Swales (1990, p. 44-45) resume características em comum de como os gêneros são percebidos atualmente nas quatro disciplinas (folclore, literatura, linguística e retórica):

1. desconfiança na classificação e no prescritivismo fácil ou prematuro (a classificação não é feita a priori, mas sim como resultado de estudos de textos existentes);

2. crença de que os gêneros são importantes por integrarem o passado e o presente (os gêneros evoluem, mas se baseiam fortemente na tradição);

3. reconhecimento de que os gêneros estão situados dentro de comunidades discursivas, em que as crenças e práticas de apresentação dos membros são relevantes (ênfase no estudo do contexto e inserção);

4. ênfase no objetivo comunicativo e na ação social (escrever com conhecimento do gênero é garantia de sucesso no alcance do objetivo);

5. interesse na estrutura genérica e em sua lógica (estudo dos passos e movimentos característicos dentro do texto);

6. entendimento da dupla capacidade gerativa dos gêneros: estabelecer objetivos retóricos e promover seu alcance. 
Com base nessas ideias e na constatação de que o estudo dos gêneros se ampliou e ganhou importância nas últimas décadas, Swales (1990, p. 45-57) oferece uma caracterização de gêneros apropriada para objetivos aplicados:

1. Um gênero é uma classe de eventos comunicativos.

Um evento comunicativo é aquele em que a linguagem desempenha um papel significativo e indispensável, e compreende não apenas o discurso em si e seus participantes, mas também o papel desse discurso e do ambiente de sua produção e recepção, incluindo associações históricas e culturais.

2. O critério principal para tornar um conjunto de eventos comunicativos em um gênero é algum conjunto compartilhado de objetivos comunicativos.

O determinante principal para o pertencimento de um texto a um gênero é mais seu objetivo compartilhado na comunidade, do que semelhanças de forma ou outros critérios. Portanto, os gêneros são veículos comunicativos para o alcance de objetivos.

3. Os exemplares ou instâncias de gêneros variam em sua prototipicalidade.

O protótipo de cada gênero é, de certa forma, um ideal ou parâmetro. Os textos existentes, contudo, assumem graus variados de semelhança com esse protótipo. A questão do pertencimento a um gênero passa, portanto, pelo alcance de um certo grau mínimo de semelhança com o protótipo para esse gênero.

4. A lógica que está por trás de um gênero estabelece restrições a contribuições permissíveis em termos de conteúdo, posicionamento e forma.

Cada novo texto de um gênero "conversa" com os textos anteriores pertencentes ao mesmo gênero e compartilha propósitos. Reconhecimento de propósitos por parte dos usuários fornece uma lógica, que, por sua vez, dá ensejo a convenções limitadoras. As convenções evoluem e podem ser questionadas, mas continuam a exercer influência. Os usuários de um gênero estabelecem um diálogo entre si, mesmo que seus escritos não sejam uma reação aos escritos de outros usuários.

5. A nomenclatura de uma comunidade discursiva em relação aos gêneros é uma fonte importante de insight.

Aqui percebe-se uma relação interessante dos estudos de gênero com a terminologia. Os usuários de um determinado gênero desenvolvem uma nomenclatura usada por uma comunidade discursiva ou se apoiam em uma 
nomenclatura conhecida para se fazerem entender, dificultando o entendimento de quem não participa ou não é iniciado nessa comunidade discursiva.

Ao final de todas essas considerações tão profícuas, Swales (1990) apresenta uma definição de gênero:

Um gênero compreende uma classe de eventos comunicativos, cujos exemplares compartilham os mesmos propósitos comunicativos. Esses propósitos são reconhecidos pelos membros mais experientes da comunidade discursiva original e constituem a razão do gênero. A razão subjacente dá o contorno da estrutura esquemática do discurso e influencia e restringe as escolhas de conteúdo e estilo. O propósito comunicativo é o critério que é privilegiado e que faz com que o escopo do gênero se mantenha enfocado estreitamente em determinada ação retórica compatível com o gênero. Além do propósito, os exemplares do gênero demonstram padrões semelhantes, mas com variações em termos de estrutura, estilo, conteúdo e público-alvo. Se forem realizadas todas as expectativas em relação àquilo que é altamente provável para o gênero, o exemplar será visto pela comunidade discursiva original como um protótipo. Os gêneros têm nomes herdados e produzidos pelas comunidades discursivas e importados por outras comunidades. Esses constituem uma comunicação etnográfica valiosa, porém normalmente precisam de validação adicional. (SWALES, 1990, p. 58) ${ }^{10}$

A mudança ocorrida no estudo de gêneros escritos é relativamente recente. Historicamente, os pesquisadores, quando queriam examinar um determinado gênero, buscavam perceber regularidades de forma e efeito em vários textos supostamente pertencentes àquele gênero. A reinterpretação do gênero como ação social, empreendida pela abordagem sociorretórica no estudo dos gêneros, gerou uma busca por um padrão complexo de atividade social repetida e desempenho retórico em resposta a uma situação recorrente. Segundo essa abordagem, então, quais seriam os elementos constituintes de um gênero?

Paré e Smart (1994) formularam essa pergunta na pesquisa do uso e influência dos gêneros em ambientes de trabalho. Suas conclusões, no entanto, podem ser utilizadas em outras instâncias de pesquisa de gêneros, por serem amplas e abrangentes. Com base em uma perspectiva construcionista social, os autores afirmam que: "um gênero escrito pode ser visto como uma estratégia retórica ampla sancionada dentro de uma comunidade, a fim de regularizar transações autor/leitor de forma a permitir a criação de um conhecimento específico” (1994, p. 146).

\footnotetext{
${ }^{10}$ A tradução do trecho em destaque está em HEMAIS \& BIASI-RODRIGUES, 2005, p. 114.
} 
Bazerman sugere que um gênero está associado a um padrão de regularidade que inclui não apenas características repetidas em vários textos, mas também regularidades na produção e interpretação desses textos em relações sociais de autores e leitores. Utilizando-se da teoria dos atos de fala de Austin, Bazerman afirma que, nos textos que constituem um gênero, a análise do efeito perlocucionário (“o modo como as pessoas recebem os atos e determinam as consequências deste ato para futuras interações”), para além das tipificações da forma textual, ilumina o caráter psicossocial de um gênero, isto é, os gêneros emergem nos processos sociais em que pessoas tentam se compreender de forma suficiente a bem coordenar atividades e compartilhar significados para o alcance de objetivos práticos (BAZERMAN, 2005, p. 31).

Incorporando a contribuição de Bazerman, Paré e Smart (1994) procuraram definir os gêneros como um perfil distintivo de regularidades por quatro dimensões: um conjunto de textos, os processos de composição envolvidos na criação desses textos, as práticas de leitura usadas para interpretá-los e os papéis sociais desempenhados por autores e leitores.

Quanto às regularidades nas características textuais, os padrões repetidos na estrutura, movimentos retóricos e estilo dos textos são os aspectos mais prontamente observáveis do gênero. Assim sendo, podem-se observar componentes individuais de um texto genérico, sua sequência usual e sua função ou objetivo comum. Os textos pertencentes a um gênero empregam movimentos retóricos particulares, e esses movimentos geram um estilo comum discernível nos textos genéricos. Os movimentos retóricos são blocos de informações de extensões variadas, desempenhando funções particulares. Os movimentos retóricos reunidos constituem a forma e a função do gênero. Nesse sentido, Swales desenvolveu o modelo CARS (Create $\underline{A}$ Research Space) que será preliminarmente descrito e aplicado mais adiante nesta seção ao material selecionado (HEMAIS \& BIASI-RODRIGUES, 2005, p. 120-127).

Já quanto às regularidades nos papéis sociais, percebe-se que autores e leitores desempenham vários papéis nas organizações e comunidades e na criação e uso dos textos, porém certos papéis são específicos a determinado tipo de texto. Esses papéis e redes de relacionamentos que os ligam são genéricos, servindo para regular a interação social, bem como a escrita e a leitura envolvidas na produção 
de conhecimento. No caso dos prefácios dos tradutores, como veremos adiante, o papel desempenhado pelo tradutor vai bem além do didatismo ou do depoimento episódico, para servir como exemplo a ser seguido, para o bem ou para o mal, ou fomentador de uma consciência maior do papel do tradutor na sociedade. Existe um propósito patente de divulgação de um projeto tradutório e, muitas vezes, um propósito subjacente de desejo de aumento de visibilidade do tradutor em termos sociais. O tradutor, na escrita de um prefácio, pode desempenhar papéis variados de educador, instrutor, divulgador e questionador. Mais adiante, abordaremos especificamente a contribuição de Bakhtin e Miller para a teoria dos gêneros e, na análise a ser desenvolvida posteriormente, veremos exemplos retirados do material de pesquisa.

Em relação às regularidades nos processos de composição, Paré e Smart (1994, p. 150) utilizam essa noção para abarcar uma ampla gama de atividades por parte do autor do texto:

1. um evento iniciador;

2. coleta de informações (como entrevistas, participação em reuniões, observação de atividades de trabalho e leitura de documentos);

3. análise das informações (identificação de padrões significativos, definição de problemas e formação de opiniões);

4. escrita individual e reescrita;

5. atividades colaborativas (brainstorming, composição conjunta, compartilhamento de versões preliminares, revisão e avaliação) e

6. a tecnologia de produção (digitação, processamento de texto, correio eletrônico).

O ambiente de pesquisa de Paré e Smart é o ambiente institucional, observando dois gêneros específicos: o relatório escrito por um assistente social ao juiz com seu parecer a respeito de processos de menores considerados culpados de crimes e a proposta de automação bancária. Apesar de o universo dos prefácios/posfácios de tradutores ser bem díspar, alguns desses passos são comuns ou semelhantes aos descritos pelos autores Paré e Smart no processo composicional. Normalmente, os prefácios/posfácios são escritos após a tradução e se referem a ela no passado, apesar de, na apresentação dos livros, os prefácios se situarem antes dos textos propriamente ditos. Eles desempenham uma dupla 
função quando situados antes do texto: a preparação da leitura (informações didáticas) e a antecipação de questões (informações sobre o projeto tradutório). Imagina-se que o leitor lerá o prefácio antes do texto (o que nem sempre é verdade, pois ele pode ler o prefácio após o texto ou nem sequer lê-lo). Já, ao se situar após o texto, o posfácio do tradutor normalmente fala mais de questões tradutórias, desempenhando função menos didática e mais reflexiva.

No que concerne às regularidades nas práticas de leitura, Paré e Smart compartilham uma noção igualmente ampla (PARÉ \& SMART, 1994, p. 152):

1. a forma como o leitor aborda um texto (onde, quando e por que lê-lo);

2. como o leitor negocia seu processo de leitura do texto (previsão do que se segue, decisão a respeito de quais partes ler e quais saltar);

3. como o leitor constrói conhecimento a partir do texto (as questões formuladas, as estruturas interpretativas explicitadas) e

4. como o leitor usa o conhecimento resultante (por exemplo, para praticar uma ação, tomar uma decisão ou participar do processo de tomada de decisão e produção de outros textos).

No que tange aos prefácios/posfácios de tradutores, estes se dirigem implicitamente a duas classes de leitores muito particulares: os críticos e outros tradutores. Ao descreverem seu processo tradutório e justificarem certas decisões, os tradutores visam a escapar de críticas mal informadas à tradução por parte dos críticos e de seus pares. Estes podem ficar convencidos, gerando aceitação e elogios por parte dos críticos e aceitação e inspiração para os outros tradutores. Os prefácios dos tradutores são muitas vezes usados como espaço de pedido de desculpas, visando a elevar a boa vontade desses leitores especiais para com a tradução.

Paré e Smart (1994, p. 153) concluem, então, que o estudo de gêneros deve abarcar essas quatro dimensões (exame das características textuais, dos processos de escrita, das práticas de leitura e dos papéis sociais) para ver como atuam como uma heurística positiva ou negativa. No trabalho a ser desenvolvido, alguns desses aspectos serão analisados, mas outros não, pois dependeriam de entrevistas com tradutores e leitores.

Paré e Smart, por fim, ressaltam que a definição de categorias de análise gera um ganho e uma perda. O ganho é no controle e a perda é na realidade: 
“Gêneros são ações sociais complexas, e as dimensões que descrevemos não são discretas nem mutuamente exclusivas; elas são recíprocas e interativas” (PARÉ \& SMART, 1994, 153). Ampliando a definição de gênero de Miller (1994, p. 159), "gêneros são ações retóricas tipificadas baseadas em situações recorrentes”, sugerem que "gêneros são ações retóricas tipificadas $\underline{e}$ ações recorrentes” (PARÉ \& SMART, 1994, p. 153-154), o que muda ligeiramente o enfoque. As citações de Paré e Smart como de Miller acima clareiam e fundamentam a análise das recorrências nos prefácios/posfácios de tradutores. Mais do que coincidências, essas repetições podem mostrar, por um lado, que os tradutores leem os prefácios/posfácios de outros tradutores, e dialogam com eles, reafirmando posições e reiterando ações. O fato de terem um espaço na edição para apresentarem suas ideias poderia parecer, à primeira vista, uma boa oportunidade para os tradutores saírem das sombras e marcarem posições de valorização de seu trabalho. Porém, o que se vê na maior parte das vezes é uma repetição ad nauseam de chavões e ideias feitas que só servem para esvaziar essa oportunidade de afirmação e desperdiçar a chance de reposicionamento na sociedade. As recorrências no gênero prefácio de tradutor reforçam a posição subserviente, falsamente humilde e pouco inovadora de seus usuários. É uma ação social às avessas.

Para a observação de regularidades textuais, que nos interessam particularmente neste trabalho, Swales desenvolveu o modelo CARS, descrito a seguir. Apesar de Swales nortear sua abordagem da observação dos gêneros para o ensino de produção de textos, o seu modelo de análise serve como aplicação em pesquisas. Embora tenha feito reformulações de suas ideias ao longo do tempo, há uma ideia que permeia toda a sua produção, a de que o gênero deve ser visto e interpretado não só por meio da análise de elementos linguísticos, mas também em seu contexto. As influências que sofreu para elaborar sua própria abordagem foram múltiplas e variadas:

1. estudos das variedades funcionais do inglês,

2. estudos das quatro habilidades na aprendizagem;

3. abordagens de noções e funções na área de aprendizagem; 
4. a análise do discurso (estrutura temática, coesão, coerência e macropadrões) e 5. teoria de ensino de produção de textos (HEMAIS \& BIASI-RODRIGUES, 2005, p. 109-110).

Analisando as conclusões aos estudos de gêneros oriundas do folclore, literatura, linguística e retórica, Swales deu uma contribuição significativa para a definição de gênero vista acima: a ideia de classe (gênero como classe de eventos comunicativos, sendo que nos eventos a linguagem verbal tem papel significativo e indispensável), a ideia de que os eventos compartilham um propósito comunicativo, a prototipicidade, a razão ou lógica subjacente ao gênero e a terminologia elaborada pela comunidade discursiva para seu próprio uso. Destes, o conceito de comunidade discursiva e o de propósito discursivo merecem maiores detalhes.

Swales definiu a noção de comunidade discursiva (1990, p. 24-26) e a redefiniu posteriormente ainda na década de 1990. É importante ressaltar que o conceito de comunidade discursiva é diferente do de comunidade interpretativa de Stanley Fish (1980), que é a comunidade que nos fornece uma forma particular de ler e interpretar um texto, destacando que as leituras de um texto são culturalmente construídas. Já Swales define comunidade discursiva a partir de quatro características: 1 . uma comunidade discursiva é um conjunto amplamente acordado de objetivos públicos comuns (objetivos compartilhados são o critério mais importante na identificação de uma comunidade discursiva); 2. uma comunidade discursiva possui mecanismos de intercomunicação entre seus membros (os participantes da comunidade devem ter mecanismos de comunicação comuns); 3. uma comunidade discursiva usa seus mecanismos participatórios principalmente para fornecer informações e feedback (os membros da comunidade se envolvem nas comunicações recebidas e participam das suas atividades); 4. uma comunidade discursiva utiliza e possui um ou mais gêneros na persecução comunicativa de suas metas (uma comunidade discursiva tem a capacidade de desenvolver seu próprio elenco de gêneros) e desenvolve um léxico próprio (por vezes, dificultando bastante o entendimento pelos "leigos" situados fora da comunidade). O conceito de comunidade interpretativa de Fish está relacionado à leitura, interpretação e recepção de textos, ao passo que o conceito de comunidade discursiva de Swales está relacionado à elaboração de discursos, principalmente 
no âmbito de gêneros discursivos determinados, promovendo o desenvolvimento de formas características e jargões.

Em suas reformulações posteriores à noção de comunidade discursiva, Swales tentou sanar os pontos fracos de sua definição acima, a saber, o fato de a comunidade discursiva ser concebida como um grupo verdadeiro e estável, marcado pelo consenso em suas posições, e a não introdução da noção de avanço e novidade que caracterizam as comunidades. Em sua reformulação, Swales conclui que uma comunidade retórica "persiste por instanciação e envolvimento, em vez de existir por associações e coletividade” (SWALES, 1993, apud HEMAIS \& BIASI-RODRIGUES, 2005, p. 116-117).

A definição original também não falava da existência de conflitos dentro das comunidades e, além disso, só se aplicava a comunidades já formadas, sem contemplar as comunidades em fase embrionária ou em transição, que não possuem gêneros que as identifiquem devido à instabilidade e a seus traços linguísticos.

Quanto a se os tradutores brasileiros compõem ou não uma comunidade discursiva, segundo a noção original, mais estreita e fechada, é provável que não. Os tradutores brasileiros normalmente trabalham isolados, mas alguns, ao longo do tempo, e mais marcadamente nas últimas décadas, tiveram a preocupação de se reunirem em associações, para discutir questões práticas e de defesa do ofício. A partir dos anos 1970, quando os primeiros cursos de tradução no país começam a se formar, uma consciência crítica se desenvolveu entre os tradutores mais jovens juntamente com seus professores, estendendo-se posteriormente para a comunidade de tradutores em geral. Esse movimento não foi feito sem resistências dos tradutores mais antigos, que viam com desconfiança os cursos e as ideias acadêmicas desenvolvidas, muitas delas distanciadas da prática tradutória real. Hoje, com os fóruns não só de reunião física, como principalmente virtuais, os tradutores encontraram canais de comunicação e discussão importantíssimos para o desenvolvimento da profissão. Nesse sentido, na visão mais alargada de comunidade discursiva de Swales, certamente os tradutores brasileiros compõem uma delas, tendo como um de seus gêneros característicos o prefácio do tradutor.

A noção de propósito comunicativo também sofreu uma revisão por Swales com o passar do tempo, principalmente incorporando contribuições da 
gramática sistêmico-funcional de Halliday e priorizando o contexto. Por ser menos visível do que a forma, o propósito comunicativo é sempre mais difícil de identificar. Em coautoria com Askehave, Swales (ASKEHAVE \& SWALES, 2001) acaba chegando a uma noção de propósito comunicativo não predominante ou central, mas como um critério privilegiado da investigação. Eles propõem dois procedimentos possíveis para a identificação do gênero: um procedimento textual/linguístico (exame da estrutura do gênero, estilo e conteúdo) e procedimento contextual (identificação da comunidade, seus valores, suas expectativas, e seu repertório de gêneros, além dos traços dos gêneros que fazem parte do repertório da comunidade). Percebe-se, portanto, que a visão de Swales a respeito dos gêneros foi se complexificando com o tempo, apontando uma interdependência entre o texto e o contexto.

O trabalho de Swales que deu origem ao modelo CARS foi elaborado com base em um corpus inicial de 48 introduções de artigos de pesquisa e, em uma segunda etapa, em mais de 110 introduções de três áreas diferentes (física, educação e psicologia). Os resultados da pesquisa ressaltaram, em um primeiro momento, uma regularidade de quatro movimentos no gênero artigos de pesquisa, isto é: movimento 1 - estabelecer o campo de pesquisa; movimento 2 - sumarizar pesquisas prévias; movimento 3 - preparar a presente pesquisa; movimento 4 introduzir a presente pesquisa (SWALES, 1984, p. 80, apud HEMAIS \& BIASIRODRIGUES, 2005, p.120-122).

Em uma reformulação posterior, o autor reduziu os quatro movimentos para três e acrescentou vários passos em cada um dos movimentos, como segue:

\section{MOVIMENTO 1: ESTABELECER O TERRITÓRIO}

Passo 1 - Estabelecer a importância da pesquisa e/ou

Passo 2 - Fazer generalização(ões) quanto ao tópico e/ou

Passo 3 - Revisar a literatura (pesquisas prévias)

\section{MOVIMENTO 2: ESTABELECER O NICHO}

Passo 1A - Contra-argumentar ou

Passo 1B - Indicar lacuna(s) no conhecimento ou

Passo 1C - Provocar questionamento ou

Passo 1D - Continuar a tradição 


\section{MOVIMENTO 3: OCUPAR O NICHO}

Passo 1A - Delinear os objetivos

Passo 1B - Apresentar a pesquisa

Passo 2 - Apresentar os principais resultados

Passo 3 - Indicar a estrutura do artigo

Entre os passos, Swales subdividiu-os em opcionais e obrigatórios, descrevendo-os minuciosamente e ilustrando suas características com trechos prototípicos (SWALES, 1990, p. 141, apud HEMAIS \& RODRIGUES, 2005, p. 120-121).

Acredito que trabalho semelhante possa ser feito com os prefácios/posfácios de tradutores, que apresentam movimentos e passos, só que em posições variantes e nem todos sempre presentes. Os prefácios/posfácios de tradutores, quando comparados aos artigos de pesquisa, apresentam uma estrutura bem menos rígida e delimitada. As apresentações de pesquisa se moldam a um formato preexistente, enquanto que os prefácios/posfácios de tradutores têm características mais autorais, emotivas e literárias. Os tradutores literários, como é o caso aqui, costumam estabelecer laços afetivos com as obras que traduzem e fazem afirmações entremeadas de reminiscências e sensações.

Adriana Rigueira (RIGUEIRA, 2010), que estudou a organização retórica e avaliação em resenhas de filme, faz uma observação em relação ao seu objeto de estudo, quando comparado ao gênero "resenha acadêmica", que pode muito bem ser transposta para os prefácios/posfácios de tradutor. Ela diz que a resenha de filme é um gênero mais informal, com possibilidades mais "elásticas”, menos presas a formas, permitindo uma liberdade de expressão maior e criando uma maior proximidade com o leitor. Ela afirma: “autores de gêneros voltados para o grande público, como os gêneros jornalísticos, possuem mais liberdade de posicionamento interpessoal que aqueles que trabalham em contextos acadêmicos” (RIGUEIRA, 2010, p. 16). De toda feita, traços característicos podem ser ressaltados, sendo que os movimentos podem ser numerados para efeitos de identificação, mas normalmente não aparecem em ordem rígida.

Os movimentos e passos abaixo foram depreendidos da leitura dos prefácios recolhidos na pesquisa, em uma sequência lógica. Contudo, como 
veremos pela análise de casos concretos, a ser realizada no final deste capítulo, é difícil que os prefácios apresentem todos esses itens, seguindo a sequência apontada.

MOVIMENTO 1 - APRESENTAÇÃO DA EDIÇÃO

MOVIMENTO 2 - BIOGRAFIA DO(S) AUTOR(ES)

Passo 2A - Fatos histórico-biográficos

Passo 2B - Escola literária de pertencimento

Passo 2C - Fontes e influências

MOVIMENTO 3 - O CONJUNTO DA OBRA E A OBRA ESPECÍFICA

Passo 3A - Significado da obra específica no conjunto da obra

Passo 3B - Análise literária (estilo, temas, construção literária)

Passo 3C - Exemplos concretos

MOVIMENTO 4 - DIFICULDADES/PECULIARIDADES DA TRADUÇÃO

Passo 4A - Exemplos concretos

MOVIMENTO 5 - JUSTIFICATIVAS PARA O PROJETO TRADUTÓRIO

Passo 5A - Descrição do projeto tradutório

Passo 5B - Contribuições teóricas

Passo 5C - Possíveis deficiências da tradução

Passo 5D - Perspectiva humilde, com ou sem pedido de desculpas

Um outro aspecto da teoria dos gêneros discursivos que ganhou bastante destaque nas últimas décadas foi o do gênero como ação social, defendido por Carolyn Miller, em grande parte baseado no conceito de dialogismo de Bakhtin, avançado no seu famoso artigo “Os gêneros do discurso” (BAKHTIN, 2011), e também nos conceitos de reação e interatividade. Swales (1990, 2004), Miller (1994) e Bazerman (2005), já mencionados anteriormente, são expoentes da escola de estudos de gêneros norte-americana, que se caracteriza, de modo geral, por uma ênfase na natureza social do discurso. Além de Bakhtin, o grupo recebeu a influência da nova retórica no contexto norte-americano, associada ao ensino de estratégias de persuasão e preocupações pedagógicas acerca do ensino de composição argumentativa, contribuindo em grande parte para a popularização da retórica no contexto acadêmico (CARVALHO, 2005, p. 130-131). Essa nova 
abordagem traz à posição de frente as noções de propósito e contexto e, segundo Carvalho: "passa-se então a olhar a fala ou a escrita como instâncias cujo objetivo é atingir determinado propósito em certa situação social, em vez de se prestar atenção exclusiva ao texto ele mesmo, como artefato linguístico apenas” (CARVALHO, 2005, p. 131).

O termo gênero usado em linguística tem sido associado ao trabalho de Bakhtin voltado para a interação verbal e à orientação dialógica do discurso. Bakhtin se distancia da oração como unidade de análise, pois reconhece o enunciado como unidade de comunicação verbal, delimitada pela alternância dos falantes. Assim sendo, mais importante do que o enunciado em si é o ato de comunicação, a possibilidade de diálogo e interação entre os falantes. Para ele também importa a noção de propósito ou “finalidade”, uma preocupação que permeia muitas das teorias de gêneros hoje em voga. Ressalta ainda a questão da estabilidade dos enunciados como característica do gênero: “cada enunciado particular é individual, mas cada campo de utilização da língua elabora seus tipos relativamente estáveis de enunciados, os quais denominamos gêneros do discurso” BAKHTIN, 2011, p. 262). A questão da estabilidade dos gêneros está também na base de muitas das teorias de gênero atuais, algumas encarando os gêneros como mais estáveis (escola australiana), outras como mais dinâmicos (escola norte-americana). Como consequência, as primeiras tendem a dar mais importância às análises linguísticas de características textuais e as segundas mais atenção às relações entre texto e contexto.

A distinção que Bakhtin faz entre gêneros primários e secundários contribuiu bastante para que a teoria dos gêneros saísse da seara da literatura e ganhasse mundo:

Não se deve, de modo algum, minimizar a extrema heterogeneidade dos gêneros discursivos e a dificuldade daí advinda de definir a natureza geral do enunciado. Aqui é de especial importância atentar para a diferença essencial entre os gêneros discursivos primários (simples) e secundários (complexos) - não se trata de uma diferença funcional. Os gêneros discursivos secundários (complexos - romances, dramas, pesquisas científicas de toda espécie, os grandes gêneros publicísticos, etc.) surgem nas condições de um convívio cultural mais complexo e relativamente muito desenvolvido e organizado (predominantemente o escrito) artístico, científico, sociopolítico, etc. No processo de sua formação eles se incorporam e reelaboram diversos gêneros primários (simples), que se formaram nas condições da comunicação discursiva imediata. (BAKHTIN, 2011, p. 263) 
Os gêneros secundários, assim, derivam dos primários, o que remete à questão de sua estabilidade relativa: são respostas a situações sociais recorrentes, mas também meios de organizar a experiência humana, atribuindo-lhes sentido. Os gêneros nos ajudam a interpretar o mundo e nele agirmos com eficácia, desde que conheçamos as características e exigências dos variados gêneros. Bakhtin aponta que, nos gêneros secundários, o locutor/escritor formula perguntas e as responde, opõe objeções e ele mesmo as refuta, mesmo que isso se realize nos limites de um único enunciado (BAKHTIN, 2011, 293-295).

No caso dos prefácios/posfácios de tradutores, a ideia de diálogo e interação entre os autores é bastante patente. Dentre os leitores informados que leem prefácios de tradutores estão especialmente outros tradutores. As questões levantadas nos prefácios/posfácios de tradutores certamente influenciarão outros tradutores em futuras traduções ou suscitarão discussões, debates e discordâncias. Cria-se, então, um “diálogo” em que não é o término da fala de alguém que dá a vez para outro alguém falar, mas é a publicação de um prefácio/posfácio de tradutor que dá a vez para outro tradutor se manifestar a respeito de questões levantadas e outras suscitadas pelos textos iniciais, sendo essa uma característica marcante dessa comunidade discursiva. A noção de gênero secundário de Bakhtin guarda semelhanças com a noção de subgênero, pois tal como o gênero secundário deriva do primário, o subgênero deriva do gênero. Assim, talvez fosse mais pertinente encarar o prefácio de tradutor como um subgênero em relação ao gênero prefácio, que guarda semelhança na organização retórica, mas que possui características próprias, específicas ao contexto da tradução.

De especial interesse é a abordagem de Miller (1984/1994) do gênero como ação social e sua ênfase nas noções de recorrência e ação retórica.

O gênero como ação social aponta para critérios pragmáticos como delimitação para os gêneros, ultrapassando definitivamente as fronteiras do texto. Na situação retórica é preciso, então, perceber não só características do contexto ou das demandas situacionais identificadas pelos usuários e dentro das quais operam, mas também a motivação dos participantes do discurso, assim como os efeitos por eles pretendidos e/ou percebidos. A questão é retórica e não meramente situacional, pois se percebeu que os propósitos dos usuários são componentes essenciais da situação. Segundo Miller, para a teoria dos gêneros é 
importante que as situações retóricas sejam recorrentes, para que possam ser tipificadas a partir de analogias e semelhanças relevantes. O gênero, assim, tem as seguintes características:

1. refere-se a categorias convencionais do discurso com base em tipificação em larga escala da ação retórica;

2. é interpretável por meio das regras que o regulam;

3. é distinto em termos de forma, mas é uma fusão entre forma e conteúdo;

4. ajuda a constituir a substância de nossa vida cultural e

5. é mediador entre o público e o privado, conectando o singular com o recorrente (MILLER, 1984/1994, p. 36-37).

A definição de Miller para o gênero é então “ações retóricas tipificadas baseadas em situações recorrentes” (MILLER, 1984/1994, p. 32). O gênero seria então um tipo particular de fusão entre conteúdo e forma, gerando um significado simbólico. O conteúdo seria retirado da “ação conjunta” da comunidade retórica, que confere a seus membros sensações, conceitos, imagens, ideias e atitudes comuns. A forma é percebida na maneira como o conteúdo é simbolizado. Um texto tem uma forma característica quando leva ao leitor a prever a parte seguinte, orientando a leitura e a interpretação. A forma molda a reação do leitor ou ouvinte ao conteúdo fornecendo instruções sobre como perceber e interpretar, sendo que essa orientação predispõe a plateia a prever, ficar gratificada e a reagir de uma determinada forma. Segundo Miller: “Assim, a forma se torna um tipo de metainformação, com valor semântico (como informação) e sintático (ou formal). Forma e conteúdo estabelecem uma relação hierárquica um com o outro” (MILLER, 1984/1994, p. 32).

Os prefácios/posfácios de tradutores constituem ações retóricas que recorrem em certas situações, com menos tipificação do que Miller afirmaria. O conteúdo vem da "ação conjunta" da comunidade de tradutores e editores. Os primeiros escrevem seus prefácios seguindo “modelos” mentais do que seja um prefácio de tradutor, com base nos que já leram e os editores regulam e revisam tais textos, quando não fazem determinação do que neles deve constar. Isso quanto ao conteúdo. Já quanto à forma do prefácio, ela teria a característica de apresentar informações de modo a mostrar ao leitor como perceber e interpretar o prefácio. As contribuições de Swales (1990, 2004) e Miller (1984/1994) ajudam 
de formas diferentes a analisar os prefácios/posfácios de tradutores. Swales apresenta um modelo de análise da organização retórica (o quê e como se diz) dos gêneros e Miller apresenta indicação para a análise dos gêneros de sua ação retórica (consequências do quê e como se diz na vida dos indivíduos, mudando ou mantendo o status quo).

A relação hierárquica entre forma e conteúdo anunciada por Miller está implícita na teoria dos atos de fala, onde o significado, segundo Searle (apud MILLER 1984/1994, p. 32), tem dois elementos: uma elocução ou proposição e a ação que costuma realizar, indicada como força ilocucionária. Porém, esse significado em forma de ação só existe em um contexto interpretativo mais amplo.

Outro teórico que também trabalha na perspectiva do gênero como ação social, apoiando-se igualmente na teoria dos atos de fala de Austin e Searle (apud BAZERMAN, 2005, p. 35) é Charles Bazerman. Ele incorpora a teoria dos atos de fala à teoria dos gêneros, partindo da constatação de que nem sempre conseguimos nos fazer entender, isto é, a geração de um efeito perlocucionário que não reflete nossa intenção ilocucionária. Assim sendo:

\begin{abstract}
Uma maneira de coordenar melhor nossos atos de fala uns com os outros é agir de modo típico, modos facilmente reconhecidos como realizadores de determinados atos em determinadas circunstâncias. Se percebemos que um certo tipo de enunciado ou texto funciona bem numa situação e pode ser compreendido de uma certa maneira, quando nos encontrarmos numa situação similar, a tendência é falar ou escrever alguma coisa também similar. Se começamos a seguir padrões comunicativos com os quais as outras pessoas estão familiarizadas, elas podem reconhecer mais facilmente o que estamos dizendo e o que pretendemos realizar. Assim, podemos antecipar melhor quais serão as reações das pessoas se seguimos essas formas padronizadas e reconhecíveis. Tais padrões se reforçam mutuamente. As formas de comunicação reconhecíveis e auto-reforçadoras emergem como gêneros. (BAZERMAN, 2005, p. 29)
\end{abstract}

A particularidade de Bazerman dentre outros teóricos é que a sua noção de gênero está estreitamente ligada ao reconhecimento e distinção pelos usuários de cada gênero ("gêneros são o que nós acreditamos que eles sejam”), além de incorporar a teoria dos atos de fala à sua análise. Somente os membros dessa comunidade retórica têm condições de interpretar certas situações e as reações a elas como sendo recorrentes e dali extrair semelhanças significativas e distintivas a fim de constituir um tipo. A implicação metodológica que daí deriva é a consulta aos usuários de um gênero para verificar que regularidades são 
consideradas relevantes em relação a características textuais, como também aos papéis sociais assumidos pelo gênero.

No trabalho a ser empreendido, será preciso analisar mais profundamente exemplos concretos de prefácios/posfácios de tradutores, a fim de perceber as características gerais desse gênero e como cada exemplo varia em relação às expectativas genéricas. Como a minha intenção neste trabalho é simplesmente perceber recorrências nos prefácios/posfácios que possam apresentar indícios de uma retórica própria a esse subgênero, selecionei seis prefácios para ver como os movimentos de Swales ocorrem em casos específicos, todos contidos no Anexo II. Nesses seis prefácios selecionados, procurei trazer espécimes variados de prefácios, que falam ou não da tradução propriamente dita, de tradutores e obras variados. Portanto, o critério de seleção principal foi a variedade e não a semelhança ou constância.

\section{2 \\ Exemplos selecionados}

Nos exemplos selecionamos abaixo, reproduzidos no Anexo II, proponhome a ver não só a questão dos movimentos e passos depreendidos por mim a partir do modelo de Swales, mas também qual o conceito de tradução que está por trás das afirmações do tradutor, bem como se ele sofre alguma influência detectável da teoria da tradução. Por fim, serão traçadas algumas conclusões gerais da análise. A numeração dos prefácios abaixo se refere à enumeração determinada no Anexo II.

\section{Prefácio 7 - Ferreira Gullar}

ROSTAND, Edmond. Cyrano de Bergerac. Trad. Ferreira Gullar. Rio de Janeiro: José Olympio, 2011, pp. 9-10.

Nos exemplares de prefácios listados no Anexo II, o Prefácio 7, de Ferreira Gullar, apresenta vários desses passos, em ordem diferente. Trata-se da tradução do clássico teatral Cyrano de Bergerac, de Edmond Rostand. O primeiro parágrafo está enquadrado no Movimento 2, Passos 2B, 2A e 2C, pois apresenta a escola literária de pertencimento, as condições históricas de estreia da peça e sua 
influência para a posteridade. No segundo e terceiro parágrafos, o tradutor já passa a tratar da tradução, abordando o Movimento 3 rapidamente e passando logo para o Movimento 5. O parágrafo final apresenta os Passos 5C e 5D, meio às avessas, pois diz que se há deficiências na tradução a culpa é dele e que aí não cabe desculpa.

\section{A Tradução}

Esta peça é fruto de um romantismo tardio. Foi montada pela primeira vez em 1897, quando em todos os campos da arte - no teatro, na literatura, na música, na pintura - já se desencadeara o processo de renovação que iria determinar as vanguardas do século XX. Não obstante, Cyrano de Bergerac estreou com enorme êxito e, desde então, afirmouse como um clássico da literatura teatral. As razões que levaram à consagração desta obra de Edmond Rostand são muitas e de difícil determinação, mas uma delas é certamente a sua qualidade teatral: Cyrano é a proposição de um espetáculo sempre fascinante.

O texto original está escrito em versos dodecassílabos de realização fluente e brilhante. Mas, nos momentos poéticos e patéticos, o autor não consegue furtar-se aos vícios do romantismo academizado e piegas. Procurei tanto quanto possível, na minha tradução, evitar essas derrapagens, afastando-me do discurso do autor.

Essa não é, porém, a única diferença entre o meu texto em português e o original em francês. De saída, substituí o verso alexandrino pelo decassílabo, que me parece mais espontâneo e musical em nossa língua. Tampouco me ative ao sistema de rimas parelhas que Rostand adotou ao longo de toda a peça. Uso arbitrariamente das rimas: ora parelhas, ora intercaladas, ora internas, ora perfeitas, ora sonantes, enfim, sem prender-me a qualquer sistema regular. Trata-se, portanto, de uma tradução livre que não segue palavra por palavra o texto original.

Isso levou, em certos momentos, à supressão de falas e à substituição de trechos inteiros por outros, de minha autoria, em que procurei, no entanto, preservar o sentido original e a intenção do autor. Tudo isso decorre da atitude básica que tomei diante da tarefa que me foi solicitada por Flávio Rangel: realizar uma tradução que funcione teatralmente. Seria impossível conseguir esse resultado se me dispusesse a traduzir ipsis literis o texto de Rostand. De fato, a leitura atenta do original francês revela que muitas das falas surgiram na forma em que estão por necessidade de adequarse $\mathrm{o}$ autor ao sistema de métrica e rima que escolhera. $\underline{\mathrm{A}}$ peça escrita em prosa teria certamente diálogos bem diversos
MOVIMENTO 2

Passo 2B - escola

literária

Passo 2A - fatos

históricos

Passo 2C -

influências

MOVIMENTO 3

Passo 3B construção literária

MOVIMENTO 5

Passo 5A -

descrição do

projeto tradutório

Passo 5B -

contribuição

teórica

Passo 5A -

descrição do projeto tradutório (cont.)

Situação real da encomenda e adequação ao "cliente"/objetivo da tradução Conclusão do tradutor a partir das exigências de produção na origem do texto Passo 5A - 
na maioria das situações vividas pelos personagens.

Não seria, portanto, aconselhável, ao fazer a tradução tendo que enfrentar em português dificuldades semelhantes às que $\mathrm{o}$ autor enfrentou em francês - , que me submetesse à forma estrita do original. Se assim procedesse o resultado seria inevitavelmente um texto prolixo, duro, inespontâneo, teatralmente inviável.

Estas são as explicações que gostaria de dar. Fora isso, todas as deficiências que a tradução apresente são deficiências mesmo.

Não cabe desculpa. descrição do projeto tradutório (cont.) Situação real da encomenda adequação ao "cliente"/objetivo da tradução Passo 5C deficiências tradução Passo 5D desculpas

Ferreira Gullar nasceu em São Luiz, Maranhão, em 13/09/1930, e é poeta, crítico e jornalista, além de tradutor. Traduziu suas obras para o alemão, inglês e espanhol. Com a tradução de "Cyrano de Bergerac", de Edmond Rostand, publicada em 1985, é agraciado com o prêmio Molière, até então inédito para a categoria tradutor. Em 2002, é indicado ao Prêmio Nobel de Literatura. Em 2010, foi o vencedor do Prêmio Luís de Camões, o mais importante prêmio literário da Comunidade de Países de Língua Portuguesa, criado em conjunto pelos governos do Brasil e de Portugal.

A motivação para a tradução da peça foi a encomenda de Flavio Rangel, diretor teatral, de um texto para ser encenado. Este objetivo final influencia e molda as decisões de tradução (substituição do verso alexandrino pelo decassílabo, substituição do esquema de rimas parelhas por um sistema híbrido, supressão de falas, substituição de trechos). A peça foi encenada em 1985 com direção de Rangel e tendo Antônio Fagundes no papel do protagonista, estreando no Teatro Cultura Artística de São Paulo. O original é uma peça de teatro, escrita em 1897, baseada na vida de Hector Savinien de Cyrano de Bergerac, escritor francês (1619-1655). A peça inteira é escrita em forma de poema, com pares de versos rimados. Os primeiros quatro atos se passam em 1640 e o quinto, em 1655. O texto busca recuperar o ideal romântico, numa época em que o Realismo estava em voga.

Gullar insere-se na categoria dos tradutores-escritores, é um poeta reconhecido e premiado. Isto lhe dá uma chancela para expressar claramente suas opções tradutórias, que poderiam ser controversas se expressadas por um tradutor 
menos renomado. Após a tradução ter sido premiada e a peça ter sido encenada com sucesso, o prefácio, justificando seu projeto tradutório, já nasce referendado. Trata-se de um clássico no original, transformado em clássico na tradução, de um tradutor-escritor de renome no sistema alvo, escrevendo um prefácio que possivelmente se tornará um clássico no gênero.

O renome e a fama do tradutor se refletem na posição de seu nome no livro, isto é, na capa, precedido pelo termo “tradução livre”, provavelmente parafraseado do prefácio: “Trata-se, portanto, de uma tradução livre que não segue palavra por palavra o texto original”. Na pesquisa feita com vistas a esta tese, observou-se com frequência que tradutores-escritores de renome frequentemente têm seu nome exposto na capa, junto com o nome do autor, normalmente em tipo menor, mas bem visível.

Em relação ao conceito de fidelidade, três aspectos podem ser percebidos nesse prefácio: 1. Infidelidade à forma do original: “Uma leitura atenta do original francês revela que muitas das falas surgiram na forma em que estão por necessidade de adequar-se o autor ao sistema de métrica e rima que escolhera”, demonstrando uma adaptação ao sistema literário meta; 2. Infidelidade ao discurso do autor: "Procurei tanto quanto possível, na minha tradução, evitar essas derrapagens, afastando-me do discurso do autor”, em que faz um juízo de valor pejorativo de certos trechos do original, que considera piegas ("Nos momentos poéticos e patéticos, o autor não consegue furtar-se aos vícios do romantismo academicizado e piegas”); 3. Fidelidade ao sentido e à intenção do autor: “(...) substituição de trechos inteiros por outros, de minha autoria, em que procurei, no entanto, preservar o sentido original e a intenção do autor”.

Nesse último trecho, o tradutor deixa a entender que não está alinhado com as teorias de tradução de viés mais desconstrutivista, mas adere a uma ideia de um “significado transcendental” e estável e uma concepção mais representacionista da linguagem. Parece que, para ele, existe um sentido original que pode ser reconstruído e uma intenção do autor que pode ser captada pelo tradutor. O tradutor faz ver ainda que a tradução literal (ipsis litteris) não funciona em um texto poético-teatral: "Se assim procedesse o resultado seria inevitavelmente um texto prolixo, duro, inespontâneo, teatralmente inviável”. 
As conclusões a que pude chegar são as seguintes: 1. o prefácio de Ferreira Gullar, apesar de não trazer todos os movimentos e passos apontados como recorrentes em prefácios de tradutores, os traz na ordem semelhante à do esquema geral; 2. o tradutor tem uma concepção híbrida de tradução: ao passo que é “avançado” quanto à sua concepção de tradução livre, adaptando e suprimindo trechos e mudando a metrificação e o esquema de rimas e ritmo, é mais “conservador” e "idealista” no que tange ao aspecto semântico, detectando um "sentido original” e uma "intenção do autor"; 3. o não pedido de desculpas final alude à recorrência excusatória dos tradutores em seus prefácios - que remete à ideia de que a tradução é sempre inferior ao original —-, mas, por negar, reflete sua posição privilegiada no sistema literário-meta.

\section{Prefácio 8 - Silviano Santiago}

PRÉVERT, Jacques. Poemas. Trad. Silviano Santiago. Col. Poesia de Todos os Tempos. Rio de Janeiro: Nova Fronteira, 1985, pp. 7-11.

O Prefácio 8, mais longo, de Silviano Santiago, para uma coletânea de poemas de Jacques Prévert, constitui um ensaio, dividido em 3 partes. Na Parte 1, o tradutor já inicia fazendo uma análise literária (Movimento 3 - Passo 3B), abordando os Passos 2B (o surrealismo) e 2C (comparação com os poetas brasileiros de 1922) deslocados para o Movimento 3. Em seguida, é apresentado um exemplo concreto (Passo 3C). A análise literária continua, falando dos temas e estilo do autor. Na Parte 2, o tradutor volta para o Movimento 2, Passo 2A, desta vez apresentando dados históricos da obra (como surgiu) e do autor (datas de nascimento e morte), e Passo 2C, desta vez falando da influência de Prévert na canção popular francesa. Em seguida, o tradutor apresenta a edição (Movimento 1), pois, além de tradutor, foi seu organizador. Na Parte 3, o tradutor volta a falar da influência de Prévert sobre os modernistas brasileiros (Passo 2C), explicando seu projeto tradutório (Movimento 5 - Passo 5A), que foi usar poetas como Manuel Bandeira e Murilo Mendes como "modelo" para a tradução, acrescentando dados sobre teoria da leitura, com uma perspectiva claramente comparatista (Passo 5B). No último parágrafo, o tradutor assume uma perspectiva humilde amparada por suas convicções teóricas (tradução como leitura), falando em fidelidade. 


\section{INTRODUÇÃO \\ Cotidiano e humor: o pequeno homem}

1

No século XX, a popularidade de um poeta se mede e se aquilata de várias formas, todas negativas. Com os dedos grosseiros da leitura ideológica, dizemos que o poeta popular nada mais faz do que dar ao leitor o que ele já espera. Com as luvas de pelica das poéticas e manifestos, dizemos que ele nada mais executa do que um produto de consumo fácil que dilui o que de forte, tenso e agressivo existe nos radicais, criativos e pouco acessíveis poemas. Com os dedos sangrentos do bisturi crítico, dizemos que ele nada mais é do que um empalhador de sinceridade ou um curandeiro dos clichês.

Fica uma pergunta ao ler os poemas de Jacques Prévert. Devemos desvencilhar-nos, por ocasião da sua leitura, dos dedos grosseiros do julgamento ideológico, das luvas de pelica da análise literária e dos dedos sangrentos da compreensão crítica?

Não sei se devemos desvencilhar-nos desse aparato constituído a duras penas. Mas sei que podemos desvencilhar-nos dele.

E ao desvencilhar, deparamos com poemas de execução simples e calculada, onde ressaltam as cores cinza do cotidiano, os meios-tons do humor e o colorido berrante do sarcasmo e até mesmo da piada.

Os melhores poemas de Jacques Prévert se escrevem desta forma: no fundo cinza do quadro são desenhadas em meio-tom situações delirantemente banais que, posteriormente, são coloridas com as chamadas cores puras. A arte de Prévert, antes de ser a dos poetas surrealistas conhecidos nossos (movimento ao qual querem dependurá-lo com se pudesse dependurar uma laranja na laranjeira sem risco de artificialidade) é a dos pintores fauves. Ou seja, aquela arte em que a composição primitiva, ingênua ou infantil se obscurece com coloridos violentos e se ilumina com a dosagem certa de lirismo.

O lirismo para Prévert, como para alguns dos nossos poetas de 22, se escreve com a combinação certa de cotidiano e humor, fazendo ressaltar no poema uma visão em pequena escala do homem. Ressalta do poema o pequeno, mas não o comum do homem. Essa visão miniaturizada do homem, em oposição aos grandes painéis sociais e históricos pitados por Eliot em The Waste Land, ou Pound nos Cantos, condiz com a pequenez do ser humano diante de um século que o

\section{MOVIMENTO 3}

Passo 3B - análise literária (estilo, temas, construção literária)

\section{MOVIMENTO 2}

Passo 2B - escola literária

pertencimento

surrealismo/fauvismo

Passo 2C - fontes e influências (os poetas brasileiros da Semana de 22/Eliot) 
pulveriza com máquinas, motores, rotativas, engrenagens, guerras, violência e morte. Nesse labirinto inapelavelmente assassino em que se encontra metido, perdidas as esperanças das grandes soluções, o "esforço humano" (para retomar um título de Prévert) passa a ser uma resposta ao mundo hostil pela voz inflexível, débil, bem-humorada, mas persuasiva e salvadora do pequeno homem. O seu oposto é o grande homem:

No ateliê do talhador de pedra

onde o encontrei

lhe tiravam as medidas

para a posteridade.

Fincado no aqui e agora, eis o pequeno homem enquanto indivíduo plenamente consciente do seu poder marginal frente ao achatamento coletivista e uniformizador operado pela sociedade industrial. Eis o indivíduo e a sua rebeldia que podem abrir uma perspectiva de prazer e de futuro (e não de glória) por anos. Indivíduos rebeldes são o jovem Próspero, que recusa ir com o pai à pesca da baleia, o "Cancre" (traduzido por "Juquinha") que diz não ao professor e diz sim ao que ama, o Van Gogh fulminado pela sua própria tempestade interior, e assim ao infinito, constituindo uma comunidade de "infelizes" (diria o bom burguês), semelhante à dos peixes que, vítimas da pesca milagrosa, encontram a felicidade numa gargalhada no dia da Crucificação. A grande mágica lírica de Prévert é a de fazer sorrir os chamados pequenos.

A mudança de perspectiva na apresentação dos acontecimentos históricos ou dos fatos banais é, portanto, a mensagem principal da poesia de Prévert. A mudança liberta-nos do bom senso (por que a versão do bom senso é sempre a certa?) massificador e coloca-nos diante do insólito do nunca pensado, levando-nos enfim a indagações iconoclastas sobre a sorte dos que não tiveram a sorte de estar ao lado do bom senso vitorioso.

No fundo, quer dizer-nos Prévert, o bom senso vitorioso e antes de mais nada o guardião dos repressivos valores burgueses na nossa sociedade. "Mais vale despertar inveja do que piedade", pensa o pai chefe de cantão com os sapatos engraxados e os pés vermelhos de sangue, do sangue da filha que trucidou por não aceitá-la como mãe solteira. Toda a família da "perdida" se encontra diante de uma feérica, banal e sangrenta vindima, cujo lema é roupa suja se lava em casa.
MOVIMENTO 3

Passo 3C - exemplo

concreto

Passo 3B - análise literária 
Jacques Prévert (1900-1977), embora frequentando o meio surrealista parisiense desde o período áureo na década de 20, era desses poetas cujos poemas durante muito tempo apenas circulavam de mão em mão. Poemas que, de repente, foram musicados e se tornaram canções populares de sucesso. Antes de ser conhecido como poeta-de-livros, Prévert teve fama como letrista de canções. Yves Montand e Juliette Gréco foram alguns dos seus intérpretes. Quem não se lembra de "Barbara", "Je suis comme je suis" ou "Les portes de la nuit"?

Só em 1945 é que saiu publicado o seu primeiro livro, Paroles. Seguiram-no La pluie et le beau temps (1955), Histoires (1963) e Grand bal du printemps (1976).

A presente antologia foi organizada a partir de textos extraídos desses livros, em particular do primeiro e do terceiro. A escolha é de responsabilidade do tradutor.

Ao lado de poemas e canções, Prévert escreveu alguns dos melhores roteiros para o cinema francês dos anos 40 e 50. Suas histórias foram filmadas por cineastas do porte de Jean Renoir e Marcel Carné. Entre os filmes que tiveram excelente acolhida por parte do público e da crítica especializada, citemos: Les visiteurs du soir, Les enfants do paradis, Le quai des brumes, Le jour se lève e Les amants de Vérone.

\section{3}

Levando em consideração os elementos sobressalentes da poesia de Prévert, acreditamos que - de modo geral - a sua dicção se assemelha à dos bons poetas brasileiros escrevendo nos anos 30. Poetas estes que já se encontram desvinculados da linguagem agressiva da vanguarda dos anos 20, mas daqueles anos guardando ainda a simplicidade coloquial na escolha do vocabulário e nas construções sintáticas, perpassando também o coloquial com a alta voltagem do humor e até da piada. Foi a partir de "modelos" como Manuel Bandeira, Carlos Drummond e Murilo Mendes que procuramos transpor os versos de Prévert para o português.

A tradução - como a estamos compreendendo - é uma decisão de leitura por parte de quem traduz. Enquanto tal, a tradução é exegética do poema, como a leitura crítica, mas desta distancia-se em pelo menos um ponto crucial. Enquanto a leitura crítica do poema procura, pela erudição e pelo método, organizar, revelar e domar o múltiplo semântico que é a essência do texto poético, a tradução requer que o que é polissêmico no texto de origem permaneça polissêmico no texto traduzido, sem

\section{MOVIMENTO 2}

Passo 2A - Fatos

histórico-biográficos

Passo 2C - Fontes e influências (canção

popular francesa)

\section{MOVIMENTO 1}

Apresentação da Edição

Passo 2C - Fontes e influências (canção e cinema franceses)

Passo 2C - Fontes e influências (poetas modernistas

brasileiros)

MOVIMENTO 5

Passo 5A - descrição do projeto tradutório

Passo 5B

contribuições teóricas (apoio na teoria da leitura, enfoque 


\begin{tabular}{|l|l|l}
\hline que se desvele para o leitor o enigma que tece o texto & comparatista) \\
literário. & \\
Coube ao tradutor não impor ao texto a ser traduzido uma & \\
dicção poética esclarecedora do poema, mas buscar no & \\
repertório das dicções possíveis na sua literatura nacional & \\
um equivalente que fosse justo. Coube ao tradutor domar & \\
primeiro o equivalente, ou seja, a dicção poética & \\
escolhida como justa, para só depois efetuar o trabalho de & \\
tradução. & \\
Neste sentido, o tradutor é um exegeta de asas curtas, & \\
certamente um duplo plagiador. Plagia o texto a ser & \\
traduzido e plagia os poetas nacionais que selecionou & \\
como modelos de dicção. & \\
Mais modesto do que o seu companheiro crítico literário, & Passo \\
o voo exegético do tradutor fica sempre aquém das & perspectiva humilde \\
fronteiras semânticas do texto, já que não lhe compete & \\
quebrar o mistério do poema, nem prontificar-se à tarefa & \\
didática de ajuda na compreensão do poema. O tradutor & \\
guarda para o outro (para o seu leitor) o potencial & \\
polissêmico de leitura que existe em todo poema. Por isso & Noção de fidelidade \\
é que o mais fiel amigo do tradutor é o leitor do poema & \\
traduzido. Para ele - só para ele - é que existe a tradução. & \\
Em outra perspectiva que não a do leitor do poema & \\
traduzido, pouco se salva de uma tradução - salvo, é & \\
claro, a fidelidade que é o que também se salva nos & Passo 5C - Possíveis \\
casamentos monogâmicos enquanto duram. Além da & deficiências \\
fidelidade, em uma tradução tudo é hipótese, & tradução \\
aproximação, desacerto com acerto e até mesmo acerto & \\
sem acerto, transgressão com pedido de perdão e, & \\
finalmente, posse sem direito autoral. & \\
& \\
& \\
&
\end{tabular}

Silviano Santiago nasceu em Formiga, Minas Gerais, em 29/09/1936. É ensaísta, poeta, professor universitário, contista e romancista brasileiro. Tem poucas traduções publicadas, tendo desenvolvido o trabalho de tradutor de forma acessória a suas outras muitas atividades literárias e acadêmicas. Especialista em literatura francesa, fez doutorado na Universidade de Paris sobre a obra Moedeiros falsos, de André Gide. Sua vida acadêmica é extensa, tendo lecionado nas Universidades do Novo México, Rutgers, Toronto, Nova York, Buffalo e Indiana, no exterior, e na PUC-Rio e UFF, no Brasil. Em 2013, recebeu o prestigioso Prêmio Machado de Assis, da Academia Brasileira de Letras, pelo conjunto da obra.

Tal como Ferreira Gullar, Silviano Santiago insere-se na categoria dos tradutores-escritores, é um professor, ensaísta e escritor reconhecido e premiado. 
O prefácio acima reflete bastante bem todos os seus interesses e constitui um verdadeiro estudo literário da obra de Prévert, tocando em assuntos concernentes à teoria literária, análise literária e literatura comparada, mostrando seus conhecimentos aprofundados nessas matérias. Como ele mesmo conta, a publicação surgiu de um trabalho de seleção e compêndio que ele realizou, com base em suas preferências pessoais. Isso demonstra o seu prestígio diante da editora, que lhe deu carta branca para produzir uma coletânea bilíngue, da qual foi o único responsável. Essa posição de destaque nos meios literários e intelectuais do sistema meta ficam refletidos na posição do nome do tradutor na edição: na capa, destacando sua outra atribuição na edição ("Seleção e tradução de Silviano Santiago, edição bilíngue”). O nome do tradutor também aparece na primeira orelha, com uma menção elogiosa e referência ao projeto tradutório (“Agora, qualquer leitor brasileiro pode entrar em contato direto com os poemas de Prévert, graças à tradução feita pelo escritor e professor Silviano Santiago. Este, com sensibilidade e artesanato, tentou apreender a linguagem coloquial e bemhumorada, a faceirice poética do francês, valendo-se dos recursos legados por um Drummond ou um Bandeira, tornando assim a leitura dos poemas em português agradável e prazerosa”.)

Suas contribuições teóricas relacionam a tradução à teoria da leitura (“A tradução é uma decisão de leitura por parte de quem traduz”) e a tradução à teoria literária, estabelecendo diferenças entre a tradução de poesia e a leitura crítica. Aí já começa a esboçar o seu projeto tradutório, que consistiu em: 1. manter a polissemia do poema original ("a tradução requer que o que é polissêmico no texto de origem permaneça polissêmico no texto traduzido, sem que se desvele para o leitor o enigma que tece o texto literário”); 2. procurar na literatura nacional um equivalente para o estilo do autor ("Coube ao tradutor não impor ao texto a ser traduzido uma dicção poética esclarecedora do poema, mas buscar no repertório das dicções possíveis na sua literatura nacional um equivalente que fosse justo"); 3. encontrar a dicção poética apropriada antes de proceder à tradução ("Coube ao tradutor domar primeiro o equivalente, ou seja, a dicção poética escolhida como justa, para só depois efetuar o trabalho de tradução”).

No que tange ao seu conceito de fidelidade, o tradutor fica a meio caminho entre o conceito de traductio (ver Capítulo 2), uma tradução fiel, mas criativa, 
dando pesos pelo menos iguais aos componentes linguísticos, semânticos e estilísticos ("Mais modesto do que o seu companheiro crítico literário, o voo exegético do tradutor fica sempre aquém das fronteiras semânticas do texto, já que não lhe compete quebrar o mistério do poema, nem prontificar-se à tarefa didática de ajuda na compreensão do poema”) e um conceito mais revolucionário e contemporâneo de que a tradução é fruto de uma leitura, não só do tradutor, como também do leitor final ("O tradutor guarda para o outro (para o seu leitor) o potencial polissêmico de leitura que existe em todo poema. Por isso é que o mais fiel amigo do tradutor é o leitor do poema traduzido. Para ele - só para ele - é que existe a tradução”). A fidelidade para ele (“a fidelidade que é o que também se salva nos casamentos monogâmicos enquanto duram”) é um conceito construído entre autor, tradutor e leitor, com base na monogamia, mas só enquanto a relação durar. É, portanto, um compromisso tênue e transitório, pois a parte que cabe à hipótese, aproximação, desacerto com acerto e até mesmo acerto sem acerto e transgressão é certamente mais vasta do que a parte da fidelidade ao sentido literal e ao sentido contido e circunscrito no texto original. Santiago mostra claramente aí ecos de suas leituras da teoria da tradução enquanto ligada à teoria da leitura e à desconstrução. Não se trata, contudo, de um teórico desconstrutivista, pois permanece nele algo de essencialista. O pedido de desculpas do tradutor encontrase presente como possibilidade, mas não como desculpas efetivas ("transgressão com pedido de perdão”), tocando de leve na questão político-profissional dos direitos autorais (“e, finalmente, posse sem direito autoral”). O tradutor, portanto, parece bastante atento às discussões que estavam sendo trazidas à baila no momento da tradução do livro (1985), o que demonstra sua inserção nas reflexões envolvendo as questões fundamentais da tradução, como teoria e prática, mesmo não sendo um tradutor profissional muito produtivo. Por seu prestígio nos meios acadêmicos, literários e editoriais, o espaço de um prefácio longo foi-lhe concedido pelo editor.

\section{Prefácio 9 - Mário Laranjeira}

LARANJEIRA, Mário. Poetas franceses da Renascença. Col. Biblioteca Martins Fontes. São Paulo: Martins Fontes, 2004, pp. IX-X. 
O Prefácio 9, de Mário Laranjeira, serve como apresentação para uma antologia criada pelo próprio tradutor de poemas franceses renascentistas. Nos dois primeiros parágrafos, o tradutor apresenta a edição, sua história e escolhas (Movimento 1). Como se trata de uma antologia de vários autores, e não de um só como a obra anterior, o tradutor não abordou os Movimentos 2 e 3, passando diretamente para o Movimento 5, em que fala de seu projeto tradutório (Passo $5 \mathrm{~A}$ ), que se resume em buscar "obter do leitor dos poemas em língua portuguesa um comportamento-resposta do leitor da língua original” o mais próximo possível do comportamento-resposta do leitor e remete a um livro de teoria da tradução de sua autoria (Passo 5B), fazendo uma distinção entre "tradução poética” e “tradução de poesia”. No parágrafo seguinte, aponta mais uma peculiaridade da edição (volta ao Movimento 1) em relação à grafia arcaizante do francês e os "laivos de arcaísmos” no português. O tradutor fecha a sua apresentação com a esperança de ter contribuído para um melhor entendimento do período da literatura em questão.

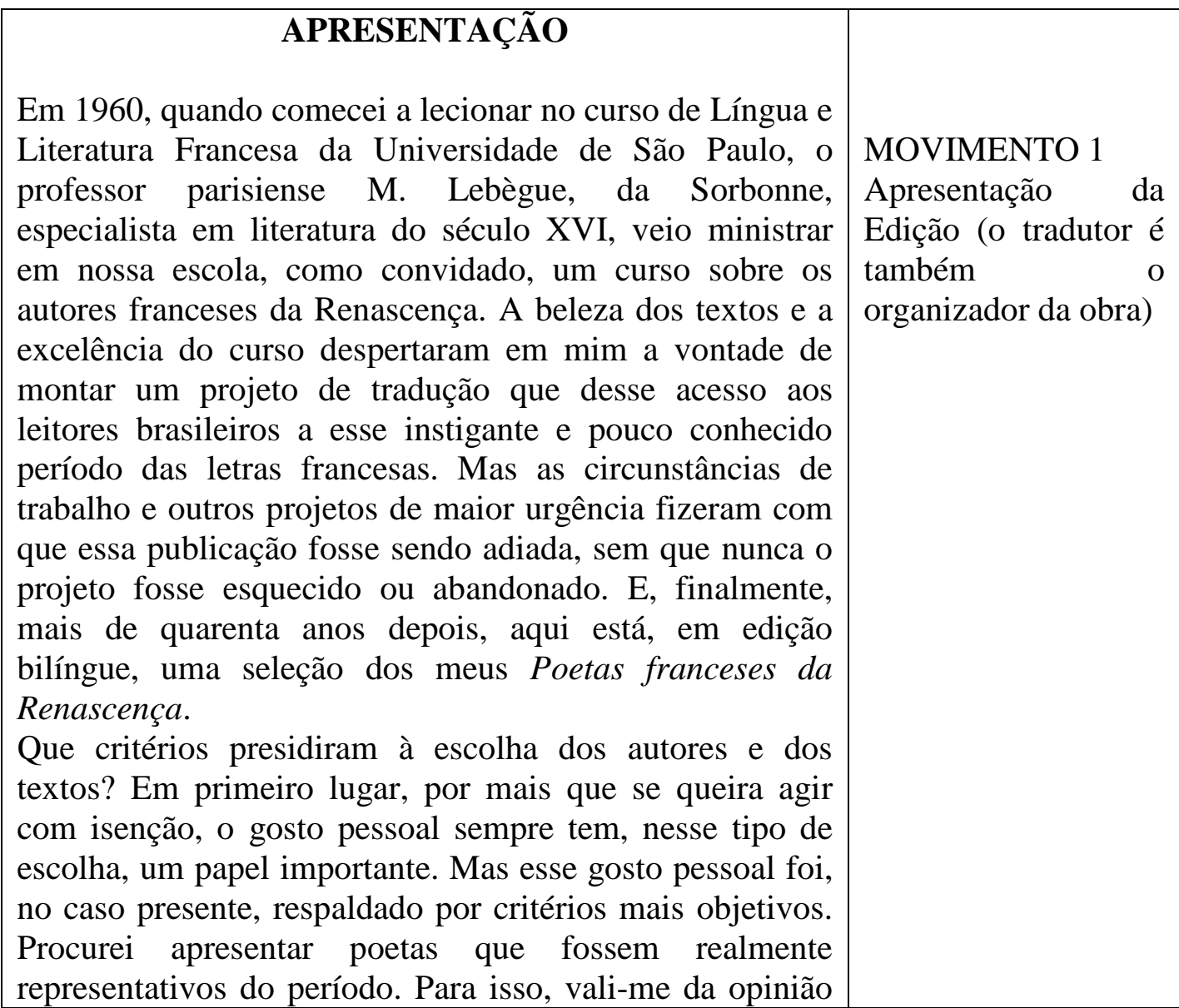


de críticos abalizados e, principalmente, escolhi textos que costumam estar presentes na maioria das seleções e das antologias que contemplam essa fase literária. Como se trata de um período relativamente remoto da literatura francesa, creio que o tempo já se encarregou de eliminar dos florilégios toda a ganga representada pelos modismos passageiros.

Quanto à minha atitude como tradutor, sigo princípios que já expus em trabalhos anteriores, particularmente em Poética da tradução (EDUSP, 1993), ou seja, diante da impossibilidade óbvia de se produzir, pela tradução, na língua-cultura de chegada, um texto idêntico e formal. Isso quer dizer que, além de se manterem os sentidos mais próximos possíveis, busca-se recriar, na tradução poética, a métrica, os ritmos, as sonoridades, as rimas do original e sua disposição, e mesmo a apresentação visual do poema. São esses elementos formais que induzem o leitor a uma leitura "poética" do texto, buscando nele não informação, mas emoção estética. Assim, tenta-se obter do leitor dos poemas em língua portuguesa um comportamentoresposta o mais próximo possível do comportamentoresposta do leitor da língua original. É isso que faz a diferença entre a "tradução poética" e a simples tradução de poesia.

$\mathrm{Na}$ transcrição dos textos originais, mantive a escrita que constava nas obras utilizadas, quer fosse mantida grafia arcaizante do século XVI, quer fosse ela adaptada às normas do francês moderno. Já o português usado na tradução, embora apresente esporadicamente laivos de arcaísmos, manteve-se nos padrões atuais da língua.

Espero que este trabalho possa contribuir para o conhecimento, entre nós, desse importante período da literatura francesa.

\section{MOVIMENTO 5}

Passo 5B

Contribuiç̧ões

teóricas

Passo 5A

Descrição do projeto tradutório

MOVIMENTO 1

Apresentação da Edição

Mário Laranjeira nasceu em Casa Branca, Estado de São Paulo, em 1929. Possui graduação em Letras pela Universidade de São Paulo (1959), mestrado em Letras (Letras Clássicas) pela Universidade de São Paulo (1972) e doutorado em Letras (Letras Clássicas) pela Universidade de São Paulo (1989). Atualmente é professor aposentado e orientador da Universidade de São Paulo. Tem experiência na área de Língua e Literatura Francesa, com ênfase em Tradução, atuando principalmente nos seguintes temas: tradução literária, tradução poética, língua francesa e língua portuguesa. Fez estágios de pesquisa em tradução literária e poética no Collège International des Traducteurs Littéraires, em Arles, França, país onde atuou como professor visitante em Toulouse, Rennes e Bordeaux. É 
tradutor de Poetas de França Hoje (EDUSP/FAPESP), que lhe valeu o Prêmio Jabuti na categoria Tradução em 1997. Foi agraciado também com o Prêmio Paulo Rónai da Biblioteca Nacional. É autor de um livro sobre teoria da tradução que já se transformou em um clássico da tradução poética no Brasil, A poética da tradução (EDUSP/FAPESP, 1993), citado no prefácio acima. Foi um dos fundadores da ABRAPT (Associação Brasileira de Pesquisadores em Tradução). Pode, portanto, ser classificado como tradutor-acadêmico.

Devido ao trabalho como teórico da tradução, principalmente da tradução de poesia, a descrição do seu projeto tradutório é bastante extensa em se levando em consideração a extensão do prefácio como um todo. Suas reflexões teóricas e seu projeto tradutório tomam por base principalmente sua tese de doutoramento defendida no Departamento de Letras Modernas da Universidade de São Paulo, em dezembro de 1989, que trata da tradução poética e, mais especificamente, da tradução de poesia, em que demonstra uma especial afeição pela teoria da semanálise de Julia Kristeva. Sua descrição da contribuição de Kristeva abaixo deixa ver que o projeto tradutório descrito acima guarda grande semelhança com esta teoria:

É evidente que o tradutor, que é inicialmente um leitor, deverá partir do poema original com sua estrutura a "ser descrita", a ser analisada; mas não pode parar aí como diante de um objeto estático, não pode vê-la como um "objeto acabado". Deve, isto sim, "captar as combinatórias" que constituem a sua significância e, através, da dinâmica das relações significantes, "restituir”, "gerar”, na línguacultura de chegada, uma estruturação que mantenha com a significância do original uma relação homogênea. Ou seja, na tradução do poema, o que se busca transladar não é o sentido, visto como inerente a uma estrutura linguística, mas a significância. (LARANJEIRA, 1993, p. 81)

Devido a seus conhecimentos e a suas próprias contribuições teóricas, Laranjeira, apesar de não se afiliar de forma alguma à teorização da desconstrução, há muito abandonou a ideia de fidelidade estrita, até porque trabalha com tradução de poesia, em que fica bastante patente a impossibilidade da tradução literal (“... sigo princípios que já expus em trabalhos anteriores, particularmente em Poética da tradução (EDUSP, 1993) ou seja, diante da impossibilidade óbvia de se produzir, pela tradução, na língua-cultura de chegada, um texto idêntico e formal”). 
Este prefácio, portanto, reflete bastante bem a posição teórica e tradutória do tradutor/prefaciador, dando ênfase à tradução e fugindo ao padrão mais comum de um prefácio puramente didático. Sua posição de destaque na edição fica consubstanciada na localização do nome do tradutor, que também atuou como antologizador, na capa (“seleção, apresentação e tradução de Mário Laranjeira”). Além disso, na orelha, o tradutor também encontrou espaço para escrever um texto que resume o seu prefácio, fazendo alusão à tradução:

Esta antologia faz uma introdução à literatura francesa da Renascença (século XVI) e reúne alguns textos dos autores mais representativos do período, acompanhados de suas respectivas traduções, com a finalidade de preencher uma lacuna que até agora impedia os nossos leitores de ter acesso a esse riquíssimo acervo.

Procurou-se manter, na tradução, estrita homologia formal e semântica com os textos originais. Conservaram-se o mesmo número de versos e a estrofação de cada poema, assim como a distribuição das rimas. Esperamos estar dando uma contribuição para a cultura dos povos de língua portuguesa ao incorporar ao seu patrimônio esses poetas franceses da Renascença.

O texto, na orelha, vem seguido de um minicurrículo do tradutor, que foi aproveitado para escrever o parágrafo acima contendo os dados biográficos do professor e tradutor. Tudo isso mostra que Mário Laranjeira teve participação essencial na edição e goza de grande prestígio no mundo acadêmico, o que se reflete na posição e destaque de seu nome na edição e na concessão de espaço pela editora para a publicação de um prefácio.

\section{Prefácio 10 - Renata Cordeiro}

CORDEIRO, Renata. Pequena antologia de poemas franceses: de François Villon a Fernando Pessoa. São Paulo: Landy, 2002.

No Prefácio 10, Renata Cordeiro faz a introdução a uma antologia de poemas franceses organizada por ela. Nos quatro primeiros parágrafos, a tradutora apresenta a edição (Movimento 1), teorizando sobre a tarefa da antologização. Em seguida (parágrafo 5), a tradutora passa a falar das dificuldades/peculiaridades da tradução (Movimento 4), dando um exemplo concreto (Passo 4A). A seguir, a tradutora passa para o Movimento 5, descrevendo rapidamente seu projeto tradutório ("a tradutora procurou manter as marcas pessoais de cada autor, mas que, fatal e necessariamente, imprimiu as que lhes são específicas”), ao mesmo 
tempo que dá uma contribuição teórica, inspirada na psicanálise. Neste momento, a tradutora deixa patente suas leituras sobre teoria da tradução de cunho mais desconstrutivista, de inspiração, por exemplo, em Rosemary Arrojo. De fato, pela biografia da tradutora, sabe-se que ela cursou Especialização em Tradução na USP, tendo acesso a várias leituras que compuseram a teoria da tradução nos anos 1970-1980. Para finalizar, a tradutora volta ao Movimento 1 (apresentação da edição), entremeando como passagem para o Movimento 2, Passo 2A e 2C. Encerra com uma mensagem semelhante à de Mário Laranjeira (a quem cita), no Prefácio 9, de que espera ter contribuído por meio dessa antologia para melhorar o conhecimento do público a respeito da poesia francesa.

\section{INTRODUÇÃO}

Toda antologia é uma provocação. Tem por objetivo provocar o leitor que nada conhece o desejo de explorar novos mundos, cujas entradas lhe são indicadas. Já para o leitor familiarizado com o assunto, a antologia é uma provocação à interação, à aceitação ou à recusa, à destruição do que lhe está sendo proposto, e à reconstrução pessoal.

E nada é mais humano do que uma antologia, porque só o homem tem a necessidade de compor antologias à imagem da sua própria história. É difícil, ou até mesmo impossível, imaginar um deus que as componha: os "trechos escolhidos" são sinal de uma deficiência, são a resposta à incapacidade da memória de registrar tudo.

O homem, à medida que cresce, se vai tornando uma espécie de "antologia permanente”, posto que é a memória que tria, escolhe, elege, esclarece, censura, fazendo as lembranças que retém ordenarem o futuro. A memória guarda as imagens necessárias à vida de cada um. Nesse sentido, a antologia é o retrato da condição humana.

Mas se a antologia é uma operação necessária que vem socorrer a deficiência fundamental da memória, uma antologia de poemas é, por assim dizer, a memória da memória, porque o poema é, antes de mais nada, aquilo que é concebido para ser retido, a suma dos instantes confiados à memória que os capturou na rede das palavras, é um recurso contra o esquecimento. É algo dito de alguma forma, uma fusão tão perfeita que dissociar a forma do conteúdo se torna impossível. Quando isso

\section{MOVIMENTO 1}

Apresentação da Edição (o tradutor é também o organizador da obra) 
ocorre, anula-se o poema. O que não significa que todo poema seja um conjunto de versos, rimados ou não, pois há muitos versos agrupados que não podem ser chamados de poema e muitos poemas que não são em versos, mas em prosa, como o prova Baudelaire (sem falar nas imagens...).

Uma vez que a antologia de poemas é a memória da memória, claro está que a sua autora é guiada pela sua história, em todos os níveis, sendo a sua eleição fundamentalmente pessoal. Portanto, é movida pelo seu "gosto", que obviamente começou a se formar desde o instante em que veio ao mundo. Grande responsabilidade, que aumenta mais ainda quando a autora de uma antologia de poemas é também sua tradutora.

Sim, a tradução! O poema é um texto que pode ser traduzido, sendo o seu resultado a subsistência do reflexo do poema que continua a ser poema - um outro e o mesmo. Porém, visto que é impossível dissociar a forma do conteúdo, esse trabalho de tradução apresenta muitas dificuldades. Tome-se, a título de exemplo, o poema "Mar e Amor", de Pierre de Marbeuf (1596-1645), presente nesta antologia. Trata-se de uma gama sutil de ecos de sons e sentidos baseados numa paronomásia. O que fazer em português com o seguinte verso:

"La mère de l'amour eut la mer pour berceau?"

“A mãe do amor teve o mar por berço?”

Nessa alusão ao nascimento de Afrodite (Vênus), o problema não é cultural, pois "mère" / mãe se confunde com "mer" / mar, já que são homófonos. Uma possível solução seria o emprego da palavra “mare”, sinônimo de "mãe” em português. Além dessas dificuldades, há outras, tais como: "eaux” / "maux", que foram traduzidos pela coisa mais óbvia: água/mágoa.

Difícil tarefa a da tradutora de poesia, mas de todo possível, como já o provaram. E assim como o autor original imprimiu na sua composição os elementos que faziam dele um ser único, a tradutora também imprimirá na sua tradução as suas características pessoais, tanto culturais e históricas quanto psicológicas e até mesmo biológicas. Portanto, o leitor aqui verá o resultado de um processo em que a tradutora procurou manter as marcas pessoais de cada autor, mas que, fatal e necessariamente, imprimiu as que lhes são
MOVIMENTO 4

Dificuldades/Peculiaridades da Tradução

Passo 4A - Exemplos concretos

MOVIMENTO 5

Passo 5B - Contribuições teóricas 
específicas.

Uma antologia de poemas franceses. Por quê?

Porque a língua francesa, guardadas as devidas proporções, foi no passado o que o inglês é hoje no mundo, ou seja, a língua universal, e porque ao longo da sua história, o Brasil sempre bebeu em fontes francesas, pelo menos até a metade do século XX. A cultura e a língua francesas influenciaram, por exemplo, a poesia e o movimento dos inconfidentes, o romantismo, o parnasianismo, e estão na base da formação acadêmica brasileira.

Esta antologia parte das origens medievais da poesia francesa - privilegia Villon - e vai até o começo do século XX, no âmbito de uma arte poética codificada antes da aventura moderna de uma escrita livre de coerções. Tem por base a antologia de André Gide, ${ }^{1}$ mas apenas por base, pois foi formada ao longo dos anos e não apresenta forçosamente os poemas franceses mais famosos. Também forma incluídas composições de escritores que se consagraram em prosa, a exemplo de Proust, uma de Fernando Pessoa que, mesmo não sendo um poeta francês, fez, na qualidade de poeta universal, poemas nesse idioma, bem como de quebequenses. Os poemas são apresentados em ordem cronológica de acordo com a data de nascimento dos autores e no fim do livro há biografias resumidas de cada um. Para um contato com a poesia francesa contemporânea, a autora/tradutora remete o leitor ao brilhante trabalho do professor Mário Lanranjeira. $^{2}$

Espera-se que o leitor se sinta provocado e que procure conhecer mais fundo a poesia em língua francesa, podendo mergulhar em outras antologias mais amplas que certamente o deixarão fascinado.

São Paulo, junho de 2002.

1. Anthologie de la poésie française. Paris: Gallimard, 1986 (Bibliothèque de la Pléiade). Dentre os outros livros consultados, destacam-se: COLLOGNAT-BARÈS, Annie. Anthologie de la poesia française. De Villon à Verlaine. Paris: Le Livre de Poche, 1998, e REES, William. The Penguin Book of French Poetry 1820-1950. Londres: Penguin Books, 1990. Também foram consultados livros específicos dos autores, em particular os da "Collection Poésie", da Gallimard.

2. Poetas de França hoje 1945-2995. São Paulo: Edusp/Fapesp, 1996.

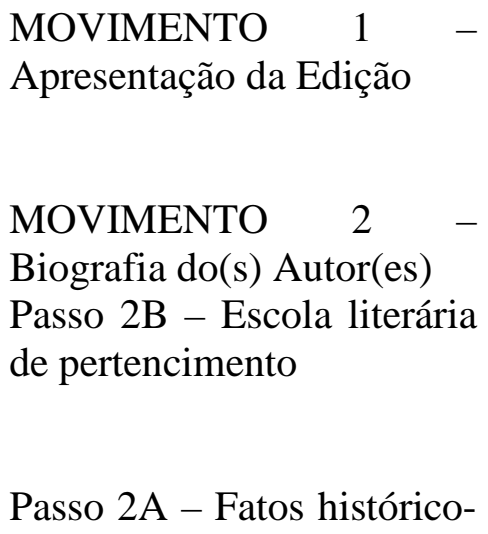

Passo 2A - Fatos históricobiográficos

MOVIMENTO $3-\mathrm{O}$ Conjunto da Obra e a Obra Específica

Passo 3A - Significado da obra específica no conjunto da obra

MOVIMENTO 1 Apresentação da Edição 
Renata Cordeiro possui bacharelado e licenciatura em Filosofia e pósgraduação em Tradução - Francês/Português pela Universidade de São Paulo (1983 - 1991). É tradutora pública e intérprete comercial do idioma francês do Estado de São Paulo. Além do livro acima, Renata Cordeiro foi responsável pela publicação de mais dois livros, abrangendo a concepção, seleção, introdução, tradução, notas, apêndice, escolha e fornecimento das imagens do miolo e da capa. Essas obras receberam Prêmio do Ministério da Educação, na categoria Tradução Jovem II (vinculado ao Prêmio estadunidense), no ano do Bicentenário Andersen, sendo um deles, do próprio Andersen: Contos e Histórias. O outro é de Charles Perrault, Histórias ou contos de outrora. Ambos foram publicados pela editora Landy.

Renata Cordeiro pode ser classificada principalmente como tradutora profissional, mas também como tradutora-acadêmica, por ter cursado pósgraduação na área de estudos de tradução. Por este fato, de poder ser classificada ao mesmo tempo como tradutora profissional e tradutora-acadêmica, e principalmente por gozar do status de ser responsável pela antologia, Renata se encontra empoderada para falar sobre a tradução e até mesmo demonstrar como seus estudos em teoria da tradução a fizeram refletir sobre o seu trabalho. Este foi um dos prefácios encontrados que mais mostram essa relação entre conhecimento da teoria da tradução e o impacto sobre o trabalho tradutório. Talvez se ela fosse somente tradutora profissional, sem ser antologizadora, não lhe teria sido concedido o espaço de um prefácio para externar suas ideias, a seu exclusivo critério. Seu nome aparece na capa (“concepção e tradução de Renata Cordeiro”) e é também de sua lavra o texto que aparece nas orelhas, em que trata da atividade de antologização e considerações sobre poética, sem tocar no tópico da tradução.

\section{Prefácio 11- Rosa Freire d'Aguiar}

CÉLINE, Louis-Ferdinand. Viagem ao fim da noite. Trad. Rosa Freire d'Aguiar. São Paulo: Companhia das Letras, 1994.

O Prefácio 11, de Rosa Freire d’Aguiar, apresentando a obra de Céline, não trata da tradução, eliminando os Movimentos 4 e 5, nem apresenta a edição, também eliminando o Movimento 1. Em compensação, esmiúça os Movimentos 2 
e 3, principalmente os Passos 2A (fatos histórico-biográficos) e 3A (significado da obra específica no conjunto da obra).

\begin{tabular}{|c|c|}
\hline 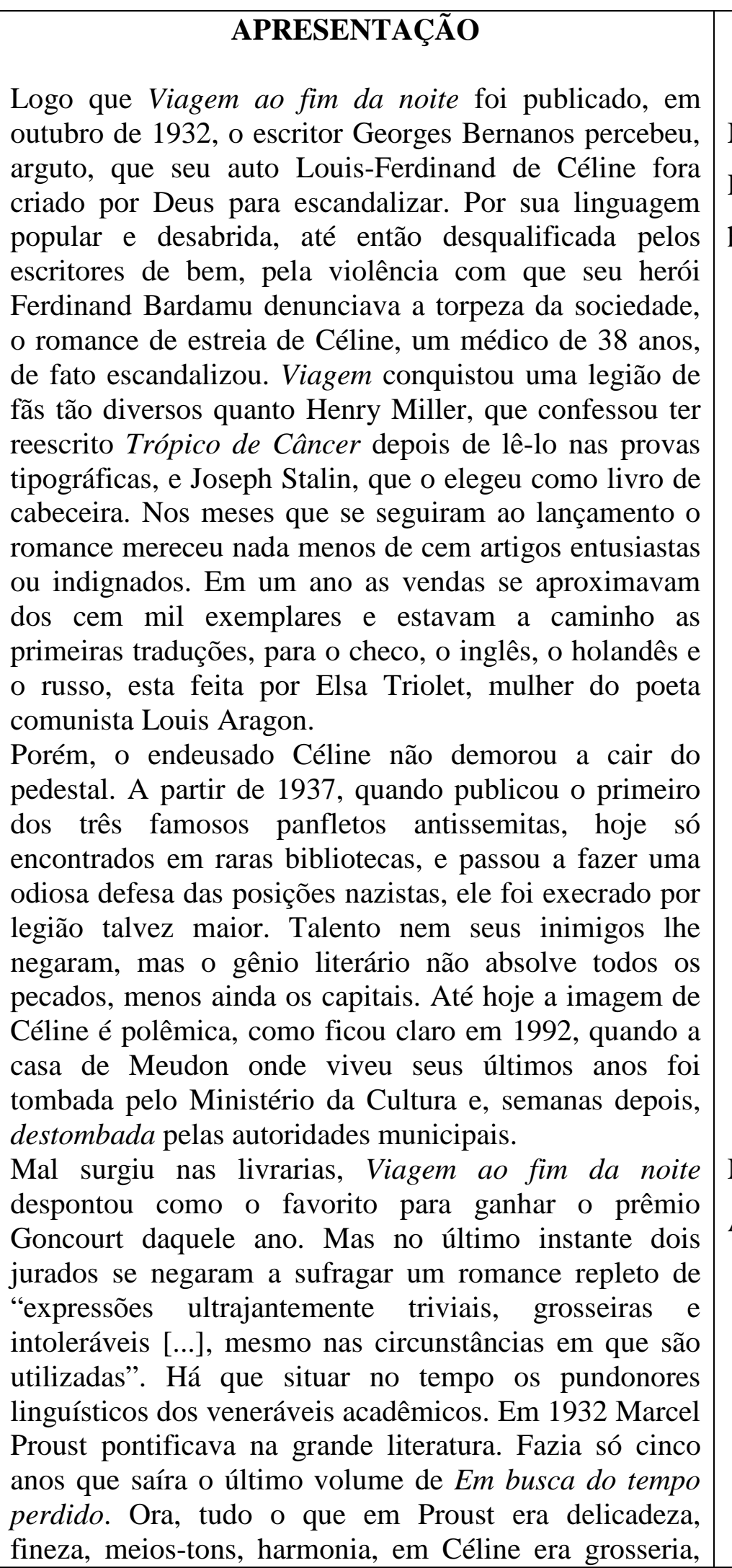 & $\begin{array}{l}\text { MOVIMENTO } 2 \\
\text { Passo 2A - Fatos } \\
\text { histórico-biográficos }\end{array}$ \\
\hline
\end{tabular}


crueza, violência, deformação. Hoje, um e outro são fervorosamente cultuados por devotos no mundo inteiro. Mas há sessenta anos, a audácia de Céline parecia tanto maior quanto ele pretendia, assim como seu intimidativo predecessor, renovar a língua francesa. O que fez; só que, digamos, às avessas, a partir da linguagem oral e popular. Foi este o grande achado de Céline, ser um Proust da plebe, segundo a fórmula de um crítico da época. Bardamu é um anticonformista, um revoltado, um iconoclasta; assim será a linguagem de seu criador. Juntar palavras que não se juntam, mudá-las de seu lugar habitual na frase, usar elipses que comprometem a clareza do texto, gírias e palavrões, criar uma pontuação sui generis que até hoje arrepia os cabelos dos revisores mas marca o ritmo inconfundível de sua prosa: Viagem ao fim da noite já contém os elementos do estilo de Céline, que no entanto vai elaborá-lo cada vez mais nos sete romances seguintes.

Céline muito fabulou sobre sua vida e sua obra. Disse uma vez que Viagem lhe consumiu cinquenta mil páginas, reduzidas depois para as seiscentas da primeira edição. Hoje se sabe que seu processo criativo se baseava, ao contrário, muito mais em acréscimos do que em supressões. Era comum que ele esticasse uma frase com interjeições e expletivos só para reforçar sua oralidade. Entre a primeira e a segunda versão, o romance passou de 534 para 89 laudas datilografadas.

A via aberta por Céline do "escrever como se fala" espontaneidade aliás aparente, como evidenciam em Viagem ao fim da noite os trechos altamente literários foi desde então palmilhada à exaustão por muitos escritores. Talvez por isso o impacto que o romance cause no leitor de hoje decorra menos da linguagem, inovadora em sua época, do que da virulência com que Bardamu vomita o horror que sente por seus semelhantes. O romance se inicia em 1914 com uma guerra mundial que deixou, só na França, mais de um milhão e meio de mortos. Termina por volta de 1930 com a crise econômica que vai se alastrando pela Europa. Entre as duas datas, Bardamu testemunha a decadência extravagante dos années folles, a crise do colonialismo, a desumanidade do capitalismo, a miséria da periferia urbana. É no front, porém, que ele adquire a certeza que há de balizar sua viagem ao fim, ao fundo da noite: "a verdade deste mundo é a morte", diz. Ricos e pobres, homens e mulheres vivem para empurrar, mais ou menos sutilmente, o vizinho, o parente, o amigo para a morte. Um estudo psicanalítico do romance sugere que este desejo homicida que Bardamu enxerga em todos os
Passo

3A

Significado da obra específica no conjunto da obra

Movimento 2

Passo 2C - Fontes e influências

Passo 2A - Fatos histórico-biográficos 
que o cercam, com a notável exceção das crianças e da prostituta Molly, seria a interpretação muito pessoal que Céline dava ao conceito freudiano de instinto de morte. Louis-Ferdinand Destouches (Céline era o nome de sua avó materna e madrinha) nasceu em Courbevoie em 27 de maio de 1894. Seu pai, de origem burguesa, trabalhava numa companhia de seguros; sua mãe, de família de pequenos comerciantes, terá a partir de 1889 uma loja de artigos de renda, moda e lingerie na elegante Passage Choseuil de Paris. Marguerite Destouches sonhava em ver o filho bem colocado no comércio. Mais valiam, portanto, os estágios nos bons estabelecimentos do ramo do que os estudos no Liceu. Louis só fez o curso primário. Dos 13 aos 15 anos viveu em internatos da Alemanha e da Inglaterra para aprender línguas, e dos 15 aos 18 foi "aprendiz" em uma loja de tecidos finos e em duas joalherias. Fazia o serviço militar na Lorena quando em agosto de 1914 estourou a guerra. Em outubro, ferido gravemente por bala no braço direito, foi transferido para Paris. Foram poucas as semanas na frente de batalha, mas traumáticas, deixando-lhe como sequelas para o resto da vida a insônia, os distúrbios de audição causados por explosões de granadas, e as enxaquecas. Depois de uma temporada em que trabalhou no consulado-geral em Londres, o jovem Louis, reformado, partiu para a África, como gerente de uma plantação na colônia dos Camarões, de onde voltou com malária. Em 1924, já formado em medicina e separado da mulher Edith Follet, com quem teve sua única filha, Colette, ele foi para Genebra trabalhar na seção de higiene da Sociedade das Nações, iniciando aí uma carreira de funcionário internacional que o levou a percorrer a Europa, os Estados Unidos e a África em missões médicas.

Um livro que denunciava com tanta veemência a guerra, o colonialismo, o taylorismo, a pobreza dos subúrbios, só podia ser de um homem "de esquerda". E assim foi Céline etiquetado. Para o jornal anarquista Le Libertaire, "como não simpatizar com sua insubmissão total à velha sociedade burguesa?”. Para o Monde, semanário próximo do Partido Comunista e dirigido por Henri Barbusse, "Céline é um dos nossos". Para Claude LéviStrauss, no L'Étudiant Socialiste, Viagem era "a obra mais considerável dos últimos dez anos”. Para Simone de Beauvoir, anos depois, "seu anarquismo parecia próximo do nosso". Houve quem frisasse as ambiguidades ideológicas do romance, mas coube ao escritor comunista Paul Nizan pôr o lúcido pingo dos is: "Essa revolta pura pode levar Céline a qualquer lugar: até nós, contra nós ou a lugar nenhum”.

Passo 2B - Escola literária de pertencimento 
Levou-o longe demais. Já em 1933 ele começou a denunciar a "demagogia e a hipocrisia" dos intelectuais que faziam "promessas revolucionárias ao proletariado". Em 1936, irritado com a rejeição quase unânime a seu segundo romance, Morte a crédito, contra-atacou acusando seus críticos de serem "todos judeus". Mas foi em 1937 que iniciou a grande viagem ao antissemitismo e ao racismo, defendidos com uma histeria que até hoje causa perplexidade. No fim de uma noite dessas, não havia aurora possível. O primeiro panfleto, Bagatelles pour un massacre, saiu em dezembro. L'école des cadavres, um ano depois. O terceiro, Les beaux draps, em fins de 1940, quando na França ocupada pelos nazistas Céline frequentava as recepções de Otto Abertz, embaixador do Terceiro Reich, e já vigorava o estatuto dos judeus. Os três títulos tiveram considerável sucesso, vendendo até 1944, respectivamente, 86 mil, 38 mil e 44 mil exemplares. Nesses anos de Ocupação, Céline escreveu aos jornais pró-nazistas cerca de trinta cartas e deu onze entrevistas aprovando a perseguição aos judeus e o ódio racial.

Nos últimos aos de vida Céline foi exímio em embaralhar as pistas que desvendariam os episódios comprometedores do seu passado. Mas a realidade vai se impondo. Recentemente, em maio de 1994, o escritor alemão Ernst Jünger confirmou por escrito que era mesmo Céline o homem sentado à sua frente em Paris, numa noite de dezembro de 1941, a exigir dos militares alemães que fuzilassem ou enforcassem os judeus.

Sabendo-se condenado à morte pela Resistência, em 17 de junho de 1944, onze dias após o desembarque das tropas aliadas na Normandia, Céline conseguiu dos alemães um salvo-conduto e fugiu de seu apartamento de Montmartre com a segunda mulher, Lucette Alamanzor, e o gato Bébert. Seu destino era a Dinamarca, onde escondera uma reserva em ouro amealhada com os vultuosos direitos autorais que recebera até então - a outra parte desse pecúlio, guardada desde antes da guerra num cofre de banco em Amsterdam, acabaria em mãos nazistas. Mas não era fácil atravessar a Alemanha, e o dr. Destouches aceitou então ser o médico da colônia de dois mil franceses, a fina flor do colaboracionismo, que em fins de 1944 tentava salvar a pele em Sigmaringen, junto com o marechal Pétain e os ex-ministros do regime de Vichy. A temporada alemã está contada na trilogia D'un château l'autre, Nord e Rigodon.

Os seis anos de exílio na Dinamarca foram amargos. Acusado na França de traição à pátria, ele se livrou da extradição mas passou um ano e meio numa prisão em
Passo 2A - Fatos

histórico-biográficos 
Copenhaguen. As mais de mil cartas enviadas nesse período a um punhado de amigos mostra um Céline acuado, sofrendo de delírio de perseguição, obcecado por dinheiro. Na lista dos inimigos imaginários, que estariam conspirando para destruí-lo, ele agora incluía "as valquírias, os Vermelhos, os Batavos, os Gringos, os Judeus, os Maçons, Pretos, Gaullistas e Vichystas”. Ele, que odiava a vida no campo, teve que ir morar, por falta de recursos, numa casa isolada na beira do Báltico, emprestada por seu advogado dinamarquês. Tentou ser reeditado em vários países. Propôs a produtores americanos suas peças de teatro, balés e roteiros de cinema. Sonhou com o asilo nos Estados Unidos, na Suíça e até na Groenlândia. "Boicote total. Sou o antiCristo."

Em fevereiro de 1950 Céline foi condenado em Paris a um ano de prisão, ao humilhante estado de indignidade nacional e ao confisco de metade de seus bens atuais e futuros. Anistiado meses depois, retornou à França em julho de 1951, com Lucette e Bébert, e comprou uma casa em Meudon. Reinscreveu-se na Ordem dos Médicos, pendurou uma placa no portão de casa, mas foi Lucette quem ganhou algum dinheiro dando aulas de dança. Durante o processo de Céline, seu amigo Henry Miller expressara o desejo de que "o mundo podia muito bem fechar os olhos para os 'erros' de certos homens eminentes que tanto contribuíram para nossa cultura”. Céline não viveu para tanto. Morreu em $1^{\circ}$ de julho de 1961, de congestão cerebral, aos 67 anos. Menos de trinta pessoas acompanharam seu enterro ao cemitério de Meudon.

Rosa Freire d’Aguiar nasceu no Rio de Janeiro em 28 de agosto de 1948. Nos anos 1970 e 80 foi correspondente em Paris das revistas Manchete e IstoÉ. Retornou ao Brasil em 1986 e no ano seguinte traduziu seu primeiro livro, para a editora Paz e Terra: O conde de Gobineau no Brasil, de Georges Raeders. Em mais de vinte anos de atividade, verteu mais de sessenta títulos nas áreas de literatura e ciências humanas. Além do francês, idioma do qual transpôs para o português, entre outros, Céline, Orsenna, Lévi-Strauss, Debret e Balzac, traduz do espanhol e do italiano, línguas que também aperfeiçoou durante os anos de jornalista na Europa. Entre os prêmios que recebeu estão o da União Latina de Tradução Científica e Técnica (2001) por O universo, os deuses, os homens 
(Companhia das Letras), de Jean-Pierre Vernant, e o Jabuti (2009) pela tradução de A elegância do ouriço (Companhia das Letras), de Muriel Barbery.

Rosa Freire d'Aguiar pode ser classificada como tradutora profissional. Apesar de não ser escritora, Rosa goza de muito prestígio na editora para a qual trabalha preferencialmente, a Companhia das Letras, por sua competência comprovada e grande experiência, bem como no cenário cultural em geral. Além disso, no cenário dos estudos econômicos, Rosa também é conhecida por ser viúva do famoso economista Celso Furtado, diretora do Centro Internacional Celso Furtado de Políticas para o Desenvolvimento, que funciona dentro do BNDES, e é responsável para republicação da obra completa, incluindo a ainda inédita, do grande pensador brasileiro.

Apesar de não ser uma tradutora-escritora ou uma tradutora-acadêmica, Rosa, por sua agentividade no cenário cultural e intelectual, garante um espaço certo para seus prefácios. No espaço dos prefácios, contudo, Rosa fala pouco sobre as traduções propriamente ditas. No prefácio acima, não toca nesse assunto e em outros, como se vê no Anexo I, fala por alto, dando mais ênfase a fatos históricos e literários envolvendo os autores a quem traduz. Em outros espaços, como em depoimentos e palestras, é mais generosa no compartilhamento das dificuldades e nas soluções criativas que encontra ao fazer seu trabalho, a exemplo da longa entrevista que concedeu a Marlova Aseff e Dorothée de Bruchard transformada em livro (Memória de tradutora com Rosa Freire d'Aguiar, 2004). Neste prefácio tão interessante e fluido, contudo, se atém a fatos históricobiográficos, análise do estilo do autor, influências e o significado da obra específica no conjunto da obra. Talvez pense que os leitores comuns não se interessariam pelas peculiaridades da tradução, ou que o editor não encararia tais detalhes com bons olhos. Como saber? O fato é que não parece coincidência que a tradutora profissional não dê detalhes sobre a tradução, diferentemente do que ocorre com os tradutores-escritores e tradutores-acadêmicos acima, levando a arriscar uma generalização de que estes se sentem mais à vontade ou empoderados para falar de tais assuntos do que os tradutores profissionais.

O nome de Rosa aparece na quarta capa, e não na capa, situação que se repete em outras traduções suas para a Companhia das Letras (os Ensaios, de Montaigne, por exemplo). Este parece ser um padrão da editora, o de não ostentar 
o nome dos tradutores na capa, como se pôde constatar no site da editora na Internet. Portanto, segundo os padrões da editora, Rosa goza do máximo de visibilidade possível nas publicações de suas traduções para a Companhia.

\section{Prefácio 12 - André Teles e Rodrigo Lacerda.}

DUMAS, Alexandre. O conde de Monte Cristo. Trad. André Teles e Rodrigo Lacerda. Rio de Janeiro: Zahar, 2012.

Apesar de o livro ter sido traduzido pelos dois tradutores, o prefácio foi escrito exclusivamente por Rodrigo Lacerda, conforme dito em entrevista transcrita em sua página na Internet (www.rodrigolacerda.com.br), onde também descreve o método de tradução a dois. Nessa entrevista, Rodrigo conta que André Teles fez a primeira versão da tradução, depois, ele, Rodrigo, cotejou linha a linha com os textos em francês, traduzindo os saltos, tirando dúvidas, homogeneizando o texto, refazendo a pontuação. Depois André aprovava ou não as sugestões de Rodrigo. Finalmente, entraram na fase dos ajustes finais de padronização. No momento da edição, enquanto Rodrigo escrevia a apresentação, André selecionava as ilustrações. Este prefácio, intitulado Apresentação, é uma versão resumida da apresentação contida na edição em formato padrão (esta edição é em formato de bolso).

Neste prefácio, Rodrigo descreve fatos histórico-biográficos (Movimento 2), a construção literária (Movimento 3), apresenta a edição (Movimento 1) e fala brevemente sobre o projeto tradutório (Movimento 5).

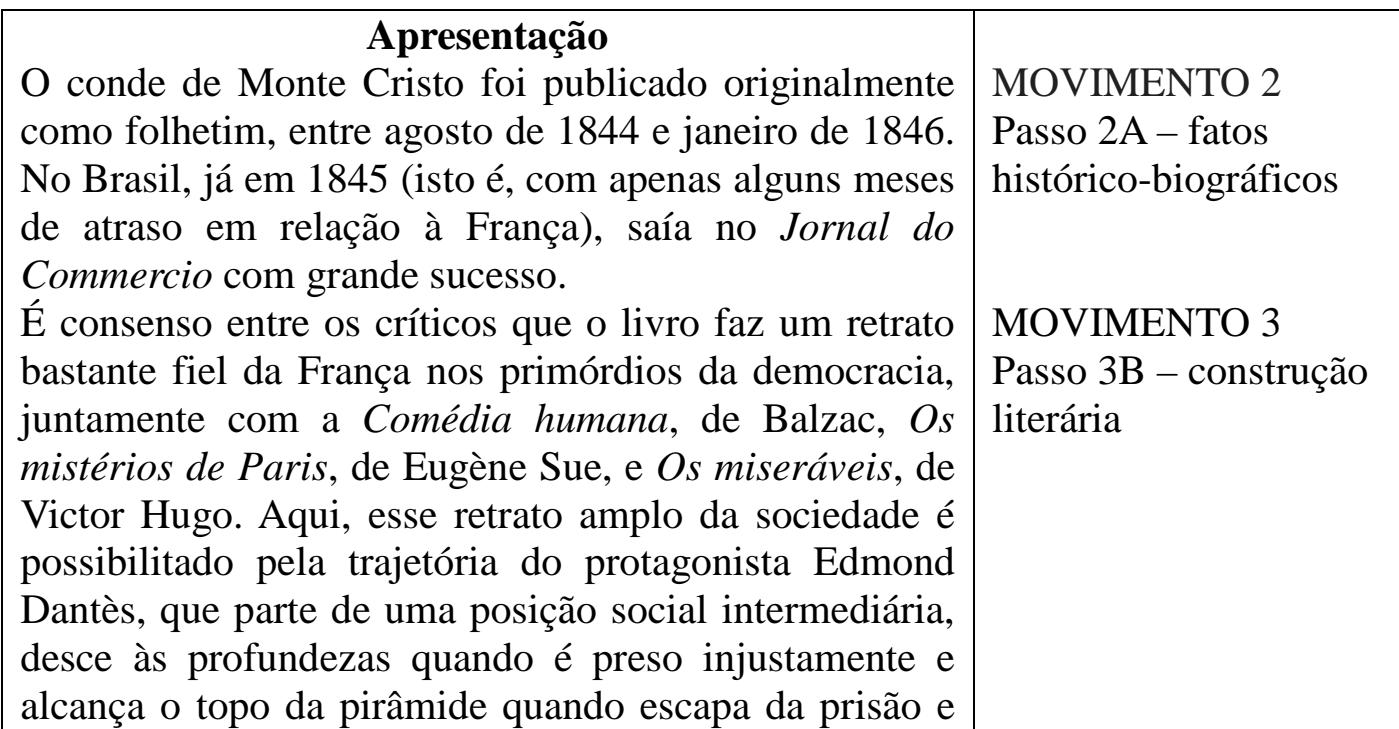


enriquece.

À medida que Dantès marcha para a vingança, distancia-se dos homens comuns e oferece a leitores de todos os tempos um pouco de redenção: a revanche da justiça legal, a reinstauração da ordem moral. Ninguém pode lhe negar que, realmente, faz de tudo para obtêlas. Ao suspense intrínseco ao tema - "Ele vai conseguir se vingar?” (no fundo intuímos que vai) soma-se o suspense maior: "Qual será sua vingança?"

Dumas trabalhava em colaboração com dezenas de outros escritores e pesquisadores. O único de seus assistentes a realmente chegar perto de uma coautoria foi Auguste Maquet (1813-88), com quem Dumas trabalhou em cerca de vinte romances, inclusive $O$ conde de Monte Cristo.

Tudo indica que Maquet, ex-professor universitário, redigia um primeiro esboço a partir de seus conhecimentos históricos e pesquisas. Em seguida, este era reescrito por Dumas, que acrescentava seu estilo romanesco e autêntico jorro de imaginação. O texto final foi sempre de Dumas - e não por acaso, quando a dupla se desfez e Maquet entrou com um processo contra o parceiro, exigindo uma soma exorbitante por direitos autorais, a Justiça determinou o pagamento de royalties suplementares, mas negou-lhe o privilégio de assinar como coautor.

A presente tradução baseou-se nas melhores edições existentes: a da Pléiade, a da Calmann-Lévy (em seis volumes, reprodução da edição standard de 1895), a da Bouquins e a da Folio. Sem mudanças substantivas no original, adaptamos a pontuação para as normas vigentes, modernizamos com moderação as formas de tratamento e privilegiamos, sempre, a fluência da leitura. As ilustrações aqui incluídas, de autoria de Gustave Staal, entre outros, integraram a $3^{\mathrm{a}}$ edição francesa de $O$ conde de Monte Cristo.

(Esta é uma versão reduzida da apresentação de Rodrigo Lacerda para $O$ conde de Monte Cristo: edição definitiva - comentada e ilustrada, publicado pela Zahar em 2008.)

MOVIMENTO 2

Passo 2A - fatos

histórico-biográficos
MOVIMENTO 1

Apresentação da edição

MOVIMENTO 5

Passo 5A - descrição do projeto tradutório

MOVIMENTO 1

Apresentação da edição

André Telles nasceu 04/06/1956, no Rio de Janeiro. É tradutor de francês (principalmente), inglês e espanhol, além de ter feito traduções indiretas de outras línguas. Graduado em Letras (PUC-Rio), foi livreiro (1980-1990) e editorassistente (1990-2000) na Jorge Zahar Editor. Originalmente tradutor de filosofia e psicanálise, passou, a partir de 2002, a se dedicar mais à tradução literária, 
assumindo a profissão de tradutor em tempo integral. Recebeu o Prêmio de Melhor Tradução Infanto-Juvenil de 2005, dado pela Fundação Nacional do Livro Infantil e Juvenil, por Em busca do tempo perdido, de Stéphane Heuet.

Rodrigo Lacerda, nascido em 1969, é filho de Sebastião Lacerda, editor da Nova Fronteira, e neto do político Carlos Lacerda. Formou-se em História pela PUC-SP em 1994. Ainda na PUC-SP concluiu o mestrado e em seguida o doutorado em literatura em 2005, com tese sobre o escritor João Antonio. Seu primeiro livro, O mistério do Leão Rampante, foi publicado em 1995 e ganhou o Prêmio Jabuti em 1996. Trabalhou na própria Nova Fronteira e também nas editoras Edusp, Nova Aguilar, Cosac \& Naify, Mameluco Produções e Duetto. Ganhou o prêmio ABL de 2010 na categoria ficção, com o romance Outra vida (Alfaguara, 2009).

Esta edição do Conde de Monte Cristo traz o nome dos tradutores na quarta capa, seguido da menção “Tradução vencedora do Prêmio Jabuti”. Devido a um dos tradutores ser um escritor premiado, apesar de não tão conhecido do grande público, e o outro ex-funcionário da editora que publicou a tradução, além de tradutor experiente, e à tradução ter sido premiada, foi-lhes dado espaço para publicar um prefácio, que, na verdade, foi escrito somente por Rodrigo, mas conta com o aval de André.

O prefácio traz somente uma frase sobre o projeto tradutório: "Sem mudanças substantivas no original, adaptamos a pontuação para as normas vigentes, modernizamos com moderação as formas de tratamento e privilegiamos, sempre, a fluência da leitura”. A frase dá a entender que foram feitas mudanças menores no original (pontuação e formas de tratamento), privilegiando a fluência de leitura.

No blog do escritor (www.rodrigolacerda.com.br), no entanto, entendemos que não foi bem assim:

"Você chegou a consultar edições brasileiras do romance? Sim. Mas não foi um cotejo detalhado, que eu fiz mesmo foi entre as várias edições francesas. Quisemos dar uma dicção inteiramente nova para a nossa tradução.

Quais defeitos encontrou nas antigas traduções? O André Telles deu grande fluência ao texto original, e eu tratei de homogeneizála. Nesse sentido, acho que nenhuma outra versão para o português tem um texto tão moderno e ao mesmo tempo tão fiel quanto a nossa”. 
No que tange ao conceito de fidelidade, apesar de as palavras fidelidade/fiel não aparecerem explicitamente no prefácio, há uma menção indireta ao conceito: "sem mudanças substantivas no original”. Como não dizem expressamente, podemos depreender de outros elementos na frase (mudanças na pontuação e pronomes de tratamento) que se trata de uma fidelidade ao enredo, ao estilo do autor e à integralidade do texto original. Por outro lado, a “modernização” já não seria por si só uma “infidelidade”? Não haveria uma contradição entre ser “fiel” e "modernizar”?

Apesar de terem empreendido mudanças consideráveis ao original (retiradas de todas as marcas características do romance em folhetim), o(s) tradutor(es) se apega(m) a um conceito de "fidelidade" bastante tradicional, como se isso fosse sinônimo de qualidade de uma tradução. Parece que o tradutor(es) não foi/foram exposto(s) à Teoria da Tradução e continua(m) se apegando a noções há muito questionadas e discutidas.

Na comparação entre o prefácio de Ferreira Gullar, por exemplo, e este, percebemos que no referente à tradução poético-teatral o tradutor abre mais espaço para falar de seu projeto tradutório, assumindo suas liberdades e adaptações. Já no referente à tradução de prosa, o(s) tradutor(es) fala(m) muito pouco do projeto tradutório, amenizando a força da "modernização” empreendida e dedicando muito mais espaço a referências histórico-bibliográficas e à descrição da edição. O prefácio do(s) tradutor(es) de prosa é mais tradicional em seu teor descritivo e menos autoral do que o prefácio do tradutor de poesia/teatro. Mesmo em se tratando de tradutores de grande visibilidade, apesar de a fama de Gullar ser bem maior, o(s) tradutor(es) de prosa foi/foram mais tímido(s) ao falar de seu projeto tradutório, dando a entender que a tradução de prosa tem um componente bem menos autoral/interpretativo do que a tradução de poesia/teatro.

Como bem se viu pelos exemplos analisados acima, nem todos os Movimentos e Passos previstos no modelo estrutural de prefácios de traduções esboçados por mim a partir daquele desenvolvido por Swales para introduções de artigos acadêmicos aparecem em exemplos de prefácios específicos, nem tampouco os Movimentos e Passos sempre estão presentes, ou aparecem na mesma sequência. Daí se conclui que, se o conceito de gênero utilizado exigir que as regularidades sejam bastante rígidas, talvez os prefácios de tradutor não 
configurem um gênero, ou subgênero. Contudo, um certo grau de regularidade existe e não pode ser descartado. Elementos regulares estão presentes, mas o grau de regularidade varia bastante, muito mais do que em gêneros mais estritos, como as apresentações de pesquisa analisadas por Swales.

Outra observação que salta aos olhos é que os movimentos 2 e 3 são mais frequentes do que os movimentos 4 e 5 . Os movimentos 2 e 3 dizem respeito à obra original e seu autor, isto é, ao pólo de partida ou de origem, ao passo que os movimentos 4 e 5 dizem respeito à tradução e ao projeto tradutório, isto é, ao pólo de chegada ou meta. Em outros momentos nesta tese, falamos sobre o habitus de pária do tradutor, que mais uma vez se configura nessa tendência a dar mais ênfase ao autor e à obra original do que à tradução.

Além das regularidades, foram ressaltados os aspectos que variam de um exemplo a outro: o conceito de fidelidade que o tradutor expressa e reflete em seu projeto tradutório, as contribuições teóricas que dá ou se exime de dar, as influências da teoria da tradução, ou de outras teorias, sobre seu trabalho, e, por fim, mas não menos importante, o destaque dado ao seu nome na edição.

O exercício feito nos seis espécimes selecionados acima poderia ser feito com todos, ou quase todos, os prefácios/posfácios de tradutor encontrados. Apesar de não esgotar as possibilidades de análise de prefácios/posfácios de tradutor, a sistemática apresentada pode servir de base para novas análises, encontrando-se meios de aprofundar as análises, trazendo à baila aspectos que, de outra forma, talvez passassem despercebidos. Percebemos, portanto, que a teoria dos gêneros discursivos serve de base para estudar as regularidades e recorrências nesse gênero, mas a análise dos conceitos de fidelidade e tradução, a percepção dos pontos de contato entre teoria e prática e o destaque dado ao nome do tradutor na edição - frequentemente refletindo sua posição de destaque/apagamento na sociedade — podem servir como rota para analisar o que se diferencia em cada prefácio/posfácio de tradutor.

Além disso, outro aspecto ficou patente: existe uma correlação estreita entre o prestígio que o tradutor goza no cenário intelectual, acadêmico e/ou literário, a posição de seu nome na capa ou quarta capa, textos de sua autoria nas orelhas (e outros sinais de destaque, como minicurrículos) e existência de prefácio/posfácio de tradutor. Como uma primeira conclusão para a teoria do 
paratexto do livro traduzido, pode-se dizer que é lícito esperar que, se o tradutor escreveu um prefácio/posfácio, seu nome e sua posição receberão destaque na edição. E vice-versa, pois fica difícil dizer o que vem primeiro: a concessão de espaço para a escritura de um prefácio gerando destaques para o nome do tradutor na edição, ou o contrário.

No capítulo a seguir, apresentaremos a metodologia usada na análise dos dados gerais que se seguirá. 


\section{Análise de dados}

\section{1}

\section{Considerações metodológicas}

Em termos de metodologia para a história da tradução, há quatro análises seminais principais que naturalmente servirão de norte para a presente pesquisa, como já adiantado no Capítulo 2, e agora abordadas.

A primeira delas é “As relações nada perigosas entre história, filosofia e tradução”, de autoria de Marcia A. P. Martins (1996). O segundo texto é de autoria de Adriana Pagano (2001) e intitula-se “As pesquisas historiográficas em tradução”. A terceira, e mais completa, análise é o livro de Anthony Pym, Method in Translation History (1998), já citado anteriormente neste trabalho em outros capítulos. Mais contemporaneamente, houve a análise de Daniel Simeoni, que se propôs pensar em qual seria um método próprio aos estudos da tradução, principalmente em "Between sociology and history: method in context and in practice” (2007).

Segundo Martins (1996), é preciso fazer uma distinção entre "se o objeto de estudo será a atividade tradutória como tem sido praticada, que funções vem desempenhando etc. ou os estudos sobre a tradução, discursos, modelos, reflexões, teorias” (1996, p. 42). Como essa distinção não vem sendo feita com clareza, o resultado é que a história da prática da tradução e a história das teorias de tradução apareciam imbricadas. Além desta, para Martins, haveria uma segunda questão metodológica essencial, que é determinar o objeto de estudo e o corpus a ser analisado, o que implica em uma série de escolhas metodológicas. Se, por um lado, a proposta for escrever histórias das teorias de tradução, o ponto de partida seria um corpus de textos teóricos importantes sobre o pensamento sobre a tradução, o que pode incluir textos de vários gêneros específicos (prefácio, resenha, carta etc.) (MARTINS, 1996, p. 45). Se, por outro lado, a proposta for escrever histórias da prática da tradução, pode-se organizar a tarefa usando critério de tipologias de texto, tradutores, épocas, funções e estilos/estratégias de 
tradução. Neste último caso, o corpus é eminentemente constituído pelos textos traduzidos em si. Assim sendo, com base nas reflexões de Martins, a presente pesquisa historiográfica inclui-se no grande eixo da história das teorias de tradução, com base em um gênero discursivo específico, o dos prefácios/posfácios.

Pagano (2001) complementa as conclusões de Martins, apontando que a historiografia da tradução, como ramo dos Estudos da Tradução, disciplina que se consolida a partir da década de 1980, se enriqueceu com o alargamento de seus suportes teóricos, incorporado abordagens advindas dos Estudos Culturais, dos Estudos Pós-Coloniais e dos Estudos sobre a Imprensa e a História do Livro. Esse movimento levou a que a historiografia da tradução tenha buscado "aliar o registro de fatos e nomes a uma análise mais aprofundada da tradução em seu contexto social e histórico, vinculando seu estudo a fatores culturais que operam na produção e reescrita de textos” (2001, p. 127). No presente estudo, pretendo ampliar ainda mais essa abordagem teórica abarcando a teoria dos gêneros discursivos, oriunda da linguística aplicada, sem perder de vista que o foco principal do trabalho é “a palavra e o comportamento do tradutor”, tal como tão bem descreve Pagano no trecho abaixo:

\footnotetext{
A documentação historiográfica, geralmente consistindo de material paratextual das obras traduzidas (capas, orelhas, contracapas, prefácios e notas), levantamento de dados historiográficos em fontes diversas, depoimentos, crítica, resenhas e comentários, precisa, sempre que possível, ter como eixo principal a palavra e o comportamento do tradutor e de todos aqueles que participam do processo de reescrita de um texto.

Essa ênfase na figura do tradutor vem ao encontro de propostas dentro dos Estudos da Tradução de se estudar o discurso do tradutor, não apenas em elementos do paratexto das traduções, como também em outras instâncias discursivas, como são depoimentos, ensaios, memórias, diários e correspondência epistolar. (PAGANO, 2001, p. 127-128)
}

Sehnaz Tahir-Gurçaglar (2002) chama a atenção para a importância da análise dos paratextos, incluindo peritextos, epitextos e extratextos, em projetos de história da tradução, pois eles fornecem informações sobre as visões de editores e/ou tradutores sobre o que constitui tradução. Essa afirmação de TahirGurçaglar reforça a intenção da presente pesquisa de buscar o estudo do conceito de tradução conforme proferido pelos próprios tradutores em seus prefácios. 
Várias outras perguntas serão suscitadas pela análise dos paratextos e nem todas encontrarão resposta, o que não constitui um problema nesse tipo de pesquisa, mas sim um alargamento do questionamento e da análise.

A exploração por meio de paratextos provoca perguntas, algumas das quais podem nunca encontrar respostas. Porém, tudo o que pedimos de modelos de pesquisa é que gerem perguntas. É por isso que os paratextos merecem receber mais atenção nos atuais modelos de pesquisa em história da tradução. (TAHIRGURÇAGLAR, 2002, p. 59)

A terceira base metodológica para este estudo adveio do livro de Pym, o único de que tenho notícia inteiramente destinado a questões metodológicas em história da tradução. Pym afirma que a história é uma combinação de arqueologia (listas), crítica (análise e argumentação) e explicação (storytelling). A primeira atividade, a elaboração de listas de documentos tradutórios - traduções propriamente ditas ou textos sobre tradução - deve ser precedida de perguntas sobre sua seleção e a delimitação do corpus.

Existem basicamente duas abordagens metodológicas para essa questão: o método dedutivo e o método indutivo. O método dedutivo envolve o uso de listas para extrair corpora, que são então sujeitas a uma série de operações, incluindo a aplicação de definições de trabalho, determinação de distribuições no tempo e espaço e análises explicativas para os resultados. O modo de operação deste método é convencionalmente chamado de dedutivo, isto é, de uma lista mais ampla depreende-se um campo de estudos mais restrito e de maior importância específica. O método indutivo, por sua vez, é incremental e evita a construção de longas listas, partindo de uma área pequena que vai se ampliando aos poucos, conforme são descobertas novas peças para o quebra-cabeça. De qualquer forma, a construção do corpus, partindo de listas amplas ou pequenas áreas de estudo, constitui uma forma de “colocar a mão na massa” (PYM, 1998, p. 38).

Pym faz uma diferenciação entre catálogos e corpus: “um corpus é um catálogo com objetivo especial e um catálogo é um corpus com propósito geral” (PYM, 1998, p. 42). Segundo ele:

Os catálogos de traduções são listas de traduções dentro de um campo específico para o qual o ideal é ter dados sobre todas as traduções. A principal função de um catálogo é alcançar o máximo de completude para permitir que informações particulares sejam encontradas. Corpora, por outro lado, são mais bem 
compreendidos como listas de traduções elaboradas de acordo com critérios estritamente controlados - dos quais a completude pode ou não ser um - a fim de testar uma hipótese ou um conjunto de hipóteses. (PYM, 1998, p. 42)

Como veremos na descrição abaixo e na explicação da metodologia empregada, montou-se um corpus (e não um catálogo), já que não havia a preocupação com uma completude estrita, sendo que o levantamento pode continuar a ser feito em outros locais e bibliotecas. O levantamento seguiu parâmetros bem definidos (prefácios de tradutores em obras francesas traduzidas, consideradas obras canônicas da literatura francesa, a partir de meados do século XX). Quanto ao método utilizado, ele foi mais dedutivo, pois, de uma lista de títulos, depreendeu-se uma lista de obras que continham prefácios. Destas foi composta uma lista de obras que continham prefácios de tradutores e dela, então, uma lista mais estrita de prefácios de tradutores que falassem da tradução propriamente dita. Portanto, partiu-se de uma área maior para uma menor. Uma primeira hipótese bem geral é que se encontrariam prefácios de tradutores que falassem da tradução, o que se confirmou, apesar de em um número restrito.

Outro aspecto para o qual Pym chama a atenção é a determinação de frequências e tendências, com a construção de algum tipo de gráfico. A ideia não é mergulhar na matemática e na estatística, nem restringir a análise ao resultado desses cálculos. As estatísticas podem ser enganosas, mas grande parte das ciências sociais está baseada em resultados estatísticos. Eles podem confirmar ou refutar hipóteses, sendo um meio de criar novos questionamentos. Portanto, pretende-se neste trabalho depreender alguns números que nos ajudem a tirar conclusões pertinentes para este trabalho.

Por fim, gostaria de ressaltar a distinção que Pym traça entre os "tradutores" (pessoas reais, de carne e osso) e o "tradutor" (figura abstrata), por ter um profundo impacto sobre uma historiografia da tradução cujo principal foco seja a pessoa humana. Pym chama a atenção para o fato de que um grande número de tradutores costuma ter mais de uma profissão ou exercer mais de uma atividade, ao mesmo tempo ou ao longo do tempo, e que com isso obtêm mais poder social e intelectual do que se fossem só tradutores. A tradução como profissão entendida como um emprego de tempo integral e de longa duração, em vez de aumentar o prestígio e influência dos tradutores, restringe a sua capacidade 
de desafiar as estruturas de poder (PYM, 1998, p. 164). Uma maior agentividade de tradutor, portanto, está ligada a uma atuação profissional mais ampla. O tradutor que "só" traduz, por estar sempre transmitindo a palavra do outro, pode se esquecer, até por não ter muito tempo disponível (não se deve esquecer os prazos curtos e baixa remuneração da maior parte dos trabalhos de tradução) para expressar suas próprias ideias ou lutar pelo maior reconhecimento de sua profissão. Mais um dado que pode explicar por que, já no capítulo anterior, se configurou uma tendência de que os tradutores-escritores e os tradutoresacadêmicos tenham mais visibilidade nas edições traduzidas do que os tradutoresprofissionais, recebendo destaque para seus nomes e trajetórias profissionais e espaço para escrever prefácios nas edições.

Porém, qual deveria ser a extensão adequada da curiosidade que o historiador da tradução deveria ter sobre a vida pessoal dos tradutores, pergunta-se Pym. O termômetro deve ser a importância que fatos da vida pessoal possam ter para explicar ou lançar luz sobre fenômenos da tradução. Bisbilhotar a vida dos tradutores por simples curiosidade não leva a nada, mas se fatos pessoais esclarecerem modos de traduzir, posturas profissionais ou influência intelectual, então esses fatos passam a ter grande importância. Pym ressalta ainda que não são somente as causas pessoais que importam, mas também as causas sociais que ajudam a moldar eventos (PYM, 1998, p. 170):

\begin{abstract}
Para quase toda causação interna que se possa encontrar na biografia pessoal de um tradutor, existe um modo social de causação mais amplo que permite e aceita que fatores internos deixem sua marca no mundo público das traduções. Nenhum dos lados pode ser entendido sem o outro; vidas privadas não devem se tornar buracos negros. (PYM, 1998, p. 171-172)
\end{abstract}

A partir dessas sugestões, pode-se traçar um método de pesquisa que ligue a vida privada dos tradutores à visibilidade nas edições traduzidas que estou querendo ressaltar. Em primeiro lugar, é importante saber um mínimo da biografia dos tradutores para poder classificá-los nas categorias de tradutores-escritores, tradutores-acadêmicos e tradutores profissionais. Para tanto, foi eleita a principal fonte de pesquisa o DITRA - Dicionário de Tradutores Literários no Brasil. Segundo informações constantes no site na Internet (http://www.dicionariodetradutores.ufsc.br/pt/index.htm), este dicionário 
constituiu um desdobramento do projeto integrado Tradução, Tradição e Inovação: o papel das traduções do alemão, espanhol, francês, italiano e latim no sistema literário brasileiro (1970-2005), do Grupo de Pesquisa Literatura Traduzida, com objetivo de fazer um levantamento dos tradutores literários no Brasil e traçar o seu perfil. O projeto, aprovado pelo $\mathrm{CNPq}$, contou com pesquisadores professores e estudantes. A publicação online é de responsabilidade do Núcleo de Tradução da UFSC. Os critérios para a escolha dos tradutores incluídos nos verbetes foram inspirados nos dados do Index Translationum, da UNESCO, que compila as traduções feitas no mundo todo e que constitui o mais amplo e respeitado repertório sobre o assunto, e em pesquisas bibliográficas em bibliotecas e em sites. Vários instrumentos foram utilizados para chegarem às informações biobibliográficas dos verbetes. Além do contato direto com os tradutores, foram pesquisados a plataforma Lattes, do CNPq, e os sites da Associação Brasileira de Tradutores, do Sindicato dos Tradutores, da Câmara Brasileira do Livro, do projeto Releituras e também as listas e páginas pessoais de tradutores.

Em segundo lugar, a maior fonte de pesquisa sobre biodata dos tradutores foi a Wikipedia. Por não ser um site totalmente acurado, já que funciona com base em contribuições do grande público e não em um esforço de uma instituição de pesquisa, essa enciclopédia virtual sofre críticas e reparos de especialistas que podem não concordar com as informações contidas nos verbetes, propondo-se a aperfeiçoá-las. Além da Wikipedia, muitas informações podem ser obtidas em sites de editoras e páginas pessoais dos tradutores.

Pelo que se viu até o momento, a metodologia usada nesta pesquisa é uma metodologia híbrida entre a metodologia histórica e a metodologia sociológica. Isso seria impensável antes da década de 1970, como observa Daniel Simeoni (SIMEONI, 2007, p. 189). Na verdade, antes dessa época, havia uma diferença nítida e até mesmo uma oposição entre o método histórico e o método sociológico. O método histórico tradicional consistia de quatro operações: análise, categorização, definição e estabelecimento de relações entre essas definições, sendo essa rigidez uma tentativa de afastar seus praticantes de abstrações e considerações metafísicas. Outra característica que definia o método histórico tradicional era se basear somente em fontes primárias. Já a investigação 
sociológica, que surgiu um pouco antes da virada do século $\mathrm{XX}$, nunca se ateve a fontes primárias e tinha como objetivo principal a extração de regras ou leis, que permitissem detectar tendências e fazer previsões, ao contrário do objetivo da descrição de fatos que sempre caracterizou a investigação histórica (SIMEONI, 2007, p. 190).

As polaridades mais clássicas entre os dois métodos, segundo Simeoni, são: 1 . a sociologia está mais interessada no presente e a história no passado; 2. a sociologia é uma ciência "nomotética”, em busca de leis comportamentais, enquanto que a história é "idiográfica”, baseada no princípio da irrepetibilidade dos eventos; 3. os dados sociológicos servem mais a um tratamento estatístico e quantitativo do que os fatos históricos retirados de dados primários encontráveis em arquivos.

Essas oposições sistemáticas ficaram menos rígidas e nítidas com o enfrentamento de oposições de fontes externas, tendo seus discursos metodológicos que se modificar. A relativa paz percebida entre os princípios metodológicos dessas disciplinas nos últimos anos se deve a alguns fatores:

1. a internacionalização das disciplinas tomou grande impulso após a década de 1970, diminuindo um pouco as diferenças metodológicas e discursivas entre historiadores e sociólogos dos diversos países;

2. a expansão dos estudos culturais na esfera de influência angloamericana e da nova história cultural na Europa minaram o monopólio exercido por historiadores e sociólogos em questões de história e sociedade;

3. a virada antropológica da década de 1970, com seu interesse no estudo de artefatos culturais vistos como "textos" historicamente situados enfraqueceu a primazia das duas disciplinas, relativizando o princípio da literalidade no tratamento de fontes primárias, o que fez com que a maioria dos historiadores atuais tenha integrado em sua abordagem de investigação de eventos do passado a ideia de que o acesso à "verdade" é inevitavelmente mediado pelo momento em que a história está sendo escrita;

4. com a perda do apelo da base nacional, ou nacionalista, de ambas disciplinas após o término da Segunda Guerra, historiadores e 
sociólogos europeus passaram a olhar além de suas fronteiras em busca de inspiração (SIMEONI, 2007, p. 192-193).

A situação de confronto entre as duas disciplinas se suavizou tanto que não é raro hoje encontrar historiadores e sociólogos usando os mesmos conceitos transdisciplinares e itinerantes, como "habitus”, “campo”, “anomia”, etc. Esses conceitos se tornaram propriedade comum e podem se adaptar a qualquer uso particular que quem é de fora dessas disciplinas possa fazer (SIMEONI, 2007, p. 193). Eu acrescentaria que isso não é verdade somente em relação à história e à sociologia, mas também à linguística, à teoria literária e à filosofia da linguagem, como bem vimos ao descrever as abordagens dos teóricos contemporâneos da história intelectual, na seção 2.2 do Capítulo 2.

Contudo, apesar do movimento centrípeto generalizado da globalização nas ciências humanas e sociais, algo das diferenças entre a história e a sociologia ainda permanece. O sociólogo parece dar a impressão de que tem respostas ou hipóteses específicas que exigem testes, enquanto que o historiador parece mais hesitante em ir além das perguntas ou das respostas específicas ao seu objeto de estudo. Como ainda não existe um método próprio aos estudos de tradução, mas antes métodos tomados de empréstimo de outras disciplinas, impõem-se principalmente duas opções ao historiador da tradução: o caminho pessoal, e inevitavelmente cultural, e o disciplinar. Segundo o autor, no entanto, nos estudos de tradução, mais do que em qualquer disciplina, é essencial desenvolver um método flexível a vários ângulos de interpretação que se insira em enquadramentos mutuamente compatíveis e não exclusivistas de entendimento, abordagem mais coadunada com a primeira opção (SIMEONI, 207, p. 194-195).

Tendo em mente as indicações e reflexões mencionadas acima — que me deram o aval para utilizar perspectivas tanto históricas quanto sociológicas empreendi o levantamento dos dados primários principalmente no acervo de obras gerais na Biblioteca Nacional, no Rio de Janeiro, de março de 2011 a março de 2012. O levantamento teve por fim iniciar uma pesquisa historiográfica sobre o discurso dos tradutores encontrado em prefácios de sua autoria e outros elementos do paratexto que se refiram aos tradutores ou à tradução, encontrados em obras francesas traduzidas no Brasil a partir de meados do século XX. 
Como apontei na Introdução, esse recorte temporal se justifica por duas razões. Em primeiro lugar, as obras anteriores aos anos 1950 não estão catalogadas em acervo virtual, mas ainda em fichas manuais, na Biblioteca Nacional. A pesquisa nessas condições seria muito mais demorada do que foi já com as restrições padrão de pesquisa na BN (acesso intermediado aos livros, por meio de preenchimento manuscrito de fichas de pedido, e acesso a somente dois livros por vez). Em segundo lugar, verificou-se, por uma pesquisa geral anterior à definição do corpus, que é rara a ocorrência de prefácios de tradutores em livros traduzidos publicados antes dessa época. Assim sendo, a pesquisa em livros publicados antes de 1950 seria, além de muito demorada, pouco produtiva.

Esse levantamento foi feito durante vários meses, pois algumas dificuldades se apresentam na pesquisa na Biblioteca Nacional. Em primeiro lugar, para se entrar com laptop na Biblioteca, é preciso obter uma autorização do Chefe do Setor de Obras Gerais, autorização esta que tem duração de 30 dias. O método usual de pesquisa é a cópia a lápis em papel. Expirado o prazo, a autorização deverá ser renovada. Em segundo lugar, só é possível pegar dois livros por vez, que demoram a chegar à mesa do leitor/pesquisador por depender de busca manual dos funcionários da instituição. Esses entraves burocráticos não tornam a pesquisa muito produtiva, nem muito rápida. A esses problemas, acrescem-se outros tantos, como a falta de sistema de ar condicionado que perdura há muitos meses após uma inundação em 2012, o que torna a pesquisa impossível de ser feita em dias de muito calor; a demora de até dois dias úteis caso as obras se encontrem nos Anexos do prédio principal da Biblioteca Nacional; o extravio de livros dentro da própria biblioteca por terem sido guardados na estante errada, etc. Além dessas dificuldades de ordem institucional, houve ainda a dificuldade de se achar material com as características exigidas: prefácios/posfácio de tradutores falando de seu trabalho ou de tradução. As obras trazem uma gama enorme de prefácios/posfácios, mas poucos pertinentes a esta pesquisa. Assim sendo, foi preciso fazer muitas visitas para obter material em volume significativo.

O levantamento se processou segundo as seguintes linhas gerais:

1. Foi elaborada uma lista de autores clássicos ou expoentes da literatura francesa, na prosa, poesia e teatro. A lista dos autores em ordem alfabética foi: Balzac (59 livros), Baudelaire (32 livros), Corneille (5 livros), Dumas (4 livros), 
Flaubert (15 livros), Mallarmé (5 livros), Maupassant (34 livros), Molière (29 livros), Prévert (6 livros), Proust (37 livros), Racine (14 livros), Rimbaud (9 livros), Saint-Exupéry (11 livros), Stendhal (26 livros), Verlaine (4 livros), Verne (16 livros), Zola (27 livros). Do meu acervo pessoal, foram consultadas obras não só destes, mas de outros autores: Beauvoir (2), Camus (2), Céline (2), Daudet (1), Dumas (1), Flaubert (1), Hugo (3), Huysmans (1), Mallarmé (1), Montaigne (1), Ponge (1), Rimbaud (1), Rostand (1), Sartre (1) e Yourcenar (1), além de duas antologias de poemas (Laranjeira (1) e Veiga (1)). O total de livros pesquisados foi de 360. A lista de livros, com comentários, encontra-se no Anexo I, apresentada em ordem alfabética de autores.

2. O segundo passo foi procurar no acervo digital os livros disponíveis para consulta de cada autor. Algumas referências constam no acervo, mas os livros não puderam ser consultados, seja porque estavam em fase de catalogação, seja porque estavam fora de lugar na estante. Outras referências dizem respeito a várias edições ou reimpressões de uma mesma obra, sem diferença entre elas, tendo sido contadas somente uma vez quando isso aconteceu. Além disso, foram encontradas obras no original em francês e edições portuguesas, que foram descartadas por não fazerem parte do corpus da pesquisa.

3. Nos livros consultados, foram levantados todos os tipos de paratextos e identificados por autoria, se atribuída. Em caso de existência de um prefácio/posfácio ou algum outro tipo de paratexto escrito pelo tradutor, que pode se apresentar sob variadas denominações (Apresentação, Introdução, Prefácio, Posfácio etc. ou sem título), este era lido atentamente para se conhecer o seu conteúdo. Não foram consideradas notas dos tradutores ou de outros, nem de rodapé, nem finais, pois, para analisar notas, é preciso entrar no texto propriamente dito, o que fugiria da minha proposta inicial.

4. Nesses paratextos do tradutor, verificou-se se o tradutor falava de seu trabalho ou da tradução realizada ou se só fazia considerações gerais sobre a obra, o autor, a escola literária em que o autor se inseriu, a recepção da obra e/ou do autor no Brasil, ou ambos. Se detectados paratextos do tradutor falando de seu trabalho naquela tradução específica ou em geral, os trechos relevantes eram copiados (vide Anexo I e Capítulo 5). 
5. Verificou-se ainda se nos paratextos heterográficos (de autoria de outrem, que não autor ou tradutor, p. ex. editor ou prefácio de encomenda) havia menções à tradução ou ao tradutor. Em caso afirmativo, os trechos relevantes também foram copiados (vide Anexo I e Capítulo 5).

6. Foi observada ainda a posição do nome do tradutor na obra (se na folha de rosto, verso da folha de rosto, quarta capa ou capa, ou se somente na ficha catalográfica). Essas observações foram anotadas (vide Anexo I e Capítulo 5).

7. Verificou-se se existia alguma menção ao currículo do tradutor, como p. ex., nas páginas iniciais, orelhas ou quarta capa. Essas observações foram anotadas (vide Anexo I e Capítulo 5).

Esse levantamento, organizado em ordem por autor, será analisado segundo as perguntas de pesquisa, com base na fundamentação teórica apresentada nos capítulos anteriores.

Antes de entrar na análise dos trechos dos prefácios de tradutores que falam de tradução, no item 5.3, é interessante fazer uma reflexão sobre a posição das línguas, autores e tradutores o cenário literário mundial, a fim de situar as traduções de obras literárias francesas para o português do Brasil.

\section{2}

\section{Visão geral da posição das línguas, autores e tradutores no cenário literário mundial}

A atividade da fatia editorial dos livros selecionados nesta pesquisa traduções literárias francesas no Brasil — se insere no quadro mais amplo da atividade editorial como um todo e, especificamente, das relações França-Brasil, historicamente muito dinâmicas. Esse dinamismo perdeu força após a Segunda Guerra, quando aos poucos a língua inglesa foi tomando a dianteira e desbancando o francês como principal língua de trocas culturais e intelectuais, sem falar de como língua de negócios, no Brasil. Esse estado de coisas se reflete hoje no mercado editorial com a língua francesa não apenas ocupando o terceiro lugar como língua mais traduzida no Brasil (no final do século XX, ocupava o segundo lugar), mas também com o inglês ocupando cerca de 70\% do mercado de traduções, seguido pelo espanhol. Os dados que possuímos (Étude du BIEF sur les 
éditions au Brésil, 2013), gentilmente cedidos pelo Bureau du Livre Français au Brésil, seção Rio de Janeiro, mostram o número de títulos que tiveram seus direitos autorais cedidos por assunto, pela França ao Brasil, em 2011:

Número de títulos cedidos por assunto (2011) ${ }^{11}$

\begin{tabular}{|l|l|}
\hline Ciências Humanas & 97 \\
\hline Literatura infanto-juvenil & 48 \\
\hline Quadrinhos & 36 \\
\hline Ensaios e documentos & 35 \\
\hline Ficção & 34 \\
\hline Coedições vendidas de literatura infanto-juvenil & 20 \\
\hline Ciência aplicada & 10 \\
\hline Livros de arte & 8 \\
\hline Religião e espiritualidade & 7 \\
\hline Livros técnicos & 3 \\
\hline
\end{tabular}

O BIEF (Bureau International de l’Édition Française) informa ainda que, apesar de, nas novas gerações, o ensino de francês ter sido substituído pelo do espanhol, os profissionais do livro estimam não encontrar muitas dificuldades de encontrar bons tradutores de francês. Esse é um dos indícios de que, apesar de o francês ter perdido espaço primeiro para o inglês e depois para o espanhol no mercado editorial brasileiro, ainda é uma língua de prestígio, à qual muitos tradutores mais intelectualizados se dedicam, nem tanto em tempo integral, mas como parte de suas atividades. Nos livros analisados nesta pesquisa, isso fica bem claro. Há uma maioria de tradutores-escritores e tradutores-acadêmicos, e uma menor parte de tradutores profissionais e diletantes, situação que talvez fosse diferente em levantamento semelhante em relação à literatura de língua inglesa traduzida. Seria necessário ter dados precisos para confirmar essa hipótese, mas, pela raridade de cursos de formação de tradutores de francês no Brasil, pode-se imaginar que a maioria dos tradutores editoriais hoje existentes seja autodidata em tradução, ou também formada em cursos de tradução de inglês/espanhol ou,

\footnotetext{
${ }^{11}$ Repères statistiques, Internacional 2010-2011, BIEF/SNE, juin 2012.
} 
principalmente, composta de intelectuais, acadêmicos e escritores que dominam a língua francesa.

A língua francesa, que antes integrava a grade curricular de muitos bons colégios no Brasil, hoje perdeu espaço para o espanhol como segunda língua estrangeira ensinada. Além disso, o idioma não é mais uma opção de língua estrangeira nos vestibulares nem no ENEM, saiu do concurso para ingresso no Instituto Rio Branco, deixou de ser uma habilitação em muitos cursos de Letras de universidades particulares, permanecendo sendo ensinada somente em escolas bilíngues franco-brasileiras e como habilitação em algumas universidades públicas. Com isso, cursos particulares como a Aliança Francesa, ou cursos livres em universidades, passaram a ser das poucas opções de ensino da língua (e de tradução em níveis avançados) para os interessados. Apesar de menos ensinada para o público em geral, a língua francesa continua a ser uma língua de prestígio, dominada em nível iniciante e intermediário por alguns e dominada em nível avançado (e traduzida) por uns poucos. Os tradutores de francês aumentam seu capital simbólico por continuarem a optar por essa língua como língua de trabalho, mesmo que tenham que ir contra as exigências do mercado e da dominância da lei de oferta e procura. Como Prunc bem ressalta, há uma correlação entre o prestígio de certas culturas e o status social dos tradutores dessa língua (PRUNC, 2007, p. 45). Quanto mais raros e/ou formados por seu próprio esforço os bons tradutores de uma língua, mais prestígio eles obtêm.

Os estudos mais aprofundados e recentes sobre o fluxo de traduções e consagração do capital literário foram feitos por Pasquale Casanova e Johan Heilbron, e publicados em 2010. Heilbron, ao falar de desigualdade e luta pelo poder no universo linguístico/literário, divide as línguas entre centro e periferia. Já Casanova prefere distinguir entre línguas dominantes e línguas dominadas. As línguas dominantes possuem capital literário considerável, em parte devido ao número de textos considerados universais escritos nessas línguas (como é o caso do francês). Já as línguas dominadas possuem pequeno capital literário e recaem em quatro subgrupos distintos: 1. Línguas que não possuem sistema de escrita estabelecido; 2. Línguas com curto histórico de uso; 3. Línguas estabelecidas faladas em países “pequenos” com relativamente pequeno número de falantes (por exemplo, o holandês); 4. Línguas com grande número de falantes e grandes 
tradições literárias, mas que não são muito valorizadas nos mercados literários internacionais (por exemplo, árabe e chinês). O português, pelo menos em sua variante brasileira, ainda se encaixa neste último subgrupo (CASANOVA, p. 286). Portanto, segundo a visão de Casanova, as traduções brasileiras de obras literárias francesas se dariam entre uma língua dominante e uma língua dominada. A questão da dominação se reflete em grande parte na atitude tradutória, principalmente de tradutores que não são escritores, de se submeter ao texto de partida como se ele fosse quase intocável e "imexível”. O mesmo não é frequente no caso contrário, de tradução de obras literárias brasileiras em francês, como pude comprovar na minha pesquisa de mestrado sobre as obras de Mário de Andrade em francês (CUNHA, 1999).

Segundo Casanova, dessa classificação acima, podem-se depreender quatro situações: 1 . Tradução para uma língua dominada de um texto escrito em uma língua dominante; 2. Tradução para uma língua dominante de um texto escrito em uma língua dominada; 3. Tradução para uma língua dominante de um texto escrito em uma língua dominante; 4. Tradução para uma língua dominada de um texto escrito em uma língua dominada. Seu interesse reside principalmente nas duas primeiras situações, que analisa sob duas rubricas: "tradução como acumulação de capital”, no primeiro caso, e "tradução como consagração”, no segundo caso. O primeiro caso é o que nos interessa aqui. A tradução como acumulação de capital ocorre quando autores de um campo literário dominado tentam entrar no mercado literário mundial "nacionalizando" as grandes obras literárias que tenham valor universal, por exemplo, Shakespeare ou Racine (CASANOVA, 2010, p. 290-294).

Casanova chama atenção para a necessidade de se perceber a posição de dominação não só da língua, mas também a posição que o autor do texto fonte e o tradutor (e outros agentes consagradores) ocupam nos campos literários de origem e alvo, para se entender com mais detalhes o que está em jogo em cada tradução literária. Outros já haviam falado sobre a posição das línguas envolvidas e dos autores traduzidos, mas a posição do tradutor, que é a que mais me interessa neste trabalho, é assunto relativamente novo.

Casanova afirma que "depois de feita a tradução, a posição do texto traduzido (ou do autor), e principalmente seu grau de legitimidade, dependerá da 
posição do tradutor” (CASANOVA, 2010, p. 299), isto é, do capital do tradutorconsagrador (ao qual se deve acrescentar o capital do editor, o prestígio da série ou da publicação em que o texto é publicado etc.). Assim sendo, diz ela: "É possível deduzir o grau de legitimidade do livro traduzido a partir da posição do mediador em seu campo nacional, da posição da língua meta e, em segundo lugar, da posição do editor” (CASANOVA, 2010, p. 299). O tradutor como consagrador, ao produzir a tradução, designa um texto que vale a pena ser lido, entendido e comentado. Aí, Casanova introduz a noção de "consagradores consagrados” ou consagradores cujo poder de consagração depende do grau de sua própria consagração. Estes, que Casanova também chama de "consagradores carismáticos”, na minha classificação, seriam os tradutores-escritores. Assim, quanto mais consagrados forem como autores, mais consagradores poderão ser do texto traduzido por eles. Já os “consagradores institucionais” se identificam, na minha classificação, com os "tradutores acadêmicos” (CASANOVA, 2010, p. 300). Como se pode depreender da análise de Casanova, os tradutores profissionais teriam uma posição inferior na dinâmica de consagração de uma tradução, o que se reflete na posição do nome do tradutor na edição, como já apontamos nos casos analisados no Capítulo 4.

Segundo Casanova ainda, “é interessante notar que, depois que um autor é canonizado e suas obras se tornam clássicos, o processo de reverte e aí então é o autor que consagra o tradutor” (CASANOVA, 2010, p. 301). Eu diria que, em termos de obras canônicas, os dois processos se complementam. O tradutor que tem mais força de consagração aumenta a vendagem da tradução de uma obra já reconhecida e é consagrado por ela, num processo que se retroalimenta. A conclusão que se chega é que a tradução de obras canônicas de uma língua/campo literário dominante para uma língua/campo literário dominado é tanto mais bemsucedida em termos de consagração quanto mais o tradutor é consagrado, e a consagração do tradutor muitas vezes é medida pela (ou se reflete na) existência de um prefácio de sua autoria e em uma posição de destaque de seu nome na publicação ou menções à tradução em outras partes do paratexto. Vamos ver, então, a seguir como isso se circunstanciou nas obras examinadas. 


\section{3}

\section{Análise dos dados levantados na pesquisa}

Depois de definido e explicitado todo o embasamento teórico, a metodologia e a visão geral das línguas, o próximo passo do trabalho será tratar os dados obtidos na pesquisa, de forma a buscar resposta para as perguntas que pautaram o levantamento: 1. Existem conceitos/ideias que se repetem na fala de tradutores sobre seu trabalho em prefácios/posfácios?; 2. Esses conceitos/ideias sofrem modificações com o passar do tempo?; 3. O discurso do tradutor sofre, com o passar do tempo, influências perceptíveis da teoria de tradução?). Com relação à presente pesquisa, para uma possível contribuição a uma teoria do paratexto do livro traduzido que pretendo construir aqui, a resposta preliminar à primeira pergunta é afirmativa, como vimos no Capítulo 4 e endossaremos neste capítulo. Quanto às duas outras perguntas, a resposta é variável ou não conclusiva como tendência, como veremos a seguir. Diferentes - e até opostos - conceitos sobre tradução convivem nas mesmas épocas. A questão depende muito mais do tradutor, suas convicções, leituras e formação, do que da época. Quanto a uma maior influência das teorias de tradução com o passar do tempo, isso não se verificou em termos lineares. Tradutores contemporâneos em edições muito recentes podem nem mesmo fazer qualquer menção à teoria, por desconhecimento ou desinteresse.

\section{3 .1}

\section{Tipos de prefácios}

Nos 360 livros pesquisados, foram encontrados os seguintes tipos de prefácios/posfácios:

1. prefácios contidos na obra original e traduzidos para a edição brasileira: do autor, do editor da publicação francesa (p. ex., Prefácio 5, Anexo II), de encomenda. Esses prefácios foram produzidos por demandas da publicação original e são importados ipsis litteris para a publicação brasileira. Podem pertencer a várias edições da obra original e estar muito distanciados no tempo.

2. prefácios/posfácios produzidos para a edição brasileira: 
2.1 do editor (p. ex., Prefácios 1 e 4, Anexo II): tratam da importância do autor e da obra e ressaltam o acontecimento cultural de tradução desta obra no universo brasileiro. Podem situar a publicação no acervo da editora e, quando a publicação fizer parte de uma série ou coleção, apresentá-la dentro desse pertencimento maior. Nesse contexto, podem ou não falar da tradução e/ou do tradutor, sempre enaltecendo-os.

2.2 de encomenda (p. ex., Prefácio 6, Anexo II): são prefácios escritos por estudiosos do autor ou da obra e apresentam as linhas gerais do pensamento do autor ou a importância daquele livro no conjunto da obra do autor. São didáticos, elucidativos e, por vezes, bastante densos, apresentando suporte teórico e discussões acadêmicas. Podem ou não se referir à tradução e/ou ao tradutor, apesar de ser mais raro do que nos prefácios/posfácios dos editores, que procuram enaltecer as boas características da publicação, sendo uma boa tradução feita por tradutor qualificado uma delas.

2.3 do tradutor (p. ex. Prefácios 7 a 12, Anexo II): o tradutor nesses prefácios/posfácios pode funcionar como o estudioso do item 2.2, por ser efetivamente profundo conhecedor do autor ou da obra. Muitas escolhas de quem vai traduzir uma obra se baseiam no conhecimento do autor por parte do tradutor, além de suas capacidades tradutórias. Nesse sentido, não dão ênfase particular à descrição do projeto tradutório ou às dificuldades encontradas, o que seria uma característica mais específica dos prefácios/posfácios de tradutores mais autorais, quando não só as funções de narração e descrição aparecem, mas também surge uma função emotiva mais marcada. Alguns desses prefácios/posfácios possuem características híbridas (didáticos e autorais), com movimentos recorrentes e regularidades, como vimos no capítulo sobre o prefácio do tradutor como gênero discursivo.

Desses todos, os que nos interessam mais de perto são os prefácios/posfácios do tradutor, apesar de que, sempre que foi encontrada uma menção à tradução ou ao tradutor nos prefácios dos editores ou de encomenda, tal menção foi anotada. Serão os prefácios/posfácios de tradutores que efetivamente constituirão nosso objeto primordial de análise.

2.4 anônimos (p. ex., Prefácios 2 e 3, Anexo II): Apesar de não assinados, a autoria pode ser atribuída ao editor ou ao tradutor. 
Em termos numéricos, dos 360 exemplares pesquisados, isto é, 338 exemplares analisados na Biblioteca Nacional e 22 em acervo próprio, foram encontrados 278 exemplares contendo algum tipo de elemento paratextual prefacial ou posfacial (de autoria do autor, do editor, do tradutor, de terceiros), ou em termos percentuais, $77,22 \%$ dos exemplares continham esses elementos. Do total de exemplares, apenas 102 exemplares, ou 28,33\% continham prefácios de tradutores, sendo que somente $15 \%$ do total continham prefácios/posfácios de tradutores que faziam menção à tradução. A proporção entre esses percentuais pode ser mais bem visualizada na tabela abaixo, cujos resultados foram extraídos do Anexo I. Os percentuais abaixo não totalizam 100\%, pois alguns exemplos se inserem em mais de uma categoria.

\begin{tabular}{|c|c|c|}
\hline $\begin{array}{l}\text { Exemplares contendo } \\
\text { prefácios/posfácios em geral }\end{array}$ & 278 & $77,22 \%$ \\
\hline $\begin{array}{lr}\text { Exemplares } & \text { contendo } \\
\text { prefácios/posfácios } & \text { de } \\
\text { tradutores } & \end{array}$ & 102 & $28,33 \%$ \\
\hline $\begin{array}{l}\text { Exemplares } \\
\text { prefácios/posfácios } \\
\text { tradutores com menção à } \\
\text { tradução }\end{array}$ & 54 & $15 \%$ \\
\hline $\begin{array}{l}\text { Exemplares que não continham } \\
\text { qualquer tipo de } \\
\text { prefácio/posfácio }\end{array}$ & 82 & $22,77 \%$ \\
\hline
\end{tabular}

Dos exemplares em que não foi encontrado qualquer tipo de prefácio/posfácio (82 exemplares), a maioria é de edições populares, de bolso ou econômicas, predominantemente de autores como Maupassant, Molière, Proust, Verne e Zola. A exiguidade de espaço para paratextos de modo geral nesse tipo de edição e o fato de esses autores serem todos muito conhecidos do público brasileiro - mas não necessariamente muito lidos — podem justificar essa inexistência. Nos exemplares que contêm elementos prefaciais/posfaciais, estes 
variam muito de extensão, sendo, de modo geral, os mais longos e mais frequentes proporcionalmente aos prefácios/posfácios de obras de poesia.

\section{3 .2}

\section{Tipos de tradutores}

A seguinte classificação foi criada e definida por mim, em grande parte com base no que encontrei na pesquisa:

1. Tradutor-escritor: aquele que, além de traduzir como atividade cotidiana ou esporadicamente, é também um escritor ou poeta.

2. Tradutor acadêmico: aquele que possui uma vida acadêmica, como professor universitário ou pesquisador, ou é um erudito, um estudioso, um intelectual.

3. Tradutor profissional: aquele profissional experiente, que vive de tradução como profissional autônomo, formado ou não por cursos universitários ou afins/similares e que tem a tradução como meio exclusivo ou majoritário de vida.

4. Tradutor diletante: aquele que se dedica à tradução por gosto, e não por ofício ou obrigação. Apesar de diletantismo, de modo geral, ser identificado com amadorismo, aqui não pretendo introduzir qualquer juízo de valor quanto a seu trabalho, mesmo porque não li nem avaliei as traduções em questão. "Diletante" foi usado aqui por falta de designação melhor, e pelos tradutores incluídos nessa classificação não se enquadrarem nas classificações anteriores.

Em termos de prestígio e visibilidade, o que vemos é uma hierarquia entre esses quatro tipos de tradutor, com ordem decrescente de exposição nos prefácios, inclusive em termos de explicitação de seu projeto tradutório e no destaque de seu nome nas edições, ocupando os dois primeiros tipos as duas primeiras posições de destaque nas edições.

Ter um espaço na edição para escrever um prefácio e seu uso efetivo é um instrumento de poder, de influência e de marketing pessoal. Esse espaço é cobiçado, mas pouco concedido pelos editores, que ou não acham importante que o tradutor apresente suas ideias em prefácios com alto grau de conteúdo expressivo (em contraposição aos prefácios meramente didáticos em que o tradutor exerce uma função que poderia ter sido desempenha por outro especialista em um prefácio de encomenda) ou não querem chamar a atenção para 
a tradução e seu alto grau criativo e adaptativo em obras literárias canônicas, continuando a querer fazer crer ao leitor que ele está lendo Balzac, ou qualquer outro escritor francês clássico, em obra produzida diretamente em português, sem mediação pela interpretação de um sujeito-tradutor, que reescreve o texto segundo sua própria leitura enviesada, como toda leitura, na minha opinião, necessariamente é.

Como vimos no item 5.1, Anthony Pym chama a atenção para o fato de que os tradutores que obtêm mais poder social e intelectual são justamente aqueles que exercem múltiplas funções no universo acadêmico, literário e editorial (como a escrita de textos autorais, o ensino, a pesquisa, atividade editoriais etc.), e não aqueles que são monoprofissionais (PYM, 1998, 164). Isso porque esses últimos ficam mais submetidos ao status quo, por dependerem financeiramente total ou em grande parte de seus clientes e seguirem as regras implícitas e explícitas sem muito questionamento, pois estão mais preocupados com sua produtividade em termos de laudas, palavras e caracteres traduzidos, de olho no cheque que será recebido no final do trabalho para o pagamento das contas do mês, assumindo uma atividade mais passiva diante do desafio ao status quo. A pressão financeira e dos prazos - que são definidos sem muita margem de negociação pelas editoras — não possibilita que os tradutores profissionais disponham de muito tempo para grandes reflexões teóricas e ou elaboração de prefácios, caso esse espaço lhe seja concedido, o que não ocorre geralmente com os tradutores-escritores, que têm mais manobra de negociação de prazos e valores. Os tradutores que possuem várias outras atividades profissionais exercem um poder mais efetivo de definir o rumo de suas traduções e influenciar a apresentação das edições de suas traduções.

Apesar de essa visão parecer um pouco pessimista e ácida, o corpus desta pesquisa parece corroborar essa conclusão de Pym de que os tradutores profissionais acabam desprovidos de poder de expressão e influência devido às condições exaustivas de trabalho dessa profissão e da falta de prestígio de uma atividade intelectual até hoje considerada menor em relação à autoria de textos originais e atividades acadêmicas, intelectuais e editoriais. Pym ressalta que, no universo europeu, muitas pessoas que almejam penetrar no mundo literário se dedicam à tradução por um tempo, para abandoná-la tão logo surjam outras oportunidades que tragam mais realização pessoal. No Brasil, o quadro parece ser 
um pouco diferente. Veem-se muitos tradutores que se dedicam ao ofício da tradução durante uma vida inteira sem ter qualquer pretensão de se tornarem autores, pelo mero amor ao ofício ou pela vontade de tornar um autor conhecido em seu país. Contudo, no Brasil como na Europa, a rotatividade na profissão parece ser alta, apesar de não dispormos de estatísticas brasileiras que comprovem essa afirmação. Muitos jovens se interessam pela profissão como uma primeira forma de auferir renda e depois a abandonam quando ascendem a outras formas mais prestigiosas e lucrativas de ganhar a vida. Outros, na fase da aposentadoria, passam a se interessar pela atividade por não quererem parar de trabalhar completamente e por se verem atraídos pela possibilidade de realizar um trabalho sem sair de casa, mas já com suas pensões e o amparo na velhice garantidos. Por tudo isso, não me enganaria ao dizer —em termos gerais, mesmo que haja exceções à regra, como veremos adiante - que a atividade, quanto mais profissionalmente exercida (em termos de exclusividade de função e faixa etária ativa, sem fazer qualquer juízo de valor em relação à qualidade das traduções), menos prestigiada é em termos de acesso a canais de expressão e destaque, sendo um deles, claramente, os prefácios.

\section{3 .3}

\section{Os prefácios de tradutores que não tratam de tradução}

Os prefácios de tradutores que não tratam de tradução constituem a maioria e se inserem na retórica tradicional dos prefácios em geral, não necessariamente escritos por tradutores. A retórica dos prefácios traz elementos claros e bem definidos de persuasão, visando a convencer o leitor e ler/comprar a obra. Desde a Antiguidade, a arte de argumentar estava relacionada ao bom uso da palavra e "compreendia a presença de um orador que, por meio de seu discurso (o logos), construía uma imagem positiva de si (o seu éthos) com vistas a convencer um auditório (o páthos)” (OLIVEIRA \& NEVES, 2012, p. 2969). Essas características, percebidas no discurso oral, vão depois ser estendidas ao discurso escrito, com toda uma sofisticação dos mecanismos de convencimento e persuasão, visando à construção de um discurso sedutor. 
Toda essa tradição se apresenta fortemente na elaboração de prefácios, escritos por figuras de autoridade na "república das letras", especialistas no autor ou na obra em questão, que podem ser escritos por tradutores quando estes são reconhecidos como sendo tais figuras de autoridade. É como se o tradutor aí agisse como especialista e não como tradutor, ocupando uma função diferente daquela que ocupou durante a realização da tradução. Relembrando D’hulst (ver Capítulo 3), o tradutor pode oscilar entre desempenhar as funções de tradutor propriamente dito, historiador e crítico, e o prefácio de tradutor pode aparecer somente como um complemento do tratado literário ou do texto de crítica literária quando não fala da tradução propriamente dita. O prefácio, como é escrito normalmente após a tradução da obra, apesar de preceder no espaço do livro ao texto propriamente dito, pode criar no tradutor a possibilidade de se colocar em outra função que não necessariamente - ou não tradicionalmente - sua experiência na feitura daquela tradução específica. O tradutor, assim, se revestiria de um novo papel e passaria a reproduzir uma retórica muito antiga no tempo e muito rígida em sua aplicação. Por isso os prefácios de tradutor normalmente possuem movimentos e passos (ver Capítulo 4) que se assemelham em muito aos movimentos e passos utilizados em prefácios escritos por prefaciadores outros. O que distinguiria os prefácios de tradutor em relação aos de outros prefaciadores é justamente o que os afasta da retórica tradicional: o falar da tradução, do projeto tradutório, com uma atitude humilde (aqui o tradutor figura de autoridade dá lugar ao tradutor figura de submissão, mostrando como sua posição pode ser deslizante e sua atitude falsamente submissa - afinal, se não acreditasse que tinha feito um bom trabalho não estaria escrevendo um prefácio que o coloca em destaque!). Relembrando Prunc (ver Capítulo 3), o habitus esquizofrênico do tradutor de por vezes se apresentar e agir como sacerdote e às vezes como pária pode se mostrar em prefácios de diferentes tipos e num só prefácio. Como figura de autoridade, historiador e crítico ele é sacerdote, como tradutor submisso é pária. É interessante notar que a escolha vocabular muda, a assertividade das frases se perde e a modalização aumenta quando se passa de uma função para outra. Não faz parte do escopo desta pesquisa estudar essas marcas no texto, mas isso consistiria uma interessante outra pesquisa. 
O prefácio de tradutor que fala de tradução, portanto, foge à regra, é um empreendimento “desviado”, de certa forma. Essa é a explicação para o resultado parco de prefácios de tradutor que falam de tradução. Não está previsto na retórica tradicional dos prefácios que esse assunto surja e seja tratado. O resultado numérico obtido nessa pesquisa muito provavelmente se repetiria em qualquer que fosse o corpus. ${ }^{12} \mathrm{O}$ número de prefácios de tradutor que falam da tradução aumenta mais quando se trata de retraduções, em que a justificativa para a existência mesma de uma nova tradução para obras canônicas se faz necessária.

Nos exemplos que aparecem nos Anexos I e II de prefácios de tradutores que não falam de tradução percebe-se claramente que poderiam ter sido escritos por outro prefaciador figura de autoridade, e não necessariamente pelo tradutor. Não há muito que comentar sobre eles que já não tenha sido dito no Capítulo 4 . Podem-se estudar as figuras de linguagem utilizadas, seus mecanismos de convencimento, as estratégias de persuasão empregadas, seus aspectos promocionais e outras características, o que constituiriam pesquisas muito interessantes, mas que fugiriam ao objetivo da presente pesquisa. $\mathrm{O}$ que nos interessa mais de perto são justamente os prefácios “desviados” de sua função retórica tradicional, isto é, os que tratam de tradução, e os aspectos que os levam a distanciar-se da regra.

\section{3 .4}

\section{Os prefácios de tradutores que tratam de tradução}

Os prefácios/posfácios que nos interessam particularmente, os de tradutores, também são diferentes em extensão, mas nem tanto em relação aos temas, como vimos no Capítulo 4. Eles se diferenciam mais pelo fato de mencionarem ou não a tradução e, principalmente, pelo que falam quando tratam desse tópico. Para facilitar a análise, destacamos abaixo em uma lista os 59 prefácios de tradutores a que nos dedicaremos com mais atenção. Nessa lista, são apresentados os dados da publicação, bem como os trechos destacados em que os tradutores falam da tradução, outros elementos paratextuais em que aparece

\footnotetext{
${ }^{12}$ A pesquisa de Ellen McRae, em um corpus de 810 obras literárias de prosa traduzidas em inglês de 29 línguas diferentes, mostra que somente $20 \%$ dos livros traziam prefácios e destes somente a metade (10\%) tinha prefácios que discutiam o ato tradutório (McRAE, 2012, p. 66).
} 
menção à tradução ou ao tradutor, a posição do seu nome na edição e a classificação por tipo de tradutor com base nas categorias depreendidas por mim, em item acima. A minha intenção ao destacar essas informações é fazer uma correlação entre a existência do prefácio do tradutor, o destaque ao nome do tradutor, a existência de reforço a esse destaque em outros elementos paratextuais e o tipo de tradutor que escreveu o prefácio. Para determinar o tipo, foram lidos os verbetes do DITRA e mais referências na Internet, por meio do Google. Quando o tradutor se encaixou em mais de uma classificação, ele foi classificado em mais de um item.

1. BALZAC, Honoré de. Seráfita. Trad. Carmen Lúcia C. L. Gerlach e Juliane Bürger. Col. Paideuma. Florianópolis: Editora da UFSC, 2006.

Trechos destacados no prefácio do tradutor: "Nosso interesse em traduzir Seráfita foi impulsionado pela maneira apurada com que nesta obra Balzac desvenda o esplendor da vida espiritual, mostrando que a Comédia Humana possui o mesmo vigor tanto para discutir as questões metafísicas quanto as materiais. Pensar em uma nova tradução de Balzac em português é antes pensar em Balzac. Quem é Balzac? Quem é este autor que queremos decifrar? (...)”

“A retomada dessa tradução resgata todos esses valores da obra, além de realizar uma nova leitura, utilizando termos mais coloquiais, mudando o tratamento do ‘tu’ para o ‘você' (o ‘tu’ havia sido utilizado pelo gaúcho Mario Quintana na última tradução efetuada em 1955) e atualizando expressões, para que o texto fique mais próximo dos leitores dos nossos dias.

Com esta nova tradução de Seráfita desejamos aproximar dos leitores contemporâneos, e mesmo dos já habitués da obra balzaquiana, estas delicadas páginas que revelam um autor clássico preocupado em discutir temas transcendentais, como compreensão, fé, liberdade, amor, vida e morte, misticismo e espiritualidade”. (p. 8-9)

Referência ao tradutor na orelha: “A Câmara Catarinense do Livro conferiu o troféu Boi-de-Mamão à Carmen Lúcia Gerlach, na categoria tradução, pelo livro Madame Hermet e outros contos fantásticos (EdUFSC, com o apoio cultural da Aliança Francesa), de Guy de Maupassant, em 14 de setembro de 2000, na cidade de Florianópolis”. 
Posição do nome do tradutor na edição: capa.

Tipo de tradutor: acadêmicas e profissionais.

As referências a Carmen Lúcia Gerlach são mais copiosas na Internet do que as a Juliane Bürger. Sabe-se que traduzem profissionalmente, mas existem também indicações de sua atividade acadêmica. Carmen Lucia aparece em referências a trabalhos acadêmicos ligados à UFSC e, a partir de um minicurrículo contido em outra obra do acervo, sabe-se que é professora da UFSC, além de tradutora de obras de ficção e ensaios, e o nome de Juliane aparece como resenhista de um livro de Antoine Berman, Pour une critique des traductions: John Donne, na publicação Cadernos de tradução (NUPLITT). Fica evidente, portanto, que conhecem autores ligados à teoria da tradução. No trecho acima, contudo, esse conhecimento não se faz claro, não há indicação disso no prefácio. O que de fato apontam no trecho acima é o dilema clássico em que o tradutor de obras canônicas afastadas no tempo se encontra: "modernizar" o texto, aproximando-o do leitor contemporâneo, ou deixá-lo com traços e características textuais que o aproximam mais da época em que foi escrito? As tradutoras claramente dizem que optaram pela primeira opção, mas não apresentam um suporte teórico que justifique a sua opção. A justificativa se dá por contraposição ao projeto tradutório de Mário Quintana na tradução da mesma obra, feita muitos anos antes. É interessante que levantem o problema do pretenso “envelhecimento” da tradução anterior explicitamente e o projeto tradutório modernizante da retradução. O tratamento da questão, no entanto, não é aprofundado, indicado para um leitor não iniciado no debate teórico.

O fato de a publicação ter sido realizada por uma editora universitária, justamente a universidade à qual Carmen Lucia está ligada, explica o nome das tradutoras na capa, reforçando o destaque a que o nome das tradutoras recebeu com a referência ao prêmio concedido a Carmen Lucia por uma tradução também publicada pela mesma editora universitária. Trata-se, assim, de um prefácio reforçado por outros elementos de destaque, publicado por uma editora universitária, de tradutoras com atividade acadêmica, em que percebe-se um reforço cruzado e reiterativo das referências de visibilidade às tradutoras. Não se pode dizer, contudo, que o prefácio seja dirigido a um público acadêmico iniciado em teoria da tradução, mas a um público mais amplo. O discurso das tradutoras no prefácio não mostra 
influências perceptíveis de teorias de tradução. Não há também referência aos conceitos de fidelidade ou tradução.

2. BALZAC, Honoré de. Uma paixão no deserto. Trad. Lúcia Machado de Almeida. Col. Asa Delta. São Paulo: Ed. Paulinas, 1988.

Trechos destacados no prefácio do tradutor: “A tradutora fez o possível para ser fiel ao colorido e belo estilo de Honoré de Balzac (Tours, França, 1799-1850), também autor de Eugénie Grandet, Le Père Goriot, Le Lys dans la Valée e de outros livros que compõem a série de narrativas intitulada 'A Comédia Humana'.” (pag. 10)

Posição do nome do tradutor na edição: capa.

Tipo do tradutor: escritor.

Encontrei um artigo na Internet, contendo uma biografia da tradutora, intitulado “O centenário de Lúcia Machado de Almeida”, escrito por Angelo Mendes $\begin{array}{lllll}\text { Corrêa, } & \text { na } & \text { revista } & \text { eletrônica } & \text { Verbo }\end{array}$ (http://www.verbo21.com.br/v4/index.php?option=com_content\&view=article\&id =231:o-centenario-de-lucia-machado-de-almeida\&catid=61:resenhas-e-ensaiosjunho-2010\&Itemid=103). Com base no artigo, sabe-se que a tradutora-escritora pertence a uma família de escritores renomados ("irmã de Aníbal Machado, tia de Maria Clara Machado e prima de Murilo Mendes”) e possui uma obra vasta e reconhecida no meio literário. Além de ter escrito vários títulos da literatura juvenil, "escreveu três livros considerados fundamentais para o conhecimento mais profundo sobre o Ciclo do Ouro em Minas Gerais: Passeio a Sabará, Passeio a Ouro Preto e Passeio a Diamantina. Assim como outro, fruto de suas viagens a Portugal: Passeio ao Alto Minho”. O fato de ser uma escritora renomada justifica a posição de seu nome na capa.

O trecho do prefácio em que a tradutora faz referência à tradução é curto, mas traz indicações interessantes. A primeira delas é se referir a si mesma na terceira pessoa (“a tradutora fez o possível para se manter fiel...”) e não na primeira pessoa do singular. Esse procedimento, além de marcar a idade da tradutora — o livro foi publicado em 1988, quando a tradutora estava com 78 anos de idade (ela morreu em 2005 aos 95 anos), porém não se sabe ao certo se o prefácio foi escrito no mesmo ano -, por ser um procedimento retórico de distanciamento e 
neutralidade muito comum em textos mais antigos, também exibe um traço de humildade, presente na expressão “fez o possível para se manter fiel”, em que mostra sua tentativa, mas não necessariamente sua vitória nesse sentido. O conceito de fidelidade que a tradutora veicula se assemelha ao conceito de traductio (ver Capítulo 2), fidelidade ao “colorido” e ao belo estilo do autor, mas não fidelidade ao literal, contudo, ainda é um conceito carregado de logocentrismo, muito afastado das ideias desconstrutivistas derridianas (ver Capítulo 2). Não há indicação no prefácio de aproximação às teorias de tradução.

3. BAUDELAIRE, Charles. Flores das Flores do mal. Trad. Guilherme de Almeida. Rio de Janeiro: Ed. 34, 2010.

Trechos destacados no prefácio do tradutor: "Colheita livre, obedecendo apenas ao arbítrio de um gosto meu, todo pessoal, os vinte e um poemas de Baudelaire, ora por mim reproduzidos em português, são, de fato, o que "eu” julgo as flores das Flores do mal. Versos - como aqueles de que falei na introdução aos meus Poetas de França - que eu sempre soube de cor e que, à força de dizê-los, citá-los e recitá-los, acabei por me surpreender ouvindo-os de mim mesmo, na minha língua mesma. E, por isso, com seu ritmo nativo intacto, com seu espírito inato incólume.

Assim, no meu processo de re-criação, não há propriamente luta de poeta contra poeta, de um contra outro idioma: e sim uma automática justaposição, passiva conformação, espécie de entente cordiale, de tácita e recíproca sujeição. Daí porque não houve imposições no escolher, nem conflito no transfundir - talvez o mérito único desta obra: o da bem simples sinceridade. E, por isso, uma repugnância minha, invencível, pelas desmoralizadas e desmoralizantes expressões "tradução", ou "versão", que me soam sabem a coisa vulgar, muito outra daquilo que intimamente representa, para mim, o extenuante labor de oito anos, que tanto me custou este minguado ramalhete das "minhas" Flores do mal. Resolvi, pois, correr do meu vocabulário com tais palavras. Nesta marginália, servir-me-ei de outra terminologia: “recriação” (já preconizada no citado prefácio aos Poetas de França), "reprodução", "reação”, “correspondência”, etc.; e, principalmente, "transfusão". É este, dentre tantos, o termo que mais acertado me pareceu, mais significativo das minhas intenções. O uso corrente já não o separa 
da ideia de sangue. Transfusão do sangue: a revivificação de um organismo pela infiltração de um sangue alheio, mas de “tipo” igual. Uma língua, uma poesia reabastecendo-se da seiva de outra, análoga, para mais e melhor se afirmar. Ser o veículo dessa transmissão... - A que mais aspirar?

Algumas notas teóricas, à margem de cada uma dessas acimadas mudas, pareceram-me práticas para o leitor casual, porventura curioso do meu trabalho e da minha "maneira”; e úteis sobretudo a mim mesmo, como esclarecedoras do meu íntimo, único e ainda incompreendido intuito com as muitas e muitas recomposições que venho ultimamente tentando: o de provar o meu extremado amor à língua pátria, de que gosto de gostar, sensorialmente até, como de uma mulher se gosta, orgulhoso e ciumento dos segredos das suas formas e dos seus pensamentos; o meu enamorado enlevo por esta dócil, versátil, capacíssima língua nossa, de pequeno curso e grandes recursos, que tão bem sabe dizer, e de que tanto mal se diz”. (pág. 97-98).

Referência à tradução na “Apresentação" de Manuel Bandeira: "Poetas como Racine, Baudelaire, Mallarmé são dificílimos de traduzir. Quando Thiers Martins Moreira era diretor do Serviço Nacional de Teatro pediu-me que traduzisse a Phèdre de Racine. Não anuí. Ele insistiu, insistiu. Afinal me safei com esta: “Thiers, se você traduzir ou encontrar alguém que traduza este verso de Phèdre: 'Le jour n'est pas plus pur que le fond de mon coeur', eu prometo traduzir o resto”. E expliquei: “Esse verso é um diamante; eu não sei traduzir diamantes. Mas Guilherme de Almeida sabe traduzir diamantes. Ele não gosta das expressões “tradução”, “versão”. Conta que os versos que passou para a nossa língua sempre os soube de cor e à força de dizê-los e redizê-los, citá-los e recitá-los, acabou por se surpreender ouvindo-os de si mesmo, na sua língua mesma. Os vinte e um poemas de Baudelaire que estão neste volume são para Guilherme de Almeida "as flores das Flores do mal”; os que ele sempre soube de cor e acabou "ouvindo-os na sua língua mesma”. Língua que ele conhece tão bem, em todas as épocas, que pôde realizar o tour de force de trasladar ao português dos trovadores medievais uma balada, a mais bela balada, de Villon. Estas Flores das "Flores do mal” de Baudelaire são outros tantos tours de force. Ninguém entre nós ou em Portugal se sairia melhor da perigosa empresa”.

Referência à tradução no posfácio de Marcelo Tápia: “Assume-se, na concepção 
deste florilégio, a criação e a autoria dos poemas em português, o que é expresso no próprio título e na disposição gráfica da capa da edição original, com o nome do tradutor ocupando o lugar normalmente reservado ao do autor. Ainda que incerta a afirmação "sentir, pensar e dizer como o autor” — já que a leitura de um poema por outro leitor será sempre outra —, no propósito do poeta está inserto o ato de produzir, fazer, criar.

Guilherme presta uma surpreendente e fundamental contribuição ao pensamento sobre tradução poética em nosso país - entre os poetas que se dedicaram a discutir o assunto, e a revelar seu modo de ver e de trabalhar, é um verdadeiro vidente com lampejos de afirmação antecipatória - anunciando definições e lançando múltiplas possibilidades de reflexão sobre o tema, a partir, centralmente, das “Notas” que, escritas em um caderno à parte vieram a integrar esta antologia”. (pág. 127-128).

\section{Posição do nome do tradutor na edição: capa.}

Tipo de tradutor: escritor.

O verbete "Guilherme de Andrade de Almeida” no DITRA destaca a atividade do tradutor como escritor e poeta, ligado ao movimento modernista. O verbete faz referências a obras de Álvaro Faleiros, de 2012 e 2013 — sem, contudo, apresentar a referência bibliográfica completa —, em que este destaca que a publicação Flores das Flores do mal foi uma das primeiras “em que a tradução é elucidada de poema a poema”. Além disso, o conceito de tradução que o tradutor veicula, de "recriação" e de "transfusão", já em 1944, data da primeira edição do livro, além de falar em “tácita e recíproca sujeição” — que me fez lembrar a noção de “endividamento recíproco” de Derrida — parece fugir radicalmente do conceito de tradução como translatio, e mesmo como traductio, aproximando-se de um conceito desconstrutor dos conceitos tradicionais de tradução, termo que ele, aliás, rejeita para falar de seu trabalho, por se aparentar a uma atividade mais mecânica e não recriadora, como ele faz. Segundo o verbete do DITRA: "Para Faleiros (2013) o tradutor Guilherme de Almeida evoca um conceito caro à prática da tradução poética, a saber: o princípio da compensação plausível tão somente no âmbito da nova perspectiva da tradução, entendida como forma”. Por isso, o conceito de tradução a que Almeida faz referência parece ser uma concepção avant la lettre de um conceito de tradução que só iria ser teorizado 
mais tarde.

O destaque ao tradutor, que começa na capa com seu nome ocupando o lugar normalmente reservado ao do autor, continua além do seu próprio prefácio, no prefácio de Manuel Bandeira e no posfácio de Marcelo Tápia. Manuel Bandeira, em um prefácio escrito quando da publicação da primeira edição da obra, ressalta a dificuldade do empreendimento de se traduzir Baudelaire. Marcelo Tápia, em um prefácio escrito para a edição contemporânea, de 2010, ressalta o espírito vanguardista do projeto tradutório e da concepção de tradução de Almeida, além de fazer aproximações com a teoria da tradução e da leitura. A existência de prefácios escritos em momentos diferentes, para edições diferentes, lembra as observações de Genette de que o paratexto é um conjunto heteróclito de textos, que surgem e desaparecem em edições sucessivas, retraçando um pouco da história da obra. Percebe-se claramente, na leitura dos dois itens do paratexto, que o tempo passou e a reflexão sobre tradução muito avançou. A disposição dos dois elementos paratextuais, um como prefácio e outro como posfácio, dá uma indicação, por sua posição, do distanciamento temporal entre os dois.

Esta é uma edição que dá enorme destaque ao trabalho do tradutor, como muitas edições de tradução de poemas, ressaltando especificamente seu vanguardismo e empenho.

4. BAUDELAIRE, Charles. "O dandismo”. In Manual do dândi: a vida com estilo. Trad. Tomaz Tadeu. Col. Mimo. Belo Horizonte: Autêntica Editora, 2009.

Trechos destacados no prefácio do tradutor (e organizador do volume: três textos sobre dandismo, de Baudelaire, Balzac e d’Aurevilly): “Para evitar repetição, já que aparece frequentemente nos três textos, faço aqui, antecipadamente, uma observação sobre a tradução da palavra toilette, que traduzi, consistentemente, por “toalete”. Deve-se ter em mente, entretanto, que, em francês, a palavra tem uma abrangência mais ampla que o seu equivalente em português. Aparentemente, no português brasileiro atual, a sua utilização restringe-se a duas das acepções registradas pelo dicionário Houaiss: "ato de se lavar, pentear, maquilar, vestir, etc.” e “aposento sanitário; banheiro”. Em francês, toilette refere-se também ao conjunto das peças de vestuários, adereços, enfeites, cosméticos e demais artifícios utilizados no cultivo e manutenção de uma certa aparência. É, em geral, 
com esse sentido que a palavra aparece nos textos que compõem a presente antologia” (pág. 8-9)

Posição do nome do tradutor na edição: folha de rosto e ficha catalográfica.

Tipo de tradutor: acadêmico.

Segundo o verbete do DITRA, Tomaz Tadeu dedicou sua vida profissional à Educação. Nascido em 1948, começou a traduzir por volta de 1984, mas passou a atuar exclusivamente como tradutor somente após a aposentadoria, em 1998. Por ter sido professor universitário (Universidade Federal do Rio Grande do Sul), classifiquei-o como tradutor acadêmico.

No corpus, há três obras traduzidas por Tadeu, duas de Baudelaire e uma de Mallarmé, sendo que as três trazem prefácios do tradutor (dois prefácios falam de tradução - o desta obra e o da tradução de Mallarmé). Em duas obras, Tadeu atua também como organizador da edição, porém não tem seu nome na capa — o que é muito comum quando o tradutor atua também como organizador da edição - , o que pode ser uma regra da editora, já que as três obras do corpus foram publicadas pela mesma editora, a Autêntica, de Belo Horizonte.

Neste prefácio, quando o tradutor fala da tradução, se atém a um item de escolha lexical, mostrando as diferentes acepções em francês e português da palavra toilette/toalete. Trata-se, portanto, de um ponto específico de equivalência que o tradutor decidiu ressaltar, apesar de com certeza não ter sido o único a causar problema ou ter sido motivo de reflexão. O tradutor não dá indicações do conceito de fidelidade e tradução que perpassaram seu projeto tradutório, se é que havia um projeto tradutório explícito.

A edição, portanto, enfatiza o tradutor pela existência do prefácio, pelo fato de ter sido o organizador da edição, mas não a ponto de colocar seu nome da capa.

5. BAUDELAIRE, Charles. Ensaios sobre Edgar Allan Poe. Trad. Lucia Santana Martins. São Paulo: Editora Ícone, 2003.

Trechos destacados no prefácio do tradutor: "É preciso, sobretudo, ater-se ao texto literal; certas coisas se teriam tornado obscuras caso eu tivesse querido parafrasear meu autor em lugar de manter-me presa servilmente ao pé da letra. Preferi usar um francês difícil, por vezes barroco, a fim de dar, em toda a verdade, a técnica filosófica de Edgar Poe’. 
Na presente tradução, esforcei-me por seguir esse mesmo método, guardando, tanto quanto possível, a sintaxe complexa que dá o tom retórico característico desses textos.

Este trabalho aparece sob a forma de livro, sobretudo pela convicção de que continua sendo importante estudar o grande poeta francês sob suas mais variadas facetas. Espero que os críticos mais severos levem isso em consideração”. (pág. 8)

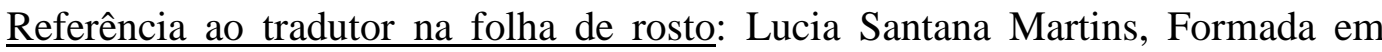
Letras pela Universidade de São Paulo, Especialista em Teoria Literária e Literatura Comparada pela Unicamp.

Posição do nome do tradutor na edição: folha de rosto e ficha catalográfica. Tipo de tradutor: acadêmico.

Por falta de maiores informações sobre a tradutora, além da referência contida na folha de rosto, classifiquei a tradutora como acadêmica. Na Internet, há referências a outros trabalhos da tradutora, mas não tive acesso a um conjunto mais significativo das obras que traduziu. Percebe-se pelo tom do prefácio, no trecho extraído acima, que se trata de uma especialista em literatura, mas não necessariamente uma tradutora muito profícua. Teria sido preciso pesquisar com mais profundidade para descobrir mais sobre ela. Duas observações podem ser feitas a partir do extrato acima: 1. que a tradutora delineou um projeto tradutório em que pretendeu "se manter presa servilmente ao texto literal", procurando reproduzir "um francês difícil, por vezes barroco" do original. Seu projeto tradutório parece ligado ao conceito de tradução como translatio, isto é, uma tradução mais literal do texto original (“é preciso, sobretudo, ater-se ao texto original”); 2. que a tradutora guarda uma atitude servil diante do autor do texto original (“guardar a sintaxe completa”), bem como diante de uma possível reação adversa dos críticos à sua tradução (“espero que os críticos mais severos levem isso em consideração”). O tal pedido de desculpas a que me referi no Capítulo 4 está presente neste prefácio. Afora o fato de a edição ter um prefácio do tradutor e de conter dados biográficos da tradutora, não é dado um maior destaque ao nome dela.

6. BAUDELAIRE, Charles. Flores do mal. Trad. Juremir Machado da Silva. Porto Alegre: Sulina, 2003. 
Trechos destacados no prefácio do tradutor ("Reescandalizar Baudelaire, ou como ser fielmente infiel”): "Eu quis, num gesto de heresia total, dar-lhe um pouco do ar do nosso tempo, frívolo, pós-moderno, efêmero, obsceno, apesar da quebra de qualquer referência capaz de estabelecer um valor moral seguro, “em que tudo o que é sólido desmancha no ar” e, contudo, permanece cristalizado no imaginário social.

Não se trata de “popularizar Baudelaire” nem de desvalorizar o grande trabalho de Haddad ou dos outros. Mas, talvez, de seguir o que o próprio Haddad semeia, citando Theodore Savory, ao sintetizar seis alternativas para traduzir: dar as palavras do original/dar as ideias do original; criar um trabalho original/ser apenas uma tradução; refletir o estilo do original/refletir o estilo do tradutor; fazer uma tradução contemporânea do autor/contemporânea do tradutor; acrescentar ou tirar do original/conservar o original; traduzir verso em prosa/traduzir verso em verso. Haveria muito mais a discutir em termos de teoria da tradução. Não é o caso aqui. Basta dizer que segui a ideia da síntese, indicada até mesmo por Haddad, e pratiquei tudo e o seu contrário, conforme as necessidades.

Selecionei, traduzi literalmente, "transcriei”, aliterei, “desaliterei”, inventei palavras, cometi galicismos, mantive, ao máximo, o original, cortei, aqui ou ali, acrescentei, na estrita linha do sugerido pelo poeta, isto ou aquilo, interpretei, adulterei, “atualizei”, tornei vulgar, cometi anacronismos, desobedeci a tudo, principalmente à métrica, saí, algumas vezes, das palavras do original para tentar chegar mais ainda até elas e sempre me ative às ideias do original, mesmo quando me desviei ligeiramente delas, em termos de vocabulário, para entrar, novamente, de cabeça nelas. Fui terrivelmente infiel em nome da mais absoluta fidelidade.

Devo tudo a Haddad, Junqueira e Almeida. Em alguns momentos, adotei literalmente a solução encontrada por um deles. Em outros, cruzei-os num mesmo poema, ficando ora com a escolha de um, ora com a escolha de outro. Os leitores não terão dificuldade em encontrar os ecos, as citações e as marcas literais desses três tradutores nesta seleção sem notas, mas com atestado de dívida, como um filme que cita outros sem apresentar notas de rodapé. Nesse sentido, há colagem, mescla, “sampleamento”. Alguns dirão, possivelmente, tradução “conectiva” e “coletiva”, embora completamente individual e autoral, no bom ou no mal sentido, sendo eu um mau resultado tem exclusivamente a minha assinatura. 
O grande tradutor Ivo Barroso denunciou, recentemente, o saque a traduções consagradas, inclusive de As Flores do Mal. Com razão. Neste caso, estou seguro, há nova tradução, talvez pior, certamente com absurdos, alexandrinos expandidos e outros barbarismos. Não seria totalmente uma surpresa se um crítico o escrevesse: se era para piorar as traduções de Baudelaire, o resultado foi perfeitamente alcançado. Acontece-me de imaginar que para voltar à origem a alcançar sensações profundas, em arte, é preciso, às vezes, piorar as coisas. Até mesmo as apresentações de um livro. Esta, “interessantíssima”, em se tratando de marketing, não deve ser das mais canônicas. Eu só queria voltar a sentir o cheiro de sangue, de sêmen, de morte e de flores, que sempre encontro em Les Fleurs du Mal.

(...)

Os critérios aqui são, exclusivamente, a paixão e o caos. Desta tradução, o mínimo que se pode dizer é que já nasce datada, com gírias e clichês da minha época. Pós-moderna, quer encontrar qualidades em seus defeitos, totalidade na sua absoluta parcialidade e permanência na sua efemeridade. Tradução “indefinitiva”, mais fascinada pelo vulgar do que pelo rebuscado, mais interessada nos bordéis do que nas academias, mas, ainda assim, elitista, pois voltada aos que seriam capazes de cometer atentados-suicida pela poesia. Anacrônico, Baudelaire era um homem-bomba poético. (pág. 7-9).

Referência à tradução na orelha (escrita pelos editores): "Aos poucos, contudo, as traduções murcharam, as palavras envelheceram, os versos amarelaram e o escândalo converteu-se em academicismo, o mais terrível dos pesticidas que se pode despejar sobre a poesia. Essas “flores” do mal moderno precisavam de uma revitalização pós-moderna. Eis, portanto, o tempo das flores do mal transgênicas, das quais tudo se pode arrancar menos o delírio das palavras, a volúpia das imagens, o foco dos corpos, a demência dos sonhos, a genialidade do poeta. Estas “84 flores do mal” são mais um elogio à "parte maldita” que faz do inútil por excelência (a poesia) o melhor da vida. Bem dito Baudelaire!"

Posição do nome do tradutor na edição: capa.

Tipo de tradutor: escritor e acadêmico.

Por meio do verbete do DITRA, ficamos sabendo que Juremir Machado da Silva possui graduação em jornalismo, curso concluído no Brasil, e mestrado, 
doutorado e pós-doutorado em sociologia, pela Universidade de Paris. Costuma traduzir na área de ciências humanas e recebeu um prêmio pela tradução de uma obra de Edgar Morin. Possui obra própria, tanto na área ficcional quanto na área de ciências humanas. A tradução literária não constitui a maior parte de sua obra como tradução, mas a tradução de Baudelaire lhe deu projeção, e este prefácio é conhecido por ter explicitado suas ideias sobre tradução.

O conceito de tradução que o tradutor claramente explicita no prefácio é afeito ao pós-modernismo, pois admite ter seguido vários procedimentos, por vezes contraditórios, para ser “infielmente fiel”. Ele admite que sua tradução é datada e indefinitiva, paga tributo aos tradutores que o precederam (faz referência ao prefácio de Haddad, que veremos a seguir) e admite ter feito colagem de algumas soluções apontadas por eles, sem acanhamento de afirmar que bebe na fonte de um hipertexto das traduções de Baudelaire no Brasil. O tradutor parece querer resgatar o maldito nos poemas de Baudelaire, cujas traduções haviam se tornado excessivamente acadêmicas. Parece tudo muito avançado em suas ideias, mas o tradutor não consegue se furtar à tradicional mea culpa ("sendo eu um mau resultado tem exclusivamente a minha assinatura”), tão característica do prefácio de tradutor.

Há grande destaque na edição ao nome do tradutor e a seu projeto tradutório que pretende "reescandalizar" Baudelaire, com o aparecimento de seu nome na capa e reforço de suas escolhas no texto contido na orelha.

7. BAUDELAIRE, Charles. O spleen de Paris: pequenos poemas em prosa. Trad. Leda Tenório da Motta. Col. Lazuli. Rio de Janeiro: Imago, 1995.

Trechos destacados no prefácio do tradutor: "Em versão brasileira, Aurélio Buarque de Holanda daria aos Pequenos Poemas, em 1966, para a editora Civilização Brasileira, um tratamento antológico, digno de seu trabalho de poeta e lexicógrafo. A nova tradução que aqui se propõe reconhece esse trabalho inaugural e parte para a difícil tarefa de retomá-lo. Mais atenta, talvez, à letra do texto, que procura não interpretar — e mais sujeita, portanto, às estranhezas do estilo baudelairiano — , procura alcançar, por vias mais atuais, a modernidade que o próprio Baudelaire põe no centro do seu conceito de arte”. (pág. 14)

Referência ao tradutor na orelha: “Esplendidamente traduzidos por Leda Tenório 
da Motta, numa linguagem "mais atenta às estranhezas do estilo baudelairiano”, esses poemas renascem agora em português, num instante oportuno. Pois neste momento, em que a experiência da cidade e as novas tecnologias vêm estimulando a poesia e a crítica a reinventar, mais uma vez, a modernidade, a lição de Baudelaire pode servir como medida comparativa dos nossos sucessos - e das nossas ingenuidades”.

Posição do nome do tradutor na edição: folha de rosto e ficha catalográfica.

Tipo de tradutor: escritor e acadêmico.

Pelo verbete do DITRA, ficamos sabendo que Leda Tenório da Motta fez mestrado e doutorado em Comunicação e Semiótica em Paris, tendo estudado com grandes nomes da área da filosofia, crítica literária e teoria literária. Possui obra própria nas áreas de literatura e crítica literária. Possui, portanto, toda uma reflexão sobre a linguagem. Neste prefácio, contudo, a tradutora, ao falar de tradução, atém-se a justificar seu projeto literário de retraduções de poemas já traduzidos anteriormente por um grande nome na "república das letras” nacional, Aurélio Buarque de Holanda. Seu projeto é atentar mais para o sentido literal do texto, não interpretar e ressaltar as estranhezas do estilo baudelairiano, o que dá a entender que a tradução de Holanda seria, para ela, academicista em excesso. No entanto, não chega ao ponto de propor um projeto tradutório tão arrojado quanto o de Juremir Machado da Silva em As flores do mal, dando a transparecer que sua concepção de tradução poética é mais tradicional, mais apegada ao texto original, buscando reproduzir o estilo do autor, sem interpretar suas ideias. Parece que Holanda, por ser lexicógrafo, teria dado mais importância à procura do mot juste e menos ao estilo do poeta.

A edição dá destaque ao trabalho da tradutora, concedendo-lhe o espaço de um prefácio e uma referência elogiosa no texto incluído na orelha, mas não chega a ponto de levar o nome da tradutora para a capa. Leda Tenório da Motta é uma tradutora conhecida e conceituada, mas não possui o status de outros tradutores de Baudelaire no Brasil, a cujo nome ficaram indelevelmente ligados.

8. BAUDELAIRE, Charles. As flores do mal. Trad. Jamil Almansur Haddad. São Paulo: Círculo do Livro, 1995.

Trechos destacados no prefácio do tradutor: "De como traduzir poesia - Theodore 
H. Savory, em sua The Art of Translation, sintetiza as seis alternativas que parecem compendiar todos os conflitos de tradução:

a) A tradução deve dar as palavras do original. Uma tradução deve dar as ideias do original.

b) Uma tradução dever ser lida como um trabalho original. Uma tradução deve ser lida como uma tradução.

c) Uma tradução deve refletir o estilo do original. Uma tradução deve possuir o estilo do tradutor.

d) Uma tradução deve ser lida como se contemporânea do original. Uma tradução deve ser lida como se contemporânea do tradutor.

e) Uma tradução deve acrescentar ou tirar do original. Uma tradução nunca deve acrescentar nem tirar do original.

f) Uma tradução de verso deve ser em prosa. Uma tradução de verso deve ser em verso.

Nesta linha de ideias pode ser enunciado o trinômio de Woodhouselee:

a) A tradução deve ser um completo translado das ideias do original.

b) O estilo e a maneira de escrever devem ser do mesmo caráter que o original.

c) A tradução deve ter toda a influência (“ease”) da composição original.

O drama inteiro dos caminhos escolhidos por Savory é que ele impõe a opção, quando muitas vezes seria mais de desejar a síntese. Mas examinemos de mais perto alguns dos seus itens. (Theodore H. Savory, The Art of Translation, Jonathan Cape, Londres, pág. 43)

Quanto à primeira alternativa, o que é que afinal de contas devemos entender por palavras do original? Até que ponto podemos transportá-las? Ele próprio diz que: “Thalassa! Thalassa!” é uma coisa, ao passo que "La Mer!” é outra, muito mais inócua e não diz nada em confronto com a exclamação helênica. Esse ponto é axial. De há muito que se retém a concepção mallarmaica de que a poesia é feita de palavras. E quais as palavras portuguesas que dizem o mesmo que determinadas palavras francesas? Note-se que, sem sair da França, a palavra Mort é uma coisa quando barroca, outra quando romântica e outra ainda, quando existencialista. Agora quando dizemos Morte, é possível que estejamos afetando o 
vocábulo de um mínimo de alteração. Pode ser dramático forçar uma palavra a qualquer espécie de emigração. As simples translações temporais, e sem sair da cortiça do próprio idioma, vimos que podem alterar muito, senão a substância, alguma coisa do revestimento exterior do termo. Agora quando a emigração é espacial, a deformação é muito maior ainda.

E quanto ao problema das ideias: até que ponto as ideias de um poema são o poema? Dentro do conceito mais ortodoxo de poesia pura, pelo menos o que nos foi legado por Bremond, poesia é uma espécie de música misteriosa e os elementos intelectuais de que se compõem não têm nada que ver com a sua essência mais recôndita. Aliás, um mestre de Baudelaire, como Edgar Allan Poe, seria capaz de pensar algo de parecido quando dela exclui os elementos didáticos ou narrativos, configurando-nos a ideia da presença de um esforço centenário para excluir dos territórios do poema maiores significações, em última instância, práticas.

Todos estes itens em essência colocam o problema da fidelidade que, consoante a desalentada referência de Postgate, é “admirada pelo consenso geral mas não pela prática universal” (Idem, ibidem, pág. 51)

Em geral, se tivéssemos que optar por uma das alternativas, ficaríamos sempre com a segunda. O ideal de encontro das palavras portuguesas que correspondam às francesas, muitas vezes é plenamente realizável. Semanticamente, no caso, é de muita valia a pequena mágica da transposição. É, como logo se vê, a possibilidade de transpor a palavra forasteira para a nossa, alterando-lhe, porém a categoria gramatical. Sechehaye dá uma de suas regras: Toda ideia, seja qual for a sua categoria gramática do ponto de vista lógico, pode ser levada à categoria de entidade. É o que se chama "a universal materialização de nossas ideias do substantivo”. A recíproca é menos rigorosamente verdadeira: a transposição de um substantivo ou adjetivo para o verbo só pode fazer-se condicionalmente, dado o obstáculo lógico: a entidade é ideia em si, sem outra determinação que não seja ela própria: tudo pode então ser considerado como substantivo. Mas a qualidade ou o processo supõe certas condições especiais de sua percepção; o processo desenvolve-se no tempo, a qualidade é situada em qualquer entidade e todas as entidades substantivas não estão igualmente aptas a revestirem-se desses caracteres. 
Dá ainda outras regras de transposição: Toda ideia de relação e toda ideia de processo podem ser expressas adjetivamente. E toda ideia de qualidade pode ser transposta na categoria de processo. (Albert Sechehaye, Essai sur la structure logique de la phrase, Champion, pág. 112 em diante).

Parece-nos faltar, nestas conjecturas todas, uma maior consideração referente ao aspecto sociológico do problema e que nos parece básico. São os elementos que não estão nem no tradutor nem no traduzido, mas na época e na sociedade de um e de outro. Di-lo Sérgio Milliet: "O que nos falta para bem traduzir uma obra estrangeira é a identidade de condicionamento social. As obras literárias refletem um ambiente, uma tradição, uma geografia e uma economia. Para penetrá-las e reproduzi-las, não basta o conhecimento perfeito da língua em que foram escritas, bem como daquela para a qual são vertidas. É preciso sobretudo senti-las da mesma maneira e espontaneamente. Ora, a própria diferença da língua mostra que este sentir é diferente, pois se fosse igual seria igual também a língua... Logo...” (Sérgio Milliet, Diário Crítico, $6^{\circ}$ volume, Divisão do Arquivo Histórico, São Paulo, 1950, pág. 189). Com essa referência, veja-se como são bastante sociológicas as condições do esquema de Savory por mais que sejam referência aparente ao que há de estritamente individual no labor intelectual.

Sociologicamente, o problema de Baudelaire ficará melhor enquadrado, desde que nos coloquemos em face do elogio que lhe fez Victor Hugo, que é bem uma definição, quando afirmava que trazia o poeta um frisson novo à poesia. Fundamental este louvor, pois a noção de "frêmito" no caso é muito mais sociológica do que psicológica, pois a arte que o desencadeou lançou-se como um impacto contra um determinado tipo de sociedade que acabará levando-o à barra dos tribunais. Para termos tido um "frêmito" igual, seria preciso que os versos fossem lançados em meio de uma sociedade brasileira correspondente à francesa que estremeceu com Baudelaire. E qual teria sido esta sociedade? A do declínio do patriarcalismo? A de Cruz e Souza? Parece que o poeta brasileiro que mais deu certo frisson deve ter sido Augusto dos Anjos. Porém o transtorno das sensibilidades que o poeta de Eu acarretava era apenas em parte de sentido baudelairiano. Chocava mais por sua ruptura com os conceitos tradicionais de linguagem poética, uma vez que se utilizou de jargão científico que ele soube, não obstante muita incompreensão, transformar em poesia. A reação contra Augusto 
dos Anjos foi a princípio apenas (o que não deixa de ser muito grave) uma reação de riso, e que servia muito bem para marcar o desencontro entre poesia e público. Com a passagem do tempo, o "frêmito" diminui muito e mesmo - é claro - tendose em vista o caso do leitor francês, muito menos o "transtornado" hoje ao impacto de alguns poemas de que o foram ancestrais seus. Esse transtorno deve ter sido grande e disto se terá consciência principalmente se nos dermos ao trabalho de cotejar o nosso poeta com o ramerrão lírico que lhe foi anterior. Assim teremos noção clara do salto produzido.

A ideia de "frêmito" repousava no simples fato do escândalo e esta nossa edição do Centenário surge numa hora em que o burguês perdeu, ou pelo menos vai perdendo, completamente, a sua possibilidade de se escandalizar com o que quer que seja; é, entre outras coisas, um momento de existencialismo a justificar toda a casta de “autenticidades”. Em São Paulo, uma poetisa publicou um livro de poemas com retrato de mulher nua na capa, porém tão realisticamente reproduzida que juntou à ilustração uma tanga que o leitor poderia remover, revelando-se-lhe então uma paisagem de compêndio de anatomia. Ninguém tomou susto nenhum com esta sexualização total do desenho. E susto não haverá mais com nenhuma poesia, embora possa por vezes condimentar-se de carniças, paixões platônicas ou tribádicas.

Seria possível nos nossos dias um frêmito igual ao baudelairiano? Para conseguilo, talvez se tivesse que mudar fundamentalmente a poesia original. Haveria outro remédio: mudar a sociedade. Não é à toa que o nosso já citado Savory entende que, deste ponto de vista, se quisermos traduzir Cícero, de modo que nos impressione como deve ter impressionado os romanos, seria preciso que ele nos desse a impressão de ser pelo menos o Sr. Winston Churchill.

Seja como for, de nada valerão todas as teorizações do mundo, se não formos capazes de sua "atualização" prática, se não as chamarmos a uma condição de presença. As doutrinas apresentam virtualidades cujo único teste de fecundidade e êxito reside na sua aplicação a um caso concreto.

Note-se que o próprio Baudelaire, certa feita, opinava que os traços que o artista mais costumava gabar, longe sempre estiveram de ser os que ele mais possuía, ou, mais precisamente, o homem de arte mais levado a louvar exatamente aquelas virtudes de que é mais carente. Como uma coisa é a poética que idealizamos e 
outra a poesia que realizamos, pode haver discrepância entre como planejamos traduzir e como de fato traduzimos.

Por sua vez, Guilherme de Almeida, a propósito de sua versão de Bénédiction, diz: "E se, de um lado, descuidei de propósito, da qualidade das rimas... insistindo nas paupérrimas... e usando apenas as graves... de outro lado, cuidei, tanto quanto possível, de sustentar as consoantes de apoio...”. (Guilherme de Almeida, As flores das flores do mal, José Olympio, Rio de Janeiro, 1944, págs. 117-118).

Um apego desta natureza, estrito, à técnica original chega-nos a ser deveras discutível. De resto, algumas regras da versificação francesa, por muito tradicionalmente usadas que sejam, não deixam de entremostrar evidências de exagero. É o caso, provavelmente, da alternância das rimas masculinas e femininas, incompreensível no nosso caso. O conceito de rimas ricas, com a obrigatoriedade da consoante de apoio, não encontra maior adesão por parte de poetas e mesmo leitores de poesia brasileiros. No caso vernáculo, satisfazemo-nos muito mais com os elementos raridade e surpresa, convenientemente dosados. Este critério quanto à rima foi o que principalmente seguimos - critério brasileiro, embora em muitas circunstâncias possa deixar de ser francês. A disparidade de normas entre as poéticas francesa e brasileira pode ser exemplificada pela obrigação de visualidade da rima que os franceses geralmente também impõem: não apenas a homofonia como ainda a homografia. Como no Brasil se iria dar maior importância a um detalhe desta natureza, depois da sucessão, alucinatória, de reformas ortográficas que transformam "gosa” em "goza” sem que por isso nos sintamos no dever indeclinável de deixar de rimar esta palavra com "rosa"? Acrescente-se ainda o vezo dos nossos poetas de rimarem as palavras não tanto como se escrevem mas como popularmente se pronunciam (rimas de às com ais, de ejo com eijo, de ós com óis, de oso com ouso, de uz com úis). Note-se ainda a nossa maior tolerância com relação às rimas imperfeitas (janela e estrela etc.) e principalmente para com as rimas toantes. Não usamos maior cópia desse tipo de rimas livres mas a tradição poética brasileira, principalmente a romântica, poderia justificá-las plenamente, por mais que na França pudessem passar por menos aceitáveis.

Há um espírito da poesia brasileira tão respeitável quanto o espírito da língua em que esta poesia vaza. E a transgressão deve ser interdita em ambos os casos. Não 
adianta de nada chegarmos a ser perfeitos como técnica francesa, porém suscetíveis de crítica do ponto de vista da versificação nacional.

Se o espírito da poesia aludido coloca por vezes a necessidade de fuga ao original (momento, portanto, em que a fidelidade é conseguida muito mais por discrepância que por similaridade vis-à-vis do modelo) é claro que a conjetura básica deve ser a do espírito do idioma. E, neste caso, é de primordial importância o problema da língua donde estamos vertendo. O caso do francês põe-nos diante da questão cabulosíssima do galicismo. Até que ponto é um fantasma a recear, é o que iremos ver. Até que ponto se poderá magoar com ele a "última flor do Lácio inculta e bela", aquela ruibarbosiana "flor da vernaculidade"? A função de bárbaros que, nós, os tradutores podemos exercer, já foi frisada por Mário Barreto: “A tradução é de ordinário o veículo por onde entra, sem sentir-se, o contrabando da barbárie... Embora Camilo Castelo Branco fosse entendidíssimo nos segredos e regras da arte de escrever corretamente, nas suas versões de obras francesas topamos com incorreções, galicismos e demais barbarismos”. (...)

Do primeiro ponto de vista, a nossa conclusão destoa do que habitualmente se pensa: não é essencial que tradutor e traduzido sejam iguais ou afins. O problema básico aqui seria de amor: bastaria gostar do poeta e verter. (...)

Quanto ao segundo problema a que acenamos, o caso da tradução de poemas confundir-se-á de certo modo com o da criação original, isso se, pelo menos, nos colocarmos dentro da linha de Edgar Allan Poe, na sua teorização em torno dos elementos conscientes, voluntários que entram na elaboração do poema, combatendo assim qualquer interpretação que visa dar à criação poética gênese de paroxismo mediúnico. (...)

Poesia é feita de palavras e as palavras estão nos Dicionários. O problema da tradução de Baudelaire, insistamos, não é o do transe mediúnico, pois que nele o próprio elemento braçal se associa ao intelectual. O tradutor de Baudelaire será aquele que for capaz de debruçar-se sobre A Cabeleira ou sobre Convite para a Viagem ou sobre Lesbos e trabalhar até que no fim da madrugada lhe seja entregue o jornal da manhã. (...)

(...) Não sabemos bem o que fizemos nem aonde chegamos, graças a Deus e graças aos Dicionários. A verdade é que o material de construção é aparatoso. Para traduzir. Para anotar. Para prefaciar”. (pág. 15-24) 
Posição do nome do tradutor na edição: folha de rosto e ficha catalográfica.

Tipo de tradutor: escritor.

Este prefácio de tradutor tornou-se um clássico no gênero, pela sua extensão, profundidade e teor. O tradutor teoriza, cita autores, se contrapõe a ideias bem aceitas em termos de tradução poética em seu tempo. Após discorrer sobre aspectos semânticos, sociológicos, gramaticais e de versificação, afirma que uma tradução deve ser lida como uma tradução, pois nunca será um igual, nem deve pretender ser. Contrapõe-se à ideia de Ivo Barroso de que o tradutor de poesia deveria estar como em um transe mediúnico com o autor, ser um “cavalo” sobre o qual se manifesta este espírito que o precedeu. Tradução de poesia é exercício braçal, mas antes de tudo prazeroso. E é isso, um exercício. Outros tradutores proporão outras soluções, cometendo até mesmo barbarismos. Mas isso também é louvável, pois é através dos barbarismos que as línguas se enriquecem. Dá a entender que, em termos de tradução de poesia, tudo é importante, forma, fundo e conteúdo, a mescla de opções e não opções estanques. Faz-se o que é possível a cada circunstância, mas isso não constitui fracasso por parte do tradutor.

Sua concepção de fidelidade, portanto, não é estrita, nem restrita. Tradução não é reprodução, mas sim recriação. Exercício prazeroso de reescrita.

A extensão e a profundidade do prefácio, por si só, já dá grande destaque à figura do tradutor, não se estendendo — talvez por não precisar — a alçar o seu nome à capa. É a ele que se refere Juremir Machado da Silva em seu prefácio a As flores do mal, como vimos acima. Em uma futura antologia de prefácios de tradutor, certamente este prefácio de Jamil Almansur Haddad teria seu lugar cativo.

9. ALMEIDA, Guilherme de. Flores das "Flores do Mal”. Col. Clássicos de Bolso. Rio de Janeiro: Ediouro, 1993.

Trechos destacados no prefácio do tradutor: o mesmo do item 3.

Referência à tradução na “Apresentação” de Manuel Bandeira: a mesma do item 3.

Posição do nome do tradutor na edição: folha de rosto e ficha catalográfica.

Tipo de tradutor: escritor. 
10. BAUDELAIRE, Charles. As flores do mal. Trad. Jamil Almansur Haddad. São Paulo: Max Limonad Editora, 1985.

Trechos destacados no prefácio do tradutor: o mesmo do item 8.

Posição do nome do tradutor na edição: capa.

Tipo de tradutor: escritor.

11. BAUDELAIRE, Charles. As flores do mal. Trad. Jamil Almansur Haddad. São Paulo: Abril Cultura, 1984.

Trechos destacados no prefácio do tradutor ("Tempo em verso"): o mesmo do item 8 .

Posição do nome do tradutor na edição: capa.

Tipo de tradutor: escritor.

12. BAUDELAIRE, Charles. As flores do mal. Trad. Jamil Almansur Haddad. São Paulo: Max Limonad Editora, 1985.

Trechos destacados no prefácio do tradutor: o mesmo do item 8.

Posição do nome do tradutor na edição: capa.

Tipo de tradutor: escritor.

13. CORNEILLE, Pierre. O Cid. Trad. Angela Leite Lopes. Col. Dramaturgias. Rio de Janeiro: Sette Letras, 1998.

Trechos destacados no prefácio do tradutor (“O tempo em verso"): “Apresento aqui uma tradução de $O$ Cid de Pierre Corneille que realizei em 1991 para o ciclo de leitura de clássicos franceses promovido pela RioArte no Espaço Cultural Sérgio Porto. As duas outras peças que compunham o ciclo eram Fedra de Racine e Escola de mulheres de Molière, ambas com tradução de Millôr Fernandes. Uma coisa me chamou a atenção: a maioria das peças clássicas francesas, compostas no original em alexandrinos (versos de doze pés, rimados), são traduzidas no Brasil em versos livres

Há entre nós uma certa prevenção contra versos rimados, com métrica amarrada. Alega-se que são difíceis de serem compreendidos pelo público, que são acadêmicos, artificiais. Como agravante, não teríamos uma tradição do verso, como os europeus. 
(...)

O verso é também uma forma de pôr em cena o engajamento corporal exigido pela fala. Em cena, falar é viver. Portanto, respirar: inspirar, transformar o sopro em sentido, dando-lhe vigor, alcance, direção. Respiração que imprime um ritmo, interno e exterior, que por sua vez pede e produz a escuta, percepção aguçada de si e do outro, estabelecendo o canal da contracenação.

(...)

Decorre daí um último aspecto que gostaria de notar: a tradição recitativa francesa é o resultado de uma língua que tem como característica uma certa monotonia rítmica, devido à predominância de palavras oxítonas em seu vocabulário, o que acarreta pouca variedade de acentuações e, consequentemente, de entonações.

Já o português, com palavras paroxítonas, proparoxítonas e oxítonas, permite uma maior variação rítmica e permite principalmente um maior jogo com a previsibilidade das rimas.

Não possuo, pessoalmente, conhecimentos nessa área que me permitam fazer um estudo comparativo entre os dois idiomas. Tiro essas considerações do meu trabalho de tradução, que não é nem analítico nem comparativo, tem antes algo da contracenação. E da observação do trabalho dos atores brasileiros, que desconhecem muitas vezes o quanto seu idioma é também um elemento de jogo, e não um mero veículo de enunciação”. (pág. 7-10)

Trecho retirado da "Nota" da tradutora: "Não concebo um Cid sem rimas. Numa peça em versos, rimada, o espectador vai sendo levado o tempo todo pela expectativa, pela surpresa ou pelo previsível - há um jogo que se arma na linguagem ao mesmo tempo que na trama em si. Procurei então manter esse rigor na construção do texto em português, optando pelo decassílabo porque o português é uma língua mais concisa que o francês. Procurei estabelecer a métrica a partir do ritmo próprio da língua falada: afinal, versos foram escritos para serem ditos.

As passagens seguidas por um * indicam que ali o alexandrino foi mantido; são passagens famosas que perderiam algo com a redução para dez pés.

Na Cena 6 do Ato I e na Cena 2 do Ato V, mantive a métrica original: são as famosas ‘estâncias'”. (pág. 5)

Posição do nome do tradutor na edição: capa. 
Tipo de tradutor: acadêmico.

Pelo verbete do DITRA, sabe-se que Angela Leite Lopes é uma tradutora especializada em teatro, que traduz muito por encomenda de atores e diretores teatrais que pretendem encenar determinado texto. Neste prefácio isso fica bastante claro, pois aqui a tradutora analisa o que funciona ou não na tradução de um texto teatral escrito originalmente em francês e traduzido em português para ser encenado. Suas observações são muito ricas e deixam claro que não se restringe a um conceito de fidelidade muito estrito. Sua preocupação não é propriamente com o sentido literal, mas mais com o ritmo e a entonação, não se furtando a fazer as modificações que julga necessárias no texto para privilegiar a encenação. Seu status de tradutora teatral reconhecida se consubstancia na colocação de seu nome na capa e na presença de um prefácio de sua autoria.

14. DUMAS, Alexandre. O conde de Monte Cristo. Trad. Nélia Maria Pinheiro Padilha von Tempski-Silka. Col. Clássicos da Literatura. Curitiba: Juruá Editora, 2001.

Trechos destacados no prefácio do tradutor: “Apesar da ansiedade contida no tema, toda a história é perpassada do senso de humor, característica que é uma constante nas grandes percepções. Por tudo isso, traduzir o Conde transformou-se numa viagem, em que cada etapa precisava ser ultrapassada com intensidade (vide grande número de notas explicativas, contudo em geral não obrigatórias para que o leitor compreenda e aproveite da agradável leitura) e cuidado, para tentar não empanar o brilho do cenário descortinado. Por se tratar de um romance de época, mantiveram-se as formas de tratamento mais respeitoso de então, todavia usando os termos da atualidade no Brasil: se recorresse aos termos do século XIX, p.e., teria que utilizar a vossa mercê, vosmecê etc., dando a impressão de estar redigindo José de Alencar, ou até mesmo o nosso magistral Machado de Assis.

Preferiu-se substituir o vós pelo senhor(a), e o tu pelo você, que é o que fazemos hoje em dia, correntemente, evitando essa forma que existe no português brasileiro, e que embora empregada em certas regiões, geralmente o é de forma inadequada (usa-se muitas vezes o tu com o verbo na terceira pessoa). O tratamento respeitoso era e é empregado na Europa, inclusive para crianças, amigos de longa data, e mesmo com relação a empregados de categoria mais 
elevada, traduzindo maior formalidade na comunicação geral, do que acontece no Brasil. Ademais, traduziu-se respeitando o texto original, modificando o tratamento, até para a mesma pessoa, cada vez que o original o fazia. Sempre que possível, os nomes próprios foram conservados no original. Deparei-me, por vezes, com dúvida, ao utilizar na tradução vocábulos mais elaborados que possuem sinonímia popular; cedi em alguns casos, em benefício da compreensão do maior número de leitores (p.e. traduzindo facúndia por eloquência); outras inúmeras vezes não, pois o tradutor - apesar de poder optar entre uma tradução literal e outra interpretativa - não tem o direito de alterar o estilo do autor, senhor de sua obra, em benefício da incultura proposital. Ele, o autor, não faria esse tipo de modificação, a pedidos em sua própria língua; então, que direito teríamos de fazê-lo ao apresentar uma tradução da mesma? Acredito que um dos grandes males cometidos em nosso século é confundir a dantes inimaginável possibilidade de comunicação e de divulgação de conhecimentos, com a depreciação do nível de cultura. É o que popularmente chamamos o "nivelamento por baixo”. Julgam assim poder trazê-la mais facilmente à maioria das pessoas; a grande armadilha, entretanto, se encontra no aviltamento dos conteúdos culturais, e na não disseminação majoritária desses; o único resultado disso é o de atingir a mediocridade. O caminho para encontrar a verdade e a beleza tem uma sequência, exige esforço e não se queimam etapas, assim como no desenvolvimento econômico planejado. Mesmo este último, já descobrimos em nosso século que não se mantém, na ausência de sedimentação, e que esta só se realiza no tempo (outros diriam no timing) certo. No progresso das nações, isso pode significar séculos; na leitura, mesmo a de puro e simples lazer, pode significar o puro, simples e benéfico uso do dicionário”. (pág. 11-12)

Posição do nome do tradutor na edição: folha de rosto e ficha catalográfica.

Tipo de tradutor: profissional.

No CV encontrado na Internet (baixado do ProZ), ficamos sabendo que Nélia Maria Pinheiro Padilha von Tempski-Silka é economista, com pós-graduação em economia, e que trabalhou durante muitos anos na área de administração, planejamento e supervisão de projetos. É tradutora profissional principalmente do e para o francês, sendo tradutora juramentada de francês no Paraná. Seu histórico de economista se faz entrever na observação “O caminho para encontrar a verdade 
e a beleza tem uma sequência, exige esforço e não se queimam etapas, assim como no desenvolvimento econômico planejado”. No prefácio, a tradutora fala da questão espinhosa de se traduzir pronomes de tratamento e continua levantando a questão do acerto do registro na tradução e da escolha lexical entre sinônimos de registro mais tenso e mais distenso. Quanto a seu projeto de tradução, apesar de reforçar seu respeito ao texto original antes de tudo ("traduziu-se respeitando o texto original”) e ao estilo do autor, a tradutora se preocupa com a legibilidade do texto traduzido pelo público leitor contemporâneo (“cedi em alguns casos, em benefício da compreensão do maior número de leitores”), mas não cedendo à tentação de "nivelar por baixo". Parece-me que ela busca um equilíbrio entre os dois métodos propostos por Schleiermacher — o primeiro, que aproxima o leitor do original, causando-lhe estranhamento, e o segundo, que traz o original até o leitor —, tendendo mais para o primeiro.

É interessante notar que o nome da tradutora não aparece na capa, o que reforça a impressão de que apresentar na capa o nome de tradutores profissionais - que podem ser totalmente desconhecidos dos críticos e leitores intelectualizados não ajuda a vender o livro.

15. FLAUBERT, Gustave. Três contos. Trad. Flávio Moreira da Costa. Porto Alegre: L\&PM Pocket, 2005.

Trechos destacados no prefácio do tradutor: "P.S.: Ainda nos anos 70 do "século passado” depois de uma temporada na França, sem pressa, e sem qualquer razão objetiva, fui traduzindo os contos de Flaubert, talvez como parte do meu aprendizado como ficcionista, mas também para meu bel-prazer. Em 1981, ao fundar e dirigir a coleção Clássicos Francisco Alves, esta tradução teve sua primeira edição. Na verdade, inibido pela minha própria ousadia de traduzir um mestre como Flaubert, recorri a um expediente: a tradução veio “co-assinada” por Manuel Freitas Costa, homenageando assim meu bisavô de Coimbra, a quem não cheguei a conhecer e a quem transformei assim em meu personagem borgiano, ao mesmo tempo em que “dividia” a responsabilidade da empreitada. A segunda edição saiu em 1985, igual à anterior. Já a terceira edição, revista e bilíngue, foi lançada pela mesma Editora Francisco Alves, em 1995, constando apenas meu nome como tradutor. (Tomei coragem depois de boas críticas.) Esta edição, que 
surge em forma de bolso na Coleção da L\&PM, apresenta mais uma definitiva revisão, feita com a ajuda cuidadosa e competente de Celina Portocarrero.” (pág. 9-10)

Posição do nome do tradutor na edição: folha de rosto e ficha catalográfica. Tipo de tradutor: escritor.

Pelo verbete do DITRA, sabe-se que Flávio Moreira da Costa, além de escritor premiado e intelectual de prestígio, é também tradutor de obras do inglês, francês e espanhol, que escolhe traduzir por afinidade com a sua atividade de escritor, o que se deixa entrever pela sua observação "talvez como parte do meu aprendizado como ficcionista, mas também para meu bel-prazer”. Neste prefácio, ele relata um caso acontecido que poderia ser analisado de forma muito profícua por especialistas em tradução e psicanálise, o fato de ter acrescentado o nome do avô já falecido como cotradutor da obra, para se aliviar da responsabilidade das possíveis críticas que poderia vir a receber pela tradução. Por um lado, trata-se do uso de um mecanismo ficcional (a parceria com um falecido) levado ao paratexto, o que presta testemunho da criatividade e do talento do autor. Por outro, denuncia o tal sentimento de apreensão que costuma tomar os tradutores diante de possíveis críticas (“constando apenas meu nome como tradutor. (Tomei coragem depois de boas críticas.)”). Trata-se de usar o nome de um falecido como escudo e proteção. Ora, será que um escritor e tradutor reconhecido precisaria mesmo desse artifício? Será que de fato se sentia inseguro ou quis só pregar uma peça nos leitores e críticos? Nunca se saberá, mas o que fica patente é que o habitus de pária está bem enraizado até mesmo nos tradutores-escritores e intelectuais de renome. O nome do tradutor, apesar de ser escritor conhecido, não aparece na capa.

16. FLAUBERT, Gustave. Novembro. Trad. Sérgio Medeiros. São Paulo: Iluminuras, 2000.

Trechos destacados no prefácio do tradutor (25 páginas): "Enquanto revisava a minha versão de Novembro, pus-me a ler as passagens que mais apreciava a uma leitora entusiástica que me incentivou a continuar o trabalho e a quem só posso agora dedicar esta tradução, esperando que ela lhe agrade: Dirce Waltrick do Amarante”.

Posição do nome do tradutor na edição: folha de rosto e ficha catalográfica. 
Tipo de tradutor: escritor.

No verbete do DITRA, ficamos sabendo que Sérgio Luiz Rodrigues Medeiros é tradutor e conhecedor de línguas indígenas, tendo dedicado muito de seu tempo ao estudo dessas línguas. Sua obra própria se divide entre o estudo das literaturas e línguas indígenas e a poesia. Como tradutor, traduziu na área de etnografia e ficção.

Neste pequeno do prefácio em que fala da tradução, cita sua amizade com outra tradutora (de fato, formam um casal), professora universitária (UFSC) e pesquisadora de renome nos meios intelectuais, Dirce Waltrick do Amarante, nos contando de um processo de trabalho que realizou com a companheira de ler passagens para ela, a fim de ouvir seus comentários e perceber sua reação. A passagem não deixa entrever a sua concepção de tradução, mas testemunha de um processo de trabalho interessante entre tradutores que se ajudam e se apoiam. Talvez esses processos sejam muito mais comuns do que se imagina. Contudo, não fica registro, a menos que alguém o diga, se a parceria não fica consubstanciada como coautoria da tradução ou participação na tradução, como é o caso aqui. O destaque que a existência do prefácio de tradutor dá à sua pessoa não transbordou a instância prefacial a ponto de chegar à capa.

17. MALLARMÉ, Stéphane. Igitur ou A loucura de Elbehnon. Trad. José Lino Grünewald. Rio de Janeiro: Nova Fronteira. 1985.

Trechos destacados no prefácio do tradutor: “Críticos e especialistas de formação tão heterogênea, como Ezra Pound, Walter Benjamin ou Roman Jakobson, chegam a conclusões análogas quanto ao problema da tradução, mormente a de poesia: a) traduzir é trair (ou seja, trair o necessário ao nível semântico, a fim de que sejam mantidos os efeitos e a estrutura significante; b) a tradução é um problema de forma, ou seja, adaptação idiomática do propósito estrutural. Assim é que, neste poema, a fim de sustentar em português o citado propósito estrutural na oitava linha, em lugar de verter diretamente e palavra hivers para o equivalente de significado, invernos, preferimos lançar a palavra adversos, que assim sustenta a reiteração dos versos auto-referentes nas quatro linhas dos dois primeiros quartetos”. (pág. 72)

Posição do nome do tradutor na edição: folha de rosto e ficha catalográfica. 
Tipo de tradutor: escritor.

Poeta e tradutor literário premiado, José Lino Grünewald é um nome de peso na tradução poética, o que justifica a existência de um prefácio de tradutor. O fato de seu nome não constar na capa não se deve ao seu renome, mas sim ao costume de a editora Nova Fronteira não fazê-lo, pelo menos nos livros traduzidos pela editora que manuseei.

Neste prefácio, José Lino ressalta uma questão muito discutida na tradução de poesia: se o nível da forma, que ele aqui denomina de nível estrutural do poema, deve ser priorizado em relação ao nível semântico, e em que medida. Ele cita um caso pontual em que assim procedeu. Ora, em tradução de poesia, os níveis formal, semântico e sintático são igualmente importantes, mas sempre haverá um mecanismo de compensação em operação, pois, em certos momentos, em na tradução de um poema será preciso sacrificar o nível semântico em prol dos outros, o que deverá ser compensado em outra passagem, para que, na “contabilidade geral”, os três níveis sejam igualmente respeitados. Assim sendo, seu conceito de tradução aqui veiculado é o de adaptação, de mudança no sentido em prol da reprodução de efeitos estéticos, que ele considerou importantes. Como só cita um exemplo em que assim se utilizou desse procedimento, podemos imaginar que seu respeito pelo nível semântico seja, não obstante, bastante elevado, tão elevado quanto aos outros dois. É interessante perceber que o tradutor cita teóricos que pensaram a tradução, e a tradução poética em especial, para embasar suas ideias. Percebeu-se nesta pesquisa que, em se tratando de prefácio de tradutor de poesia, isso é bastante comum, enquanto que, nos prefácios de tradutores de prosa, o recurso à teoria é bastante infrequente.

18. MALLARMÉ, Stéphane. Rabiscado no teatro. Trad. Tomaz Tadeu. Col. Mimo. Belo Horizonte: Autêntica, 2010.

Trechos destacados no prefácio do tradutor: "Foi, pois, com certa hesitação, que acrescentei à presente tradução minhas "notas de leitura”. Que elas não sejam tomadas como mais do que isso. Que sejam vistas como apontamentos que se emprestam a um amigo ou a uma amiga que vai ler, ou até já leu, o mesmo livro. Dispensáveis, talvez. Utilizáveis, se houver necessidade.

Fiz o possível para que elas permanecessem no nível superficial de leitura. Ou 
seja, elas não contêm nenhuma interpretação profunda, baseada em alguma teoria estética, literária ou filosófica particular, excetuando-se a visão estética ou filosofia mais geral de Mallarmé. (...)

Por outro lado, elas não reivindicam qualquer tipo de autoridade. Gostaria que fossem lidas como se estivessem precedidas de um cauteloso "acho que...”. Além disso, leve-se em conta que uma explicação é sempre uma escolha que elimina outras possibilidades. Não pretendi eliminá-las. Nem poderia. Algumas delas baseiam-se em notas de leitores anteriores e foram colhidas nas mais diferentes e inesperadas fontes. Em geral, eram apenas indícios, mas que me serviram como ponto de partida para um maior desenvolvimento. A maior parte delas, entretanto, resulta de minha própria e exclusiva leitura.

\section{(...)}

A tradução guiou-se pelo princípio de reproduzir, na medida do possível, a sintaxe “anormal” de Mallarmé, na medida do possível, a sintaxe “anormal” de Mallarmé, sem buscar “corrigi-la”. Tentou-se dar ao leitor de língua portuguesa a mesma sensação de um leitor de língua francesa ao ler a prosa de Mallarmé no original.

(...)

Naturalmente, preservou-se, tanto no texto original quanto na tradução, a preferência de Mallarmé pelos dois pontos, em vez dos três convencionais, para assinalar reticências”. (pág. 8-12)

Referência à tradução na quarta capa: "A presente tradução procura conservar as peculiaridades da sintaxe de Mallarmé, tentando proporcionar ao leitor de língua portuguesa uma estranheza parecida à sentida pelo leitor de língua francesa diante do original. Os mais perplexos podem se socorrer das abundantes "notas de leitura” do tradutor que acompanham esta edição”.

Posição do nome do tradutor na edição: folha de rosto e ficha catalográfica.

Tipo de tradutor: acadêmico.

Na lista, em item acima, já consta uma tradução de Tomaz Tadeu, e as características do trabalho do tradutor que ressaltamos no primeiro comentário são retomadas aqui. Lá então, ressaltei que Tomaz Tadeu aparentemente não se filia a qualquer abordagem teórica da tradução, o que ele mais uma vez deixa transparecer aqui (“elas não contêm nenhuma interpretação profunda, baseada em alguma teoria estética, literária ou filosófica particular”), excetuando-se a teoria 
estética do próprio poeta. Aqui, mais do que anteriormente, pode-se considerar o projeto tradutório de Tomaz Tadeu como “estrangeirizante” “"A tradução guiouse pelo princípio de reproduzir, na medida do possível, a sintaxe "anormal” de Mallarmé, na medida do possível, a sintaxe “anormal” de Mallarmé, sem buscar “corrigi-la”. Tentou-se dar ao leitor de língua portuguesa a mesma sensação de um leitor de língua francesa ao ler a prosa de Mallarmé no original”), privilegiando reproduzir efeitos provocados pelo original, sem corrigir a sintaxe para facilitar o trabalho de leitura pelo leitor mais desavisado da estética mallarmaica. O tradutor procura se defender de possíveis críticas, dizendo que suas notas "permanecem no nível superficial de leitura” e são mais opiniões do que pareceres de especialista — podendo ser inclusive dispensadas —, recusando-se a se colocar em posição de autoridade. O tradutor assume, no trecho em que fala da tradução, claramente o habitus de pária e não de sacerdote.

19. MALLARMÉ, Stéphane. Brinde fúnebre e outros poemas. Trad. Julio Castañon Guimarães. Rio de Janeiro: 7 Letras, 2007.

Trechos destacados no prefácio do tradutor: "Diante do que se sumarizou até aqui, pode-se dizer que, se toda tradução é sempre um desafio e poucas vezes uma conquista, no caso de “Toast funèbre” e "Prose”, tentar traduzi-los constitui um trabalho bem difícil. Não tenho conhecimento de tradução de “Toast funèbre” em português. "Prose", além da que aqui se intenta, conta com outras duas traduções, segundo me consta.

(...)

Em “Toast funèbre”, o metro mais longo e as longas estrofes permitem, na tradução, uma maior flexibilidade na ordenação do discurso. Observe-se que, usando rimas emparelhadas, a divisão das cinco estrofes se dá em pontos em que o par de versos rimados se divide, ficando um verso em uma estrofe e outro na estrofe seguinte. O procedimento naturalmente torna mais sensível o encadeamento de todo o texto. Se esses dados apontam na direção de uma maior mobilidade para o tradutor, este na verdade se vê preso a várias outras amarras bem cerradas.

Diante do alexandrino empregado por Mallarmé, o tradutor, atendo-se ao metro de doze sílabas, preferiu optar por uma grande liberdade em termos de possibilidades 
de acentuação. Com isto, procurou fugir do efetivo risco de um verso excessivamente truncado em português. Quanto à métrica, valeu-se de todos os recursos que a escansão permite, ainda que nem sempre observando os conselhos da tradição, no propósito, porém, de obtenção de um melhor resultado de conjunto. No tocante às rimas, seguiu-se o esquema emparelhado e o emprego de rimas consoantes. No entanto, alguns casos de uso de rimas idênticas, isto é, entre vocábulos homônimos, não foram recuperados exatamente onde se verificam no original. Valendo-se da compensação, procurou-se criar situações similares em outros passos. (...)

Nesse poema, parece-me, sobressai, mais que a significação imediata da elaboração das sonoridades, a tessitura de um longo discurso - e é este que estabelece, em seu complexo fluxo, como que uma linha musical. Em termos gramaticais, isto se verifica nos extensos períodos. A tradução procura se manter atenta a essa ordenação, numa tentativa de frágil equilíbrio entre a lógica discursiva, o desenho sonoro, a tensão sintática.

(...) $\mathrm{O}$ tradutor não pode deixar de perceber esses elementos constitutivos do poema para tentar recompô-lo, sob pena de pisar em falso em sua recomposição. No caso do verso mencionado, era preciso levar em conta todos esses aspectos até mesmo para optar por uma formulação que desfaz a inversão - no cuidado de não produzir truncamentos no texto em português, devido à má tendência em tradução de acumular inversões para obter soluções de métrica e rima, e ao mesmo tempo na suposição de que, no caso, o apagamento da inversão seria perda compensada pela manutenção dos outros elementos mencionados.

(...) Em termos métricos, fez-se uso de diversas possibilidades de escansão, às vezes até com um inevitável abuso, sempre que em proveito da viabilidade da tradução, mesmo quando eventualmente se tratava de recurso não recomendável pelas melhores lições da métrica portuguesa. No entanto, esta raramente terá enfrentado situações extremadas como as dos poemas mallarmeanos, de modo que a efetiva infração vem a ser a própria tentativa de inserção desses poemas na língua portuguesa.

(...) Ciente desses parâmetros é que a tradução tem que procurar atuar - às voltas quase sempre com uma sintaxe tortuosa, um sentido obscuro e uma versificação virtuosística. 
(...) Muitas das soluções adotadas nas traduções que proponho provavelmente não vieram direto do tradutor mas de muitos outros textos poéticos em língua portuguesa ou para esta transplantados. Um ou dois pequenos exemplos têm origem clara. No verso “J’occupe mon antique soin”, de "Prose”, a tradução “Cuido do meu antigo afã” sem dúvida, pela escolha do vocábulo "afã”, repercute o verso o "Um branco afã de nossa vela” com que Augusto de Campos traduz "Le blanc souci de notre toile”, verso final de "Salut” ou “Brinde”. (...)

Talvez mais do que proporcionar um texto à altura, suposta ou ideal, do original, uma tradução de poema terá mérito se colocar em circulação algumas das questões envolvidas na operação poética. O que já não será parca esperança. No entanto, todas as explicações passam por pequeno colapso diante da verificação, com Drummond, no poema “Água-desfecho” de A paixão medida, de que todos operamos “Sem o ouvido sutil de Mallarmé”. (pág. 63-103)

Posição do nome do tradutor na edição: capa.

Tipo de tradutor: escritor.

Julio Castañon Guimarães é poeta, ensaísta, tradutor e pesquisador do Setor de Filologia da Fundação Casa de Rui Barbosa. Figura de autoridade na crítica e na criação literária, Julio se utiliza da oportunidade do espaço de um prefácio para ir mais fundo do que de hábito na discussão de questões ligadas à tradução de poesia. Chega a ressaltar aspectos bem específicos de escansão, metrificação e sintaxe incomum, justificando suas escolhas. Afora essas tecnicalidades, dois aspectos chamam a atenção nestes trechos do prefácio do tradutor: 1. a sua concepção soturna e desesperançada de tradução ("toda tradução é sempre um desafio e poucas vezes uma conquista”), em que parece mostrar que encara o exercício da tradução poética menos como uma atividade lúdica e criativa em si mesma do que como uma façanha em que se deve obter sucesso obrigatoriamente; 2. o aspecto intertextual desse exercício tradutório, em que certos versos fazem lembrar outros versos de outros poetas e em que os poemas "conversam” entre si ("Muitas das soluções adotadas nas traduções que proponho provavelmente não vieram direto do tradutor mas de muitos outros textos poéticos em língua portuguesa ou para esta transplantados”), não havendo nada de mau em um tradutor de poesia se "aproveitar” de boas soluções de outros tradutores em seu próprio trabalho. O primeiro aspecto me parece apontar para uma concepção do 
poema traduzido (e de todo texto traduzido, por extensão) sempre ser "menor" do que o poema original. Essa concepção de tradução vai totalmente de encontro à concepção derridiana de que há um duplo endividamento entre texto/autor original e texto traduzido/tradutor, importando mais o jogo de disseminação da palavra poética do que propriamente a ideia de status e de autoria, em que o que veio antes no tempo é necessariamente melhor do que o que vem depois. Por outro lado, o segundo aspecto leva a crer justamente o contrário, quando o tradutor diz se inspirar em outras soluções tradutórias e em outros poemas em língua original ou não para criar seus poemas traduzidos. Parece, portanto, que o tradutor veicula uma concepção conflitante de tradução (de pendor mais "logocêntrico") e de escritura e de criação (de pendor mais desconstrutivista) (ver Capítulo 2). De qualquer forma, o status de que o tradutor desfruta no mundo literário lhe garantiu o espaço de um prefácio longo e de ter seu nome na capa.

20. MAUPASSANT, Guy de. Os anos cor-de-rosa. Trad. Clémence M. C. JouëtPastré. São Paulo: Ed. Cone Sul, 1998.

Trechos destacados no prefácio do tradutor: “A tradução dessa peça apresentou vários desafios, a começar pelo título que contém a metáfora, muito pouco conhecida em francês contemporâneo, "feuille de rose”. Tal metáfora, utilizada nos meios libertinos do final do século XIX, representa o ânus (rose $=$ rosa) e a língua $($ feuille $=$ folha). Optou-se, na versão para o português, por manter o tom falsamente ingênuo do título em francês. Para tanto fez-se um jogo de palavras que recupera a sonoridade de “ânus” em “anos”.

Em virtude de diferenças culturais e linguísticas, foi necessário fazer algumas adaptações como, por exemplo, na personagem que tem um forte sotaque da região da cidade de Marselha. Neste caso, optou-se por um sotaque gaúcho pois que, além de ser praticamente impossível (e de não fazer sentido) reproduzir o sotaque marselhês em português, a personagem de Maupassant tem alguns atributos que fazem parte do estereótipo do gaúcho no Brasil, ou seja, é um indivíduo que faz questão de enfatizar suas qualidades de “macho”.” (pág. 10) Menção ao tradutor em "Sobre a tradutora”: "Clémence M. C. Jouët-Pastré é professora de língua francesa na UNICAMP e na Aliança Francesa de Campinas desde 1989. Tem um mestrado em Educação na Universidade de Massachusetts 
(EUA) e um mestrado em Linguística Aplicada na Universidade Estadual de Campinas. Escreveu vários artigos e um livro sobre ensino de francês como língua estrangeira. Atualmente está terminando uma tese de doutoramento na USP sobre as traduções brasileiras das Flores do Mal de Charles Baudelaire. Publicou diversas traduções de artigos e livros das áreas de Linguística, Linguística Aplicada, Análise do Discurso e História. À la Feuille de Rose - Maison Turque é sua primeira tradução de texto literário.” (pág. 81)

Posição do nome do tradutor na edição: capa.

Tipo de tradutor: acadêmico.

Soubemos a partir do site na Internet da Universidade Harvard que Clémence Jouët-Pastré é atual Diretora Adjunta e Orientadora da Graduação em Estudos em Português do Brasil nessa universidade, o que, além dos dados biográficos que constam da edição, fez com que fosse classificada sem muita hesitação como tradutora acadêmica. Neste trecho do prefácio, a tradutora fala de dois aspectos que lhe causaram problema ao realizar seu trabalho, deixando entrever sua concepção de tradução. O primeiro aspecto foi a dificuldade de tradução do jogo de palavras contido no título. Diante da impossibilidade de reproduzir o jogo de palavras, ela tentou, pelo menos, apontar para a polissemia através da sonoridade e do fato de as palavras "ânus" e "anos" serem pronunciadas da mesma forma. Esse tipo de desafio é bastante comum em tradução literária, e a tradutora lançou mão do mecanismo de compensação, tendo uma ideia bastante criativa, de forma a que o jogo de palavras não se perdesse completamente. $\mathrm{O}$ outro aspecto é de maior interesse para esta pesquisa: o fato de ter transplantado o sotaque marselhês para o sotaque gaúcho, ancorada no fato bem conhecido de que marselheses e gaúchos são machões. Esta solução é um indício claro de uma concepção “domesticadora” de tradução, de que a tradutora encara a tradução como um exercício criativo que visa a fazer com que o leitor se reconheça no texto, reduzindo o estranhamento. O prestígio de que a tradutora desfruta no mundo acadêmico rendeu-lhe o espaço de um prefácio de tradutor, dados biográficos incluídos no livro e seu nome na capa. 
21. MOLIÈRE. As eruditas. Trad. Millôr Fernandes. Col. L\&PM Pocket. Porto Alegre: L\&PM, 2003.

Trechos destacados no prefácio do tradutor: “Les femmes savantes, esta peça de Molière, tem sido levada no Brasil com o grosseiro título de As sabichonas. O mínimo que se pediria na tradução é preservar a ambiguidade. Se você atribui a uma mulher, ironicamente, ser erudita, sempre poderá se dirigir a ela, elogiosamente: “Aceite minha admiração, madame, a senhora é uma admirável erudita”. Poderá o leitor encarar a mesma senhora dizendo-lhe: “Não conheço sabichona igual?” E tua graça, Molière?

Se a tradução começa com esse título - jamais contestado, aliás, exceto pelo orador que vos fala - imaginem aonde vai o resto.

Mas a falta de percepção de títulos - não é implicância intelectualóide, é impaciência com grosseria que já mostra a qualidade do resto a seguir - é espantosa. A peça, supervalorizada, de Tennessee Williams, Cat in a hot tin roof, que traduzi, corretamente, como Gata em telhado de zinco quente, tem sido levada sempre, no Brasil, com o título nonsense de Gata em teto de zinco quente. Sem se advertirem, tradutores, resenhistas, atores e diretores, de que não se trata de um erro trivial. É um erro ridículo. Gata em teto é, na melhor das hipóteses, um lustre vagabundo, de mau gosto. Sem falar que nunca vi, em casa burguesa como é a da peça - um teto de zinco. Telhado, sim. E é nesse telhado que saltita (o título o saltitar nervoso de uma gata em cio incontido), a gata. "Sencillo, non, mamita?”

Para só ficar nisso e não ficar só aí, há pouco - escrevo em novembro de 2002 lançou-se no Brasil o último filme de Stanley Kubrick, com o título provocador de Eyes wide shut. Pois bem, não sabendo traduzir o título, ou nem sequer percebendo o que estava escrito, os tradutores colocaram em português: Olhos bem fechados. Kubrick que, prudentemente, tinha morrido meses antes, mesmo assim deu três voltas no túmulo. O que ele queria dizer era: Olhos escancaradamente fechados”. (pág. 7-8)

Referência ao tradutor na quarta capa: "Esta tradução e adaptação de Millôr Fernandes preserva os versos rimados do texto em francês, bem como a ironia, a coloquialidade e a comicidade originais, e faz justiça ao gênio de Molière”.

Posição do nome do tradutor na edição: capa. 
Tipo de tradutor: escritor.

Millôr Fernandes é uma figura muito conhecida no mundo das letras por atuar não só como escritor e tradutor, mas também como jornalista, ilustrador e humorista. Costuma traduzir peças de teatro e, ele próprio, é dramaturgo. Autodidata confesso, Millôr, segundo o DITRA, diz que aprendeu a traduzir traduzindo. Conhecido por ser um grande contador de casos, Millôr faz jus a sua fama neste prefácio em que, de forma divertida, aponta o assunto tão batido nas críticas dos erros de tradução. Desta vez, Millôr fala de erros na tradução de títulos a propósito de sua tradução, que vai de encontro à solução em tradução anterior, do título dessa peça de Molière. Neste prefácio, Millôr não faz referência a teorias formais de tradução nem busca elaborar uma teorização própria, preferindo tratar de aspectos anedóticos, de um ponto de vista mais leve e jocoso. Seus textos sobre tradução, a exemplo deste, são agradáveis de se ler, mas não trazem um conceito claro de tradução. Ao mesmo tempo em que dá a perceber, por este trecho, que se atém ao literalismo - pelo menos na tradução de títulos —, no verbete do DITRA há uma referência de que teria dito que "ao traduzir é preciso ter todo o rigor e nenhum respeito pelo original.” (em entrevista a Luiz Costa Pereira Júnior e Marco Antônio Araújo. In: Revista Língua Portuguesa on line). Não é possível inferir uma concepção de tradução apenas por este prefácio, além de que uma reflexão mais aprofundada do assunto não parece estar entre seus interesses. Contudo, é um tradutor que sempre chama atenção para si por suas atividades autorais e jornalísticas e por ser uma figura muito conhecida nos meios intelectuais, como bem mostra a presença do prefácio de tradutor e seu nome na capa.

22. MOLIÈRE. O doente imaginário. Trad. Marilia Toledo. São Paulo: ed. 34, 2010.

Trechos destacados no prefácio do tradutor: "Esta adaptação espelha, com pequenos ajustes, as versões encenadas no Teatro Vivo (2007) e no Teatro Folha (2008) (...) Nela foram feitos diversos cortes e simplificações a fim de adequar a obra de Molière a um espetáculo para crianças, reduzindo a um terço o tempo de encenação e tornando o enredo e a linguagem mais acessíveis a esse público.

(...) 
Como além de ter sido escrito em francês, o texto de Molière tem mais de trezentos anos, sua linguagem foi atualizada e facilitada, buscando uma maior identificação dos espectadores. O desafio, como em toda adaptação, foi equilibrar essa necessidade de simplificação com o respeito à personalidade do autor, preservando o que sua criação tem de mais essencial, tanto no conteúdo como na forma”. (pág. 10-11)

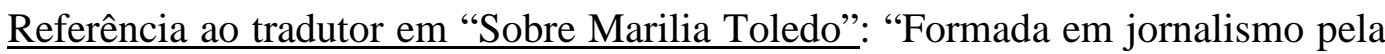
Fundação Cásper Líbero, Marilia Toledo estreou como autora de teatro para crianças em 2000, (...)

Marilia também assinou peças adultas (...)

Desde 2009 conduz, ao lado de Kleber Montanheiro, o Miniteatro, espaço cultural dedicado ao repertório da Cia. da Revista”. (pág. 138)

Referência ao tradutor na quarta capa: “A premiada autora de teatro Marilia Toledo nos oferece agora a sua adaptação da obra, voltada aos jovens, que ressalta toda a graça do original, mantendo-se sempre fiel ao espírito crítico e bemhumorado de Molière”. 4. Orelhas:

“A adaptação de Marilia Toledo ressalta justamente o aspecto farsesco da obra, facilitando uma primeira aproximação do jovem espectador ao universo de Molière. A propriedade de sua opção ficou provada nas bem-sucedidas encenações deste texto, tanto no teatro como na televisão" (depois repete o CV de “Sobre Marilia Toledo”).

Posição do nome do tradutor na edição: capa.

Tipo de tradutor: escritor.

Pelo mini CV da tradutora, contido na obra, sabe-se que ela, além de tradutora, é autora teatral. Nessa obra, Marilia procura não só fazer uma adaptação aos tempos mais modernos, como também uma adaptação para o público jovem. Portanto, sua proposta de tradução como adaptação fica clara, pelo menos em se tratando de textos teatrais, que são sua especialidade. A preocupação com a encenação e com o público alvo coloca em segundo plano a literalidade da tradução, apesar de tentar não descaracterizar o estilo do autor. Vê-se uma diferença grande entre a tradução de teatro para ser encenada e para ser lida. No primeiro caso, a tendência é que o tradutor tome mais liberdades em relação ao texto original, devido à sua 
preocupação com a "encenabilidade" do texto. O prestígio da tradutora no universo teatral lhe angariou o espaço de um prefácio e o nome na capa.

23. PRÉVERT, Jacques. Poemas. Trad. Silviano Santiago. Col. Poesia de todos os tempos. Rio de Janeiro: Nova Fronteira, $3^{\mathrm{a}}$ edição.

Trechos destacados no prefácio do tradutor (“Cotidiano e humor: o pequeno homem”): “Levando em consideração os elementos sobressalentes da poesia de Prévert, acreditamos que — de modo geral - a sua diç̧ão se assemelha à dos bons poetas brasileiros escrevendo nos anos 30. Poetas estes que já se encontram desvinculados da linguagem agressiva da vanguarda dos anos 20, mas daqueles anos guardando ainda a simplicidade coloquial na escolha do vocabulário e nas construções sintáticas, perpassando também o coloquial com a alta voltagem do humor e até da piada. Foi a partir de "modelos” como Manuel Bandeira, Carlos Drummond e Murilo Mendes que procuramos transpor os versos de Prévert para o português.

A tradução - como a estamos compreendendo - é uma decisão de leitura por parte de quem traduz. Enquanto tal, a tradução é exegética do poema, como a leitura crítica, mas desta distancia-se em pelo menos um ponto crucial. Enquanto a leitura crítica do poema procura, pela erudição e pelo método, organizar, revelar e domar o múltiplo semântico que é a essência do texto poético, a tradução requer que o que é polissêmico no texto de origem permaneça polissêmico no texto traduzido, sem que se desvele para o leitor o enigma que tece o texto literário.

Coube ao tradutor não impor ao texto a ser traduzido uma dicção poética esclarecedora do poema, mas buscar no repertório das dicções possíveis na sua literatura nacional um equivalente que fosse justo. Coube ao tradutor domar primeiro o equivalente, ou seja, a dicção poética escolhida como justa, para só depois efetuar o trabalho de tradução.

Neste sentido, o tradutor é um exegeta de asas curtas, certamente um duplo plagiador. Plagia o texto a ser traduzido e plagia os poetas nacionais que selecionou como modelos de dicção.

Mais modesto do que o seu companheiro crítico literário, o vôo exegético do tradutor fica sempre aquém das fronteiras semânticas do texto, já que não lhe compete quebrar o mistério do poema, nem prontificar-se à tarefa didática de 
ajuda na compreensão do poema. O tradutor guarda para o outro (para o seu leitor) o potencial polissêmico de leitura que existe em todo poema. Por isso é que o mais fiel amigo do tradutor é o leitor do poema traduzido. Para ele - só para ele é que existe a tradução.

Em outra perspectiva que não a do leitor do poema traduzido, pouco se salva de uma tradução - salvo, é claro, a fidelidade que é o que também se salva nos casamentos monogâmicos enquanto duram. Além da fidelidade, uma tradução tudo é hipótese, aproximação, desacerto com acerto e até mesmo acerto sem acerto, transgressão com pedido de perdão e, finalmente, posse sem direito autoral”. (pág. 10-11)

Referência à tradução na orelha: “Agora qualquer leitor brasileiro pode entrar em contato direto com os poemas de Prévert, graças à tradução feita pelo escritor e professor Silviano Santiago. Este, com sensibilidade e artesanato, tentou apreender a linguagem, coloquial e bem-humorada, a faceirice poética do francês, valendo-se dos recursos legados por um Drummond ou um Bandeira, tornando assim a leitura dos poemas em português agradável e prazerosa”.

Posição do nome do tradutor na edição: capa.

Tipo de tradutor: escritor e acadêmico.

Este prefácio já foi analisado no Capítulo 4.

24. PRÉVERT, Jacques. Poemas. Trad. Silviano Santiago. Col. Poesia de todos os tempos. Rio de Janeiro: Nova Fronteira, 1985.

Trechos destacados no prefácio do tradutor ("Cotidiano e humor: o pequeno homem”): o mesmo do item 23.

Referência à tradução na orelha: a mesma do item 23.

Posição do nome do tradutor na edição: capa.

Tipo de tradutor: escritor e acadêmico.

Este prefácio já foi analisado no Capítulo 4.

25. PROUST, Marcel. O indiferente e o fim do ciúme. Trad. Sérgio Coelho. Col. Canto Literário. São Paulo: Scrinium, 1997.

Trechos destacados no prefácio do tradutor: “(...) Quanto ao fato de $O$ fim do ciúme já ter tradução para o português, ao invés de um inconveniente, pode vir a 
ser uma interessante oportunidade para que, através de uma eventual comparação, se reafirme a ideia de que, no caso de uma obra rica como a de Proust, cada tradução é uma interpretação, e que no tradutor sempre se ocultará, tímido, um crítico.

E o que esse tímido crítico tem a revelar? O que está presente na leitura desta obra?

Através do exercício da tradução não resistem, na verdade, as ideias gerais sobre Proust. Sua prosa não consiste em um somatório de frases intermináveis, de sentido vago, fruto de um empenho frívolo e pretensioso. Se, de fato, frases que se desdobram e se entrelaçam em um labirinto de nuanças são a marca mais indelével do autor, Proust se resume a isso.” (pág. 14-15)

"Munidos agora com todos esses dados, podemos finalmente debruçarmo-nos sobre a frase propriamente proustiana, procurando, através do exercício da tradução, compartilhar de algum segredo desses anjos. Peguemos como amostra uma frase especialmente intrincada - citada primeira em francês, para que o leitor possa vivenciar a angústia de opção do tradutor.” (pag. 21)

"Peço licença ao leitor, que me acompanhou com paciência até aqui, para dedicar esse meu começo de carreira como tradutor (que pôde ter a honra de traduzir a estreia de Proust) à memória de meu pai, que então iniciava entre amigos de toda a vida, a sua vida intelectual.” (pág. 27)

Posição do nome do tradutor na edição: folha de rosto e ficha catalográfica.

Tipo de tradutor: profissional.

A partir da Internet, pouco se descobre sobre Sérgio Coelho, a não ser que, se é com Proust que inicia sua carreira de tradutor, depois disso se tornou um tradutor profícuo. Para diminuir a chance de errar, decidi então classificá-lo como tradutor profissional, pois é nessa categoria que parece se encaixar com base nas referências surgidas em uma busca no Google. Coelho, nestes trechos do prefácio, apresenta uma concepção de tradução como crítica e como leitura. Encara a tradução como exercício, resultado de múltiplas leituras e interpretações, e não como um produto final perfeitamente acabado que espelha uma única e correta leitura. Sua postura aparentemente tímida, que recusa a priori o posto de figura de autoridade, não é servil ao autor/texto original. Veicula, portanto, um conceito de tradução mais afeito às ideias desconstrutivistas do que às ideias de tradução 
como traductio ou translatio. Seguindo a regra mais geral que se depreendeu desta pesquisa (tradutores escritores de renome figuram mais na capa do que os tradutores profissionais), Coelho, apesar de ter angariado espaço para escrever um prefácio de tradutor, não teve seu nome estampado na capa.

26. PROUST, Marcel. Em busca do tempo perdido: No caminho de Swann e À sombra das moças em flor. Vol.1 Trad. Fernando Py. Rio de Janeiro: Ediouro, 2002.

Trechos destacados no prefácio do tradutor: "V - Conclusão: critérios desta tradução

Não é tarefa tranquila traduzir uma obra de vulto como a de Proust. Ainda mais quando já existem outras em português. Mas não há dúvida de que é uma aventura intelectual largamente compensadora, um trabalho altamente gratificante. Desde que se adotem critérios seguros e sejam obedecidas o mais fielmente possível as peculiaridades essenciais do autor. No caso, a fluência musical da frase, a por vezes enorme extensão desta e dos parágrafos, sem dividi-los em blocos retalhados, o movimento ondulatório dos períodos, etc. E mais, tratando-se de uma edição brasileira, construir frases e períodos à nossa maneira, sem lusitanismos nem regionalismos de qualquer espécie.

Devemos, todavia, esclarecer o leitor quanto aos critérios adotados para traduzir os títulos dos romances do ciclo, sobretudo devido ao caráter de simetria que oferecem. Em dois casos, a transposição é literal e não sofre problemas: Sodome et Gomorhe é Sodoma e Gomorra e La Prisonnière é A Prisioneira. Em À L'ombre des jeunes-filles en fleurs preferimos verter jeunes-filles para moças, vocábulo de uso corrente no Brasil. Em Le temps retrouvé, julgamos mais acertado o título O Tempo Recuperado, pois de modo algum se trata de uma redescoberta. De outra parte, Du côté de chez Swann, se traduzido literalmente, daria A respeito do lado da casa do Swann, ou , se forçarmos um pouco, Para os lados da casa de Swann. Preferimos adotar o título já consagrado no Brasil, pois o termo "caminho" indica melhor em português a situação do côté francês: o que, para Proust, era um "lado” inconciliável com outro, fica melhor como “caminho”, pois indica todo um trajeto a percorrer, uma distância a vencer, uma tarefa a cumprir. O mesmo, portanto, para Le Côté de Guermantes - O Caminho de 
Guermantes é toda a trajetória do Narrador nos salões da alta-roda.

Resta o caso de A Fugitiva. Fiel à construção simétrica de sua obra, Proust batizou os dois romances seguintes a Sodoma e Gomorra de A Prisioneira e A Fugitiva. Entretanto, em 1922, publicou-se na França uma tradução de poemas de Tagore intitulada precisamente A Fugitiva. Diante disso, para evitar mal-entendidos, Proust desistiu do título e o romance apareceu postumamente como Albertine disparue (Albertina desaparecida). Ainda hoje se discute qual título caberia melhor ao livro; e assim, atendendo ao caráter rigorosamente simétrico de Em Busca do Tempo Perdido, e considerando já não haver motivos para evitar a identidade de título com uma coletânea da qual ninguém se lembraria não fosse esse episódio, adotamos A Fugitiva, que certamente Marcel Proust preferia e teria escolhido com o tempo - se tivesse vivido o suficiente para ver toda a obra publicada em livro.” (pág. 12-13)

Menção ao tradutor na quarta capa e na orelha: Na quarta capa, trecho do prefácio. Na orelha, texto do tradutor. O tradutor tem grande destaque na publicação.

Posição do nome do tradutor na edição: folha de rosto e ficha catalográfica. Tipo de tradutor: escritor.

Além de tradutor literário muito produtivo, Fernando Py é poeta, colunista, crítico literário e redator, o que me fez classificá-lo na categoria escritor. Apesar do grande destaque dado à figura e ao nome do tradutor nessa edição, por meio da concessão de espaço para um prefácio longo, referência ao prefácio na quarta capa e texto do tradutor na orelha do livro, seu nome não consta na capa. Nesse caso específico, a ausência do nome na capa não empana a ênfase na importância do tradutor. A tradução anterior de Em busca do tempo perdido foi feita nos tempos lendários do grupo de tradutores da Editora Globo, composto por escritores de peso no cenário literário nacional, de que muito se fala como tendo sido um episódio único na história da tradução no Brasil. Assim sendo, a retradução de Py aparece como sendo uma ousadia. Contudo, Py não se intimidou; pelo contrário, questionou soluções de tradução de nomes como Mário Quintana e Carlos Drummond de Andrade. Aqui, neste trecho do prefácio escrito por ele, após dar indicações das diretrizes que nortearam seu projeto tradutório (ser fiel às peculiaridades essenciais do autor, obedecer à fluência musical da frase e traduzir em português brasileiro), passa a discutir as traduções dos títulos dos livros. Neste 
prefácio, o tradutor parece veicular uma concepção de tradução de fidelidade ao estilo do autor e à musicalidade do texto, mais do que ao sentido literal propriamente dito. O fato de se recusar a utilizar lusitanismos marca a maior distinção desta tradução em relação às outras anteriores, já apartadas no tempo. De fato, parece que o tradutor pretendeu “atualizar” a tradução para o leitor mais contemporâneo, justificando seu projeto de retradução de uma obra clássica em relação a uma tradução tornada clássica. Há um certo grau de adaptação em sua tradução, apesar de se manter fiel ao estilo do autor. Parece-me, contudo, que o intento maior do tradutor não foi fazer uma tradução modernizante ou domesticadora, mas tão somente aproximá-la do leitor mais contemporâneo, corrigindo possíveis distorções de tradução.

27. PROUST, Marcel. Em busca do tempo perdido. No caminho de Swann: Combray. Adapt. e desenhos Stéphane Heuet. Trad. e notas André Telles. Rio de Janeiro: Jorge Zahar, 2004.

Trechos destacados no prefácio do tradutor: "Há duas edições brasileiras da obra: uma publicada pela Editora Globo, com tradução de Mario Quintana, Manuel Bandeira, Carlos Drummond de Andrade e Lúcia Miguel Pereira; e outra publicada pela Ediouro, com tradução de Fernando Py”.

Referência à tradução na quarta capa: “O texto de Marcel Proust é aqui compilado de forma fiel ao original, o que permite ao leitor um contato direto com a obra do autor. No final do volume, informações, curiosidades e notas fornecem referências para a leitura.” - “A adaptação de Stéphane Heuet, longe de ser uma traição é uma notável introdução à leitura de Proust”, Daniel Couty, Le Monde.

Posição do nome do tradutor na edição: folha de rosto e ficha catalográfica.

Tipo de tradutor: profissional.

Trata-se de uma adaptação de Stéphane Heuet, conhecido ilustrador e adaptador francês, do clássico de Proust, traduzido por André Telles. Já falei do tradutor no Capítulo 4 e do fato de esta tradução ter ganhado o Prêmio de Melhor Tradução Infanto-Juvenil de 2005, dado pela Fundação Nacional do Livro Infantil e Juvenil. Nada se fala da tradução além da referência às traduções anteriores, da Editora Globo e de Fernando Py. Este é um caso muito particular de adaptação para o público infanto-juvenil no corpus. 
28. PROUST, Marcel. Em busca do tempo perdido: No caminho de Swann e À sombra das moças em flor. Vol.1 Trad. Fernando Py. Rio de Janeiro: Ediouro, 2004.

Trechos destacados no prefácio do tradutor: o mesmo do item 26.

Menção ao tradutor na quarta capa e na orelha: o mesmo do item 26.

Posição do nome do tradutor na edição: folha de rosto e ficha catalográfica.

Tipo de tradutor: escritor.

Ver comentários em item acima.

29. RACINE, Jean. "Fedra”. In Hipólito e Fedra. Trad. Joaquim Brasil Fontes. São Paulo: Iluminuras, 2007.

Trechos destacados no prefácio do tradutor (“In Me Tota Ruens Venus”) (88 páginas):_Sobre os autores e as obras. Trata-se de um estudo que descreve o caminho que leva à tradução destas três tragédias - Hipólito de Eurípides, Fedra de Sêneca, Fedra de Racine —, ao mostrar como, por que e para que a primeira destas tragédias se atualiza de novo e de novo em uma nova tragédia, em tempos diversos; longas digressões pessoais.

Referência ao tradutor em "Sobre o tradutor” (com foto): “Joaquim Brasil Fontes é tradutor da lírica de Safo para o português (Poemas e fragmentos, São Paulo: Iluminuras) e autor, entre outros livros, de Eros, tecelão de mitos (São Paulo, Iluminuras), A musa adolescente (São Paulo: Iluminuras), Poética do fragmento (Belém: Instituto de Artes do Pará), O livro dos simulacros (Florianópolis: Cavicórdio), Os anos de exílio do jovem Mallarmé (São Paulo: Ateliê, no prelo) e As obrigatórias metáforas (São Paulo: Iluminuras).” (pág. 491).

Posição do nome do tradutor na edição: capa.

Tipo de tradutor: acadêmico.

O tradutor, acadêmico e intelectual exímio conhecedor de línguas modernas e antigas, não dá aqui indicação de sua concepção de tradução. O prestígio do tradutor nos meios acadêmicos e intelectuais angariou-lhe o espaço de um prefácio e seu nome na capa.

30. RACINE, Jean. Esther. Trad. Modesto de Abreu. Rio de Janeiro: Academia de Letras do Estado do Rio de Janeiro, 1997. 
Trechos destacados no prefácio do tradutor: "No meu entender, pois, sobressai, como a verdadeira obra-prima de Racine, em todos os sentidos, pela beleza do verso e pela rigorosa psicologia das situações, o drama que ele extraiu, com raríssima felicidade, do Livro de Esther, da Bíblia, e que temos a satisfação de oferecer hoje aos nossos estimados e possíveis leitores em língua portuguesa e nos mesmos versos alexandrinos que procuramos, tanto quanto possível imitar e seguir”. (pág. 36)

Referência ao tradutor nas orelhas: dados biográficos do tradutor.

Posição do nome do tradutor na edição: capa.

Tipo de tradutor: escritor.

O tradutor é escritor e membro da Academia de Letras do Estado do Rio de Janeiro, tendo inclusive um prêmio com uma medalha com seu nome. Parece que seu nome estar na capa se deve em grande parte pela edição ter sido realizada pela mesma Academia da qual é membro. No curto trecho do prefácio em que trata de tradução, o tradutor dá a entrever que sua concepção de tradução é mais literalizante, com a tentativa inclusive de reproduzir os versos em alexandrinos em português, empresa que muitos tradutores de poesia sequer cogitam por ser esse tipo de verso mais afeito à língua/estética francesa do que à portuguesa. Vemos observações a este respeito em outros prefácios coletados na presente pesquisa.

31. RIMBAUD, Arthur. O barco ébrio. Trad. Jayro Schmidt. Col. Tra(duz)ir. Florianópolis: Editora da UFSC, 2006.

Trechos destacados no prefácio do tradutor: $O$ barco ébrio é um poema de fluxos e refluxos: jusante do rio e do mar. Traduzi-lo foi remar em favor de sua fluência. Não manter a rima, entre outras coisas, seria suprimir a vertigem sonora, caudalosa do barco. Mas isso, em tantas passagens, colocou dificuldades sintáticas nem sempre moderadas, obstáculos que foram contornados no mesmo campo semântico do poema original, na realidade contornos em conserto, incluindo inversões de versos e de palavras, aproveitando a transposição de la mer para $o$ mar. Banhar-se nestes detalhes, barco em palavras, foi expandir o tom marginal e inquieto do poeta. Para o que exponho, dou exemplos que são abrangentes.

(...) Por falar nisso, traduzir o poema de Rimbaud, povoado de desafios, geralmente leva a soluções que amenizam e suprimem as passagens de uma língua 
para outra. É claro que a supressão às vezes é inevitável, mas sem amputar o original como acontece em grande parte das traduções.

De qualquer maneira, traduzir é deformar, mas de cujas deformações uma língua pode ser outra língua: línguas de línguas. Toda tradução, neste aspecto, é um fantasma, algo que não é definitivo: não por incerteza, mas por convicção de que um poema é igual a si mesmo”. (pág. 15-16)

$\underline{\text { Referência ao tradutor e à tradução no prefácio de Fábio Brüggemann, “Arthur, }}$ Jayro e eu, bêbados”: muitas referências, não sendo possível reproduzi-las todas aqui.

Posição do nome do tradutor na edição: capa.

Tipo de tradutor: escritor.

Pelo verbete na Wikipedia e pela página na Internet www.jayroschmidt.com.br, ficamos sabendo que Jayro Schmidt é pintor, gravador, escritor, tradutor e professor de pintura e história da arte. Jayro é autor de vários ensaios nas áreas de artes, literatura e pintura. A sua produção como tradutor não é vasta, ele não tem um interesse patente pelos estudos de tradução e atua como artista plástico e professor de artes em instituições artísticas e não como professor universitário. Por este motivo decidi classificá-lo como escritor e não como acadêmico. Por sua biobibliografia, Jayro parece ser um intelectual inquieto, que se interessa por muitos assuntos, mas cujas incursões pela tradução não são frequentes.

A edição dá um grande destaque ao tradutor, com várias referências a seu nome e à tradução no prefácio de Fábio Brüggemann, por seu nome na capa e a existência de um prefácio do tradutor. Por ter sido uma edição realizada em Florianópolis, onde o tradutor mora, atua profissionalmente e possui renome, entende-se por que há um relevo tão grande à figura do tradutor. Talvez se fosse uma edição realizada em outra cidade, seu nome não tivesse tanto destaque.

Apesar de não se ver uma filiação clara a alguma abordagem teórica da tradução, Jayro veicula uma concepção de tradução de tendência desconstrutivista (“(...) traduzir é deformar, mas de cujas deformações uma língua pode ser outra língua: línguas de línguas. Toda tradução, neste aspecto, é um fantasma, algo que não é definitivo: não por incerteza, mas por convicção de que um poema é igual a si mesmo.”), o que parece refletir suas leituras sobre linguagem e filosofia — ou filosofia da linguagem —, ligadas aos estudos literários. Ele não fala em 
fidelidade no trecho destacado, apresenta a tradução de poesia como um empreendimento de perdas e ganhos, em que os níveis semântico, formal e rítmico/rímico possuem importância semelhante, talvez com a precedência dos dois últimos em relação ao primeiro, o que é bastante comum na tradução de poesia. Sente-se mesmo como se ele tivesse feito um trabalho de coautoria com Rimbaud, por não apresentar uma postura subserviente em relação ao original, apesar de seu respeito pela obra (“É claro que a supressão às vezes é inevitável, mas sem amputar o original como acontece em grande parte das traduções”).

32. RIMBAUD, Arthur. Poesia completa. Trad. Ivo Barroso. Rio de Janeiro: Topbooks, 1995.

Trechos destacados no prefácio do tradutor: "No que respeita a este primeiro volume - POESIA COMPLETA DE ARTHUR RIMBAUD - queremos que o leitor esteja ciente de alguns princípios que nortearam sua tradução: em primeiro lugar, buscamos traduzir e não recriar, transcriar, parafrasear, poundear ou fazer um poema novo em cima de um motivo de Rimbaud. Por isso que traduzir, para nós, implica uma fidelidade a bem dizer canina, ou fotográfica, em que o tradutor acompanha o original passo a passo, palavra por palavra, expressão por expressão, no intuito de preservar ao máximo possível a forma e a essência do poema em português. Em seguida, procuramos evitar cuidadosamente as inversões, os circunlóquios, as transposições, as alterações dos esquemas rímicos e, principalmente, o enxerto de palavras que não figurassem no original. Penitenciamo-nos de inevitáveis supressões, que contudo tivemos a preocupação de fazer recair sobre os elementos menos imperativos do verso.

Essa fidelidade, no caso de Rimbaud, longe de empobrecer o texto, faz-lhe a devida justiça, pois sua poesia já é suficientemente grandiosa para que se pretenda melhorá-la, reelaborá-la ou - pior que tudo - “modernizá-la”, acrescentando-lhe elementos espúrios incompatíveis com sua pureza de diamante. (...)

Contudo, essa fidelidade a que nos referimos como sendo o objetivo máximo da tradução, ou, pelo menos, desta tradução, não nos obriga à produção de versos anódinos ou destituídos do centelhamento que identifica a verdadeira poesia. Queremos ser fiéis e, ao mesmo tempo, despertar no leitor brasileiro um sentimento estético, uma empatia semelhante àquela que o leitor francês 
experimenta diante da peça original. Ao esforço despendido na obtenção dessa árdua dualidade é que se poderia chamar de criatividade ou inventiva. Esforço que se traduziu, em certos casos, numa sucessão de tentativas, que se prolongaram anos a fio, para que se pudesse obter um verso com a cadência do original e concomitantemente sua métrica, suas combinações cromáticas e sonoras, sua découpage ou seu alongamento, e até mesmo suas repetições ou cavilhas quando decorrentes de intenção estilística. A volumosa literatura crítica disponível nos permitiu optar por soluções que espelham o resultado dos trabalhos de exegese mais criteriosos, com ênfase nas interpretações da "crítica psicanalítica”, que tem feito da obra de Rimbaud um campo inesgotável de pesquisas.

Em nosso trabalho, não tomamos liberdades com Rimbaud; mas houve passos em que, por já nos escassear tempo de vida ou paciência de espera, tivemos de "traílo”. Nem sempre nos foi possível vertê-lo "sinfonicamente”, ou seja, observando imagem, sentido, metro e rima. Em alguns de seus poemas longos, principalmente da fase inicial, entre desfigurar ou simplificar demasiadamente o conteúdo para mantê-lo rimado, a exaustão nos levou a optar por uma transposição “de orquestra de câmara”, ou seja, mantivemos a métrica mas sacrificamos a rima. Contudo, em 90\% dos poemas a orquestra tradutória se apresenta au grand complet, mesmo nas quase intraduzíveis “gozações” e glosas de Album zutique, onde aparece o desnorteante soneto monossilábico (“O cocheiro bêbado”), causador de insônias e frustrações de quantos lhe tentaram acompanhar a carruagem.

(...)

Nossa intenção inicial era publicar este volume totalmente destituído de notas de pé de página ou adendos explanatórios; queríamos que o leitor brasileiro reagisse diante dos versos apenas, sem maiores esclarecimentos. Porém a exegese da obra de Rimbaud se tornou hoje em dia um campo tão vasto que o leitor não versado em francês, ou mais ainda aquele que o seja, haveria de estranhar em muitos passos as soluções tradutórias por nós adotadas, se desconhecesse as razões que nos levaram a elas”. (pág. 10-12)

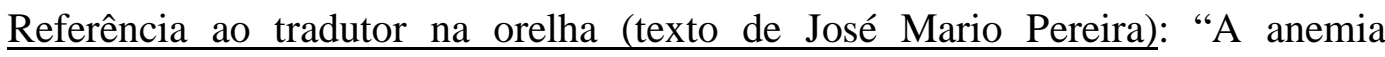
nacional em relação a Rimbaud começou a findar quando, em 1973, o mineiro Ivo Barroso, poeta de fina sensibilidade, tradutor de raça e responsável pela execução de tarefas de extrema singularidade (...), entregou ao público a sua versão de Une 
saison en enfer (Uma estadia no inferno), saudada por mestre Alceu Amoroso Lima como marco na história da tradução no Brasil. A certa altura de sua apresentação, escreve: “A tradução do poema, por Ivo Barroso, foi feita ao mesmo tempo com o maior respeito pelo pensamento do autor, na fidelidade aos mais sutis reflexos de sua expressão verbal, e com a constante preocupação de uma correspondência integral na linguagem vernácula mais depurada.

Dentro do mesmo espírito que sempre orientou o seu sacerdócio como tradutor, Ivo trabalhou nesta Poesia completa. Foram anos de dedicação absoluta, melhor dizendo, de obsessão integral, garimpando mundo afora livros, variantes, curiosidades sobre o poeta que, na expressão de George Steiner, “deixou sua impressão digital na linguagem, no nome e no temperamento do poeta moderno, como Cézanne o fez com as maçãs.

(...) Toda a poesia de Rimbaud, devido à habilidade e ao talento de Ivo Barroso, está aqui neste livro, sem dúvida ponto alto em nossa prática de tradução, e é mais um tento marcado por ele em seu projeto de pôr em português a obra completa do adolescente de Charleville (...)

Quem ler o Rimbaud de Ivo não vai ter dúvidas: o poeta que um dia decretou a necessidade de se "reinventar o amor” encontrou, 140 anos depois de morto, o seu outro eu. É assim que os leitores ganham agora esta tradução exemplar, onde todos os ritmos, trocadilhos, assonâncias, elipses, e demais singularidades da poesia de Rimbaud foram respeitadas.

Voltaire, numa passagem das Cartas Inglesas, comentando uma tradução sua de Pope, confessa não se sentir atraído pela tradução fiel, palavra a palavra. Essa observação, precursora das ideias de Pound, a que nossos concretistas referem-se como transcriação, não é receita cara a Ivo Barroso. (...)”.

Posição do nome do tradutor na edição: capa.

Tipo de tradutor: escritor.

Assim como o prefácio de Guilherme de Almeida a Flores das flores do mal, comentado acima, este prefácio de Ivo Barroso teria um lugar cativo em uma antologia de prefácios de tradutores no Brasil. Ele é muito comentado, aludido, referenciado em outros prefácios e obras sobre tradução poética, tendo se tornado um clássico no gênero. A concepção de tradução que Barroso apresenta neste prefácio poderia constituir, aos olhos de Rosemary Arrojo (ver Capítulo 2), uma 
pérola do logocentrismo. Seu projeto tradutório ("não recriar, transcriar, parafrasear, poundear ou fazer um poema novo em cima de um motivo de Rimbaud”) parte de um conceito de tradução totalmente literal, a que ele denomina de "canina” ou "fotográfica” (“o tradutor acompanha o original passo a passo, palavra por palavra, expressão por expressão, no intuito de preservar ao máximo possível a forma e a essência do poema em português”). O tradutor não para por aí. Além de querer reproduzir a forma e a essência do poema em português, quer também reproduzir os mesmos efeitos produzidos no leitor francês, acreditando ter sido bem-sucedido em 90\% das vezes. Em nenhum outro prefácio do corpus, encontrei um relato que se parecesse tanto com o ideal menardiano descrito por Borges. É interessante notar que o tradutor fala de fidelidade estrita justamente em tradução de poesia, que é um tipo de tradução onde a noção de recriação é tão bem aceita e divulgada.

33. RIMBAUD, Arthur. Iluminuras. Trad. Rodrigo Garcia Lopes e Maurício Arruda Mendonça. São Paulo: Iluminuras, 1996.

Trechos destacados no prefácio do tradutor: "Pois para quem em como intenção poética chegar, via poesia, ao "desconhecido”, ao ainda não ouvido, não sentido, não visto, essas invenções de novos “paraísos artificiais” pediam formas novas, novos caminhos: olhos abertos. O poeta, para ele, é alguém a quem fica reservada apenas a tradução: um "tradutor", um decifrador das mensagens enviadas do “Estúdio Realidade” e do seu imaginário. Aquele que vai “au fond de l’inconnu pour trouver du nouveau”, como já dizia Charles Baudelaire no poema "Le Voyage”. (pág. 137)

Posição do nome do tradutor na edição: capa.

Tipo de tradutor: escritores e acadêmicos.

No Dicionário Cravo Albin da Música Popular Brasileira (http://www.dicionariompb.com.br/rodrigo-garcia-lopes/biografia) existe um verbete “Rodrigo Garcia Lopes”, onde ficamos sabendo que, além de tradutor, ele é cantor, compositor, instrumentista (violonista) e jornalista. Seguindo duas carreiras paralelas, nas áreas de letras/jornalismo e música, Lopes possui mestrado e doutorado em Letras, tendo sido professor universitário de língua e literatura no Brasil e nos EUA, mas possui obra como compositor e musicista. Pelo blog 
Epigrafias (http://epigrafias.blogspot.com.br/) e pelo perfil de Mauricio Arruda Mendonça no Linkedin, ficamos sabendo que o tradutor é poeta e dramaturgo premiado (Prêmio Shell 2012), além de ser mestre e doutorando pela Universidade Estadual de Londrina. Com base nos dois perfis, decidi classificálos como escritores e acadêmicos.

Não fica claro, pelo trecho destacado do prefácio de tradutor, qual o conceito de tradução que os tradutores têm ou tiveram nesse projeto tradutório. O que se entende é que queriam marcar uma diferença em relação às traduções anteriores (“essas invenções de novos "paraísos artificiais” pediam formas novas, novos caminhos: olhos abertos”). Contudo, pode-se inferir pelo fato de chamarem as traduções de “invenções” e, por inspiração do próprio Rimbaud, considerarem o poeta um tradutor do seu imaginário, que sua concepção de tradução é mais de cunho adaptativo, intertextual, do que propriamente literal. O destaque dado aos tradutores pela concessão do espaço do prefácio é reiterado pelo nome na capa.

34. RIMBAUD, Arthur. Uma temporada no inferno e Iluminações. Trad. Lêdo Ivo. Col. Clássicos Francisco Alves. Rio de Janeiro: Francisco Alves, 1982. Trechos destacados no prefácio do tradutor: “Quando acabei de traduzir Rimbaud, caiu sobre a paisagem que eu fitava uma inaudita chuva de granizo. Tudo ficou sereno, de repente, e o arco-íris que, criança, contemplei na paisagem total, atravessou o céu de lado a lado e tinha as cores das vogais do soneto de Rimbaud”. (pág. 9)

"Talvez, na raiz das traduções a que nos aventuramos, se consubstancie um ato de fidelidade a um colegial que, certa noite, na cidade do Recife, entrou na Biblioteca Pública para ler, pela primeira vez, as poesias de Jean Arthur Rimbaud e, à medida que percorria as páginas do livro, sentia faltar-lhe a terra aos pés, presa da vertigem de um abismo florido e azul.

Assim as traduções de Une Saison en Enfer e das Illuminations, produzidas dezesseis anos depois, como quem chama a atenção alheia para duas constelações sempre vistas da janela, no fixo céu noturno, possuem, também, um sentido de homenagem e reconhecimento.

Por mais familiares que os textos se afigurem ao leitor contumaz, no ato de serem traduzidos eles exibem sete faces diferentes, como se as leituras anteriores fossem 
apenas divertimentos ociosos ou estágios. E o tradutor, que deve ser, na seita literária, o mais atento de todos os leitores, os vê em sua plena abundância de sinais e inferências, desde os conceitos sibilinos e as paragens equívocas que o poeta ali plantou como quem guarda tesouros ao sol, até as sonoridades e as visões mais vertiginosas, como as que juncam os blocos de Une Saison en Enfer ou das Illuminations.

Finda a tarefa de encontrar equivalências sonoras e conceituais para os textos submetidos ao processo da tradução, transplantados para uma nova forma, o tradutor teria uma longa história a contar: a de sua temporada no coração de um determinado sistema de criação poética, e de sua mudança para outra língua, como um conjunto de móveis levados para outra casa.

Mas isto faz parte do ofício, ou dos ossos ou ócios do ofício e se perde, confissão dispersa, nas dobras do trabalho acabado. Pois traduzir é dispor também de uma biblioteca, para a consulta das palavras no manuseio dos grandes dicionários, as pesquisas das bibliografias fidedignas, as comparações dos textos, as iluminações biográficas. De seu oficiante, esse rito intelectual exige devoção, paciência, atenção, humildade e todas as qualidades que se esquivam aos apressados e aos impacientes. E o beneficia, como prêmio imprescindível, com esse favor celeste que São Jerônimo, patrono dos tradutores segundo Valery Larbaud, dá aos seus modestos companheiros de tarimba.

Mas traduzir não se limita a saber compulsar calepinos, farejar singularidades semânticas e dissipar erudições fragmentárias; é preciso também dispor de amigos para as confidências e as consultas, os conselhos e os debates. No caso das traduções aqui reunidas, mais de uma vez o aprendiz de tradutor bateu às melhores das portas: aquelas em que habitam Manuel Bandeira e Murilo Mendes.

No seu admirável Sous l'Invocation de Saint Jérôme, breviário leigo dos tradutores, Valery Larbaud, o moderno patrono da Ordem que ele colocou sob a proteção de São Jerônimo, tradutor da Bíblia para o latim, faz o elogio, postula os deveres e expõe as técnicas dos figurantes de sua corporação. E salienta que, muitas vezes colocado em último plano e injustiçado, vivendo de esmolas, o tradutor não tem apenas cuidados e aflições, mas também alegrias e prazeres. “Em même temps qu'il accroît sa richesse intellectuelle, il enrichit sa litérature nationale et honore son propre nom. Ce n'est pas une entreprise obscure et sans 
grandeur que celle de faire passer dans une langue et dans une littérature une oeuvre importante d'une autre littérature”.

O trecho acima não deve ser interpretado unicamente pelo seu lado ambicioso, na área dos proveitos públicos. O antigo frequentador da biblioteca provinciana deseja recriar sua emoção, na pessoa de um leitor imaginário e contudo próximo; deseja abrir a porta de um dos reinos poéticos do mundo; e deseja finalmente que alguém, percorrendo o labirinto de visões, o ninho de maravilhas de um contexto que se renova a cada leitura, eternamente jovem, seja depois seguido, nutrido e fecundado por qualquer dos versos destes dois livros consulares da poesia moderna”. (pág. 39-40)

Quarta capa (texto do tradutor): “Nesta tradução de Uma Temporada no Inferno e Iluminações, procurei transplantar para a língua portuguesa uma leitura que me era familiar (e eu diria mesmo extremamente familiar), em sua dimensão poética, mas ainda em sua dimensão crítica e biográfica. Como era um ato de amor e fervor, eu poderia vangloriar-me de conhecer profundamente não apenas toda a obra poética de Rimbaud, verso por verso, mas também toda a parafernália crítica e biográfica que se expandiu em torno de sua figura genial - esse passante que Victor Hugo chamou de "Shakespeare menino" e que silenciou logo após a sua aparição, dando adeus aos parapeitos antigos da Europa e indo buscar, sob o sol africano, a inencontrável vida verdadeira”.

Referência ao tradutor no prefácio de Manuel Bandeira: "Lêdo Ivo é um poeta de coragem: teve a audácia de traduzir Rimbaud. E o Rimbaud mais difícil: o da Saison en Enfer e das Illuminations. Esse Rimbaud, como tantos outros poetas Racine de Phèdre, o Mallarmé arrevesado, o Valéry da Jeune Parque e do Cimetière Marin - são intraduzíveis. Quando algum grande poeta se sai bem da tarefa é porque fez um pouco outra coisa: as belezas formais da tradução não são as do original, são outras. É o caso do Rilke traduzindo Valéry.

Não terei tempo agora de cotejar com o original de Rimbaud a tradução de Lêdo Ivo. Mas imagino que o seu principal trabalho terá consistido em achar em português os sucedâneos dos sortilégios verbais do Vidente. Comparem-se estas três linhas de "Ornières”: même des cercueils sous leurs dais de nuit dressant les panaches d'èbene, filant trot des grandes juments bleues et noires” com a tradução de Ivo: “Até esquifes sob seus dosséis de noite, erguendo os penachos de ébano, 
correndo ao trote de grandes éguas azuis e negras". "Grandes juments bleues et noires" difere muito, do ponto de vista da alquimia verbal, de "grandes éguas azuis e negras”.

A tradução literal deu certo, no entanto: “égua” é mais belo que “juments”, “azuis e negras” é tão belo quanto “Bleues et noires”. Mas se não fosse assim, Ivo teria que dar um jeito fora da letra para não trair a forma - esta forma que é essencial em Rimbaud (Claudel comparou-lhe a sonoridade à do "bois moelleux et sec d'un Stradivarius”).

Que dizer de certos poemas da Saison en Enfer? Eu duvidei e fiz pouco quando Ivo me falou de sua tradução. Devo, porém, reconhecer que ele lavrou um tento, aproximando-se bastante do original sem mentir à poesia do original. Seria muito difícil, senão impossível fazer melhor”.

Posição do nome do tradutor na edição: capa.

Tipo de tradutor: escritor.

O renomado escritor e tradutor Lêdo Ivo, cujo nome ficou, no Brasil, indelevelmente ligado ao de Rimbaud por essas traduções, apresenta um conceito de tradução como crítica e de tradução como mudança de casa, carregando os mesmos móveis (“a de sua temporada no coração de um determinado sistema de criação poética, e de sua mudança para outra língua, como um conjunto de móveis levados para outra casa”), e de tradução como leitura ("no ato de serem traduzidos eles exibem sete faces diferentes, como se as leituras anteriores fossem apenas divertimentos ociosos ou estágios”). Ele não apresenta a sua tradução como fiel ao original, mas como fiel ao menino que ele foi e descobriu um mundo novo ao tomar contato com o universo poético rimbaudiano ("na raiz das traduções a que nos aventuramos, se consubstancie um ato de fidelidade a um colegial que, certa noite, na cidade do Recife, entrou na Biblioteca Pública para ler, pela primeira vez, as poesias de Jean Arthur Rimbaud”). Percebe-se, por essas observações, que seu conceito de tradução se afasta bastante daquele de Ivo Barroso (ver item acima) e pende mais para o conceito de recriação, crítica e leitura, do que para uma concepção estrita de fidelidade ao sentido literal do original. Sua fama e capacidade reconhecidas na tradução poética lhe garantiram o espaço de um prefácio longo e seu nome na capa, além de menções muito elogiosas de ninguém menos do que Manuel Bandeira. 
35. RIMBAUD, Arthur. Rimbaud: em metro e rima. Trad. Milton Lins. Recife: UPE, 1998.

Trechos destacados no prefácio do tradutor: "No início de 1997, numa reunião da Academia de Letras e Artes do Nordeste, Lucilo Varejão Neto apresentou uma versão em prosa do soneto Le Dormeur du Val, que me deixou fascinado. Distribuiu cópias a todos e, dias depois, gentilmente, me presenteou com um pequeno caderno, contendo mais cinco sonetos e outros poemas. Traduzi inicialmente, com metrificação e rima, $O$ que dorme no vale; e comecei o trabalho de transposição dos sonetos recebidos: O Armário, Minha Boêmia, Oração do Entardecer, as Vogais e Os Aduaneiros. O gosto que senti ao vê-los metrificados e rimados em vernáculo me fez continuar a verter os outros poemas, mais longos, dos originais de Lucilo. Assim aconteceu com o Navio Embriagado e com as demais poesias.

(...) O meu roteiro é simples. Como o Bateau Ivre espero navegar "mais que uma rolha indo ao sabor das vagas”. Não há critério cronológico nem de escolha das rotas nem dos portos, isto é, vou traduzindo à proporção que “descubro” os títulos e decido: agora é este. Não há estudo crítico nem biográfico nem tentativa de análise da personalidade incomum de Rimbaud. Os estudiosos valorizam muito algumas palavras que decidem capitais para interpretar o que quis dizer. Considero que ninguém sabe o queria dizer em seus versos aquele jovem de dotes excepcionais, nem porque empregou esta ou aquela palavra forte ou significativa. O que disse ficou dito para que nós outros leiamos e nos enleemos, sem vãs tentativas de interpretação genérica.

De minha parte eu me sentirei muito gratificado se ocasionais leitores das minhas traduções vierem a aceitá-las como as verti, confiando no que realizei com dificuldade, mas com prazer e fascínio, buscando, a cada passo, transmitir a emoção que sentia como a sentia, no afã de conseguir converter o metro e a rima franceses em sílabas contadas e sons idênticos finais em português, da melhor maneira que as minhas limitações me permitiram em curto espaço de tempo. Quando mergulhei na obra de Rimbaud já sabia que iria conviver com um gênio. Por isso me dispus a enfrentar e mesmo aceitar tudo que surgisse de imprevisto. Encontrei termos chulos e versos obscenos e até chocantes para a minha estruturação ética. 
(...) Prefiro ficar com a música, o ritmo e o encanto das imagens esquisitas dos seus versos metrificados e rimados”. (pág. 13-15)

Referência à tradução no Prefácio de Mario Marcio da Almeida Santos: “(...) Traduzir poesia é um trabalho de criação, de criação paralela. É tentar recapturar um estado de alma diferente e vivido numa circunstância temporal e cultural diversa. É empatia. Implica, logo de início, encontrar equivalentes sonoros e conceituais para os textos submetidos ao processo de transladação para outro sistema de criação poético; enfim, é ter um perfeito domínio da estrutura semântica dos dois idiomas. Resumindo: erudição. Muita.

(...) Milton Lins, com a eficácia de sua diç̧ão lírica, conseguiu o milagre de abrir as portas de um dos reinos poéticos mais fechados e seletos do mundo ocidental o de Rimbaud - dando-nos um contexto que se renova a cada leitura e nos faz amar a sonoridade pura do francês literário, mesmo quando visto por outra perspectiva linguística.

(...) Milton Lins é uma dessas raras pessoas com capacidade de traduzir Rimbaud. Homem sensível, há nele os condicionamentos básicos para enfrentar o desafio: equilíbrio, cultura, erudição e... por que não dizer? Leves toques de genialidade. O resultado é Rimbaud em Metro e Rima.

Algumas traduções do livro são antológicas.” (pág. 9-10).

Quarta capa: Dados biográficos e foto do tradutor: "Milton Lins nasceu no Cabo, Pernambuco, e viveu a maior parte de sua vida no Recife. Também esteve radicado em Gravatá, no Rio de Janeiro, Carpina, São Paulo, Paris, Houston, voltando sempre ao seu Recife, que tanto ama.

Publicou seu primeiro livro, "Prestações de Contos”, em 1993. Em 1995, outro conjunto de histórias curtas, "Recontando Histórias”. Em 1996, fez imprimir “O Sino Escarlate”, com o qual ganhou o prêmio de ficção do ano na Academia Pernambucana de Letras. Em 1997, dois livros: “Livro Preto”, anotações de viagem, e “ABC”, contos. A partir de janeiro do mesmo ano, começou as traduções de toda a Poesia rimada de Arthur Rimbaud, ora em publicação.

Tem inéditos um livro de contos e um acervo de traduções isoladas de numerosos poetas de línguas estrangeiras, a partir do século XV. Trabalha, atualmente, na obra de André Chénier”.

$\underline{\text { Referência à tradução na orelha (texto do Prof. Emanuel Dias, Vice-Reitor da }}$ 
UPE):_"O renomado Professor e Médico Milton Lins contribui com mais uma obra expressiva e marcante, trazendo desta feita uma literatura rica e belíssima da comunidade francesa para o povo pernambucano, nordestino e brasileiro.

Mais uma vez a Universidade de Pernambuco se sente honrada em poder contribuir com obras de valor produzidas por prata da casa”.

Referência à tradução em texto de Edson Bery da Fonseca: "Li as traduções de Rimbaud, comparei-as com as outras anteriores e, sem favor, achei as suas soluções bem melhores. Fiquei particularmente encantado com as 12 versões em metros decrescentes do belíssimo soneto "Le Dormeur du Val". Com seu magistral virtuosismo, você como que purificou o soneto de Rimbaud como Liszt purificou a $5^{\text {a }}$ Sinfonia de Beethoven ao transcrevê-la para piano e Bussoni a Tocata de Fuga em Ré Menor de Bach”.

Posição do nome do tradutor na edição: capa.

Tipo de tradutor: escritor.

Com base nos dados biográficos de Milton Lins, contido na própria edição, classificou-se o tradutor como escritor, por ter vários títulos publicados (principalmente contos). No verbete da Wikipedia, ficamos sabendo também que Milton Lins seguiu uma carreira paralela como médico e cirurgião cardíaco. A concepção de tradução que o tradutor apresenta no prefácio também, como no item anterior, está identificada com o conceito de leitura (“O que disse ficou dito para que nós outros leiamos e nos enleemos, sem vãs tentativas de interpretação genérica”), de interpretação subjetiva mais do que calcada em sinais e marcas textuais, de uma tradução que é própria e poderia ser outra. Não há, portanto, como no prefácio do item anterior, a pretensão de dar a palavra final na tradução desses poemas, mas de apresentar uma tradução possível e, mais importante, uma tradução sentida e prazerosa. O tradutor também demonstra humildade diante de sua tarefa e de seu resultado ("De minha parte eu me sentirei muito gratificado se ocasionais leitores das minhas traduções vierem a aceitá-las como as verti”). Todo o aparato paratextual louva e elogia a empreitada do tradutor, o que, associado ao seu nome na capa, mostra o status elevado que o tradutor tem na comunidade leitora em que a edição foi realizada. 
36. RIMBAUD, Arthur. Uma temporada no inferno. Trad. Paulo Hecker Filho. Col. L\&PM Pocket, 1997.

Trechos destacados no prefácio do tradutor: "Fosse o que fosse, como traduzir? Poesia se faz, além do sentido, com palavras, a rigor é intraduzível. Nem por isso se vai dispensar a de outros idiomas, já que é sempre possível um reflexo. Como num espelho, eu diria, assim deve ser. Nada de recriar o texto, o que pode dar, ainda que raramente, outro poema, mas outro. E sim sendo fiel ao original, transpondo-lhe o sentido com a consciência dos efeitos estéticos que apresenta. Foi a tentativa que fizemos. Sempre uma tentativa”. (pág. 8)

Posição do nome do tradutor na edição: capa.

Tipo de tradutor: escritor.

Ficamos sabendo pelo verbete "Paulo Hecker" no DITRA, que o tradutor foi jornalista e escritor, além de tradutor. O conceito de tradução que o tradutor apresenta no prefácio se afasta do conceito de recriação e se aproxima do conceito de fidelidade estrita ao original, de reflexo como no espelho, de transposição de sentido e efeitos estéticos. Identifica-se, portanto, com o conceito de traductio (ver Capítulo 2), a face mais criativa da conservadora translatio, mas ainda assim amarrada a um essencialismo característico de um conceito de tradução como transposição de sentido. Não acredita em uma tradução poética tão estrita, como Ivo Barroso, por exemplo, mas acredita em fidelidade ao original e na possibilidade de refletir algo que é a rigor intraduzível. Seu nome figura na capa, o que além do espaço concedido no prefácio, dá testemunho do status elevado que os tradutores de poesia gozam, a exemplo dos itens anteriores.

37. RIMBAUD, Arthur. Prosa poética. Trad. Ivo Barroso. Rio de Janeiro: Topbooks, 1998.

Trechos destacados no prefácio do tradutor: os mesmos do item 32.

Referência à tradução na Nota do editor: "Relativamente à obra magna de Rimbaud - UMA ESTAÇÃO NO INFERNO - antes da tradução de Ivo Barroso já circulavam em português a versão de Xavier Placer (UMA ESTAÇÃO NO INFERNO), de 1952; a de Lêdo Ivo (UMA TEMPORADA NO INFERNO), de 1957, reeditada em 1982; e, em Portugal, a de Mário Cesariny de Vasconcelos (UMA ÉPOCA NO INFERNO), de 1960, reeditada sob o título de UMA 
ESTAÇÃO NO INFERNO em 1989. A tradução de Ivo Barroso teve sua primeira edição em 1977 e a segunda em 1983. A da presente edição foi inteiramente revista para atender a novas interpretações e estudos da crítica moderna. Mas conservou-se o luminoso prefácio com que Alceu Amoroso Lima (Tristão de Athayde) a consagrou de início. Quanto aos demais textos, inclusive as ILUMINAÇÕES, são todos de tradução recente, aqui publicados pela primeira vez”. (pág. 09-10)

Posição do nome do tradutor na edição: capa.

Tipo de tradutor: escritor.

O prefácio é o mesmo já comentado anteriormente. Esta edição se distingue da anterior pela referência contida na Nota do editor às traduções que a precederam, fazendo uma fortuna crítica das traduções de Rimbaud no Brasil. Isso só faz aumentar o prestígio do tradutor conforme refletido nesta edição, consubstanciado pelo nome do tradutor, mais uma vez, na capa.

38. SAINT-EXUPÉRY, Antoine. Cartas da juventude. Trad. Carmen Lúcia Cruz Lima Gerlach e Juliane Bürger. Santa Catarina: Editora da UFSC, 2000.

Trechos destacados no prefácio do tradutor: “O pensamento que norteou nossa tradução está expresso na citação de Walter Benjamin, em A tarefa do tradutor: 'Como os cacos de um vaso, para que, nos mínimos detalhes, se possam recompor, ao invés de se assemelhar, logo, também a tradução, ao invés de se fazer semelhante ao sentido original, deve, muito mais e cuidadosamente, chegar até o detalhe, trazendo para a forma de sua própria língua o modo-de-significar do original'. Buscamos a palavra brasileira que mais se aproximasse da expressividade de Saint-Exupéry”. (pág. 9)

Referência à tradução e às tradutoras das orelhas: "Carmen Lúcia Cruz Lima Gerlach é professora de Universidade Federal de Santa Catarina. Traduziu com Terezinha O. Michels o livro Maupassant, a semiótica do texto, de Algirdas Greimas, e, com Maria José Werner Salles, Madame Hermet e outros contos fantásticos, de Guy de Maupassant (prêmio de tradução Boi de Mamão, da Câmara Catarinense do Livro), ambos publicados pela Editora da UFSC. Atuou ainda na obra Ilha de Santa Catarina: relato de viajantes estrangeiros nos séculos XVII e XIX (Lunardelli/Ed. da UFSC). 
Juliane Bürger é professora de língua francesa e mestranda do Curso de PósGraduação em Literatura pela UFSC e realiza trabalhos como intérprete e tradutora."

Posição do nome do tradutor na edição: folha de rosto e ficha catalográfica. Tipo de tradutor: acadêmicas e profissionais.

As tradutoras são as mesmas do prefácio do item 1, de Balzac. Naquele prefácio, não havia uma referência clara a um teórico da tradução, mas neste as tradutoras se referem a Benjamin e a seu texto clássico para a teoria da tradução. Apesar de esse texto de Benjamin ser um tanto hermético e se abrir à possibilidade de interpretações diversas, este trecho que as tradutoras escolheram para citar aponta para um conceito de tradução não literal, não afeito à forma, nem tampouco ao significado do original, mas ao “modo-de-significar” do original. O que quer que isso queira dizer, parece que aí a tradução é vista como algo que recompõe cacos de um todo e não o sentido das palavras em outra língua, mas algo que vai além disso, buscando recriar uma metafísica da língua original. É uma concepção filosófica benjaminiana muito particular que não se pode classificar dentre os conceitos de tradução rescenseados no Capítulo 2. Ele não é um conceito desconstrutivista da linguagem e da tradução, mas também não é um conceito essencialista que faz da busca da fidelidade o objetivo e a própria razão de ser da tradução, ficando sob uma terceira perspectiva.

É interessante notar que a outra edição (item 1), de 2006, pela mesma editora universitária, traz o nome das tradutoras na capa. Nesta, o nome delas só consta na folha de rosto e na ficha catalográfica. Podemos levantar pelo menos duas hipóteses para o acontecido: 1. a editora não possui uma regra clara a respeito da posição do nome do tradutor nas edições; 2. nos seis anos que se passaram entre uma edição e outra, as tradutoras se tornaram mais conhecidas e tiveram seu status elevado na comunidade acadêmica, fazendo com que seu nome fosse alçando a um espaço de maior visibilidade paratextual. Seria preciso fazer uma pesquisa junto à editora para confirmar uma dessas duas hipóteses ou elaborar novas hipóteses a ser confirmadas. De qualquer forma, esse caso mostra como a posição do nome do tradutor nas edições brasileiras ainda é mutável e mutante, mesmo dentro da mesma casa editora e em se tratando dos mesmos tradutores. 
39. SAINT-EXUPÉRY, Antoine. Terra dos homens. Trad. Rubem Braga. Col. Sagarana. Rio de Janeiro: José Olympio, 1968.

Trechos destacados no prefácio do tradutor: "Revendo meu trabalho para a segunda edição brasileira deste livro, devo apresentar agradecimentos a um leitor que fez, em carta, a crítica de minha tradução. Trata-se do Sr. Charles Astor, aviador francês, que vive em nosso país. Acolhi quase todos os reparos de sua crítica autorizada, e muito lhe agradeço as lições que me deu”.

Posição do nome do tradutor na edição: capa.

Tipo de tradutor: escritor.

No trecho extraído do tradutor e escritor Rubem Braga, nada deixa a entrever sobre seu conceito de tradução e seu projeto tradutório, a não ser que essa tradução sofreu emendas devido ao comentário de um leitor especialista.

40. STENDHAL. Do amor. Trad. Wilson Louzada. Col. Rubáiyát. Rio de Janeiro: José Olympio, 1958.

Trechos destacados no prefácio do tradutor: "Esta edição do De l'Amour, de Stendhal, não é uma tradução integral da referida obra. O tradutor escolheu de preferência trechos de sua primeira parte - na opinião do crítico Maurice Bardèche, citado no prefácio, a mais íntima e pessoal do livro, a mais stendhaliana, digamos assim - obedecendo porém, no todo, certa ou erradamente, antes de tudo ao seu gôsto pessoal na seleção adotada, o que deu à obra, um nítido caráter de antologia.” (pág. 25)

Posição do nome do tradutor na edição: folha de rosto e ficha catalográfica.

Tipo de tradutor: profissional.

O tradutor foi classificado como tradutor profissional por falta de informações sobre ele. Ele não consta como verbete no DITRA e não foram encontradas referências ao seu nome na Internet, afora sua atuação como tradutor. Não se pode depreender sua concepção de tradução, a não ser pelo fato de que, para ele, não é preciso se traduzir a integralidade de uma obra, mas somente as partes que mais lhe agradam. Percebe-se que o compromisso em traduzir a integralidade das obras literárias é uma preocupação mais contemporânea. As edições que estampam “edição integral” passaram a ser utilizadas na segunda metade do século XX. Antes disso, a tradução de partes escolhidas em jornais e folhetins era uma prática 
corrente e bem aceita. Esta tradução, publicada em 1958, se utiliza desse artifício e parece ter tido recepção favorável, já que continuou a ser publicada mesmo muito tempo depois, como se vê no item seguinte.

41. STENDHAL. Do amor. Trad. Wilson Louzada. Col. Clássicos de Bolso. Rio de Janeiro: Technoprint, 1994.

Trechos destacados no prefácio do tradutor: os mesmos do item precedente.

Posição do nome do tradutor na edição: capa.

Tipo de tradutor: profissional.

Ver comentário do item anterior.

42. STENDHAL. Lucien Lewen. Trad. Marcos Santarrita. Col. Clássicos Francisco Alves. Rio de Janeiro: Francisco Alves, 1983.

Trechos destacados no prefácio do tradutor: “O texto, na edição francesa do Livre de Poche, está cheio de parênteses, chaves e outros sinais gráficos indicando acréscimos, enxertos, etc., feitos à redação original, às margens das páginas manuscritas, nas costas, por toda parte, o que deve ter transformado seu estabelecimento num trabalho de quebra-cabeça. (...)

O tradutor omitiu os sinais gráficos, dificilmente aceitáveis numa edição não crítica, e recusou-se na maioria das vezes, e em umas poucas não conseguiu, dar sua própria interpretação do sentido ou da forma exata de algumas frases inacabadas. Nos casos de recusa, assim agiu por não se achar à altura de uma parceria com Stendhal, uma co-autoria, e por entender que, mesmo para um leitor francês, elas parecerão toscas e de sentido no mínimo dúbio.” (pág. 694) Posição do nome do tradutor na edição: capa.

Tipo de tradutor: escritor.

O escritor, jornalista e tradutor Marcos Santarrita, neste trecho destacado do prefácio, a propósito de falar sobre uma decisão editorial de omissão de sinais gráficos contidos no original, apresenta, de forma enviesada, uma concepção de tradução que não aceita a ideia de coautoria entre tradutor e autor, que posiciona o autor do original acima a além do tradutor. Percebe-se uma diferença nítida de hierarquia entre os dois ("assim agiu por não se achar à altura de uma parceria com Stendhal, uma co-autoria”). Também se refere a si mesmo na terceira pessoa 
do singular, o que pode ser considerado um sinal de modéstia. De qualquer forma, o tradutor mostra uma postura submissa diante do original, como se a única "liberdade" que tivesse tomado em relação a ele tivesse sido uma liberdade menor, em relação a frases inacabadas, que também teriam parecido toscas ao leitor francês. O elevado status do tradutor nos meios literários se faz sentir na presença de um prefácio de tradutor, bem como do nome na capa.

43. VERLAINE, Paul. Festas galantes. Trad. Onestaldo de Pennafort. Rio de Janeiro: Civilização Brasileira, 1983.

Trechos destacados no prefácio do tradutor: “(...) Depois do que fica dito acima, não é preciso acentuar as inúmeras dificuldades que oferece a tradução, - tal como a quisemos fazer, integral e tanto quanto possível fiel — poesia a poesia, estrofe a estrofe, verso a verso, rima a rima, com as mesmas sílabas métricas e o mesmo número de versos - de uma tal obra e de um tal poeta, e de um poeta cuja arte se singulariza especialmente pela mais alinhada, pela mais requintada musicalidade.

De la musique avant toute chose é um dos postulados estéticos formulados por Verlaine, em sua famosa Art Poétique.

Tais dificuldades crescem ainda de vulto face a esta circunstância: as diferenças de fundo, que contrabalançam se não sobrepujam às semelhanças aparentes entre os dois idiomas, o francês e o português.

(...) Antes de terminar, será oportuno fazermos alguns reparos acerca das liberdades que nos permitimos tomar na nossa tradução, feita há cinquenta anos e desde então retocada em cada edição (...)”. (pág. 13-14)

Quarta capa: texto de Paulo Rónai, louvando o tradutor.

Orelhas: texto de Manuel Bandeira, louvando o tradutor.

Posição do nome do tradutor na edição: capa.

Tipo de tradutor: escritor.

O premiado poeta e tradutor apresenta neste prefácio uma concepção de tradução que se assemelha ao conceito de traductio (ver Capítulo 2), o de uma fidelidade não literal, criativa (“tanto quanto possível fiel”), mas ainda assim de uma tradução bem apegada ao original ("poesia a poesia, estrofe a estrofe, verso a verso, rima a rima, com as mesmas sílabas métricas e o mesmo número de 
versos”). Certamente, não se trata de um conceito de tradução como recriação com muitas liberdades, mas somente no que as línguas apresentam como recursos e restrições diferentes. E nisso se contrapõe à postura de Guilherme de Almeida, por exemplo. Apresenta uma concepção de tradução como de work in progress já que afirma que, a cada edição, a tradução sofreu retoques. O material paratextual assinado por escritores e tradutores afamados e o nome do tradutor na capa reafirmam o elevado status que o tradutor possui nos meios literários brasileiros.

44. VERNE, Julio. Um padre em 1839. Trad. Estela dos Santos Abreu. São Paulo: Scipione, 1996.

Trechos destacados no prefácio do tradutor: Nota da Tradutora: “Graças à cidade de Nantes (França), proprietária dos manuscritos de Júlio Verne, publica-se hoje a tradução deste romance inédito do mais célebre e mundialmente traduzido autor francês. Trata-se do primeiro romance, que Verne redigiu aos dezenove anos.

Como sempre, o texto publicado na França foi estabelecido por Christian Robin, que fornece várias chaves explicativas em seu Posfácio, à página 201.

Não são estranháveis pequenas incongruências do original - respeitadas nesta tradução - pois é muito provável que Verne nunca tenha relido seu manuscrito inacabado”. (pág. 8)

Posição do nome do tradutor na edição: folha de rosto e ficha catalográfica.

Tipo de tradutor: acadêmica.

No verbete do DITRA, Estela dos Santos Abreu assume um perfil acadêmico devido às referências à sua carreira de professora universitária (FGV e UFF) e por seu doutorado em Ciências da Educação na Universidade de Paris V. Estela é uma tradutora muito reverenciada por suas inúmeras traduções, tendo o seu trabalho como agente literária igualmente muito respeitado nos meios editoriais. Neste prefácio, Estela dá poucas pistas quanto à sua concepção de tradução, afora o fato de apontar para a manutenção de incongruências do original, o que atesta a sua valorização da integralidade do texto. Sem fazer referências explícitas a teorias sistematizadas de tradução, Estela demonstra ser uma tradutora absolutamente conscienciosa, formada na prática e com uma produção muito copiosa. Nesta edição, seu nome não aparece na capa, talvez por não ser uma escritora ou acadêmica conhecida nos meios da produção literária/acadêmica. Contudo, nos 
meios editoriais, sua atuação não fica circunscrita à tradução, assumindo, talvez como ninguém, uma agentividade que lhe faz assumir inúmeros e diferentes papéis na elaboração de livros traduzidos.

45. ZOLA, Émile. Eu acuso! Org. e trad. Ricardo Lísias. São Paulo: Hedra, 2007. Trechos destacados no prefácio do tradutor: "Entre tantas particularidades, a tradução de Eu acuso! procurou manter em língua portuguesa a veemência do texto de Émile Zola. As diversas frases exclamativas foram vertidas para o português, o tom indignado foi mantido, e a sintaxe direta, conservada. Fizemos pequenas alterações de pontuação apenas onde o sentido exigia.

Apenas um termo merece destaque, justamente o mais importante de todo o texto: o tal bordereau, que seria a origem de todo o caso Dreyfus. O suposto documento que continha informações confidenciais sobre a segurança francesa, encontrado com os alemães e atribuída a Dreyfus, é apresentado por Zola como bordereau. Como sublinhamos, nem a defesa do acusado pôde ter acesso a esse "documento". Enquanto o texto se desenvolve, bordereau acaba significando as provas que a justiça oculta e, ao mesmo tempo, usa para condenar os acusados de traição. Dessa forma, optamos por utilizar o cartorial “documento”, para traduzir bordereau, mantendo assim o caráter de papel desconhecido que Zola tentou imprimir ao termo, ao mesmo tempo que dava certo ar de patético a solene ilegalidade do processo.

A presente tradução foi baseada na edição da Librio, publicada em francês com apresentação de Philippe Oriol em 1998. Aqui e ali observamos as soluções encontradas pela tradutora da edição inglesa, Eleanor Levieux, publicada pela editora da Universidade de Yale, em 1996. Por fim, consultamos também a tradução brasileira, publicada pela extinta Edições Atlanta, no Rio de Janeiro.” (pág. 30-31)

Posição do nome do tradutor na edição: capa (o tradutor também é organizador da edição).

Tipo de tradutor: escritor.

Ricardo Lísias, além de jovem e controvertido (dois de seus romances de grande sucesso O céu dos suicidas e Divórcio trazem inúmeras coincidências biográficas, o que gerou muita polêmica, principalmente envolvendo o nome de sua ex- 
mulher) escritor de sucesso, tem graduação e mestrado em Letras e atua como professor de língua portuguesa, ministra alguns cursos de literatura e é colaborador eventual de alguns veículos da imprensa. Sua produção como tradutor é menor do que a como escritor e seu renome se deve, sem dúvida, muito mais à sua atividade autoral. Nesta edição, o tradutor atuou também como organizador, o que, aliado ao fato de ser um escritor contemporâneo de sucesso, deve ter reforçado a decisão editorial de colocar seu nome na capa. Neste prefácio, o tradutor não dá indicações da concepção de tradução que pautou seu projeto tradutório, do qual ficamos sabendo apenas que se baseou em determinada edição francesa e que traduções para o inglês e português foram consultadas.

46. DUMAS, Alexandre. O Conde de Monte Cristo. Trad. André Telles e Rodrigo Lacerda. Rio de Janeiro: Zahar, 2012.

Trechos destacados no prefácio do tradutor: “A presente tradução baseou-se nas melhores edições existentes: a da Pléiade, a da Calman-Lévy (em seis volumes, reprodução da edição standard de 1895), a da Bouquins e a da Folio. Sem mudanças substantivas no original, adaptamos a pontuação para as normas vigentes, modernizamos com moderação as formas de tratamento e privilegiamos, sempre a fluência da leitura. As ilustrações aqui incluídas, de autoria de Gustave Staal, entre outros, integraram a $3^{\mathrm{a}}$ edição francesa de $O$ conde de Monte Cristo.” Posição do nome do tradutor na edição: quarta capa.

Tipo de tradutor: André Telles (tradutor profissional) e Rodrigo Lacerda (escritor).

Este prefácio já foi comentado no Capítulo 4.

47. FLAUBERT, Gustave. Madame Bovary. Trad. Fúlvia M. L. Moretto. São Paulo: Nova Alexandria, 2009.

Trechos destacados no prefácio do tradutor: (...) Aliás, Flaubert dá uma extrema importância ao estilo indireto livre, já que o diálogo lhe traz problemas no que diz respeito às orações intercaladas. Em carta de 13-14 de abril de 1853 escreve, enquanto trabalha no diálogo entre a Sra. Bovary e o pároco: "Isto deve ter seis ou sete páginas no máximo e sem nem uma reflexão, nem uma análise (tudo em diálogo direto). Além disso, como acho muito canalha fazer diálogos substituindo 
'ele disse, ele respondeu’ por travessão, podes imaginar que a repetição das mesmas estruturas da frase não é fácil de evitar”. É por esta razão que eliminamos os travessões em nossa tradução. Com essa eliminação Flaubert consegue maior rapidez e sobretudo uma certa ambiguidade, fundamental na evocação do baço e melancólico mundo provinciano do romance”. (pág. 12)

Referência à tradução na quarta capa: O "romance dos romances", Madame Bovary apresenta-se aqui naquela que é considerada a melhor tradução em língua portuguesa, no brilhante trabalho de Fúlvia Moretto, que também assina a introdução e as notas.

Posição do nome do tradutor na edição: quarta capa.

Tipo de tradutor: acadêmico.

Fúlvia Moretto é professora titular aposentada de Língua e Literatura Francesa da Faculdade de Ciências e Letras do Campus Araraquara (UNESP). Ganhou o Prêmio Nacional de Tradução do Instituto Nacional do Livro em 1987 pela tradução de Devaneios de um caminhante solitário, de Rousseau. É poeta, tradutora e ensaísta. Apesar de ser autora de livros de ensaio e de ter uma produção como tradutora significativa, é como professora universitária que é mais conhecida e reconhecida, daí ter sido classificada como acadêmica. Neste prefácio, a tradutora revela seu passado de professora de literatura, ressaltando a maior característica da narrativa flaubertiana, o discurso indireto livre, que resultou na decisão da eliminação dos travessões pela tradutora. Não se pode entrever pelo curto trecho qual seja a concepção de tradução que pautou seu projeto tradutório. O seu nome aparece na quarta capa, que é uma posição de destaque, ela teve a concessão de um espaço para escrever um prefácio de sua autoria e foi referida na quarta capa como responsável pela melhor tradução do romance em língua portuguesa, revelando seu elevado status de tradutora com sólido passado acadêmico. O fato de ter sido professora - e ser especialista em - língua e literatura francesa, e não professora ou especialista da área de estudos da tradução, pode explicar a falta de explicitação de seu conceito de tradução e do seu projeto no prefácio.

48. HUGO, Victor. O corcunda de Notre Dame. Trad. Jorge Bastos. Rio de Janeiro: Zahar, 2013. 
Trechos destacados no prefácio do tradutor: “A tradução propriamente do romance não apresenta maiores problemas além do esforço que mesmo o leitor francês médio é obrigado a fazer lendo o original, se quiser seguir de perto os caprichos estilísticos e eruditos, mas pincipalmente os enxertos “de época” que Victor Hugo faz no romance, sem se preocupar muito em especificar a citação. Ou ainda nas frases longuíssimas em que vão se acrescentando, entre vírgulas, novas ideias, para somente vinte linhas depois voltar à proposição inicial (o que a tradução moderna às vezes pode vantajosamente remediar, preocupando-se com a respiração do leitor atual)”.

Referência à tradução na “Apresentação": "Jorge Bastos é tradutor, responsável por quase cinquenta traduções, dentre elas a biografia Victor Hugo (2 vols.), de Max Gallo, o ensaio Victor Hugo na arena política, de Michel Winock, e obras de autores como Voltaire, Raymond Aron, Michel Serres, Elie Wiesel e Amin Maalouf. Foi livreiro e editor, e é autor de Atrás dos cantos e $O$ deserto e As tentações de santo Antão.”

Posição do nome do tradutor na edição: quarta capa.

Tipo de tradutor: profissional.

Em verbete no DITRA, ficamos sabendo que Jorge Bastos é um autodidata, sem formação acadêmica, tendo sido livreiro e se dedicado à tradução a maior parte da vida. No verbete, há ainda a seguinte observação: "Não costuma escrever sobre tradução, nem mesmo sobre sua própria prática. Escreve frequentemente, porém, a pedido dos editores, textos de apresentação ou orelhas para os livros que traduz. (...) Não se apoia em nenhuma teoria da tradução, 'apenas no bom senso’.

Do conceito de tradução que perpassa seu trabalho e do projeto tradutório dessa obra pouco se sabe, a não ser que tem uma tendência modernizante (“o que a tradução moderna às vezes pode vantajosamente remediar, preocupando-se com a respiração do leitor atual”). A posição de destaque de seu nome na quarta capa mas não na capa - corrobora a minha percepção de que tradutores profissionais, que não tenham perfil acadêmico destacado nem sejam escritores conhecidos, normalmente não têm seus nomes alçados à capa. 
49. LARANJEIRA, Mário. Poetas franceses da Renascença. Col. Biblioteca Martins Fontes. São Paulo: Martins Fontes, 2004.

Trechos destacados no prefácio do tradutor: este prefácio foi comentado no Capítulo 4.

Posição do nome do tradutor na edição: capa

Tipo de tradutor: acadêmico.

50. MALLARMÉ, Stéphane. Brinde fúnebre e prosa. Trad. Julio Castañon Guimarães.Rio de Janeiro: Sette Letras, 1995.

Trechos destacados no prefácio do tradutor: o mesmo do item 19.

Posição do nome do tradutor na edição: capa.

Tipo de tradutor: escritor.

Ver comentário do item 19.

51. MONTAIGNE, Michel de. Os ensaios. Trad. Rosa Freire d'Aguiar. São Paulo: Companhia das Letras/Penguin, 2010.

Trechos destacados no prefácio do tradutor: “(...) A numeração seguida no sumário corresponde aos números de cada ensaio dos três livros que formam o conjunto da obra. Quando não comprometido o entendimento do texto, mantevese a pontuação adotada por Montaigne, que se reconhecia 'pouco especialista' na matéria e recorria abundantemente aos dois-pontos e pontos e vírgulas como forma de cadenciar o texto. Também foi respeitada a disposição original do texto, sem parágrafos, ou melhor, com um só parágrafo por ensaio.

(...) Esta tradução procura conciliar o respeito ao original com a legibilidade para um leitor de hoje, apresentando-lhe uma versão cuja fluência, longe de banalizar a obra, o leve ao prazer da leitura de Os ensaios.” (pág. 31-33) (CV da tradutora, junto como do organizador e prefaciador).

Posição do nome do tradutor na edição: quarta capa.

Tipo de tradutor: profissional.

Ver comentários sobre a tradutora no Capítulo 4. A postura da tradutora neste prefácio é equilibrada em termos de nem promover um estranhamento nem buscar uma facilitação. Percebe-se uma preocupação com o leitor contemporâneo, mas um respeito ao original. Não especialmente alinhada com formulações 
sistematizadas das teorias de tradução, Rosa manteve neste prefácio uma postura semelhante à vista no prefácio comentado no Capítulo 4 (em Viagem ao fim da noite, de Céline).

O caso de Rosa foge ao que afirmei no início deste capítulo quanto aos tradutores profissionais, que, por serem mais pressionados por prazos e baixos rendimentos e submissos ao status quo, não têm muita condição de influenciar a edição e conseguir o espaço de um prefácio. Rosa, apesar de tradutora profissional, foge a essa regra. Sua grande influência e agentividade — advindas em parte de suas outras atividades intelectuais - lhe garantem uma posição mais prestigiosa do que aquela ocupada normalmente pelos tradutores profissionais.

52. PONGE, Francis. A mesa. Trad. de Ignacio Antonio Neis e Michel Peterson. São Paulo: Iluminuras, 2002.

Posição do nome do tradutor na edição: capa.

Tipo de tradutor: acadêmico.

Não houve como destacar trechos do prefácio dos tradutores, porque trata-se de uma edição crítica feita por estes. Há um longo prefácio de um dos tradutores, Ignacio Antonio Neis, intitulado “O canteiro da tradução”, de cerca de 40 páginas. Este foi o mais longo e rico prefácio de tradutor encontrado no corpus. O outro tradutor, Michel Peterson, apresenta dois outros prefácios sobre a obra e o autor. É dado grande destaque aos tradutores na publicação, inclusive com uma pequena biografia ao final. $\mathrm{O}$ texto da orelha é também de um dos tradutores. $\mathrm{O}$ aparato paratextual tratando de tradução foi o maior e mais significativo de todo o corpus. Na verdade, o paratexto desta edição mereceria um estudo à parte.

Os dois tradutores foram classificados como acadêmicos por serem professores universitários da área de Letras, com profundo conhecimento da teoria da tradução e de língua e literatura francesa, além de tradutores literários e ensaístas muito produtivos.

A concepção de tradução veiculada no prefácio escrito por Ignacio Antonio Neis se assemelha muito à concepção afirmada por Mário Laranjeira: “o caminho para traduzir o poético passa pela recriação, na língua-alvo, da significância do poema”. Ele cita muitos autores, incluindo Derrida (“A tradução é uma escritura, não é simplesmente uma tradução no sentido da transcrição, é uma escritura 
produtiva que é chamada pelo texto original”) e Berman (“A uma tradução etnocêntrica e hipertextual nosso projeto opõe, seguindo Antoine Berman, uma tradução ética e poética”). Os tradutores propõem uma leitura polissêmica da tradução tanto quanto o texto original é polissêmico, explorando as riquezas de ambas as línguas envolvidas.

Este foi o aparato paratextual que mais evidenciou o conhecimento de teorias da tradução e explicitação clara e direta de um projeto tradutório. Mesmo em outras edições de tradução de poesia, onde a teoria da tradução se fez entrever nos prefácios de tradutores, não se fez uma exploração tão completa e consciente da teoria na prática.

Os tradutores têm toda a visibilidade possível: nome na capa, prefácios vários, biografia no final, trabalho crítico respeitável. A edição se destaca em todo o corpus como sendo o exemplar em que realmente teoria e prática caminham lado a lado, um exemplo raro como pude observar chegando ao final da análise do corpus.

53. ROSTAND, Edmond. Cyrano de Bergerac. Trad. Ferreira Gullar. Rio de Janeiro: José Olympio, 2011.

Trechos destacados no prefácio do tradutor: Este prefácio foi comentado no Capítulo 4.

Posição do nome do tradutor na edição: capa.

Tipo de tradutor: escritor.

54. VEIGA, Cláudio. Antologia da poesia francesa (do século IX ao século XX). Rio de Janeiro: Record, 1991.

Posição do nome do tradutor na edição: capa.

Tipo de tradutor: acadêmico.

O tradutor Claudio Veiga foi professor emérito da UFBA e presidente da Academia de Letras da Bahia por 25 anos. Profundo conhecedor da literatura francesa, escreveu vários livros e ensaios sobre poesia francesa. Nessa edição, escreveu um Panorama da Poesia Francesa como prefácio e dois Apêndices: A Tradução da Poesia Francesa no Brasil e Problemas da Tradução, sendo este último de grande interesse. Ele termina o apêndice dizendo que há duas 
possibilidades em qualquer tradução: traduzir aproximando-se do texto e da língua original, não apagando a presença desse original na tradução, ou traduzir aproximando-se da língua (e do público) de chegada, tentando fazer com que a tradução se leia como uma obra escrita em vernáculo, apontando para a formulação de Schleiermacher, apesar de não citá-lo. Embora não diga claramente, mas podendo ser depreendido nas entrelinhas, o tradutor parece fazer a primeira opção. Poder-se-ia dizer que sua posição é equilibrada entre os dois opostos, tendendo ligeiramente para o primeiro polo, o do estranhamento causado pelos resquícios da língua original (e de sua estilística) na tradução.

\section{3 .5}

\section{Menções à tradução e ao tradutor em edições que não contêm prefácio/posfácio de tradutor ou cujo prefácio/posfácio do tradutor não fala de tradução}

Houve casos em que não havia prefácio/posfácio do tradutor ou em que havia prefácio/posfácio do tradutor, mas não se fazia menção à tradução neles, e ainda assim havia menções ao tradutor ou à tradução em outros elementos paratextuais (prefácios de editores, de encomenda, textos nas orelhas ou quarta capa ou em notas diversas). De modo geral, quando isso aconteceu foi possível perceber comentários elogiosos à tradução ou ao tradutor, referências à biografia do tradutor, menções à fortuna crítica das traduções (marcando ou não as diferenças das traduções anteriores em relação à tradução em questão), menções aos projetos tradutórios. Esses trechos foram extraídos e aparecem como notas de rodapé no Anexo I. Dois casos se destacam no conjunto, os das menções às traduções de Dorothée de Bruchard e de Jenny Klabin Segall.

Apesar de as duas tradutoras não terem escrito prefácios para traduções contidas no corpus, seus nomes estão muito visíveis, sejam por constarem na capa ou quarta capa ou por menções várias de prefaciadores. Segundo informações contidas no verbete do DITRA, algumas repetidas nas menções em questão, Dorothée possui uma atuação no mercado editorial que ultrapassa a atuação como tradutora. Dois de seus empreendimentos são dignos de nota: a editora Paraula e a ONG Escritório do Livro. A Editora Paraula, que dirigiu de 1992 a 2000, em 
Porto Alegre e depois em Florianópolis, era uma pequena editora que se dedicava à publicação de clássicos bilíngues. O objetivo da editora era produzir traduções bem revisadas e valorizar o trabalho do tradutor, não adquirindo os direitos autorais sobre a tradução — como é prática do mercado — , que permaneciam propriedade dos tradutores. O Escritório do Livro é uma pequena ONG que se dedica à promoção do livro e à história do livro, que organiza um site sobre o assunto (www.escritoriodolivro.com.br). Além disso, Dorothée editou, em parceria com o Núcleo de Tradução da UFSC, o livro Memória de tradutora, com Rosa Freire d'Aguiar (já mencionado no Capítulo 4), e Memórias de um tradutor de poesia, com Geraldo de Holanda Cavalcanti. A julgar pelo que se diz de suas traduções, principalmente pelas observações de Walter Carlos Costa, os projetos tradutórios de Dorothée pretendiam não modernizar os textos, mas sim guardar — ou restituir, em se tratando de traduções anteriores - as características mais peculiares do estilo e da narrativa dos autores. Sua intenção não era facilitar o texto para o público atual, não descuidando, contudo, de produzir um texto elegante em língua portuguesa. O fato de ser perfeitamente bilíngue parece ter facilitado o trabalho da tradutora.

Quanto a Jenny Klabin Segall, mulher do pintor Lasar Segall, ela foi uma das mais prestigiadas tradutoras de obras clássicas de sua geração. Numa época em que mulheres não eram maioria entre os tradutores, nem entre os intelectuais, Jenny se destacou por sua inteligência e cultura. De família tradicional, casou-se com o pintor em 1925 (ela foi sua segunda esposa), mas não ficou à sua sombra. Sua produção como tradutora é muito respeitada e louvada, iniciando-se nos anos 1930 com suas famosas traduções do teatro clássico francês, principalmente de Molière e Racine. Nessas traduções, teve a preocupação em traduzir a integralidade das obras, traduzir em versos e respeitar a versificação do original, contrapondo-se às traduções anteriores. Por sua importância no cenário intelectual da época, bem que Jenny Klabin Segall mereceria uma biografia ressaltando seu trabalho como tradutora.

Depois de analisar os prefácios e posfácios acima, passarei, no próximo e último capítulo desta tese, às considerações finais sobre esta pesquisa. 


\section{6 \\ Conclusões da pesquisa e contribuições para a área de Estudos da Tradução}

O que há de tão especial nos prefácios de tradutor, no que se diferenciam dos prefácios contidos em obras originais, que mereça ser objeto de reflexão e análise acadêmica? Em primeiro lugar, não podemos nos esquecer de que alguns prefácios de tradutor se tornaram tão célebres que transbordaram os limites do livro traduzido, assumindo o status de texto clássico de áreas diversas. Para citar só alguns exemplos, "Die Aufgabe des Überstzers” [“A tarefa do tradutor”] foi um prefácio de tradutor, publicado em 1923, na edição da tradução feita por Walter Benjamin dos Tableaux parisiens de Charles Baudelaire, em Heidelberg, na Alemanha, e se tornou um dos textos clássicos dos estudos de tradução. "Can the Subaltern Speak?” [Pode o subalterno falar?”] foi o prefácio da acadêmica indiana por nascimento, mas transplantada americana, Gayatri Spivak à sua tradução para o inglês, publicada em 1976, da obra Grammatologie de Jacques Derrida, tornando-se depois um clássico fundador dos estudos pós-coloniais, instaurando o que depois veio mesmo a ser denominado de estudos subalternos, de viés pós-estruturalista, e que gerou outras reflexões sobre tradução por parte da autora em "The Politics of Translation” [“A política da tradução”]. O prefácio do poeta inglês John Dryden às Cartas de Ovídio, em 1680, teoriza sobre tradução sendo sua tipologia metáfrase, paráfrase e imitação —-, abrindo caminho para toda uma reflexão teórica que o sucedeu, com reflexos na teoria e na crítica literárias. Na literatura fracesa, há vários exemplos de prefácios que se tornaram clássicos, mas, se for para citar somente um, seria sem dúvida "Sur la lecture”, prefácio escrito por Proust em 1906 à sua tradução do livro de John Ruskin, Sesame and Lillies, publicado em 1865 (Sésame et les lys, Paris, Sociéte du Mercure de France). Nesse prefácio, Proust não só apresenta as ideias do autor sobre a leitura, mas também as suas próprias, lançando uma base para a discussão que se tornou muito profícua posteriormente para as teorias da leitura.

O prefácio constitui uma escrita peculiar que prepara uma leitura de um texto que não é de autoria do prefaciador, instaurando uma outra identidade que 
intermedia a relação entre autor e leitor. Quando o prefaciador é também o tradutor do texto que prefacia, essa intermediação ocorre mesmo antes da leitura do prefácio, no cerne do texto a ser lido, e instaura uma ambiguidade que perpassa e ultrapassa o texto. O prefácio do tradutor pode marcar, assim, um sofrimento ou mal-estar identitário dessa figura: coautor ou tradutor submisso?, prefácio espaço de promoção do autor ou de interpretação do tradutor?, espaço de liberdade de expressão ou de subordinação a convenções retóricas antiquadas?, espaço de autopromoção ou de humilhação pública?, possibilidade de aumento da visibilidade social por meio da visibilidade paratextual ou recorrência de uma postura de proletarização e subalternidade?

Essa forma textual segue protocolos retóricos próprios - e os subverte na apresentação do prefaciado pela visão do prefaciador, que fala, cala e até engana, assumindo funções que se confundem, se interpenetram e se contrariam. O prefácio do tradutor se constitui numa instância em que a ambivalência de estar em toda parte e de não estar em lugar nenhum, de apagamento diante de uma empresa intelectual extenuante, de se descobrir essencial ou descartável, sacerdote ou pária, se dá de forma patente e incontornável. Talvez seja uma das poucas oportunidades que o tradutor tenha de lançar luz sobre seu trabalho, suas escolhas, seu projeto tradutório, antes de ter sua voz entrelaçada e imiscuída com a voz do autor, ao final do prefácio e no início do texto. Como vimos neste trabalho, essa chance tão valiosa muitas vezes não é aproveitada em seu próprio proveito, mas sim, mais uma vez, em proveito do autor. Muitas vezes, torna-se ela uma oportunidade desperdiçada.

Neste trabalho, o corpus foi constituído a partir de um gosto pessoal (a literatura francesa traduzida) — mas que poderia ser outro —, servindo tão somente para suscitar reflexões sobre uma possível teoria do paratexto do livro traduzido, com base em um de seus elementos dos mais importantes, o prefácio do tradutor. Um dos principais pontos levantados e pesquisados neste trabalho foi o questionamento de se, e em que medida, o prefácio de tradutor pode ser considerado um gênero ou subgênero (considerando-se o prefácio um gênero) 
discursivo. Na pouca discussão realizada até hoje, em colóquios e artigos, esta parece ser uma questão central no tema. Com a minha teorização dos movimentos e passos presentes nos prefácios de tradutor, com base nas formulações de Swales (ver Capítulo 4), espero ter contribuído efetivamente para lançar luz a essa questão e abrir caminho para futuros desdobramentos desta pesquisa. O esforço de aproximação da teoria dos gêneros discursivos à teoria do paratexto, apesar de não ter sido o foco principal desta tese, demonstrou-se produtivo. As minhas teorizações não foram feitas a priori, para serem confirmadas depois, ou apenas em nível teórico, mas a própria análise do corpus suscitou o encaminhamento das teorizações. Nesse sentido, acredito ter conseguido aliar com sucesso teoria e práxis no tratamento do tema.

Assim sendo, espero, com o auxílio das conclusões abaixo, azeitar uma discussão e estimular novas contribuições para a construção dessa teoria. Outros corpora podem ser constituídos, outros elementos paratextuais podem ser analisados e outras abordagens teóricas podem ser empregadas, a fim de que se lance luz sobre essa reflexão que reúna aportes múltiplos advindos da história, da sociologia, da teoria da tradução, da crítica literária, entre outros. As conclusões deste trabalho não constituem uma palavra final, mas antes uma faísca de uma teorização que ainda tem muito por se fazer.

Para minhas perguntas iniciais da pesquisa, 1. Existem conceitos/ideias que se repetem no discurso de tradutores sobre seu trabalho em prefácios/posfácios?; 2. Esses conceitos/ideias sofrem modificações com o passar do tempo?; 3. O discurso do tradutor sofre, com o passar do tempo, influências perceptíveis das teorias de tradução?, obtive respostas diversas.

Na primeira delas, dentre as três, obtive a resposta mais veemente: sim. Como pudemos mostrar nos Capítulos 4 e 5, há uma recorrência não só de assuntos (conceitos), como também de forma de apresentação, em que movimentos e passos se repetem e se sucedem, conforme passamos de um exemplo a outro. Há mesmo uma retórica dos prefácios muito antiga, que é reproduzida pelos prefaciadores/tradutores, que talvez nem mesmo se deem conta de que estão repetindo esquemas formulaicos e, até mesmo quando os subvertem falando de tradução e do projeto tradutório específico, seguem modelos de quem os precedeu, com toques de humildade com diferentes toques de sinceridade. 
Na segunda pergunta obtive uma resposta não conclusiva. Os conceitos de tradução, em uma teorização mais antiga ou mais contemporânea, convivem lado a lado no tempo, em épocas diferentes. Não há uma “evolução” linear apontando para uma "modernização" de conceitos. Podemos encontrar uma formulação de tradução e fidelidade mais "retrógrada” em termos de teoria da tradução pautando projetos de tradução atuais e formulações avant la lettre em prefácios mais antigos, como pudemos perceber nos comentários aos prefácios destacados no Capítulo 5. Uma mesma obra, como As flores do mal, de Baudelaire, foi traduzida seguindo projetos tradutórios embasados em conceitos diametralmente opostos de tradução e fidelidade. Há até mesmo quem fale em tradução literal na transposição de poesia, talvez a modalidade de tradução que menos se preste a uma abordagem literalizante, já que o nível semântico é somente um dos níveis a serem respeitados numa tradução poética. Enfim, vê-se de tudo em todas as épocas. Koselleck (vide Capítulo 2, item 2.2), em muitos de seus estudos com base na teorização da História dos Conceitos, percebe que alguns conceitos substituem outros com o passar do tempo, modificando-se a tal ponto que a primeira conceituação se apaga, ou se deslocam para outras áreas, mas não foi o que se percebeu nesta pesquisa, em que os diversos conceitos de tradução (translatio, traductio, conceito desconstrutivista de tradução) convivem nas diversas épocas, mesmo avant la lettre, no caso do último. Para se chegar mais perto de uma resposta mais conclusiva, seria preciso alargar em muito o corpus, acrescentando obras advindas de outros sistemas literários e outras obras da literatura francesa traduzida, para se perceber se realmente existem movimentos de mudança mais consistentes nesse sentido.

Quanto à terceira e última pergunta, a resposta é, em linhas gerais, mais para a negativa. Muito poucos prefácios fazem referência a teóricos da tradução e, quando o fazem, são principalmente de tradutores de poesia. Não há indícios de que isso esteja mudando com o tempo, pelo menos não conclusivamente no corpus analisado. Ladmiral ressalta no prefácio à segunda edição de sua obra publicada originalmente em 1994, Traduire: théorèmes pour la traduction, a clivagem que existe entre quem pensa a tradução (os teóricos da tradução) e quem faz traduções (os tradutores) (LADMIRAL, 1994, p. v-xxi). Ladmiral, ao mesmo tempo teórico e prático da tradução, apresenta-se como sendo uma exceção à 
regra. Ele afirma que a tradutologia (como os estudos de tradução são normalmente denominados na França) deve ser uma ciência da prática, uma praxeologia, e, ao mesmo tempo, uma disciplina reflexiva, em que teoria e prática se combinam. Ele acha que, de fato, isso raramente acontece, o que contribui para que os tradutores práticos tenham uma prevenção contra os teóricos que fazem afirmações que não se verificam na prática. O melhor desses exemplos é a afirmação que alguns teóricos (ele cita especialmente Georges Mounin) fazem de que a tradução é teoricamente impossível, quando a tradução é uma das práticas mais antigas, e cada vez mais produtivas, do mundo (LADMIRAL, 1994, p. 8). Esse tipo de afirmação impacienta os tradutores — que já não têm muito tempo a perder, já que estão sempre pressionados por prazos exíguos - e os faz se desinteressarem de formulações teóricas no que tange à tradução, especialmente. Exceto os tradutores práticos que tiveram contato acadêmico com as teorias de tradução, os outros parecem não fazer muita questão de saber mais sobre o assunto. Além disso, os cursos de formação de tradutores no Brasil datam de no máximo 40 anos, sendo que a maioria surgiu nos últimos 20 anos. Muitos tradutores da "velha guarda", que aprenderam a traduzir traduzindo, acham que esses cursos - e, por conseguinte, o conhecimento das teorias de tradução — são perfeitamente dispensáveis. O autodidatismo é apresentado em muitos verbetes do DITRA como sendo uma característica louvável, até mesmo uma prerrogativa.

Da análise empreendida, podem-se fazer algumas observações, a serem entendidas como tendências, já que o corpus é grande para um esforço de pesquisa, mas considerado pequeno para se fazerem inferências probabilísticas:

1. Nas obras de prosa, há relativamente poucos prefácios de tradutores nas edições analisadas. Destes, são raros aqueles que tratam da tradução propriamente dita. Normalmente, os prefácios de tradutores das obras examinadas são didáticos e informativos a respeito do autor, sua importância na literatura francesa, sua vida, sua obra, a escola literária em que se insere, curiosidades, casos pitorescos etc. O tradutor, quando lhe é concedido espaço para escrever um prefácio, raramente fala 
de seu projeto tradutório. O foco de importância é dado ao autor e à obra original. Quando há alguma menção à tradução, é comum serem ressaltadas suas dificuldades e agruras, assumindo, muitas vezes, o tradutor um papel humilde e subserviente de intermediador de uma língua para outra. A falta de ênfase na tradução dá a impressão ao leitor de que não há escolhas a serem feitas pelo tradutor, de que a tradução é quase automática. Quando há menção, é sempre enfatizada a dificuldade, apresentando o tradutor um quase pedido de desculpas por sua ousadia em tocar a obra de um tão grande escritor.

2. Quanto mais o autor é um clássico consagrado na prosa, menos se fala de tradução. É como se os clássicos tivessem suas traduções “naturais”, não questionadas, não diversas. É como se o clássico em tradução já nascesse um clássico, inquestionável. Sabe-se, no entanto, que não é assim; os clássicos, principalmente quando muito afastados no tempo de suas traduções, apresentam soluções de tradução que não têm nada de automáticas. Seria preciso tecer considerações a respeito de decisões editoriais em relação à concessão de espaço ao tradutor para escrever um texto autoral, além de considerações mercadológicas a respeito desse assunto, para aprofundar essa observação.

3. As traduções e edições mais recentes tendem a dar mais voz e destaque ao tradutor, principalmente no caso de retraduções de clássicos ou traduções diretas de obras até então conhecidas por meio de traduções indiretas. Destas, edições universitárias ou de editoras de pequeno e médio porte, em contraponto a edições de grandes casas editoras, se destacam nesse quesito. É como se as grandes editoras não quisessem chamar a atenção para a figura do tradutor. Quando esse destaque é dado, por meio da presença do nome do tradutor na capa ou na quarta capa, normalmente é porque se trata de um tradutor-escritor, intelectual ou tradutor muito conhecido no mundo das letras. A tradutores profissionais que não tenham grande destaque no mundo editorial e intelectual o espaço do prefácio e o nome na capa são parcamente concedidos.

4. Observaram-se algumas edições em que não consta o nome do tradutor, principalmente mais antigas. Essa observação corrobora a observação contida no item acima: quanto mais nova a edição, maior tende a ser o destaque à figura do tradutor, seja por seu nome aparecer com mais ênfase, seja por haver um prefácio do tradutor ou alguma menção ao tradutor ou à tradução no aparato paratextual. 
5. As traduções de poesia, principalmente, e teatro, secundariamente, têm uma tendência a dar mais espaço para que os tradutores falem de seu projeto tradutório. Foram encontrados vários prefácios longos e grande destaque ao nome do tradutor nas edições pesquisadas nessas áreas. Já faz parte do senso comum considerar a tradução de poesia e teatro como mais difíceis e autorais, daí se explicaria essa diferença de ênfase à figura do tradutor na poesia e no teatro, em contraposição à prosa. Percebeu-se ainda que principalmente os tradutores de poesia podem apresentar aportes teóricos que embasem seus projetos tradutórios, o que não é tão comum nos tradutores de prosa e teatro.

6. Nos paratextos de tradutores acadêmicos (professores universitários e pesquisadores e estudiosos da tradução), é possível observar algumas interferências das teorias de tradução em seu discurso. Questionamentos a respeito da (in)visibilidade do tradutor, da leitura e interpretação dos textos e sua consequência na tradução, da atualização das traduções, novas traduções de uma mesma obra, traduções indiretas e do valor das retraduções ecoam em meio a declarações de insegurança, dúvidas e dificuldades, ou, por outro lado, de êxito e satisfação.

7. Nas retraduções, observa-se uma incidência maior de prefácios de tradutores, com referências à tradução. Talvez isso se dê porque o tradutor nessa situação sinta mais a necessidade de justificar suas escolhas em oposição às feitas pelos tradutores anteriores e encontre ressonância nos editores, que concedem o espaço a fim de valorizar o empreendimento, marcar a diferença e aumentar a vendagem do livro. O tradutor aí teria uma função mais explícita de promotor da edição.

8. Existe uma correlação entre existência do prefácio do tradutor, posição de destaque do seu nome na edição e outras referências à tradução em outros elementos paratextuais (como na orelha, por exemplo). Quando existe prefácio de tradutor, há maior probabilidade de o tradutor ter seu nome na capa ou quarta capa e ter sua tradução mencionada em outras partes do paratexto, e vice-versa. A probabilidade de tudo isso ocorrer aumenta muito se o tradutor for um escritor ou intelectual de renome.

9. Existem padrões ou características retóricas nos prefácios de tradutores, mas os movimentos e passos não aparecem na mesma ordem, nem estão sempre presentes. Nesse sentido, o prefácio do tradutor só poderia ser encarado como 
(sub)gênero discursivo se a definição de gênero que embasar essa conclusão for mais ampla, como a do segundo Swales (2004). Se for uma definição coadunada com o primeiro Swales (1994), dificilmente isso ocorreria. De qualquer forma, pode-se dizer que as recorrências observadas constituem um gênero secundário nos termos bakhtinianos. Já nos termos bazermanianos, percebe-se que, além de uma tipificação observável, os prefácios de tradutor possuem um efeito perlocucionário, enfatizando o caráter psicossocial desse subgênero ou gênero secundário.

10. Em geral, os prefácios de tradutores focam mais no autor do que no projeto tradutório propriamente dito. Quando a tradução e seu projeto tradutório são enfocados, pode-se mesmo dizer que o prefácio do tradutor subverte o que tradicionalmente se espera dele, que é enaltecer o autor e a obra. Assim sendo, a maioria dos prefácios de tradutor se mostra como um exercício retórico de conformidade com regras implícitas, que poderiam ser escritos por outros prefaciadores, e não necessariamente pelo tradutor.

11. Muitos prefácios de tradutor são usados como um espaço de reconhecimento e não como um espaço privilegiado de discussão de escolhas tradutórias, da abordagem teórica ou de pontos discutíveis específicos. Nesses casos, os prefácios serviriam como (auto) promoção do tradutor e podem se mostram bem vazios de sentido.

12. O discurso do tradutor nos prefácios tende a atender a exigências implícitas de humildade, submissão e uma suposta fidelidade ao texto original, nem sempre revelando suas reais intenções. Nem tudo que o tradutor faz é explicitado em seu discurso sobre a tradução, e algumas vezes pode até haver uma contradição explícita entre o que fez e o que descreve. Nesses casos, o tradutor diz aquilo que imagina que os leitores sofisticados, como críticos, por exemplo, querem ouvir.

13. Os prefácios de tradutor que falam de tradução, de cunho mais crítico, se endereçam a um leitor mais sofisticado, ao crítico literário ou a outros tradutores, enquanto que os prefácios de tradutor que não tratam da tradução, de cunho mais didático, se endereçam a um leitor mais ingênuo, menos iniciado.

14. Por tudo o que disse antes, percebe-se que teoria e prática encontram-se pobremente combinadas nos prefácios de tradutor pesquisados. 
Em última instância, o que distingue o paratexto do livro traduzido do paratexto do livro original são todos os elementos referentes ao tradutor e à tradução contidos na edição. Assim sendo, os pesquisadores que desejarem estudar as especificidades do paratexto do livro traduzido devem prestar atenção ao seguinte:

1. se existem prefácios/posfácios/introduções do tradutor;

2. se os elementos acima falam de tradução ou da tradução específica e o teor dessa menção;

3. se existem outros prefácios/posfácios/introduções de outrem que falem de/da tradução e o teor dessa menção;

4. se há outras menções ao tradutor ou à tradução em outros elementos paratextuais, por exemplo, orelha, quarta capa, dados biográficos dos tradutores etc.;

5. qual é a posição do nome do tradutor: posição de destaque (capa, quarta capa), uma menção comum (folha de rosto) ou somente uma menção legal (ficha catalográfica);

6. em que medida a biografia do tradutor (que derivou a minha classificação dos tradutores nesta pesquisa) determina ou influencia a posição de destaque do seu nome na edição — o estudo da biografia e a visibilidade social do tradutor não têm um interesse em si mesmas, mas lançam luz à visibilidade paratextual do tradutor;

7. o estudo das notas de tradutor é um estudo que exige a leitura do texto traduzido - ou pelo menos de trechos desse texto - , enquanto que o estudo dos prefácios/posfácios não. É na leitura e análise do texto traduzido que se pode depreender a visibilidade textual do tradutor. Nesta pesquisa, o que me interessou foram a visibilidade paratextual, por óbvio, e a visibilidade social no que se refere e influencia a visibilidade paratextual.

O material de chamada para o seminário denominado "Quand les traducteurs prennent la parole: préfaces et projets traductifs” [“Quando os 
tradutores tomam a palavra: prefácios e projetos tradutórios”], realizado na Universidade de Paris 3 - Sorbonne Nouvelle em 23 de novembro de 2013 e organizado pelo grupo Projet TTT: Textes théoriques sur la traduction/Theoretical Texts on Translation, do qual pude participar com uma comunicação sobre esta pesquisa, era constituído de uma série de perguntas, e poucas afirmações, refletindo o estado da pesquisa nessa área e abrindo inúmeras possibilidades: “O que um prefácio proporciona a um leitor? Ele é dirigido a um leitor ingênuo ou a um leitor sofisticado, ao "leitor real”, como diz Nabokov? O prefácio foca no autor cujo trabalho está sendo traduzido ou no itinerário do tradutor? É uma dádiva ao leitor ou, ao contrário, é um exercício retórico, vazio de sentido? O prefácio é um gênero codificado em si mesmo? Existem nele características ou padrões retóricos identificáveis? Estes sofreram mudança com o passar do tempo? Existem nele advertências oratórias ou mensagens implícitas? Em que o prefácio a uma tradução difere de um prefácio escrito para um texto original? O discurso do tradutor atende a essas exigências implícitas ou ele as subverte? Em que medida os tradutores revelam suas intenções? Eles querem explicar seu trabalho ou se defender? Como se deve ler nas entrelinhas? E, por fim, o que pode ser dito da teoria/ideologia esboçada em um prefácio? Como a teoria e a práxis se combinam?"

A partir de cada uma dessas perguntas, linhas de pesquisa se delineiam no estudo dos prefácios de tradutor. A partir da minha pesquisa, aponto ainda para a questão de como os prefácios de tradutor em retraduções se distinguem de outros prefácios de tradutor. Será que nas funções clássicas, depreendidas por Ladmiral com base em Habermas (LADMIRAL, 1994, p. 216) para uma tipologia de prefácios de tradutor - explicação, justificação, diferenciação em relação a outras obras e outras traduções, desculpas e, ainda, agradecimento - a função de diferenciação fica mais ressaltada do que as outras? Será que o movimento das retraduções que se vê recentemente mais acelerado no Brasil abre a possibilidade de se encarar as retraduções como uma "série aberta" infinita, múltipla de possibilidades, ou apenas uma mera tentativa de correção do que nas traduções anteriores se mostrou falho? E como os tradutores de retraduções se posicionam em seus prefácios? Assumem eles uma postura de críticos e não apenas de tradutores? Pagam tributo a quem os antecedeu ou se contrapõem frontalmente a 
seus antecessores? Para mim, ficou claro ao final da pesquisa e da análise que os prefácios de tradutores em retraduções abrem um caminho de pesquisa muito profícuo, que poderia se constituir em um desdobramento futuro.

Outro desdobramento desta pesquisa seria certamente a seleção de prefácios importantes e emblemáticos que pudessem ser reunidos em uma antologia de prefácios de tradutores. Neste corpus encontrei alguns exemplos que poderiam certamente ser selecionados em livro à parte com vistas à antologização.

Mais um desdobramento possível seriam pesquisas semelhantes que poderiam ser realizadas com corpora de obras traduzidas de outras literaturas mundiais - inglesa, espanhola, italiana, alemã, russa, por exemplo. O interesse maior dessas pesquisas seria perceber se seus resultados reiterariam as minhas conclusões nesta pesquisa ou se se diferenciariam delas e em que medida.

Ainda outra possibilidade de pesquisa seria analisar os prefácios de tradutor não em termos de movimentos e passos, ou em termos de conceitos de fidelidade e tradução, como fiz aqui, mas em termos de funções, como propõe McRae em sua pesquisa, percebendo quais são as funções que predominam nos prefácios de tradutor entre as cinco seguintes: (1) colocação em primeiro plano das diferenças de culturas e línguas; (2) promoção do entendimento da cultura fonte; (3) promoção do entendimento do papel e intervenção do tradutor; (4) ajuda a críticos a avaliar a qualidade das traduções e (5) constituição de ferramenta útil de documentação de processo (McRAE, 2012, p. 72).

Por fim, outros desdobramentos seriam analisar outros elementos paratextuais, como as notas de tradutor (de rodapé ou finais), bem como a elaboração de glossários com termos culturalmente marcados (de onde se poderia depreender a concepção que o tradutor possui das instâncias interculturais e sua importância na tradução), a concepção visual e elaboração das capas, com análise dos elementos icônicos ali contidos em sua interrelação com o tema da obra ou o autor e o destaque ao nome do tradutor, a análise do discurso promocional contido na quarta capa e orelhas com destaque para os elementos de convencimento que levem à compra do livro (sendo as referências ao nome ou à biografia do tradutor alguns desses elementos), por exemplo, de forma a contribuir, sob uma outra perspectiva, para a construção de uma teoria do paratexto do livro traduzido. Há relativamente pouco realizado do muito que ainda pode ser feito 


\section{Bibliografia}

ARIÈS, P. L'Histoire des mentalités. In: LE GOFF, J. (Dir.) La Nouvelle histoire. Col. Les Encyclopédies du Savoir Moderne. Paris: C.E.P.L., 1978.

ARROJO, R. Oficina de tradução: a teoria na prática. São Paulo: Ática, 1986.

ASKEHAVE, I.; SWALES, J.M. Genre Identification and Communicative Purpose: a Problem and a Possible Solution. Applied Linguistics, vol. 22, n. 2, p. 195-212, 2001.

AUSTIN, J.L. Performative Utterances. In: URMSON, J. U.; WARNOCK, G. J. (Orgs.) Philosophical Papers. Oxford: Clarendon Press, p. 233-252, 1970.

BAKHTIN, M. Os gêneros do discurso. Estética da criação verbal. São Paulo: Martins Fontes, p. 278-326, 1992.

BALLARD, M. De Ciceron à Benjamin: traducteurs, traductions and réflexions. Lille: Presses Universitaires de Lille, 1992.

BARTHES, R. A morte do autor. O rumor da língua. Trad. Mário Laranjeira. São Paulo: Martins, 2004. Disponível em http://www.disciplinas.stoa.usp.br. Acesso em 24/04/2012.

From Work to Text. In: RICE, P. \& WAUGH, P. Modern Literary Theory: a Reader. London: Edward Arnold, 1989, p. 166-171. Disponível em www.rlwclarke.net. Acesso em 17/12/2013.

BASTIANETTO, P.C. As funções do paratexto para a inteligibilidade da obra traduzida. TradTerm, 11, p. 53-69, 2005.

BAZERMAN, C. Atos de fala, gêneros textuais e sistemas de atividades: como os textos organizam atividades e pessoas. In: DIONISIO, A.; HOFFNAGEL, J. (Orgs.) Gêneros textuais, tipificação e interação: Charles Bazerman. São Paulo: Cortez, 2005.

BENJAMIN, W. A tarefa do tradutor. Trad.: Vários. Cadernos de Mestrado / Literatura no. 1, 2ª edição, UERJ, p. 56, 1994.

BENNINGTON, G. \& DERRIDA, J. Jacques Derrida. Coll. Les Contemporains. Paris, Seuil, 1991.

BERMAN, A. Pour une critique des traductions: John Donne. Paris: Gallimard, 1995.

BHATIA, V.J. Generic Integrity. In: Worlds of Written Discourse: a GenreBased View. London: Continuum, p. 115-133, 2004. 
BIASI-RODRIGUES, B. O gênero resumo: uma prática discursiva da comunidade acadêmica. In: BIASI-RODRIGUES, B.; ARAÚJO, J.C.; SOUSA, C.T. (Orgs.) Gêneros textuais e comunidades discursivas: um diálogo com John Swales. Belo Horizonte: Autêntica, 2009.

BORGES, J.L. Pierre Menard, autor do Quixote. Ficções. Trad. Carlos Nejar. São Paulo: Ed. Globo, 6a edição, p. 54-63, 1995.

Prólogo de prólogos. Prólogos, com um prólogo dos prólogos. Trad. Josely Vianna Baptista. São Paulo: Companhia das Letras, p. 7-10, 2010.

BOURDIEU, P. A economia das trocas simbólicas. Trad. Sergio Miceli. São Paulo: Perspectiva, 1999.

CAETANO, R. Poesia e paratexto: a descida de Sant'Anna aos infernos da modernidade. Curitiba: Editora da UFPR, 2011.

CAMPOS, H. Paul Valéry e a poética da tradução. In: COSTA, L.A. (Org.) Limites da traduzibilidade. Salvador: EDUFBA, p. 201-216, 1986.

CARVALHO, G. Gênero como ação social em Miller e Bazerman: o conceito, uma sugestão metodológica e um exemplo de aplicação. In: MEURER, J.L.; BONINI, A.; MOTTA-ROTH, D. (Orgs.). Gêneros: teorias, métodos, debates. São Paulo: Parábola, 2005.

CHEVREL, Y. Les études de réception. In: BRUNEL, P.; CHEVREL, Y. Précis de littérature comparée. Paris: PUF, p. 177-214, 1989a.

. Le Texte étranger: la littérature traduite. In: BRUNEL, P.; CHEVREL, Y. Précis de littérature comparée. Paris: PUF, 1989b. p. 57-84, 1989b.

COMPAGNON, A. Le commencement du livre et la fin de l'écriture. In: La Seconde main ou le travail de la citation. Paris: Seuil, p. 341-346, 1979.

. Le Démon de la théorie. Paris, Seuil, 1998.

CORACINI, M.J.R.F. Discurso sobre tradução: aspectos da configuração identitária do tradutor. TradTerm, 11, p. 29-51, 2005.

D’ABLANCOURT, N.P. Carta ao senhor Conrart, conselheiro e secretário do rei. (1664). Trad. Teresa Dias Carneiro. In: FAVERI, C.B. \& TORRES, M.-H.C. (orgs.) Clássicos da teoria da tradução, Vol. 2, Francês-Português, Universidade Federal de Santa Catarina, NUT - Núcleo de Tradução, p. 49-59, 2004.

D’AGUIAR, R.F. Memória de tradutora com Rosa Freire d'Aguiar. Florianópolis: Escritório do Livro, 2004. 
DELISLE, J.; WOODSWORTH, J. Os tradutores na história. Trad. Sérgio Bath. São Paulo: Editora Ática, 1998.

DERRIDA, J. La dissémination. Paris: Seuil, 1972.

Gramatologia. Trad. Miriam Schnaiderman e Renato J. Ribeiro. São Paulo: Ed. Perspectiva, 1973.

Semiologia e gramatologia (diálogo com Julia Kristeva). Trad. Luís Costa Lima. Posições. Lisboa: Plátano Editora, 1966.

UFMG, 2002.

Torres de Babel. Trad. Junia Barreto. Belo Horizonte: Editora

D’HULST, L. Rhétoriques des préfaces. Cent ans de théorie française de la traduction. Lille: Presses Universitaires de Lille, 1991.

DOSSE, F. História do estruturalismo. Trad. Álvaro Cabral. São Paulo: Editora Ensaio; Campinas, SP: Editora da Universidade Estadual de Campinas, Vol. I e II. 1994.

DUBY, G. A história continua. Trad. Clóvis Marques. Rio de Janeiro, Jorge Zahar Editor/Editora UFRJ, 1993.

DUBY, G.; LARDREAU, G. Dialogues. Paris, Flammarion, 1980.

FISH, S. Is There a Text in this Class?: the Authority of Interpretative Communities. Cambridge: Harvard University Press, 1980.

. Como reconhecer um poema ao vê-lo. Trad. Sonia Moreira. Palavra, no. 1, p. 156-165, 1993.

FOUCAULT, M. Microfísica do poder. Trad. Roberto Machado. Rio de Janeiro: Edições Graal, 1986.

FREEDMAN, A.; MEDWAY, P. Locating Genre Studies: Antecedents and Prospects. Genre and the New Rhetoric. London: Taylor \& Francis, 1994.

FROTA, M.P. Os estudos da linguagem, a ciência linguística e o saber da psicanálise: encontros e desencontros. A singularidade na escrita tradutora: linguagem e subjetividade nos estudos da tradução, na linguística e na psicanálise. Campinas e São Paulo: Pontes e FAPESP, p. 23-70, 2000.

FROW, J. Approaching Genre. Genre. London: Routledge, 2005.

GENETTE, G. Palimpsestes. Paris: Seuil, 1982.

Editorial, 2011.

Paratextos editoriais. Trad. Álvaro Faleiros. Cotia, SP: Ateliê 
HALLYN, F. Littérature et histoire des idées. In: DELCROIX, M.; HALLYN, F. (Dir.). Méthodes du texte. Paris-Gembloux: Duculot, 1987.

HEMAIS, B. \& BIASI-RODRIGUES, B. A proposta sociorretórica de John M. Swales para o estudo de gêneros textuais. In: MEURER. J.L.; BONINI, A.; MOTTA-ROTH, D. (Orgs.) Gêneros: teorias, métodos, debates. São Paulo: Parábola Editorial, 2005, p.108-129.

HERMANS, T. Images of Translation: Metaphor and Imagery in the Renaissance Discourse on Translation. In: HERMANS, T. (Ed.) The Manipulation of Literature: Studies in Literary Translation. London: Croom Helm, p. 103-135, 1985.

IDT, G. Fonction rituelle du métalangage dans les prefaces "hétérographes". Littérature, Paris, Larousse, no. 27, p. 65-74, 1977.

ISER, W. A interação do texto com o leitor. In: LIMA, L.C. (Sel., Trad., Introd.). A literatura e o leitor: textos de estética da recepção. Rio de Janeiro: Paz e Terra, p. 83-132, 1979.

JASMIN, M.G. História dos conceitos e teoria política e social: referências preliminares. $R B C S$, vol. 20, no. 57 , fevereiro/2005.

JASMIN, M.G.; FERES JÚNIOR, J. (Org.). História dos conceitos: debates e perspectivas. Rio de Janeiro: Editora PUC-Rio/Edições Loyola/IUPERJ-UCAM, 2006.

KOSELLECK, R. Histoire sociale et histoire des concepts. L'Expérience de l'histoire. Col. Hautes Études. Paris: Gallimard/Seuil, p. 101-119, 1997.

. 'Progress' and 'Decline': an Appendix to the History of Two Concepts. The Practice of Conceptual History. Translated by Todd Samuel Presner and Others. Stanford: Stanford University Press, 2002.

Futuro passado: contribuição à semântica dos tempos históricos. Trad. Wilma Patricia Maas e Carlos Almeida Pereira. Rio de Janeiro: Contraponto/Editora PUC-Rio, 2006.

LACLAU, E.; MOUfFE, C. Post-Marxism Without Apologies. In: LACLAU, E. New Reflections on the Revolution of Our Time. London: Verso, p. 97-132, 1980.

LADMIRAL, J.-R. Traduire: théorèmes pour la traduction. Col. Tel. Paris, Gallimard, 1994.

LAMBERT, J.; VAN GORP, H. Sobre a descrição de traduções. Trad. MarieHélène Torres e Lincoln P. Fernandes. In: GUERINI, A.; TORRES, M.-H. C.; 
COSTA, W.C. (Orgs.) Literatura e tradução. Rio de Janeiro: 7 Letras, p. 212, 2011.

LARANJEIRA, M. Poética da tradução. Col. Criação \& Crítica, Vol. 12. São Paulo: USP/FAPESP, 1993.

LEFEVERE, A. Tradução, reescrita e manipulação da fama literária. Trad. Claudia Matos Seligman. Bauru: EDUSC, 2007.

LEFEVERE, A. Translation: its Genealogy in the West. In: BASSNETT, S. \& LEFEVERE, A. Translation, History \& Culture. London: Pinter, p. 14-28, 1990.

LE GOFF, J. Une science en marche, une science dans l'enfance. In: LE GOFF, J. (Dir.). La nouvelle histoire. Col. Les Encyclopédies du Savoir Moderne. Paris: C.E.P.L., 1978.

L'Histoire nouvelle. In: LE GOFF, J. (Dir.). La nouvelle histoire. Col. Les Encyclopédies du Savoir Moderne. Paris: C.E.P.L., 1978.

. Uma vida para a história. Trad. José Aluysio Reis de Andrade. São Paulo: Editora UNESP, 1998.

LONG, L. History and Translation. In: KUHIWCZAK; LITAU (Orgs.) A Companion to Translation Studies. Clevedon: Multilingual Matters, 2007.

LOVEJOY, A.O. Essays in the History of Ideas. Baltimore: The Johns Hopkins Press, 1948.

MACIEL, M.E. São Jerônimo em tradução. Aletria (Programa de PósGraduação em Estudos Literários/UFMG), vol. 8, p. 53-59, dezembro/2001.

MARTINS, H. Três caminhos na filosofia da linguagem. Introdução à linguística: fundamentos epistemológicos, v. 3, São Paulo: Cortez, p. 439-473, 2004.

MARTINS, M.A.P. As relações nada perigosas entre história, filosofia e tradução. Cadernos de Tradução, Florianópolis, n. 1, p. 37-51, 1996.

McRAE, E. The Role of Translators' Prefaces to Contemporary Literary Translations into English: An Empirical Study. In: GIL-BARDAJÍ, A.; ORERO, P.; ROVIRA-ESTEVA, S. (Eds.) Translation Peripheries: Paratextual Elements in Translation. Bern: Peter Lang, p. 63-82, 2012.

MEURER, J.L.; BONINI, A.; MOTTA-ROTH, D. (Orgs.). Gêneros: teorias, métodos, debates. São Paulo: Parábola, 2005.

MILICA, I.A. William Shakespeare in Communist Romania: Freedom and Limitation in Romanian Editions. Tradução em Revista, no. 12, p. 18-38, 2012. 
MILLER, C. Genre as Social Action. In: FREEDMAN, A.; MEDWAY, P. (Eds.) Genre and the New Rhetoric. London: Taylor \& Francis, p. 23-42, 1994.

. Rhetorical Community: the Cultural Basis of Genre. In: FREEDMAN, A.; MEDWAY, P. (Eds.). Genre and the New Rhetoric. London: Taylor \& Francis, 1994.

MITTERAND, H. La préface et ses lois: avant-propos romantiques. Le Discours du roman. Paris: PUF, p. 21-34, 1980.

MOTTA-ROTH, D. A construção social do gênero resenha acadêmica. In: MEURER, J.L.; MOTTA-ROTH, D. (orgs.) Gêneros textuais e práticas discursivas. Bauru: EDUSC, 2002.

MOUNIN, G. Os problemas teóricos da tradução. Trad. Heloysa de Lima Dantas. São Paulo: Cultrix, [1963] 1975.

NORA, J.; LE GOFF, J. Faire de l'histoire. Paris: Gallimard, 1974.

OLIVEIRA, M.E. e NEVES, M.A.G. Estudo de prefácio em obras acadêmicocientíficas: estruturas e propostas. Cadernos do CNLF, vol. XVI, no. 04, t.3, p. 2967-2976, 2012.

PAGANO, A.S. As pesquisas historiográficas em tradução. In: PAGANO, A. (Org.) Metodologias de pesquisa em tradução. Belo Horizonte: Faculdade de Letras, UFMG, p. 117-146, 2001.

PARÉ, A.; SMART, G. Observing Genres in Action: Towards a Research Methodology. In: FREEDMAN, A.; MEDWAY, P. (Eds) Genre and the New Rhetoric. London: Taylor \& Francis, 1994.

PELCKMANS, P. Littérature et histoire des mentalités. In: DELCROIX, M.; HALLYN, F. (Dir.). Méthodes du texte. Paris-Gembloux: Duculot, 1987.

PESSOA, M.F.C. O paratexto e a visibilidade do tradutor. Rio de Janeiro, 2009. 90p. Dissertação (Mestrado em Letras - Estudos da Linguagem) Programa de Pós-Graduação em Letras, PUC-Rio.

PINHO, J.A. O escritor invisível: a tradução tal como é vista pelos tradutores portugueses. Lisboa: Quidnovi, 2006.

. Mãos à obra... da tradução. Cadernos de Tradução, Florianópolis/Brasil, v. 2, n. 24, 2009.

A tradução para edição. Tese de Doutorado, Faculdade de Letras, Universidade do Porto, maio de 2011.

POCOCK, J.G.A. Linguagens do ideário político. Trad. Fábio Fernandez. São Paulo: Edusp, 2003. 
PRUNC, E. Priests, Princes and Pariahs: Constructing the Professional Field of Translation. In: WOLF, M.; FUKARI, a. (eds.) Constructing a Sociology of Translation. NY/Amsterdam: John Benjamins, 2007.

PYM, A. Method in Translation History. Manchester: St. Jerome Publishing, 1998.

RICHTER, M. Pocock, Skinner and Begriffsgeschichte. The History of Political and Social Concepts: a Critical Introduction. New York/Oxford: Oxford University Press, 1995.

RIGUEIRA, A.M. Texto sobre cinema: organização retórica e avaliação em resenhas de filme. Tese de doutorado, Programa de Pós-graduação em Letras, PUC-Rio, agosto de 2010.

ROCHA, J.C.C. (Org.). Roger Chartier. A força das representações: história e ficção. Chapecó: Argos, 2011.

RODRIGUES, C.C. Prefácios e notas do tradutor: tensão e acolhimento na relação com o outro. Tradução \& Comunicação, no. 20, Ano 2010.

RÓNAI, P. Escola de tradutores. Rio de Janeiro: José Olympio, 2012.

SAUSSURE, F. Curso de linguística geral. Trad. Antônio Chelini, José Paulo Paes e Izidoro Blikstein. São Paulo: Cultrix, 2006.

SCHLEIERMACHER, F. Sobre os diferentes métodos de tradução. Trad. Margarete von Mühlen Poll. In: HEIDERMANN, W. (org.) Clássicos da teoria da tradução, Vol. 1, Alemão-Português, Universidade Federal de Santa Catarina, NUT - Núcleo de Tradução, p. 26-87, 2001.

SIMEONI, D. Between Sociology and History: Method in Context and in Practice. In: WOLF, M.; FUKARI, a. (eds.) Constructing a Sociology of Translation. NY/Amsterdam: John Benjamins, p. 187-204, 2007.

SIMON, S. Translating the Will to Knowledge: Prefaces and the Canadian literary politics. In: BASSNETT, S.; LEFEVERE, A. Translation, History, and Culture. London: Pinter, p. 110-117, 1990.

SKINNER, Q. Meaning and Understanding in the History of the Ideas. History and Theory, 8(1): 3-53, 1969.

Hermeneutics and the Role of History. New Literary History, Johns Hopkins University Press, Vol. VII, no. 1, p. 209-232, Autumn 1975.

. The Rise of, Challenge to, and Prospects for a Collingwoodian Approach to the History of Political Thought. In: CASTIGLIONE, D; HAMPSHIRE-MONK, I. The History of Political Thought in National Context. Cambridge: Cambridge University Press, p. 175-188, 2001. 
Lenguaje, política e historia. Quilmes: Universidad Nacional de Quilmes Editorial, p. 295-331 (Cap. 10), 2002a.

Visions of Politics. Regarding Method. Cambridge: Cambridge University Press, Vol. I. p. 57-89 (Cap. 4), p. 90-102 (Cap. 5), 2002b.

SWALES, J.M. The Concept of Genre. Genre Analysis. Cambridge: Cambridge University Press, p. 45-67, 1990.

- Communicative Purpose Revisited. Research Genres: Explorations and Applications. Cambridge: Cambridge University Press, p. 68-74, 2004.

Exploration and Applications. Cambridge: Cambridge University Press, 2004.

TAHIR-GÜRÇAGLAR, S. What Texts Don't Tell: the Uses of Paratexts in Translation Research. In: HERMANS, T. (ed.) Crosscultural Transgressions. Manchester, UK: St. Jerome, p. 44-60, 2002.

TORRES, M.-H.C. As traduções e seu funcionamento nas culturas. In: FALEIROS, A., ZAVAGLIA A.; MOUZAT, A. (orgs.) A tradução de obras francesas no Brasil. São Paulo: Anna Blume; Fapesp, 2011a.

acompanhame Traduzir o Brasil literário: paratexto e discurso de VENUTI, L. A invisibilidade do tradutor. Trad. Carolina Alfaro de Carvalho. paLavra, 3, p. 111-134, 1996.

VIEIRA, E.R.P. Com a palavra, caciques, pagés e tradutores. Por uma teoria pós-moderna da tradução. Tese de Doutorado em Literatura Comparada. Belo Horizonte: UFMG/FL, p. 143-168, 1992.

WIERZBICKA, A. Introduction. Semantics, Culture and Cognition. New York \& Oxford: Oxford University Press, p. 3-27, 1992.

WOLF, M. Introduction: The Emergence of a Sociology of Translation. In: WOLF, M.; FUKARI, a. (eds.) Constructing a Sociology of Translation. NY/Amsterdam: John Benjamins, 2007.

ZINS, C. Le Traducteur et la fonction du double: une voix en trop. Assises de la Traduction Littéraire, 1, 1984, Arles. Actes..., Arles: Actes Sud/Atlas, p. 34-49, 1985.

TRINGALI, D. A arte poética de Horácio. (ed. bilíngue) São Paulo: Musa Editora, 1993. 
Livro do Gênesis, Capítulo 11. Bíblia de Jerusalém. São Paulo: Paulus, p. 48-49, 2002. 


\section{ANEXO I}

\begin{tabular}{|c|c|c|c|c|c|c|c|c|c|c|}
\hline No. & Autor e título & $\begin{array}{c}\text { Localizador } \\
\text { BN }\end{array}$ & $\begin{array}{l}\text { Nome do } \\
\text { tradutor }\end{array}$ & Biodata & $\begin{array}{c}\text { Localização do } \\
\text { nome do } \\
\text { tradutor }\end{array}$ & Prefácios & $\begin{array}{c}\text { Menções à } \\
\text { tradução ou } \\
\text { aos tradutores } \\
\text { no paratexto }\end{array}$ & $\begin{array}{l}\text { Prefácio } \\
\text { do } \\
\text { tradutor }\end{array}$ & $\begin{array}{l}\text { Menção à } \\
\text { tradução no } \\
\text { prefácio do } \\
\text { tradutor }\end{array}$ & Obs. \\
\hline 1 & $\begin{array}{c}\text { BALZAC, } \\
\text { Honoré de. A } \\
\text { mulher de trinta } \\
\text { anos. Col. } \\
\text { L\&PM Pocket. } \\
\text { Porto Alegre: } \\
\text { L\&PM Editores, } \\
2001 .\end{array}$ & VI-239, 1, 92 & $\begin{array}{l}\text { Paulo } \\
\text { Neves }\end{array}$ & DITRA & $\begin{array}{c}\text { Folha de rosto e } \\
\text { ficha } \\
\text { catalográfica }\end{array}$ & $\begin{array}{c}\text { Prefácio dos } \\
\text { editores }\end{array}$ & Não & Não & Não & $\begin{array}{l}\text { Edição de } \\
\text { bolso }\end{array}$ \\
\hline 2 & $\begin{array}{c}\text { BALZAC, } \\
\text { Honoré de. O } \\
\text { amor mascarado. } \\
\text { Rio de Janeiro: } \\
\text { Bom Texto, } \\
2003 .\end{array}$ & III-259, 1, 59 & $\begin{array}{l}\text { Carlos } \\
\text { Ancêde } \\
\text { Nouguê }\end{array}$ & DITRA & $\begin{array}{c}\text { Folha de rosto e } \\
\text { ficha } \\
\text { catalográfica }\end{array}$ & $\begin{array}{l}\text { 1. Apresentações } \\
\text { dos editores da } \\
\text { edição original } \\
\text { (Jean Gillequin e } \\
\text { Cia., Paris, 1911) } \\
\text { 2. Apêndice de } \\
\text { Antonio Olinto. }\end{array}$ & Não & Não & Não & \\
\hline 3 & $\begin{array}{c}\text { BALZAC, } \\
\text { Honoré de. Os } \\
\text { jornalistas. Rio } \\
\text { de Janeiro: }\end{array}$ & $\mathrm{I}-178,1,71$ & $\begin{array}{c}\text { João } \\
\text { Domenech }\end{array}$ & & $\begin{array}{c}\text { Folha de rosto e } \\
\text { ficha } \\
\text { catalográfica }\end{array}$ & $\begin{array}{l}\text { 1. Nota do editor. } \\
\text { 2. Prefácio de } \\
\text { Carlos Heitor }\end{array}$ & Não & Não & Não & $\begin{array}{c}\text { Menção à } \\
\text { tradução de } \\
\text { Paulo Rónai } \\
\text { de } A\end{array}$ \\
\hline
\end{tabular}




\begin{tabular}{|c|c|c|c|c|c|c|c|c|c|c|}
\hline & Ediouro, 1999. & & & & & Cony. & & & & $\begin{array}{l}\text { comédia } \\
\text { humana. }\end{array}$ \\
\hline 4 & $\begin{array}{c}\text { BALZAC, } \\
\text { Honoré de. “A } \\
\text { mulher de } 30 \\
\text { anos”. In } \\
\text { MACHADO, } \\
\text { Ivan Pinheiro } \\
\text { (org.). Prazeres e } \\
\text { riscos. Porto } \\
\text { Alegre: L\&PM, } \\
\text { 2001. }\end{array}$ & $\mathrm{I}-448,1,31$ & $\begin{array}{l}\text { Paulo } \\
\text { Neves }\end{array}$ & DITRA & $\begin{array}{c}\text { Folha de rosto e } \\
\text { ficha } \\
\text { catalográfica }\end{array}$ & $\begin{array}{c}\text { Biografia e } \\
\text { bibliografia do } \\
\text { autor. }\end{array}$ & Não & Não & Não & \\
\hline 5 & $\begin{array}{c}\text { BALZAC, } \\
\text { Honoré de. O pai } \\
\text { Goriot. São } \\
\text { Paulo: Estação } \\
\text { Liberdade, } 2002 .\end{array}$ & V-246, 1, 38 & $\begin{array}{c}\text { Marina } \\
\text { Apenzeller }\end{array}$ & & Quarta capa & $\begin{array}{l}\text { Apresentação de } \\
\text { Philippe Berthier } \\
\text { (professor da } \\
\text { Sorbonne). }\end{array}$ & Não & Não & Não & \\
\hline 6 & $\begin{array}{l}\text { BALZAC, } \\
\text { Honoré de. } \\
\text { Tratado dos } \\
\text { excitantes } \\
\text { modernos, } \\
\text { Fisiologia do } \\
\text { vestir e } \\
\text { Fisiologia } \\
\text { gastronômica. } \\
\text { São Paulo: }\end{array}$ & V-233, 6, 45 & $\begin{array}{c}\text { Zilda } \\
\text { Hutchinson } \\
\text { Schild Silva } \\
\text { e Carlos } \\
\text { Nougué }\end{array}$ & $\begin{array}{l}\text { DITRA } \\
\text { (Carlos } \\
\text { Nougué) }\end{array}$ & $\begin{array}{l}\text { Folha de rosto e } \\
\text { ficha } \\
\text { catalográfica }\end{array}$ & Não & Não & Não & Não & \\
\hline
\end{tabular}




\begin{tabular}{|c|c|c|c|c|c|c|c|c|c|c|}
\hline & $\begin{array}{l}\text { Landy Editora, } \\
2004 .\end{array}$ & & & & & & & & & \\
\hline 7 & $\begin{array}{c}\text { BALZAC, } \\
\text { Honoré de. A } \\
\text { mulher de trinta } \\
\text { anos. São Paulo: } \\
\text { Estação } \\
\text { Liberdade, } 2000 .\end{array}$ & VI-105, 5, 51 & $\begin{array}{c}\text { Marina } \\
\text { Appenzeller }\end{array}$ & & Quarta capa & $\begin{array}{c}\text { Prefácio de } \\
\text { Philippe Berthier } \\
\text { (professor da } \\
\text { Sorbonne). }\end{array}$ & $\begin{array}{c}\text { Orelhas: } \\
\text { comentário do } \\
\text { editor falando } \\
\text { do autor e da } \\
\text { obra. Breve } \\
\text { comentário } \\
\text { sobre a } \\
\text { tradução. }\end{array}$ & Não & Não & \\
\hline 8 & $\begin{array}{l}\text { BALZAC, } \\
\text { Honoré de. } \\
\text { Eugénie } \\
\text { Grandet. São } \\
\text { Paulo: Nova } \\
\text { Alexandria, } \\
2002 .\end{array}$ & V-226, 3, 46 & $\begin{array}{l}\text { Otto Lamy } \\
\text { de Correa }\end{array}$ & & $\begin{array}{l}\text { Folha de rosto e } \\
\text { ficha } \\
\text { catalográfica }\end{array}$ & $\begin{array}{c}\text { 1. Prefácio à } \\
\text { primeira edição } \\
\text { (Paris, setembro de } \\
\text { 1833) } \\
\text { 2. Posfácio à } \\
\text { primeira edição } \\
\text { (novembro de } \\
\text { 1833) }\end{array}$ & Não & Não & Não & \\
\hline 9 & $\begin{array}{l}\text { BALZAC, } \\
\text { Honoré de. } O \\
\text { lírio do vale. } \\
\text { Porto Alegre: } \\
\text { L\&PM, } 2006 .\end{array}$ & III-359, 4, 30 & $\begin{array}{c}\text { Rosa Freire } \\
\text { d'Aguiar }\end{array}$ & DITRA & $\begin{array}{c}\text { Folha de rosto e } \\
\text { ficha } \\
\text { catalográfica }\end{array}$ & $\begin{array}{l}\text { 1. Apresentação de } \\
\text { Ivan Pinheiro } \\
\text { Machado: } \\
\text { referência à } \\
\text { tradução de Paulo }\end{array}$ & Não & Não & Não & $\begin{array}{c}\text { Edição de } \\
\text { bolso }\end{array}$ \\
\hline
\end{tabular}

13 "O que restou desta obra, para além de algumas falhas de construção (por exemplo, Balzac usa condessa por marquesa, ao descrever a tia de Julie, pois com a Restauração a marquesa recuperaria seu título, mas isso não fica claro o suficiente para o leitor e aparece como lapso do autor - propositadamente não foi corrigido nesta tradução)...” 


\begin{tabular}{|c|c|c|c|c|c|c|c|c|c|}
\hline & & & & & $\begin{array}{c}\text { Rónai. } \\
\text { 2. . Introdução de } \\
\text { Ivan Pinheiro } \\
\text { Machado. }\end{array}$ & & & & \\
\hline 10 & $\begin{array}{l}\text { BALZAC, } \\
\text { Honoré de. } \\
\text { Ferragus: o } \\
\text { chefe dos } \\
\text { devoradores. } \\
\text { Porto Alegre: } \\
\text { L\&PM, } 2006 .\end{array}$ & III-359, 4, 31 & $\begin{array}{l}\text { William } \\
\text { Lagos }\end{array}$ & $\begin{array}{l}\text { Folha de rosto e } \\
\text { ficha } \\
\text { catalográfica }\end{array}$ & $\begin{array}{l}\text { 1. Apresentação de } \\
\text { Ivan Pinheiro } \\
\text { Machado: } \\
\text { referência à } \\
\text { tradução de Paulo } \\
\text { Rónai. } \\
\text { 2. . Introdução de } \\
\text { Ivan Pinheiro } \\
\text { Machado. }\end{array}$ & Não & Não & Não & $\begin{array}{l}\text { Edição de } \\
\text { bolso }\end{array}$ \\
\hline 11 & $\begin{array}{c}\text { BALZAC, } \\
\text { Honoré de. A } \\
\text { menina dos olhos } \\
\text { de ouro. Porto } \\
\text { Alegre: L\&PM, } \\
\text { 2006. }\end{array}$ & IV-408, 2, 56 & $\begin{array}{c}\text { Ilana } \\
\text { Heineberg }\end{array}$ & $\begin{array}{c}\text { Folha de rosto e } \\
\text { ficha } \\
\text { catalográfica. }\end{array}$ & $\begin{array}{l}\text { 1. Apresentação de } \\
\text { Ivan Pinheiro } \\
\text { Machado. } \\
\text { 2. Introdução de } \\
\text { Ivan Pinheiro } \\
\text { Machado. }\end{array}$ & Não & Não & Não & $\begin{array}{c}\text { Edição de } \\
\text { bolso }\end{array}$ \\
\hline 12 & $\begin{array}{c}\text { BALZAC, } \\
\text { Honoré de. } \\
\text { Eugênia } \\
\text { Grandet. } \\
\text { Coleção A Obra- }\end{array}$ & VI-411, 5, 11 & $\begin{array}{c}\text { Alex } \\
\text { Marins }\end{array}$ & $\begin{array}{c}\text { Folha de rosto e } \\
\text { ficha } \\
\text { catalográfica }\end{array}$ & $\begin{array}{l}\text { 1. Prefácio de } \\
\text { Martin Claret. } \\
\text { 2. Prefácio do } \\
\text { autor na primeira }\end{array}$ & Não & Não & Não & $\begin{array}{l}\text { Edição de } \\
\text { bolso a } \\
\text { baixo preço }\end{array}$ \\
\hline
\end{tabular}




\begin{tabular}{|c|c|c|c|c|c|c|c|c|c|}
\hline & $\begin{array}{l}\text { Prima de Cada } \\
\text { Autor. São } \\
\text { Paulo: Martin } \\
\text { Claret, } 2002 .\end{array}$ & & & & $\begin{array}{l}\text { edição. 3. Posfácio } \\
\text { da primeira edição. } \\
\text { 4. Biografia. } \\
\text { 5. Complemento de } \\
\text { leitura para } \\
\text { estudantes, com } \\
\text { esclarecimentos, } \\
\text { reflexões e } \\
\text { perguntas. }\end{array}$ & & & & \\
\hline 13 & $\begin{array}{c}\text { BALZAC, } \\
\text { Honoré de. Os } \\
\text { jornalistas. Rio } \\
\text { de Janeiro: } \\
\text { Ediouro, 2004. }\end{array}$ & VI-414, 4, 25 & $\begin{array}{c}\text { João } \\
\text { Domenech }\end{array}$ & $\begin{array}{l}\text { Folha de rosto e } \\
\text { ficha } \\
\text { catalográfica }\end{array}$ & $\begin{array}{l}\text { Prefácio de Carlos } \\
\text { Heitor Cony (o } \\
\text { mesmo da edição } \\
\text { de 1999). } \\
\text { 2. Nota da edição } \\
\text { francesa. }\end{array}$ & Não & Não & Não & \\
\hline 14 & $\begin{array}{c}\text { BALZAC, } \\
\text { Honoré de. A } \\
\text { mulher de trinta } \\
\text { anos. São Paulo: } \\
\text { Martin Claret, } \\
\text { 2006. Col. A } \\
\text { Obra-Prima de } \\
\text { Cada Autor. }\end{array}$ & & $\begin{array}{c}\text { Pietro } \\
\text { Nassetti }\end{array}$ & $\begin{array}{l}\text { Folha de rosto e } \\
\text { ficha } \\
\text { catalográfica }\end{array}$ & $\begin{array}{l}\text { 1. Prefácio de } \\
\text { Martin Claret. } \\
\text { 2. Perfil do autor e } \\
\text { Balzac no Brasil. } \\
\text { 3. Posfácio da } \\
\text { primeira. } \\
\text { 4. Biografia (ao } \\
\text { final) (4 páginas). }\end{array}$ & Não & Não & Não & $\begin{array}{c}\text { Edição de } \\
\text { bolso a } \\
\text { baixo preço. }\end{array}$ \\
\hline
\end{tabular}




\begin{tabular}{|c|c|c|c|c|c|c|c|c|c|c|}
\hline & & & & & & $\begin{array}{l}\text { 5. Complemento de } \\
\text { leitura para } \\
\text { estudantes, com } \\
\text { esclarecimentos, } \\
\text { reflexões e } \\
\text { perguntas. }\end{array}$ & & & & \\
\hline 15 & $\begin{array}{c}\text { BALZAC, } \\
\text { Honoré de. A } \\
\text { duquesa de } \\
\text { Langeais. Porto } \\
\text { Alegre: L\&PM, } \\
\text { 2006. }\end{array}$ & VI-412, 3, 35 & $\begin{array}{l}\text { Paulo } \\
\text { Neves }\end{array}$ & DITRA & $\begin{array}{l}\text { Folha de rosto e } \\
\text { ficha } \\
\text { catalográfica. }\end{array}$ & $\begin{array}{l}\text { 1. Apresentação de } \\
\text { Ivan Pinheiro } \\
\text { Machado } \\
\text { 2. Introdução de } \\
\text { Ivan Pinheiro } \\
\text { Machado }\end{array}$ & Não & Não & Não & $\begin{array}{l}\text { Edição de } \\
\text { bolso }\end{array}$ \\
\hline 16 & $\begin{array}{c}\text { BALZAC, } \\
\text { Honoré de. O pai } \\
\text { Goriot. Col. A } \\
\text { Obra-Prima de } \\
\text { Cada Autor. São } \\
\text { Paulo: Martin } \\
\text { Claret, } 2004 .\end{array}$ & & $\begin{array}{c}\text { Jean } \\
\text { Melville }\end{array}$ & & $\begin{array}{l}\text { Folha de rosto e } \\
\text { ficha } \\
\text { catalográfica. }\end{array}$ & $\begin{array}{l}\text { 1. Prefácio de } \\
\text { Martin Claret. } \\
\text { 2. Perfil biográfico. } \\
\text { 3. Complemento de } \\
\text { leitura para } \\
\text { estudantes, com } \\
\text { esclarecimentos, } \\
\text { reflexões e } \\
\text { perguntas. }\end{array}$ & Não & Não & Não & $\begin{array}{c}\text { Edição de } \\
\text { bolso a } \\
\text { baixo preço }\end{array}$ \\
\hline 17 & $\begin{array}{l}\text { BALZAC, } \\
\text { Honoré de. } \\
\text { Seráfita. Col. }\end{array}$ & $\mathrm{V}-469,2,23$ & $\begin{array}{l}\text { Carmen } \\
\text { Lúcia C. L. } \\
\text { Gerlach e }\end{array}$ & & Capa & $\begin{array}{l}\text { Prefácio das } \\
\text { tradutoras. }\end{array}$ & Sim & Sim & Sim & $\begin{array}{l}\text { Menção à } \\
\text { tradução na }\end{array}$ \\
\hline
\end{tabular}




\begin{tabular}{|c|c|c|c|c|c|c|c|c|c|}
\hline & $\begin{array}{c}\text { Paideuma. } \\
\text { Florianópolis: } \\
\text { Editora da } \\
\text { UFSC, } 2006 .\end{array}$ & & $\begin{array}{l}\text { Juliane } \\
\text { Bürger }\end{array}$ & & & & & & orelha \\
\hline 18 & $\begin{array}{l}\text { BALZAC, } \\
\text { Honoré de. } \\
\text { Eugênia } \\
\text { Grandet. São } \\
\text { Paulo: Planeta } \\
\text { DeAgostini, } \\
2003 .\end{array}$ & $\begin{array}{c}\text { III, 2, 3, 45, n. } \\
\text { 26, ARM }\end{array}$ & $\begin{array}{l}\text { Lello \& } \\
\text { Irmão } \\
\text { revista por } \\
\text { João Grave }\end{array}$ & $\begin{array}{c}\text { Ficha } \\
\text { catalográfica. }\end{array}$ & Não & Não & Não & Não & $\begin{array}{c}\text { Edição mini, } \\
\text { nenhum } \\
\text { paratexto. }\end{array}$ \\
\hline 19 & $\begin{array}{c}\text { BALZAC, } \\
\text { Honoré de. A } \\
\text { vendeta e A Paz } \\
\text { conjugal. Porto } \\
\text { Alegre: L\&PM, } \\
\text { 2006. }\end{array}$ & III-359, 4, 29 & $\begin{array}{l}\text { William } \\
\text { Lagos }\end{array}$ & $\begin{array}{l}\text { Folha de rosto e } \\
\text { ficha } \\
\text { catalográfica. }\end{array}$ & $\begin{array}{l}\text { 1. Apresentação de } \\
\text { Ivan Pinheiro } \\
\text { Machado. } \\
\text { 2. Introdução de } \\
\text { Ivan Pinheiro } \\
\text { Machado. }\end{array}$ & Não & Não & Não & $\begin{array}{l}\text { Edição de } \\
\text { bolso }\end{array}$ \\
\hline 20 & $\begin{array}{c}\text { BALZAC, } \\
\text { Honoré de. O } \\
\text { coronel Chabert. } \\
\text { Col. Clássicos } \\
\text { Saraiva. São } \\
\text { Paulo: Editora } \\
\text { Saraiva, } 2006 .\end{array}$ & VI-349, 1, 61 & $\begin{array}{c}\text { Nair } \\
\text { Lacerda }\end{array}$ & $\begin{array}{l}\text { Folha de rosto e } \\
\text { ficha } \\
\text { catalográfica. }\end{array}$ & $\begin{array}{l}\text { 1. Suplemento de } \\
\text { atividades (solto) } \\
\text { dirigido a } \\
\text { estudantes com } \\
\text { resumo e } \\
\text { perguntas. 2. Carta } \\
\text { ao leitor } \\
\text { explicando a } \\
\text { proposta da }\end{array}$ & Não & Não & Não & $\begin{array}{l}\text { Edição } \\
\text { didática }\end{array}$ \\
\hline
\end{tabular}




\begin{tabular}{|c|c|c|c|c|c|c|c|c|c|}
\hline & & & & & $\begin{array}{l}\text { coleção. 3. Diários } \\
\text { de um clássico } \\
\text { (pág. 83-95) (guia } \\
\text { de leitura para } \\
\text { estudantes e } \\
\text { professores. 4. } \\
\text { Contextualização } \\
\text { histórica (p. 99- } \\
\text { 105) (para } \\
\text { estudantes e } \\
\text { professores. }\end{array}$ & & & & \\
\hline 21 & $\begin{array}{l}\text { BALZAC, } \\
\text { Honoré de. } \\
\text { Ilusões perdidas. } \\
\text { São Paulo: } \\
\text { Estação } \\
\text { Liberdade, } 2007 .\end{array}$ & VI-377, 2, 16. & $\begin{array}{l}\text { Leila de } \\
\text { Aguiar } \\
\text { Costa }\end{array}$ & $\begin{array}{l}\text { Folha de rosto e } \\
\text { ficha } \\
\text { catalográfica. }\end{array}$ & $\begin{array}{c}\text { 1. Nota dos } \\
\text { editores: } \\
\text { apresentação da } \\
\text { edição completa. } 2 . \\
\text { Prefácios do autor. } \\
\text { 3. Vida e obra de } \\
\text { Balzac (pág. } 219 \text { a } \\
\text { 238). }\end{array}$ & Não & $\begin{array}{c}\text { Sim. } \\
\text { Apresenta } \\
\text { ção da } \\
\text { tradutora } \\
\text { (pag. 11- } \\
\text { 30), } \\
\text { qualificaç } \\
\text { ão da } \\
\text { tradutora } \\
\text { como } \\
\text { especialis } \\
\text { ta em } \\
\text { Balzac. }\end{array}$ & Não & $\begin{array}{c}\text { Muitas notas } \\
\text { da tradutora: } \\
\text { a maior parte } \\
\text { sobre } \\
\text { referentes } \\
\text { culturais, } \\
\text { mas também } \\
\text { sobre } \\
\text { problemas } \\
\text { de tradução. }\end{array}$ \\
\hline 22 & $\begin{array}{l}\text { BALZAC, } \\
\text { Honoré de. } \\
\text { Esplendores e }\end{array}$ & $\begin{array}{l}\text { Anexo II - } \\
772,2,39\end{array}$ & $\begin{array}{c}\text { Ilana } \\
\text { Heineberg }\end{array}$ & $\begin{array}{c}\text { Folha de rosto e } \\
\text { ficha }\end{array}$ & $\begin{array}{l}\text { 1. Apresentação de } \\
\text { Ivan Pinheiro } \\
\text { Machado. } 2 .\end{array}$ & Não & Não & Não & $\begin{array}{l}\text { Edição de } \\
\text { bolso. }\end{array}$ \\
\hline
\end{tabular}




\begin{tabular}{|c|c|c|c|c|c|c|c|c|c|c|}
\hline & $\begin{array}{l}\text { misérias das } \\
\text { cortesãs. Porto } \\
\text { Alegre: L\&PM, } \\
2006 .\end{array}$ & & & & catalográfica. & $\begin{array}{l}\text { Introdução de Ivan } \\
\text { Pinheiro Machado. }\end{array}$ & & & & \\
\hline 23 & $\begin{array}{c}\text { BALZAC, } \\
\text { Honoré de. A } \\
\text { vendeta e A Paz } \\
\text { conjugal. Porto } \\
\text { Alegre: L\&PM, } \\
2006 .\end{array}$ & III-359, 4, 29 & $\begin{array}{l}\text { William } \\
\text { Lagos }\end{array}$ & & $\begin{array}{l}\text { Folha de rosto e } \\
\text { ficha } \\
\text { catalográfica. }\end{array}$ & $\begin{array}{l}\text { 1. Apresentação de } \\
\text { Ivan Pinheiro } \\
\text { Machado. } 2 \text {. } \\
\text { Introdução de Ivan } \\
\text { Pinheiro Machado. }\end{array}$ & Não & Não & Não & $\begin{array}{c}\text { Edição de } \\
\text { bolso. }\end{array}$ \\
\hline 24 & $\begin{array}{c}\text { BALZAC, } \\
\text { Honoré de. O pai } \\
\text { Goriot. Porto } \\
\text { Alegre: L\&PM, } \\
\text { 2007. }\end{array}$ & $\begin{array}{c}\text { Anexo II - } \\
698,1,9\end{array}$ & $\begin{array}{l}\text { Celina } \\
\text { Portocarrer } \\
\text { o e Ilana } \\
\text { Heineberg }\end{array}$ & $\begin{array}{c}\text { DITRA } \\
\text { (Celina } \\
\text { Portocarrer } \\
\text { o) }\end{array}$ & $\begin{array}{l}\text { Folha de rosto e } \\
\text { ficha } \\
\text { catalográfica. }\end{array}$ & $\begin{array}{l}\text { 1. Apresentação de } \\
\text { Ivan Pinheiro } \\
\text { Machado. } \\
\text { 2. Introdução de } \\
\text { Ivan Pinheiro } \\
\text { Machado. }\end{array}$ & Não & Não & Não & $\begin{array}{c}\text { Edição de } \\
\text { bolso. }\end{array}$ \\
\hline 25 & $\begin{array}{c}\text { BALZAC, } \\
\text { Honoré de. A } \\
\text { vendeta e } A \text { Paz } \\
\text { conjugal. Porto } \\
\text { Alegre: L\&PM, } \\
\text { 2006. }\end{array}$ & III-359, 4, 29 & $\begin{array}{l}\text { William } \\
\text { Lagos }\end{array}$ & & $\begin{array}{l}\text { Folha de rosto e } \\
\text { ficha } \\
\text { catalográfica. }\end{array}$ & $\begin{array}{l}\text { 1. Apresentação de } \\
\text { Ivan Pinheiro } \\
\text { Machado. } \\
\text { 2. Introdução de } \\
\text { Ivan Pinheiro } \\
\text { Machado. }\end{array}$ & Não & Não & Não & $\begin{array}{l}\text { Edição de } \\
\text { bolso. }\end{array}$ \\
\hline
\end{tabular}




\begin{tabular}{|c|c|c|c|c|c|c|c|c|c|c|}
\hline 26 & $\begin{array}{l}\text { BALZAC, } \\
\text { Honoré de. } \\
\text { Esplendores e } \\
\text { misérias das } \\
\text { cortesãs. Porto } \\
\text { Alegre: L\&PM, } \\
\text { 2006. }\end{array}$ & $\begin{array}{c}\text { Anexo II - } \\
772,2,39\end{array}$ & $\begin{array}{c}\text { Ilana } \\
\text { Heineberg }\end{array}$ & & $\begin{array}{l}\text { Folha de rosto e } \\
\text { ficha } \\
\text { catalográfica. }\end{array}$ & $\begin{array}{l}\text { 1. Apresentação de } \\
\text { Ivan Pinheiro } \\
\text { Machado. } \\
\text { 2. Introdução de } \\
\text { Ivan Pinheiro } \\
\text { Machado. }\end{array}$ & Não & Não & Não & $\begin{array}{c}\text { Edição de } \\
\text { bolso. }\end{array}$ \\
\hline 27 & $\begin{array}{c}\text { BALZAC, } \\
\text { Honoré de. } \\
\text { Ilusões perdidas. } \\
\text { Porto Alegre: } \\
\text { L\&PM, 2007. }\end{array}$ & $\begin{array}{c}\text { Anexo II - } \\
807,3,44\end{array}$ & $\begin{array}{l}\text { Ivone C. } \\
\text { Benedetti }\end{array}$ & DITRA & $\begin{array}{l}\text { Folha de rosto e } \\
\text { ficha } \\
\text { catalográfica. }\end{array}$ & $\begin{array}{l}\text { 1. Apresentação de } \\
\text { Ivan Pinheiro } \\
\text { Machado. } \\
\text { 2. Introdução de } \\
\text { Ivan Pinheiro } \\
\text { Machado. }\end{array}$ & Não & Não & Não & $\begin{array}{c}\text { Edição de } \\
\text { bolso. }\end{array}$ \\
\hline 28 & $\begin{array}{c}\text { BALZAC, } \\
\text { Honoré de. } \\
\text { Tratados da vida } \\
\text { moderna. São } \\
\text { Paulo: Estação } \\
\text { Liberdade, 2009. }\end{array}$ & VI-43, 4, 19 & $\begin{array}{l}\text { Leila de } \\
\text { Aguiar } \\
\text { Costa }\end{array}$ & & Quarta capa. & $\begin{array}{c}\text { Vida e obra de } \\
\text { Balzac (pág. } 219 \text { a } \\
\text { 238). }\end{array}$ & Não & $\begin{array}{c}\text { Sim. } \\
\text { Posfácio } \\
\quad \text { da } \\
\text { tradutora } \\
\text { (pag. } \\
\text { 199-218). }\end{array}$ & Não & \\
\hline 29 & $\begin{array}{c}\text { BALZAC, } \\
\text { Honoré de. A } \\
\text { história dos treze } \\
\text { (Ferragus, A } \\
\text { duquesa de } \\
\text { Langeais, A } \\
\text { menina dos olhos }\end{array}$ & $\begin{array}{c}\text { Anexo VI- } \\
108,5,1\end{array}$ & $\begin{array}{c}\text { William } \\
\text { Lagos, } \\
\text { Paulo } \\
\text { Neves, } \\
\text { Ilana } \\
\text { Heineberg. }\end{array}$ & $\begin{array}{l}\text { DITRA } \\
\text { (Paulo } \\
\text { Neves) }\end{array}$ & $\begin{array}{l}\text { Folha de rosto e } \\
\text { ficha } \\
\text { catalográfica. }\end{array}$ & $\begin{array}{l}\text { 1. Apresentação de } \\
\text { Ivan Pinheiro } \\
\text { Machado. } \\
\text { 2. Nota publicada } \\
\text { ao final da edição } \\
\text { original de } A \\
\text { menina dos olhos }\end{array}$ & Não & Não & Não & \\
\hline
\end{tabular}




\begin{tabular}{|c|c|c|c|c|c|c|c|c|c|}
\hline & $\begin{array}{l}\text { de ouro). Porto } \\
\text { Alegre: L\&PM, } \\
2008 .\end{array}$ & & & & $\begin{array}{c}\text { de ouro. } 3 \text {. Texto } \\
\text { de Victor Hugo } \\
\text { lido no funeral em } \\
21 \text { de abril de } \\
1850 .\end{array}$ & & & & \\
\hline 30 & $\begin{array}{l}\text { BALZAC, } \\
\text { Honoré de. } \\
\text { Código dos } \\
\text { homens honestos. } \\
\text { Rio de Janeiro: } \\
\text { Nova Fronteira, } \\
2005 .\end{array}$ & III-16, 3, 29 & Léa Novaes & $\begin{array}{l}\text { Folha de rosto e } \\
\text { ficha } \\
\text { catalográfica. }\end{array}$ & $\begin{array}{l}\text { 1. Apresentação de } \\
\text { Flávio Moreira da } \\
\text { Costa. }\end{array}$ & Não & Não & Não & \\
\hline 31 & $\begin{array}{c}\text { BALZAC, } \\
\text { Honoré de. A } \\
\text { mulher de trinta } \\
\text { anos. Rio de } \\
\text { Janeiro: José } \\
\text { Olympio, 1948. }\end{array}$ & $\mathrm{I}-395,6,22$ & $\begin{array}{l}\text { Rachel de } \\
\text { Queiroz }\end{array}$ & Capa & Não & Não & Não & Não & $\begin{array}{c}\text { Sem } \\
\text { paratextos }\end{array}$ \\
\hline 32 & $\begin{array}{c}\text { BALZAC, } \\
\text { Honoré de. } \\
\text { Eugénie } \\
\text { Grandet. São } \\
\text { Paulo: Estação } \\
\text { Liberdade, 2009. }\end{array}$ & VI-436, 2, 61 & $\begin{array}{c}\text { Marina } \\
\text { Appenzeller }\end{array}$ & Quarta capa & $\begin{array}{l}\text { 1. Apresentação de } \\
\text { Pierre Citron (pág. } \\
9 \text { a 26. 2. Prefácio } \\
\text { à primeira edição, } \\
\text { 1833. 3. Posfácio à } \\
\text { primeira edição. } 4 . \\
\text { Vida e obra de } \\
\text { Balzac. }\end{array}$ & Não & Não & Não & \\
\hline
\end{tabular}




\begin{tabular}{|c|c|c|c|c|c|c|c|c|c|c|}
\hline 33 & $\begin{array}{c}\text { BALZAC, } \\
\text { Honoré de. Um } \\
\text { começo de vida. } \\
\text { Rio de Janeiro: } \\
\text { Garnier, } 1909 .\end{array}$ & VI-289, 1, 8 & $\begin{array}{c}\text { K. } \\
\text { D’Avellar }\end{array}$ & & $\begin{array}{l}\text { Folha de rosto e } \\
\text { ficha } \\
\text { catalográfica. }\end{array}$ & Não & Não & Não & Não & $\begin{array}{c}\text { Sem } \\
\text { paratextos. }\end{array}$ \\
\hline 34 & $\begin{array}{c}\text { BALZAC, } \\
\text { Honoré de. } \\
\text { Histórias } \\
\text { fascinantes. } \\
\text { Seleção, tradução } \\
\text { e prefácio de } \\
\text { Ruth Guimarães. } \\
\text { São Paulo: } \\
\text { Cultrix, [ ]. }\end{array}$ & & $\begin{array}{c}\text { Ruth } \\
\text { Guimarães }\end{array}$ & DITRA & $\begin{array}{l}\text { Folha de rosto e } \\
\text { ficha } \\
\text { catalográfica. }\end{array}$ & Não & $\begin{array}{c}\text { Orelhas: } \\
\text { importância do } \\
\text { autor, a } \\
\text { Comédia } \\
\text { Humana, } \\
\text { volume de } \\
\text { histórias curtas } \\
\text { selecionadas } \\
\text { pela tradutora (e } \\
\text { romancista). }\end{array}$ & Sim & Não & \\
\hline 35 & $\begin{array}{l}\text { BALZAC, } \\
\text { Honoré de. } \\
\text { Memórias de } \\
\text { duas jovens } \\
\text { casadas. Rio de } \\
\text { Janeiro: } \\
\text { Bibliotheca do } \\
\text { Correio da } \\
\text { Manhã, [ ]. }\end{array}$ & VI-302, 1, 29. & $\begin{array}{l}\text { Ernesto } \\
\text { Alves }\end{array}$ & & $\begin{array}{l}\text { Folha de rosto e } \\
\text { ficha } \\
\text { catalográfica. }\end{array}$ & Não & Não & Não & Não & $\begin{array}{c}\text { Sem } \\
\text { paratextos }\end{array}$ \\
\hline 36 & $\begin{array}{c}\text { BALZAC, } \\
\text { Honoré de. Um }\end{array}$ & VI-337, 3, 15 & $\begin{array}{l}\text { Ubiratan } \\
\text { Machado }\end{array}$ & & Capa & & Não & Sim & Não & \\
\hline
\end{tabular}




\begin{tabular}{|c|c|c|c|c|c|c|c|c|c|}
\hline & $\begin{array}{c}\text { caso tenebroso. } \\
\text { Col. Clássicos } \\
\text { Francisco Alves. } \\
\text { Rio de Janeiro: } \\
\text { Francisco Alves, } \\
1983 .\end{array}$ & & & & & & & & \\
\hline 37 & $\begin{array}{l}\text { BALZAC, } \\
\text { Honoré de. } \\
\text { Contos de } \\
\text { Balzac. São } \\
\text { Paulo: Cultrix, } \\
1986 .\end{array}$ & V-417, 1, 4. & $\begin{array}{c}\text { Ruth } \\
\text { Guimarães }\end{array}$ & DITRA & $\begin{array}{l}\text { Folha de rosto e } \\
\text { ficha } \\
\text { catalográfica. }\end{array}$ & & $\begin{array}{l}\text { Orelhas: } \\
\text { importância do } \\
\text { autor, a } \\
\text { Comédia } \\
\text { Humana, } \\
\text { volume de } \\
\text { histórias curtas } \\
\text { selecionadas } \\
\text { pela tradutora (e } \\
\text { romancista). }\end{array}$ & Sim & Não \\
\hline 38 & $\begin{array}{c}\text { BALZAC, } \\
\text { Honoré de. O pai } \\
\text { Goriot. Col. } \\
\text { Clássicos de } \\
\text { Bolso. Rio de } \\
\text { Janeiro: Ediouro, } \\
\text { 1994. }\end{array}$ & VI-27, 4, 45 & $\begin{array}{l}\text { Sergio } \\
\text { Rubens }\end{array}$ & & $\begin{array}{c}\text { Folha de rosto e } \\
\text { ficha } \\
\text { catalográfica }\end{array}$ & & & Sim & Não \\
\hline 39 & $\begin{array}{c}\text { BALZAC, } \\
\text { Honoré de. A } \\
\text { mulher de trinta } \\
\text { anos. São Paulo: }\end{array}$ & & $\begin{array}{l}\text { Casimiro } \\
\text { Fernandes e } \\
\text { Wilson }\end{array}$ & & $\begin{array}{l}\text { Folha de rosto e } \\
\text { ficha } \\
\text { catalográfica }\end{array}$ & $\begin{array}{l}\text { 1. Apresentação e } \\
\text { nota Paulo Rónai. } \\
\text { 2. Notas de Paulo }\end{array}$ & Não & Não & Não \\
\hline
\end{tabular}




\begin{tabular}{|c|c|c|c|c|c|c|c|c|c|c|}
\hline & $\begin{array}{l}\text { Abril Cultural, } \\
1985 .\end{array}$ & & Lousada & & & Rónai. & & & & \\
\hline 40 & $\begin{array}{c}\text { BALZAC, } \\
\text { Honoré de. A } \\
\text { pele de onagro. } \\
\text { Porto Alegre: } \\
\text { L\&PM, } 2008 .\end{array}$ & $\begin{array}{c}\text { Anexo II-808, } \\
1,22\end{array}$ & $\begin{array}{l}\text { Paulo } \\
\text { Neves }\end{array}$ & DITRA & $\begin{array}{c}\text { Folha de rosto e } \\
\text { ficha } \\
\text { catalográfica }\end{array}$ & $\begin{array}{l}\text { 1. Apresentação de } \\
\text { Ivan Pinheiro } \\
\text { Machado: a mesma } \\
\text { dos volumes } \\
\text { anteriores. } 2 \text {. } \\
\text { Introdução do } \\
\text { editor sobre Balzac } \\
\text { como precursor do } \\
\text { realismo mágico. } \\
\text { 3. Cronologia. }\end{array}$ & Não & Não & Não & $\begin{array}{l}\text { Sem orelhas. } \\
\text { Edição de } \\
\text { bolso. }\end{array}$ \\
\hline 41 & $\begin{array}{c}\text { BALZAC, } \\
\text { Honoré de. } \\
\text { Ascensão e } \\
\text { queda de César } \\
\text { Birotteau. Porto } \\
\text { Alegre: L\&PM, } \\
\text { 2009. }\end{array}$ & $\begin{array}{c}\text { Anexo II-462, } \\
5,46\end{array}$ & $\begin{array}{c}\text { Herculano } \\
\text { Villas-Boas }\end{array}$ & & $\begin{array}{c}\text { Folha de rosto e } \\
\text { ficha } \\
\text { catalográfica }\end{array}$ & $\begin{array}{l}\text { 1. Apresentação de } \\
\text { Ivan Pinheiro } \\
\text { Machado: a mesma } \\
\text { dos volumes } \\
\text { anteriores. } 2 \text {. } \\
\text { Introdução do } \\
\text { editor falando da } \\
\text { especificidade da } \\
\text { obra. } 3 . \\
\text { Cronologia. }\end{array}$ & Não & Não & Não & $\begin{array}{c}\text { Sem orelhas. } \\
\text { Edição de } \\
\text { bolso. }\end{array}$ \\
\hline 42 & $\begin{array}{c}\text { BALZAC, } \\
\text { Honoré de. } \\
\text { Eugénie } \\
\text { Grandet. Col. } \\
\text { Universidade de }\end{array}$ & $\begin{array}{c}\text { Anexo II, 810, } \\
\text { 2, } 55 .\end{array}$ & $\begin{array}{c}\text { Moacyr } \\
\text { Werneck de } \\
\text { Castro. }\end{array}$ & & Capa & $\begin{array}{l}\text { 1. Prefácio de } \\
\text { Fernando Góes. } \\
\text { 2. Introd., notas e } \\
\text { variantes de }\end{array}$ & Não & Não & Não & $\begin{array}{c}\text { Sem orelhas. } \\
\text { Edição de } \\
\text { bolso. }\end{array}$ \\
\hline
\end{tabular}




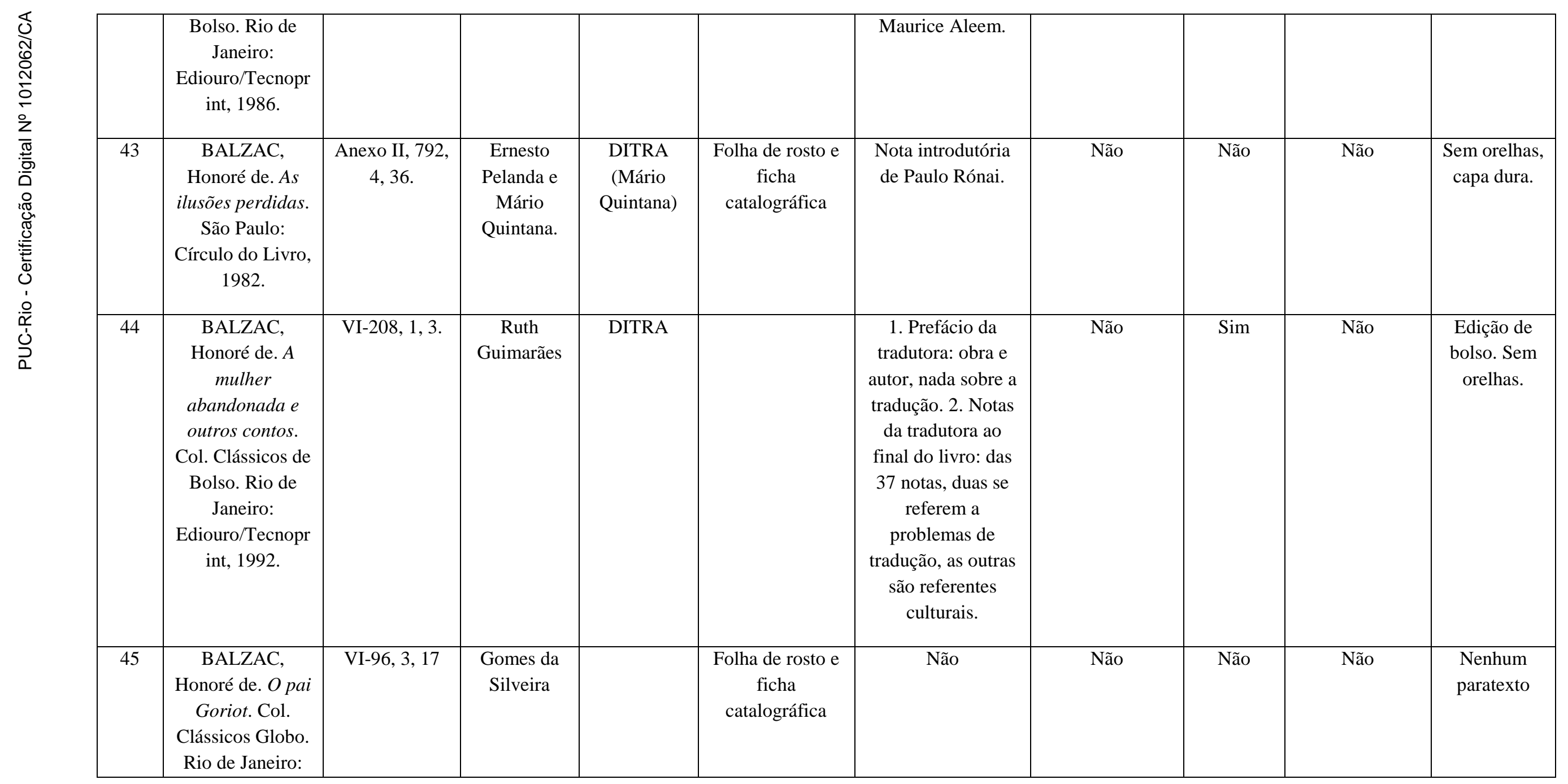




\begin{tabular}{|c|c|c|c|c|c|c|c|c|c|c|}
\hline & Globo, 1987. & & & & & & & & & \\
\hline 46 & $\begin{array}{c}\text { BALZAC, } \\
\text { Honoré de. Uma } \\
\text { paixão no } \\
\text { deserto. Col. Asa } \\
\text { Delta. São Paulo: } \\
\text { Ed. Paulinas, } \\
1988 .\end{array}$ & $\mathrm{V}-279,7,47$ & $\begin{array}{c}\text { Lúcia } \\
\text { Machado de } \\
\text { Almeida }\end{array}$ & & Capa & $\begin{array}{l}\text { 1. Apresentação da } \\
\text { coleção. } \\
\text { 2. Prefácio da } \\
\text { tradutora. }\end{array}$ & Não & Sim & Sim & Sem orelhas \\
\hline 47 & $\begin{array}{c}\text { BALZAC, } \\
\text { Honoré de. Os } \\
\text { melhores contos } \\
\text { de Balzac. São } \\
\text { Paulo: Círculo do } \\
\text { Livro, [ ]. }\end{array}$ & $\mathrm{V}-418,4,8$. & $\begin{array}{c}\text { Ruth } \\
\text { Guimarães }\end{array}$ & DITRA & $\begin{array}{c}\text { Folha de rosto e } \\
\text { ficha } \\
\text { catalográfica }\end{array}$ & $\begin{array}{c}\text { Prefácio da } \\
\text { tradutora: o mesmo } \\
\text { apresentado em } \\
\text { edições anteriores, } \\
\text { nenhuma menção à } \\
\text { tradução. }\end{array}$ & Não & Sim & Não & Sem orelhas \\
\hline 48 & $\begin{array}{c}\text { BALZAC, } \\
\text { Honoré de. A } \\
\text { mulher de trinta } \\
\text { anos. Col. } \\
\text { Universidade de } \\
\text { Bolso. Rio de } \\
\text { Janeiro: } \\
\text { Ediouro/Tecnopr } \\
\text { int, 1988. }\end{array}$ & $\mathrm{I}-154,2,43$ & $\begin{array}{l}\text { Marques } \\
\text { Rebelo }\end{array}$ & & Сара & $\begin{array}{l}\text { 1. Prefácio de H. } \\
\text { Perdigão: verbete } \\
\text { do Dicionário } \\
\text { Universal de } \\
\text { Literatura. 2. Nota: } \\
\text { história da obra e } \\
\text { do personagem. }\end{array}$ & Não & Não & Não & $\begin{array}{l}\text { Não tem } \\
\text { orelhas. } \\
\text { Edição de } \\
\text { bolso }\end{array}$ \\
\hline 49 & $\begin{array}{c}\text { BALZAC, } \\
\text { Honoré de. A } \\
\text { mulher de trinta }\end{array}$ & & $\begin{array}{l}\text { Casimiro } \\
\text { Fernandes e } \\
\text { Wilson }\end{array}$ & & $\begin{array}{c}\text { Folha de rosto e } \\
\text { ficha } \\
\text { catalográfica }\end{array}$ & $\begin{array}{l}\text { 1. Prefácio de } \\
\text { Paulo Rónai (o } \\
\text { mesmo que }\end{array}$ & Não & Não & Não & \\
\hline
\end{tabular}




\begin{tabular}{|c|c|c|c|c|c|c|c|c|c|c|}
\hline & $\begin{array}{c}\text { anos. São Paulo: } \\
\text { Círculo do Livro, } \\
\text { [ ] }\end{array}$ & & Louzada & & & $\begin{array}{l}\text { aparece em outras } \\
\text { edições). } 2 \text {. } \\
\text { Posfácio: o autor e } \\
\text { sua obra. }\end{array}$ & & & & \\
\hline 50 & $\begin{array}{c}\text { BALZAC, } \\
\text { Honoré de. A } \\
\text { comédia } \\
\text { humana. Vol. III. } \\
\text { São Paulo: } \\
\text { Globo, } 1989 .\end{array}$ & & $\begin{array}{l}\text { Vidal de } \\
\text { Oliveira }\end{array}$ & & $\begin{array}{l}\text { Folha de rosto e } \\
\text { ficha } \\
\text { catalográfica }\end{array}$ & $\begin{array}{l}\text { 1. Orientação, } \\
\text { introduções e notas } \\
\text { de Paulo Rónai. } \\
\text { Nas introduções de } \\
\text { Rónai nada se fala } \\
\text { sobre tradução, } \\
\text { mas sobre o autor e } \\
\text { a obra. Nas notas, } \\
\text { muitas, há } \\
\text { comentários sobre } \\
\text { referentes } \\
\text { culturais, } \\
\text { distrações de } \\
\text { Balzac, e questões } \\
\text { de tradução (em } \\
\text { menor número). }\end{array}$ & Não & Não & Não & $\begin{array}{l}\text { Um dos } \\
\text { volumes da } \\
\text { edição } \\
\text { completa da } \\
\text { obra pela } \\
\text { Editora } \\
\text { Globo. }\end{array}$ \\
\hline 51 & $\begin{array}{c}\text { BALZAC, } \\
\text { Honoré de. A } \\
\text { pele de onagro. } \\
\text { Col. Clássicos de } \\
\text { Bolso. Rio de } \\
\text { Janeiro: } \\
\text { Ediouro/Tecnopr }\end{array}$ & IV-23, 7, 20 & $\begin{array}{c}\text { Fernando } \\
\text { Py }\end{array}$ & DITRA & Сара & Não & Não & Não & Não & $\begin{array}{l}\text { Edição de } \\
\text { bolso. Sem } \\
\text { orelhas. }\end{array}$ \\
\hline
\end{tabular}




\begin{tabular}{|c|c|c|c|c|c|c|c|c|c|}
\hline & int, 1996. & & & & & & & & \\
\hline 52 & $\begin{array}{c}\text { BALZAC, } \\
\text { Honoré de. A } \\
\text { comédia } \\
\text { humana. Vol. II. } \\
\text { Trad. São Paulo: } \\
\text { Globo, } 1989 .\end{array}$ & $\mathrm{I}-193,1,1$. & $\begin{array}{l}\text { Vidal de } \\
\text { Oliveira }\end{array}$ & $\begin{array}{l}\text { Folha de rosto e } \\
\text { ficha } \\
\text { catalográfica }\end{array}$ & $\begin{array}{l}\text { 1. Orientação, } \\
\text { introduções e notas } \\
\text { de Paulo Rónai. } \\
\text { Nas introduções de } \\
\text { Rónai nada se fala } \\
\text { sobre tradução, } \\
\text { mas sobre o autor e } \\
\text { a obra. Nas notas, } \\
\text { muitas, há } \\
\text { comentários sobre } \\
\text { referentes } \\
\text { culturais, } \\
\text { distrações de } \\
\text { Balzac, e questões } \\
\text { de tradução (em } \\
\text { menor número). }\end{array}$ & Não & Não & Não & $\begin{array}{l}\text { Um dos } \\
\text { volumes da } \\
\text { edição } \\
\text { completa da } \\
\text { obra pela } \\
\text { Editora } \\
\text { Globo. }\end{array}$ \\
\hline 53 & $\begin{array}{c}\text { BALZAC, } \\
\text { Honoré de. A } \\
\text { prima Bete. Col. } \\
\text { Clássicos de } \\
\text { Bolso. Rio de } \\
\text { Janeiro: } \\
\text { Ediouro/Tecnopr } \\
\text { int, 1993. }\end{array}$ & IV-23, 3, 37 & Celina Luz & Сара & Não & Não & Não & Não & $\begin{array}{c}\text { Edição de } \\
\text { bolso. Sem } \\
\text { orelhas. }\end{array}$ \\
\hline 54 & $\begin{array}{l}\text { BALZAC, } \\
\text { Honoré de. } O\end{array}$ & III-13, 5, 41. & N/A & & Nota biográfica: & Não & Não & Não & $\begin{array}{l}\text { Não tem } \\
\text { outros }\end{array}$ \\
\hline
\end{tabular}




\begin{tabular}{|c|c|c|c|c|c|c|c|c|c|c|}
\hline & $\begin{array}{l}\text { lírio do vale. } \\
\text { Col. Grandes } \\
\text { Romances } \\
\text { Universais. São } \\
\text { Paulo: W. M. } \\
\text { Jackson, } 1959 .\end{array}$ & & & & & sobre o autor. & & & & $\begin{array}{c}\text { paratextos, } \\
\text { nem orelhas, } \\
\text { capa dura, } \\
\text { sem } \\
\text { ilustrações. }\end{array}$ \\
\hline 55 & $\begin{array}{c}\text { BALZAC, } \\
\text { Honoré de. O } \\
\text { primo Pons. Col. } \\
\text { Clássicos de } \\
\text { Bolso. Rio de } \\
\text { Janeiro: } \\
\text { Ediouro/Tecnopr } \\
\text { int, 1997. }\end{array}$ & $\mathrm{I}-5,3,56$ & $\begin{array}{l}\text { Fernando } \\
\text { Py }\end{array}$ & DITRA & Сара & $\begin{array}{c}\text { Introdução do } \\
\text { tradutor: sobre a } \\
\text { obra, nenhuma } \\
\text { menção à tradução. }\end{array}$ & Não & Não & Não & $\begin{array}{l}\text { Edição de } \\
\text { bolso. Sem } \\
\text { orelhas. }\end{array}$ \\
\hline 56 & $\begin{array}{l}\text { BALZAC, } \\
\text { Honoré de. A } \\
\text { mulher de trinta } \\
\text { anos. Col. } \\
\text { Imortais da } \\
\text { Literatura } \\
\text { Universal. São } \\
\text { Paulo: Nova } \\
\text { Cultural, [ ]. }\end{array}$ & & N/A & & & $\begin{array}{c}\text { Biografia de } \\
\text { Balzac. }\end{array}$ & Não & Não & Não & $\begin{array}{c}\text { Sem orelhas, } \\
\text { nada na } \\
\text { quarta capa. }\end{array}$ \\
\hline 57 & $\begin{array}{c}\text { BALZAC, } \\
\text { Honoré de. O } \\
\text { xale de selim e } \\
\text { outros contos. }\end{array}$ & & $\begin{array}{c}\text { Ruth } \\
\text { Guimarães }\end{array}$ & DITRA & $\begin{array}{c}\text { Folha de rosto e } \\
\text { ficha } \\
\text { catalográfica }\end{array}$ & $\begin{array}{c}\text { Seleção dos contos } \\
\text { a partir de } A \\
\text { Mulher } \\
\text { Abandonada e }\end{array}$ & Não & Não & Não & $\begin{array}{c}\text { Seleção dos } \\
\text { textos de } \\
\text { Maura }\end{array}$ \\
\hline
\end{tabular}




\begin{tabular}{|c|c|c|c|c|c|c|c|c|c|c|}
\hline & $\begin{array}{l}\text { Rio de Janeiro: } \\
\text { Ediouro, } 1996 .\end{array}$ & & & & & Outros Contos. & & & & Sardinha. \\
\hline 58 & $\begin{array}{c}\text { BALZAC, } \\
\text { Honoré de. A } \\
\text { mulher de trinta } \\
\text { anos. Col. } \\
\text { L\&PM Pocket. } \\
\text { Porto Alegre: } \\
\text { L\&PM, 1999. }\end{array}$ & $\mathrm{I}-417,1,47$ & $\begin{array}{l}\text { Paulo } \\
\text { Neves }\end{array}$ & DITRA & $\begin{array}{c}\text { Folha de rosto e } \\
\text { ficha } \\
\text { catalográfica }\end{array}$ & $\begin{array}{c}\text { Prefácio dos } \\
\text { editores falando da } \\
\text { obra. }\end{array}$ & Não & Não & Não & $\begin{array}{c}\text { Edição de } \\
\text { bolso. }\end{array}$ \\
\hline 59 & $\begin{array}{c}\text { BALZAC, } \\
\text { Honoré de. } \\
\text { Eugénie } \\
\text { Grandet. Col. } \\
\text { Biblioteca Folha, } \\
\text { Clássicos da } \\
\text { Literatura } \\
\text { Universal. Rio de } \\
\text { Janeiro: Ediouro; } \\
\text { São Paulo: } \\
\text { Publifolha, 1998. }\end{array}$ & $\mathrm{I}-47,3,25$ & $\begin{array}{c}\text { Moacyr } \\
\text { Werneck de } \\
\text { Castro }\end{array}$ & & $\begin{array}{c}\text { Folha de rosto e } \\
\text { ficha } \\
\text { catalográfica }\end{array}$ & $\begin{array}{c}\text { 1. Prefácio da } \\
\text { primeira edição. } 2 . \\
\text { Posfácio da } \\
\text { primeira edição. } 3 . \\
\text { Posfácio de } \\
\text { Fernando Góes: a } \\
\text { obra. } 4 \text {. Posfácio } \\
\text { de Maurice Allem: } \\
\text { os personagens e a } \\
\text { história do } \\
\text { romance. }\end{array}$ & Não & Não & Não & \\
\hline 60 & $\begin{array}{c}\text { BAUDELAIRE, } \\
\text { Charles. } \\
\text { Pequenos } \\
\text { poemas em }\end{array}$ & VI-187, 2, 52 & $\begin{array}{c}\text { Dorothée de } \\
\text { Bruchard }\end{array}$ & DITRA & Capa & $\begin{array}{l}\text { Prefácio da } \\
\text { tradutora }\end{array}$ & Não & Sim & Não & $\begin{array}{l}\text { Orelhas: } \\
\text { Orelhas de } \\
\text { Walter } \\
\text { Carlos }\end{array}$ \\
\hline
\end{tabular}




\begin{tabular}{|c|c|c|c|c|c|c|c|c|c|c|}
\hline & $\begin{array}{l}\text { prosa. Ed. } \\
\text { Bilíngue. } \\
\text { Florianópolis: } \\
\text { Editora da } \\
\text { UFSC, } 1996 .\end{array}$ & & & & & & & & & $\begin{array}{l}\text { Costa, "Paris } \\
\text { é aqui”. }{ }^{14} \\
\text { CV da } \\
\text { tradutora. }^{15}\end{array}$ \\
\hline 61 & $\begin{array}{c}\text { BAUDELAIRE, } \\
\text { Charles. Flores } \\
\text { das "flores do }\end{array}$ & $\begin{array}{c}\text { ANEXO II - } \\
876,1,06\end{array}$ & $\begin{array}{l}\text { Guilherme } \\
\text { de Almeida }\end{array}$ & DITRA & $\begin{array}{c}\text { Folha de rosto e } \\
\text { ficha } \\
\text { catalográfica }\end{array}$ & Não & Não & Não & Não & $\begin{array}{l}\text { Edição } \\
\text { bilíngue, } \\
\text { sem }\end{array}$ \\
\hline
\end{tabular}

14 "Eis a segunda edição, cuidadosamente revisada, deste clássico da modernidade que é Pequenos poemas em prosa, em tradução de Dorothée de Bruchard. A primeira edição, de 1988, encontra-se esgotada há algum tempo e um novo texto se impunha para os muitos que procuravam esta versão. Neste intervalo, a tradutora acumulou experiência como leitora, tradutora e revisora de traduções de Baudelaire e outros autores franceses.

A singularidade desta tradução reside em produzir, a partir de um exame minucioso do original, um texto brasileiro preciso, consistente e elegante. A tradutora, embora bilíngue e com formação universitária em literatura comparada, não confiou no mero instinto nem seguiu simplesmente as leituras canônicas. Esteve o tempo todo atenta contra os automatismos todos que impedem ver o detalhe inovador, o pequeno desvio decisivo e a presença da tradição, forte em tantas passagens. Em outras palavras, não pretendeu supermodernizar Baudelaire nem adaptá-lo aos nossos particulares costumes modernistas. O resultado é um Baudelaire radical, mas que divide com outros escritores de seu país e tempo, ideias, preferências estéticas e padrões estilísticos. A tradutora resistiu também à tentação - que às vezes produz reais resultados - de sobrepor sua dicção à do poeta, já tão típica e perfeitamente passável ao português.

O leitor encontrará neste livro Baudelaire em toda sua grandeza e singularidade. A grande cidade com seus esplendores e misérias aparece aqui filtrada pela sensibilidade do poeta que se solidariza com os excluídos e os solitários, mas sem sentimentalismo. A ironia, que inclui a auto-ironia, e o sarcasmo percorrem todo o texto, onde o desencanto se mistura com certo entusiasmo pelas novas possibilidades trazidas pela metrópole moderna. Vemos o poeta ora cantar ora lamentar a multidão e o vemos fustigar incansavelmente a mediocridade e sonhar com a fraternidade futura ou com a evasão a lugares remotos e exóticos.

O mais surpreendente, contudo, é que a expressão desta nova percepção se dá de modo pessoal e original, em que as velhas virtudes francesas da frase se combinam com a revolução do poema em prosa, que Baudelaire eleva e fixa como forma. Ao contrário de outros inovadores da literatura, Baudelaire é bem acessível ao leitor esforçado e ao que ele disse da Paris do século XIX pode ser sentido por quem tem a vivência, direta ou virtual, das grandes urbes brasileiras deste século. Não será por acaso que sua obra vem ganhando numerosas traduções entre nós. Chegamos tarde, e incompletamente, à modernidade, mas nossa adesão parece entusiasmada e Baudelaire nos ajuda a senti-la e a conhecê-la e, também, a conhecer-nos melhor”.

15 “A TRADUTORA - Dorothée de Bruchard nasceu em Porto Alegre, em 1958. Na Universidade Federal de Santa Catarina cursou a graduação em Letras, na Aliança Francesa fez o Nancy e veio depois a dar aula. Mas nascida de pais franceses, a vivência em dois países e a busca do equilíbrio entre duas culturas é que a levaram, quase que naturalmente, ao ato de traduzir.

Para a L\&PM traduziu quadrinhos (...) ; para publicações UFSC e o Jornal de Santa Catarina, textos de Flaubert, Valéry, Victor Hugo, Rousseau e Baudelaire”. 


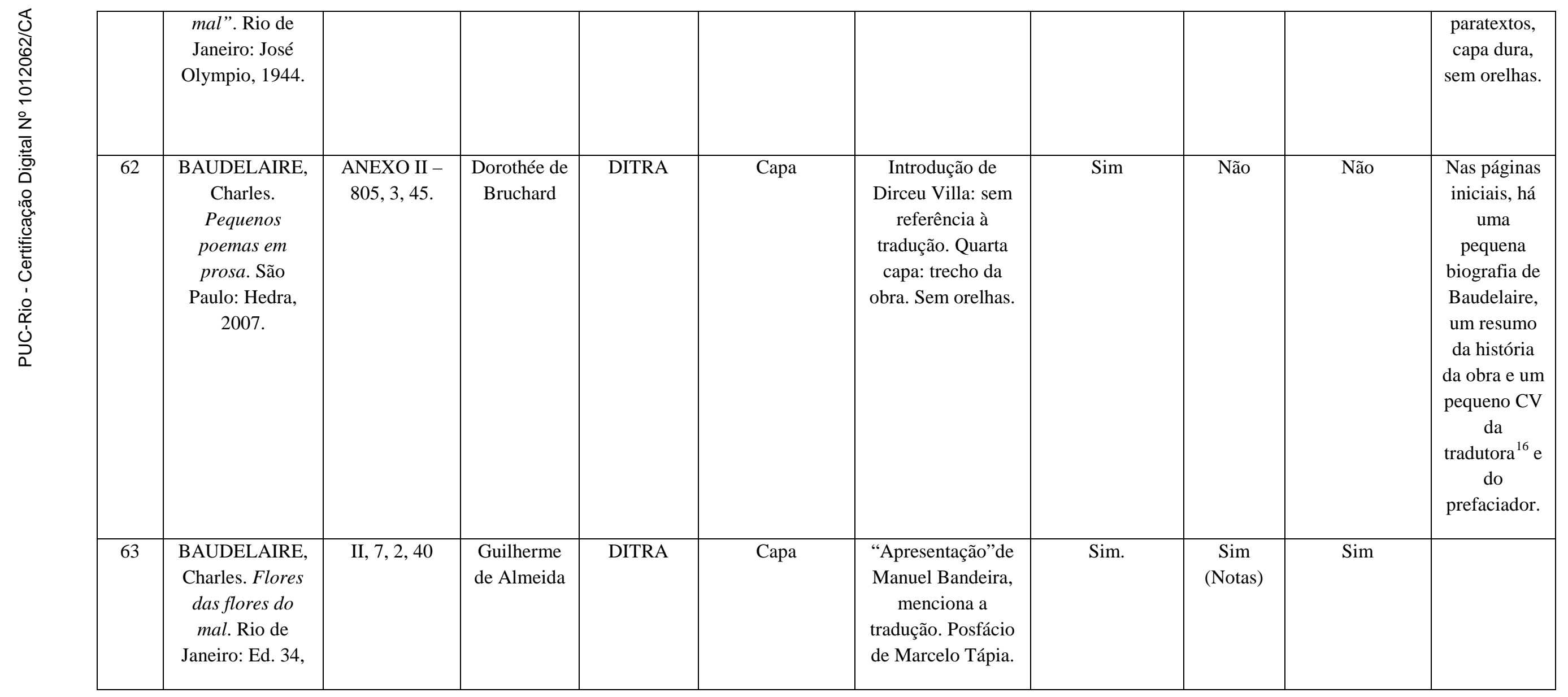

16 "Dorothée de Bruchard é graduada em letras, pela Universidade Federal de Santa Catarina, e mestra em Literatura Comparada pela University of Nottingham, Inglaterra. Em 1993 funda a Editora Paraula, dedicada à publicação de clássicos em edições bilíngues. Traduziu Rousseau, Mallarmé, Cendrars, Schwob e atualmente coordena a ONG Escritório do Livro, onde pesquisa a história e a arte do livro”. 


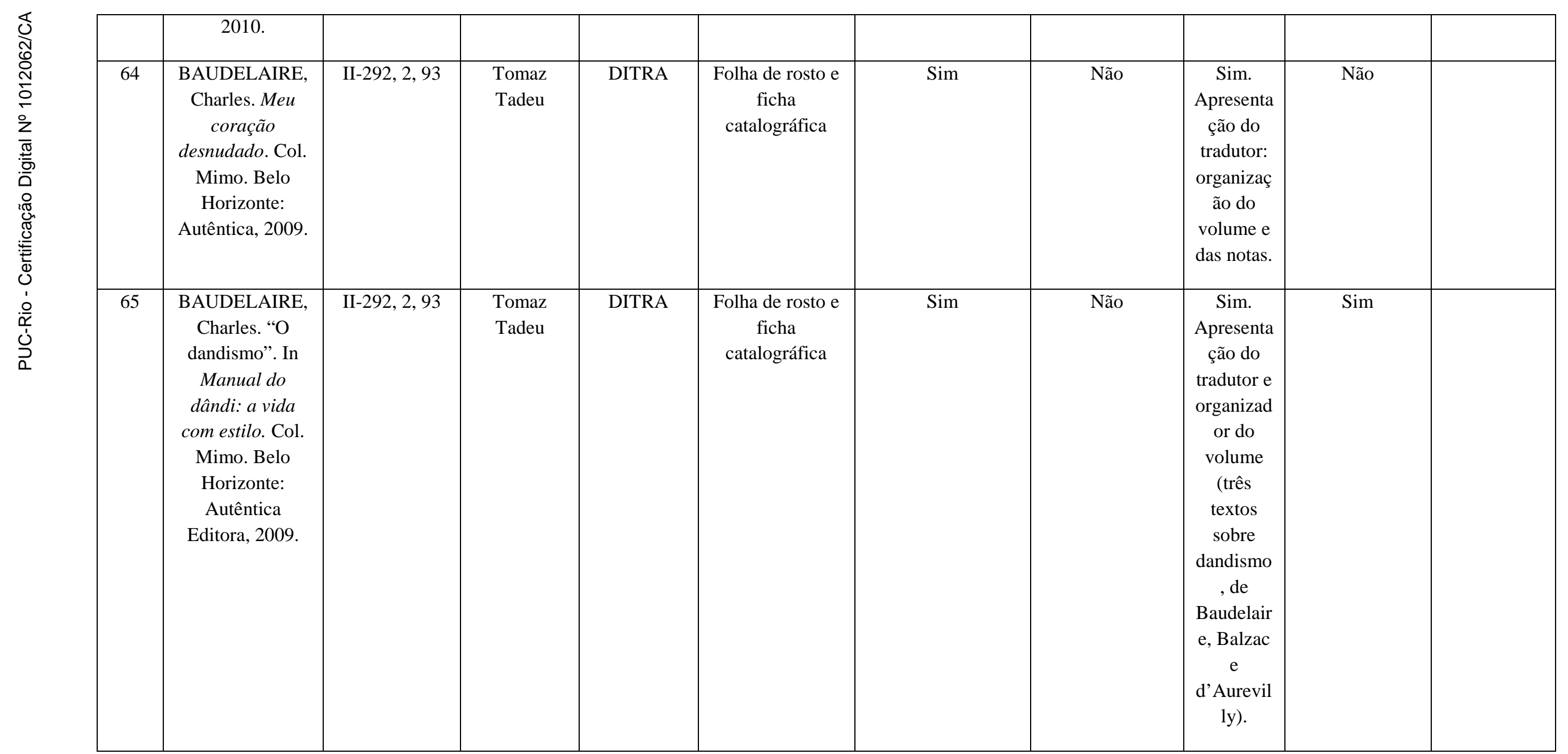




\begin{tabular}{|c|c|c|c|c|c|c|c|c|c|}
\hline 66 & $\begin{array}{c}\text { BAUDELAIRE, } \\
\text { Charles. O } \\
\text { desejo de pintar } \\
\text { e outros poemas } \\
\text { em prosa. São } \\
\text { Paulo: Noovha } \\
\text { America, } 2008 .\end{array}$ & I-469, 3, 01 & Mario Vale & $\begin{array}{l}\text { Capa e quarta } \\
\text { capa, ressaltando } \\
\text { que o tradutor } \\
\text { foi também o } \\
\text { ilustrador da } \\
\text { obra. }\end{array}$ & $\begin{array}{l}\text { Sim. "Conversa } \\
\text { entre dois } \\
\text { pintores", texto de } \\
\text { Denise Cantuárya } \\
\text { (organizadora) }^{17}\end{array}$ & Sim & Não & Não & $\begin{array}{c}\text { Ao final do } \\
\text { volume, há } \\
\text { uma } \\
\text { biografia de } \\
\text { Baudelaire e } \\
\text { do } \\
\text { tradutor/ilust } \\
\text { rador Mario } \\
\text { Vale (com } \\
\text { foto) }\end{array}$ \\
\hline 67 & $\begin{array}{l}\text { BAUDELAIRE, } \\
\text { Charles. }\end{array}$ & IV-224, 2, 7 & $\begin{array}{c}\text { Gilson } \\
\text { Maurity }\end{array}$ & Capa & $\begin{array}{l}\text { Sim. Introdução de } \\
\text { Ivo Barroso }{ }^{19}\end{array}$ & Sim & Não & Não & \\
\hline
\end{tabular}

17 "Em O desejo de pintar e outros poemas em prosa de Charles Baudelaire, Mario Vale cria as imagens ao mesmo tempo em que elas ajudam a inaugurar uma nova fase em seu trabalho. O já conhecido ilustrador das cenas do cotidiano infantil com recorte/colagem, dos cartoons bem-humorados e dos livros de imagens, apresenta, agora, ao público, o seu lado tradutor.

Melhor contando o seu lado leitor de poesia, Mario reescreveu os textos na tradução, partilhou dos conflitos do autor diante da sociedade francesa do século XIX, período no qual foram criados os poemas, e só depois gerou as imagens. Conviveu com a contradição entre se aprofundar na obra do poeta e o medo de não dar conta da árdua tarefa imposta por essa tradução: ‘É muita responsabilidade traduzir esse poeta, eu sou apenas um apaixonado pelos textos...' (...)

Providenciar versões do impossível é a tarefa do artista. Escolher um autor para ser recriado na tradução e na ilustração é uma opção crítica e uma possibilidade fascinante de reler um texto! Nesse sentido, a voz do poeta francês Charles Baudelaire é elaborada em $O$ desejo de pintar, ampliando o acesso ao poema em sua língua original de maneira inquietante por Mario Vale”. (pág. 3-4)

18 "Mario Vale nasceu em Belo Horizonte, onde vive e trabalha em eu ateliê voltado para as montanhas, num local chamado Retiro das Pedras.

Formado em Direito pela Universidade Católica de Minas Gerais, atualmente, conjuga as atividades de artista plástico, cartunista, programador visual e autor/ilustrador de livros infantis. (...)

O desejo de pintar e outros poemas em prosa de Charles Baudelaire é, para Mario, um novo movimento, uma improvisação, um exercício de leitura expresso na tradução dos textos, nos desenhos e na admiração sobre o poeta relatada a dois amigos em uma conversa mineira.” (pág. 42)

19 "Parece que se deve a Paulo M. Oliveira a mais antiga tradução brasileira desses poemas, que saíram pela editora Athena em 1937. A mais difundida é sem dúvida a de Aurélio Buarque de Holanda, publicada inicialmente em 1950 pela Livraria José Olympio Editora, na Coleção Rubáiyát, e reeditada a partir de 1977 pela Nova Fronteira. O prof. Aurélio, responsável por um dos mais abalizados dicionários da língua, fez uma tradução castiça, que pode ser considerada clássica. Em 1996, surgiu outra, vinda de 


\begin{tabular}{|c|c|c|c|c|c|c|c|c|c|}
\hline & $\begin{array}{c}\text { Pequenos } \\
\text { poemas em } \\
\text { prosa. Col. } \\
\text { Grandes } \\
\text { Traduções. Rio } \\
\text { de Janeiro: } \\
\text { Record, 2006. }\end{array}$ & & & & & & & & \\
\hline 68 & $\begin{array}{l}\text { BAUDELAIRE, } \\
\text { Charles. Escritos } \\
\text { sobre a arte. São } \\
\text { Paulo: Hedra, } \\
\text { 2008. }\end{array}$ & II-446, 1, 39 & $\begin{array}{c}\text { Plínio } \\
\text { Augusto } \\
\text { Coêlho }\end{array}$ & Capa & $\begin{array}{l}\text { Sim. Introdução, } \\
\text { de Dirceu Villa. }\end{array}$ & Não & Não & Não & $\begin{array}{c}\text { Numa } \\
\text { página } \\
\text { inicial, } \\
\text { consta uma } \\
\text { biografia de } \\
\text { Baudelaire, } \\
\text { uma } \\
\text { explicação } \\
\text { sobre a obra, }\end{array}$ \\
\hline
\end{tabular}

Florianópolis, editada pela Universidade de lá, e devida a Dorothée de Bruchard. Com o título de Spleen de Paris, temos a edição portuguesa da Divulgação, Porto, de 1963, e a brasileira de Leda Tenório da Mota, da Imago, com data de 1995. A tradução de Aurélio foi escolhida por nós, com algumas alterações, para figurar na obra Poesia e prosa de Charles Baudelaire, da Nova Aguilar, de 1995.

O leitor tem agora às mãos uma nova tradução, a de Gilson Maurity, feita pelo prazer de transpor para a sua língua um texto pelo qual se havia apaixonado. Sabe-se que uma das melhores maneiras de se ler um texto é traduzindo-o, pois muito se aprende com a tradução, que proporciona uma intimidade maior com as palavras que, se somente lidas, passam por nossos olhos muitas vezes sem despertar toda a carga significativa que conservam. Feita, assim, por uma necessidade visceral, esta difere das demais por ter seu autor se esmerado em torná-la acessível ao grande público, evitando rebuscamentos de estilo ou utilização de palavras pouco frequentes na linguagem atual. Enfim, uma edição ao alcance até mesmo dos leitores que achavam Baudelaire um autor difícil”. (pág. 9) 


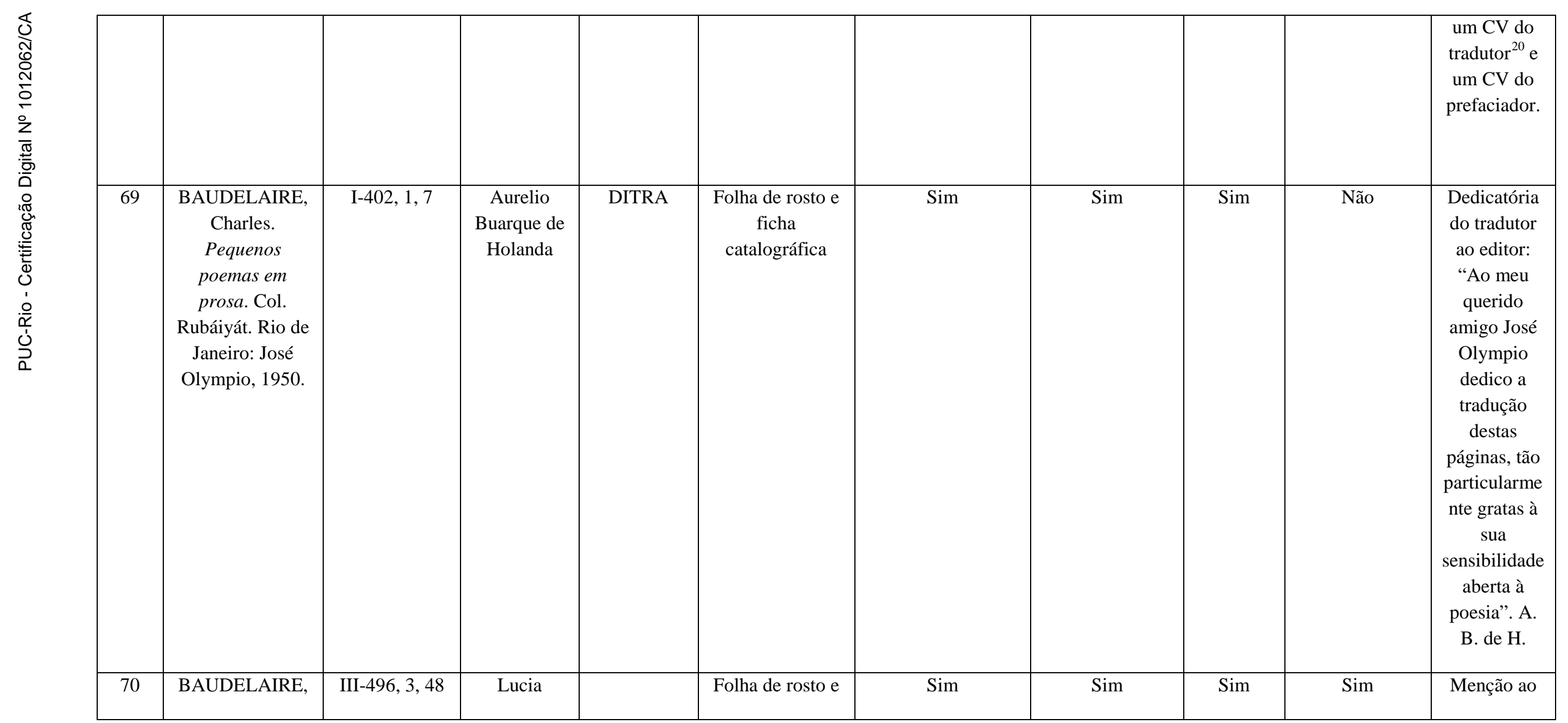

20 "Plínio Augusto Coêlho fundou em 1984 a Novos Tempos Editora, em Brasília, dedicada à publicação de obras libertárias. A partir de 1989, transfere-se para São Paulo, onde cria a Editora Imaginário, mantendo a mesma linha de publicações. É idealizador e co-fundador do IEL (Instituto de Estudos Libertários)”. 


\begin{tabular}{|c|c|c|c|c|c|c|c|c|c|c|}
\hline & $\begin{array}{c}\text { Charles. Ensaios } \\
\text { sobre Edgar } \\
\text { Allan Poe. São } \\
\text { Paulo: Editora } \\
\text { Ícone, } 2003 .\end{array}$ & & $\begin{array}{l}\text { Santana } \\
\text { Martins }\end{array}$ & & $\begin{array}{c}\text { ficha } \\
\text { catalográfica }\end{array}$ & & & & & $\begin{array}{l}\text { nome da } \\
\text { tradutora na } \\
\text { folha de } \\
\text { rosto. }\end{array}$ \\
\hline 71 & $\begin{array}{l}\text { BAUDELAIRE, } \\
\text { CHARLES. As } \\
\text { flores do mal. } \\
\text { São Paulo: M. } \\
\text { Claret, } 2005 .\end{array}$ & VI-411, 5, 53 & $\begin{array}{l}\text { Pietro } \\
\text { Nassetti }\end{array}$ & & & & & & & $\begin{array}{c}\text { Livro não } \\
\text { encontrado } \\
\text { (fora de } \\
\text { lugar). }\end{array}$ \\
\hline 72 & $\begin{array}{l}\text { BAUDELAIRE, } \\
\text { Charles. } O \\
\text { poema do haxixe. } \\
\text { Col. B. São } \\
\text { Paulo: } \\
\text { Aquariana, } 2003 .\end{array}$ & $\begin{array}{l}\text { II- } 436,2,34, \\
\text { n. } 01\end{array}$ & $\begin{array}{l}\text { Eduardo } \\
\text { Brandão }\end{array}$ & & $\begin{array}{l}\text { Folha de rosto e } \\
\text { ficha } \\
\text { catalográfica }\end{array}$ & $\begin{array}{l}\text { Sim. Apresentação } \\
\text { de Fernando Alves, } \\
\text { diretor da coleção. }\end{array}$ & Não & Não & Não & \\
\hline 73 & $\begin{array}{c}\text { BAUDELAIRE, } \\
\text { Charles. Flores } \\
\text { do mal. Porto } \\
\text { Alegre: Sulina, } \\
2003 .\end{array}$ & $\mathrm{V}-225,6,46$ & $\begin{array}{c}\text { Juremir } \\
\text { Machado da } \\
\text { Silva }\end{array}$ & DITRA & Capa & Não & Não & $\begin{array}{c}\text { Sim. } \\
\text { Introduçã } \\
\text { o do } \\
\text { tradutor. }\end{array}$ & Sim & $\begin{array}{l}\text { Orelhas, } \\
\text { texto dos } \\
\text { editores. }\end{array}$ \\
\hline 74 & $\begin{array}{l}\text { BAUDELAIRE, } \\
\text { Charles. A } \\
\text { fanfarlo. Porto } \\
\text { Alegre: Paraula, }\end{array}$ & VI-213, 5, 59 & $\begin{array}{c}\text { Elisa } \\
\text { Tamajusuku } \\
\text {, Carmen } \\
\text { Maria }\end{array}$ & & $\begin{array}{c}\text { Folha de rosto e } \\
\text { ficha } \\
\text { catalográfica }\end{array}$ & $\begin{array}{l}\text { Sim. Introdução } \\
\text { sobre a obra. }\end{array}$ & Não & Não & Não & \\
\hline
\end{tabular}




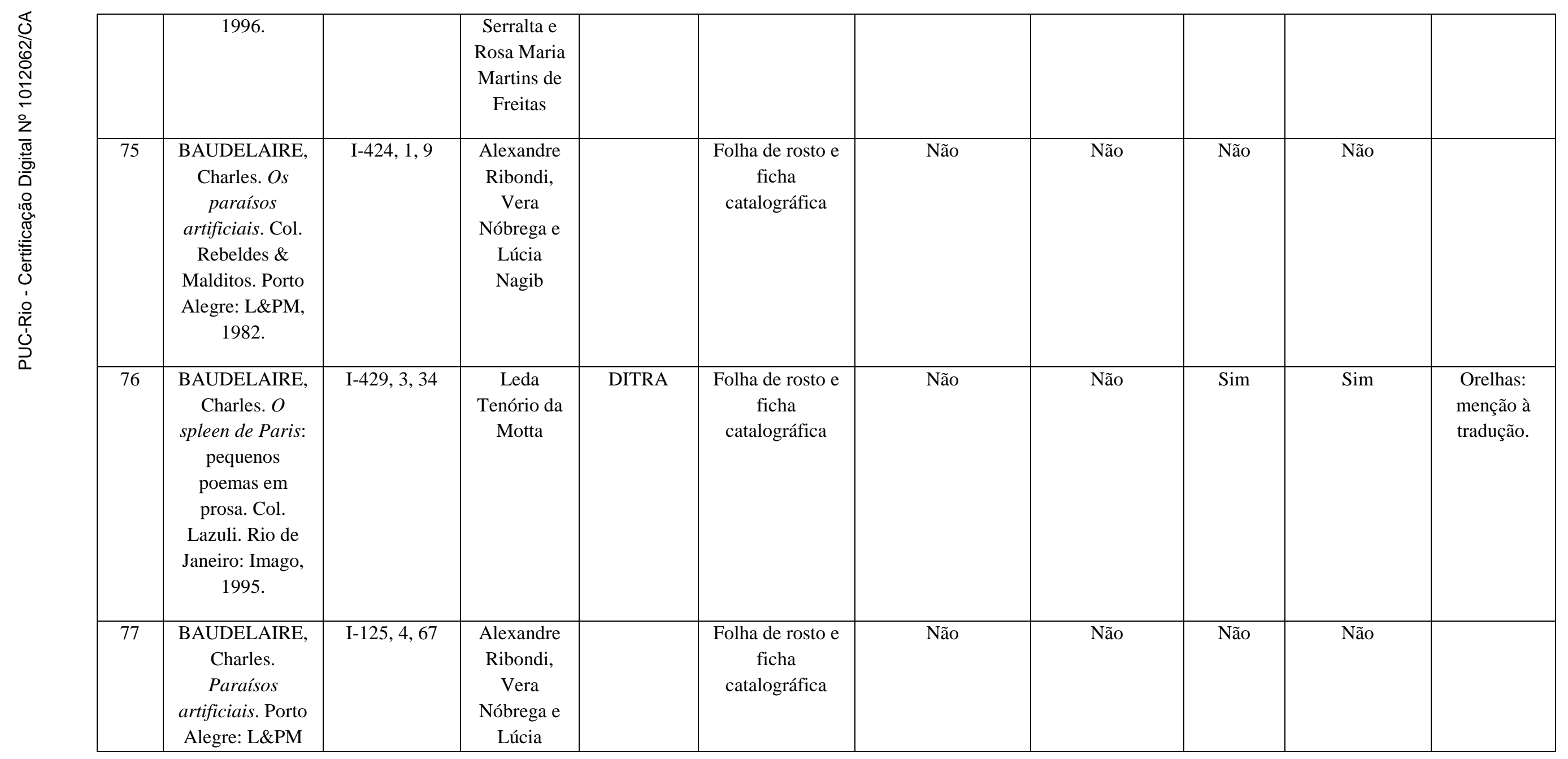




\begin{tabular}{|c|c|c|c|c|c|c|c|c|c|}
\hline & Pocket, 1998. & & Nagib & & & & & & \\
\hline 78 & $\begin{array}{c}\text { BAUDELAIRE, } \\
\text { Charles. Sobre a } \\
\text { modernidade. } \\
\text { São Paulo: Paz e } \\
\text { Terra, } 1996 .\end{array}$ & VI-257, 1, 51 & Não consta & & Não & Não & Não & Não & $\begin{array}{l}\text { Edição de } \\
\text { bolso, sem } \\
\text { orelhas. }\end{array}$ \\
\hline 79 & $\begin{array}{l}\text { BAUDELAIRE, } \\
\text { Charles. Obras } \\
\text { estéticas: } \\
\text { filosofia da } \\
\text { imaginação } \\
\text { criadora. } \\
\text { Petrópolis: } \\
\text { Vozes, } 1993 .\end{array}$ & VI-20, 2, 28 & $\begin{array}{c}\text { Edison } \\
\text { Darci Heldt }\end{array}$ & $\begin{array}{c}\text { Folha de rosto e } \\
\text { ficha } \\
\text { catalográfica }\end{array}$ & $\begin{array}{l}\text { Sim. Apresentação } \\
\text { do revisor, João } \\
\text { Ricardo Moderno. }\end{array}$ & Não & Não & Não & \\
\hline 80 & $\begin{array}{c}\text { BAUDELAIRE, } \\
\text { Charles. Poesia e } \\
\text { prosa. Org. Ivo } \\
\text { Barroso. Rio de }\end{array}$ & VI-60, 5, 58 & $\begin{array}{l}\text { Vários } \\
\text { tradutores. }\end{array}$ & $\begin{array}{l}\text { Nas páginas } \\
\text { iniciais. }\end{array}$ & $\begin{array}{c}\text { Sim. Nota } \\
\text { editorial, escrita } \\
\text { por Ivo Barroso. }\end{array}$ & Sim & $\begin{array}{c}\text { Sim. } \\
\text { Ensaio } \\
\text { crítico de } \\
\text { um dos }\end{array}$ & Não & \\
\hline
\end{tabular}

\footnotetext{
21 “Além disso, ao selecionarmos na volumosa produção baudelairiana o material que iríamos conservar na presente edição, buscamos, ademais de uma adequada escolha dos textos exemplares, encontrar acima de tudo as traduções em nossa língua que fossem mais qualitativamente representativas dessa escolha, de modo a que tivéssemos, ao final do trabalho, estabelecido o que se poderia considerar um texto baudelairiano definitivo em português. Diversamente das edições bilíngues em que o leitor pode cotejar o original com o texto traduzido e ajustá-lo ou enriquecê-lo em função de seus conhecimentos da língua de origem, o que se procurou nesta edição foi antes substituir inteiramente o texto da língua primitiva pelo seu mais perfeito equivalente na língua do leitor, dando-lhe a garantia de que dessa superposição textual terá nascido um novo original, digno de fé, pronto a servir doravante de texto-padrão para as citações ou referências à obra do poeta em língua portuguesa. A ideia de aliar uma rigorosa seleção do texto original a uma busca (quando já existentes) ou à produção de traduções que, dentro dos parâmetros atuais, sejam as mais representativas de suas propriedades estilísticas, erige-se, desta forma, em diretriz básica desta e das demais edições da Biblioteca Universal com que a Editora Nova Aguilar se emprenha em entregar ao público luso-brasileiro obras que sejam verdadeiros padrões de qualidade literária”. (pág. 13)
} 


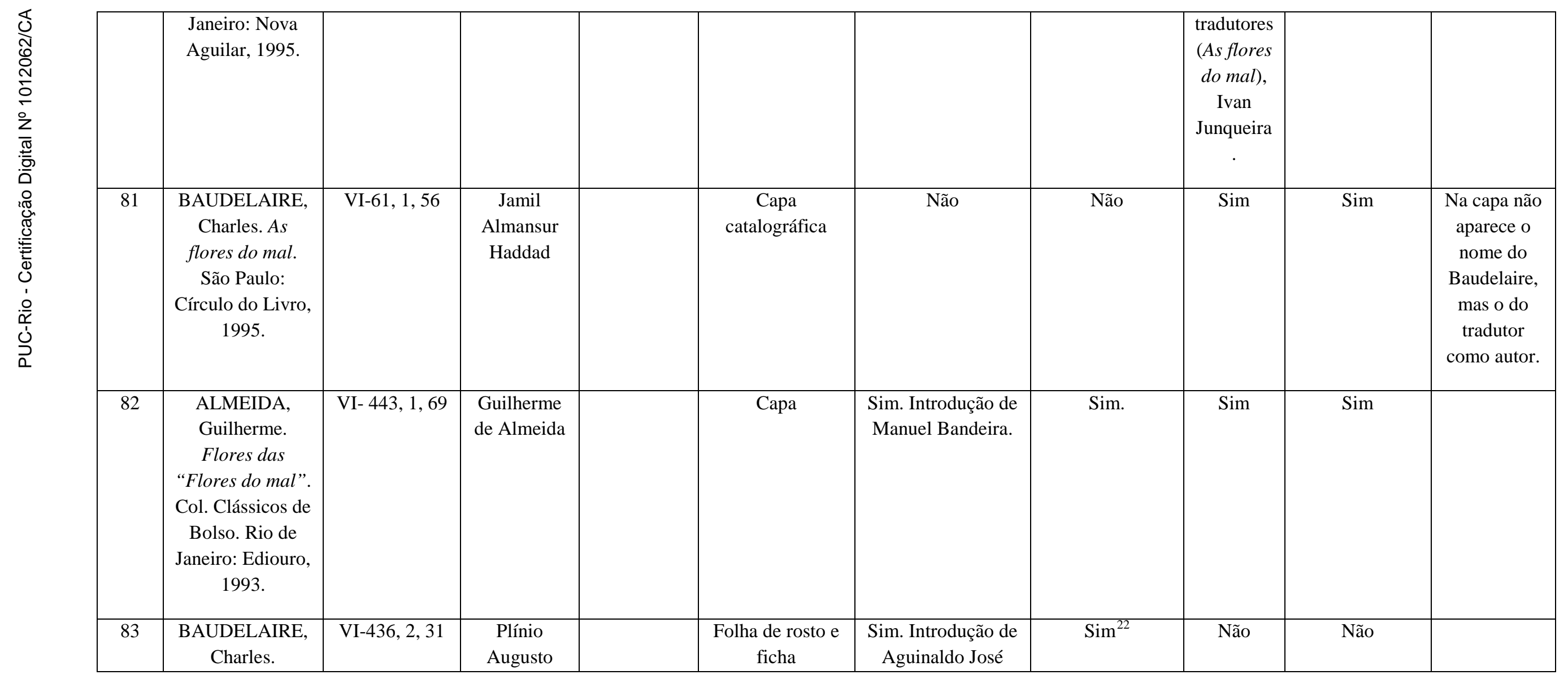

22 “Considerando as questões por nós levantadas neste texto introdutório, torna-se desnecessário ressaltar a importância da tradução dos quatro ensaios sobre arte, para o leitor brasileiro. Eles compõem, no seu conjunto, um veio fértil que deve ser articulado a outros afluentes teórico-críticos que vêm sendo desenvolvidos pelas Ciências da Linguagem no nosso século" (pág. 22) 


\begin{tabular}{|c|c|c|c|c|c|c|c|c|c|c|}
\hline & $\begin{array}{c}\text { Reflexões sobre } \\
\text { meus } \\
\text { contemporâneos. } \\
\text { Col. Biblioteca } \\
\text { da Modernidade. } \\
\text { São Paulo: } \\
\text { Imaginário, } \\
1992 .\end{array}$ & & Coêlho & & catalográfica & $\begin{array}{c}\text { Gonçalves, “O } \\
\text { olhar refratário de } \\
\text { Charles } \\
\text { Baudelaire". }\end{array}$ & & & & \\
\hline 84 & $\begin{array}{l}\text { BAUDELAIRE, } \\
\text { Charles. As } \\
\text { flores do mal. } \\
\text { São Paulo: Max } \\
\text { Limonad Editora, } \\
1985 .\end{array}$ & VI-271, 5, 36 & $\begin{array}{c}\text { Jamil } \\
\text { Almansur } \\
\text { Haddad }\end{array}$ & & Сара & Não & Não & Sim & $\begin{array}{c}\text { Sim (a mesma } \\
\text { do item 81) }\end{array}$ & \\
\hline 85 & $\begin{array}{c}\text { BAUDELAIRE, } \\
\text { Charles. } \\
\text { Pequenos } \\
\text { poemas em } \\
\text { prosa. Col. } \\
\text { Paideuma. } \\
\text { Florianópolis: } \\
\text { Editora UFSC, }\end{array}$ & $\begin{array}{c}\text { ANEXO II - } \\
811,1,16\end{array}$ & $\begin{array}{c}\text { Dorothée de } \\
\text { Bruchard }\end{array}$ & DITRA & Capa & Não & Não & Sim & Não & $\begin{array}{l}\text { Orelha: texto } \\
\text { de Walter } \\
\text { Carlos } \\
\text { Costa. }{ }^{23} \\
\text { Ao final do } \\
\text { livro, Nota } \\
\text { (a mesma do }\end{array}$ \\
\hline
\end{tabular}

23 “(...) A tradução de Dorothée de Bruchard, cuidadosa e elegante, nos revela um Baudelaire mais vigoroso e mais ousado do que o conhecido até agora entre nós. Baudelaire - que, além de sua obra criativa e de crítica, produziu também traduções ainda hoje exemplares dos contos de Edgar Allan Poe - bem merece começar uma nova coleção.

(...) A coleção Paideuma tem como objetivo colocar à disposição do público leitor brasileiro obras fundamentais da cultura universal, sobretudo de ciências humanas, arte e literatura. Uma atenção especial será dada à tradução, realizada a partir das melhores edições originais, privilegiando a informação e os procedimentos presentes na língua de partida. Faremos o possível para evitar a habitual estratégia de adaptação e da diluição, que tem privado nossa cultura do acesso a certos matizes das grandes obras escritas em língua estrangeira. Em alguns casos (poesia, certos textos filosóficos), a edição será bilíngue”. 


\begin{tabular}{|c|c|c|c|c|c|c|c|c|c|c|}
\hline & 1988. & & & & & & & & & item 62). \\
\hline 86 & $\begin{array}{l}\text { BAUDELAIRE, } \\
\text { Charles. A } \\
\text { modernidade de } \\
\text { Baudelaire. Rio } \\
\text { de Janeiro: Paz e } \\
\text { Terra, } 1988 .\end{array}$ & VI-209, 1, 58 & $\begin{array}{l}\text { Suely } \\
\text { Cassal }\end{array}$ & & $\begin{array}{l}\text { Folha de rosto e } \\
\text { ficha } \\
\text { catalográfica }\end{array}$ & $\begin{array}{l}\text { Sim. Introdução } \\
\text { não assinada. } \\
\text { Ensaio do } \\
\text { organizador, } \\
\text { Teixeira Coelho, } \\
\text { “A modernidade de } \\
\text { Baudelaire”. }\end{array}$ & Não & Não & Não & \\
\hline 87 & $\begin{array}{l}\text { BAUDELAIRE, } \\
\text { Charles. As } \\
\text { flores do mal. } \\
\text { Rio de Janeiro: } \\
\text { Nova Fronteira, } \\
1985 .\end{array}$ & IV-201, 3, 41 & $\begin{array}{c}\text { Ivan } \\
\text { Junqueira }\end{array}$ & DITRA & Capa & Sim & Não & Não & Não & $\begin{array}{l}\text { Orelhas, } \\
\text { referência ao } \\
\text { tradutor. }{ }^{24}\end{array}$ \\
\hline 88 & $\begin{array}{l}\text { BAUDELAIRE, } \\
\text { Charles. As } \\
\text { flores do mal. } \\
\text { Rio de Janeiro: } \\
\text { Nova Fronteira, }\end{array}$ & VI-233, 5, 2. & $\begin{array}{c}\text { Ivan } \\
\text { Junqueira }\end{array}$ & DITRA & Capa & Sim & Não & Não & Não & $\begin{array}{c}\text { Orelhas, } \\
\text { referência ao } \\
\text { tradutor (a } \\
\text { mesma do } \\
\text { item 86). }\end{array}$ \\
\hline
\end{tabular}

24 “O poeta Ivan Junqueira, responsável por esta tradução completa de As flores do mal, traduziu também os poemas de T. S. Eliot e A obra em negro e Como a água que corre, de Marguerite Yourcenar. É autor de volumes de poesia Os mortos e A rainha arcaica (Prêmio Nacional de Poesia do INL), do livro de ensaios À sombra de Orfeu (Prêmio Assis Chateaubriand, da Academia Brasileira de Letras) e das antologias críticas Testamento de Pasárgada (sobre a poesia de Manuel Bandeira) e Dias idos e vividos (sobre a prosa de não-ficção de José Lins do Rego)”. 


\begin{tabular}{|c|c|c|c|c|c|c|c|c|c|c|}
\hline & 1985. & & & & & & & & & \\
\hline 89 & $\begin{array}{l}\text { BAUDELAIRE, } \\
\text { Charles. As } \\
\text { flores do mal. } \\
\text { São Paulo: Abril } \\
\text { Cultura, } 1984 .\end{array}$ & VI-325, 1, 2 & $\begin{array}{c}\text { Jamil } \\
\text { Almansur } \\
\text { Haddad }\end{array}$ & & Capa & Não & Não & Sim & $\begin{array}{c}\text { Sim (a mesma } \\
\text { do item 81) }\end{array}$ & \\
\hline 90 & $\begin{array}{l}\text { BAUDELAIRE, } \\
\text { Charles. As } \\
\text { flores do mal. } \\
\text { São Paulo: Max } \\
\text { Limonad Editora, } \\
1981 .\end{array}$ & VI-405, 4, 23 & $\begin{array}{c}\text { Jamil } \\
\text { Almansur } \\
\text { Haddad }\end{array}$ & & Capa & Não & Não & Sim & $\begin{array}{l}\text { Sim (a mesma } \\
\text { do item 81). }\end{array}$ & \\
\hline 91 & $\begin{array}{c}\text { CORNEILLE, } \\
\text { Pierre. O Cid. } \\
\text { Col. } \\
\text { Dramaturgias. } \\
\text { Rio de Janeiro: } \\
\text { Sette Letras, } \\
1998 .\end{array}$ & $\mathrm{I}-87,1,20$ & $\begin{array}{c}\text { Angela } \\
\text { Leite Lopes }\end{array}$ & DITRA & Capa & Não & Não & $\begin{array}{l}\text { Sim. } \\
\text { Introduçã } \\
\text { o da } \\
\text { tradutora, } \\
\text { “O tempo } \\
\text { em } \\
\text { verso”. }\end{array}$ & Sim & $\begin{array}{c}\text { Nota da } \\
\text { tradutora. } \\
\\
\text { A obra foi } \\
\text { dirigida pela } \\
\text { tradutora. }\end{array}$ \\
\hline 92 & $\begin{array}{l}\text { CORNEILLE, } \\
\text { Pierre. El Cid. } \\
\text { Col. Elefante. } \\
\text { Rio de Janeiro: } \\
\text { Ediouro, } 1988 .\end{array}$ & IV-234,7, 44 & $\begin{array}{l}\text { Ganymédes } \\
\text { José }\end{array}$ & & Capa & Sim & Não & Não & Não & $\begin{array}{c}\text { Trata-se de } \\
\text { uma } \\
\text { reescritura } \\
\text { do original, } \\
\text { em prosa, } \\
\text { mas isso não } \\
\text { é }\end{array}$ \\
\hline
\end{tabular}




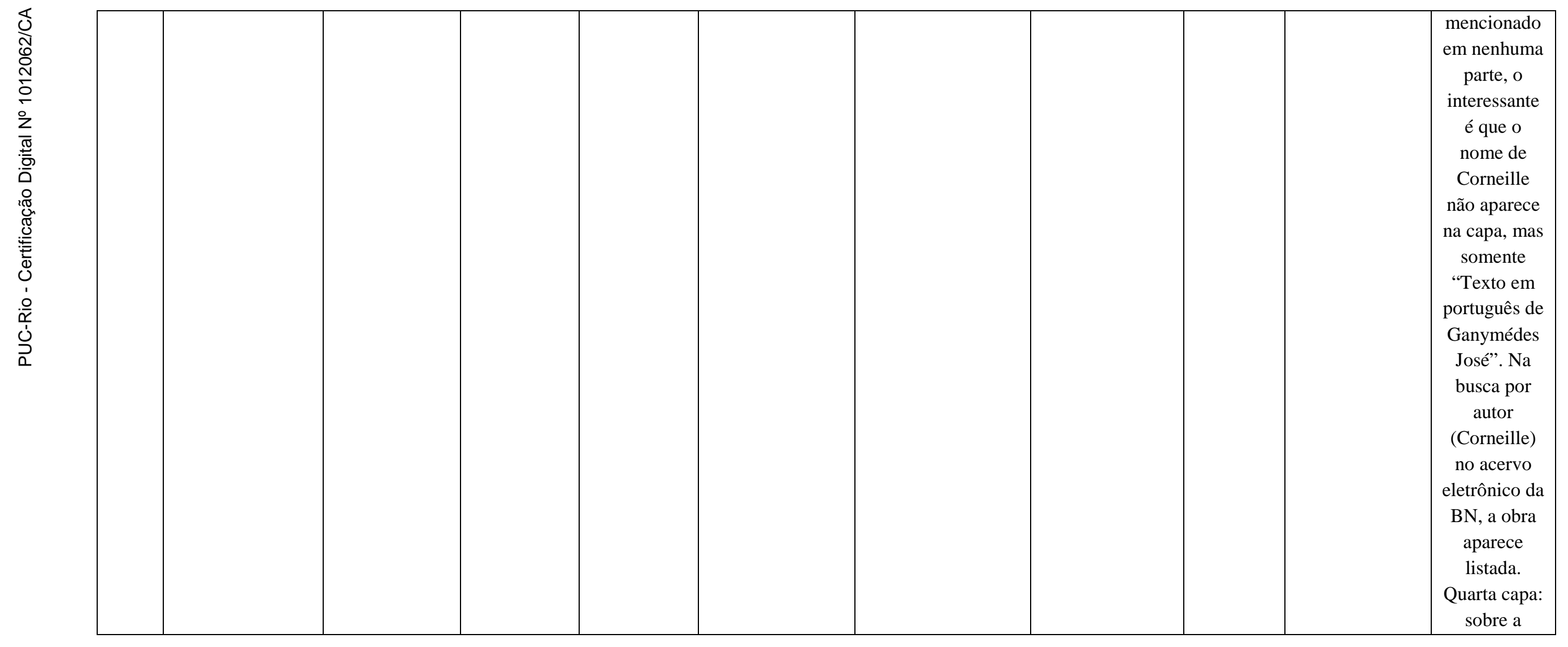




\begin{tabular}{|c|c|c|c|c|c|c|c|c|c|}
\hline & & & & & & & & & $\begin{array}{l}\text { coleção e o } \\
\text { "autor". }\end{array}$ \\
\hline 93 & $\begin{array}{l}\text { CORNEILLE, } \\
\text { Pierre. O Cid e } \\
\text { Horácio. Col. } \\
\text { Universidade de } \\
\text { Bolso. Rio de } \\
\text { Janeiro: Ediouro, } \\
\text { 1988. }\end{array}$ & $\begin{array}{c}\text { ANEXO II- } \\
749,1,47\end{array}$ & $\begin{array}{l}\text { Jenny } \\
\text { Klabin } \\
\text { Segall }\end{array}$ & Capa & $\begin{array}{l}\text { Sim. Prefácio de } \\
\text { Paulo Rónai: sobre } \\
\text { o autor e a obra. }\end{array}$ & Não & Não & Não & \\
\hline 94 & $\begin{array}{c}\text { CORNEILLE, } \\
\text { Pierre. O Cid e } \\
\text { Horácio. Col. } \\
\text { Clássicos de } \\
\text { Bolso. Rio de } \\
\text { Janeiro: Ediouro, } \\
\text { 1994. }\end{array}$ & VI-27, 3, 27. & $\begin{array}{l}\text { Jenny } \\
\text { Klabin } \\
\text { Segall }\end{array}$ & Capa & $\begin{array}{l}\text { Sim. Prefácio “A } \\
\text { vida de Pierre } \\
\text { Corneille” de } \\
\text { Paulo Rónai. } \\
\text { Prefácios “A } \\
\text { tragéda corneliana” } \\
\text { e "Horácio” de } \\
\text { Paulo Rónai. }\end{array}$ & Não & Não & Não & \\
\hline 95 & $\begin{array}{l}\text { CORNEILLE, } \\
\text { Pierre. O Cid, } \\
\text { Horácio e }\end{array}$ & V-414, 2, 48 & $\begin{array}{c}\text { Jenny } \\
\text { Klabin } \\
\text { Segall }\end{array}$ & Capa & $\begin{array}{c}\text { Nota à Presente } \\
\text { Edição, escrita pelo } \\
\text { editor. }^{26}\end{array}$ & Sim & Não & Não & Orelhas $^{27}$ \\
\hline
\end{tabular}

25 “A legendária e imortal figura de El Cid, exaltada no Romanceiro Espanhol e que aparece em numerosas obras, entre as quais na famosa tragicomédia de Corneille, empolgou o mundo inteiro, continuando fascinante até hoje, como nesta apresentação em português, de Ganymédes José, autor já muito conhecido e festejado em nossas letras, principalmente por seus milhares de leitores da Ediouro".

26 “O objetivo desta edição foi republicar as famosas traduções de Jenny Klabin Segall de obras do Teatro Clássico francês. As primeiras datam dos anos 30 e tiveram mais de uma edição. 


\begin{tabular}{|c|c|c|c|c|c|c|c|c|c|}
\hline & $\begin{array}{l}\text { Polieucto. Col. } \\
\text { Biblioteca } \\
\text { Martins Fontes. } \\
\text { São Paulo: } \\
\text { Martins Fontes, } \\
2005 .\end{array}$ & & & & & & & & \\
\hline 96 & $\begin{array}{c}\text { DUMAS, } \\
\text { Alexandre. } \\
\text { Memórias de } \\
\text { Garibaldi. Col. } \\
\text { L\&PM Pocket. } \\
\text { Porto Alegre: } \\
\text { L\&PM, } 1999 .\end{array}$ & $\mathrm{I}-135,3,61$ & $\begin{array}{c}\text { Antonio } \\
\text { Caruccio- } \\
\text { Caporale }\end{array}$ & $\begin{array}{c}\text { Folha de rosto e } \\
\text { ficha } \\
\text { catalográfica }\end{array}$ & $\begin{array}{l}\text { Sim. Apresentação } \\
\text { de Alexandre } \\
\text { Dumas: "Uma } \\
\text { palavra ao leitor" }\end{array}$ & Não & Não & Não & $\begin{array}{c}\text { Edição de } \\
\text { bolso. }\end{array}$ \\
\hline 97 & $\begin{array}{c}\text { DUMAS, } \\
\text { Alexandre. A } \\
\text { rainha Margot. } \\
\text { São Paulo: }\end{array}$ & VI-174, 4, 11. & $\begin{array}{c}\text { Fernando } \\
\text { Nuno }\end{array}$ & Capa & $\begin{array}{l}\text { Sim. Prefácio não } \\
\text { assinado: “Convite } \\
\text { a ler”. }{ }^{28} \text { Posfácios: } \\
\text { “A vida do autor }\end{array}$ & Sim & Não & Não & \\
\hline
\end{tabular}

Trata-se de uma obra única. Guilherme de Almeida afirma no prefácio à primeira edição que Jenny Klabin não se limitou a "traduzir”, fazendo muito mais : "reproduziu”, quer dizer 'produziu de novo', sentindo, pensando e dizendo como, onde, por que e quando Molière sentiu, pensou e disse”. Em vista disso, obrigamo-nos a reproduzir, sem alterações, o texto original.

As edições utilizadas, fornecidas por Maurício Segall, a quem agradecemos, foram as da Martins Fontes. Nosso trabalho de revisão limitou-se à correção de alguns erros claros de composição e à atualização ortográfica. Foram mantidas a pontuação e a sequência do texto.

Nos casos em que as divisões do texto de Jenny Klabin Segall não coincidiram com as das edições francesas consultadas, mantivemos sempre a ordem proposta pela tradutora”. (pág. XI)

27 "Apresentamos neste volume três obras de Corneille em traduções de Jenny Klabin Segall, que se dedicou à divulgação das obras-primas do teatro universal em versos de valor reconhecido por toda a imprensa da época".

28 “O texto que você vai ler agora é uma adaptação que mantém o estilo e a linguagem básica do autor. Para tornar a obra (que na versão original é mais de duas vezes mais longa que o texto deste volume) mais adequada ao leitor de hoje, foram cortadas as longas descrições e várias repetições excessivas”. (pág. 9) 


\begin{tabular}{|c|c|c|c|c|c|c|c|c|}
\hline & $\begin{array}{l}\text { Companhia das } \\
\text { Letras, } 2001 .\end{array}$ & & & & $\begin{array}{c}\text { de A rainha } \\
\text { Margot”, “Uma } \\
\text { obra do } \\
\text { romantismo”, “A } \\
\text { história por trás da } \\
\text { história de } \\
\text { Margot”, “Onde o } \\
\text { Brasil entrou nesta } \\
\text { história”. }\end{array}$ & & & \\
\hline 98 & $\begin{array}{c}\text { DUMAS, } \\
\text { Alexandre. } O \\
\text { conde de Monte } \\
\text { Cristo. Col. } \\
\text { Clássicos da } \\
\text { Literatura. } \\
\text { Curitiba: Juruá } \\
\text { Editora, 2001. }\end{array}$ & VI-128, 3, 1 & $\begin{array}{l}\text { Nélia Maria } \\
\text { Pinheiro } \\
\text { Padilha von } \\
\text { Tempski- } \\
\text { Silka }\end{array}$ & $\begin{array}{l}\text { Folha de rosto e } \\
\text { ficha } \\
\text { catalográfica }\end{array}$ & Não & Não & $\begin{array}{c}\text { Sim. } \\
\text { Introduçã } \\
\text { o da } \\
\text { tradutora. }\end{array}$ & Sim \\
\hline 99 & $\begin{array}{c}\text { DUMAS, } \\
\text { Alexandre. Os } \\
\text { três } \\
\text { mosqueteiros. } \\
\text { São Paulo: } \\
\text { Círculo do Livro, } \\
1996 .\end{array}$ & VI-45, 5, 41 & $\begin{array}{l}\text { Octávio } \\
\text { Mendes } \\
\text { Cajado }\end{array}$ & $\begin{array}{l}\text { Folha de rosto e } \\
\text { ficha } \\
\text { catalográfica }\end{array}$ & Não & Não & Não & Não \\
\hline 100 & $\begin{array}{l}\text { FLAUBERT, } \\
\text { Gustave. } \\
\text { Madame Bovary. }\end{array}$ & III-443, 1, 57 & $\begin{array}{l}\text { Sérgio } \\
\text { Duarte }\end{array}$ & Сара & $\begin{array}{l}\text { Sim. Prefácio de } \\
\text { Carpeaux: sobre o }\end{array}$ & Não & Não & Não \\
\hline
\end{tabular}




\begin{tabular}{|c|c|c|c|c|c|c|c|c|c|c|}
\hline & $\begin{array}{c}\text { Pref. De Otto } \\
\text { Maria Carpeaux. } \\
\text { Col. Clássicos de } \\
\text { Bolso. Rio de } \\
\text { Janeiro: Ediouro, } \\
1996 \text { (?). }\end{array}$ & & & & & autor e a obra. & & & & \\
\hline 101 & $\begin{array}{l}\text { FLAUBERT, } \\
\text { Gustave. Três } \\
\text { contos. Porto } \\
\text { Alegre: L\&PM } \\
\text { Pocket, } 2005 .\end{array}$ & VI-418, 4, 49 & $\begin{array}{l}\text { Flávio } \\
\text { Moreira da } \\
\text { Costa }\end{array}$ & & $\begin{array}{l}\text { Folha de rosto e } \\
\text { ficha } \\
\text { catalográfica }\end{array}$ & Não & Não & Sim & Sim & \\
\hline 102 & $\begin{array}{c}\text { FLAUBERT, } \\
\text { Gustave. Cartas } \\
\text { exemplares. Rio } \\
\text { de Janeiro: } \\
\text { Imago, 2005. }\end{array}$ & VI-493, 2, 42 & $\begin{array}{c}\text { Carlos } \\
\text { Eduardo } \\
\text { Lima } \\
\text { Machado }\end{array}$ & DITRA & $\begin{array}{l}\text { Folha de rosto e } \\
\text { ficha } \\
\text { catalográfica }\end{array}$ & Não & Não & Não & Não & \\
\hline 103 & $\begin{array}{l}\text { FLAUBERT, } \\
\text { Gustave. } \\
\text { Madame Bovary. } \\
\text { Col. Obra-Prima } \\
\text { de Cada Autor. } \\
\text { São Paulo: } \\
\text { Martin Claret, } \\
2005 .\end{array}$ & VI-411, 2, 28 & $\begin{array}{l}\text { Araújo } \\
\text { Nabuco }\end{array}$ & & $\begin{array}{l}\text { Folha de rosto e } \\
\text { ficha } \\
\text { catalográfica }\end{array}$ & Não & Não & Não & Não & \\
\hline 104 & $\begin{array}{l}\text { FLAUBERT, } \\
\text { Gustave. }\end{array}$ & VI-24, 1, 52 & $\begin{array}{c}\text { Não tem o } \\
\text { nome do }\end{array}$ & & & Não & Não & Não & Não & \\
\hline
\end{tabular}




\begin{tabular}{|c|c|c|c|c|c|c|c|c|c|c|}
\hline & $\begin{array}{l}\text { Salambô. Belo } \\
\text { Horizonte: } \\
\text { Itatiaia, } 2005 .\end{array}$ & & tradutor & & & & & & & \\
\hline 105 & $\begin{array}{l}\text { FLAUBERT, } \\
\text { Gustave. } \\
\text { Bibliomania, } \\
\text { seguido de Crime } \\
\text { do livreiro } \\
\text { catalão. Rio de } \\
\text { Janeiro: Casa da } \\
\text { Palavra, 2001. }\end{array}$ & VI-213, 1, 21. & $\begin{array}{c}\text { Carlito } \\
\text { Azevedo }\end{array}$ & & Capa & $\begin{array}{l}\text { Sim. Nota dos } \\
\text { editores: sobre a } \\
\text { obra (de } \\
\text { juventude). No } \\
\text { final: sobre o autor, } \\
\text { e sobre Merimée e } \\
\text { Nodier (pretensos } \\
\text { autores da notícia } \\
\text { do crime do } \\
\text { livreiro catalão). }\end{array}$ & Não & Não & Não & \\
\hline 106 & $\begin{array}{l}\text { FLAUBERT, } \\
\text { Gustave. } \\
\text { Novembro. São } \\
\text { Paulo: } \\
\text { Iluminuras, } \\
2000 .\end{array}$ & VI-112, 2, 4 & $\begin{array}{c}\text { Sérgio } \\
\text { Medeiros }\end{array}$ & DITRA & $\begin{array}{c}\text { Folha de rosto e } \\
\text { ficha } \\
\text { catalográfica }\end{array}$ & Não & Não & $\begin{array}{c}\text { Sim. } \\
\text { Introduçã } \\
\text { o do } \\
\text { tradutor } \\
\text { (25 } \\
\text { páginas) } \\
\text { sobre o } \\
\text { autor e } \\
\text { sua obra. }\end{array}$ & Sim & $\begin{array}{c}\text { O tradutor } \\
\text { foi também } \\
\text { organizador } \\
\text { da edição. }\end{array}$ \\
\hline 107 & $\begin{array}{l}\text { FLAUBERT, } \\
\text { Gustave. } \\
\text { Madame Bovary. } \\
\text { Col. Clássicos de } \\
\text { Bolso. Rio de }\end{array}$ & VI-371, 1, 12 & $\begin{array}{l}\text { Sérgio } \\
\text { Duarte }\end{array}$ & & Сара & $\begin{array}{l}\text { Sim. Pref. de Otto } \\
\text { Maria Carpeaux. }\end{array}$ & Não & Não & Não & \\
\hline
\end{tabular}




\begin{tabular}{|c|c|c|c|c|c|c|c|c|c|c|}
\hline & $\begin{array}{l}\text { Janeiro: Ediouro, } \\
\text { (?). }\end{array}$ & & & & & & & & & \\
\hline 108 & $\begin{array}{c}\text { FLAUBERT, } \\
\text { Gustave. Três } \\
\text { contos. Trad. } \\
\text { Col. Clássicos } \\
\text { Francisco Alves. } \\
\text { Rio de Janeiro: } \\
\text { Francisco Alves, } \\
1981 .\end{array}$ & VI-365, 3,50 & $\begin{array}{l}\text { Manuel } \\
\text { Freitas } \\
\text { Costa e } \\
\text { Flávio } \\
\text { Moreira da } \\
\text { Costa }\end{array}$ & $\begin{array}{c}\text { DITRA } \\
\text { (Flavio } \\
\text { Moreira da } \\
\text { Costa) }\end{array}$ & Capa & Não & Não & Não & Não & $\begin{array}{c}\text { Orelhas: } \\
\text { texto do } \\
\text { tradutor } \\
\text { Flávio } \\
\text { Moreira da } \\
\text { Costa: sobre } \\
\text { a obra, } \\
\text { nenhuma } \\
\text { menção à } \\
\text { tradução. }\end{array}$ \\
\hline 109 & $\begin{array}{l}\text { FLAUBERT, } \\
\text { Gustave. } \\
\text { Madame Bovary. } \\
\text { São Paulo: } \\
\text { Círculo do Livro, } \\
1982 .\end{array}$ & VI-365, 3, 42 & $\begin{array}{l}\text { Araújo } \\
\text { Nabuco }\end{array}$ & & $\begin{array}{c}\text { Folha de rosto e } \\
\text { ficha } \\
\text { catalográfica }\end{array}$ & Não & Não & Não & Não & \\
\hline 110 & $\begin{array}{c}\text { FLAUBERT, } \\
\text { Gustave. } \\
\text { Bouvard e } \\
\text { Pécuchet. São } \\
\text { Paulo: Estação } \\
\text { Liberdade, 2007. }\end{array}$ & VI-443, 1, 63 & $\begin{array}{c}\text { Marina } \\
\text { Appenzeller }\end{array}$ & & Quarta capa & $\begin{array}{l}\text { Sim. Nota dos } \\
\quad \text { editores. } \\
\text { Apresentação de } \\
\text { Stéphanie Dord- } \\
\text { Crouslé, } \\
\text { especialista em } \\
\text { Flaubert e autora } \\
\text { de uma obra de } \\
\text { crítica genética }\end{array}$ & Não & Não & Não & \\
\hline
\end{tabular}




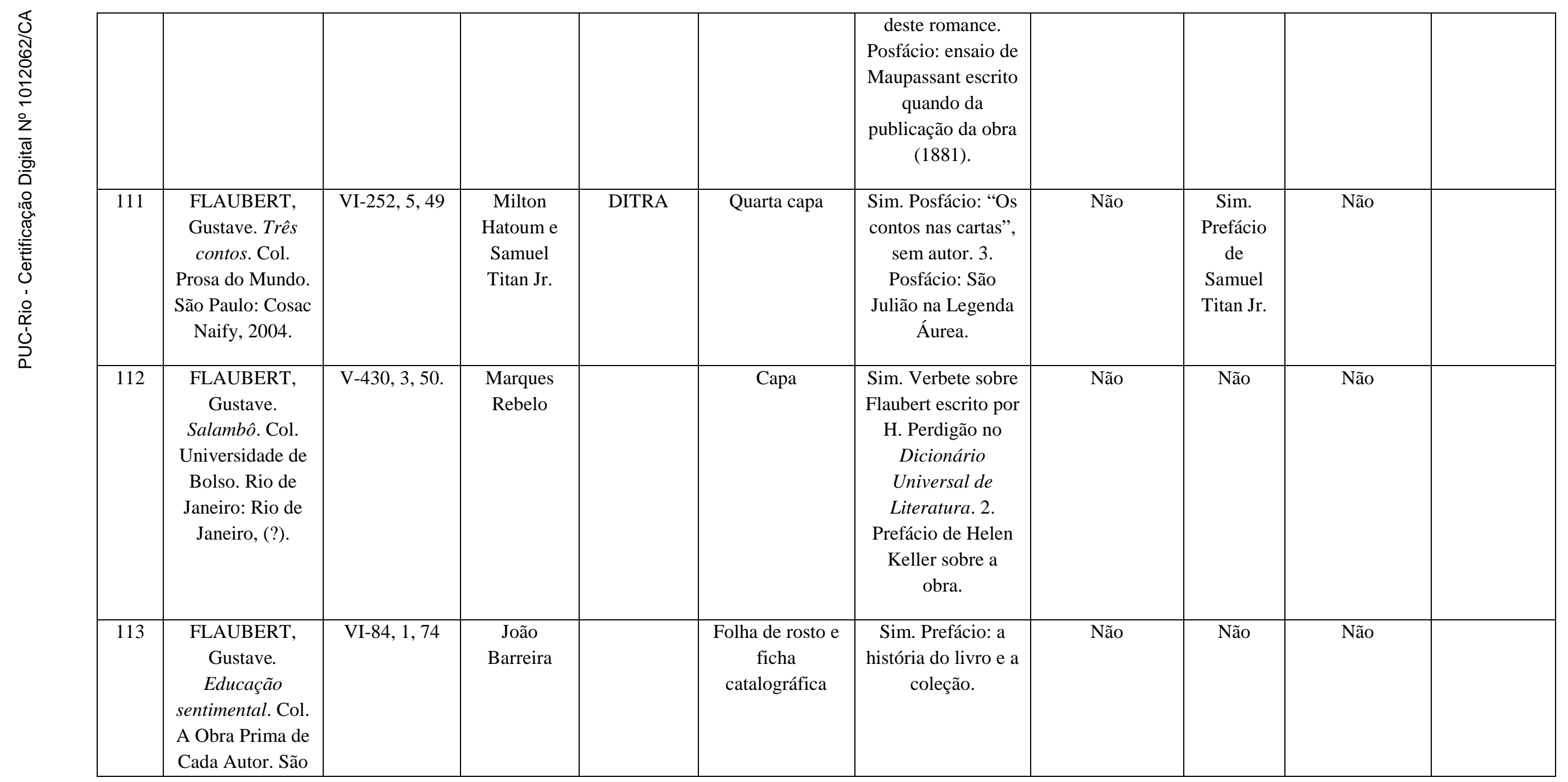




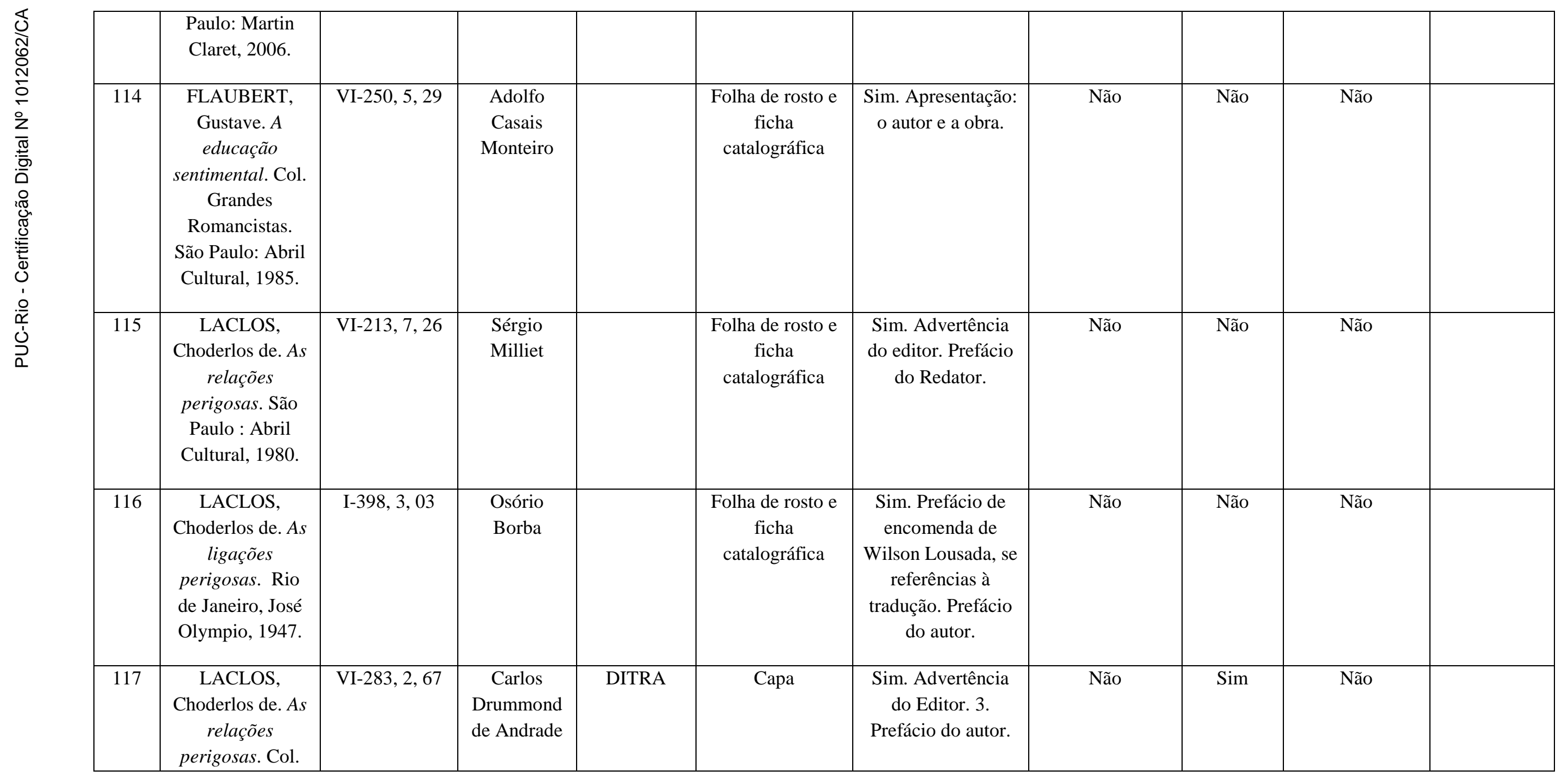




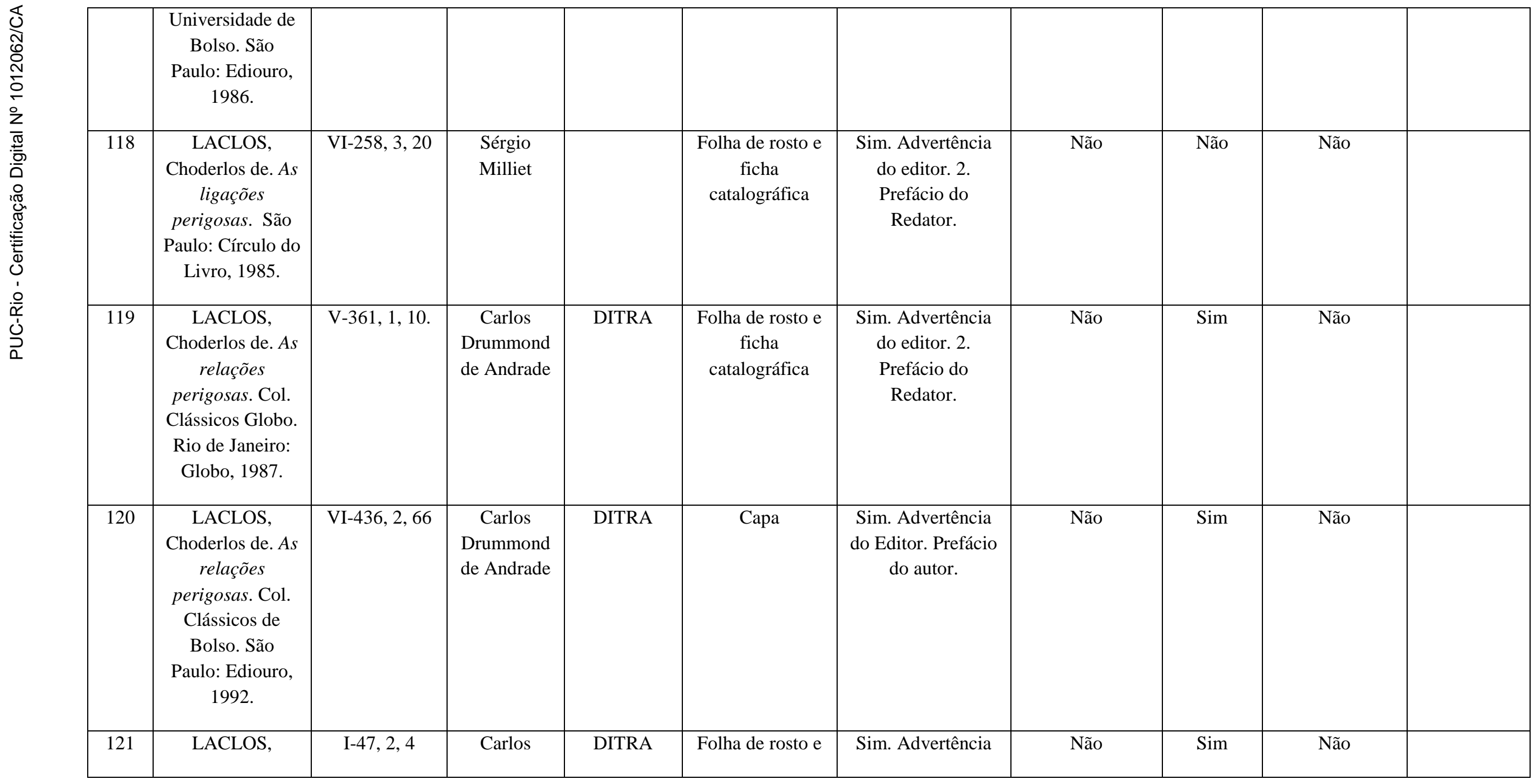




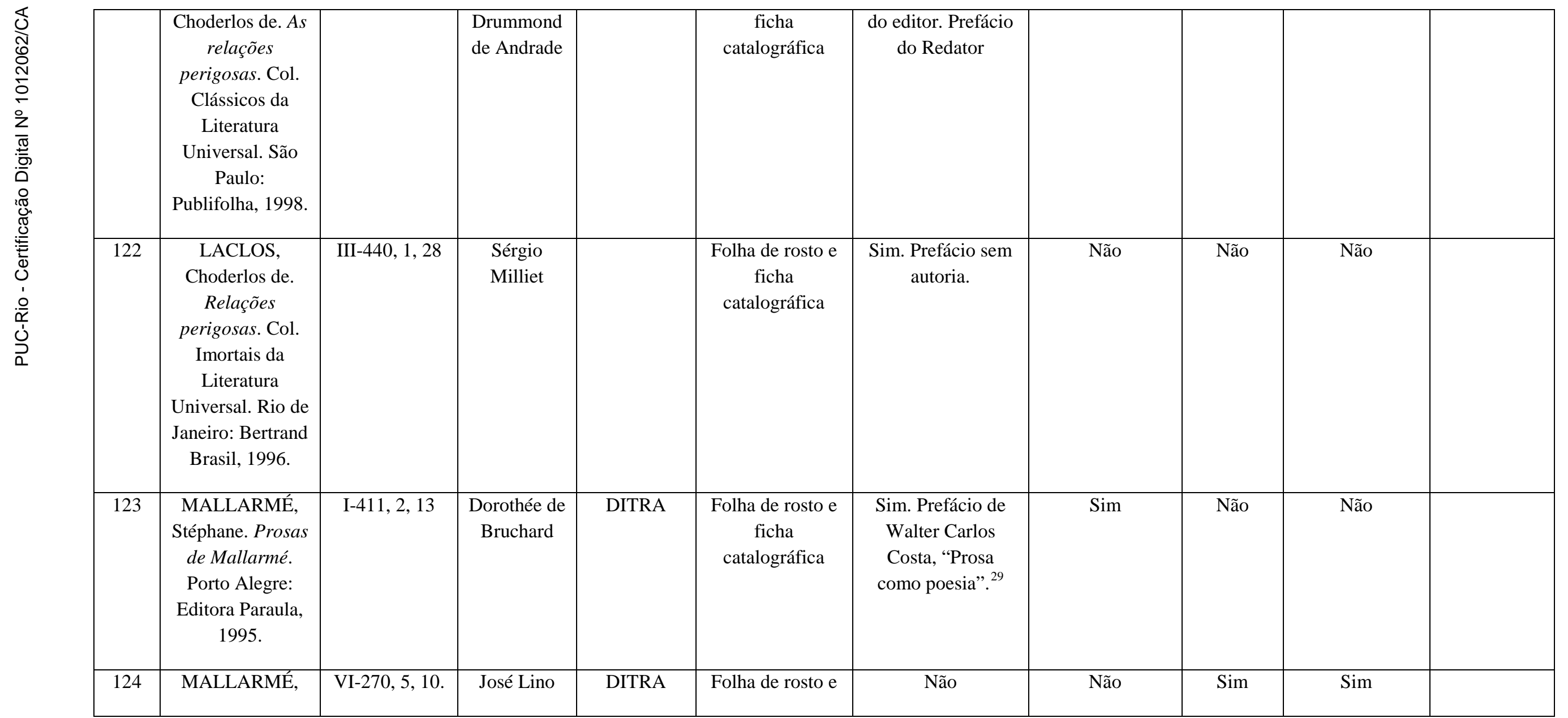

29 ”Destas prosas, tão cuidadas como a melhor poesia - que a tradução buscou re-produzir em português do Brasil - saímos sacudidos. Tanto leitor apenas curioso como o prosador preocupado encontrarão aqui matéria farta”. (pág. viii) 


\begin{tabular}{|c|c|c|c|c|c|c|c|c|c|c|}
\hline & $\begin{array}{l}\text { Stéphane. Igitur } \\
\text { ou A loucura de } \\
\text { Elbehnon. Rio de } \\
\text { Janeiro: Nova } \\
\text { Fronteira. } 1985 .\end{array}$ & & Grünewald & & $\begin{array}{c}\text { ficha } \\
\text { catalográfica }\end{array}$ & & & & & \\
\hline 125 & $\begin{array}{l}\text { MALLARMÉ, } \\
\text { Stéphane. } \\
\text { Rabiscado no } \\
\text { teatro. Col. } \\
\text { Mimo. Belo } \\
\text { Horizonte: } \\
\text { Autêntica, 2010. }\end{array}$ & V-396, 1, 12 & $\begin{array}{l}\text { Tomaz } \\
\text { Tadeu }\end{array}$ & DITRA & $\begin{array}{c}\text { Folha de rosto e } \\
\text { ficha } \\
\text { catalográfica }\end{array}$ & Não & Não & $\begin{array}{c}\text { Sim. } \\
\text { Muitas } \\
\text { notas } \\
\text { (forte } \\
\text { presença } \\
\text { do } \\
\text { tradutor). }\end{array}$ & Sim & $\begin{array}{c}\text { Menção à } \\
\text { tradução na } \\
\text { quarta capa. }\end{array}$ \\
\hline 126 & $\begin{array}{l}\text { MALLARMÉ, } \\
\text { Stéphane. Brinde } \\
\text { fúnebre e outros } \\
\text { poemas. Rio de } \\
\text { Janeiro: } 7 \text { Letras, } \\
\text { 2007. }\end{array}$ & I-467, 3, 80. & $\begin{array}{c}\text { Júlio } \\
\text { Castañon } \\
\text { Guimarães }\end{array}$ & & Capa & Não & Não & Sim & Sim & \\
\hline 127 & $\begin{array}{l}\text { MALLARMÉ, } \\
\text { Stéphane. Contos } \\
\text { indianos. São } \\
\text { Paulo: Hedra, } \\
2006 .\end{array}$ & $\begin{array}{c}\text { ANEXO II- } \\
765,5,44 .\end{array}$ & $\begin{array}{c}\text { Dorothée de } \\
\text { Bruchard }\end{array}$ & DITRA & Capa & $\begin{array}{l}\text { Sim. . Introdução } \\
\text { de Dirceu Villa. }\end{array}$ & $\mathrm{Sim}^{30}$ & Não & Não & $\begin{array}{c}\text { Página } \\
\text { introdutória, } \\
\text { biografia de } \\
\text { Mallarmé, } \\
\text { informações } \\
\text { sobre a obra }\end{array}$ \\
\hline
\end{tabular}

30 "Entretanto, mesmo aí Mallarmé modificaria um detalhe essencial, que é o tempo verbal. Ele reescreve: 'Tant que le jeune homme but, la pieuse femme le considéra attentivement': ‘Enquanto o jovem bebeu, a piedosa mulher considerou-o atentamente’, como lemos na presente tradução de Dorothée de Bruchard (...)” (pág. 23) 


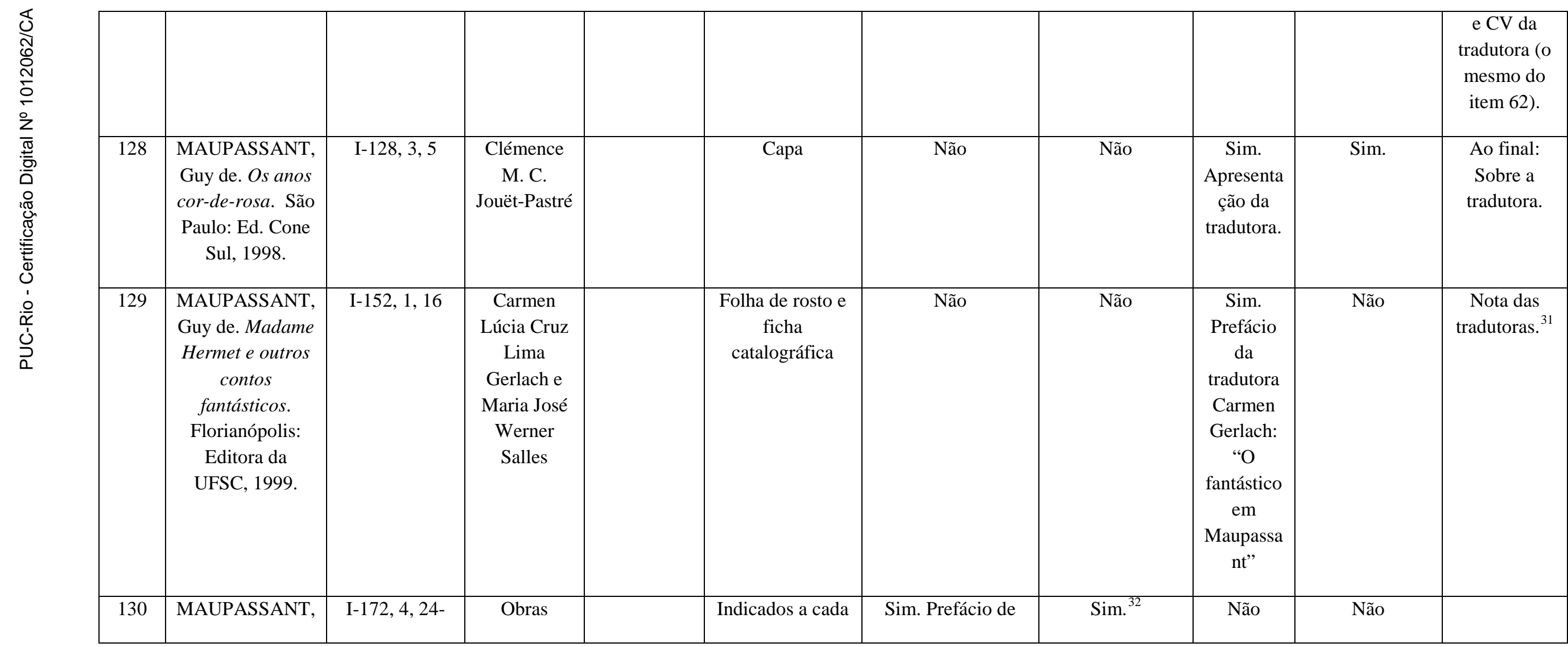

31 “Ambas professoras, autoras de ensaios e estudiosas de Guy de Maupassant há mais de vinte anos, esmeramo-nos em fazer uma tradução que fosse o mais fiel possível ao intento do exemplar mestre. Para tanto, examinamos as traduções já feitas de alguns contos e verificamos que alguns dos tradutores usaram um registro de língua elaborado para um autor cuja escolha do léxico recai sobre palavras simples, numa sintaxe igual a de um falante comum.” (pág. 21)

Segue-se minicurrículo das tradutoras (Carmen Gerlach é professora da UFSC e Maria José é professora da Aliança Francesa de Florianópolis) e agradecimentos à Embaixada da França no Brasil pelo patrocínio. 


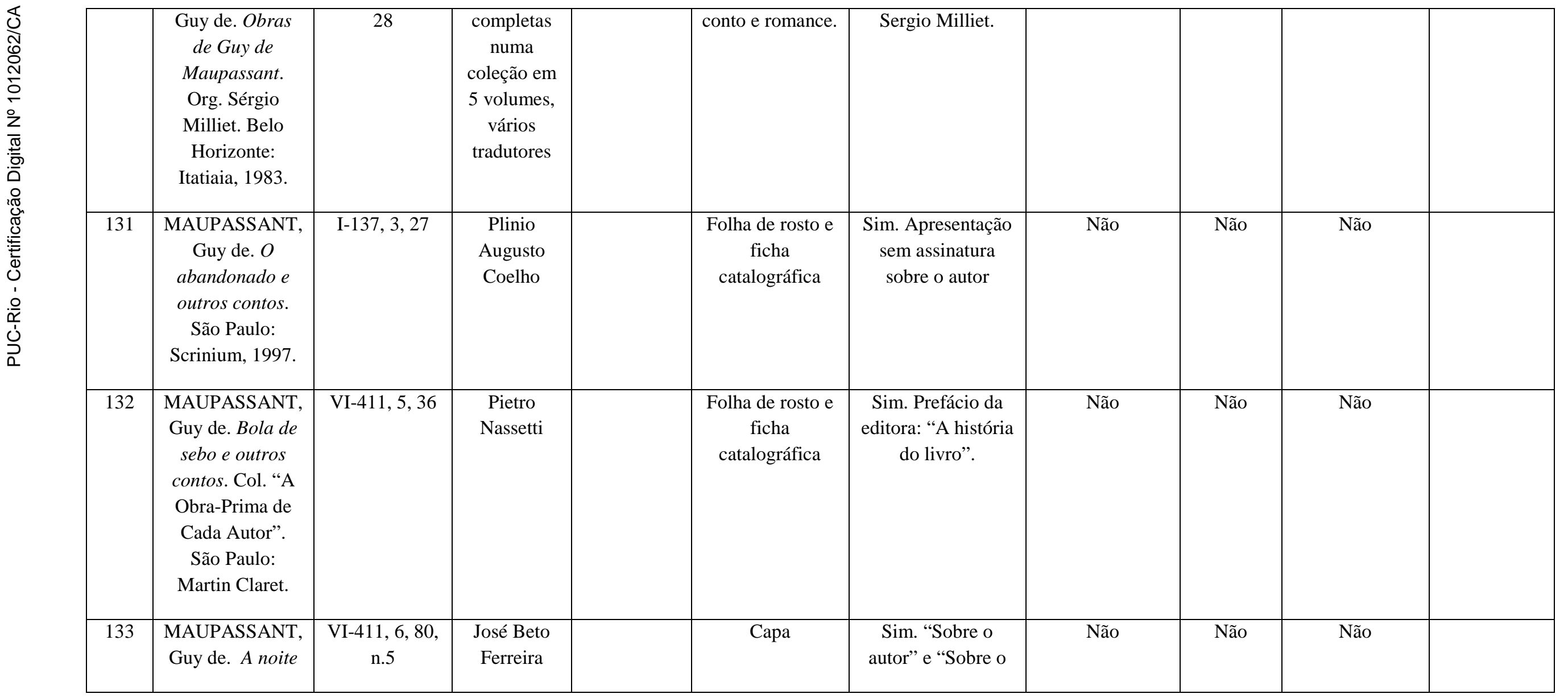

32 “A tradução dos romances e novelas foi entregue a escritores nacionais de renome. Procedeu-se em seguida a uma revisão cuidadosa, não com o intuito de alterar o estilo e dar uniformidade à obra completa, o que seria quase impossível, a menos de se apelar para um único tradutor, mas a fim de assegurar a fidelidade da tradução, em particular quanto às expressões populares ou de gíria, amiúde usadas por Maupassant”. (pág. 12) 


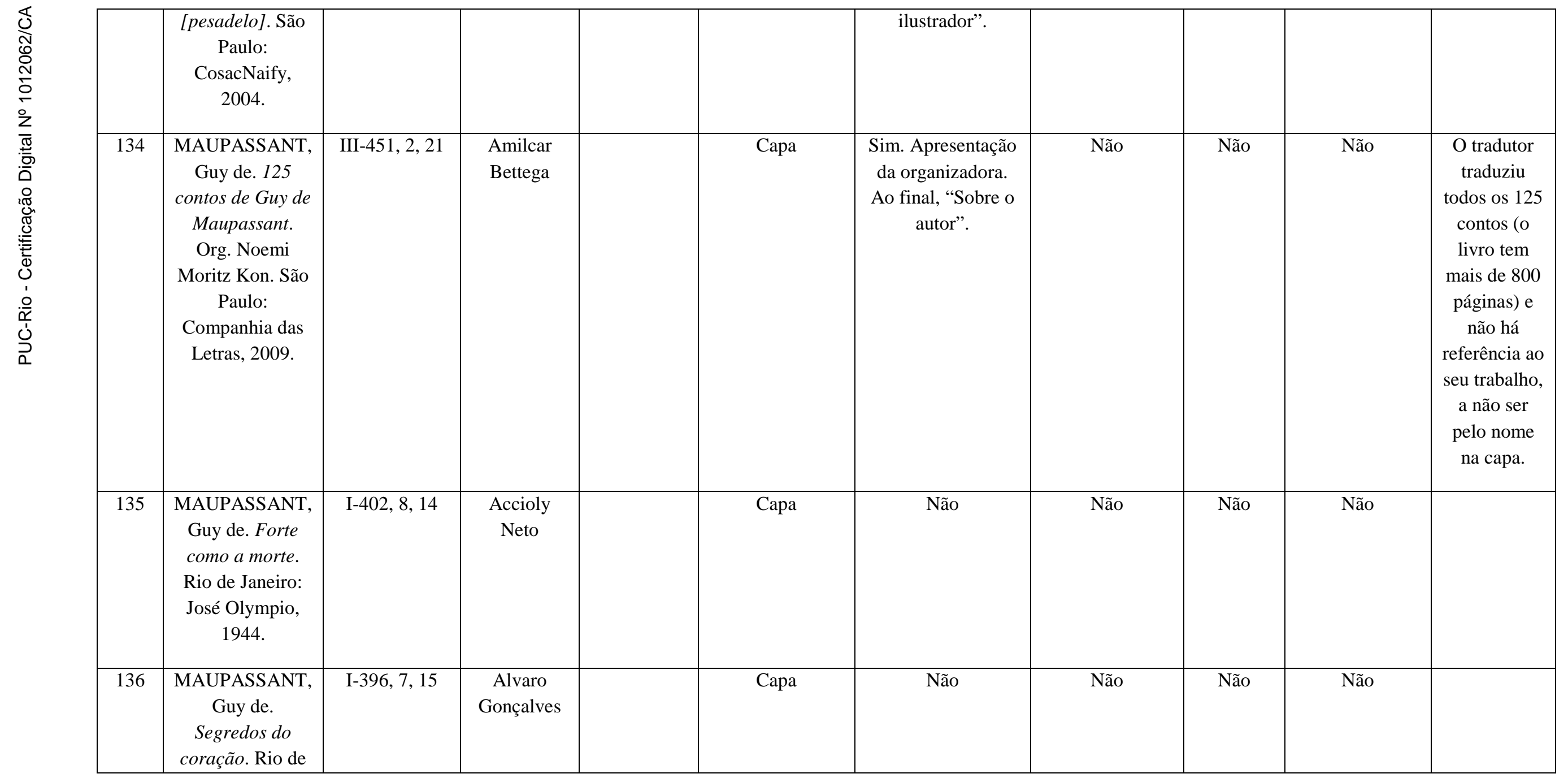




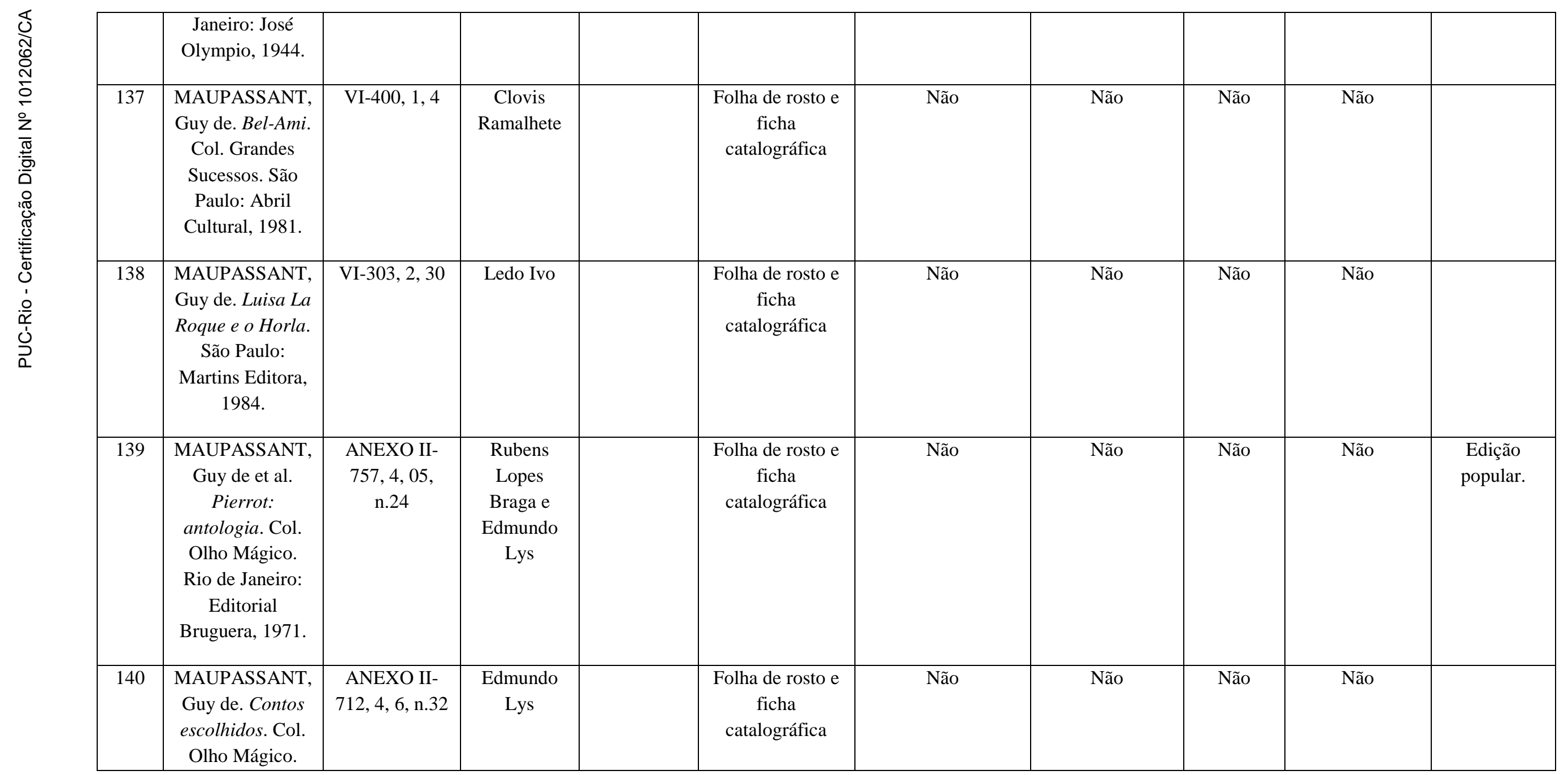




\begin{tabular}{|c|c|c|c|c|c|c|c|c|}
\hline & $\begin{array}{c}\text { Rio de Janeiro: } \\
\text { Editorial } \\
\text { Bruguera, } 1971 .\end{array}$ & & & & & & & \\
\hline 141 & $\begin{array}{c}\text { MAUPASSANT, } \\
\text { Guy de. } \\
\text { Mademoiselle } \\
\text { Fifi. Col. Olho } \\
\text { Mágico. Rio de } \\
\text { Janeiro: Editorial } \\
\text { Bruguera, } 1971 .\end{array}$ & $\begin{array}{l}\text { ANEXO II- } \\
757,4,05, n . \\
35\end{array}$ & $\begin{array}{l}\text { Áurea Brito } \\
\text { Weisenberg }\end{array}$ & $\begin{array}{c}\text { Folha de rosto e } \\
\text { ficha } \\
\text { catalográfica }\end{array}$ & Não & Não & Não & Não \\
\hline 142 & $\begin{array}{l}\text { MAUPASSANT, } \\
\text { Guy de. Bola de } \\
\text { sebo. Col. Olho } \\
\text { Mágico. Rio de } \\
\text { Janeiro: Editorial } \\
\text { Bruguera, } 1971 .\end{array}$ & $\begin{array}{l}\text { ANEXO II- } \\
712,4,6, \mathrm{n} . \\
31\end{array}$ & $\begin{array}{l}\text { Edmundo } \\
\text { Lys }\end{array}$ & $\begin{array}{l}\text { Folha de rosto e } \\
\text { ficha } \\
\text { catalográfica }\end{array}$ & Não & Não & Não & Não \\
\hline 143 & $\begin{array}{c}\text { MAUPASSANT, } \\
\text { Guy de. Ilka - } \\
\text { uma antologia. } \\
\text { Col. Olho } \\
\text { Mágico. Rio de } \\
\text { Janeiro: Editorial } \\
\text { Bruguera, } 1971 .\end{array}$ & $\begin{array}{l}\text { ANEXO II - } \\
757,4,05, n . \\
25\end{array}$ & $\begin{array}{l}\text { Rubens } \\
\text { Lopes } \\
\text { Braga }\end{array}$ & $\begin{array}{l}\text { Folha de rosto e } \\
\text { ficha } \\
\text { catalográfica }\end{array}$ & Não & Não & Não & Não \\
\hline 144 & $\begin{array}{l}\text { MAUPASSANT, } \\
\text { Guy de. O vestal } \\
\text { da senhora }\end{array}$ & II-355, 6, 14 & $\begin{array}{l}\text { Joaquim } \\
\text { Novaes } \\
\text { Teixeira }\end{array}$ & $\begin{array}{l}\text { Folha de rosto e } \\
\text { ficha } \\
\text { catalográfica }\end{array}$ & Não & Não & Não & Não \\
\hline
\end{tabular}




\begin{tabular}{|c|c|c|c|c|c|c|c|c|c|c|}
\hline & $\begin{array}{l}\text { Husson e Inútil } \\
\text { beleza. São } \\
\text { Paulo: Martins } \\
\text { Editora, s/d. }\end{array}$ & & & & & & & & & \\
\hline 145 & $\begin{array}{l}\text { MAUPASSANT, } \\
\text { Guy de. Uma } \\
\text { vida. Col. } \\
\text { Grandes } \\
\text { Romancistas. } \\
\text { São Paulo: Abril } \\
\text { Cultural, } 1985 .\end{array}$ & XI-265, 4, 59. & $\begin{array}{l}\text { Ascendino } \\
\text { Leite }\end{array}$ & & $\begin{array}{l}\text { Folha de rosto e } \\
\text { ficha } \\
\text { catalográfica }\end{array}$ & $\begin{array}{l}\text { Sim. Apresentação } \\
\text { de Sergio Milliet. }\end{array}$ & $\begin{array}{l}\text { Sim (o mesmo } \\
\text { do item 120). }\end{array}$ & Não. & Não. & \\
\hline 146 & $\begin{array}{c}\text { MAUPASSANT, } \\
\text { Guy de. Contos } \\
\text { de Guy de } \\
\text { Maupassant. São } \\
\text { Paulo: Cultrix, } \\
1985 .\end{array}$ & VI-268, 1, 8 & $\begin{array}{l}\text { Ondina } \\
\text { Ferreira }\end{array}$ & & $\begin{array}{c}\text { Folha de rosto e } \\
\text { ficha } \\
\text { catalográfica }\end{array}$ & Não & Não & Sim & Não & $\begin{array}{c}\text { Menção à } \\
\text { tradução na } \\
\text { quarta } \\
\text { capa. }^{33}\end{array}$ \\
\hline 147 & $\begin{array}{l}\text { MAUPASSANT, } \\
\text { Guy de. Bola de } \\
\text { sebo e outros } \\
\text { contos. Col. } \\
\text { Biblioteca dos } \\
\text { Séculos. Porto } \\
\text { Alegre: Editora }\end{array}$ & VI-384, 4, 64 & $\begin{array}{c}\text { Mario } \\
\text { Quintana, } \\
\text { Casimiro } \\
\text { Fernandes e } \\
\text { Justino } \\
\text { Martins }\end{array}$ & $\begin{array}{c}\text { DITRA } \\
\text { (Mario } \\
\text { Quintana) }\end{array}$ & $\begin{array}{l}\text { Folha de rosto e } \\
\text { ficha } \\
\text { catalográfica }\end{array}$ & Não & Não & Não & Não & \\
\hline
\end{tabular}

\footnotetext{
33 “A seleção e a tradução destes “Contos” foram confiadas a Ondina Ferreira, autora também do pequeno ensaio com que se abre o volume.”
} 


\begin{tabular}{|c|c|c|c|c|c|c|c|c|c|}
\hline & Globo, 1986. & & & & & & & & \\
\hline 148 & $\begin{array}{l}\text { MAUPASSANT, } \\
\text { Guy de. Uma } \\
\text { vida. Col. } \\
\text { Clássicos de } \\
\text { Bolso. São } \\
\text { Paulo: } \\
\text { Technoprint, } \\
\text { 1994. }\end{array}$ & VI-27, 3, 45 & $\begin{array}{c}\text { Elias } \\
\text { Davidovich }\end{array}$ & Capa & $\begin{array}{l}\text { Sim. Prefácio sobre } \\
\text { o autor. }\end{array}$ & Não & Não & Não & $\begin{array}{c}\text { Edição de } \\
\text { bolso }\end{array}$ \\
\hline 149 & $\begin{array}{c}\text { MAUPASSANT, } \\
\text { Guy de. Forte } \\
\text { como a morte. } \\
\text { Col. Clássicos de } \\
\text { Bolso. São } \\
\text { Paulo: } \\
\text { Technoprint, } \\
1994 .\end{array}$ & VI-28, 1, 51 & $\begin{array}{l}\text { Sérgio } \\
\text { Rubens }\end{array}$ & Сара & $\begin{array}{l}\text { Sim. Prefácio sobre } \\
\text { o autor. }\end{array}$ & Não & Sim. & Não & \\
\hline 150 & $\begin{array}{l}\text { MAUPASSANT, } \\
\text { Guy de. Uma } \\
\text { vida. Col. } \\
\text { Universidade de } \\
\text { Bolso. São } \\
\text { Paulo: Ediouro, } \\
\text { 1986. }\end{array}$ & VI-318, 3, 57 & $\begin{array}{l}\text { Marques } \\
\text { Rebelo }\end{array}$ & Capa & $\begin{array}{l}\text { Sim. Prefácio sobre } \\
\text { o autor, de H. } \\
\text { Perdigão. }\end{array}$ & Não & Não & Não & \\
\hline 151 & $\begin{array}{l}\text { MAUPASSANT, } \\
\text { Guy de. Bola de }\end{array}$ & VI-252, 2, 59 & $\begin{array}{c}\text { Mario } \\
\text { Quintana }\end{array}$ & $\begin{array}{l}\text { Folha de rosto e } \\
\text { ficha }\end{array}$ & Não & Não & Não & Não & \\
\hline
\end{tabular}




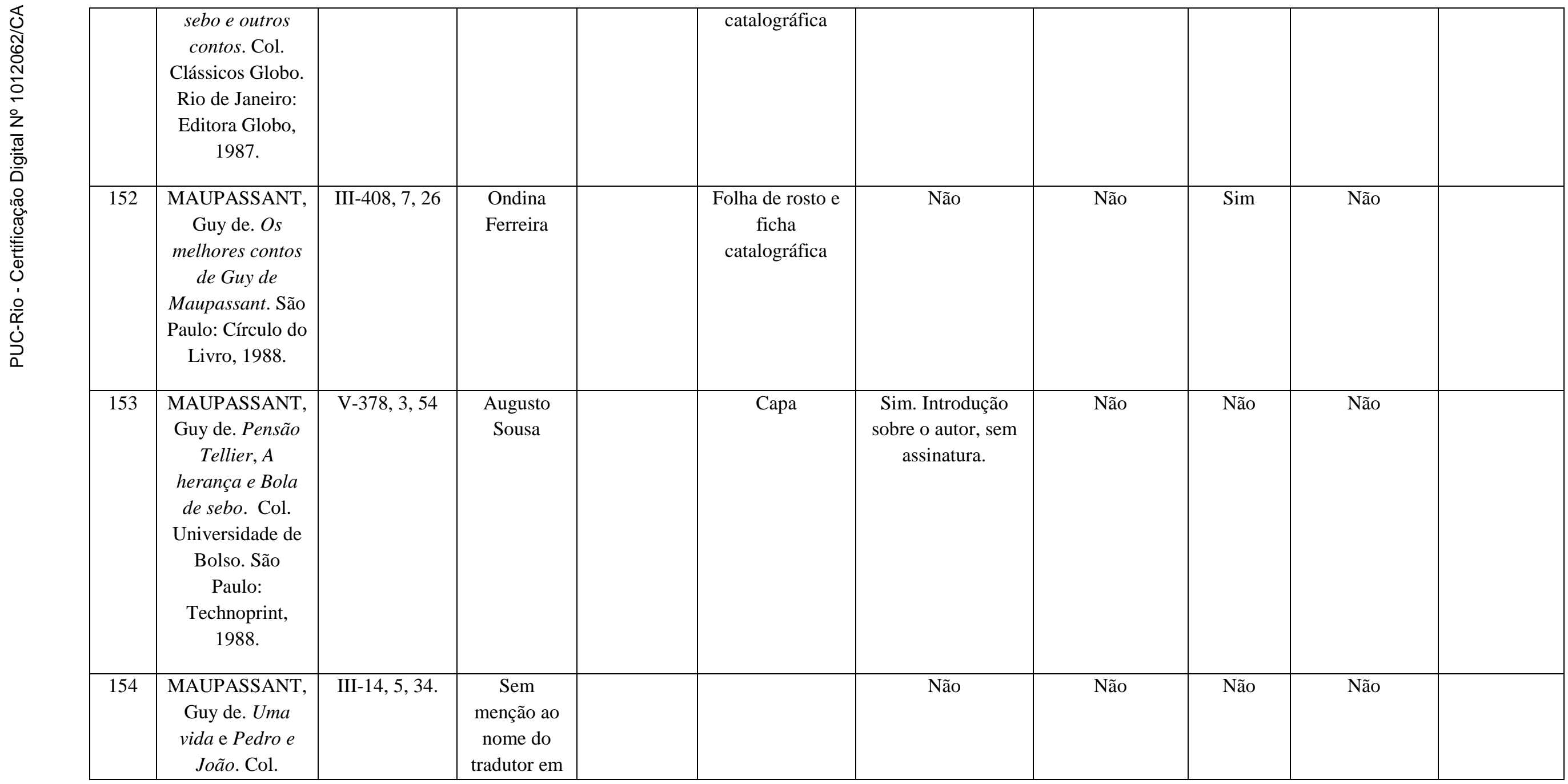




\begin{tabular}{|c|c|c|c|c|c|c|c|c|c|}
\hline & $\begin{array}{c}\text { Grandes } \\
\text { Romances } \\
\text { Universais. São } \\
\text { Paulo: W. M. } \\
\text { Jackson, } 1959 .\end{array}$ & & lugar algum & & & & & & \\
\hline 155 & $\begin{array}{c}\text { MAUPASSANT, } \\
\text { Guy de. Gustave } \\
\text { Flaubert. } \\
\text { Campinas: } \\
\text { Pontes, } 1990 .\end{array}$ & III-333, 2, 42 & Betty Joyce & Capa & $\begin{array}{l}\text { Sim. Prefácio de } \\
\text { Guy de Valmont } \\
\text { sobre o autor e a } \\
\text { obra. }\end{array}$ & Não & Não & Não & \\
\hline 156 & $\begin{array}{l}\text { MAUPASSANT, } \\
\text { Guy de. Bola de } \\
\text { sebo. São Paulo; } \\
\text { Scipione, } 1993 .\end{array}$ & VI-5, 2, 44 & $\begin{array}{l}\text { Paulo } \\
\text { Mendes } \\
\text { Campos }\end{array}$ & Capa & $\begin{array}{l}\text { Sim. Prefácio: } \\
\text { “Quem foi } \\
\text { Maupassant?” } \\
\text { Posfácio sobre o } \\
\text { tradutor: “Quem } \\
\text { foi Paulo Mendes } \\
\text { Campos?” }\end{array}$ & $\mathrm{Sim}^{34}$ & Não & Não & $\begin{array}{l}\text { A tradução é } \\
\text { apresentada } \\
\text { como } \\
\text { adaptação. }\end{array}$ \\
\hline 157 & $\begin{array}{l}\text { MAUPASSANT, } \\
\text { Guy de. O } \\
\text { cordão e Meu tio } \\
\text { Julio. Porto }\end{array}$ & VI-21, 3, 27 & $\begin{array}{c}\text { Elisa } \\
\text { Tamajusuku } \\
\text {, Maria } \\
\text { Alves }\end{array}$ & $\begin{array}{c}\text { Folha de rosto e } \\
\text { ficha } \\
\text { catalográfica }\end{array}$ & Não & Não & Não & Não & \\
\hline
\end{tabular}

34 “Além de poeta, cronista e contista, Paulo foi um tradutor brilhante; publicou mais de quinze obras e está presente em numerosas antologias da literatura brasileira no Brasil e no exterior".

Para a Série Reencontro, adaptou Bouvard e Pécuchet, de Flaubert (Menção Honrosa do Prêmio Jabuti 88), Bola de Sebo e outras histórias, de Maupassant (Menção Honrosa do Prêmio Jabuti 89), O Sr. Pickwick em flagrantes, de Dickens, e Cartas do meu moinho, de Daudet (Prêmio Monteiro Lobato de melhor tradução juvenil, FNLIJ 90).” (pág. 101) 


\begin{tabular}{|c|c|c|c|c|c|c|c|c|c|}
\hline & $\begin{array}{l}\text { Alegre: Editora } \\
\text { Paraula, } 1993 .\end{array}$ & & $\begin{array}{c}\text { Müller, } \\
\text { Maria } \\
\text { Isabel } \\
\text { Geraldi } \\
\text { Pizzato, } \\
\text { Maria Stella } \\
\text { Dischinger } \\
\text { da Cunha }\end{array}$ & & & & & & \\
\hline 158 & $\begin{array}{c}\text { MAUPASSANT, } \\
\text { Guy de. Pensão } \\
\text { Tellier, A } \\
\text { herança e Bola } \\
\text { de sebo. Col. } \\
\text { Clássicos de } \\
\text { Bolso. São } \\
\text { Paulo: } \\
\text { Technoprint, } \\
\text { 1993. }\end{array}$ & VI-36, 4, 46 & $\begin{array}{l}\text { Augusto de } \\
\text { Sousa }\end{array}$ & Capa & $\begin{array}{c}\text { Sim. Introdução } \\
\text { sobre o autor e a } \\
\text { obra, não assinada. }\end{array}$ & Não & Não & Não & \\
\hline 159 & $\begin{array}{c}\text { MAUPASSANT, } \\
\text { Guy de. Bola de } \\
\text { sebo. São Paulo: } \\
\text { Scipione, } 1997 . \\
\text { Col. Série } \\
\text { Reencontro. }\end{array}$ & $\mathrm{I}-52,2,47$ & $\begin{array}{c}\text { Paulo } \\
\text { Mendes } \\
\text { Campos }\end{array}$ & Сара & $\begin{array}{l}\text { Sim. Prefácio: } \\
\text { “Quem foi } \\
\text { Maupassant?” } \\
\text { Posfácio sobre o } \\
\text { tradutor: “Quem } \\
\text { foi Paulo Mendes } \\
\text { Campos?” }\end{array}$ & $\begin{array}{l}\text { Sim (o mesmo } \\
\text { do item 156). }\end{array}$ & Não & Não & $\begin{array}{l}\text { A tradução é } \\
\text { apresentada } \\
\text { como } \\
\text { adaptação. }\end{array}$ \\
\hline 160 & $\begin{array}{l}\text { MAUPASSANT, } \\
\text { Guy de. A }\end{array}$ & $\mathrm{I}-11,6,52$ & Augusto de & $\begin{array}{c}\text { Folha de rosto e } \\
\text { ficha }\end{array}$ & Não & Não & Não & Não & \\
\hline
\end{tabular}




\begin{tabular}{|c|c|c|c|c|c|c|c|c|c|c|}
\hline & $\begin{array}{c}\text { herança. Rio de } \\
\text { Janeiro: Ediouro, } \\
1997 .\end{array}$ & & Sousa & & catalográfica & & & & & \\
\hline 161 & $\begin{array}{l}\text { MAUPASSANT, } \\
\text { Guy de. Contos } \\
\text { fantásticos: } O \\
\text { Horla \& outras } \\
\text { histórias. Col. } \\
\text { L\&PM Pocket. } \\
\text { Porto Alegre: } \\
\text { L\&PM, 1997. }\end{array}$ & VI-84, 1, 53 & $\begin{array}{c}\text { José } \\
\text { Thomaz } \\
\text { Brum }\end{array}$ & & $\begin{array}{c}\text { Folha de rosto e } \\
\text { ficha } \\
\text { catalográfica }\end{array}$ & Não & Não & $\begin{array}{l}\text { Sim. } \\
\text { Prefácio } \\
\text { do } \\
\text { organizad } \\
\text { or e } \\
\text { tradutor } \\
\text { sobre o } \\
\text { gênero } \\
\text { "contos } \\
\text { fantástico } \\
\text { s. }\end{array}$ & Não & \\
\hline 162 & $\begin{array}{l}\text { MOLIÈRE. Don } \\
\text { Juan: o } \\
\text { convidado de } \\
\text { pedra. Col. } \\
\text { L\&PM Pocket. } \\
\text { Porto Alegre: } \\
\text { L\&PM, 2002. }\end{array}$ & VI-304, 1, 18 & $\begin{array}{c}\text { Millôr } \\
\text { Fernandes. }\end{array}$ & DITRA & Capa & Não & Não & Não & Não & $\begin{array}{l}\text { Quarta } \\
\text { capa }^{35}\end{array}$ \\
\hline 163 & $\begin{array}{l}\text { MOLIÈRE. As } \\
\text { eruditas. Col. } \\
\text { L\&PM Pocket. }\end{array}$ & $\mathrm{V}-219,5,13$ & $\begin{array}{c}\text { Millôr } \\
\text { Fernandes }\end{array}$ & DITRA & Capa & $\begin{array}{l}\text { Sim. "Sobre o } \\
\text { autor" e "Sobre o } \\
\text { tradutor". }\end{array}$ & Sim & Sim & Sim & Quarta capa \\
\hline
\end{tabular}

35 “(...) a coleção L\&PM Pocket publica na magnífica tradução de Millôr Fernandes. Aqui, Millôr traz um Molière vivo e contemporâneo, mantendo na íntegra a fina ironia, o sarcasmo e o senso de humor que consagraram o genial autor francês e o tornaram, para sempre moderno”. 


\begin{tabular}{|c|c|c|c|c|c|c|c|c|c|}
\hline & $\begin{array}{l}\text { Porto Alegre: } \\
\text { L\&PM, } 2003 .\end{array}$ & & & & & & & & \\
\hline 164 & $\begin{array}{l}\text { MOLIÈRE. O } \\
\text { doente } \\
\text { imaginário. Ed. } \\
\text { bilíngue. Belo } \\
\text { Horizonte: } \\
\text { Crisálida, 2002. }\end{array}$ & VI-413, 2, 14 & $\begin{array}{l}\text { Leonardo } \\
\text { Gonçalves }\end{array}$ & Capa & Não & Não & Sim & Não & $\begin{array}{l}\text { Ao final, } \\
\text { "Sobre o } \\
\text { tradutor". }{ }^{36}\end{array}$ \\
\hline 165 & $\begin{array}{l}\text { MOLIÈRE. As } \\
\text { sabichonas. } \\
\text { Biblioteca } \\
\text { Martins Fontes. } \\
\text { São Paulo: } \\
\text { Martins Fontes, } \\
2005 .\end{array}$ & VI-294, 3, 24 & $\begin{array}{l}\text { Jenny } \\
\text { Klabin } \\
\text { Segall }\end{array}$ & $\begin{array}{c}\text { Folha de rosto e } \\
\text { ficha } \\
\text { catalográfica }\end{array}$ & $\begin{array}{l}\text { Sim. Apresentação } \\
\text { da } 1^{\text {a }} \text {. Edição, sem } \\
\text { assinatura. }{ }^{37} \\
\text { Nota à presente } \\
\text { edição. }\end{array}$ & Sim. & Não & Não & $\begin{array}{c}\text { Orelhas (o } \\
\text { mesmo do } \\
\text { item 95). }\end{array}$ \\
\hline 166 & MOLIÈRE. $O$ & VI-294, 3, 25 & Jenny & Folha de rosto e & Sim. & Sim (o mesmo & Não & Não & Orelhas $^{38}$ \\
\hline
\end{tabular}

\footnotetext{
36 "Sobre o tradutor": Leonardo Gonçalves, nascido em 1975, é estudante do curso de letras na UFMG. (...) Agora inicia-se como autor e tradutor. Publicou traduções em periódicos de Belo Horizonte. É autor (...) do livreto de cordel, A rainha da cocada preta (Crisálida, 2000) (pág. 195)

37 "Trazendo novamente Molière para o idioma português, Jenny Klabin Segall, já conhecida por traduções anteriores desse autor, assim como as das "Três Tragédias de Racine" e de "Fausto" de Goethe, deu-lhe um tratamento linguístico e de estilo perfeitamente inseridos na clave da tradução em que se conserva a essência conceptual e artística do escritor, o que quer dizer, naturaliza-o.

Com este novo trabalho continua Jenny Klabin Segall a dedicar-se à tarefa de trazer para o vernáculo, em traduções integrais em verso, as obras-mestras do Teatro Universal, tendo adotado o critério do respeito rigoroso à forma original, no que condiz tanto ao número de versos como à sua disposição e de suas rimas.

Apresentando este e os demais volumes do Teatro Clássico em traduções de Jenny Klabin Segall, estamos certos de efetivamente contribuir para a dramaturgia e estudos de teatro entre nós”. (Pág. X)
} 


\begin{tabular}{|c|c|c|c|c|c|c|c|c|c|}
\hline & $\begin{array}{c}\text { tartufo e } O \\
\text { misantropo. } \\
\text { Biblioteca } \\
\text { Martins Fontes. } \\
\text { São Paulo: } \\
\text { Martins Fontes, } \\
2005 .\end{array}$ & & $\begin{array}{c}\text { Klabin } \\
\text { Segall }\end{array}$ & $\begin{array}{c}\text { ficha } \\
\text { catalográfica }\end{array}$ & & $\begin{array}{c}\text { do item } \\
\text { anterior). }\end{array}$ & & & \\
\hline 167 & $\begin{array}{l}\text { MOLIÈRE. A } \\
\text { escola dos } \\
\text { maridos e O } \\
\text { marido da } \\
\text { fidalga. } \\
\text { Biblioteca } \\
\text { Martins Fontes. } \\
\text { São Paulo: } \\
\text { Martins Fontes, } \\
\text { 2005. }\end{array}$ & VI-294, 3, 23 & $\begin{array}{c}\text { Jenny } \\
\text { Klabin } \\
\text { Segall }\end{array}$ & $\begin{array}{c}\text { Folha de rosto e } \\
\text { ficha } \\
\text { catalográfica }\end{array}$ & $\begin{array}{l}\text { Sim. Prefácio à } 1^{\text {a }} \text {. } \\
\text { Edição: de } \\
\text { Guilherme de } \\
\text { Almeida (o mesmo } \\
\text { da edição da } \\
\text { Ediouro). Nota à } \\
\text { Presente Edição. }\end{array}$ & $\begin{array}{l}\text { Sim (o mesmo } \\
\text { do item 166). }\end{array}$ & Não & Não & Orelhas $^{39}$ \\
\hline
\end{tabular}

38 “Jenny Klabin Segall é dessas criaturas que se revelam em pequenas doses, de surpresa em surpresa, e a última surpresa que ela nos reservou foi agora dar publicidade um encantador volume de versos, contendo duas traduções de Molière... O livro todo se apresenta de uma homogeneidade perfeita de Alexandrinos de rimas ricas, conservando de Molière a graça e seus métodos de criação, as suas virtudes de autor”. Tarsila do Amaral.

39 “Traduzir Molière não é tarefa fácil. Traduzir a sua prosa em versos pode constituir até um perigo. Mas desses dois cometimentos se saiu muito bem a sra. Jenny Klabin Segall.

... Traduzir prosa fluente, cheia de meandros, repleta de sinuosidades de Molière, para versos [em português] representa uma dessas tarefas em que a responsabilidade anda de par com a pretensão e onde não se pode precisar bem onde começa uma e onde termina a outra. Mas o fato imprevisível, o fato real e desconcertante é que isso foi conseguido, com um tremendo esforço, já se pode prever, mas com uma segurança, uma maestria, um domínio completo, absoluto.

Molière aparece, nesses versos [em português], em toda a sutileza das duas frases, em toda a tortuosidade finíssima dos seus ditos, em toda a plenitude de sua força”. São Paulo, 7 de novembro de 1937, Nelson Werneck Sodré. 


\begin{tabular}{|c|c|c|c|c|c|c|c|c|c|}
\hline 168 & $\begin{array}{l}\text { MOLIÈRE. O } \\
\text { doente } \\
\text { imaginário. Col. } \\
\text { A Obra-Prima de } \\
\text { Cada Autor. São } \\
\text { Paulo: Martin } \\
\text { Claret, 2006. }\end{array}$ & VI-411, 6, 54 & $\begin{array}{l}\text { Daniel } \\
\text { Fresnot }\end{array}$ & $\begin{array}{l}\text { Folha de rosto e } \\
\text { ficha } \\
\text { catalográfica }\end{array}$ & $\begin{array}{l}\text { Sim. Prefácio: a } \\
\text { história do livro e a } \\
\text { coleção. }\end{array}$ & Não & Sim & Não & \\
\hline 169 & $\begin{array}{l}\text { MOLIÈRE. O } \\
\text { tartufo ou } O \\
\text { impostor. Col. A } \\
\text { Obra-Prima de } \\
\text { Cada Autor. São } \\
\text { Paulo: Martin } \\
\text { Claret, } 2006 .\end{array}$ & VI-411, 6, 51 & $\begin{array}{c}\text { Jean } \\
\text { Melville }\end{array}$ & $\begin{array}{l}\text { Folha de rosto e } \\
\text { ficha } \\
\text { catalográfica }\end{array}$ & $\begin{array}{c}\text { Sim. Prefácio: a } \\
\text { história do livro e a } \\
\text { coleção. } \\
\text { Introdução sobre o } \\
\text { autor e sua obra. } \\
\text { Prefácio: A gênese } \\
\text { da comédia } \\
\text { Tartufo, por Robert } \\
\text { Jouanny. Prefácio } \\
\text { de Molière }\end{array}$ & Não & Não & Não & \\
\hline 170 & $\begin{array}{c}\text { MOLIËRE. As } \\
\text { preciosas } \\
\text { ridículas. Col. } \\
\text { Teatro e Vida, } \\
\text { Vol. } 4 . \\
\text { Mairiporã: } \\
\text { Editora Veredas, } \\
1997 .\end{array}$ & $\begin{array}{l}\text { ANEXO II - } \\
757,1,64\end{array}$ & $\begin{array}{c}\text { Maria } \\
\text { Cristina } \\
\text { Guimarães }\end{array}$ & $\begin{array}{l}\text { Folha de rosto e } \\
\text { ficha } \\
\text { catalográfica }\end{array}$ & $\begin{array}{l}\text { Sim. Notícia no } \\
\text { início não assinada } \\
\text { sobre a peça. } \\
\text { Prefácio de } \\
\text { Molière. }\end{array}$ & Não & Não & Não & \\
\hline 171 & $\begin{array}{l}\text { MOLIÈRE. Don } \\
\text { Juan. São Paulo: }\end{array}$ & II- $475,1,65$ & Celina & Сара & $\begin{array}{l}\text { Sim. Apresentação } \\
\text { do autor e da peça, }\end{array}$ & Não & Não & Não & Menção à \\
\hline
\end{tabular}




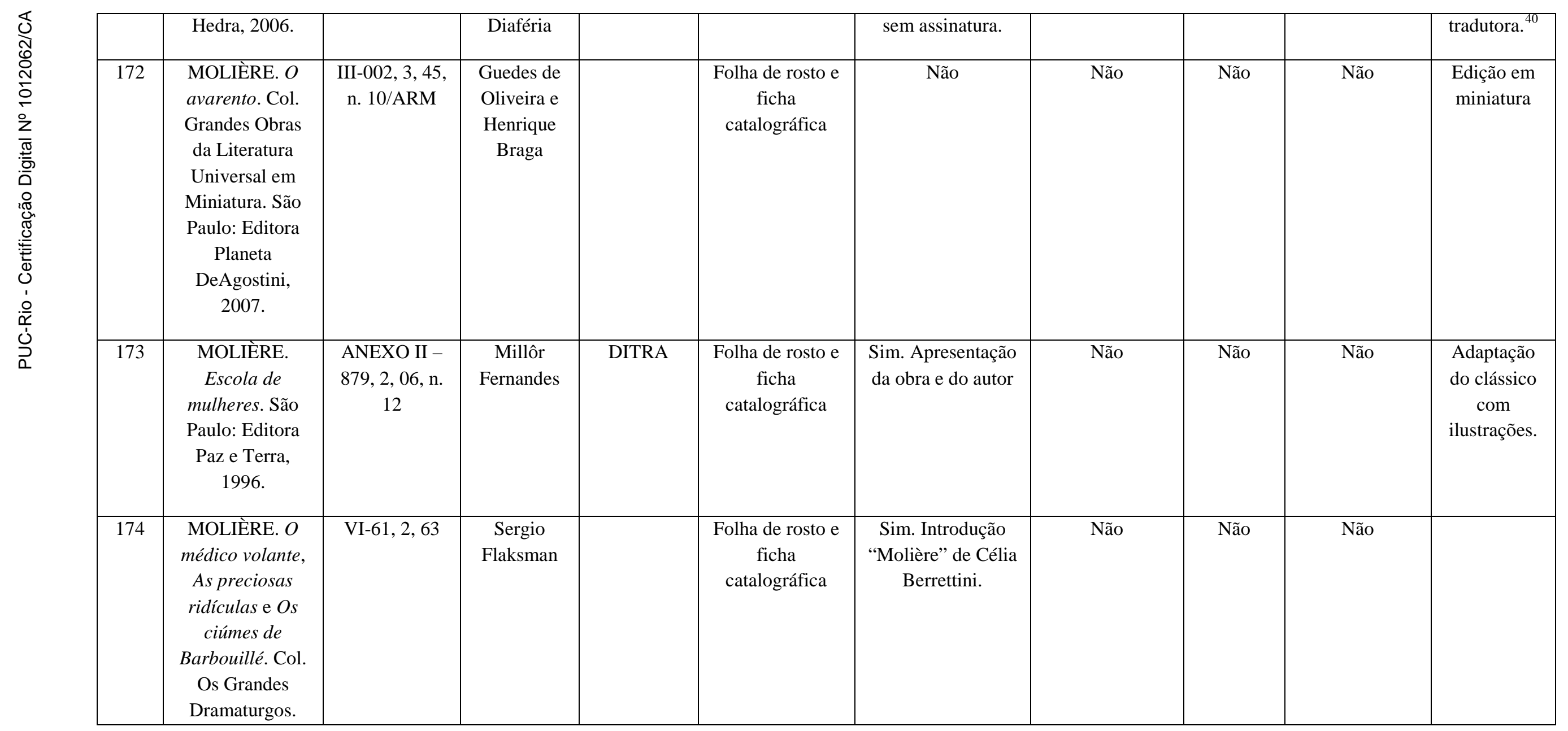

40 “Celina Diaféria é formada pela Faculdade de Filosofia, Ciências Humanas e Letras da USP e leciona língua portuguesa e literatura em São Paulo”. 


\begin{tabular}{|c|c|c|c|c|c|c|c|c|c|c|}
\hline & $\begin{array}{c}\text { São Paulo: } \\
\text { Editora Peixoto } \\
\text { Neto, } 2007 .\end{array}$ & & & & & & & & & \\
\hline 175 & $\begin{array}{l}\text { MOLIÈRE. O } \\
\text { avarento. Série } \\
\text { Recontar Juvenil. } \\
\text { São Paulo: } \\
\text { Escala } \\
\text { Educacional, } \\
2009 .\end{array}$ & $\begin{array}{c}\text { ANEXO II - } \\
896,1,01, \mathrm{n} . \\
06\end{array}$ & $\begin{array}{l}\text { Socorro } \\
\text { Acioli }\end{array}$ & & Capa & $\begin{array}{l}\text { Sim. Posfácio } \\
\text { sobre o autor e a } \\
\text { obra. }\end{array}$ & Não & Não & Não & $\begin{array}{c}\text { Sobre a } \\
\text { adaptadora: } \\
\text { CV da } \\
\text { autora e } \\
\text { pesquisadora } \\
\text { de literatura } \\
\text { infanto- } \\
\text { juvenil. }\end{array}$ \\
\hline 176 & $\begin{array}{l}\text { MOLIÈRE. O } \\
\text { doente } \\
\text { imaginário. São } \\
\text { Paulo: ed. 34, } \\
\text { 2010. }\end{array}$ & IV-396, 2, 5 & $\begin{array}{l}\text { Marilia } \\
\text { Toledo }\end{array}$ & & Capa & $\begin{array}{l}\text { Sim. "Sobre } \\
\text { Molière”, "Sobre } \\
\text { Marilia Toledo" e } \\
\text { "Sobre Laerte” } \\
\text { (ilustrador). }\end{array}$ & Sim. & Sim. & Sim. & Quarta capa. \\
\hline 177 & $\begin{array}{l}\text { MOLIÈRE. } O \\
\text { tartufo, Escola } \\
\text { de mulheres e } O \\
\text { burguês fidalgo. } \\
\text { São Paulo: Abril } \\
\text { Cultural, } 1983 .\end{array}$ & VI-350, 1, 50 & $\begin{array}{c}\text { Jacy } \\
\text { Monteiro, } \\
\text { Millôr } \\
\text { Fernandes e } \\
\text { Octavio } \\
\text { Mendes } \\
\text { Cajado }\end{array}$ & $\begin{array}{c}\text { DITRA } \\
\text { (Millôr } \\
\text { Fernandes) }\end{array}$ & $\begin{array}{l}\text { Folha de rosto e } \\
\text { ficha } \\
\text { catalográfica }\end{array}$ & $\begin{array}{l}\text { Sim. Introdução } \\
\text { sobre o autor e sua } \\
\text { obra. }\end{array}$ & Não & Não & Não & \\
\hline 178 & $\begin{array}{l}\text { MOLIÈRE. } \\
\text { Escola de } \\
\text { mulheres e }\end{array}$ & VI-25, 1, 50. & $\begin{array}{l}\text { Jenny } \\
\text { Klabin } \\
\text { Segall }\end{array}$ & & Capa & $\begin{array}{c}\text { Sim. Estudo } \\
\text { introdutório de } \\
\text { Paulo Rónai sobre }\end{array}$ & Sim & Não & Não & $\begin{array}{l}\text { Edição de } \\
\text { bolso }\end{array}$ \\
\hline
\end{tabular}




\begin{tabular}{|c|c|c|c|c|c|c|c|c|}
\hline & $\begin{array}{c}\text { Escola de } \\
\text { maridos. Col. } \\
\text { Clássicos de } \\
\text { Bolso. Rio de } \\
\text { Janeiro: Ediouro, } \\
\text { 1994. }\end{array}$ & & & & $\begin{array}{l}\text { a obra e o autor. } 2 . \\
\text { Prefácio de Paulo } \\
\text { Rónai à comédia } \\
\text { "Escola de } \\
\text { mulheres”, sem } \\
\text { menção à tradução. } \\
\text { 3. Prefácio de } \\
\text { Guilherme de } \\
\text { Almeida à comédia } \\
\text { "Escola de } \\
\text { maridos"41 }\end{array}$ & & & \\
\hline 179 & $\begin{array}{c}\text { MOLIÈRE. O } \\
\text { avarento e As } \\
\text { sabichonas. Col. } \\
\text { Clássicos de }\end{array}$ & VI-25, 4, 57 & $\begin{array}{c}\text { Bandeira } \\
\text { Duarte e } \\
\text { Jenny } \\
\text { Klabin }\end{array}$ & Capa & $\begin{array}{c}\text { Sim. Estudo } \\
\text { bibliográfico da } \\
\text { comédia “O } \\
\text { avarento” e resumo }\end{array}$ & Sim & Não & Não \\
\hline
\end{tabular}

41 "Não sei voltar a mim do envolvente encanto e da surpresa suave que me proporcionou a leitura_- ainda dos originais - destas traduções, por Jenny Klabin Segall, de dois grandes momentos da obra de Molière.

Por mais que eu esperasse dessa senhora de tão fina cultura - esposa de Lasar Segall, um dos mais incisivos mestres da pintura moderna; vivendo, pois, num ambiente que é todo arte; respirando, portanto, uma atmosfera que é toda espírito; conseguindo, assim, tão superiormente resolver o problema dificílimo que Daudet enunciou no seu "Femmes d'Artistes" -; por mais que eu esperasse dessa dona de tantos privilégios, nunca poderia imaginar ser possível, por quem quer que fosse, nem mesmo por ela, recriar Molière em português.

A prática de verter poesias - a que ultimamente me tenho dado - autoriza-me , de certo modo, a bem poder avaliar o infinito de boa vontade e de iluminada paciência que à exímia tradutora foi preciso para chegar, como chegou, entre as mais entusiásticas palmas, ao "rideau" final dessas duas peças.

Jenny Klabin Segall não se limitou a "traduzir", isto é, a trasladar de uma língua para outra, ou, simplesmente, a interpretar Molière em português. Fez mais, muito mais: "reproduziu”, quer dizer, "produziu de novo", sentindo, pensando e dizendo como, onde, porque e quando Molière sentiu, pensou e disse. O Precioso sabor original mantém-se intato na versão: intato no fundo e na forma. No fundo: pela identidade do espírito, das mínimas intenções, dos mais sutis propósitos. Na forma: pelo condimento estimulante da linguagem, leve e deliciosamente arcaizada, e pela técnica do verso, conservado, quanto possível, igual no seu corte, ritmo e rima (esta, às vezes, observada rigorosamente, até mesmo nos seus gêneros - “masculine”, ou aguda, e “féminine”, ou grave, alternadas). Neste particular, “A Escola de Maridos” é uma desnorteante surpresa.

Molière que renasce entre nós..

Beijo, com admiração e respeito, a mão sábia e mágica que operou tão paciente, lindo e inesperado milagre”. (pág. 87) 


\begin{tabular}{|c|c|c|c|c|c|c|c|c|}
\hline & $\begin{array}{c}\text { Bolso. Rio de } \\
\text { Janeiro: Ediouro, } \\
1994 .\end{array}$ & & Segall & & $\begin{array}{l}\text { da História do } \\
\text { Teatro Francês por } \\
\text { Bandeira Duarte. } \\
\text { Em “Análise e } \\
\text { tradução brasileira } \\
\text { da peça”, } \\
\text { comentário sobre a } \\
\text { tradução do } \\
\text { título. }{ }^{42} \text { Estudo } \\
\text { introdutório de “As } \\
\text { sabichonas” por } \\
\text { Paulo Rónai. }\end{array}$ & & & \\
\hline 180 & $\begin{array}{c}\text { MOLIÈRE. O } \\
\text { avarento e As } \\
\text { sabichonas. Col. } \\
\text { Universidade de } \\
\text { Bolso. Rio de } \\
\text { Janeiro: Ediouro, } \\
\text { 1987. }\end{array}$ & V-331, 7, 46. & $\begin{array}{c}\text { Bandeira } \\
\text { Duarte e } \\
\text { Jenny } \\
\text { Klabin } \\
\text { Segall }\end{array}$ & Capa & $\begin{array}{c}\text { Sim. Estudo } \\
\text { bibliográfico da } \\
\text { comédia “O } \\
\text { avarento” e resumo } \\
\text { da História do } \\
\text { Teatro Francês por } \\
\text { Bandeira Duarte. } \\
\text { Em “Análise e } \\
\text { tradução brasileira } \\
\text { da peça”, } \\
\text { comentário sobre a } \\
\text { tradução do título }\end{array}$ & Sim & Não & Não \\
\hline
\end{tabular}

42 “Se Molière vivesse hoje, não chamaria a sua peça de "O Avarento”, mas "O Agiota”. É esta última a verdadeira expressão do velho Harpagon, brotando de cada uma de suas atitudes, de cada um de seus gestos. Mais ampla do que a que lhe dá o título original, a classificação de "agiota” explica as supostas incoerências e é explicada pela cena em que Harpagon encontra no próprio filho o candidato a um empréstimo de condições absurdas”. (pág. 73) 


\begin{tabular}{|c|c|c|c|c|c|c|c|c|c|c|}
\hline & & & & & & $\begin{array}{l}\text { (a mesma do item } \\
\text { anterior). Estudo } \\
\text { introdutório de “As } \\
\text { sabichonas” por } \\
\text { Paulo Rónai. }\end{array}$ & & & & \\
\hline 181 & $\begin{array}{c}\text { MOLIÈRE. A } \\
\text { escola de } \\
\text { maridos e } O \\
\text { marido da } \\
\text { fidalga. Col. } \\
\text { Clássicos de } \\
\text { Bolso. Rio de } \\
\text { Janeiro: Ediouro, } \\
\text { 1992. }\end{array}$ & VI-479, 3, 39 & $\begin{array}{l}\text { Jenny } \\
\text { Klabin } \\
\text { Segall }\end{array}$ & & $\begin{array}{c}\text { Folha de rosto e } \\
\text { ficha } \\
\text { catalográfica }\end{array}$ & $\begin{array}{l}\text { Sim. Prefácio de } \\
\text { Guilherme de } \\
\text { Almeida, citado em } \\
\text { outras edições, } \\
\text { elogiando a } \\
\text { tradução. }\end{array}$ & Sim & Não & Não & \\
\hline 182 & $\begin{array}{l}\text { MOLIÈRE. Don } \\
\text { Juan. Col. } \\
\text { L\&PM Pocket. } \\
\text { Porto Alegre: } \\
\text { L\&PM, } 1997 .\end{array}$ & $\mathrm{I}-415,1,36$ & $\begin{array}{c}\text { Millôr } \\
\text { Fernandes }\end{array}$ & DITRA & $\begin{array}{l}\text { Folha de rosto e } \\
\text { ficha } \\
\text { catalográfica }\end{array}$ & Não & Não & Não & Não & $\begin{array}{l}\text { Quarta } \\
\text { capa }^{43}\end{array}$ \\
\hline 183 & $\begin{array}{l}\text { MOLIÈRE. O } \\
\text { avarento. Col. } \\
\text { Clássicos de } \\
\text { Ouro. Rio de } \\
\text { Janeiro: Ediouro, }\end{array}$ & VI-337, 1, 71 & $\begin{array}{l}\text { Bandeira } \\
\text { Duarte }\end{array}$ & & $\begin{array}{l}\text { Folha de rosto e } \\
\text { ficha } \\
\text { catalográfica }\end{array}$ & Não & Não & Não & Não & \\
\hline
\end{tabular}

43 “(...) a coleção L\&PM Pocket publica na magnífica tradução de Millôr Fernandes. Aqui, Millôr traz um Molière vivo e contemporâneo, mantendo na íntegra a fina ironia, o sarcasmo e o senso de humor que consagraram o genial autor francês e o tornaram, para sempre moderno". 


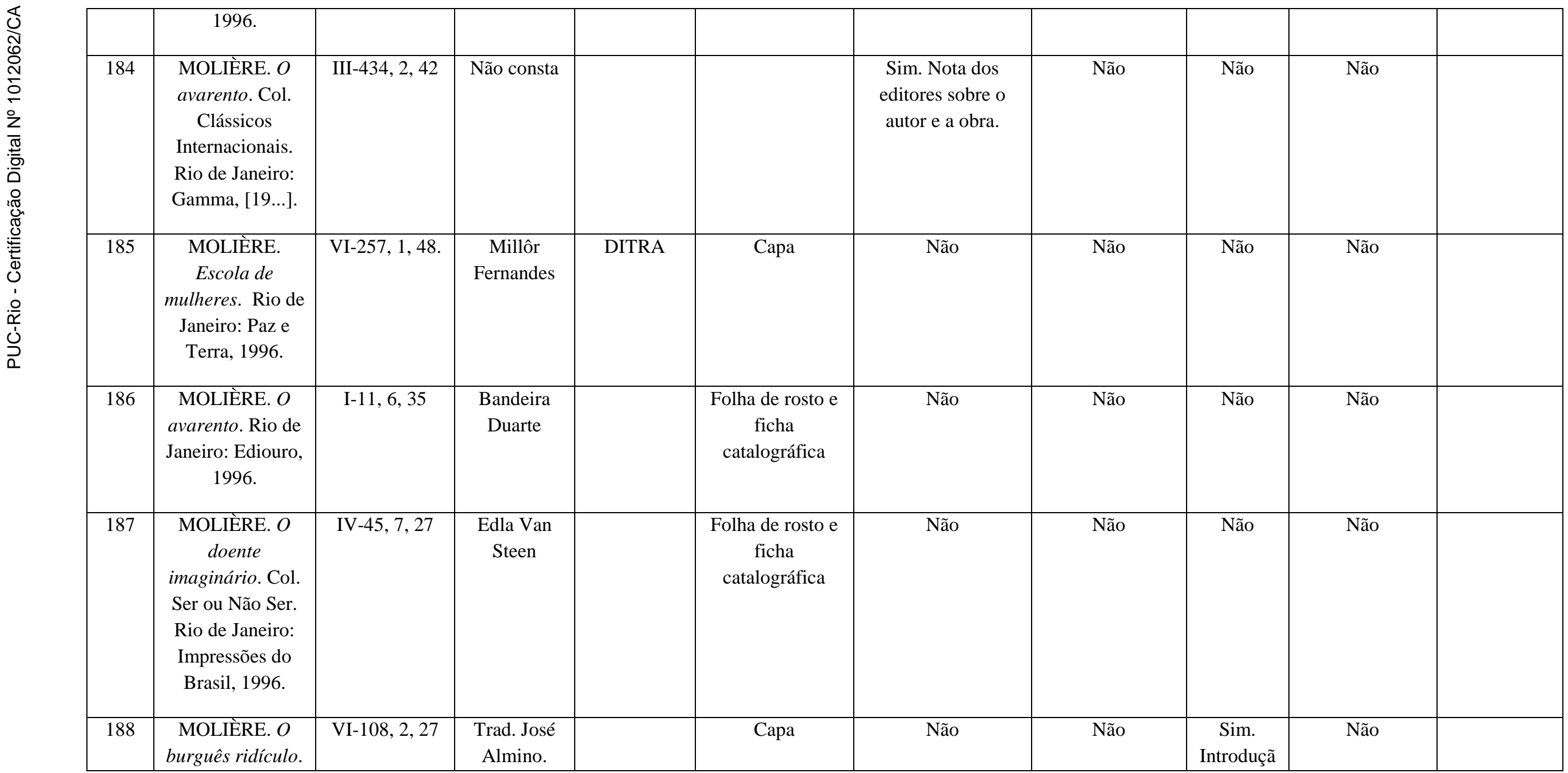




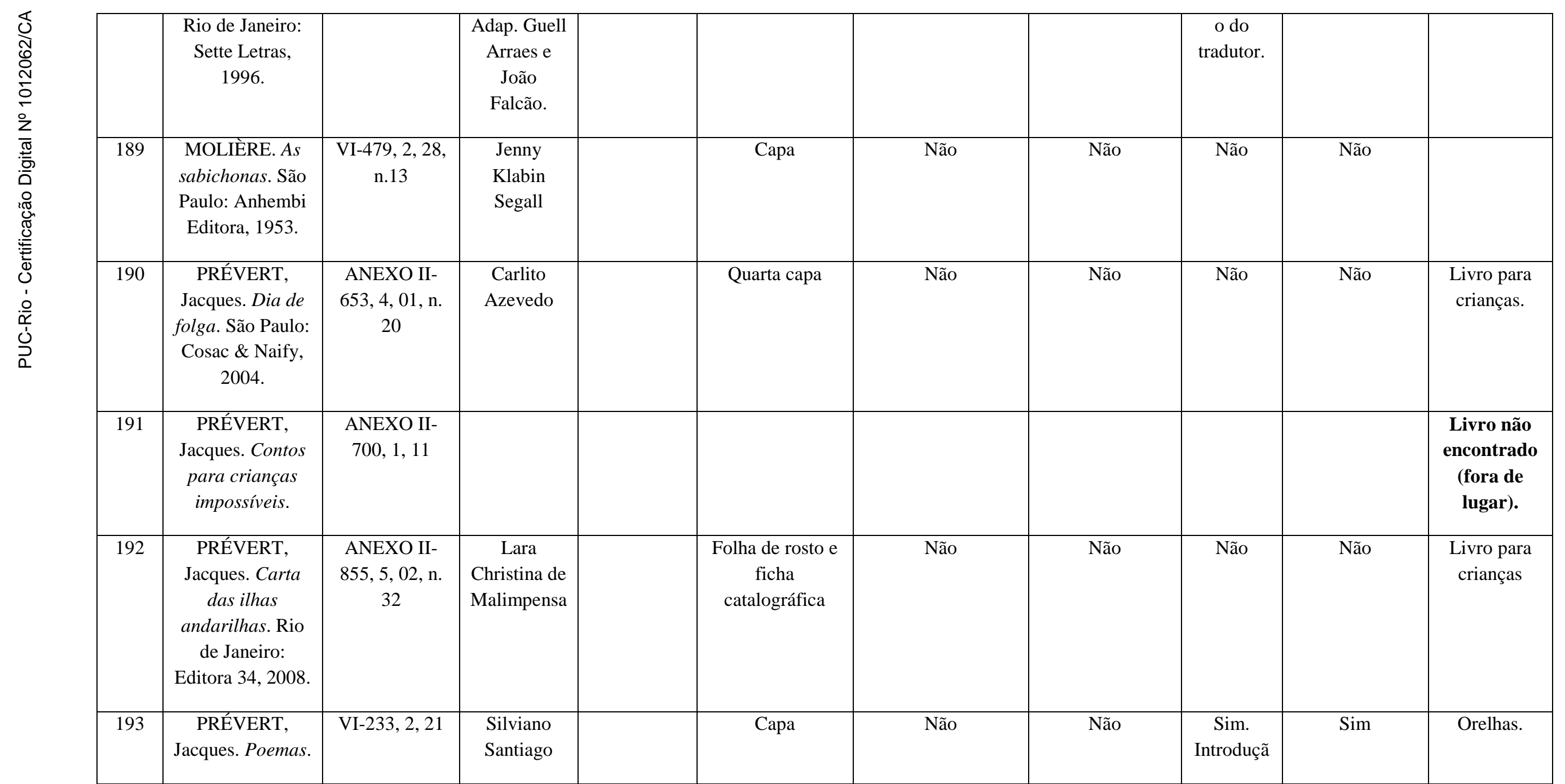




\begin{tabular}{|c|c|c|c|c|c|c|c|c|c|c|}
\hline & $\begin{array}{c}\text { Col. Poesia de } \\
\text { todos os tempos. } \\
\text { Rio de Janeiro: } \\
\text { Nova Fronteira, } \\
3^{\text {a edição. }}\end{array}$ & & & & & & & $\begin{array}{c}\text { o do } \\
\text { tradutor, } \\
\text { "Cotidian } \\
\text { o e } \\
\text { humor: o } \\
\text { pequeno } \\
\text { homem". }\end{array}$ & & \\
\hline 194 & $\begin{array}{c}\text { PRÉVERT, } \\
\text { Jacques. Poemas. } \\
\text { Col. Poesia de } \\
\text { todos os tempos. } \\
\text { Rio de Janeiro: } \\
\text { Nova Fronteira, } \\
1985 .\end{array}$ & VI-288, 2, 46 & $\begin{array}{l}\text { Silviano } \\
\text { Santiago }\end{array}$ & & Capa & Não & Não & $\begin{array}{c}\text { Sim. } \\
\text { Introduçã } \\
\text { o do } \\
\text { tradutor, } \\
\text { "Cotidian } \\
\text { o e } \\
\text { humor: o } \\
\text { pequeno } \\
\text { homem". }\end{array}$ & Sim & Orelhas. \\
\hline 195 & $\begin{array}{c}\text { PROUST, } \\
\text { Marcel. Um } \\
\text { amor de Swann. } \\
\text { Col. L\&PM } \\
\text { Pocket. Porto } \\
\text { Alegre: L\&PM, } \\
\text { 2005. }\end{array}$ & VI-411, 4, 39 & $\begin{array}{c}\text { Celina } \\
\text { Portocarrer } \\
\text { o }\end{array}$ & DITRA & $\begin{array}{c}\text { Folha de rosto e } \\
\text { ficha } \\
\text { catalográfica }\end{array}$ & $\begin{array}{l}\text { Sim. Biografia de } \\
\text { Proust. }\end{array}$ & Não & Sim & Não & $\begin{array}{c}\text { Edição de } \\
\text { bolso }\end{array}$ \\
\hline 196 & $\begin{array}{c}\text { PROUST, } \\
\text { Marcel. No } \\
\text { caminho de } \\
\text { Swann. Rio de }\end{array}$ & V-218, 6, 35. & $\begin{array}{c}\text { Fernando } \\
\text { Py }\end{array}$ & DITRA & $\begin{array}{l}\text { Folha de rosto e } \\
\text { ficha } \\
\text { catalográfica }\end{array}$ & Não & Não & Não & Não & \\
\hline
\end{tabular}




\begin{tabular}{|c|c|c|c|c|c|c|c|c|c|c|}
\hline & $\begin{array}{c}\text { Janeiro: O } \\
\text { Globo; São } \\
\text { Paulo: Folha de } \\
\text { São Paulo, } 2003 .\end{array}$ & & & & & & & & & \\
\hline 197 & $\begin{array}{c}\text { PROUST, } \\
\text { Marcel. O } \\
\text { indiferente e o } \\
\text { fim do ciúme. } \\
\text { Col. Canto } \\
\text { Literário. São } \\
\text { Paulo: Scrinium, } \\
\text { 1997. }\end{array}$ & $\mathrm{I}-137,3,29$ & $\begin{array}{l}\text { Sergio } \\
\text { Coelho }\end{array}$ & & $\begin{array}{c}\text { Folha de rosto e } \\
\text { ficha } \\
\text { catalográfica }\end{array}$ & Não & Não & $\begin{array}{l}\text { Sim. } \\
\text { Apresenta } \\
\text { ção do } \\
\text { tradutor. }\end{array}$ & Sim & \\
\hline 198 & $\begin{array}{c}\text { PROUST, } \\
\text { Marcel. Contre } \\
\text { Sainte Beuve: } \\
\text { notas sobre } \\
\text { crítica e } \\
\text { literatura. São } \\
\text { Paulo: } \\
\text { Iluminuras, } \\
1988 .\end{array}$ & $\mathrm{I}-159,7,23$ & $\begin{array}{c}\text { Trad. } \\
\text { Haroldo } \\
\text { Ramanzini. } \\
\text { Rev. trad. } \\
\text { Marilene } \\
\text { Felinto. }\end{array}$ & & $\begin{array}{l}\text { Folha de rosto e } \\
\text { ficha } \\
\text { catalográfica }\end{array}$ & $\begin{array}{l}\text { Sim. Prefácio de } \\
\text { Aguinaldo José } \\
\text { Gonçalves: sobre } \\
\text { crítica literária. } \\
\text { Introdução do } \\
\text { editor francês: o } \\
\text { ataque de Proust a } \\
\text { Sainte-Beuve. }\end{array}$ & Não & Não & Não & \\
\hline 199 & $\begin{array}{c}\text { PROUST, } \\
\text { Marcel. Em } \\
\text { busca do tempo } \\
\text { perdido: No } \\
\text { caminho de } \\
\text { Swann e À }\end{array}$ & VI-131, 6, 1 & $\begin{array}{c}\text { Fernando } \\
\text { Py }\end{array}$ & DITRA & $\begin{array}{c}\text { Folha de rosto e } \\
\text { ficha } \\
\text { catalográfica }\end{array}$ & Não & Não & Sim & Sim & $\begin{array}{l}\text { Quarta capa: } \\
\text { Trecho do } \\
\text { prefácio do } \\
\text { tradutor. } \\
\text { Orelhas: } \\
\text { texto }\end{array}$ \\
\hline
\end{tabular}




\begin{tabular}{|c|c|c|c|c|c|c|c|c|c|c|}
\hline & $\begin{array}{c}\text { sombra das } \\
\text { moças em flor. } \\
\text { Vol.1 Rio de } \\
\text { Janeiro: Ediouro, } \\
2002 .\end{array}$ & & & & & & & & & $\begin{array}{l}\text { assinado } \\
\text { pelo } \\
\text { tradutor. O } \\
\text { tradutor tem } \\
\text { grande } \\
\text { destaque na } \\
\text { publicação. }\end{array}$ \\
\hline 200 & $\begin{array}{c}\text { PROUST, } \\
\text { Marcel. Em } \\
\text { busca do tempo } \\
\text { perdido: O } \\
\text { caminho de } \\
\text { Guermantes e } \\
\text { Sodoma e } \\
\text { Gomorra. Vol.2 } \\
\text { Rio de Janeiro: } \\
\text { Ediouro, 2002. }\end{array}$ & VI-131, 6, 2 & $\begin{array}{c}\text { Fernando } \\
\text { Py }\end{array}$ & DITRA & $\begin{array}{c}\text { Folha de rosto e } \\
\text { ficha } \\
\text { catalográfica }\end{array}$ & Não & Não & Sim & Não & $\begin{array}{l}\text { Prefácio do } \\
\text { tradutor } \\
\text { sobre a obra } \\
\text { (não se } \\
\text { repete o } \\
\text { longo } \\
\text { prefácio do } \\
\text { tradutor do } \\
\text { primeiro } \\
\text { volume). } \\
\text { Quarta capa: } \\
\text { Trecho do } \\
\text { prefácio do } \\
\text { tradutor. } \\
\text { Orelhas: } \\
\text { assinado } \\
\text { pelo } \\
\text { tradutor. O } \\
\text { tradutor tem } \\
\text { grande } \\
\text { destaque na }\end{array}$ \\
\hline
\end{tabular}




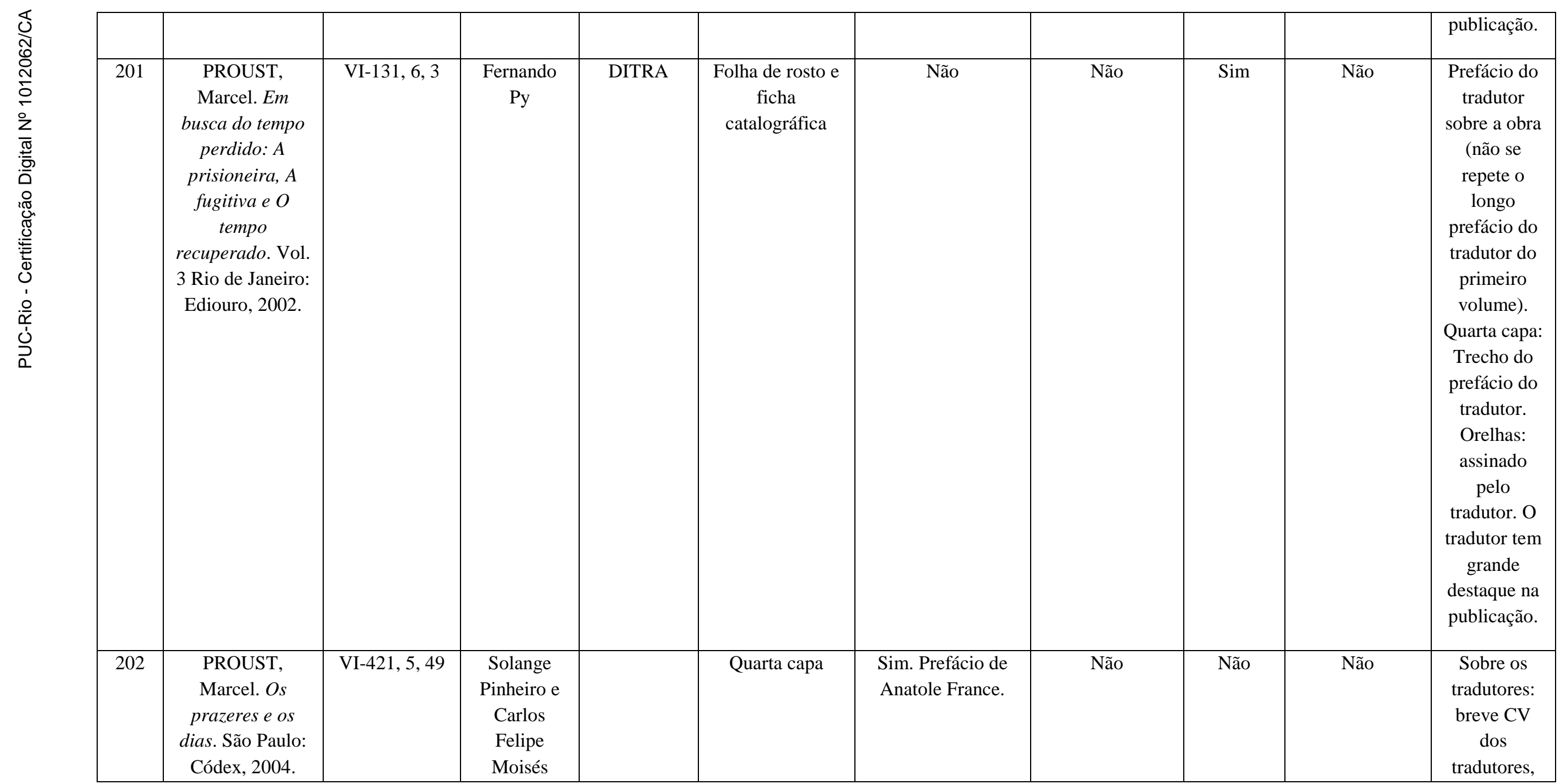




\begin{tabular}{|c|c|c|c|c|c|c|c|c|c|c|}
\hline & Localizador: & & (poemas) & & & & & & & $\begin{array}{l}\text { destaque } \\
\text { para a } \\
\text { carreira de } \\
\text { poeta do } \\
\text { tradutor de } \\
\text { poesia. }\end{array}$ \\
\hline 203 & $\begin{array}{c}\text { PROUST, } \\
\text { Marcel. O fim do } \\
\text { ciúme e outros } \\
\text { contos. São } \\
\text { Paulo: Hedra, } \\
\text { 2007. }\end{array}$ & $\begin{array}{l}\text { Anexo II - } \\
771,1,41\end{array}$ & $\begin{array}{c}\text { Dorothée de } \\
\text { Bruchard }\end{array}$ & DITRA & Capa & $\begin{array}{l}\text { Sim. Introd. } \\
\text { Guilherme I. da } \\
\text { Silva. }\end{array}$ & Não & Não & Não & $\begin{array}{l}\text { Breve CV da } \\
\text { tradutora (o } \\
\text { mesmo do } \\
\text { item 62). }\end{array}$ \\
\hline 204 & $\begin{array}{c}\text { PROUST, } \\
\text { Marcel. Em } \\
\text { busca do tempo } \\
\text { perdido. Vol. I: } \\
\text { No caminho de } \\
\text { Swann. São } \\
\text { Paulo: Editora } \\
\text { Globo, 2006. }\end{array}$ & $\begin{array}{c}\text { Anexo II - } \\
762,3,31\end{array}$ & $\begin{array}{c}\text { Mario } \\
\text { Quintana }\end{array}$ & DITRA & Capa & $\begin{array}{c}\text { Sim. Prefácio, } \\
\text { cronologia, notas e } \\
\text { resumo de } \\
\text { Guilherme Ignácio } \\
\text { da Silva. Posfácio } \\
\text { de Jeanne-Marie } \\
\text { Gagnebin: ensaio } \\
\text { de literatura } \\
\text { comparada entre a } \\
\text { obra e a Primeira } \\
\text { meditação, de } \\
\text { Descartes. }\end{array}$ & Não & Não & Não & $\begin{array}{c}\text { Nenhuma } \\
\text { menção à } \\
\text { tradução, } \\
\text { além do } \\
\text { nome do } \\
\text { tradutor } \\
\text { famoso na } \\
\text { capa. }\end{array}$ \\
\hline 205 & $\begin{array}{c}\text { PROUST, } \\
\text { Marcel. Em } \\
\text { busca do tempo }\end{array}$ & VI-403, 3, 10 & $\begin{array}{c}\text { Mario } \\
\text { Quintana }\end{array}$ & DITRA & Capa & $\begin{array}{l}\text { Sim. Prefácio, } \\
\text { cronologia, notas e } \\
\text { resumo de }\end{array}$ & Não & Não & Não & $\begin{array}{l}\text { Nenhuma } \\
\text { menção à } \\
\text { tradução, }\end{array}$ \\
\hline
\end{tabular}




\begin{tabular}{|c|c|c|c|c|c|c|c|c|c|c|}
\hline & $\begin{array}{c}\text { perdido. Vol. 2: } \\
\text { À sombra das } \\
\text { raparigas em } \\
\text { flor. São Paulo: } \\
\text { Editora Globo, } \\
2006 .\end{array}$ & & & & & $\begin{array}{l}\text { Guilherme Ignácio } \\
\text { da Silva. Posfácio } \\
\text { de Rolf Renner: } \\
\text { ensaio filosófico- } \\
\text { literário traduzido } \\
\text { pelo mesmo } \\
\text { tradutor da obra. }\end{array}$ & & & & $\begin{array}{c}\text { além do } \\
\text { nome do } \\
\text { tradutor } \\
\text { famoso na } \\
\text { capa. }\end{array}$ \\
\hline 206 & $\begin{array}{c}\text { PROUST, } \\
\text { Marcel. Em } \\
\text { busca do tempo } \\
\text { perdido. Vol. 3: } \\
\text { O caminho de } \\
\text { Guermantes. São } \\
\text { Paulo: Editora } \\
\text { Globo, 2007. }\end{array}$ & VI-403, 3, 11 & $\begin{array}{c}\text { Mario } \\
\text { Quintana }\end{array}$ & DITRA & Capa & $\begin{array}{c}\text { Prefácio, } \\
\text { cronologia, notas e } \\
\text { resumo de } \\
\text { Guilherme Ignácio } \\
\text { da Silva. Posfácio } \\
\text { de Philippe } \\
\text { Willemart: ensaio } \\
\text { filosófico-literário- } \\
\text { psicanalítico } \\
\text { traduzido pelo } \\
\text { mesmo tradutor da } \\
\text { obra. }\end{array}$ & Não & Não & Não & $\begin{array}{c}\text { Nenhuma } \\
\text { menção à } \\
\text { tradução, } \\
\text { além do } \\
\text { nome do } \\
\text { tradutor } \\
\text { famoso na } \\
\text { capa. }\end{array}$ \\
\hline 207 & $\begin{array}{c}\text { PROUST, } \\
\text { Marcel. Em } \\
\text { busca do tempo } \\
\text { perdido. Vol. 4: } \\
\text { Sodoma e } \\
\text { Gomorra. São } \\
\text { Paulo: Editora } \\
\text { Globo, 2008. }\end{array}$ & VI-403, 3, 9 & $\begin{array}{c}\text { Mario } \\
\text { Quintana }\end{array}$ & DITRA & Сара & $\begin{array}{c}\text { Prefácio, } \\
\text { cronologia, notas e } \\
\text { resumo de } \\
\text { Guilherme Ignácio } \\
\text { da Silva. Posfácio } \\
\text { de Regina Salgado } \\
\text { Campos: Proust e o } \\
\text { Affaire Dreyfus, a } \\
\text { questão da }\end{array}$ & Não & Não & Não & $\begin{array}{c}\text { Nenhuma } \\
\text { menção à } \\
\text { tradução, } \\
\text { além do } \\
\text { nome do } \\
\text { tradutor } \\
\text { famoso na } \\
\text { capa. }\end{array}$ \\
\hline
\end{tabular}




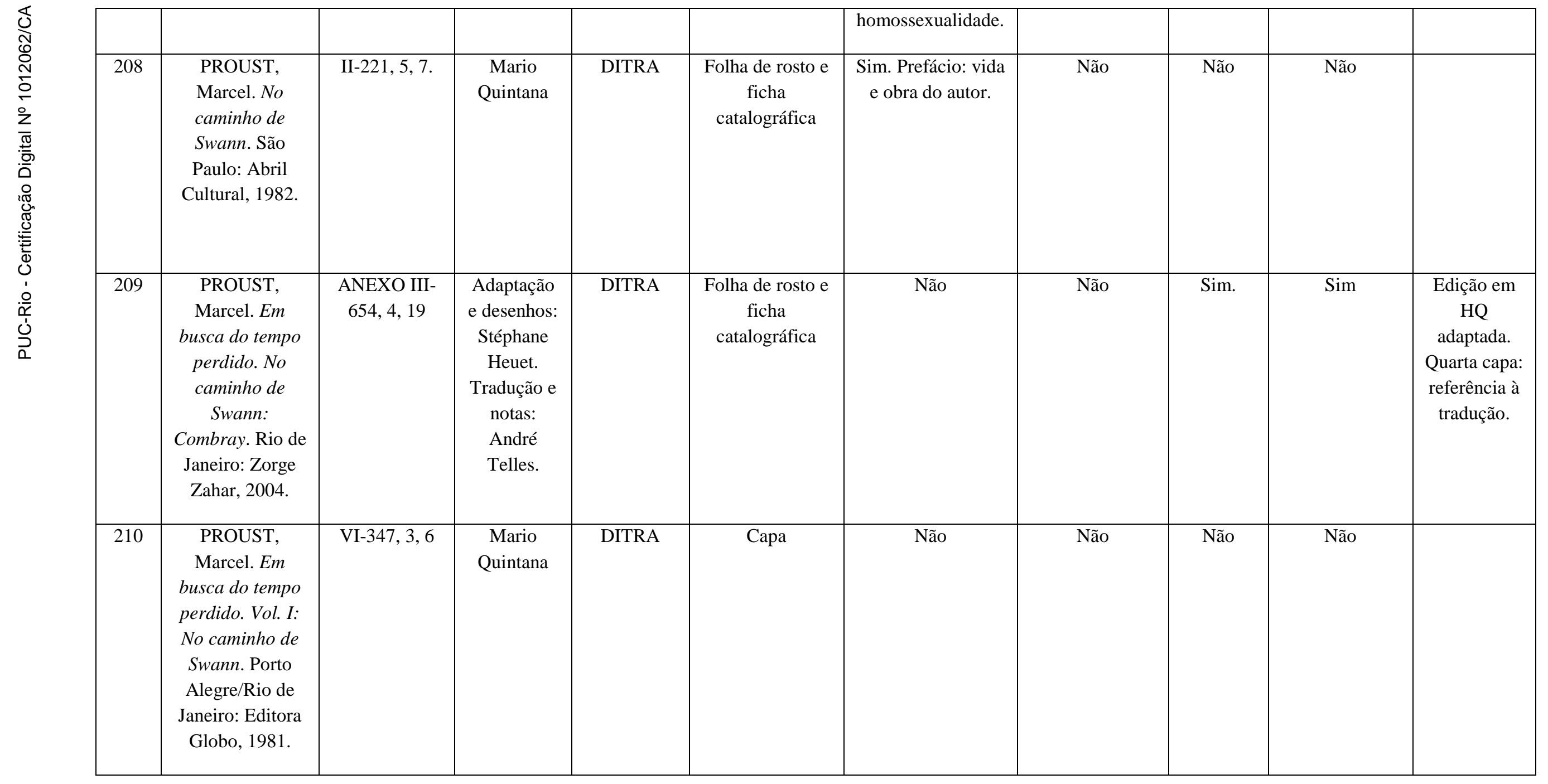




\begin{tabular}{|c|c|c|c|c|c|c|c|c|c|}
\hline 211 & $\begin{array}{c}\text { PROUST, } \\
\text { Marcel. Em } \\
\text { busca do tempo } \\
\text { perdido. Vol. 2: } \\
\text { À sombra das } \\
\text { raparigas em } \\
\text { flor. Porto } \\
\text { Alegre/Rio de } \\
\text { Janeiro: Editora } \\
\text { Globo, } 1981 .\end{array}$ & $\begin{array}{l}\text { Anexo II - } \\
788,3,27\end{array}$ & $\begin{array}{c}\text { Mario } \\
\text { Quintana }\end{array}$ & DITRA & Capa & Não & Não & Não & Não \\
\hline 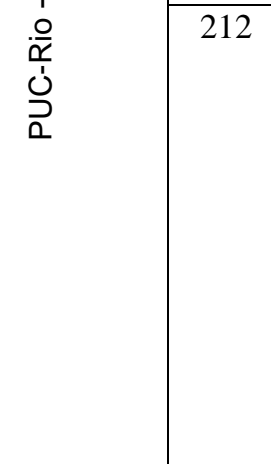 & $\begin{array}{c}\text { PROUST, } \\
\text { Marcel. Em } \\
\text { busca do tempo } \\
\text { perdido. Vol. 3: } \\
\text { O caminho de } \\
\text { Guermantes. } \\
\text { Porto Alegre/Rio } \\
\text { de Janeiro: } \\
\text { Editora Globo, } \\
1983 .\end{array}$ & VI-345, 2, 15 & $\begin{array}{c}\text { Mario } \\
\text { Quintana }\end{array}$ & DITRA & Capa & Não & Não & Não & Não \\
\hline 213 & $\begin{array}{c}\text { PROUST, } \\
\text { Marcel. Em } \\
\text { busca do tempo } \\
\text { perdido. Vol. 4: } \\
\text { Sodoma e } \\
\text { Gomorra. Porto } \\
\text { Alegre/Rio de } \\
\text { Janeiro: Editora }\end{array}$ & VI-345, 2, 16 & $\begin{array}{c}\text { Mario } \\
\text { Quintana }\end{array}$ & DITRA & Capa & Não & Não & Não & Não \\
\hline
\end{tabular}




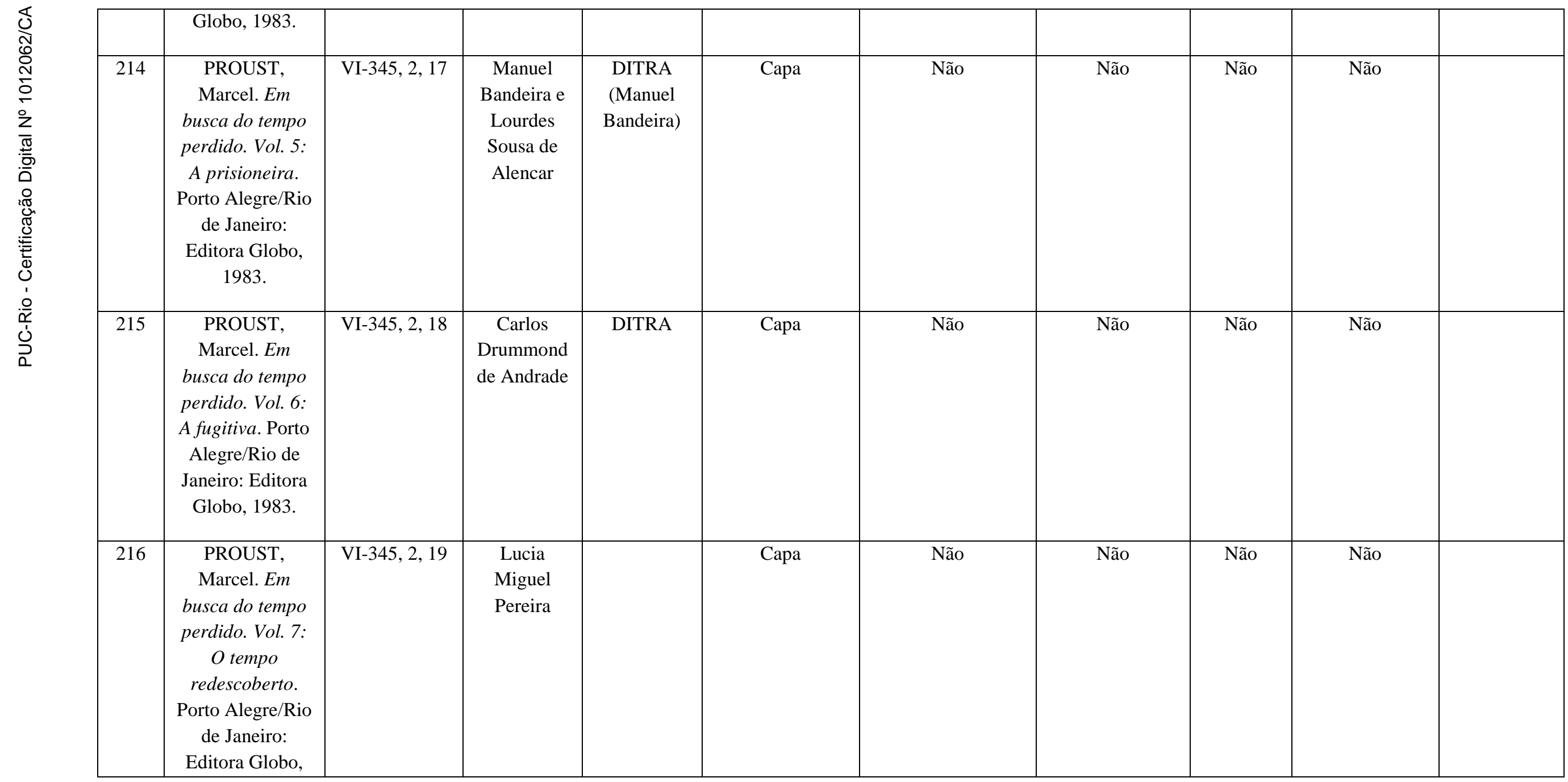




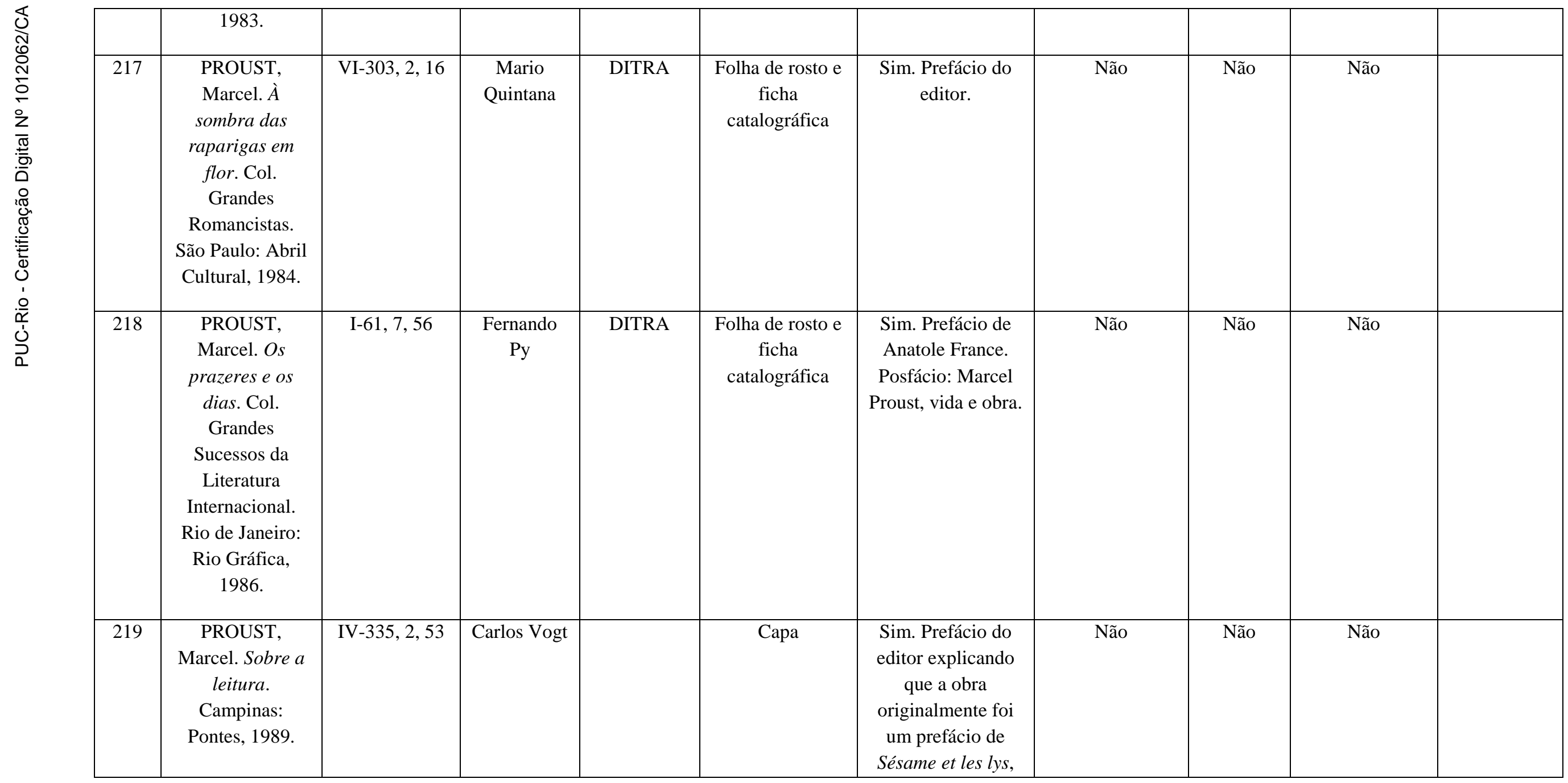




\begin{tabular}{|c|c|c|c|c|c|c|c|c|c|c|}
\hline & & & & & & de John Ruskin. & & & & \\
\hline 220 & $\begin{array}{c}\text { PROUST, } \\
\text { Marcel. Em } \\
\text { busca do tempo } \\
\text { perdido. Vol. I } \\
\text { No caminho de } \\
\text { Swann. Col. } \\
\text { Clássicos de } \\
\text { Bolso. Rio de } \\
\text { Janeiro: Ediouro, } \\
\text { 1992. }\end{array}$ & VI-208, 1, 5 & $\begin{array}{c}\text { Fernando } \\
\text { Py }\end{array}$ & DITRA & Сара & Não & Não & Sim & Não & $\begin{array}{c}\text { Edição de } \\
\text { bolso }\end{array}$ \\
\hline 221 & $\begin{array}{c}\text { PROUST, } \\
\text { Marcel. Em } \\
\text { busca do tempo } \\
\text { perdido. Vol. I À } \\
\text { sombra das } \\
\text { moças em flor. } \\
\text { Col. Clássicos de } \\
\text { Bolso. Rio de } \\
\text { Janeiro: Ediouro, } \\
\text { 1993. }\end{array}$ & VI-2, 4, 47 & $\begin{array}{c}\text { Fernando } \\
\text { Py }\end{array}$ & DITRA & Сара & Não & Não & Sim & Não & $\begin{array}{c}\text { Edição de } \\
\text { bolso }\end{array}$ \\
\hline 222 & $\begin{array}{c}\text { PROUST, } \\
\text { Marcel. Em } \\
\text { busca do tempo } \\
\text { perdido. Vol. III } \\
\text { O caminho de } \\
\text { Guermantes. }\end{array}$ & VI-26, 4, 33 & $\begin{array}{c}\text { Fernando } \\
\text { Py }\end{array}$ & DITRA & Сара & Não & Não & Sim & Não & $\begin{array}{c}\text { Edição de } \\
\text { bolso }\end{array}$ \\
\hline
\end{tabular}




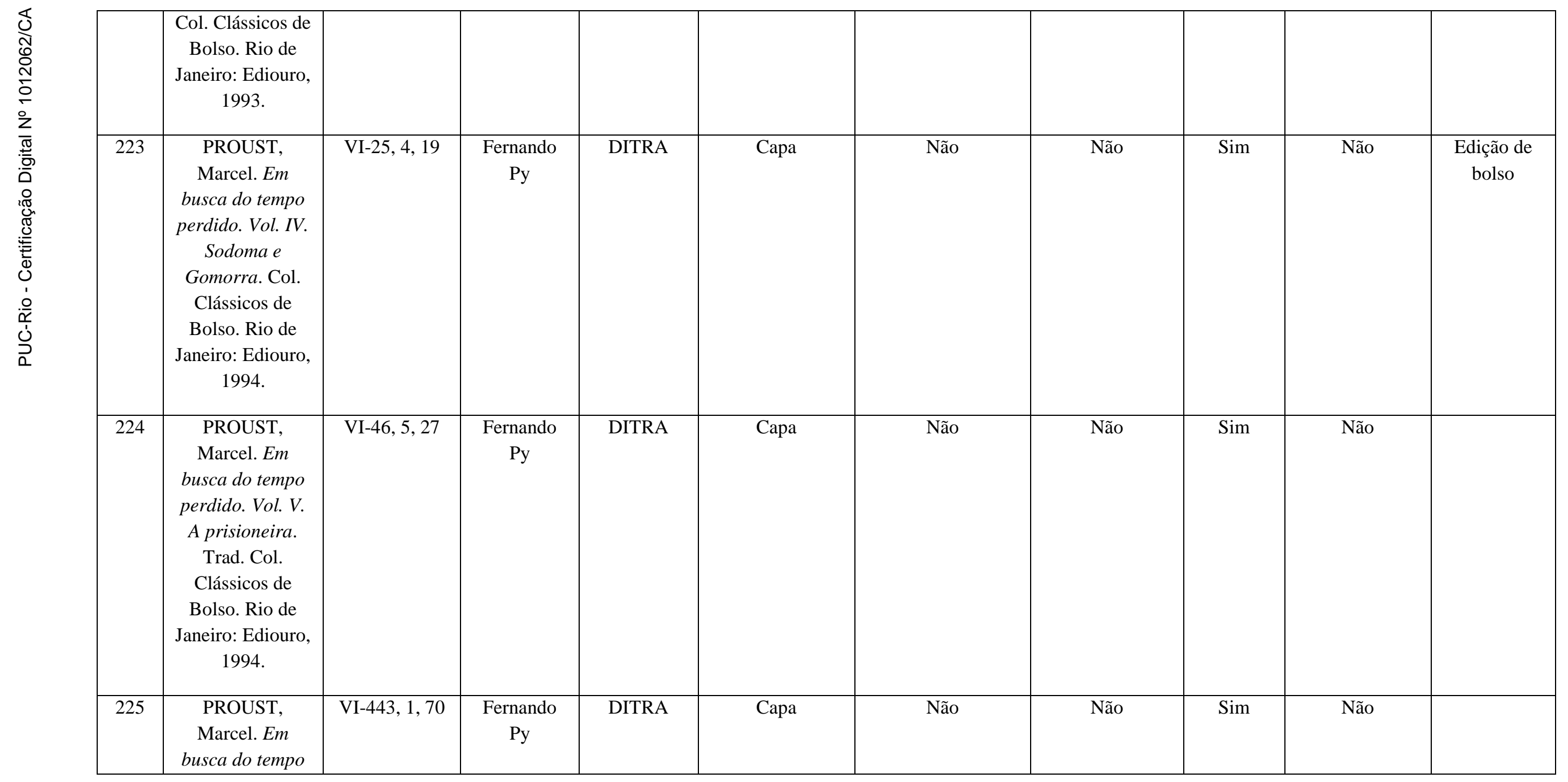




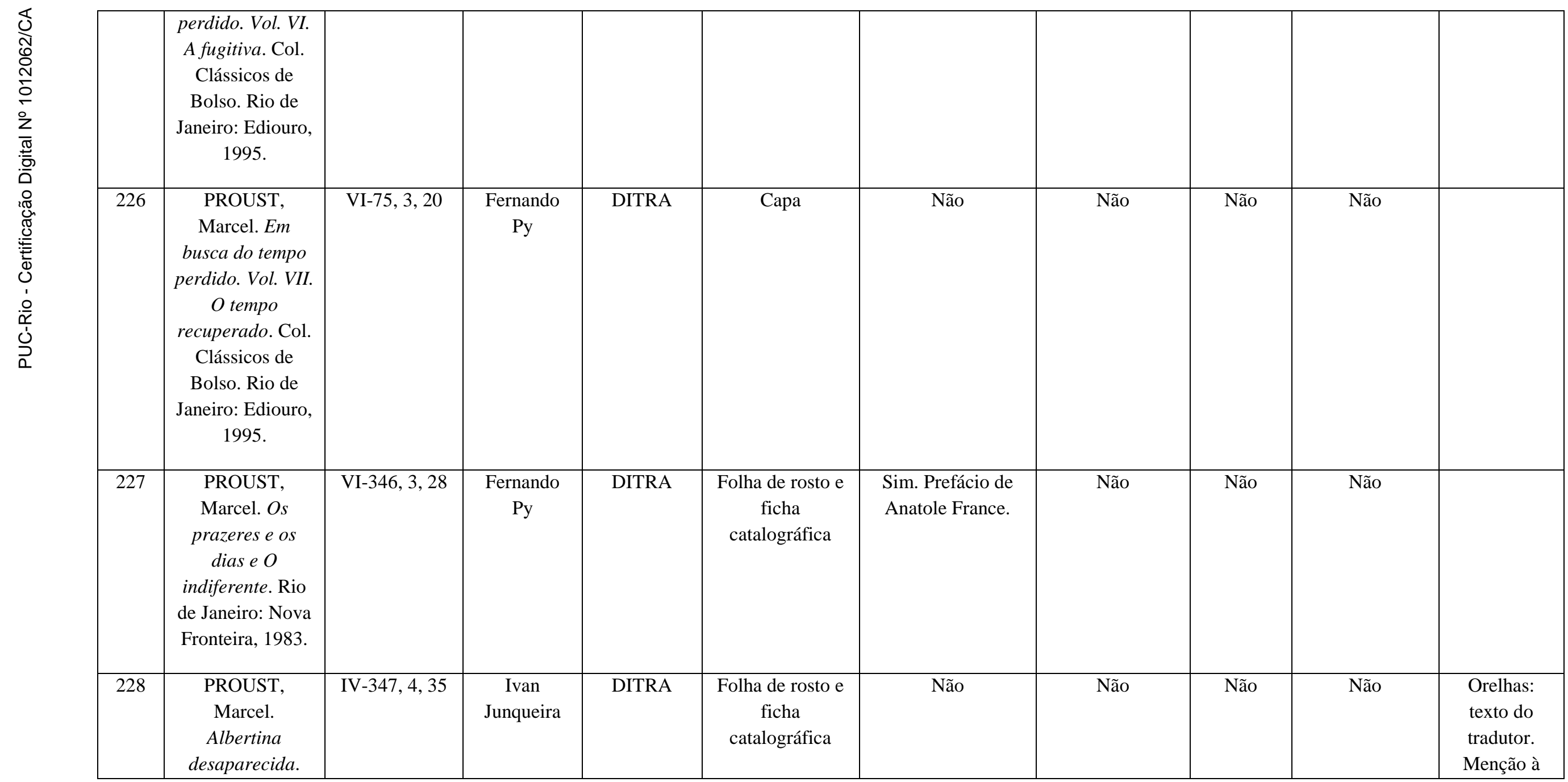




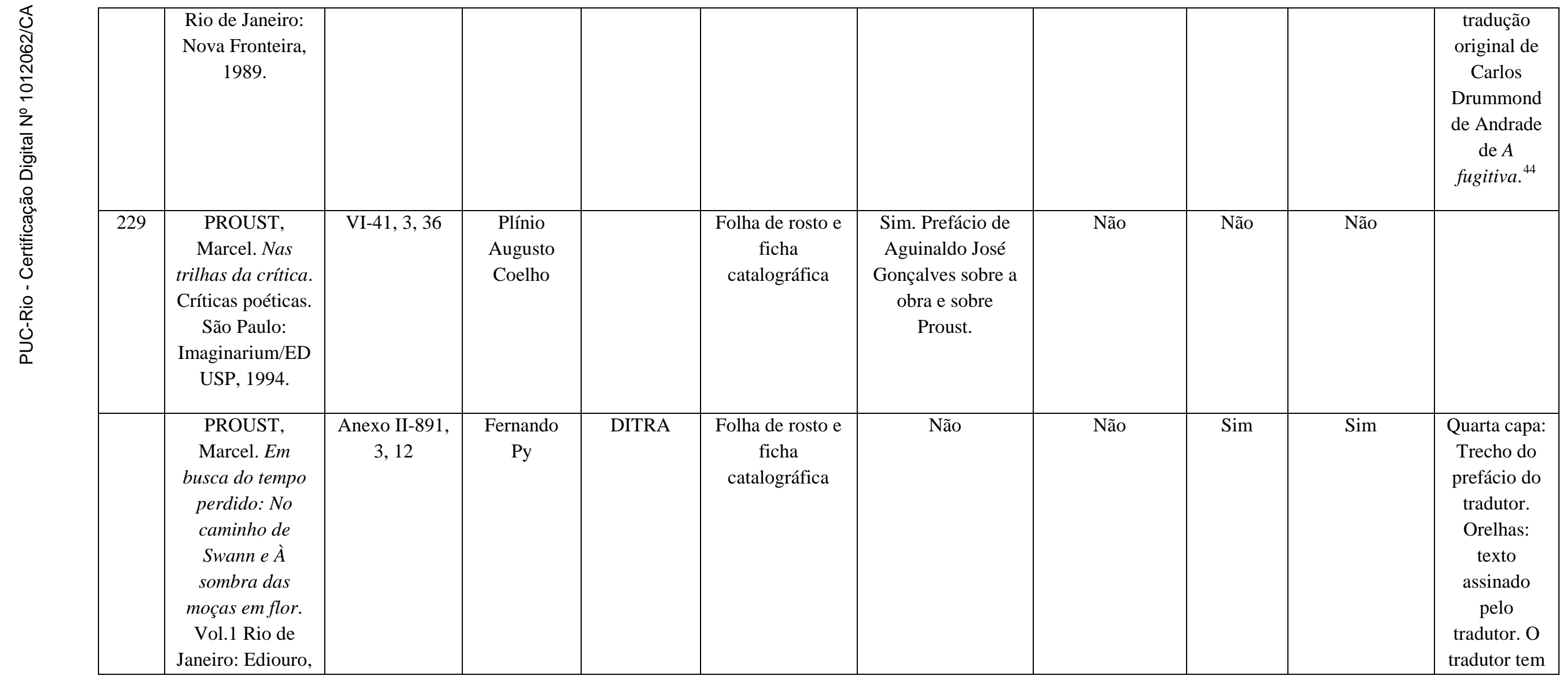

44 “Também não queria Proust, como atesta uma carta que escreveu a Gaston Gallimard em junho de 1922, o título de A fugitiva, sob o qual foi o romance não apenas republicado em 1954, mas também como passaria a ser conhecido em outras línguas, inclusive na nossa, a partir da excepcional tradução de Carlos Drummond de Andrade, à qual por incontáveis vezes recorremos para cotejo e mesmo para a adoção de certas soluções que nos pareceram absolutamente insuperáveis”. 


\begin{tabular}{|c|c|c|c|c|c|c|c|c|c|c|}
\hline & 2004. & & & & & & & & & $\begin{array}{c}\text { grande } \\
\text { destaque na } \\
\text { publicação. }\end{array}$ \\
\hline 230 & $\begin{array}{c}\text { PROUST, } \\
\text { Marcel. Em } \\
\text { busca do tempo } \\
\text { perdido: O } \\
\text { caminho de } \\
\text { Guermantes e } \\
\text { Sodoma e } \\
\text { Gomorra. Vol.2 } \\
\text { Trad. Rio de } \\
\text { Janeiro: Ediouro, } \\
\text { 2004. }\end{array}$ & $\begin{array}{c}\text { Anexo II-891, } \\
\text { 3, } 13\end{array}$ & $\begin{array}{c}\text { Fernando } \\
\text { Py }\end{array}$ & DITRA & $\begin{array}{l}\text { Folha de rosto e } \\
\text { ficha } \\
\text { catalográfica }\end{array}$ & Não & Não & Sim & Sim & $\begin{array}{l}\text { Trecho do } \\
\text { prefácio do } \\
\text { tradutor. } \\
\text { Orelhas: } \\
\text { texto } \\
\text { assinado } \\
\text { pelo } \\
\text { tradutor. O } \\
\text { tradutor tem } \\
\text { grande } \\
\text { destaque na } \\
\text { publicação. }\end{array}$ \\
\hline 231 & $\begin{array}{l}\text { RACINE, Jean. } \\
\text { Andrômaca. São } \\
\text { Paulo: Martin } \\
\text { Claret, } 2006 .\end{array}$ & $\begin{array}{c}\text { ANEXO II- } \\
817,6,54\end{array}$ & $\begin{array}{c}\text { Jenny } \\
\text { Klabin } \\
\text { Segall e } \\
\text { Mendo } \\
\text { Trigoso }\end{array}$ & & $\begin{array}{c}\text { Folha de rosto e } \\
\text { ficha } \\
\text { catalográfica }\end{array}$ & $\begin{array}{l}\text { Sim. Prefácio da } \\
\text { editora: “A história } \\
\text { do livro”. }\end{array}$ & Não & Não & Não & \\
\hline 232 & $\begin{array}{l}\text { RACINE, Jean. } \\
\text { “Fedra”. In } \\
\text { Hipólito e Fedra. } \\
\text { São Paulo: } \\
\text { Iluminuras, } \\
2007 .\end{array}$ & VI-276, 5, 49 & $\begin{array}{l}\text { Joaquim } \\
\text { Brasil } \\
\text { Fontes }\end{array}$ & DITRA & Capa & $\begin{array}{l}\text { Sim. Ao final, } \\
\text { "Sobre o Tradutor" } \\
\text { (com foto). }\end{array}$ & Sim. & Sim. & $\begin{array}{l}\text { Sim. Longo } \\
\text { prefácio do } \\
\text { tradutor, “In } \\
\text { Me Tota Ruens } \\
\text { Venus” (pág. } \\
\text { 11-99). }\end{array}$ & $\begin{array}{l}\text { Orelhas: } \\
\text { texto de Jaa } \\
\text { Torrano, } \\
\text { menção à } \\
\text { tradução, } \\
\text { fazendo } \\
\text { referência ao }\end{array}$ \\
\hline
\end{tabular}




\begin{tabular}{|c|c|c|c|c|c|c|c|c|c|}
\hline & & & & & & & & & $\begin{array}{c}\text { texto } \\
\text { introdutório. } \\
\text { Muito } \\
\text { destaque ao } \\
\text { tradutor. }\end{array}$ \\
\hline 233 & $\begin{array}{l}\text { RACINE, Jean. } \\
\text { Fedra, Ester e } \\
\text { Atália. Col. } \\
\text { Biblioteca }\end{array}$ & VI-27, 3, 36 & $\begin{array}{c}\text { Jenny } \\
\text { Klabin } \\
\text { Segall }\end{array}$ & Capa & $\begin{array}{l}\text { Sim. 1. Prefácio à } \\
1^{\text {a }} \text { Edição, de } \\
\text { Roger Bastide. }{ }^{45} \\
\text { 2. Nota à Presente }\end{array}$ & Sim. & Não & Não & $\begin{array}{l}\text { Orelhas, } \\
\text { texto de } \\
\text { Roger } \\
\text { Bastide. }^{46}\end{array}$ \\
\hline
\end{tabular}

${ }^{45}$ Vêem-se desde logo as dificuldades que Jenny Klabin Segall tinha de superar no seu desejo de oferecer aos brasileiros uma tradução das três obras primas de Racine. Cada uma dessas tragédias tem uma música diferente, evoca uma civilização original; toda essa poesia sutil ou feroz, que surge do verso raciano, a poesia da Grécia fabulosa, da nação judia chorando nas cidades do exílio, ou dos Profetas de Israel, não iria desaparecer ao passar do francês para o português? Não é o menor mérito dessas três traduções o de terem sabido acolher e guardar em suas páginas, sem nada lhes tirar da graça u da violência, as músicas de Racine.

Essas músicas eram tão mais difíceis de reproduzir quanto resultam da escolha das palavras e de sua sonoridade. É pelas aliterações, os "e" mudos, as vogais cantantes, as elipses e as inversões, os anacolutos e as elipses, como pelo corte dos versos, que Racine conseguiu atingir as suas mais perfeitas harmonias. Só havia, pois, um método possível para não trair o gênio do autor, isto é, a máxima fidelidade ao texto. Tive o privilégio de ter em minhas mãos o manuscrito ainda em rascunho de Jenny Klabin Segall. Todas as correções tinham por fim seguir mais exatamente o ritmo do verso, a ordem das palavras, a equivalência dos sons, respeitar os cortes, as inversões ou as sínteses de expressão, a fim de nos dar, não uma adaptação de Racine em português, mas um Racine [em] português.

É esse Racine [em] português que hoje tenho o prazer de prefaciar. Os brasileiros em geral conhecem bem a literatura francesa, mas a literatura que conhecem é a moderna. Ora, para penetrar o gênio da França é preciso introduzir-se na sua literatura clássica, é preciso frequentar Molière e Racine, ler Fedra e O misantropo. É preciso saborear esses frutos amadurecidos ao sol do Grande século, onde se metamorfosearam em mel os sucos vindos do mais profundo da tradição antiga e da tradição cristã. De hoje em diante o brasileiro que não pode ler o texto francês estará em condições, graças à arte paciente e ao êxito raro de Jenny Klabin Segall, de saborear esses frutos e encantar-se com músicas perfeitas. Foi necessária à tradutora uma grande familiaridade não somente com as obras racinianas, mas também com a mitologia antiga e o lirismo bíblico, muito amor e o conhecimento do segredo das duas línguas, que se julgam próximas e são entretanto muito diferentes, para conseguir passar do francês ao português um Racine que conserva todas as qualidades de Racine. Um estilo que, na sua simplicidade aparente, é o mais complexo e o mais difícil dos estilos, pois que é feito de reticências, de escapadas e de uminosidades”. (pág. IX-XI)

46 "As três obras de Racine incluídas neste volume em tradução de Jenny Klabin Segall, que se dedicou à tradução das obras-primas do teatro universal, em versos de valor reconhecido, representam alguns dos pontos mais latos da literatura clássica europeia. 


\begin{tabular}{|c|c|c|c|c|c|c|c|c|c|c|}
\hline & $\begin{array}{l}\text { Martins Fontes. } \\
\text { São Paulo: } \\
\text { Martins Fontes, } \\
2005 .\end{array}$ & & & & & $\begin{array}{l}\text { Edição, escrita pelo } \\
\text { editor (mesmo do } \\
\text { item 95) }\end{array}$ & & & & \\
\hline 234 & $\begin{array}{l}\text { RACINE, Jean. } \\
\text { Andrômaca e } \\
\text { Britânico. Col. } \\
\text { Biblioteca } \\
\text { Martins Fontes. } \\
\text { São Paulo: } \\
\text { Martins Fontes, } \\
2005 .\end{array}$ & VI-31, 2, 32 & $\begin{array}{l}\text { Jenny } \\
\text { Klabin } \\
\text { Segall }\end{array}$ & & Сара & $\begin{array}{l}\text { Sim. 1. } \\
\text { Apresentação da } \\
\text { 1ª }^{\text {a }} \text { Edição. }{ }^{47} \\
\text { 2. Nota à Presente } \\
\text { Edição (mesmo do } \\
\quad \text { item 95). }\end{array}$ & Sim. & Não & Não & $\begin{array}{l}\text { Orelhas, } \\
\text { menção à } \\
\text { tradução. }\end{array}$ \\
\hline 235 & $\begin{array}{l}\text { RACINE, Jean. } \\
\text { Fedra. Col. } \\
\text { L\&PM Pocket. } \\
\text { Porto Alegre: } \\
\text { L\&PM Pocket, } \\
2002 .\end{array}$ & $\mathrm{I}-136,3,36$ & $\begin{array}{c}\text { Millôr } \\
\text { Fernandes }\end{array}$ & DITRA & Capa & Não & Não & Não & Não & $\begin{array}{l}\text { Quarta capa: } \\
\text { texto de } \\
\text { Millôr } \\
\text { Fernandes } \\
\text { sobre o } \\
\text { enredo. }\end{array}$ \\
\hline 236 & $\begin{array}{l}\text { RACINE, Jean. } \\
\text { Fedra, Ifigênia, }\end{array}$ & $\mathrm{I}-174,1,32$ & Ivo Bender & DITRA & Capa & Sim & Não & Sim & Não & $\begin{array}{l}\text { Orelhas: } \\
\text { texto de }\end{array}$ \\
\hline
\end{tabular}

(...) o grande mérito dessas traduções é a sua fidelidade. Comparei cena por cena, verso por verso, o original e a tradução. As cesuras, o ritmo, a alternância das rimas masculinas e femininas, o próprio movimento das frases são respeitados: não se trata de refazer a mesma peça, de adaptá-la, trata-se de uma tradução. E essa tradução é tal que a crítica poderia, se quisesse, estudar através dela os caracteres próprios do estilo de Molière ou de Racine e mesmo os processos gerais de versificação.

Dir-se-ia que Jenny Klabin Segall brincou com as dificuldades”.

47 “São essas as duas obras - pela primeira vez acessíveis ao público ledor da língua portuguesa - que apresentamos neste segundo volume de traduções integrais de Jenny Klabin Segall, a qual se tem dedicado à divulgação das obras-primas do teatro clássico universal, em traduções em verso de cujo valor fazem fé unânimes vozes de imprensa sobre obras anteriormente editadas”. (pág. X) 


\begin{tabular}{|c|c|c|c|c|c|c|c|c|c|}
\hline & $\begin{array}{c}\text { Tebaida ou Os } \\
\text { irmãos inimigos. } \\
\text { Col. Clássicos } \\
\text { Mercado Aberto. } \\
\text { Porto Alegre: } \\
\text { Mercado Aberto, } \\
1999 .\end{array}$ & & & & & & & & $\begin{array}{c}\text { Marcelo } \\
\text { Backes, } \\
\text { sobre as } \\
\text { peças. }\end{array}$ \\
\hline 237 & $\begin{array}{c}\text { RACINE, Jean. } \\
\text { Três tragédias } \\
\text { (Phedra, Esther, } \\
\text { Athalia). Col. } \\
\text { Clássicos de } \\
\text { Bolso. Rio de } \\
\text { Janeiro: Ediouro, } \\
\text { 1994. }\end{array}$ & VI-189, 3, 51 & $\begin{array}{l}\text { Jenny } \\
\text { Klabin } \\
\text { Segall }\end{array}$ & Capa & $\begin{array}{l}\text { Sim. Prefácio de } \\
\text { Roger Bastide. }\end{array}$ & $\begin{array}{l}\text { Sim (o mesmo } \\
\text { do item 233). }\end{array}$ & Não & Não & \\
\hline 238 & $\begin{array}{c}\text { RACINE, Jean. } \\
\text { Andrômaca. Col. } \\
\text { Universidade de } \\
\text { Bolso. Rio de } \\
\text { Janeiro: Ediouro, } \\
\text { 1988. }\end{array}$ & IV-24, 5, 24 & $\begin{array}{l}\text { Jenny } \\
\text { Klabin } \\
\text { Segall }\end{array}$ & Capa & $\begin{array}{c}\text { Sim. Dois } \\
\text { prefácios de Paulo } \\
\text { Rónai: um sobre o } \\
\text { autor e a obra e o } \\
\text { outro sobre a } \\
\text { tragédia clássica. }\end{array}$ & Sim. $^{48}$ & Não & Não & \\
\hline 239 & $\begin{array}{l}\text { RACINE, Jean. } \\
\text { Esther. Rio de } \\
\text { Janeiro: }\end{array}$ & I-91, 5, 3, n. 2 & $\begin{array}{c}\text { Modesto de } \\
\text { Abreu }\end{array}$ & $\begin{array}{l}\text { Folha de rosto e } \\
\text { ficha } \\
\text { catalográfica. }\end{array}$ & Não & Não & Sim & Sim & $\begin{array}{c}\text { Orelhas: } \\
\text { "Dados } \\
\text { Biográficos }\end{array}$ \\
\hline
\end{tabular}

${ }^{48}$ No prefácio “Andrômaca”: “Acresce a musicalidade inesquecível na memória do espectador e do leitor (que a melhor tradução só imperfeitamente pode reproduzir), muitos dos quais são apontados justamente entre os mais belos da língua francesa”. (pág. 19) 


\begin{tabular}{|c|c|c|c|c|c|c|c|c|c|}
\hline & $\begin{array}{c}\text { Academia de } \\
\text { Letras do Estado } \\
\text { do Rio de } \\
\text { Janeiro, } 1997 .\end{array}$ & & & & & & & & $\begin{array}{c}\text { do } \\
\text { Tradutor”. }\end{array}$ \\
\hline 240 & $\begin{array}{c}\text { RACINE, Jean. } \\
\text { Três tragédias } \\
\text { (Phedra, Esther } \\
\text { e Athália). Col. } \\
\text { Universidade de } \\
\text { Bolso. Rio de } \\
\text { Janeiro: Ediouro, } \\
\text { 1986. }\end{array}$ & VI-340, 5, 61 & $\begin{array}{c}\text { Jenny } \\
\text { Klabin } \\
\text { Segall }\end{array}$ & Capa & $\begin{array}{l}\text { Sim, de Roger } \\
\text { Bastide. }\end{array}$ & $\begin{array}{l}\text { Sim (mesmo do } \\
\text { item 237). }\end{array}$ & Não & Não & \\
\hline 241 & $\begin{array}{c}\text { RACINE, Jean. } \\
\text { Andrômaca e } \\
\text { Britânico. Rio de } \\
\text { Janeiro: Ediouro, } \\
\text { 1994. }\end{array}$ & $\begin{array}{c}\text { ANEXO II- } \\
761,2,02\end{array}$ & $\begin{array}{c}\text { Jenny } \\
\text { Klabin } \\
\text { Segall }\end{array}$ & Capa & $\begin{array}{c}\text { Sim. Dois } \\
\text { prefácios de Paulo } \\
\text { Rónai: um sobre o } \\
\text { autor e a obra e o } \\
\text { outro sobre a } \\
\text { tragédia clássica. }\end{array}$ & $\begin{array}{c}\text { Sim (o mesmo } \\
\text { do item 238). }\end{array}$ & Não & Não & \\
\hline 242 & $\begin{array}{l}\text { RACINE, Jean. } \\
\text { Três tragédias } \\
\text { (Phedra - Esther } \\
\text { - Athália). Col. } \\
\text { Clássicos de } \\
\text { Ouro. Rio de } \\
\text { Janeiro: Ediouro, } \\
\text { 1994. }\end{array}$ & $\begin{array}{c}\text { ANEXO II- } \\
754,2,42\end{array}$ & $\begin{array}{c}\text { Jenny } \\
\text { Klabin } \\
\text { Segall }\end{array}$ & Capa & $\begin{array}{l}\text { Sim, de Roger } \\
\text { Bastide. }\end{array}$ & $\begin{array}{l}\text { Sim (o mesmo } \\
\text { do item 237). }\end{array}$ & Não & Não & \\
\hline
\end{tabular}




\begin{tabular}{|c|c|c|c|c|c|c|c|c|c|}
\hline 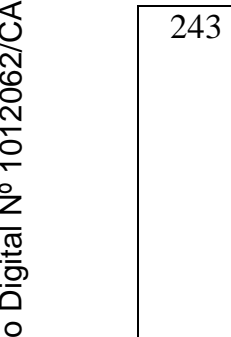 & $\begin{array}{c}\text { RACINE, Jean. } \\
\text { Andrômaca e } \\
\text { Fedra. Col. A } \\
\text { Obra-Prima de } \\
\text { Cada Autor. São } \\
\text { Paulo: Martin } \\
\text { Claret, } 2006 .\end{array}$ & $\begin{array}{l}\text { ANEXO II- } \\
817,6,54\end{array}$ & $\begin{array}{c}\text { Jenny } \\
\text { Klabin } \\
\text { Segall e } \\
\text { Mendo } \\
\text { Fragoso }\end{array}$ & $\begin{array}{c}\text { Folha de rosto e } \\
\text { ficha } \\
\text { catalográfica. }\end{array}$ & $\begin{array}{l}\text { Sim. Prefácio da } \\
\text { editora: “A história } \\
\text { do livro”. }\end{array}$ & Não & Não & Não & \\
\hline 244 & $\begin{array}{c}\text { RACINE, Jean. } \\
\text { Andrômaca e } \\
\text { Britânico. Col. } \\
\text { Clássicos de } \\
\text { Bolso. Rio de } \\
\text { Janeiro: Ediouro, } \\
\text { 1994. }\end{array}$ & $\begin{array}{l}\text { ANEXO II- } \\
761,2,02\end{array}$ & $\begin{array}{l}\text { Jenny } \\
\text { Klabin } \\
\text { Segall }\end{array}$ & Capa & $\begin{array}{l}\text { Sim. Prefácio de } \\
\text { Paulo Rónai. }\end{array}$ & Não & Não & Não & \\
\hline 245 & $\begin{array}{c}\text { RIMBAUD, } \\
\text { Arthur. O barco } \\
\text { ébrio. Col. } \\
\text { Tra(duz)ir. } \\
\text { Florianópolis: } \\
\text { Editora da } \\
\text { UFSC, } 2006 .\end{array}$ & VI-266, 3, 48 & $\begin{array}{c}\text { Jayro } \\
\text { Schmidt }\end{array}$ & Capa & $\begin{array}{l}\text { Sim. Prefácio de } \\
\text { Fábio } \\
\text { Brüggemann, } \\
\text { “Arthur, Jayro e } \\
\text { eu, bêbados”: fala } \\
\text { muito de tradução } \\
\text { e desta tradução. }\end{array}$ & Sim. & Sim. & Sim. & $\begin{array}{c}\text { Orelhas: } \\
\text { texto de } \\
\text { Daniel } \\
\text { Ballester, em } \\
\text { espanhol }\end{array}$ \\
\hline 246 & $\begin{array}{c}\text { RIMBAUD, } \\
\text { Arthur. Uma } \\
\text { estadia no } \\
\text { inferno, Poemas } \\
\text { escolhidos e A } \\
\text { carta ao vidente. }\end{array}$ & VI-411, 6, 39 & $\begin{array}{c}\text { Daniel } \\
\text { Fresnot }\end{array}$ & $\begin{array}{c}\text { Folha de rosto e } \\
\text { ficha } \\
\text { catalográfica }\end{array}$ & $\begin{array}{l}\text { Sim. Prefácio da } \\
\text { editora: “A história } \\
\text { do livro”. }\end{array}$ & Não & Não & Não & \\
\hline
\end{tabular}




\begin{tabular}{|c|c|c|c|c|c|c|c|c|c|c|}
\hline & $\begin{array}{l}\text { São Paulo: } \\
\text { Martin Claret, } \\
2005 .\end{array}$ & & & & & & & & & \\
\hline 247 & $\begin{array}{c}\text { RIMBAUD, } \\
\text { Arthur. Poesia } \\
\text { completa. Rio de } \\
\text { Janeiro: } \\
\text { Topbooks, } 1995 .\end{array}$ & VI-390, 3, 43 & Ivo Barroso & DITRA & Cара & & & Sim & Sim & $\begin{array}{c}\text { Orelhas: } \\
\text { texto de José } \\
\text { Mario } \\
\text { Pereira }^{49}\end{array}$ \\
\hline 248 & $\begin{array}{c}\text { RIMBAUD, } \\
\text { Arthur. } \\
\text { Iluminuras. São } \\
\text { Paulo: } \\
\text { Iluminuras, }\end{array}$ & $\mathrm{I}-146,5,46$ & $\begin{array}{c}\text { Rodrigo } \\
\text { Garcia } \\
\text { Lopes e } \\
\text { Maurício } \\
\text { Arruda }\end{array}$ & & Capa & Não & Não & Sim & Sim & $\begin{array}{c}\text { Orelhas: } \\
\text { texto dos } \\
\text { tradutores, } \\
\text { sem menção } \\
\text { à tradução. }\end{array}$ \\
\hline
\end{tabular}

49 “A anemia nacional em relação a Rimbaud começou a findar quando, em 1973, o mineiro Ivo Barroso, poeta de fina sensibilidade, tradutor de raça e responsável pela execução de tarefas de extrema singularidade (...), entregou ao público a sua versão de Une saison en enfer (Uma estadia no inferno), saudada por mestre Alceu Amoroso Lima como marco na história da tradução no Brasil. A certa altura de sua apresentação, escreve: “A tradução do poema, por Ivo Barroso, foi feita ao mesmo tempo com o maior respeito pelo pensamento do autor, na fidelidade aos mais sutis reflexos de sua expressão verbal, e com a constante preocupação de uma correspondência integral na linguagem vernácula mais depurada.

Dentro do mesmo espírito que sempre orientou o seu sacerdócio como tradutor, Ivo trabalhou nesta Poesia completa. Foram anos de dedicação absoluta, melhor dizendo, de obsessão integral, garimpando mundo afora livros, variantes, curiosidades sobre o poeta que, na expressão de George Steiner, "deixou sua impressão digital na linguagem, no nome e no temperamento do poeta moderno, como Cézanne o fez com as maçãs".

(...) Toda a poesia de Rimbaud, devido à habilidade e ao talento de Ivo Barroso, está aqui neste livro, sem dúvida ponto alto em nossa prática de tradução, e é mais um tento marcado por ele em seu projeto de pôr em português a obra completa do adolescente de Charleville (...)

Quem ler o Rimbaud de Ivo não vai ter dúvidas: o poeta que um dia decretou a necessidade de se "reinventar o amor" encontrou, 140 anos depois de morto, o seu outro eu. É assim que os leitores ganham agora esta tradução exemplar, onde todos os ritmos, trocadilhos, assonâncias, elipses, e demais singularidades da poesia de Rimbaud foram respeitadas.

Voltaire, numa passagem das Cartas Inglesas, comentando uma tradução sua de Pope, confessa não se sentir atraído pela tradução fiel, palavra a palavra. Essa observação, precursora das ideias de Pound, a que nossos concretistas referem-se como transcriação, não é receita cara a Ivo Barroso. (...)”. 


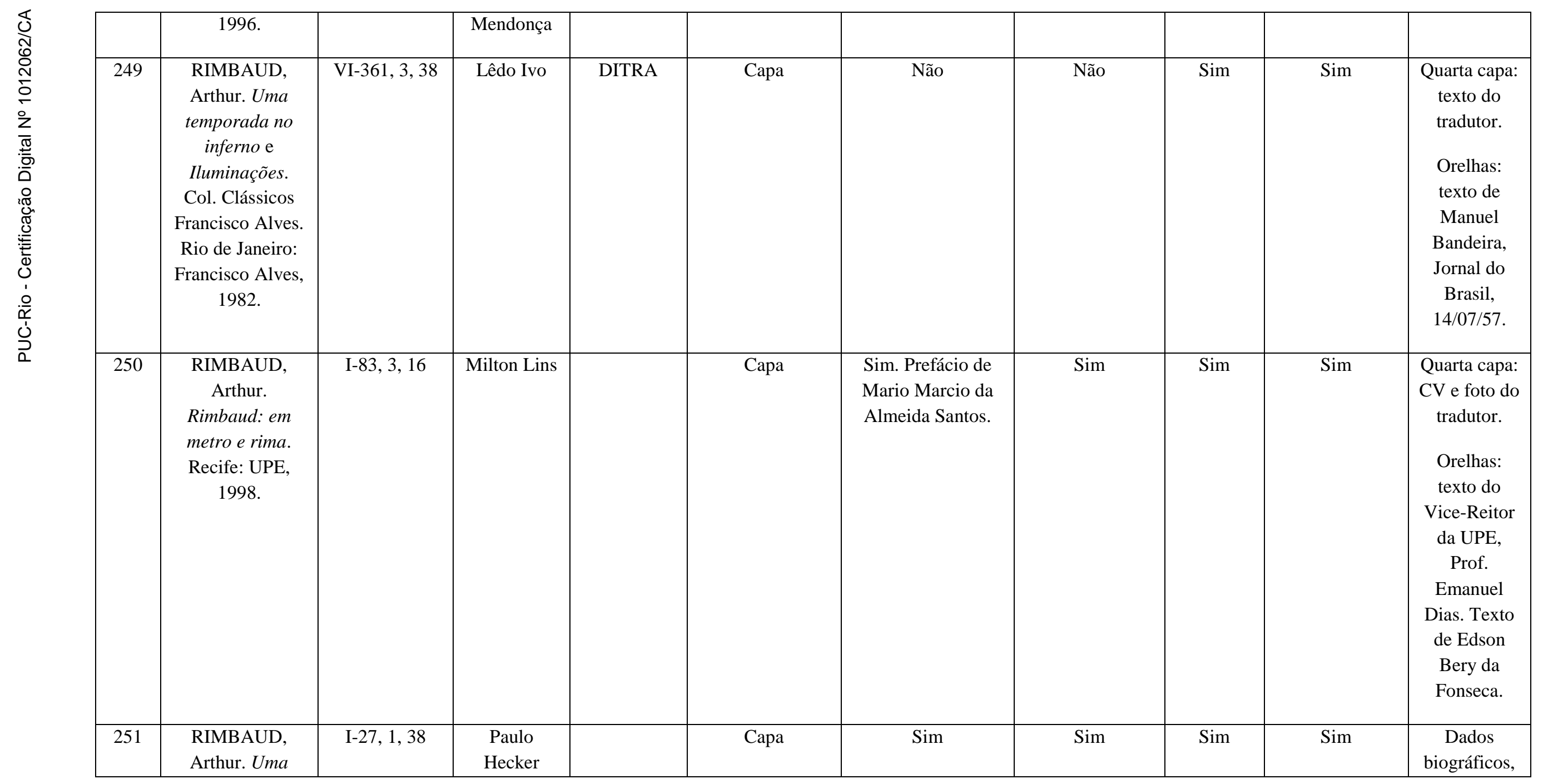




\begin{tabular}{|c|c|c|c|c|c|c|c|c|c|}
\hline & $\begin{array}{c}\text { temporada no } \\
\text { inferno. Col. } \\
\text { L\&PM Pocket, } \\
1997 .\end{array}$ & & Filho & & & & & & $\begin{array}{l}\text { escritos pelo } \\
\text { tradutor. } \\
\text { Quarta capa: } \\
\text { trecho de } \\
\text { texto de } \\
\text { Alain Borer, } \\
\text { biógrafo de } \\
\text { Rimbaud. } \\
\text { Sem orelhas, } \\
\text { edição de } \\
\text { bolso. }\end{array}$ \\
\hline 252 & $\begin{array}{l}\text { RIMBAUD, } \\
\text { Arthur. A } \\
\text { correspondência } \\
\text { de Arthur } \\
\text { Rimbaud. Col. } \\
\text { Rebeldes \& } \\
\text { Malditos. Porto } \\
\text { Alegre: L\&PM, } \\
\text { 1983. }\end{array}$ & VI-290, 4, 20 & $\begin{array}{l}\text { Alexandre } \\
\text { Ribondi }\end{array}$ & $\begin{array}{l}\text { Folha de rosto e } \\
\text { ficha } \\
\text { catalográfica. }\end{array}$ & $\begin{array}{l}\text { Sim. Apresentação } \\
\text { de Ivo Barroso. }\end{array}$ & Não & Não & Não & $\begin{array}{l}\text { Orelhas: } \\
\text { texto do } \\
\text { editores, } \\
\text { referência à } \\
\text { tradução de } \\
\text { Ivo Barroso } \\
\text { de Une } \\
\text { saison en } \\
\text { enfer, } \\
\text { publicada } \\
\text { (“(...) há } \\
\text { uma bela } \\
\text { introdução } \\
\text { biográfica de } \\
\text { Ivo Barroso, } \\
\text { autor da } \\
\text { preciosa } \\
\text { tradução }\end{array}$ \\
\hline
\end{tabular}




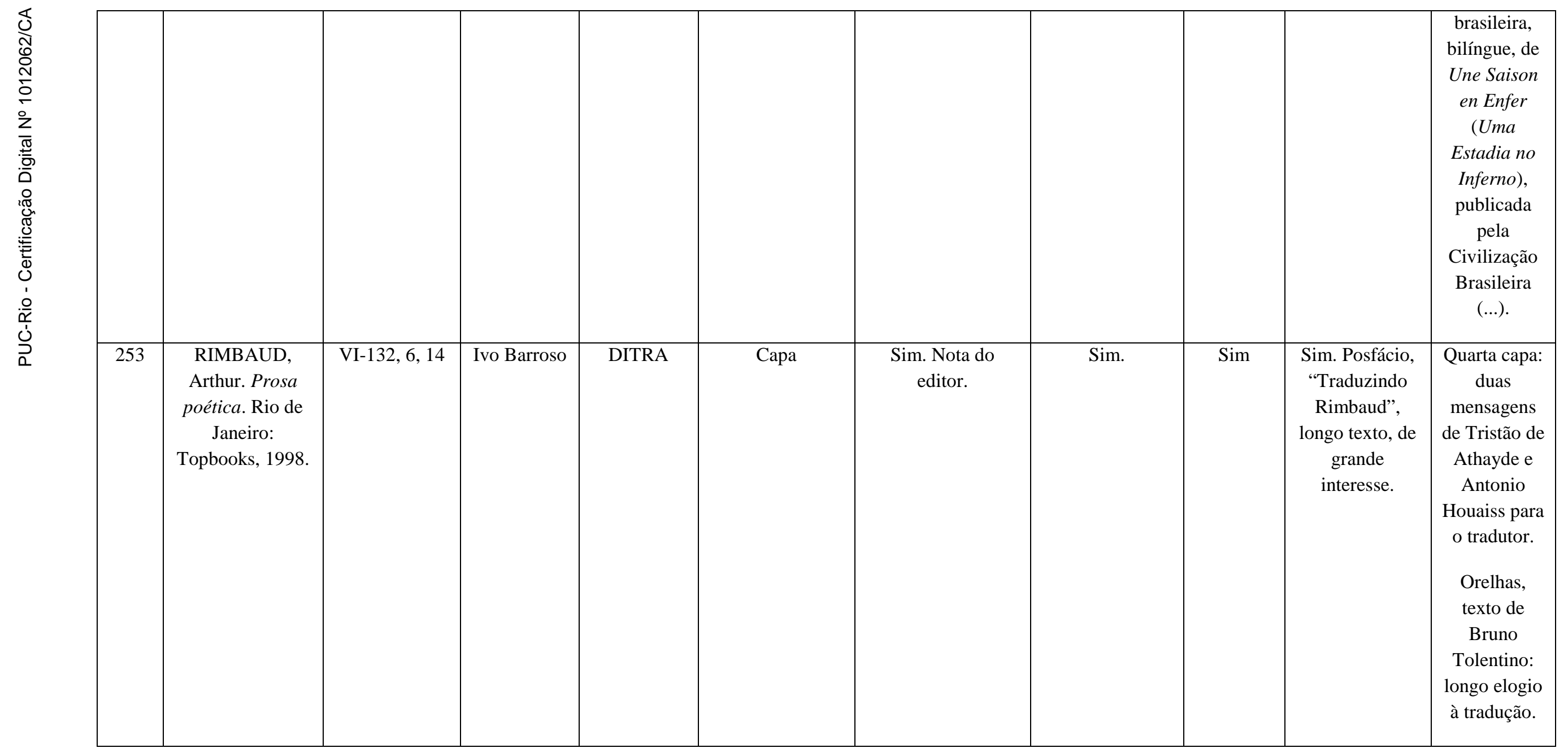




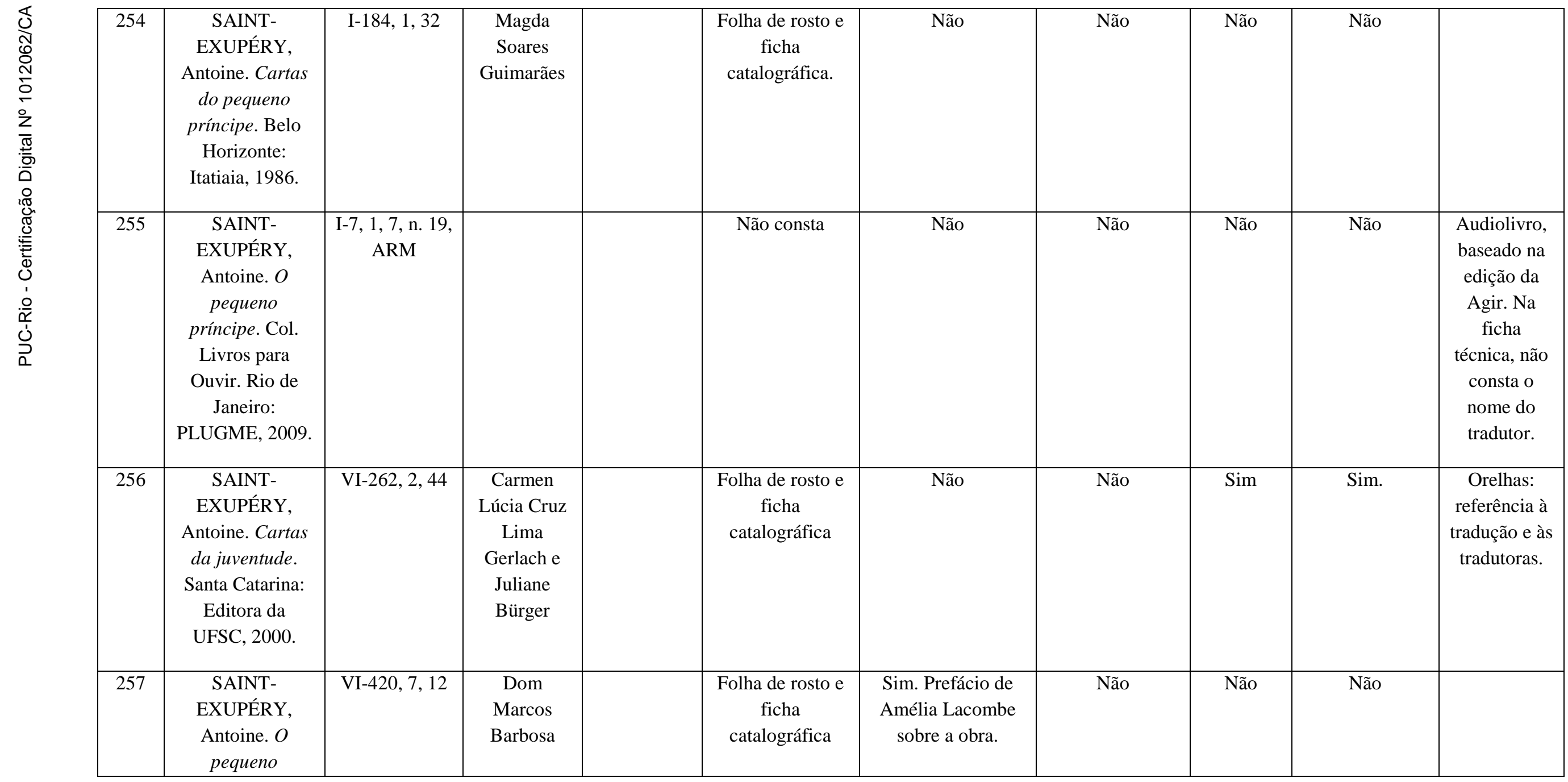




\begin{tabular}{|c|c|c|c|c|c|c|c|c|c|}
\hline & $\begin{array}{c}\text { príncipe. Rio de } \\
\text { Janeiro: Agir, } \\
2004 .\end{array}$ & & & & & & & & \\
\hline 258 & $\begin{array}{c}\text { SAINT- } \\
\text { EXUPÉRY, } \\
\text { Antoine. Terra } \\
\text { dos homens. Col. } \\
\text { Sagarana. Rio de } \\
\text { Janeiro: José } \\
\text { Olympio, 1968. }\end{array}$ & V-291, 2, 4 & $\begin{array}{c}\text { Rubem } \\
\text { Braga }\end{array}$ & Capa & $\begin{array}{l}\text { Sim. Prefácio da } \\
\text { editora: dados } \\
\text { biográficos do } \\
\text { autor. }\end{array}$ & Não & Sim. & Sim. & \\
\hline 259 & $\begin{array}{c}\text { SAINT- } \\
\text { EXUPÉRY, } \\
\text { Antoine. Terra } \\
\text { dos homens. Rio } \\
\text { de Janeiro: Nova } \\
\text { Fronteira, 1986. }\end{array}$ & VI, 220, 2, 48 & $\begin{array}{c}\text { Rubem } \\
\text { Braga }\end{array}$ & Capa & Não & Não & Não & Não & $\begin{array}{c}\text { Trata-se da } \\
\text { mesma } \\
\text { tradução de } \\
\text { Rubem } \\
\text { Braga, } \\
\text { publicada } \\
\text { pela José } \\
\text { Olympio. } \\
\text { Quarta capa, } \\
\text { menção à } \\
\text { tradução. }\end{array}$ \\
\hline 260 & $\begin{array}{c}\text { SAINT- } \\
\text { EXUPÉRY, } \\
\text { Antoine. O amor } \\
\text { do pequeno }\end{array}$ & IV-89, 7, 15 & $\begin{array}{c}\text { Alcida } \\
\text { Brant }\end{array}$ & $\begin{array}{c}\text { Folha de rosto e } \\
\text { ficha } \\
\text { catalográfica }\end{array}$ & Não & Não & Não & Não & \\
\hline
\end{tabular}

50 “A sensibilíssima tradução de Rubem Braga converte a versão brasileira de Terra dos homens, já um clássico da literatura francesa, em um duplo clássico”. 


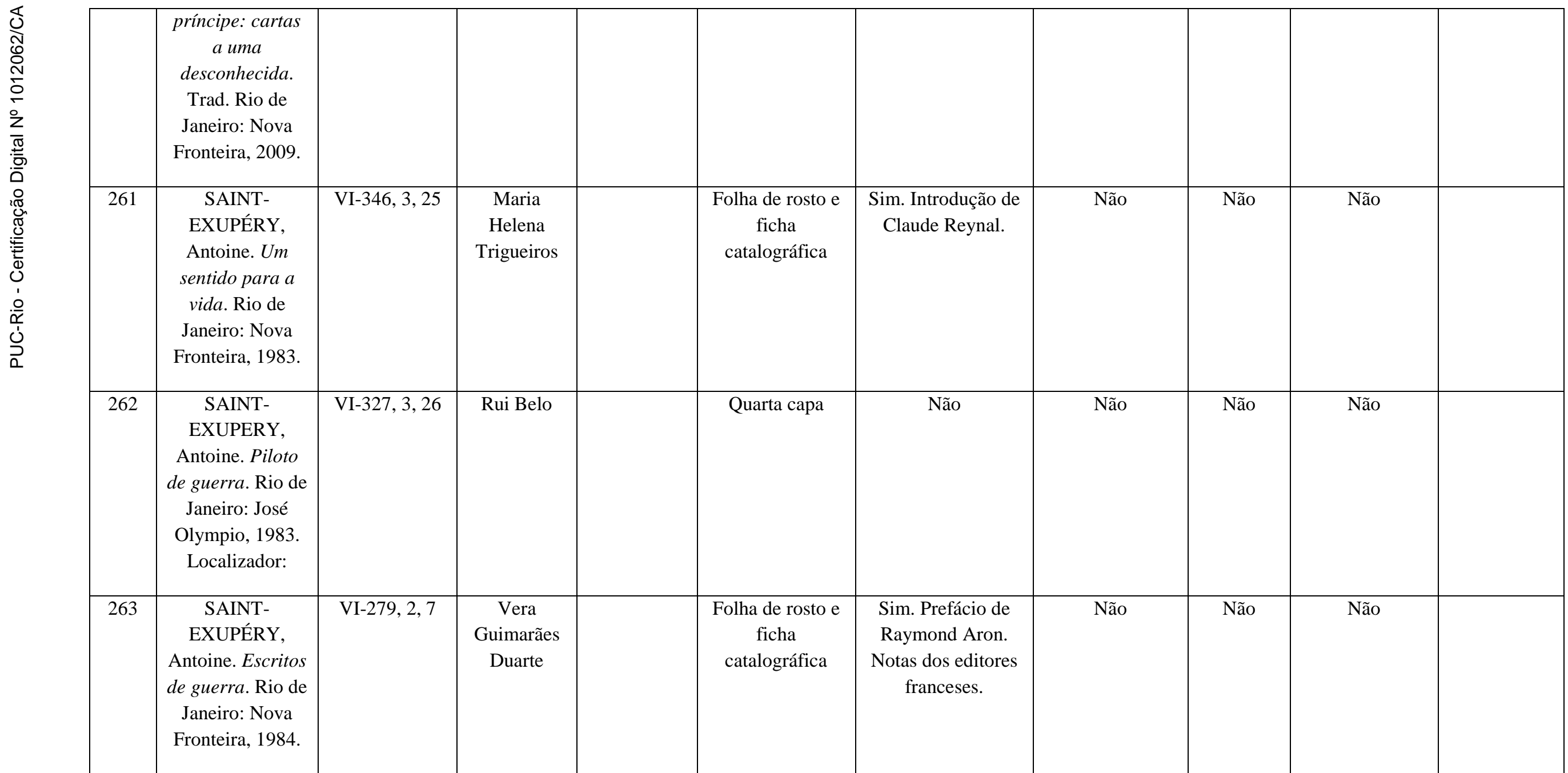




\begin{tabular}{|c|c|c|c|c|c|c|c|c|c|c|}
\hline 264 & $\begin{array}{c}\text { SAINT- } \\
\text { EXUPÉRY, } \\
\text { Antoine. } \\
\text { Cidadela. Rio de } \\
\text { Janeiro: Nova } \\
\text { Fronteira, 1982. }\end{array}$ & VI-266, 3, 63 & Ruy Bello & & $\begin{array}{c}\text { Folha de rosto e } \\
\text { ficha } \\
\text { catalográfica }\end{array}$ & Não & Não & Não & Não & \\
\hline 265 & $\begin{array}{c}\text { SAINT- } \\
\text { EXUPÉRY, } \\
\text { Antoine. Voo } \\
\text { noturno. Rio de } \\
\text { Janeiro: Nova } \\
\text { Fronteira, } 1982 .\end{array}$ & VI-298, 2, 34 & & & Não consta & $\begin{array}{l}\text { Sim. Prefácio de } \\
\text { André Gide. }\end{array}$ & Não & Não & Não & \\
\hline 266 & $\begin{array}{l}\text { STENDHAL. Do } \\
\text { amor. Col. } \\
\text { Rubáiyát. Rio de } \\
\text { Janeiro: José } \\
\text { Olympio, 1958. }\end{array}$ & II-248, 2, 26 & $\begin{array}{l}\text { Wilson } \\
\text { Lousada }\end{array}$ & & $\begin{array}{c}\text { Folha de rosto e } \\
\text { ficha } \\
\text { catalográfica }\end{array}$ & $\begin{array}{l}\text { Sim. Prefácios do } \\
\text { autor. }\end{array}$ & Não. & Sim. & Sim. & \\
\hline 267 & $\begin{array}{c}\text { STENDHAL. “O } \\
\text { cofre e o } \\
\text { fantasma”. In } \\
\text { HOLLANDA, } \\
\text { Aurélio Buarque } \\
\text { e RÓNAI, Paulo. } \\
\text { Contos } \\
\text { franceses. Rio de } \\
\text { Janeiro, Ediouro, }\end{array}$ & VI-371, 5, 4 & $\begin{array}{c}\text { Aurélio } \\
\text { Buarque de } \\
\text { Hollanda e } \\
\text { Paulo Rónai }\end{array}$ & DITRA & Capa & Não & Não & Sim & Não & $\begin{array}{l}\text { Coletânea de } \\
\text { contos de } \\
\text { vários } \\
\text { autores. Os } \\
\text { tradutores } \\
\text { também } \\
\text { foram os } \\
\text { organizadore } \\
\text { s. }\end{array}$ \\
\hline
\end{tabular}




\begin{tabular}{|c|c|c|c|c|c|c|c|c|c|}
\hline & 1982. & & & & & & & & \\
\hline 268 & $\begin{array}{c}\text { STENDHAL. O } \\
\text { vermelho e o } \\
\text { negro. São } \\
\text { Paulo: Cosac } \\
\text { Naify, 2003. }\end{array}$ & VI-208, 1, 34 & $\begin{array}{l}\text { Raquel } \\
\text { Prado }\end{array}$ & & $\begin{array}{c}\text { Sim. Prefácio de } \\
\text { Tarsila do Amaral } \\
\text { sobre o autor e a } \\
\text { obra. Apêndice de } \\
\text { Heinrich Mann } \\
\text { sobre o autor e sua } \\
\text { obra total. }\end{array}$ & Não & Não & Não & $\begin{array}{l}\text { Quarta capa: } \\
\text { trecho de } \\
\text { Erich } \\
\text { Auerbach } \\
\text { sobre o } \\
\text { autor. }\end{array}$ \\
\hline 269 & $\begin{array}{c}\text { STENDHAL. } O \\
\text { vermelho e o } \\
\text { negro. São } \\
\text { Paulo: Abril } \\
\text { Cultural, } 1981 .\end{array}$ & VI-400, 4, 47 & $\begin{array}{c}\text { Souza } \\
\text { Junior e } \\
\text { Casemiro } \\
\text { Fernandes }\end{array}$ & $\begin{array}{c}\text { Folha de rosto e } \\
\text { ficha } \\
\text { catalográfica }\end{array}$ & $\begin{array}{l}\text { Sim. Prefácio de } \\
\text { apresentação do } \\
\text { autor e da obra. }\end{array}$ & Não. & Não. & Não & \\
\hline 270 & $\begin{array}{c}\text { STENDHAL. O } \\
\text { vermelho e o } \\
\text { negro. Col. A } \\
\text { Obra-Prima de } \\
\text { Cada Autor. São } \\
\text { Paulo: Martin } \\
\text { Claret, 2004. }\end{array}$ & VI-411, 2, 29 & $\begin{array}{c}\text { Jean } \\
\text { Melville }\end{array}$ & $\begin{array}{c}\text { Folha de rosto e } \\
\text { ficha } \\
\text { catalográfica }\end{array}$ & $\begin{array}{l}\text { Sim. Prefácio da } \\
\text { editora: “A história } \\
\text { do livro. }\end{array}$ & Não. & Não. & Não & \\
\hline 271 & $\begin{array}{c}\text { STENDHAL. } \\
\text { Armance. São } \\
\text { Paulo: Estação } \\
\text { Liberdade, } 2003 .\end{array}$ & VI-215, 4, 57 & $\begin{array}{l}\text { Leila } \\
\text { Aguiar } \\
\text { Costa }\end{array}$ & Capa & $\begin{array}{l}\text { Sim. Apêndice } \\
\text { "Carta de Stendhal } \\
\text { a Mérimée”. }\end{array}$ & Não & Sim & Não & $\begin{array}{c}\text { Orelhas: } \\
\text { texto de } \\
\text { Manuel da } \\
\text { Costa Pinto } \\
\text { sobre a obra } \\
\text { e biografia }\end{array}$ \\
\hline
\end{tabular}




\begin{tabular}{|c|c|c|c|c|c|c|c|c|c|}
\hline & & & & & & & & & do autor. \\
\hline 272 & $\begin{array}{l}\text { STENDHAL. Do } \\
\text { amor. Col. } \\
\text { L\&PM Pocket. } \\
\text { Porto Alegre: } \\
\text { L\&PM, 2007. }\end{array}$ & V-469, 4, 45 & $\begin{array}{c}\text { Herculano } \\
\text { Villas-Boas }\end{array}$ & $\begin{array}{l}\text { Folha de rosto e } \\
\text { ficha } \\
\text { catalográfica }\end{array}$ & $\begin{array}{c}\text { Sim. Apresentação } \\
\text { do autor e da sua } \\
\text { obra. }\end{array}$ & Não & Não & Não & \\
\hline 273 & $\begin{array}{c}\text { STENDHAL. A } \\
\text { cartuxa de } \\
\text { Parma. Col. } \\
\text { Clássicos Globo. } \\
\text { São Paulo: } \\
\text { Globo. } 2004 .\end{array}$ & VI-354, 2, 9 & $\begin{array}{l}\text { Vidal de } \\
\text { Oliveira }\end{array}$ & Capa & $\begin{array}{c}\text { Sim. Nota } \\
\text { introdutória de } \\
\text { Manuel da Costa } \\
\text { Pinto sobre o autor } \\
\text { e a obra. Posfácio } \\
\text { Renato Janine } \\
\text { Ribeiro sobre o } \\
\text { autor a obra. }\end{array}$ & Não & Não & Não & $\begin{array}{c}\text { Orelhas: } \\
\text { sobre o } \\
\text { autor, } \\
\text { referência ao } \\
\text { posfácio. }\end{array}$ \\
\hline 274 & $\begin{array}{l}\text { STENDHAL. O } \\
\text { vermelho e o } \\
\text { negro. Col. } \\
\text { Biblioteca Folha, } \\
\text { Clássicos da } \\
\text { Literatura } \\
\text { Universal. Rio de } \\
\text { Janeiro: Ediouro, } \\
\text { 1998. }\end{array}$ & I-85, 5, 15 & $\begin{array}{l}\text { Casimiro } \\
\text { Fernandes e } \\
\text { De Souza } \\
\text { Junior }\end{array}$ & Capa & $\begin{array}{c}\text { Sim. Posfácio } \\
\text { “Stendhal e sua } \\
\text { obra” não assinado. }\end{array}$ & Não & Não & Não & \\
\hline 275 & $\begin{array}{c}\text { STENDHAL. } O \\
\text { vermelho e o } \\
\text { negro. Col. }\end{array}$ & IV-56, 6, 26 & $\begin{array}{c}\text { Maria } \\
\text { Cristina F. } \\
\text { da Silva }\end{array}$ & $\begin{array}{c}\text { Folha de rosto e } \\
\text { ficha } \\
\text { catalográfica }\end{array}$ & $\begin{array}{c}\text { Sim. Prefácio sobre } \\
\text { o autor e a obra. }\end{array}$ & Não & Não & Não & \\
\hline
\end{tabular}




\begin{tabular}{|c|c|c|c|c|c|c|c|c|c|c|}
\hline & $\begin{array}{c}\text { Imortais da } \\
\text { Literatura } \\
\text { Universal. São } \\
\text { Paulo: Círculo do } \\
\text { Livro, } 1995 .\end{array}$ & & & & & & & & & \\
\hline 276 & $\begin{array}{c}\text { STENDHAL. O } \\
\text { vermelho e o } \\
\text { negro. Col. } \\
\text { Clássicos Globo. } \\
\text { Rio de Janeiro: } \\
\text { Editora Globo, } \\
1987 .\end{array}$ & VI-223, 1, 55 & $\begin{array}{l}\text { De Souza } \\
\text { Junior e } \\
\text { Casemiro } \\
\text { Fernandes }\end{array}$ & & $\begin{array}{l}\text { Folha de rosto e } \\
\text { ficha } \\
\text { catalográfica }\end{array}$ & $\begin{array}{l}\text { Sim. Ao final, } \\
\text { Cronologia. }\end{array}$ & Não & Não & Não & \\
\hline 277 & $\begin{array}{l}\text { STENDHAL. } \\
\text { Napoleão. Rio de } \\
\text { Janeiro: } \\
\text { Boitempo, } 1995 .\end{array}$ & $\mathrm{I}-14,2,49$ & $\begin{array}{c}\text { Eduardo } \\
\text { Brandão e } \\
\text { Katia } \\
\text { Rossini }\end{array}$ & & $\begin{array}{c}\text { Folha de rosto e } \\
\text { ficha } \\
\text { catalográfica }\end{array}$ & $\begin{array}{l}\text { Sim. Prefácio de } \\
\text { Renato Janine } \\
\text { Ribeiro, “Uma } \\
\text { paixão difícil”. } \\
\text { Nota do editor. } \\
\text { Prefácio do autor. } \\
\text { 4. Ao final } \\
\text { “Cronologia”. }\end{array}$ & Não & Não & Não & $\begin{array}{c}\text { Quarta capa: } \\
\text { Trechos de } \\
\text { Renato } \\
\text { Janine } \\
\text { Ribeiro e de } \\
\text { Victor del } \\
\text { Litto. }\end{array}$ \\
\hline 278 & $\begin{array}{c}\text { STENDHAL. } \\
\text { Crônicas } \\
\text { italianas. São } \\
\text { Paulo: EDUSP, } \\
\text { 1997. }\end{array}$ & $\mathrm{I}-17,6,1$ & $\begin{array}{l}\text { Sebastião } \\
\text { Uchoa Leite }\end{array}$ & DITRA & $\begin{array}{c}\text { Folha de rosto e } \\
\text { ficha } \\
\text { catalográfica }\end{array}$ & $\begin{array}{l}\text { Sim. Prefácio de } \\
\text { Luiz Costa Lima, } \\
\text { "Stendhal e a } \\
\text { Itália”. Prefácio de } \\
\text { Stendhal. Ao final, } \\
\text { "Stendhal: Sumário } \\
\text { da Vida e da }\end{array}$ & Não & Não & Não & $\begin{array}{c}\text { Orelhas: } \\
\text { texto de } \\
\text { Manuel da } \\
\text { Costa Pinto. }\end{array}$ \\
\hline
\end{tabular}




\begin{tabular}{|c|c|c|c|c|c|c|c|c|c|}
\hline & & & & & Obra”. & & & & \\
\hline 279 & $\begin{array}{c}\text { STENDHAL. A } \\
\text { cartuxa de } \\
\text { Parma. Col. } \\
\text { Clássicos de } \\
\text { Bolso. São } \\
\text { Paulo: } \\
\text { Technoprint, } \\
\text { 1994. }\end{array}$ & VI-37, 2, 11 & $\begin{array}{l}\text { Vidal de } \\
\text { Oliveira }\end{array}$ & Сара & $\begin{array}{l}\text { Sim. Prefácio sobre } \\
\text { a obra, não } \\
\text { assinado. Prefácio } \\
\text { de Balzac sobre } \\
\text { Stendhal. }\end{array}$ & Não & Não & Não & $\begin{array}{c}\text { Quarta capa: } \\
\text { sobre a } \\
\text { coleção e a } \\
\text { obra }\end{array}$ \\
\hline 280 & $\begin{array}{l}\text { STENDHAL. Do } \\
\text { amor. Col. } \\
\text { Clássicos de } \\
\text { Bolso. Rio de } \\
\text { Janeiro: } \\
\text { Technoprint, } \\
\text { 1994. }\end{array}$ & VI-37, 2, 6 & $\begin{array}{l}\text { Wilson } \\
\text { Lousada }\end{array}$ & Capa & $\begin{array}{l}\text { Sim. Prefácios do } \\
\text { autor. }\end{array}$ & Não & Sim. & Sim & \\
\hline 281 & $\begin{array}{c}\text { STENDHAL. Do } \\
\text { amor. São Paulo: } \\
\text { Martins Fontes, } \\
1993 .\end{array}$ & VI-23, 6, 64 & $\begin{array}{l}\text { Roberto } \\
\text { Leal } \\
\text { Ferreira }\end{array}$ & $\begin{array}{c}\text { Folha de rosto e } \\
\text { ficha } \\
\text { catalográfica }\end{array}$ & $\begin{array}{l}\text { Sim. Introdução de } \\
\text { Sainte-Beuve. } \\
\text { Cronologia. Três } \\
\text { prefácios do autor. }\end{array}$ & Não & Não & Não & \\
\hline 282 & $\begin{array}{c}\text { STENDHAL. O } \\
\text { vermelho e o } \\
\text { negro. São } \\
\text { Paulo: Nova } \\
\text { Cultural, 1993. }\end{array}$ & VI-8, 1, 66 & & Não consta. & Não & Não & Não & Não & \\
\hline
\end{tabular}




\begin{tabular}{|c|c|c|c|c|c|c|c|c|}
\hline 283 & $\begin{array}{c}\text { STENDHAL. O } \\
\text { vermelho e o } \\
\text { negro. Col. } \\
\text { Clássicos de } \\
\text { Bolso. São } \\
\text { Paulo: Ediouro, } \\
\text { 1992. }\end{array}$ & $\begin{array}{l}\text { ANEXO II- } \\
788,4,23\end{array}$ & $\begin{array}{c}\text { De Souza } \\
\text { Júnior e } \\
\text { Casimiro } \\
\text { Fernandes }\end{array}$ & Сара & $\begin{array}{l}\text { Sim. Prefácio sobre } \\
\text { a obra, não } \\
\text { assinado. Prefácio } \\
\text { de H. Taine sobre a } \\
\text { obra. }\end{array}$ & Não & Não & Não \\
\hline 284 & $\begin{array}{l}\text { STENDHAL. Do } \\
\text { amor. Col. } \\
\text { Universidade de } \\
\text { Bolso. Rio de } \\
\text { Janeiro: } \\
\text { Technoprint, } \\
1987 .\end{array}$ & $\mathrm{I}-109,5,24$ & $\begin{array}{l}\text { Wilson } \\
\text { Lousada }\end{array}$ & Сара & $\begin{array}{l}\text { Sim. Prefácios do } \\
\text { autor. }\end{array}$ & Não & Sim & Sim \\
\hline 285 & $\begin{array}{l}\text { STENDHAL. O } \\
\text { vermelho e o } \\
\text { negro. Col. } \\
\text { Biblioteca dos } \\
\text { Séculos. Porto } \\
\text { Alegre: Editora } \\
\text { Globo, } 1985 .\end{array}$ & II- $410,3,4$ & $\begin{array}{c}\text { De Souza } \\
\text { Junior e } \\
\text { Casemiro } \\
\text { Fernandes }\end{array}$ & Сара & $\begin{array}{l}\text { Sim. Prefácio sobre } \\
\text { o autor, sem } \\
\text { assinatura. }\end{array}$ & Não & Não & Não \\
\hline 286 & $\begin{array}{l}\text { STENDHAL. A } \\
\text { cartuxa de } \\
\text { Parma. Vol. } 1 \mathrm{e} \\
\text { 2. Col. Grandes } \\
\text { Romancistas. } \\
\text { São Paulo: Abril }\end{array}$ & $\begin{array}{c}\text { VI-275, 3, 39- } \\
40\end{array}$ & $\begin{array}{l}\text { José } \\
\text { Geraldo } \\
\text { Vieira }\end{array}$ & $\begin{array}{c}\text { Folha de rosto e } \\
\text { ficha } \\
\text { catalográfica }\end{array}$ & Não & Não & Não & Não \\
\hline
\end{tabular}




\begin{tabular}{|c|c|c|c|c|c|c|c|c|c|}
\hline & Cultural, 1984. & & & & & & & & \\
\hline 287 & $\begin{array}{l}\text { STENDHAL. A } \\
\text { cartuxa de } \\
\text { Parma. Col. } \\
\text { Universidade de } \\
\text { Bolso. Rio de } \\
\text { Janeiro: } \\
\text { Technoprint, } \\
1987 .\end{array}$ & VI-338, 4, 37 & $\begin{array}{l}\text { Vidal de } \\
\text { Oliveira }\end{array}$ & Сара & $\begin{array}{l}\text { Sim. Prefácio sobre } \\
\text { a obra, não } \\
\text { assinado. Prefácio } \\
\text { de Balzac sobre o } \\
\text { autor e a obra. }\end{array}$ & Não & Não & Não & \\
\hline 288 & $\begin{array}{c}\text { STENDHAL. } \\
\text { Lucien Lewen. } \\
\text { Col. Clássicos } \\
\text { Francisco Alves. } \\
\text { Rio de Janeiro: } \\
\text { Francisco Alves, } \\
1983 .\end{array}$ & VI-337, 3, 13 & $\begin{array}{c}\text { Marcos } \\
\text { Santarrita }\end{array}$ & Capa & Não & Não & Sim. & $\begin{array}{l}\text { Sim. Nota do } \\
\text { Tradutor", ao } \\
\text { final. }\end{array}$ & $\begin{array}{c}\text { Orelhas: } \\
\text { texto de Jose } \\
\text { Mario } \\
\text { Pereira sobre } \\
\text { o autor e a } \\
\text { obra. }\end{array}$ \\
\hline 289 & $\begin{array}{c}\text { STENDHAL. O } \\
\text { vermelho e o } \\
\text { negro. Porto } \\
\text { Alegre: Editora } \\
\text { Globo, } 1983 .\end{array}$ & VI-335, 2, 27. & $\begin{array}{l}\text { De Souza } \\
\text { Junior e } \\
\text { Casemiro } \\
\text { Fernandes }\end{array}$ & $\begin{array}{c}\text { Folha de rosto e } \\
\text { ficha } \\
\text { catalográfica }\end{array}$ & $\begin{array}{l}\text { Sim. Prefácio sobre } \\
\text { o autor e a obra, } \\
\text { não assinado. } 2 \text {. } \\
\text { Prefácio de H. } \\
\text { Taine. }\end{array}$ & Não & Não & Não & \\
\hline 290 & $\begin{array}{c}\text { STENDHAL. O } \\
\text { vermelho e o } \\
\text { negro. Coleção } \\
\text { L\&PM Pocket. } \\
\text { Porto Alegre: }\end{array}$ & $\begin{array}{l}\text { ANEXO II- } \\
711,5,5 \text { n1 }\end{array}$ & $\begin{array}{l}\text { Paulo } \\
\text { Neves }\end{array}$ & $\begin{array}{l}\text { Folha de rosto e } \\
\text { ficha } \\
\text { catalográfica }\end{array}$ & Não & Não & Não & Não & \\
\hline
\end{tabular}




\begin{tabular}{|c|c|c|c|c|c|c|c|c|c|c|}
\hline & L\&PM, 2002. & & & & & & & & & \\
\hline 291 & $\begin{array}{l}\text { STENDHAL. A } \\
\text { cartuxa de } \\
\text { Parma. São } \\
\text { Paulo: Círculo do } \\
\text { Livro, } 1983 .\end{array}$ & $\begin{array}{c}\text { ANEXO II- } \\
700,3,21\end{array}$ & $\begin{array}{l}\text { José } \\
\text { Geraldo } \\
\text { Vieira }\end{array}$ & & $\begin{array}{l}\text { Folha de rosto e } \\
\text { ficha } \\
\text { catalográfica }\end{array}$ & $\begin{array}{l}\text { Sim. Prefácio de } \\
\text { Henri Martineau } \\
\text { sobre o autor e a } \\
\text { obra. }\end{array}$ & Não & Não & Não & \\
\hline 292 & $\begin{array}{l}\text { VERLAINE, } \\
\text { Paul. Passeio } \\
\text { sentimental } \\
\text { (poemas). São } \\
\text { Paulo: Círculo do } \\
\text { Livro, } 1989 .\end{array}$ & IV-161, 3, 47 & $\begin{array}{c}\text { Jamil } \\
\text { Almansur } \\
\text { Haddad }\end{array}$ & & $\begin{array}{l}\text { Folha de rosto e } \\
\text { ficha } \\
\text { catalográfica }\end{array}$ & $\begin{array}{l}\text { Sim. Prefácio, } \\
\text { "Verlaine e o } \\
\text { Brasil": sobre o } \\
\text { simbolismo. }\end{array}$ & Não & Não & Não & \\
\hline 293 & $\begin{array}{l}\text { VERLAINE, } \\
\text { Paul. } \\
\text { Paralelamente a } \\
\text { Verlaine. São } \\
\text { Paulo: Livraria } \\
\text { Martins, 1944. }\end{array}$ & VI-396, 2, 57. & $\begin{array}{l}\text { Guilherme } \\
\text { de Almeida }\end{array}$ & DITRA & $\begin{array}{c}\text { Folha de rosto e } \\
\text { ficha } \\
\text { catalográfica }\end{array}$ & Não & Não & $\begin{array}{c}\text { Sim. } \\
\text { "Minha } \\
\text { carta a } \\
\text { Paul } \\
\text { Verlaine" } \\
\text { do } \\
\text { tradutor, } \\
\text { sem } \\
\text { referência } \\
\text { à } \\
\text { tradução. }\end{array}$ & Não & \\
\hline 294 & $\begin{array}{l}\text { VERLAINE, } \\
\text { Paul. Festas } \\
\text { galantes. Rio de }\end{array}$ & VI-249, 2, 21. & $\begin{array}{l}\text { Onestaldo } \\
\text { de } \\
\text { Pennafort }\end{array}$ & DITRA & Сара & Não & Não & Sim & Sim. & $\begin{array}{l}\text { Quarta capa, } \\
\text { texto de } \\
\text { Paulo Rónai, }\end{array}$ \\
\hline
\end{tabular}




\begin{tabular}{|c|c|c|c|c|c|c|c|c|c|c|}
\hline & $\begin{array}{c}\text { Janeiro: } \\
\text { Civilização } \\
\text { Brasileira, } 1983 .\end{array}$ & & & & & & & & & $\begin{array}{c}\text { louvando o } \\
\text { tradutor. } 3 . \\
\text { Orelhas: } \\
\text { texto de } \\
\text { Manuel } \\
\text { Bandeira, } \\
\text { louvando o } \\
\text { tradutor. }\end{array}$ \\
\hline 295 & $\begin{array}{c}\text { VERLAINE, } \\
\text { Paul. Para ser } \\
\text { caluniado. São } \\
\text { Paulo: Editora } \\
\text { Brasiliense, } \\
1985 .\end{array}$ & VI-253, 4, 41 & $\begin{array}{c}\text { Heloisa } \\
\text { Jahn }\end{array}$ & DITRA & $\begin{array}{c}\text { Folha de rosto e } \\
\text { ficha } \\
\text { catalográfica }\end{array}$ & Não & Não & Sim. & Não & \\
\hline 296 & $\begin{array}{c}\text { VERNE, Julio. } \\
20.000 \text { léguas } \\
\text { submarinas. São } \\
\text { Paulo: } \\
\text { Companhia das } \\
\text { Letrinhas, } 2001 .\end{array}$ & I-3, 4, 62/INF. & $\begin{array}{c}\text { Adapt. Ron } \\
\text { Miller. } \\
\text { Trad. } \\
\text { Hildegard } \\
\text { Feist. }\end{array}$ & $\begin{array}{c}\text { DITRA } \\
\text { (Hidegard } \\
\text { Feist) }\end{array}$ & $\begin{array}{c}\text { Folha de rosto e } \\
\text { ficha } \\
\text { catalográfica }\end{array}$ & Não & Não & Não & Não & $\begin{array}{l}\text { Edição } \\
\text { infantil. }\end{array}$ \\
\hline 297 & $\begin{array}{c}\text { VERNE, Julio. } \\
\text { Viagem ao } \\
\text { centro da Terra. } \\
\text { Col. Reencontro } \\
\text { Infantil. São } \\
\text { Paulo: Scipione, }\end{array}$ & $\begin{array}{c}\text { I-4, 4, 13, n. } \\
\text { 6/INF. }\end{array}$ & $\begin{array}{c}\text { Adapt. } \\
\text { Lúcia } \\
\text { Tulchinski. }\end{array}$ & & $\begin{array}{c}\text { Folha de rosto e } \\
\text { ficha } \\
\text { catalográfica }\end{array}$ & Não & Não & Não & Não & $\begin{array}{l}\text { Edição } \\
\text { Infantil. }\end{array}$ \\
\hline
\end{tabular}




\begin{tabular}{|c|c|c|c|c|c|c|c|c|c|c|}
\hline & 2001. & & & & & & & & & \\
\hline 298 & $\begin{array}{c}\text { VERNE, Julio. A } \\
\text { volta ao mundo } \\
\text { em } 80 \text { dias. Col. } \\
\text { Grandes } \\
\text { Clássicos } \\
\text { Juvenis. São } \\
\text { Paulo: Ed. } \\
\text { Globo, 1996. }\end{array}$ & $\begin{array}{c}\text { ANEXO II- } \\
684,3,17\end{array}$ & $\begin{array}{c}\text { Trad. e } \\
\text { adapt. Sônia } \\
\text { Robatto. }\end{array}$ & & $\begin{array}{l}\text { Folha de rosto e } \\
\text { ficha } \\
\text { catalográfica }\end{array}$ & Não & Não & Não & Não & $\begin{array}{c}\text { Edição } \\
\text { infantil em } \\
\text { quadrinhos. }\end{array}$ \\
\hline 299 & $\begin{array}{l}\text { VERNE, Julio. } \\
\text { Miguel Strogoff e } \\
\text { O correio do } \\
\text { czar. Col. } \\
\text { Elefante. Rio de } \\
\text { Janeiro: Ediouro, } \\
\text { 1997. }\end{array}$ & I-10, 2, 36 & $\begin{array}{l}\text { Rachel de } \\
\text { Queiróz }\end{array}$ & & Сара & $\begin{array}{l}\text { Sim. Introdução } \\
\text { sobre o autor, não } \\
\text { assinada. }\end{array}$ & Não & Não & Não & \\
\hline 300 & $\begin{array}{l}\text { VERNE, Julio. } \\
\text { Um padre em } \\
\text { 1839. São Paulo: } \\
\text { Scipione, } 1996 .\end{array}$ & VI-45, 4, 43 & $\begin{array}{c}\text { Estela dos } \\
\text { Santos } \\
\text { Abreu }\end{array}$ & DITRA & $\begin{array}{l}\text { Folha de rosto e } \\
\text { ficha } \\
\text { catalográfica }\end{array}$ & $\begin{array}{l}\text { Sim. Prefácio da e } \\
\text { Posfácio de } \\
\text { Christian Robin: } \\
\text { “O primeiro } \\
\text { romance de Júlio } \\
\text { Verne dição } \\
\text { francesa. }\end{array}$ & Não & Sim. & Sim. & \\
\hline 301 & $\begin{array}{l}\text { VERNE, Julio. A } \\
\text { volta ao mundo } \\
\text { em } 80 \text { dias. Col. }\end{array}$ & $\mathrm{I}-178,1,64$ & $\begin{array}{c}\text { Heloisa } \\
\text { Jahn }\end{array}$ & DITRA & $\begin{array}{c}\text { Folha de rosto e } \\
\text { ficha } \\
\text { catalográfica }\end{array}$ & $\begin{array}{l}\text { Sim. Prefácios: } \\
\text { "Júlio Verne, um } \\
\text { escritor de vários }\end{array}$ & Não & Não & Não & \\
\hline
\end{tabular}




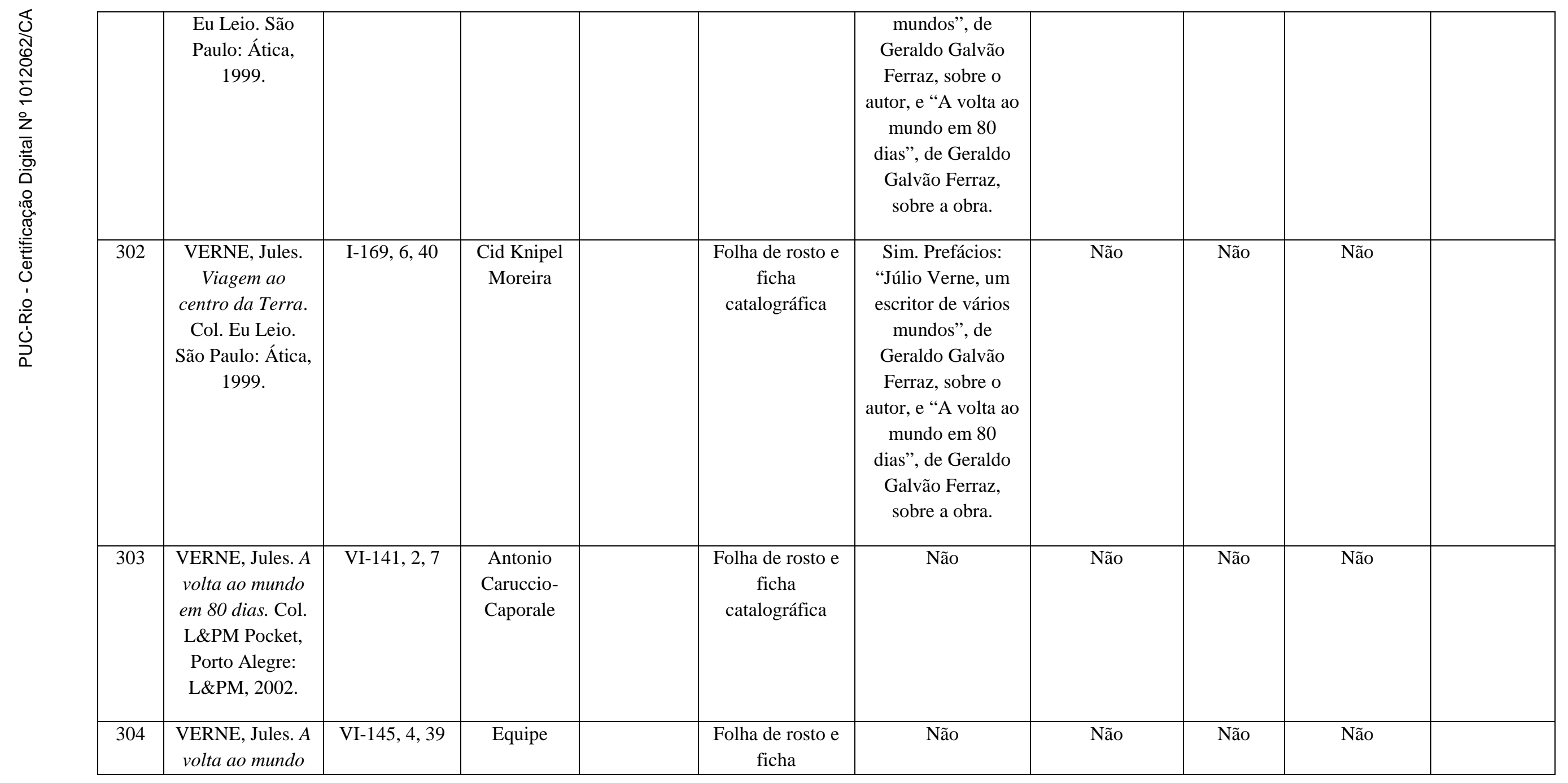




\begin{tabular}{|c|c|c|c|c|c|c|c|c|}
\hline & $\begin{array}{c}\text { em } 80 \text { dias. Trad. } \\
\text { Porto Alegre: } \\
\text { Rígel Editora, } \\
2002 .\end{array}$ & & Rígel & catalográfica & & & & \\
\hline 305 & $\begin{array}{l}\text { VERNE, Jules. O } \\
\text { raio verde. Belo } \\
\text { Horizonte: Villa } \\
\text { Rica, } 2000 .\end{array}$ & VI-408, 4,17 & $\begin{array}{l}\text { Mariângela } \\
\text { M. Queiroz }\end{array}$ & $\begin{array}{l}\text { Folha de rosto e } \\
\text { ficha } \\
\text { catalográfica }\end{array}$ & Não & Não & Não & Não \\
\hline 306 & $\begin{array}{l}\text { VERNE, Jules. } \\
\text { Os náufragos do } \\
\text { mar e A ilha } \\
\text { misteriosa. Belo } \\
\text { Horizonte: Villa } \\
\text { Rica, } 2001 .\end{array}$ & V-220, 6, 4 & $\begin{array}{l}\text { Mariângela } \\
\text { M. Queiroz }\end{array}$ & $\begin{array}{l}\text { Folha de rosto e } \\
\text { ficha } \\
\text { catalográfica }\end{array}$ & Não & Não & Não & Não \\
\hline 307 & $\begin{array}{l}\text { VERNE, Jules. } \\
\text { Os filhos do } \\
\text { capitão Grant. } \\
\text { Belo Horizonte: } \\
\text { Villa Rica, } 2000 .\end{array}$ & VI-408, 4, 19 & $\begin{array}{l}\text { Mariângela } \\
\text { M. Queiroz }\end{array}$ & $\begin{array}{c}\text { Folha de rosto e } \\
\text { ficha } \\
\text { catalográfica }\end{array}$ & Não & Não & Não & Não \\
\hline 308 & $\begin{array}{l}\text { VERNE, Jules. A } \\
\text { Ilha Chairman e } \\
\text { Dois anos de } \\
\text { férias. Belo } \\
\text { Horizonte: Villa } \\
\text { Rica, 2000. }\end{array}$ & V-220, 7, 20. & $\begin{array}{l}\text { Mariângela } \\
\text { M. Queiroz }\end{array}$ & $\begin{array}{l}\text { Folha de rosto e } \\
\text { ficha } \\
\text { catalográfica }\end{array}$ & Não & Não & Não & Não \\
\hline
\end{tabular}




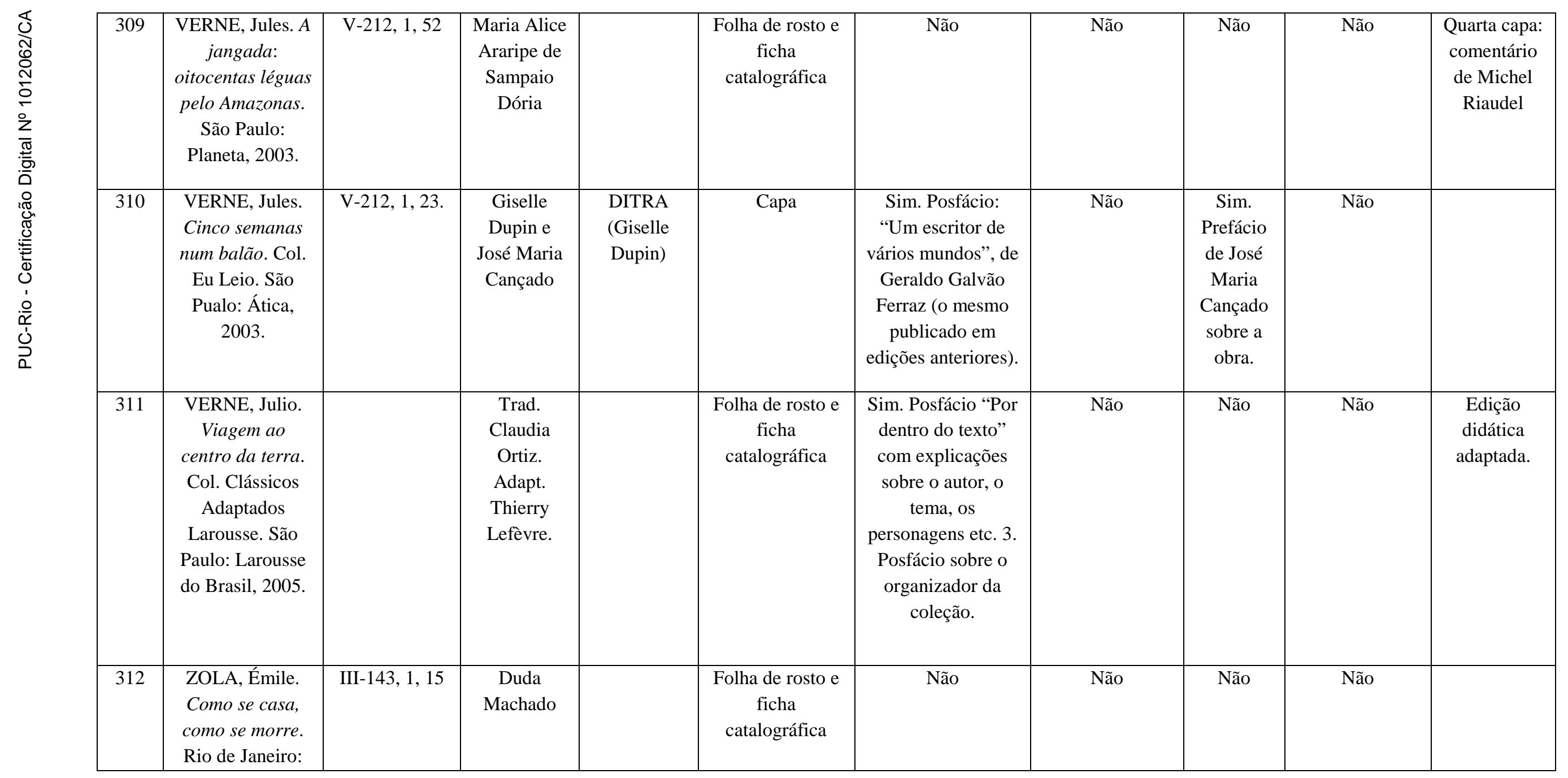




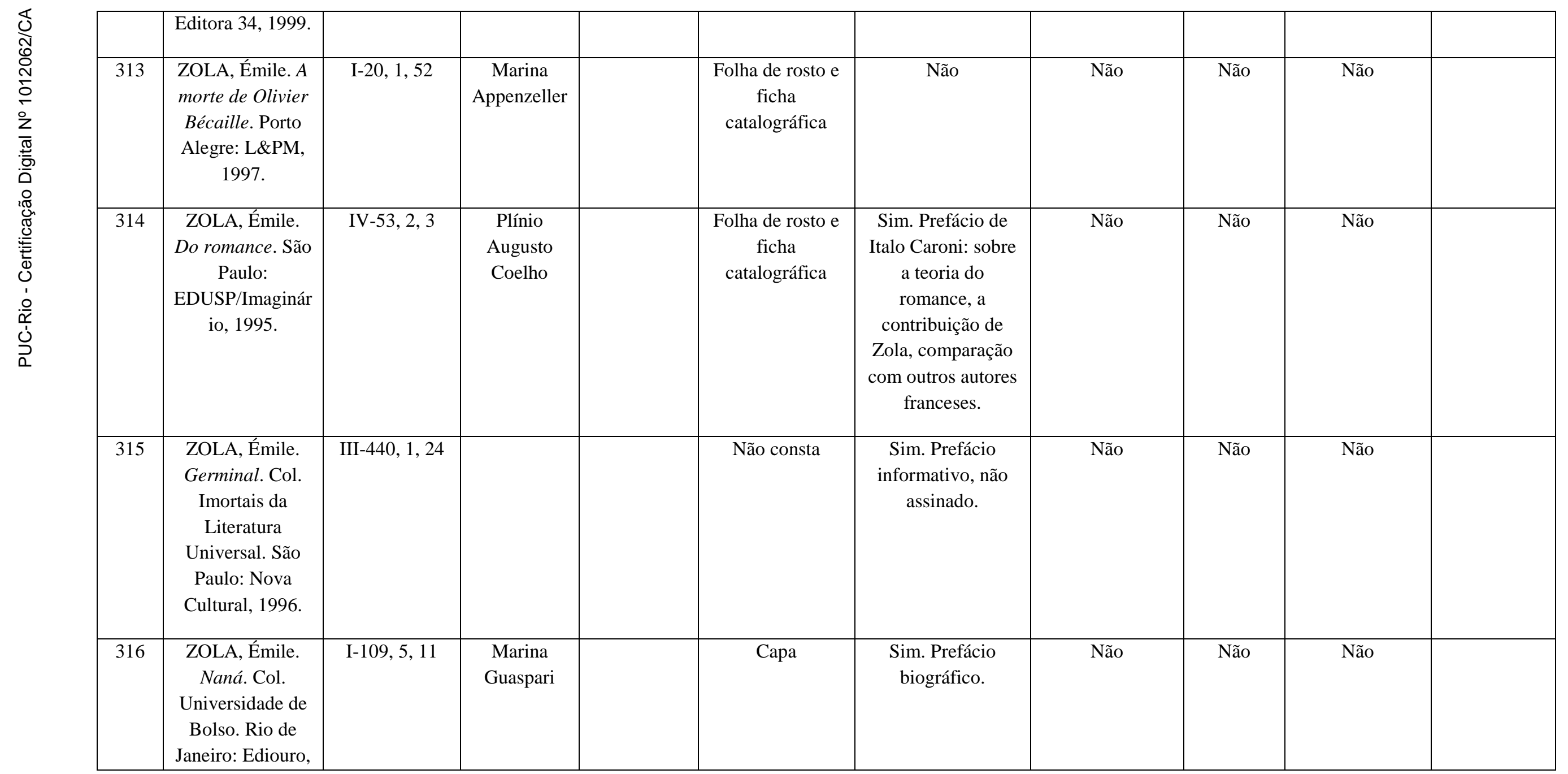




\begin{tabular}{|c|c|c|c|c|c|c|c|c|}
\hline & 1987. & & & & & & & \\
\hline 317 & $\begin{array}{l}\text { ZOLA, Émile. } \\
\text { ZOLA, Émile. } \\
\text { Germinal. Col. } \\
\text { Universidade de } \\
\text { Bolso. Rio de } \\
\text { Janeiro: Ediouro, } \\
\text { 1987. }\end{array}$ & $\mathrm{I}-64,4,38$ & $\begin{array}{l}\text { Eduardo } \\
\text { Nunes } \\
\text { Fonseca }\end{array}$ & Capa & $\begin{array}{c}\text { Sim. Dois } \\
\text { prefácios de Assis } \\
\text { Brasil, um sobre a } \\
\text { obra e outro sobre } \\
\text { o autor. }\end{array}$ & Não & Não & Não \\
\hline 318 & $\begin{array}{c}\text { ZOLA, Émile. A } \\
\text { batalha do } \\
\text { Impressionismo. } \\
\text { Rio de Janeiro: } \\
\text { Paz e Terra, } \\
1989 .\end{array}$ & III-48, 2, 35 & $\begin{array}{l}\text { Martha } \\
\text { Gambini }\end{array}$ & $\begin{array}{l}\text { Folha de rosto e } \\
\text { ficha } \\
\text { catalográfica }\end{array}$ & $\begin{array}{c}\text { Sim. Quadro } \\
\text { cronológico. Nota } \\
\text { introdutória sobre a } \\
\text { obra, uma defesa } \\
\text { do Impressionismo } \\
\text { por Zola. }\end{array}$ & Não & Não & Não \\
\hline 319 & $\begin{array}{l}\text { ZOLA, Émile. A } \\
\text { besta humana. } \\
\text { Col. } \\
\text { Universidade de } \\
\text { Bolso. Rio de } \\
\text { Janeiro: Ediouro, } \\
\text { 1987. }\end{array}$ & V-388, 4, 54 & $\begin{array}{c}\text { Marina } \\
\text { Guaspari }\end{array}$ & Capa & $\begin{array}{l}\text { Sim. Prefácio } \\
\text { biográfico. }\end{array}$ & Não & Não & Não \\
\hline 320 & $\begin{array}{l}\text { ZOLA, Émile. } \\
\text { Germinal. São } \\
\text { Paulo: Círculo do } \\
\text { Livro, } 1986 .\end{array}$ & VI-298, 4, 55. & & Não consta & Não & Não & Não & Não \\
\hline
\end{tabular}




\begin{tabular}{|c|c|c|c|c|c|c|c|c|}
\hline 321 & $\begin{array}{l}\text { ZOLA, Émile. } \\
\text { Nana. São Paulo: } \\
\text { Abril Cultural, } \\
1985 .\end{array}$ & VI-266,2, 42 & $\begin{array}{c}\text { Eugênio } \\
\text { Vieira }\end{array}$ & $\begin{array}{l}\text { Folha de rosto e } \\
\text { ficha } \\
\text { catalográfica }\end{array}$ & $\begin{array}{l}\text { Sim. Prefácio de } \\
\text { apresentação do } \\
\text { autor e da obra }\end{array}$ & Não & Não & Não \\
\hline 322 & $\begin{array}{l}\text { ZOLA, Émile. } \\
\text { Nana. Col. } \\
\text { Clássicos de } \\
\text { Bolso. Rio de } \\
\text { Janeiro: Ediouro, } \\
\text { 1994. }\end{array}$ & VI-25, 1, 45 & $\begin{array}{c}\text { Marina } \\
\text { Guaspari }\end{array}$ & Сара & $\begin{array}{l}\text { Sim. Prefácios } \\
\text { sobre o autor. }\end{array}$ & Não & Não & Não \\
\hline 323 & $\begin{array}{l}\text { ZOLA, Émile. } \\
\text { Thérèse Raquin. } \\
\text { Col. Os Grandes } \\
\text { Dramaturgos. } \\
\text { São Paulo: } \\
\text { Editora Peixoto } \\
\text { Neto, } 2007 .\end{array}$ & $\mathrm{V}-241,7,26$ & $\begin{array}{c}\text { Sergio } \\
\text { Flaksman }\end{array}$ & $\begin{array}{l}\text { Folha de rosto e } \\
\text { ficha } \\
\text { catalográfica }\end{array}$ & $\begin{array}{l}\text { Sim. Prefácio de } \\
\text { João Roberto Faria, } \\
\text { "Zola e o } \\
\text { naturalismo no } \\
\text { teatro". 2. Prefácio } \\
\text { do autor. 3. Ao } \\
\text { final, “Dossiê } \\
\text { Émile Zola": } \\
\text { Cronologia da vida } \\
\text { do autor, } \\
\text { Cronologia das } \\
\text { principais obras do } \\
\text { autor, Sugestões de } \\
\text { leitura; Autores e } \\
\text { títulos publicados, } \\
\text { a coleção. }\end{array}$ & Não & Não & Não \\
\hline
\end{tabular}




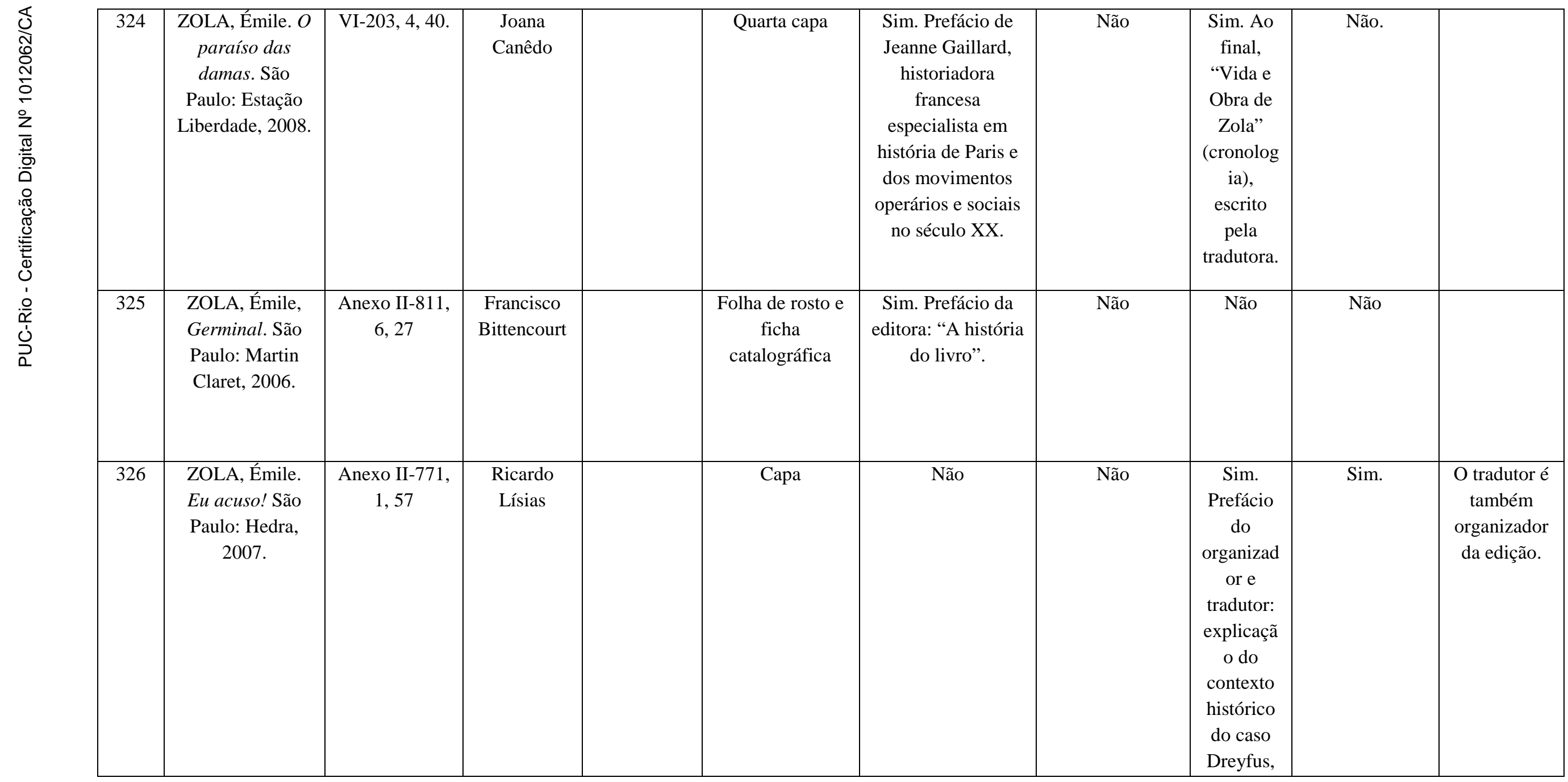




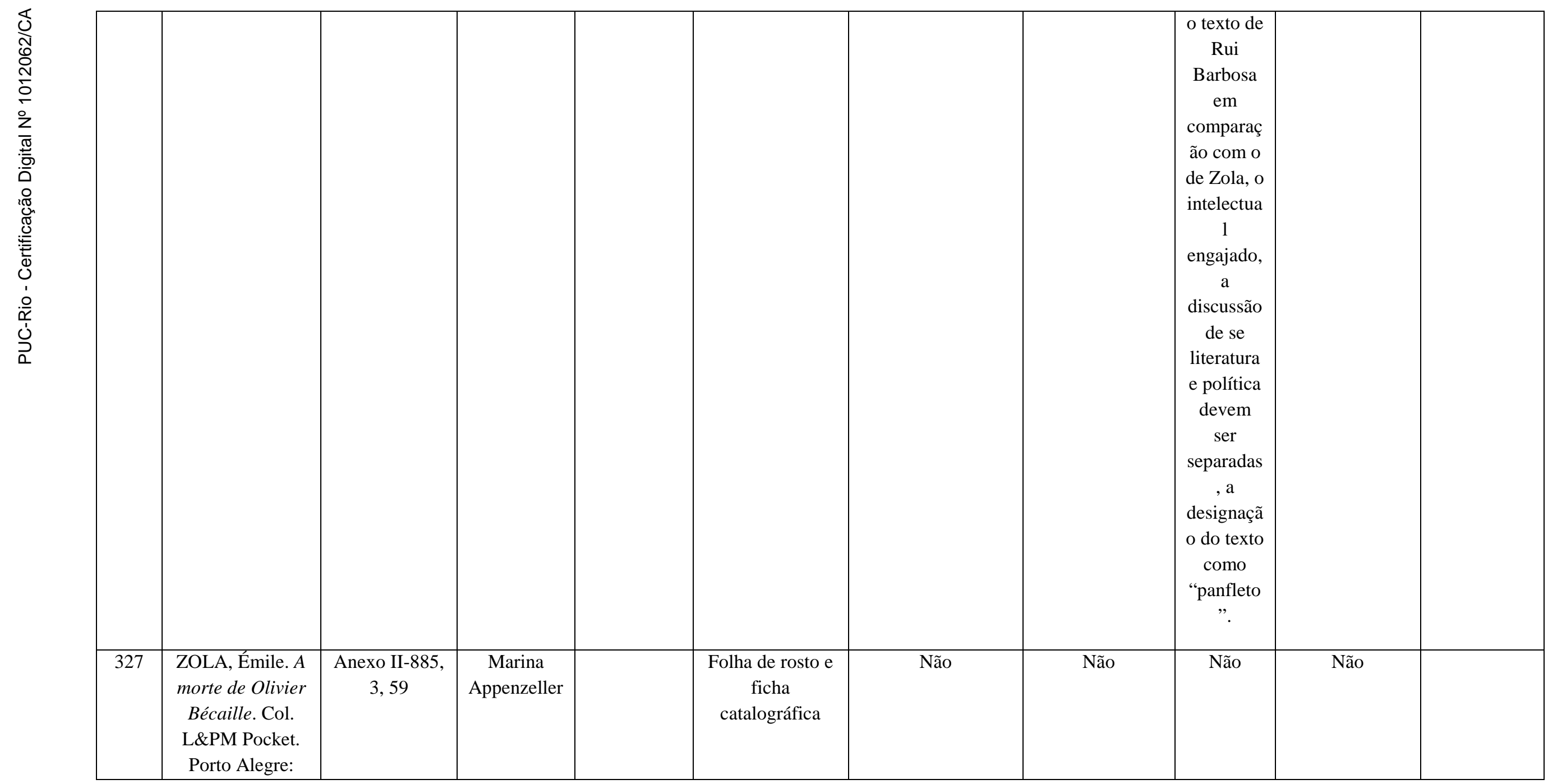




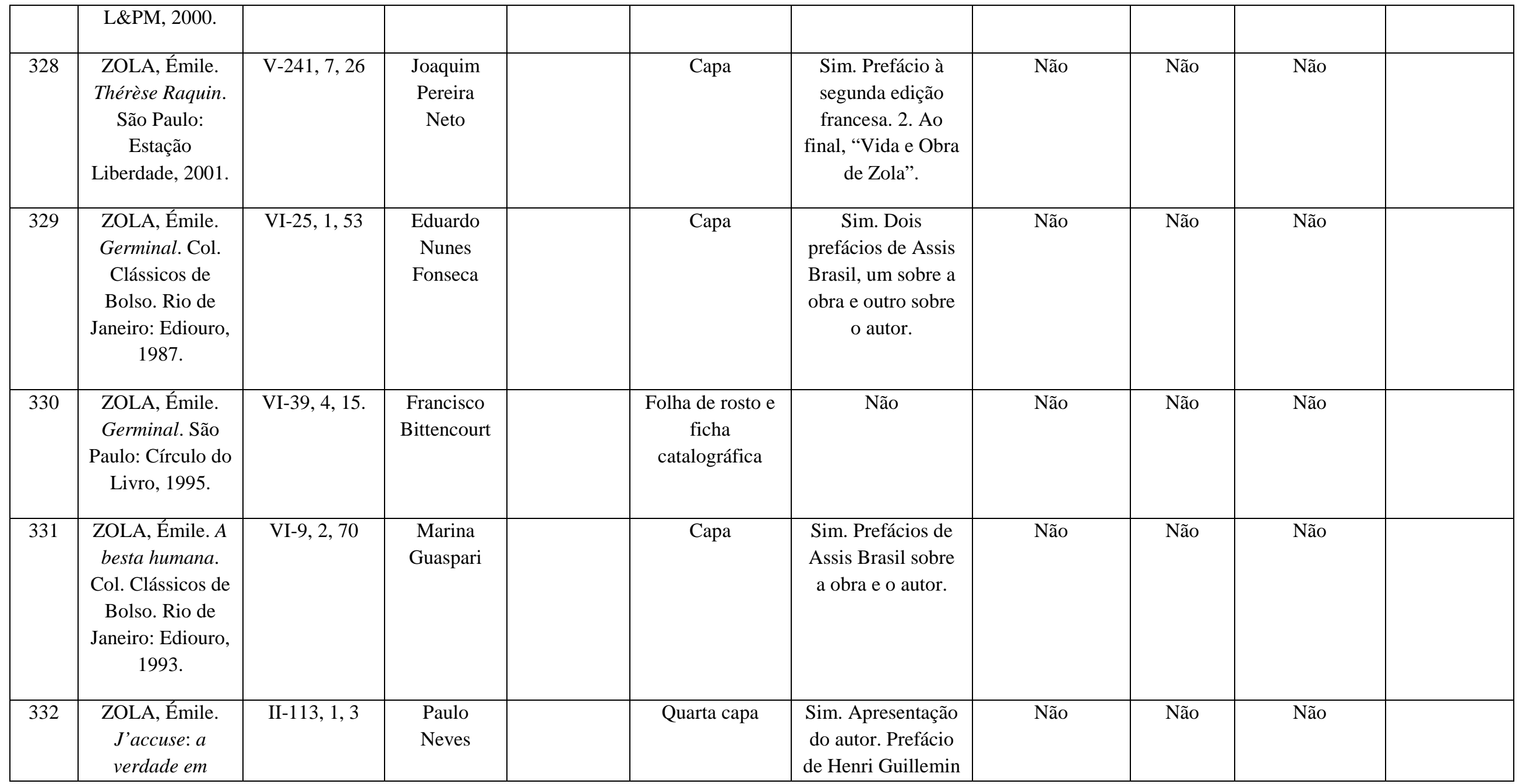




\begin{tabular}{|c|c|c|c|c|c|c|c|c|c|}
\hline & \multicolumn{2}{|l|}{$\begin{array}{c}\text { marcha. Col. } \\
\text { L\&PM Pocket. } \\
\text { Porto Alegre: } \\
\text { L\&PM, } 2009 .\end{array}$} & & & \multicolumn{2}{|l|}{$\begin{array}{l}\text { (historiador } \\
\text { francês) sobre o } \\
\text { engajamento de } \\
\text { Zola no caso } \\
\text { Dreyfus. }\end{array}$} & \multirow[b]{2}{*}{ Não } & \multirow[b]{2}{*}{ Não } & \\
\hline 333 & $\begin{array}{l}\text { ZOLA, Émile. } \\
\text { Germinal. Col. O } \\
\text { Eterno Best- } \\
\text { Seller. São } \\
\text { Paulo: Hemus, } \\
1982 .\end{array}$ & VI-383, 2, 14 & $\begin{array}{l}\text { Eduardo } \\
\text { Nunes } \\
\text { Fonseca }\end{array}$ & $\begin{array}{l}\text { Folha de rosto e } \\
\text { ficha } \\
\text { catalográfica }\end{array}$ & Não & Não & & & \\
\hline 334 & $\begin{array}{l}\text { ZOLA, Émile. } \\
\text { Nana. Col. O } \\
\text { Eterno Best- } \\
\text { Seller. São } \\
\text { Paulo: Hemus, } \\
\text { 1982. }\end{array}$ & VI-383, 2, 13 & $\begin{array}{l}\text { Eduardo } \\
\text { Nunes } \\
\text { Fonseca }\end{array}$ & $\begin{array}{c}\text { Folha de rosto e } \\
\text { ficha } \\
\text { catalográfica }\end{array}$ & Não & Não & Não & Não & \\
\hline 335 & $\begin{array}{c}\text { ZOLA, Émile. } \\
\text { Germinal. São } \\
\text { Paulo: Abril } \\
\text { Cultural, } 1981 .\end{array}$ & VI-401, 4, 2 & $\begin{array}{l}\text { Francisco } \\
\text { Bittencourt }\end{array}$ & $\begin{array}{l}\text { Folha de rosto e } \\
\text { ficha } \\
\text { catalográfica }\end{array}$ & Não & Não & Não & Não & \\
\hline 336 & $\begin{array}{l}\text { ZOLA, Émile. A } \\
\text { besta humana. } \\
\text { Col. O Eterno } \\
\text { Best-Seller. São } \\
\text { Paulo: Hemus, }\end{array}$ & VI-405, 5, 17 & $\begin{array}{l}\text { Eduardo } \\
\text { Nunes } \\
\text { Fonseca }\end{array}$ & $\begin{array}{l}\text { Folha de rosto e } \\
\text { ficha } \\
\text { catalográfica }\end{array}$ & Não & Não & Não & Não & \\
\hline
\end{tabular}




\begin{tabular}{|c|c|c|c|c|c|c|c|c|c|}
\hline & $\begin{array}{c}1982 . \\
\text { Localizador: }\end{array}$ & & & & & & & & \\
\hline 337 & $\begin{array}{c}\text { ZOLA, Émile. } \\
\text { Naná. São Paulo: } \\
\text { Circulo do Livro, } \\
1982 .\end{array}$ & VI-370, 5, 18 & $\begin{array}{c}\text { Eugenio } \\
\text { Vieira }\end{array}$ & $\begin{array}{c}\text { Ficha } \\
\text { catalográfica. }\end{array}$ & $\begin{array}{l}\text { Sim. Posfácio: “O } \\
\text { autor e sua obra”. }\end{array}$ & Não & Não & Não & \\
\hline 338 & $\begin{array}{l}\text { ZOLA, Émile. } \\
\text { Contos } \\
\text { luminosos. Col. } \\
\text { Clássicos } \\
\text { Populares. Rio } \\
\text { de Janeiro: } \\
\text { Editora } \\
\text { Monterrey, s/d. }\end{array}$ & VI-346, 1, 44 & & Não consta & Não & Não & Não & Não & $\begin{array}{l}\text { Quarta capa: } \\
\text { a obra e o } \\
\text { autor. } \\
\text { Referência à } \\
\text { tradução. }^{51} \\
\text { (interessante } \\
\text {, pois o } \\
\text { nome do } \\
\text { tradutor não } \\
\text { aparece). }\end{array}$ \\
\hline
\end{tabular}

ACERVO PRÓPRIO:

\begin{tabular}{|c|c|c|c|c|c|c|c|c|c|}
\hline No. & Autor e título & Nome do & Biodata & $\begin{array}{r}\text { Localização } \\
\text { do nome do }\end{array}$ & Prefácios & $\begin{array}{c}\text { Menções à } \\
\text { tradução ou }\end{array}$ & Prefácio do & $\begin{array}{c}\text { Menção à } \\
\text { tradução }\end{array}$ & Obs. \\
\hline
\end{tabular}

51 “Quem ler e analisar com cuidado os Contos luminosos agora oferecidos ao leitor brasileiro nesta edição de bolso ultra bem traduzida, verá que o estilo inconfundível deste imortal romancista francês é hoje tão atual quanto o de qualquer novelista da era pós-industrial”. 


\begin{tabular}{|c|c|c|c|c|c|c|c|c|}
\hline & & tradutor & tradutor & & $\begin{array}{c}\text { aos } \\
\text { tradutores } \\
\text { no } \\
\text { paratexto }\end{array}$ & tradutor & $\begin{array}{l}\text { no } \\
\text { prefácio } \\
\text { do } \\
\text { tradutor }\end{array}$ & \\
\hline 1 & $\begin{array}{c}\text { BEAUVOIR, Simone de. A } \\
\text { cerimônia do adeus, seguido } \\
\text { de Entrevistas com Jean-Paul } \\
\text { Sartre, agosto-setembro } \\
\text { 1974. Rio de Janeiro: Nova } \\
\text { Fronteira, 1982. }\end{array}$ & Rita Braga & $\begin{array}{l}\text { Folha de rosto } \\
\text { e ficha } \\
\text { catalográfica }\end{array}$ & $\begin{array}{l}\text { Sim. Prefácio da } \\
\text { autora. }\end{array}$ & Não & Não & Não & $\begin{array}{l}\text { Quarta capa: texto } \\
\text { de Gilles Lapouge } \\
\text { sobre a obra e sobre } \\
\text { Sartre, outras obras } \\
\text { da autora. }\end{array}$ \\
\hline 2 & $\begin{array}{c}\text { BEAUVOIR, Simone de. } A \\
\text { força da idade. Rio de } \\
\text { Janeiro: Nova Fronteira, } \\
1984 .\end{array}$ & Sérgio Milliet & $\begin{array}{l}\text { Folha de rosto } \\
\text { e ficha } \\
\text { catalográfica }\end{array}$ & Não & Não & Não & Não & \\
\hline 3 & $\begin{array}{c}\text { CAMUS, Albert. Núpcias, o } \\
\text { verão. Col. Logos. Rio de } \\
\text { Janeiro: Nova Fronteira, } \\
1979 .\end{array}$ & $\begin{array}{l}\text { Vera Queiroz } \\
\text { da Costa e } \\
\text { Silva }\end{array}$ & $\begin{array}{l}\text { Folha de rosto } \\
\text { e ficha } \\
\text { catalográfica }\end{array}$ & Não & Não & Não & Não & \\
\hline 4 & $\begin{array}{l}\text { CAMUS, Albert. Diário de } \\
\text { viagem. Rio de Janeiro: } \\
\text { Record, } 1985 .\end{array}$ & $\begin{array}{c}\text { Valerie } \\
\text { Rumjanek } \\
\text { Chaves }\end{array}$ & $\begin{array}{l}\text { Folha de rosto } \\
\text { e ficha } \\
\text { catalográfica }\end{array}$ & $\begin{array}{c}\text { Sim. Nota } \\
\text { sumária à edição } \\
\text { brasileira pelos } \\
\text { editores: } \\
\text { explicação de }\end{array}$ & Sim & Não & Não & $\begin{array}{c}\begin{array}{c}\text { Referência à } \\
\text { tradutora: }\end{array} \\
\text { Valerie Rumjanek } \\
\text { Chaves, a tradutora }\end{array}$ \\
\hline
\end{tabular}




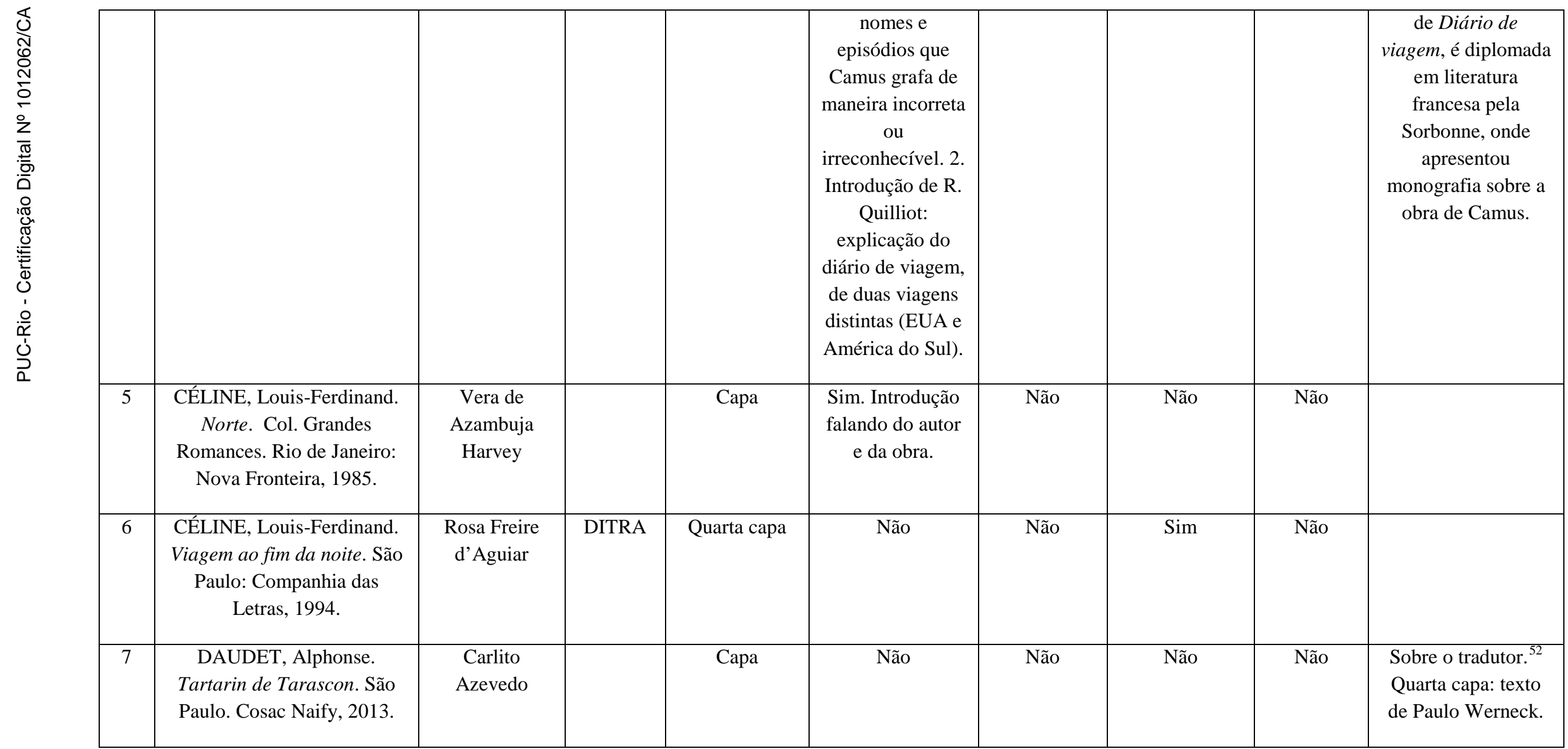

52 "O poeta e tradutor Carlito Azevedo nasceu no Rio de Janeiro, em 1961. Publicou vários livros. Com o primeiro, Collapsus Linguae (1991), ganhou o prêmio Jabuti. Sublunar (2001) reúne boa parte de sua poesia desde a estreia. Traduziu Dia de folga, de Jacques Prévert, ilustrado por Wim Hofman (Cosac Naify, 2004), e Ode a uma 


\begin{tabular}{|c|c|c|c|c|c|c|c|c|c|}
\hline 8 & $\begin{array}{c}\text { DUMAS, Alexandre. } O \\
\text { Conde de Monte Cristo. } \\
\text { Trad.. Rio de Janeiro: Zahar, } \\
2012 .\end{array}$ & $\begin{array}{l}\text { André Telles e } \\
\text { Rodrigo } \\
\text { Lacerda }\end{array}$ & $\begin{array}{l}\text { DITRA } \\
\text { (André } \\
\text { Teles) }\end{array}$ & Quarta capa & Não & Não & Sim & Sim. & \\
\hline 9 & $\begin{array}{l}\text { FLAUBERT, Gustave. } \\
\text { Madame Bovary. São Paulo: } \\
\text { Nova Alexandria, } 2009 .\end{array}$ & $\begin{array}{l}\text { Trad., Introd. e } \\
\text { Notas Fúlvia } \\
\text { M. L. Moretto. }\end{array}$ & & Сара & Não. & Não & Sim. & Sim. & $\begin{array}{l}\text { Quarta capa, menção } \\
\text { à tradução. }\end{array}$ \\
\hline 10 & $\begin{array}{l}\text { HUGO, Victor. O corcunda } \\
\text { de Notre Dame. Rio de } \\
\text { Janeiro: Zahar, } 2013 .\end{array}$ & $\begin{array}{c}\text { Trad., } \\
\text { apresentação e } \\
\text { notas de Jorge } \\
\text { Bastos. }\end{array}$ & & Quarta capa & $\begin{array}{l}\text { Sim. Nota de } \\
\text { Victor Hugo. Ao } \\
\text { final, Cronologia } \\
\text { e obras do autor. }\end{array}$ & Não & Sim & Sim. & $\begin{array}{c}\text { Nota na } \\
\text { “Apresentação". }\end{array}$ \\
\hline 11 & $\begin{array}{c}\text { HUGO, Victor. Os } \\
\text { miseráveis. São Paulo: Cosac }\end{array}$ & $\begin{array}{c}\text { Francisco } \\
\text { Ozanam }\end{array}$ & & $\begin{array}{l}\text { Folha de rosto } \\
\text { e ficha }\end{array}$ & $\begin{array}{l}\text { Sim. Notas dos } \\
\text { editores. }^{53}\end{array}$ & Sim & Não & Não & \\
\hline
\end{tabular}

estrela (Cosac Naify, 2010), de Pablo Neruda, ambos agraciados com o selo Altamente Recomendável pela Fundação Nacional do Livro Infantil e Juvenil (FNLIJ, 2009). Atuou como editor da revista Inimigo rumor e coordena a coleção de poesia Ás de Colete, publicadas pela Cosac Naify em parceria com a editora 7Letras. Como Monodrama (7Letras, 2010), foi finalista do prêmio Portugal Telecom em 2010. Atualmente edita "Risco”, página mensal de poesia do jornal O Globo.”

53 “Esta tradução, inteiramente revista, foi publicada pela primeira vez em 1957, pela extinta Editora das Américas. Alguns critérios de padronização e pontuação foram modernizados, o que resultou em um estilo mais fluente e em um texto que se pretende mais próximo dos leitores de hoje. O tradutor ampliou o já extenso repertório de notas, compilando, se não um painel completo, pois em Os miseráveis tal objetivo é de fato inalcançável, um quadro mais que representativo da cultura francesa ad época e de seu universo de referências. Obedecendo à índole hierárquica da sociedade aqui retratada, optou-se por grafar com maiúsculas os pronomes de tratamento - Sr., Sra., Srta. Etc. e os cargos e títulos - militares, administrativos, nobiliárquicos -, desde que se refiram a um ocupante em particular, seja ele personagem ficcional ou histórico. Certos fatos ou períodos históricos também aparece aqui em maiúsculas, como, por exemplo, Revolução Francesa, Antigo Regime, Antiguidade etc. Para eliminar a confusa padronização das edições francesas no que se refere ao uso de aspas, travessões e itálicos, aqui estes são usados para caracterizar, respectivamente, o pensamento dos personagens, os diálogos e as citações de textos dentro do romance. As aspas também podem indicar fragmentos de falas e reflexões dos personagens, quando reproduzidos em parágrafos da narrativa indireta; e o uso de itálicos ocorre ainda em obediência a ênfases narrativas determinadas pelo autor. Raros casos, portanto, apresentarão a concomitância de aspas e 


\begin{tabular}{|c|c|c|c|c|c|c|c|c|}
\hline & Naify, 2012. & $\begin{array}{l}\text { Pessoa de } \\
\text { Barros }\end{array}$ & catalográfica & $\begin{array}{c}\text { Prefácio “Um } \\
\text { novo olhar”, de } \\
\text { Renato Janine } \\
\text { Ribeiro, sobre o } \\
\text { autor e a obra. } 3 . \\
\text { Prefácio do autor. } \\
\text { 4. Cronologia e } \\
\text { obras do autor, ao } \\
\text { final. }\end{array}$ & & & & \\
\hline 12 & $\begin{array}{c}\text { HUGO, Victor. Os } \\
\text { miseráveis. Tomo II. São } \\
\text { Paulo: Editora Edigraf, } 1957 .\end{array}$ & & Não consta & Não & Não & Não & Não & \\
\hline 13 & $\begin{array}{c}\text { HUYSMANS, J.-K. Às } \\
\text { avessas. Trad.. São Paulo: } \\
\text { Companhia das Letras, } 1987 .\end{array}$ & $\begin{array}{l}\text { José Paulo } \\
\text { Paes }\end{array}$ & Capa & Não & Não & Sim & Não & \\
\hline 14 & $\begin{array}{l}\text { LARANJEIRA, Mário. } \\
\text { Poetas franceses da } \\
\text { Renascença. Col. Biblioteca } \\
\text { Martins Fontes. São Paulo: } \\
\text { Martins Fontes, } 2004 .\end{array}$ & $\begin{array}{c}\text { Mário } \\
\text { Laranjeiras }\end{array}$ & Capa & Não & Sim & Sim & Sim. & $\begin{array}{l}\text { Orelhas, menção à } \\
\text { tradução. CV do } \\
\text { tradutor. }\end{array}$ \\
\hline 15 & $\begin{array}{l}\text { MALLARMÉ, Stéphane. } \\
\text { Brinde fúnebre e prosa. Rio }\end{array}$ & Júlio Castañon & $\begin{array}{l}\text { Folha de rosto } \\
\text { e ficha }\end{array}$ & Não & Não & Sim & Sim. & \\
\hline
\end{tabular}

itálicos. Nomes próprios, de pessoas e lugares, foram mantidos em francês, exceção feita aos nomes de personagens históricos já consagrados em português, como Napoleão Bonaparte, Luís XVIII etc.” 


\begin{tabular}{|c|c|c|c|c|c|c|c|c|c|}
\hline & $\begin{array}{c}\text { de Janeiro: Sette Letras, } \\
1995 .\end{array}$ & Guimarães & & catalográfica & & & & & \\
\hline 16 & $\begin{array}{l}\text { MONTAIGNE, Michel de. } \\
\text { Os ensaios. São Paulo: } \\
\text { Companhia das } \\
\text { Letras/Penguin, } 2010 .\end{array}$ & $\begin{array}{l}\text { Rosa Freire } \\
\text { d'Aguiar. }\end{array}$ & DITRA & Quarta capa & $\begin{array}{l}\text { Sim. Prefácio de } \\
\text { Erich Auerbach. }\end{array}$ & Não & $\begin{array}{l}\text { Sim. Nota da } \\
\text { tradutora. }\end{array}$ & Sim. & $\begin{array}{l}\text { CV da tradutora, } \\
\text { junto como do } \\
\text { organizador e } \\
\text { prefaciador. }\end{array}$ \\
\hline 17 & $\begin{array}{l}\text { PONGE, Francis. A mesa. } \\
\text { São Paulo: Iluminuras, } 2002 .\end{array}$ & $\begin{array}{c}\text { Ignacio } \\
\text { Antonio Neis e } \\
\text { Michel } \\
\text { Peterson }\end{array}$ & & Сара & Sim & Sim & Sim. & Sim. & \\
\hline 18 & $\begin{array}{l}\text { RIMBAUD, Arthur. Prosa } \\
\text { poética. Rio de Janeiro: }\end{array}$ & Ivo Barroso & DITRA & Сара & $\begin{array}{l}\text { Sim. Nota do } \\
\text { editor. }^{54}\end{array}$ & Sim. & $\begin{array}{l}\text { Sim. Prefácio } \\
\text { do tradutor, “A }\end{array}$ & Não & $\begin{array}{l}\text { Orelhas, texto de } \\
\text { Bruno Tolentino. }{ }^{55}\end{array}$ \\
\hline
\end{tabular}

54 “(...) Relativamente à obra magna de Rimbaud - UMA ESTADIA NO INFERNO - antes da tradução de Ivo Barroso já circulavam em português a versão de Xavier Placer (UMA ESTAÇÃO NO INFERNO), de 1952; a de Lêdo Ivo (UMA TEMPORADA NO INFERNO), de 1957, reeditada em 1982; e, em Portugal, a de Mário Cesariny de Vasconcelos (UMA ÉPOCA NO INFERNO), de 1960, reeditada sob o título de UMA CERVEJA NO INFERNO em 1989. A TRADUÇÃO DE Ivo Barroso teve sua primeira edição em 1977 e a segunda em 1983. A da presente edição foi inteiramente revista para atender a novas interpretações e estudos da crítica moderna. Mas conservou-se o luminoso prefácio com que Alceu Amoroso Lima (Tristão de Athayde a consagrou de início.

Quanto aos demais textos, inclusive as ILUMINAÇÕES, são todos de tradução recente, aqui publicados pela primeira vez”. (pág. 9-10)

55 "Ao recomendar este Volume II do Rimbaud de Ivo Barroso, meticuloso e monumental labor de toda uma vida, afugento uma sombra de tristeza: o quanto se tornou rara entre nós empresa deste porte e seriedade! Aos estertores finais de um de seus períodos mais acabrunhantes, a vida do espírito no Brasil continua repleta de homúnculos que não sabem que não sabem javanês. Como é notório, depois da "morte do verso", a arte da tradução de poesia, essa lição de Mestres da estatura de um Machado, um Bandeira, um Abgar, tem sido arrastada na sarjeta mental dos mais ralos exibicionismos, confundida á mais apressada inépcia retórico-linguística. Consequentemente este é um volume de poucos pares em nosso atual circo tradutório. Aqui o leitor encontrará todo o contrário de certa endêmica modalidade nossa de febre traduziológica. Não há falhas de leitura, muito menos gafes "transcriativas" nesta exemplar conjunção de duas nobres artes: a de escrever e a de re-escrever poesia. Aqui Ivo Barroso, passé maître na arte de passar décadas a entender primeiro para traduzir depois, simplesmente (se magistralmente) appelle um chat um chat. Logo, por mero contraste, implicitamente chama a cada um de nossos Rollet un fripon... 


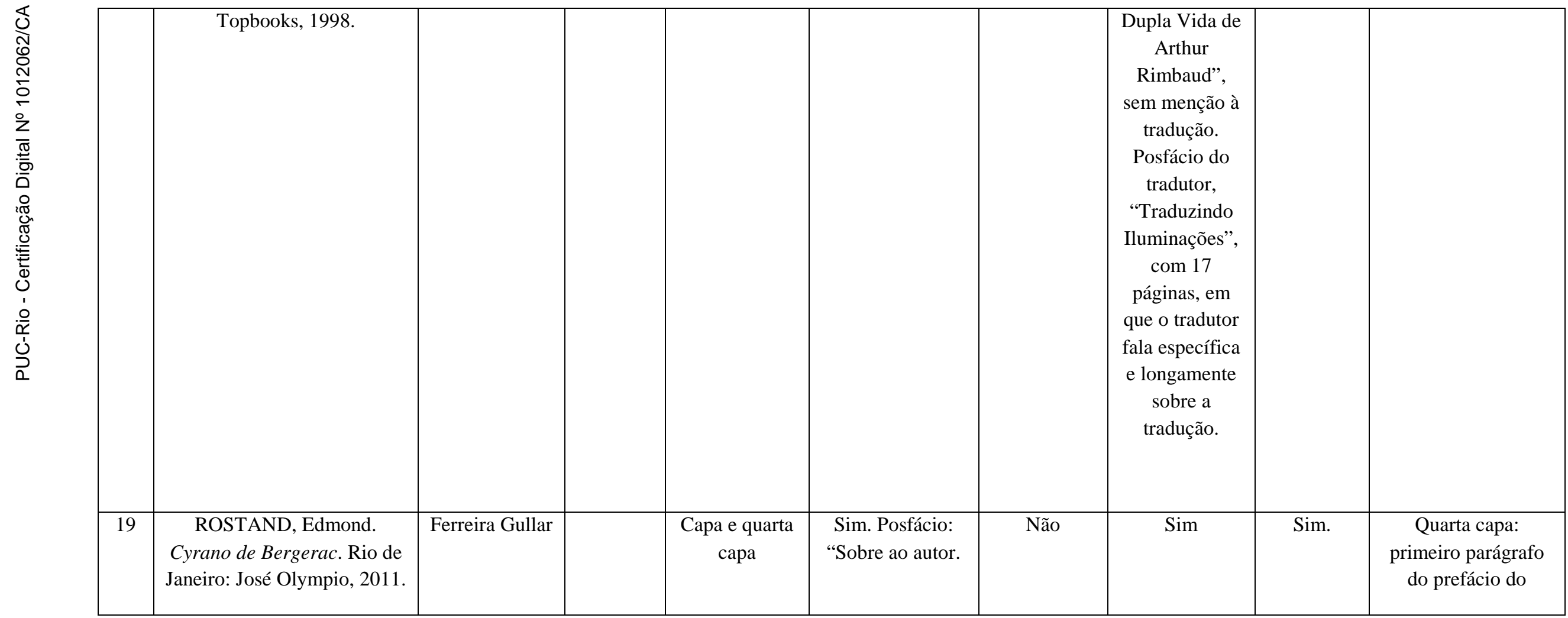

Etiemble, aqui citado, observa que até mesmo o mais delicado leitor tem sempre algo a descobrir sobre um original com a leitura de suas grandes traduções. Posso testemunhar disso: minha redescoberta de Rimbaud deve muitíssimo às repetidas leituras que tenho feito das re-criações de Ivo Barroso. Nisto estou em ótima companhia: com Didier Lamaison, por exemplo, que há pouco nos dizia haver voltado em profundidade ao seu Rimbaud da juventude precisamente ao compará-lo com o que dele Ivo faz em vernáculo. Dito isto, temo que estas paralelas (e não raro unidas) “alquimias do verbo", arriscam valer, a autor e a co-autor, o mesmo ressentimento conspiratório que cerca outro de nossos raros grandes recriadores de poesia, aquele Jorge Wanderley quase linchado por ter posto Dante Alighieri onde Ivo Barroso vem há décadas pondo o voyant de Charleville: na simbiose da mais elegante arte de osso verso". 


\begin{tabular}{|c|c|c|c|c|c|c|c|c|c|}
\hline & & & & & & & & & tradutor \\
\hline 20 & $\begin{array}{l}\text { SARTRE, Jean-Paul. As } \\
\text { palavras. Trad. J. Guinsburg. } \\
\text { Rio de Janeiro: Nova } \\
\text { Fronteira, } 1984 .\end{array}$ & J. Guinsburg & & $\begin{array}{c}\text { Folha de rosto } \\
\text { e ficha } \\
\text { catalográfica }\end{array}$ & Não & Não & Não & Não & \\
\hline 21 & $\begin{array}{l}\text { VEIGA, Cláudio. Antologia } \\
\text { da poesia francesa (do } \\
\text { século IX ao século XX). Rio } \\
\text { de Janeiro: Record, } 1991 \text {. }\end{array}$ & Cláudio Veiga & & Сара & $\begin{array}{l}\text { Sim. Prefácio de } \\
\text { Jacques Salah. }\end{array}$ & Não & Sim & Sim. & \\
\hline 22 & $\begin{array}{c}\text { YOURCENAR, Marguerite. } \\
\text { A volta da prisão. Rio de } \\
\text { Janeiro: Nova Fronteira, } \\
1992 .\end{array}$ & $\begin{array}{c}\text { Maria Luiza } \\
\text { X. de A. } \\
\text { Borges }\end{array}$ & DITRA & $\begin{array}{l}\text { Folha de rosto } \\
\text { e ficha } \\
\text { catalográfica }\end{array}$ & $\begin{array}{l}\text { Sim. Nota do } \\
\text { Editor Francês. }\end{array}$ & Não & Não & Não & \\
\hline
\end{tabular}




\section{ANEXO II}

\section{Prefácio 1: exemplo de prefácio de editor (sem referência à tradução)}

CAMUS, Albert. Diário de viagem: a visita de Camus ao Brasil. Trad. Valerie Rumjanek Chaves. Rio de Janeiro: Record, 1985.

\section{NOTA SUMÁRIA À EDIÇÃO BRASILEIRA}

A fim de não interferir em demasia no texto, não acrescentamos notas de pé de página, semelhantes às da edição original, à parte do Diário de Viagem de Camus que descreve sua passagem pelo Brasil.

No entanto, acreditamos que cabe assinalar para o leitor brasileiro várias referências que o autor faz, de modo mais ou menos obscuro, a personagens e situações que nos interessam mais de perto.

Assim, o jornalista que recebe Camus no porto do Rio de Janeiro, e a quem o autor se refere alternadamente como B. ou Barleto, é João Batista Barreto Leite Fillho, que fora correspondente dos Diários Associados na Europa durante a Segunda Guerra Mundial.

O escritor tratado como Aníbal e descrito como "espécie de tabelião magro, culto e espiritual”, reaparecendo adiante no diário como Machado, é Aníbal M. Machado, autor de João Ternura. O episódio do telegrama passado ao tradutor de Baudelaire deu-se na verdade com Murilo Mendes, é provável que Aníbal Machado apenas o tenha relatado a Camus. Em seguida, o poeta com quem Camus almoçou longamente, e a quem trata com impiedosa antipatia, identificando-o como S. ou Federico, é Augusto Frederico Schmidt. Não foi possível saber quem é o señorito presente ao encontro.

O "romancista que teria escrito os Buddenbrook brasileiros" é certamente Octavio de Faria, e o bairro "ao mesmo tempo pobre e luxuoso" ao qual Camus sobe de bonde é Santa Teresa. “Abdias, o ator negro” é o escritor, jornalista e político Abdias do Nascimento, à época diretor do Teatro Experimental do Negro, que encenara a peça Calígula, de Camus, com um elenco só de negros. A Sra. Mineur em cuja casa Camus o encontra (Gabrielle Mineur) era, na ocasião, conselheira cultual junto à embaixada francesa no Rio de Janeiro.

Os três personagens a quem Camus se refere em seguida aparecem com os nomes grafados de forma incorreta, embora reconhecível: o "poeta nacional" Manuel Bandera (Bandeira) - de quem fala com simpatia e que, por ocasião da morte de Camus, escreveria sobre aquele encontro: "Senti vontade de ser seu amigo"; o músico Kaïmi (Dorival Caymmi), "negro que compõe e escreve todos os sambas que o país canta”, e Murilo Mendès (Murilo Mendes), mais adiante chamado simplesmente de Mendes, "poeta e doente". Curiosamente, Murilo Mendes, por quem Camus sente grande afinidade, também era, a exemplo de Manuel Bandeira e do próprio Camus, ex-tuberculoso.

No registro de sua ida ao Nordeste, Camus anota com grafias curiosas o nome do bumba-meu-boi (bomba-menboi), a cachaça (cachasa, também referida em outro ponto como cachado) e, de modo ainda mais peculiar, a jangada (junsahê). Da mesma forma, já registrara com descaso pela ortografia nomes próprios diversos: Echou (Exu), Ogoun (Ogum), a capela Meyrinck (Mayrinck), Madeidura (Madureira), etc. Anota sem til os nomes de Eduardo Catalão e da 
praia de Itapoã (como já fizera com o lotação que conhecera no Rio), e escreve à espanhola - certamente devido a seu conhecimento daquela língua - nome da igreja de São Pedro, em Recife (San Pedro), e a saudação dos participantes do bumba-meu-boi ao espectador ilustre ("viva o señor Camus...”).

De volta ao Rio, Camus almoça com Murilo Mendes e "um jovem poeta a quem o inteligente sistema de trânsito do Rio premiou com 17 fraturas e um par de muletas". Trata-se de José Paulo Moreira da Fonseca, que havia sido atropelado pouco tempo antes. A mulher de Murilo Mendes, cuja companhia é tão agradável a Camus, é Maria da Saudade Cortesão, poetisa, filha de Jayme Cortesão, português exilado no Brasil por opor-se ao regime salazarista.

No dia seguinte, Camus almoça com Barreto Leite Filho (Barleto) e o escritor francês Michel Simon, tradutor de diversas obras literárias brasileiras para o francês, que mais tarde passou a assinar-se Michel Simon-Brésil para se distinguir do ator de mesmo nome. O Corrêa com quem se encontra um dia depois, “ex-editor”, é Roberto Alvim Corrêa, que fora editor em Paris e, de volta ao Brasil, era professor e crítico literário. Mais adiante, na visita ao Chile, aparece referido como Vincent Anidobre o poeta chileno Vicente Huidobro.

Finalmente, de volta ao Brasil antes de retornar à França, Camus registra ter ido com "Pedrosa e sua mulher" (o crítico de arte Mário Pedrosa e Mary Pedrosa) "ver as pinturas dos loucos, no subúrbio". Trata-se do grupo de internos do hospital psiquiátrico do Engenho de Dentro, encorajados a pintar pela Dra. Nise da Silveira. O trabalho da Dra. Nise era muito admirado por Mário Pedrosa, e resultaria, anos mais tarde, na criação do Museu do Inconsciente.

Acreditamos que esta Nota Sumária, que muito deve às observações de Otto Lara Resende, multiplicará o interesse pela leitura deste fascinante Diário de Viagem.

\section{Os Editores}

\section{Prefácio 2: exemplo de prefácio não assinado, que pode ser atribuído ao editor (com referência à tradução)}

ALMEIDA, Guilherme. Flores das Flores do mal de Baudelaire. São Paulo: Ed. 34, 2010.

\section{NOTA À PRESENTE EDIÇÃO}

As famosas traduções de Guilherme de Almeida (1890-1969) para os poemas de Baudelaire foram primeiramente reunidas no volume Flores das "Flores do mal" de Charles Baudelaire, editado pela Livraria José Olympio em 1944, juntamente com as notas em que o poeta modernista paulistano comenta o trabalho de recriação de cada um dos 21 poemas escolhidos.

O presente volume incorpora o texto de apresentação escrito por Manuel Bandeira para a edição de bolso lançada em 1965 pelas Edições de Ouro, algumas das ilustrações que Henri Matisse realizou para uma seleção de poemas de Les Fleurs du mal, publicada na França em 1947, e um posfácio de Marcelo Tápia, 
poeta, tradutor e diretor da Casa Guilherme de Almeida, que colaborou nesta edição.

A grafia foi atualizada segundo o novo Acordo Ortográfico da Língua Portuguesa, mantendo-se porém a grafia original nos casos em que a mudança pudesse comprometer recursos poéticos e efeitos estilísticos (sobretudo rimas e assonâncias) visados pelo tradutor.

\section{Prefácio 3: exemplo de prefácio não assinado, que pode ser atribuído ao editor ou ao tradutor (sem referência à tradução)}

CÉLINE, Louis-Ferdinand. Norte. Trad. Vera de Azambuja Harvey. Col. Grandes Romances. Rio de Janeiro: Nova Fronteira, 1985.

Nascido em 1894, em Courbevoie, perto de Paris, Louis-Ferdinand Céline (pseudônimo de L.-F. Destouches) preparou-se sozinho, já trabalhando, para o exame de madureza. Tendo-se alistado em 1912, foi gravemente ferido em 1914. Inválido em 75\% e reformado, foi enviado aos Camarões (1916) e depois a Londres (1917). Após a Vitória, estudou medicina e foi encarregado de missões na África e nos Estados Unidos pela Liga das Nações. De volta à França, exerceu a medicina nos subúrbios de Paris e publicou, em 1932, seu primeiro livro: Viagem ao fundo da noite, ao qual se seguiu, em 1936, Morte a crédito (publicado no Brasil pela Nova Fronteira em 1982). De 1944 a 1951, Céline viveu exilado na Alemanha e na Dinamarca. Voltando à França, instalou-se em Meudon, onde continuou a escrever sua obra (D'un château l'autre, Nord, Rigodon) e a tratar essencialmente dos pobres. Morreu em 1961.

Céline no meio da Alemanha em chamas, é este o tema de Norte. Ator, narrador e espectador ao mesmo tempo, o autor encontra-se em Baden-Baden, nos meses que precederam a derrocada do Reich, num grande e estranho hotel onde se dá mais importância ao caviar, à bouillabaisse $e$ ao champanhe do que aos bombardeios e onde a surpreendente baronesa von Seckt, sobrevivente de um mundo desaparecido, julga Hitler: "Ora, Sr. Céline, o triunfo do Diabo deve-se principalmente ao fato de que as pessoas que o conheciam já se foram..."

Depois surge Berlim com suas casas arrebentadas, a demonstração de uma organização obsessiva no meio das ruínas. Céline e seus companheiros de infortúnio (sua esposa Lili, o ator Le Vigan e o gato Bébert) são enviados a cem quilômetros da capital, a Zornhof, para uma imensa propriedade dirigida por um louco. A leste, a planície estende-se até o Ural. Em volta dos quatro franceses (pois Bébert vale por um francês), vive uma família shakespeariana, numa região habitada por poloneses, prostitutas berlinenses e pacifistas, todos bem gordos e robustos, que fabricam ataúdes por ordem do Reich.

Céline proclama-se cronista, mas descreve a Alemanha em derrocada como Dante visitava os círculos de seu Inferno.

De um lado, os grandes deste mundo, sempre ávidos de gozar a vida; do outro, os miseráveis a quem se lança um "ideal” como um osso a ser roído. E, incessantemente, "o mundo dos gregos, o mundo trágico, preocupações todos os dias e todas as noites".

O texto de Nord apresentado nesta edição é o do volume Romans II da Bibliothèque de la Pléiade. 


\section{Prefácio 4: exemplo de prefácio do editor (com referência à tradução)}

RIMBAUD, Arthur. Prosa poética. Trad. Ivo Barroso. Rio de Janeiro: Topbooks, 1998.

\section{NOTA DO EDITOR}

Três anos após o lançamento da POESIA COMPLETA, vem a TOPBOOKS entregar a seus leitores a PROSA PÉTICA - segundo dos três volumes que constituirão a obra completa de ARTHU RIMBAUD em língua portuguesa.

O presente volume encerra, além da obra capital do poeta - UMA ESTADIA NO INFERNO - e da coletânea de poemas em prosa denominada ILUMINAÇÕES, alguns textos até agora inéditos em português, como é o caso de UM CORAÇÃO SOB A SOTAINA, sarcástico relato dos tempos de colégio de Rimbaud. A estes se juntam curtos relatos fragmentários, OS DESERTOS DO AMOR e PROSAS EVANGÉLICAS, que são na verdade pré-textos ou esboços estilísticos na linha da obra magna, bem como a reveladora (e significativa) CARTA DE LAÏTOU, seguida dos rascunhos de UMA ESTADIA NO INFERNO. Em Apêndice, a CARTA DO BARÃO DE PETDECHÈVRE, cuja autoria foi, por muito tempo, atribuída a Rimbaud, com base no estilo de contundente ironia com que seu autor descreve um episódio histórico (a formação da "república" de Versalhes). Embora apócrifo, julgamos conveniente reter o documento pelo seu valor na historiografia dos estudos rimbaldianos. Ainda, nos Adendos, o leitor encontrará o lúcido artigo de René Etiemble em que analisa algumas traduções de "Génie" - verdadeira profissão de fé da arte de traduzir, encampada in totum pelo autor deste livro. Além deles estão três famosos prefácios, por assim dizer históricos, escritos para edições francesas da obra em períodos diferentes: a instigante e "saudosa" Notícia de Verlaine, para a $1^{a}$ edição das Iluminações; o dito "prefácio católico" de Paul Claudel e o "surrealista" de Aragon. O volume encerra-se com NOTAS esclarecedoras sobre os pontos difíceis ou controversos do texto ou da tradução.

Relativamente à obra magna de Rimbaud - UMA ESTADIA NO INFERNO - antes da tradução de Ivo Barrosos já circulavam em português a versão de Xavier Placer (UMA ESTAÇÃO NO INFERNO), de 1952; a de Lêdo Ivo (UMA TEMPORADA NO INFERNO), de 1957, reeditada em 1982; e, em Portugal, a de Mário Cesariny de Vasconcelos (UMA ÉPOCA NO INFERNO), de 1960, reeditada sob o título de UMA CERVEJA NO INFERNO em 1989. A tradução de Ivo Barroso teve sua primeira edição em 1977 e a segunda em 1983. A da presente edição foi inteiramente revista para atender a novas interpretações e estudos da crítica moderna. Mas conservou-se o luminoso prefácio com que Alceu Amoroso Lima (Tristão de Athayde) a consagrou de início.

Quanto aos demais textos, inclusive as ILUMINAÇÕES, são todos de tradução recente, aqui publicados pela primeira vez. 
O terceiro volume conterá a correspondência de Arthur Rimbaud com seus familiares e amigos, o diário de sua irmã Vitalie, cartas de sua mãe e da irmã Isabelle, e inúmeros documentos e referências literárias atinentes ao poeta.

\section{Prefácio 5: exemplo de prefácio do editor da obra original}

YOURCENAR, Marguerite. A volta da prisão. Trad. Maria Luiza X. de A. Borges. Rio de Janeiro: Nova Fronteira, 1992.

\section{NOTA DO EDITOR FRANCÊS}

Em abril de 1983, Marguerite Yourcenar confiara a seu editor o projeto de uma obra que se comporia de relatos de viagens realizadas naqueles últimos anos ou apenas projetadas. O volume se intitularia Le tour de la prison, numa referência à fórmula de Zenão em A obra em negro.

Dois anos mais tarde, ela definiu que a coletânea incluiria a evocação de suas passagens pelo Canadá e o Alasca, a Califórnia, o Egito, a Tailândia, o Quênia, a Índia. Ora, se subsistem alguns traços dessas viagens, através das fotografias reunidas em La voix des choses - feitas por Jerry Wilson, que acompanhou a escritora a partir de 1980 - não foi dado a Marguerite Yourcenar levar a cabo seu projeto. Ao longo desses quatro anos (1983-1987), a redação do terceiro volume de $O$ labirinto do mundo: A eternidade, o que é?, os numerosos deslocamentos, a fadiga e depois a doença muito perturbaram o andamento da obra.

Tal como nos chegou, o manuscrito de $A$ volta da prisão é constituído de quatorze textos, o último dos quais, intitulado "Pequenos cantos e grandes panoramas”, ficou inacabado. A coletânea articula-se em torno da viagem ao Japão. Onde Marguerite Yourcenar esteve de outubro a dezembro de 1982: dez textos, alternadamente narrativa e reflexão, a que se acrescentam uma evocação de San Francisco (“Azul, branca, rosa, gaia”), dois relatos de viagens ao Canadá e ao Alasca ("De um oceano a outro" e "A italiana em Argel”), bem como de um cruzeiro ao arquipélago do Havaí ("O ar e a água eternos”). No fim do volume, pareceu oportuno incluir a conferência que Marguerite Yourcenar pronunciou em Tóquio em 26 de outubro de 1982, intitulando-a "Viagens no espaço e viagens no tempo".

Marguerite Yourcenar determinou ela mesma a organização desse manuscrito, em que introduziu correções diversas vezes. Algumas não puderam ser decifradas; nesses casos, foram substituídas pela primeira versão do texto. Alguns termos, evocações de obras ou de autores, pediam esclarecimentos: estes são fornecidos nas notas a que o leitor poderá se reportar, no fim do volume.

Ao longo do texto aparecem alguns neologismos - Marguerite Yourcenar era dada a eles, e como não prejudicam a compreensão, pareceu-nos desejável conservá-los. 


\section{Prefácio 6: exemplo de prefácio de encomenda (com referência à tradução)}

VEIGA, Cláudio. Antologia da poesia francesa (do século IX ao século XX). Rio de Janeiro: Record, 1991.

\section{PREFÁCIO}

A obra que está sendo oferecida generosa e corajosamente à nossa leitura ao mesmo tempo ensinamento e distração - e que tenho a honra de prefaciar é fruto de um labor do qual eu fui, em parte, a testemunha privilegiada durante vinte anos; labor beneditino ao qual o Prof. Claudio Veiga consagrou os seus mais legítimos instantes de lazer.

Coragem e generosidade, dizíamos. Sem dúvida, há uma enorme generosidade nesta antologia bilíngue que nos apresenta uma vibrante colheita de obras-primas da poesia francesa do século XX, como também - e aí aparece ao lado do criador sensível o teórico seguro e discreto - um Panorama da Poesia Francesa. A Tradução da Poesia Francesa no Brasil e por fim Problemas da Tradução, todos eles temas que, pela clareza e concisão com que foram abordados, haverão de despertar a curiosidade e o interesse de um público muito numeroso.

Quanto à coragem, ela reside antes de mais nada na escolha de um gênero, a poesia, que nas atuais sociedades faz figura de fóssil diante dos romances descartáveis, que não são lidos, mas compulsivamente devorados, deixando na boca e na mente um travo de sexo e de sangue. A grande culinária, ao mesmo tempo artesanal e artística, não deveria desparecer atrás do fast-food da vida e das esquinas. Semelhante a ela, a poesia é quintessência, quintessência do prazer literário.

A coragem está também na própria tradução de poesia.

A tradução não é um exercício menor, uma atividade secundária ou paralela, "escolar" e desprezível, mas um ato de criação por excelência um constante e inesgotável vaivém que se estabelece entre dois seres, dois textos, duas culturas. Quem haverá de apontar as secretas razões que fazem com que se escolha um poema em lugar de outro, a fim de mergulhar, com o risco de perderse, no dom/sacrifício do ato de traduzir? Pressente-se que ali o acaso está totalmente abolido, e o que resta, premente, é a mais ardente das necessidades.

Uma troca se estabelece, sem dúvida, ao nível da substância como também do espírito, e aí estão os deslumbrantes êxitos de Nerval, no Fausto de Goethe, ou de Baudelaire nos Contos de Edgar Poe.

Além disso, é bem verdade, existem os encontros fortuitos que acrescentam à alegria da leitura o prazer da descoberta. A tradução francesa de What Maisie Knew de Henry James não lembra o estilo das Mémoires d'Hadrien? Ela foi efetivamente realizada por Marguerite Yourcenar em 1947. Não deveria haver nenhuma surpresa em reencontrar-se o sopro e o estilo de Charles Mauron, o pai da psicocrítica, na tradução de Tristam Shandy, de Sterne: ele realizou-a efetivamente em 1946.

Um contato mais estreito pode ainda manifestar-se e facilitar a tarefa do tradutor frente a um texto difícil e até mesmo hermético. Bastaria citar o proveito que soube tirar Maurice Edgar Coindreau das longas conversações que teve com Faulkner, abrindo assim as portas de sua alquimia verbal. Os exemplos poderiam 
multiplicar-se ao infinito, mas preferimos citar somente dois cuja evidência salta aos olhos: a participação de Joyce na revisão da tradução francesa do Ulysses ao Lado de Valéry Larbaud, e a edição francesa do Der Witz... revista pelo próprio Freud.

Apesar de representarem casos extremos, esses exemplos encerram um ensinamento da maior monta: por mais intuitivas que sejam, algum método deve ser aplicado. O já citado Coindreau tentou apresentar certas indagações quando precisamente estava empenhado de corpo e alma na tradução de The Sound and the Fury. O resultado, sem dúvida louvável, limitou-se a reflexões fragmentárias.

Na segunda parte do Apêndice, intitulada Problemas da Tradução, e cuja leitura deverá tornar-se obrigatória devido à qualidade e à penetração dos preceitos ali contidos, Cláudio Veiga consegue sistematizar o ato de traduzir a partir da investigação minudente de sua experiência cotidiana. Não há nada mais afastado das teorizações abstratas e estéreis do que este modo de proceder. Não há nada mais fecundo do que esta procura incessante, na argila movediça e às vezes hostil, do diamante que talvez não será jamais encontrado.

As duas disciplinas cuja falta, na maioria das nossas Universidades, se faz profundamente sentir, quero dizer a Estilística e a Literatura Comparada, Cláudio Veiga as conhece e pratica há muito tempo, e isto explica, em parte pelo menos, algumas de suas mais belas traduções. Latinista brilhante, ele se sente à vontade tanto na prática do francês quanto de sua língua materna. Além disso, ele é um clássico, um clássico no melhor sentido do termo, como só se pode sê-lo em alguns refúgios privilegiados do planeta ou da imaginação. "Cent fois sur le métier” dizia o mestre da nossa disciplina gaulesa, e Cláudio Veiga acrescenta: "disputar palmo a palmo o terreno". Não é um caso se da obra do simbolista baiano Arthur de Salles, a quem ele dedicou o modelar Sete Tons de uma Poesia Maior, um verso retorna ao seu espírito, como um leitmotiv.

Na púrpura do Verso o ouro do Sonho ardente

Fio a fio teci

Toda a realização do poeta, como também a do tradutor, estão contidas nestas poucas e preciosas palavras. É esta seguramente a linha tênue em que os dois se encontram.

Os poetas franceses tecendo ao longo desses onze séculos seus textos/tecidos, e o nosso tradutor Cláudio Veiga, após haver reencontrado as minúcias do Verso e os mistérios do Sonho, urdindo no vernáculo mais cristalino o Poema oferecido ao nosso deleite. Aqui estão, revisitadas e redivivas, as flores da poesia francesa, como que magicamente ressuscitadas pelas qualidades do artista e as virtudes do artesão.

Mais uma vez a França e a Cultura francesa contraíram com o Prof. Claudio Veiga uma nova e imensa dívida.

Jacques Salah

Doutor em Letras

Cônsul da França na Bahia 


\section{Prefácio 7: prefácio de tradutor com menção à tradução}

ROSTAND, Edmond. Cyrano de Bergerac. Trad. Ferreira Gullar. Rio de Janeiro: José Olympio, 2011, pp. 9-10.

\section{A TRADUÇÃO}

Ferreira Gullar

Esta peça é fruto de um romantismo tardio. Foi montada pela primeira vez em 1897, quando em todos os campos da arte - no teatro, na literatura, na música, na pintura - já se desencadeara o processo de renovação que iria determinar as vanguardas do século XX. Não obstante, Cyrano de Bergerac estreou com enorme êxito e, desde então, afirmou-se como um clássico da literatura teatral. As razões que levaram à consagração desta obra de Edmond Rostand são muitas e de difícil determinação, mas uma delas é certamente a sua qualidade teatral: Cyrano é a proposição de um espetáculo sempre fascinante.

O texto original está escrito em versos dodecassílabos de realização fluente e brilhante. Mas, nos momentos poéticos e patéticos, o autor não consegue furtarse aos vícios do romantismo academizado e piegas. Procurei tanto quanto possível, na minha tradução, evitar essas derrapagens, afastando-me do discurso do autor.

Essa não é, porém, a única diferença entre o meu texto em português e o original em francês. De saída, substituí o verso alexandrino pelo decassílabo, que me parece mais espontâneo e musical em nossa língua. Tampouco me ative ao sistema de rimas parelhas que Rostand adotou ao longo de toda a peça. Uso arbitrariamente das rimas: ora parelhas, ora intercaladas, ora internas, ora perfeitas, ora sonantes, enfim, sem prender-me a qualquer sistema regular. Tratase, portanto, de uma tradução livre que não segue palavra por palavra o texto original. Isso levou, em certos momentos, à supressão de falas e à substituição de trechos inteiros por outros, de minha autoria, em que procurei, no entanto, preservar o sentido original e a intenção do autor. Tudo isso decorre da atitude básica que tomei diante da tarefa que me foi solicitada por Flávio Rangel: realizar uma tradução que funcione teatralmente. Seria impossível conseguir esse resultado se me dispusesse a traduzir ipsis literis o texto de Rostand. De fato, a leitura atenta do original francês revela que muitas das falas surgiram na forma em que estão por necessidade de adequar-se o autor ao sistema de métrica e rima que escolhera. A peça escrita em prosa teria certamente diálogos bem diversos na maioria das situações vividas pelos personagens. Não seria, portanto, aconselhável, ao fazer a tradução - tendo que enfrentar em português dificuldades semelhantes às que o autor enfrentou em francês -, que me submetesse à forma estrita do original. Se assim procedesse o resultado seria inevitavelmente um texto prolixo, duro, inespontâneo, teatralmente inviável.

Estas são as explicações que gostaria de dar. Fora isso, todas as deficiências que a tradução apresente são deficiências mesmo. Não cabe desculpa.

\section{Prefácio 8: prefácio de tradutor com menção à tradução}

PRÉVERT, Jacques. Poemas. Trad. Silviano Santiago. Col. Poesia de Todos os Tempos. Rio de Janeiro: Nova Fronteira, 1985, pp. 7-11. 


\section{INTRODUÇÃO \\ Cotidiano e humor: o pequeno homem}

Silviano Santiago

1

No século XX, a popularidade de um poeta se mede e se aquilata de várias formas, todas negativas. Com os dedos grosseiros da leitura ideológica, dizemos que o poeta popular nada mais faz do que dar ao leitor o que ele já espera. Com as luvas de pelica das poéticas e manifestos, dizemos que ele nada mais executa do que um produto de consumo fácil que dilui o que de forte, tenso e agressivo existe nos radicais, criativos e pouco acessíveis poemas. Com os dedos sangrentos do bisturi crítico, dizemos que ele nada mais é do que um empalhador de sinceridade ou um curandeiro dos clichês.

Fica uma pergunta ao ler os poemas de Jacques Prévert.

Devemos desvencilhar-nos, por ocasião da sua leitura, dos dedos grosseiros do julgamento ideológico, das luvas de pelica da análise literária e dos dedos sangrentos da compreensão crítica?

Não sei se devemos desvencilhar-nos desse aparato constituído a duras penas. Mas sei que podemos desvencilhar-nos dele.

E ao desvencilhar, deparamos com poemas de execução simples e calculada, onde ressaltam as cores cinza do cotidiano, os meios-tons do humor e o colorido berrante do sarcasmo e até mesmo da piada.

Os melhores poemas de Jacques Prévert se escrevem desta forma: no fundo cinza do quadro são desenhadas em meio-tom situações delirantemente banais que, posteriormente, são coloridas com as chamadas cores puras. A arte de Prévert, antes de ser a dos poetas surrealistas conhecidos nossos (movimento ao qual querem dependurá-lo com se pudesse dependurar uma laranja na laranjeira sem risco de artificialidade) é a dos pintores fauves. Ou seja, aquela arte em que a composição primitiva, ingênua ou infantil se obscurece com coloridos violentos e se ilumina com a dosagem certa de lirismo.

O lirismo para Prévert, como para alguns dos nossos poetas de 22, se escreve com a combinação certa de cotidiano e humor, fazendo ressaltar no poema uma visão em pequena escala do homem. Ressalta do poema o pequeno, mas não o comum do homem. Essa visão miniaturizada do homem, em oposição aos grandes painéis sociais e históricos pitados por Eliot em The Waste Land, ou Pound nos Cantos, condiz com a pequenez do ser humano diante de um século que o pulveriza com máquinas, motores, rotativas, engrenagens, guerras, violência e morte. Nesse labirinto inapelavelmente assassino em que se encontra metido, perdidas as esperanças das grandes soluções, o "esforço humano" (para retomar um título de Prévert) passa a ser uma resposta ao mundo hostil pela voz inflexível, débil, bem-humorada, mas persuasiva e salvadora do pequeno homem. O seu oposto é o grande homem:

No ateliê do talhador de pedra

onde o encontrei

lhe tiravam as medidas

para a posteridade. 
Fincado no aqui e agora, eis o pequeno homem enquanto indivíduo plenamente consciente do seu poder marginal frente ao achatamento coletivista e uniformizador operado pela sociedade industrial. Eis o indivíduo e a sua rebeldia que podem abrir uma perspectiva de prazer e de futuro (e não de glória) por anos. Indivíduos rebeldes são o jovem Próspero, que recusa ir com o pai à pesca da baleia, o "Cancre" (traduzido por “Juquinha”) que diz não ao professor e diz sim ao que ama, o Van Gogh fulminado pela sua própria tempestade interior, e assim ao infinito, constituindo uma comunidade de "infelizes” (diria o bom burguês), semelhante à dos peixes que, vítimas da pesca milagrosa, encontram a felicidade numa gargalhada no dia da Crucificação. A grande mágica lírica de Prévert é a de fazer sorrir os chamados pequenos.

A mudança de perspectiva na apresentação dos acontecimentos históricos ou dos fatos banais é, portanto, a mensagem principal da poesia de Prévert. A mudança liberta-nos do bom senso (por que a versão do bom senso é sempre a certa?) massificador e coloca-nos diante do insólito do nunca pensado, levandonos enfim a indagações iconoclastas sobre a sorte dos que não tiveram a sorte de estar ao lado do bom senso vitorioso.

No fundo, quer dizer-nos Prévert, o bom senso vitorioso e antes de mais nada o guardião dos repressivos valores burgueses na nossa sociedade. "Mais vale despertar inveja do que piedade”, pensa o pai chefe de cantão com os sapatos engraxados e os pés vermelhos de sangue, do sangue da filha que trucidou por não aceitá-la como mãe solteira. Toda a família da "perdida” se encontra diante de uma feérica, banal e sangrenta vindima, cujo lema é roupa suja se lava em casa.

Jacques Prévert (1900-1977), embora frequentando o meio surrealista parisiense desde o período áureo na década de 20, era desses poetas cujos poemas durante muito tempo apenas circulavam de mão em mão. Poemas que, de repente, foram musicados e se tornaram canções populares de sucesso. Antes de ser conhecido como poeta-de-livros, Prévert teve fama como letrista de canções. Yves Montand e Juliette Gréco foram alguns dos seus intérpretes. Quem não se lembra de "Barbara", "Je suis comme je suis" ou "Les portes de la nuit”?

Só em 1945 é que saiu publicado o seu primeiro livro, Paroles. Seguiramno La pluie et le beau temps (1955), Histoires (1963) e Grand bal du printemps (1976).

A presente antologia foi organizada a partir de textos extraídos desses livros, em particular do primeiro e do terceiro. A escolha é de responsabilidade do tradutor.

Ao lado de poemas e canções, Prévert escreveu alguns dos melhores roteiros para o cinema francês dos anos 40 e 50. Suas histórias foram filmadas por cineastas do porte de Jean Renoir e Marcel Carné. Entre os filmes que tiveram excelente acolhida por parte do público e da crítica especializada, citemos: Les visiteurs du soir, Les enfants do paradis, Le quai des brumes, Le jour se lève e Les amants de Vérone. 
Levando em consideração os elementos sobressalentes da poesia de Prévert, acreditamos que - de modo geral - a sua dicção se assemelha à dos bons poetas brasileiros escrevendo nos anos 30 . Poetas estes que já se encontram desvinculados da linguagem agressiva da vanguarda dos anos 20, mas daqueles anos guardando ainda a simplicidade coloquial na escolha do vocabulário e nas construções sintáticas, perpassando também o coloquial com a alta voltagem do humor e até da piada. Foi a partir de "modelos" como Manuel Bandeira, Carlos Drummond e Murilo Mendes que procuramos transpor os versos de Prévert para o português.

A tradução - como a estamos compreendendo - é uma decisão de leitura por parte de quem traduz. Enquanto tal, a tradução é exegética do poema, como a leitura crítica, mas desta distancia-se em pelo menos um ponto crucial. Enquanto a leitura crítica do poema procura, pela erudição e pelo método, organizar, revelar e domar o múltiplo semântico que é a essência do texto poético, a tradução requer que o que é polissêmico no texto de origem permaneça polissêmico no texto traduzido, sem que se desvele para o leitor o enigma que tece o texto literário.

Coube ao tradutor não impor ao texto a ser traduzido uma dicção poética esclarecedora do poema, mas buscar no repertório das dicções possíveis na sua literatura nacional um equivalente que fosse justo. Coube ao tradutor domar primeiro o equivalente, ou seja, a dicção poética escolhida como justa, para só depois efetuar o trabalho de tradução.

Neste sentido, o tradutor é um exegeta de asas curtas, certamente um duplo plagiador. Plagia o texto a ser traduzido e plagia os poetas nacionais que selecionou como modelos de dicção.

Mais modesto do que o seu companheiro crítico literário, o voo exegético do tradutor fica sempre aquém das fronteiras semânticas do texto, já que não lhe compete quebrar o mistério do poema, nem prontificar-se à tarefa didática de ajuda na compreensão do poema. O tradutor guarda para o outro (para o seu leitor) o potencial polissêmico de leitura que existe em todo poema. Por isso é que o mais fiel amigo do tradutor é o leitor do poema traduzido. Para ele - só para ele é que existe a tradução.

Em outra perspectiva que não a do leitor do poema traduzido, pouco se salva de uma tradução - salvo, é claro, a fidelidade que é o que também se salva nos casamentos monogâmicos enquanto duram. Além da fidelidade, em uma tradução tudo é hipótese, aproximação, desacerto com acerto e até mesmo acerto sem acerto, transgressão com pedido de perdão e, finalmente, posse sem direito autoral.

\section{Prefácio 9: prefácio do tradutor com menção à tradução}

LARANJEIRA, Mário. Poetas franceses da Renascença. Col. Biblioteca Martins Fontes. São Paulo: Martins Fontes, 2004, pp. IX-X.

\section{APRESENTAÇÃO}

Em 1960, quando comecei a lecionar no curso de Língua e Literatura Francesa da Universidade de São Paulo, o professor parisiense M. Lebègue, da Sorbonne, especialista em literatura do século XVI, veio ministrar em nossa escola, como convidado, um curso sobre os autores franceses da Renascença. A 
beleza dos textos e a excelência do curso despertaram em mim a vontade de montar um projeto de tradução que desse acesso aos leitores brasileiros a esse instigante e pouco conhecido período das letras francesas. Mas as circunstâncias de trabalho e outros projetos de maior urgência fizeram com que essa publicação fosse sendo adiada, sem que nunca o projeto fosse esquecido ou abandonado. E, finalmente, mais de quarenta anos depois, aqui está, em edição bilíngue, uma seleção dos meus Poetas franceses da Renascença.

Que critérios presidira a escolha dos autores e dos textos? Em primeiro lugar, por mais que se queira agir com isenção, o gosto pessoal sempre tem, nesse tipo de escolha, um papel importante. Mas esse gosto pessoal foi, no caso presente, respaldado por critérios mais objetivos. Procurei apresentar poetas que fossem realmente representativos do período. Para isso, vali-me da opinião de críticos abalizados e, principalmente, escolhi textos que costumam estar presentes na maioria das seleções e das antologias que contemplam essa fase literária. Como se trata de um período relativamente remoto da literatura francesa, creio que o tempo já se encarregou de eliminar dos florilégios toda a ganga representada pelos modismos passageiros.

Quanto à minha atitude como tradutor, sigo princípios que já expus em trabalhos anteriores, particularmente em Poética da tradução (EDUSP, 1993), ou seja, diante da impossibilidade óbvia de se produzir, pela tradução, na línguacultura de chegada, um texto idêntico e formal. Isso quer dizer que, além de se manterem os sentidos mais próximos possíveis, busca-se recriar, na tradução poética, a métrica, os ritmos, as sonoridades, as rimas do original e sua disposição, e mesmo a apresentação visual do poema. São esses elementos formais que induzem o leitor a uma leitura "poética” do texto, buscando nele não informação, mas emoção estética. Assim, tenta-se obter do leitor dos poemas em língua portuguesa um comportamento-resposta o mais próximo possível do comportamento-resposta do leitor da língua original. É isso que faz a diferença entre a "tradução poética" e a simples tradução de poesia.

$\mathrm{Na}$ transcrição dos textos originais, mantive a escrita que constava nas obras utilizadas, quer fosse mantida grafia arcaizante do século XVI, quer fosse ela adaptada às normas do francês moderno. Já o português usado na tradução, embora apresente esporadicamente laivos de arcaísmos, manteve-se nos padrões atuais da língua.

Espero que este trabalho possa contribuir para o conhecimento, entre nós, desse importante período da literatura francesa.

Mário Laranjeira

\section{Prefácio 10: prefácio de tradutor com menção à tradução}

CORDEIRO, Renata. Pequena antologia de poemas franceses: de François Villon a Fernando Pessoa. São Paulo: Landy, 2002.

\section{INTRODUÇÃO}

Toda antologia é uma provocação. Tem por objetivo provocar o leitor que nada conhece o desejo de explorar novos mundos, cujas entradas lhe são indicadas. Já para o leitor familiarizado com o assunto, a antologia é uma 
provocação à interação, à aceitação ou à recusa, à destruição do que lhe está sendo proposto, e à reconstrução pessoal.

E nada é mais humano do que uma antologia, porque só o homem tem a necessidade de compor antologias à imagem da sua própria história. É difícil, ou até mesmo impossível, imaginar um deus que as componha: os "trechos escolhidos” são sinal de uma deficiência, são a resposta à incapacidade da memória de registrar tudo.

O homem, à medida que cresce, se vai tornando uma espécie de "antologia permanente”, posto que é a memória que tria, escolhe, elege, esclarece, censura, fazendo as lembranças que retém ordenarem o futuro. A memória guarda as imagens necessárias à vida de cada um. Nesse sentido, a antologia é o retrato da condição humana.

Mas se a antologia é uma operação necessária que vem socorrer a deficiência fundamental da memória, uma antologia de poemas é, por assim dizer, a memória da memória, porque o poema é, antes de mais nada, aquilo que é concebido para ser retido, a suma dos instantes confiados à memória que os capturou na rede das palavras, é um recurso contra o esquecimento. É algo dito de alguma forma, uma fusão tão perfeita que dissociar a fora do conteúdo se torna impossível. Quando isso ocorre, anula-se o poema. O que não significa que todo poema seja um conjunto de versos, rimados ou não, pois há muitos versos agrupados que não podem ser chamados de poema e muitos poemas que não são em versos, mas em prosa, como o prova Baudelaire (sem falar nas imagens...).

Uma vez que a antologia de poemas é a memória da memória, claro está que a sua autora é guiada pela sua história, em todos os níveis, sendo a sua eleição fundamentalmente pessoal. Portanto, é movida pelo seu "gosto", que obviamente começou a se formar desde o instante em que veio ao mundo. Grande responsabilidade, que aumenta mais ainda quando a autora de uma antologia de poemas é também sua tradutora.

Sim, a tradução! O poema é um texto que pode ser traduzido, sendo o seu resultado a subsistência do reflexo do poema que continua a ser poema - um outro e o mesmo. Porém, visto que é impossível dissociar a forma do conteúdo, esse trabalho de tradução apresenta muitas dificuldades. Tome-se, a título de exemplo, o poema "Mar e Amor", de Pierre de Marbeuf (1596-1645), presente nesta antologia. Trata-se de uma gama sutil de ecos de sons e sentidos baseados numa paronomásia. O que fazer em português com o seguinte verso:

"La mère de l'amour eut la mer pour berceau?"

“A mãe do amor teve o mar por berço?”

Nessa alusão ao nascimento de Afrodite (Vênus), o problema não é cultural, pois "mère" / mãe se confunde com "mer" / mar, já que são homófonos. Uma possível solução seria o emprego da palavra "mare", sinônimo de "mãe” em português. Além dessas dificuldades, há outras, tais como: "eaux" / "maux", que foram traduzidos pela coisa mais óbvia: água/mágoa.

Difícil tarefa a da tradutora de poesia, mas de todo possível, como já o provaram. E assim como o autor original imprimiu na sua composição os elementos que faziam dele um ser único, a tradutora também imprimirá na sua tradução as suas características pessoais, tanto culturais e históricas quanto psicológicas e até mesmo biológicas. Portanto, o leitor aqui verá o resultado de 
um processo em que a tradutora procurou manter as marcas pessoais de cada autor, mas que, fatal e necessariamente, imprimiu as que lhes são específicas.

Uma antologia de poemas franceses. Por quê?

Porque a língua francesa, guardadas as devidas proporções, foi no passado o que o inglês é hoje no mundo, ou seja, a língua universal, e porque ao longo da sua história, o Brasil sempre bebeu em fontes francesas, pelo menos até a metade do século XX. A cultura e a língua francesas influenciaram, por exemplo, a poesia e o movimento dos inconfidentes, o romantismo, o parnasianismo, e estão na base da formação acadêmica brasileira.

Esta antologia parte das origens medievais da poesia francesa - privilegia Villon - e vai até o começo do século XX, no âmbito de uma arte poética codificada antes da aventura moderna de uma escrita livre de coerções. Tem por base a antologia de André Gide, ${ }^{1}$ mas apenas por base, pois foi formada ao longo dos anos e não apresenta forçosamente os poemas franceses mais famosos. Também foram incluídas composições de escritores que se consagraram em prosa, a exemplo de Proust, uma de Fernando Pessoa que, mesmo não sendo um poeta francês, fez, na qualidade de poeta universal, poemas nesse idioma, bem como de quebequenses. Os poemas são apresentados em ordem cronológica de acordo com a data de nascimento dos autores e no fim do livro há biografias resumidas de cada um. Para um contato com a poesia francesa contemporânea, a autora/tradutora remete o leitor ao brilhante trabalho do professor Mário Laranjeira. ${ }^{2}$

Espera-se que o leitor se sinta provocado e que procure conhecer mais fundo a poesia em língua francesa, podendo mergulhar em outras antologias mais amplas que certamente o deixarão fascinado.

São Paulo, junho de 2002.

Renata Maria Parreira Cordeiro

1. Anthologie de la poésie française. Paris: Gallimard, 1986 (Bibliothèque de la Pléiade). Dentre os outros livros consultados, destacam-se: COLLOGNATBARÈS, Annie. Anthologie de la poesia française. De Villon à Verlaine. Paris: Le Livre de Poche, 1998, e REES, William. The Penguin Book of French Poetry 1820-1950. Londres: Penguin Books, 1990. Também foram consultados livros específicos dos autores, em particular os da "Collection Poésie”, da Gallimard.

2. Poetas de França hoje 1945-2995. São Paulo: Edusp/Fapesp, 1996.

\section{Prefácio 11: prefácio de tradutor sem menção à tradução}

CÉLINE, Louis-Ferdinand. Viagem ao fim da noite. Trad. Rosa Freire d’Aguiar. São Paulo: Companhia das Letras, 1994.

\section{APRESENTAÇÃO}

Logo que Viagem ao fim da noite foi publicado, em outubro de 1932, o escritor Georges Bernanos percebeu, arguto, que seu autor Louis-Ferdinand de Céline fora criado por Deus para escandalizar. Por sua linguagem popular e desabrida, até então desqualificada pelos escritores de bem, pela violência com 
que seu herói Ferdinand Bardamu denunciava a torpeza da sociedade, o romance de estreia de Céline, um médico de 38 anos, de fato escandalizou. Viagem conquistou uma legião de fãs tão diversos quanto Henry Miller, que confessou ter reescrito Trópico de Câncer depois de lê-lo nas provas tipográficas, e Joseph Stalin, que o elegeu como livro de cabeceira. Nos meses que se seguiram ao lançamento o romance mereceu nada menos de cem artigos entusiastas ou indignados. Em um ano as vendas se aproximavam dos cem mil exemplares e estavam a caminho as primeiras traduções, para o checo, o inglês, o holandês e o russo, esta feita por Elsa Triolet, mulher do poeta comunista Louis Aragon.

Porém, o endeusado Céline não demorou a cair do pedestal. A partir de 1937, quando publicou o primeiro dos três famosos panfletos antissemitas, hoje só encontrados em raras bibliotecas, e passou a fazer uma odiosa defesa das posições nazistas, ele foi execrado por legião talvez maior. Talento nem seus inimigos lhe negaram, mas o gênio literário não absolve todos os pecados, menos ainda os capitais. Até hoje a imagem de Céline é polêmica, como ficou claro em 1992, quando a casa de Meudon onde viveu seus últimos anos foi tombada pelo Ministério da Cultura e, semanas depois, destombada pelas autoridades municipais.

Mal surgiu nas livrarias, Viagem ao fim da noite despontou como o favorito para ganhar o prêmio Goncourt daquele ano. Mas no último instante dois jurados se negaram a sufragar um romance repleto de "expressões ultrajantemente triviais, grosseiras e intoleráveis [...], mesmo nas circunstâncias em que são utilizadas”. Há que situar no tempo os pundonores linguísticos dos veneráveis acadêmicos. Em 1932, Marcel Proust pontificava na grande literatura. Fazia só cinco anos que saíra o último volume de Em busca do tempo perdido. Ora, tudo o que em Proust era delicadeza, fineza, meios-tons, harmonia, em Céline era grosseria, crueza, violência, deformação. Hoje, um e outro são fervorosamente cultuados por devotos no mundo inteiro. Mas há sessenta anos, a audácia de Céline parecia tanto maior quanto ele pretendia, assim como seu intimidativo predecessor, renovar a língua francesa. O que fez; só que, digamos, às avessas, a partir da linguagem oral e popular. Foi este o grande achado de Céline, ser um Proust da plebe, segundo a fórmula de um crítico da época. Bardamu é um anticonformista, um revoltado, um iconoclasta; assim será a linguagem de seu criador. Juntar palavras que não se juntam, mudá-las de seu lugar habitual na frase, usar elipses que comprometem a clareza do texto, gírias e palavrões, criar uma pontuação sui generis que até hoje arrepia os cabelos dos revisores mas marca o ritmo inconfundível de sua prosa: Viagem ao fim da noite já contém os elementos do estilo de Céline, que no entanto vai elaborá-lo cada vez mais nos sete romances seguintes.

Céline muito fabulou sobre sua vida e sua obra. Disse uma vez que Viagem lhe consumiu cinquenta mil páginas, reduzidas depois para as seiscentas da primeira edição. Hoje se sabe que seu processo criativo se baseava, ao contrário, muito mais em acréscimos do que em supressões. Era comum que ele esticasse uma frase com interjeições e expletivos só para reforçar sua oralidade. Entre a primeira e a segunda versão, o romance passou de 534 para 89 laudas datilografadas.

A via aberta por Céline do "escrever como se fala” - espontaneidade aliás aparente, como evidenciam em Viagem ao fim da noite os trechos altamente literários - foi desde então palmilhada à exaustão por muitos escritores. Talvez 
por isso o impacto que o romance cause no leitor de hoje decorra menos da linguagem, inovadora em sua época, do que da virulência com que Bardamu vomita o horror que sente por seus semelhantes. O romance se inicia em 1914 com uma guerra mundial que deixou, só na França, mais de um milhão e meio de mortos. Termina por volta de 1930 com a crise econômica que vai se alastrando pela Europa. Entre as duas datas, Bardamu testemunha a decadência extravagante dos années folles, a crise do colonialismo, a desumanidade do capitalismo, a miséria da periferia urbana. É no front, porém, que ele adquire a certeza que há de balizar sua viagem ao fim, ao fundo da noite: "a verdade deste mundo é a morte”, diz. Ricos e obres, homens e mulheres vivem para empurrar, mais ou menor sutilmente, o vizinho, o parente, o amigo para a morte. Um estudo psicanalítico do romance sugere que este desejo homicida que Bardamu enxerga em todos os que o cercam, com a notável exceção das crianças e da prostituta Molly, seria a interpretação muito pessoal que Céline dava ao conceito freudiano de instinto de morte.

Louis-Ferdinand Destouches (Céline era o nome de sua avó materna e madrinha) nasceu em Courbevoie em 27 de maio de 1894. Seu pai, de origem burguesa, trabalhava numa companhia de seguros; sua mãe, de família de pequenos comerciantes, terá a partir de 1889 uma loja de artigos de renda, moda e lingerie na elegante Passage Choseuil de Paris. Marguerite Destouches sonhava em ver o filho bem colocado no comércio. Mais valiam, portanto, os estágios nos bons estabelecimentos do ramo do que os estudos no Liceu. Louis só fez o curso primário. Dos 13 aos 15 anos viveu em internatos da Alemanha e da Inglaterra para aprender línguas, e dos 15 aos 18 foi “aprendiz” em uma loja de tecidos finos e em duas joalherias. Fazia o serviço militar na Lorena quando em agosto de 1914 estourou a guerra. Em outubro, ferido gravemente por bala no braço direito, foi transferido para Paris. Foram poucas as semanas na frente de batalha, mas traumáticas, deixando-lhe como seqüelas para o resto da vida a insônia, os distúrbios de audição causados por explosões de granadas, e as enxaquecas. Depois de uma temporada em que trabalhou no consulado-geral em Londres, o jovem Louis, reformado, partiu para a África, como gerente de uma plantação na colônia dos Camarões, de onde voltou com malária. Em 1924, já formado em medicina e separado da mulher Edith Follet, com quem teve sua única filha, Colette, ele foi para Genebra trabalhar na seção de higiene da Sociedade das Nações, iniciando aí uma carreira de funcionário internacional que o levou a percorrer a Europa, os Estados Unidos e a África em missões médicas.

Um livro que denunciava com tanta veemência a guerra, o colonialismo, o taylorismo, a pobreza dos subúrbios, só podia ser de um homem “de esquerda”. E assim foi Céline etiquetado. Para o jornal anarquista Le Libertaire, "como não simpatizar com sua insubmissão total à velha sociedade burguesa?”. Para o Monde, semanário próximo do Partido Comunista e dirigido por Henri Barbusse, “Céline é um dos nossos". Para Claude Lévi-Strauss, no L’Étudiant Socialiste, Viagem era "a obra mais considerável dos últimos dez anos”. Para Simone de Beauvoir, anos depois, "seu anarquismo parecia próximo do nosso". Houve quem frisasse as ambiguidades ideológicas do romance, mas coube ao escritor comunista Paul Nizan pôr o lúcido pingo dos is: "Essa revolta pura pode levar Céline a qualquer lugar: até nós, contra nós ou a lugar nenhum”. 
Levou-o longe demais. Já em 1933 ele começou a denunciar a “demagogia e a hipocrisia" dos intelectuais que faziam "promessas revolucionárias ao proletariado”. Em 1936, irritado com a rejeição quase unânime a seu segundo romance, Morte a crédito, contra-atacou acusando seus críticos de serem "todos judeus”. Mas foi em 1937 que iniciou a grande viagem ao antissemitismo e ao racismo, defendidos com uma histeria que até hoje causa perplexidade. No fim de uma noite dessas, não havia aurora possível. O primeiro panfleto, Bagatelles pour un massacre, saiu em dezembro. L'école des cadavres, um ano depois. O terceiro, Les beaux draps, em fins de 1940, quando na França ocupada pelos nazistas Céline frequentava as recepções de Otto Abertz, embaixador do Terceiro Reich, e já vigorava o estatuto dos judeus. Os três títulos tiveram considerável sucesso, vendendo até 1944, respetivamente, 86 mil, 38 mil e 44 mil exemplares. Nesses anos de Ocupação, Céline escreveu aos jornais pró-nazistas cerca de trinta cartas e deu onze entrevistas aprovando a perseguição aos judeus e o ódio racial.

Nos últimos anos de vida Céline foi exímio em embaralhar as pistas que desvendariam os episódios comprometedores do seu passado. Mas a realidade vai se impondo. Recentemente, em maio de 1994, o escritor alemão Ernst Jünger confirmou por escrito que era mesmo Céline o homem sentado à sua frente em Paris, numa noite de dezembro de 1941, a exigir dos militares alemães que fuzilassem ou enforcassem os judeus.

Sabendo-se condenado à morte pela Resistência, em 17 de junho de 1944, onze dias após o desembarque das tropas aliadas na Normandia, Céline conseguiu dos alemães um salvo-conduto e fugiu de seu apartamento de Montmartre com a segunda mulher, Lucette Alamanzor, e o gato Bébert. Seu destino era a Dinamarca, onde escondera uma reserva em ouro amealhada com os vultuosos direitos autorais que recebera até então - a outra parte desse pecúlio, guardada desde antes da guerra num cofre de banco em Amsterdam, acabaria em mãos nazistas. Mas não era fácil atravessar a Alemanha, e o dr. Destouches aceitou então ser o médico da colônia de dois mil franceses, a fina flor do colaboracionismo, que em fins de 1944 tentava salvar a pele em Sigmaringen, junto como marechal Pétain e os ex-ministros do regime de Vichy. A temporada alemã está contada na trilogia D’un château l'autre, Nord e Rigodon.

Os seis anos de exílio na Dinamarca foram amargos. Acusado na França de traição à pátria, ele se livrou da extradição mas passou um ano e meio numa prisão em Copenhaguen. As mais de mil cartas enviadas nesse período a um punhado de amigos mostra um Céline acuado, sofrendo de delírio de perseguição, obcecado por dinheiro. Na lista dos inimigos imaginários, que estariam conspirando para destruí-lo, ele agora incluía "as valquírias, os Vermelhos, os Batavos, os Gringos, os Judeus, os Maçons, Pretos, Gaullistas e Vichystas”. Ele, que odiava a vida no campo, teve que ir morar, por falta de recursos, numa casa isolada na beira do Báltico, emprestada por seu advogado dinamarquês. Tentou ser reeditado em vários países. Propôs a produtores americanos suas peças de teatro, balés e roteiros de cinema. Sonhou com o asilo nos Estados Unidos, na Suíça e até na Groenlândia. "Boicote total. Sou o anti-Cristo."

Em fevereiro de 1950 Céline foi condenado em Paris a um ano de prisão, ao humilhante estado de indignidade nacional e ao confisco de metade de seus bens atuais e futuros. Anistiado meses depois, retornou à França em julho de 1951, com Lucette e Bébert, e comprou uma casa em Meudon. Reinscreveu-se na Ordem dos Médicos, pendurou uma placa no portão de casa, mas foi Lucette 
quem ganhou algum dinheiro dando aulas de dança. Durante o processo de Céline, seu amigo Henry Miller expressara o desejo de que "o mundo podia muito bem fechar os olhos para os 'erros' de certos homens eminentes que tanto contribuíram para nossa cultura”. Céline não viveu para tanto. Morreu em $1^{\circ}$ de julho de 1961 , de congestão cerebral, aos 67 aos. Menos de trinta pessoas acompanharam seu enterro ao cemitério de Meudon.

Rosa Freire d'Aguiar

\section{Prefácio 12: prefácio de tradutor com menção à tradução}

DUMAS, Alexandre. O conde de Monte Cristo. Trad. André Teles e Rodrigo Lacerda. Rio de Janeiro: Zahar, 2012.

\section{APRESENTAÇÃO}

O conde de Monte Cristo foi publicado originalmente como folhetim, entre agosto de 1844 e janeiro de 1846. No Brasil, já em 1845 (isto é, com apenas alguns meses de atraso em relação à França), saía no Jornal do Commercio com grande sucesso.

É consenso entre os críticos que o livro traz um retrato bastante fiel da França nos primórdios da democracia, juntamente com A comédia humana, de Balzac, Os mistérios de Paris, de Eugène Sue, e Os miseráveis, de Victor Hugo. Aqui, esse retrato amplo da sociedade é possibilitado pela trajetória do protagonista Edmond Dantès, que parte de uma posição social intermediária, desce às profundezas quando é preso injustamente e alcança o topo da pirâmide quando escapa da prisão e enriquece.

À medida que Dantès marcha para a vingança, distancia-se dos homens comuns e oferece a leitores de todos os tempos um pouco de redenção: a revanche da justiça legal, a reinstauração da ordem moral. Ninguém pode lhe negar que, realmente, faz de tudo para obtê-las. Ao suspense intrínseco ao tema - "Ele vai conseguir se vingar? (no fundo, intuímos que vai) —, soma-se o suspense maior: “Qual será sua vingança?”

Dumas trabalhava em colaboração com dezenas de outros escritores e pesquisadores. O único de seus assistentes a realmente chegar perto de uma coautoria foi Auguste Maquet (1813-88), com quem Dumas trabalhou em cerca de vinte romances, inclusive $O$ conde de Monte Cristo. Tudo indica que Maquet, exprofessor universitário, redigia um pequeno esboço a partir de seus conhecimentos históricos e pesquisas. Em seguida, este era reescrito por Dumas, que acrescentava seu estilo romanesco e autêntico jorro de imaginação. O texto final foi sempre de Dumas - e não por acaso, quando a dupla se desfez e Maquet entrou com um processo contra o parceiro, exigindo uma soma exorbitante por direitos autorais, a Justiça determinou o pagamento de royalties suplementares, mas negou-lhe o privilégio de assinar como coautor.

A presente tradução baseou-se nas melhores edições existentes: a Pléiade, a da Calmann-Lévy (em seis volumes, reprodução da edição standard de 1895), a da Bouquins e a da Folio. Sem mudanças substantivas no original, adaptamos a 
pontuação para as normas vigentes, modernizamos com moderação as formas de tratamento e privilegiamos, sempre, a fluência da leitura. As ilustrações aqui incluídas, de autoria de Gustave Staal, entre outros, integraram a $1^{\text {a }}$ edição francesa de $O$ conde de Monte Cristo.

Esta é uma versão reduzida da apresentação de Rodrigo Lacerda para $O$ conde de Monte Cristo: edição definitiva - comentada e ilustrada, publicado pela Zahar em 2008. 